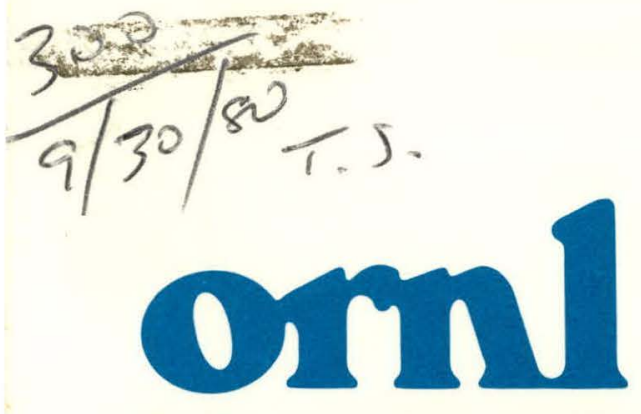

OAK RIDGE NATIONAL LABORATORY

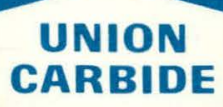

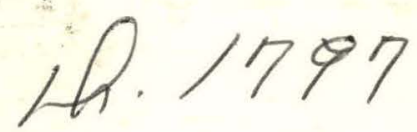

ORNL/TM-7385/V2

\title{
RADIOACTIVE WASTE MANAGEMENT \\ INTEGRATED DATA BASE: \\ A BIBLIOGRAPHY
}

\section{MASTER}

OPERATED BY

UNION CARBIDE CORPORATION FOR THE UNITED STATES DEPARTMENT OF ENERGY 


\section{DISCLAIMER}

This report was prepared as an account of work sponsored by an agency of the United States Government. Neither the United States Government nor any agency Thereof, nor any of their employees, makes any warranty, express or implied, or assumes any legal liability or responsibility for the accuracy, completeness, or usefulness of any information, apparatus, product, or process disclosed, or represents that its use would not infringe privately owned rights. Reference herein to any specific commercial product, process, or service by trade name, trademark, manufacturer, or otherwise does not necessarily constitute or imply its endorsement, recommendation, or favoring by the United States Government or any agency thereof. The views and opinions of authors expressed herein do not necessarily state or reflect those of the United States Government or any agency thereof. 


\section{DISCLAIMER}

Portions of this document may be illegible in electronic image products. Images are produced from the best available original document. 


\section{Printed in the United States of America. Available from National Technical Information Service \\ U.S. Department of C'ommerce 5285 Port Royal Road, Springfield, Virginia 22161 NTIS price codes-Printed Copy: A18 Microfiche A01}

This report was prepared as an account of work sponsored by an agency of the United States Government. Neither the United States Government nor any agency thereof, nor any of their employees, makes any warranty, express or implied, or assumes any legal liability or responsibility for the accuracy, completeness, or usefulness of any information, apparatus, product, or process disclosed, or represents that its use would not infringe privately owned rights. Reference herein to any specific commercial product, process, or service by trade name, trademark. manufacturer, or otherwise, does not necessarily constitute or imply its endorsement, recommendation, or favoring by the United States Government or any agency ihereul. Thie vlews dild upiniums of dulliurs expiessed lieiein do not necessarily state or reflect those of the United States Guvermment or dily agency thereof. 
Contract No. W-7405-eng-26

Information Division

Nuclear Fuel and Waste Programs

Program ONL-WI

RADIOACTIVE WASTE MANAGEMENT INTEGRATED DATA BASE:

A BIBLIOGRAPHY

C. A. Johnson and P. A. Garland

Ecological Sciences Information Center

Information Center Complex

Date Published: September 1980

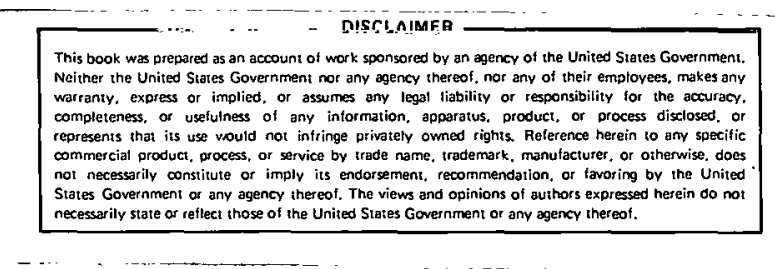

OAK RIDGE NATTONAT, TAABORATORY

Oak Ridge, Tennessee 37830

operated by

UNION CARBIDE CORPORATION

for the

DEPARTMENT OF ENERGY 


\section{THIS PAGE \\ WAS INTENTIONALLY \\ LEFT BLANK}


CONTENTS

Volume 1

Acknowledgments . . . . . . . . . . . . . . . . . . v v

Abstract . . . . ................. . vii

Introduction . . . . . . . . . . . . . . . . . . 1

Sample Reference . . . . . . . . . . . . . ... . 4

Indexes

Author . . . . . . . . . . . . . . . . . 7

Author Affiliation (Corporate Author) . . . . . . . . 37

Subject Category .. . . . . . . . . . . . . 53

Keyword . . . . . . . . . . . . . . . . . 59

Permuted Title................... 99

Volume 2

Bibliographic References . . . . . . . . . . . . . 1-402 $1954-1960$..................... . . . . 1 $1961-1965$. . . . . . . . . . . . . . . . 13

1966 - 1970 ................... 37

1971 . . . . . . . . . . . . . . . . 83

1972 . . . . . . . . . . . ....... 89

1973 ...................... 103

1974 ...................... . . . 123

1975 ....................... 159

1976 . . . . . . . . . . . . . . . . 197

1977 ....................... 259

1978 . . . . . . . . . . . ...... 341

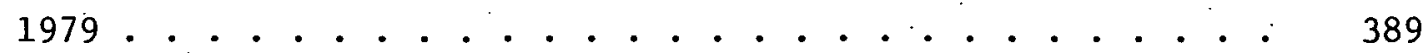




\section{4}

1

1953 OPERATING REPORT - WD-2 PLANT, LOS ALAMOS INDUSTRIAL WASTE SECTION, AEC, LAFO. Wash-275; Sanitary Engineering, Proceedings of a Conference, Baltimore, Maryland, April 15-16, 1954, (pp. 198214). (1954)

A complete analysis of the process at Los Alamos from several aspects.

An examination of the waste treatment program at Los Alamos Laboratories. Paper runs through the treatment design and process, problems and economics of the station. Data are given for operating costs and operating results. A chemical analysis of the wastes treated is included. Attention is given to unique nature and requirements of the plant.

\section{SUBJECT CATEGORY: LLW}

ORIGIN: Commercial; Defense

KEYWORDS: AQUIFERS; BENTONITE; CONTAMINATION; COST BENEFIT ANALYSIS; RADIOACTIVE EFFLUENTS; FILTRATION; FLOCCULATION; MONTMORILLONITE; PLUTONIUM; SEDIMENTS; SLUDGES; VOLUME; RADIOACTIVE WASTE PROCESSING; ECONOMICS; LASL

\section{5}

\section{2} Joseph, A.B.; Johns Hopkins University, Baltimore, MD

RADIOACTIVE WASTE DISPOSAL PRACTICES IN THE ATOMIC ENERGY INDUSTRY (A SURVEY OF THE COSTS). NYO-7830. CFSTI; 195 pp. (1955)

\section{3 figures, 6 tables}

A survey was made on methods and related costs of disposing of radioactive wastes as practiced in 1955 by twelve atomic industry installations. The scheme for making the survey as well as detailed waste disposal practices are reported. Obvious conclusions drawn from the factual data are (1) that it is more expensive per cubic foot to handle high level wastes than low level wastes and (2) that land disposal is less expensive than sea disposal. A reexamination of baling economics shows that high compression of solid wastes is more expensive than simpler forms of compaction.

SUBJECT CATEGORY: HLW; LLW

ORIGIN: Commercial

KEYWORDS: IDAHO NATIONAL ENGINEERING LABORATORY; RADIOACTIVE WASTE DISPOSAL; MARINE DISPOSAL; GROUND DISPOSAL; RADIOACTIVE WASTE STORAGE; ECONOMICS; RADIOACTIVE WASTE PROCESSING; LIQUID WASTES; ANL; US NRC; KAPL; ORNL; ROCKY FLATS PLANT; SOLID WASTES; WASTE TRANSPORTATION

3

Clark, J.R., and H.A. Pohl

EARTH DISPOSAL OF RADIOACTIVE WASTES AT SAVANNAH RIVER PLANT. TID-7517 (Part 1); Sanitary Engineering Aspects of the Atomic Energy Industry, Proceedings of a Seminar held in Cincinnati, Ohio, December 6-9, 1955, (pp. 162-169), 609 pp. (1955)

A comparison of climate and geohydrology of Hanford and Savannah River Plant is made. As compared to Hanford soils, SRP soils show, lower permea bility ( 0.2 to $1 \mathrm{gal} / \mathrm{sq} \mathrm{ft} /$ day $)$, lower ion exchange capacity $3.5 \mathrm{meq} / 100 \mathrm{~g}$, and a shallower water table (10-50 ft). Hanford soils are primarily sandy gravel soils, whereas SRP soils are dry. A discussion of SRP seepage basins, including cost assessment is included as well as a graph relating holdup time required before river disposal of $\mathrm{Sr} 90$, Cs 137, Ba 137, Ru 106, Rh 106, Pu 237, Cs 144, Pr 144 , and $\mathrm{Sr} 89$.

SUBJECT CATEGORY: LLW; TRU

\section{ORIGIN: Defense}

KEYWORDS: ION EXCHANGE; RADIOACTIVE WASTE DISPOSAL; RADIOACTIVE WASTE STORAGE; LOW-LEVEL RADIOACTIVE WASTES; COST; ECONOMICS; LIQUID WASTES; GROUND DISPOSAL; STRONTIUM 89; CESIUM 137; BARIUM 137; RUTHENIUM 106; RHODIUM 106; PLUTONIUM 237; CESIUM 144; PRASEODYMIUM 144; STRONTIUM 90 
4

Morgan, J.M., Jr.

CONSIDERATIONS IN EVALUATING A BURIAL GROUND FOR SOLID WASTES. TID-7515 (Part 1A); Sanitary Engineering Aspects of the Atomic Energy Industry, Proceedings of a Seminar held in Cincinnati, Ohio, December 6-9, 1955, (pp. 243-249), 609 pp. (1955)

At present, radwastes are buried at five different sites. It is suggested that a national land burial area be used to sequester radioactively contaminated materials. The life of such burial areas should be at least one hundred years. One square mile of burial area with a buffer zone of one-half mile should be acquired in an "empty" section of the country. Topography, geology, surface and ground water hydrology, meteorology, soil conditions, and transportation facilities are the physical factors affecting the desirability of any particular site. 'I'he general geology should show an absence of faults and folds. The area should not have limestone or dolomite formations in addition to having no previous seismological history. The topography should be flat or gently rolling for ease of burial equipment operation and covered with vegetation. Streams in and near the proposed area should be observed with respect to hydraulic and hydrology factors, silt load, bed scour, variations in flow, vertical mixing and stratification. Lakes would be included in the study. Exhaustive information on the ground water conditions with special emphasis on shallow aquifers will be necessary. In the study attention should be paid to movement, natural recharge, discharge, depth to water table, permeability, and transmissibility of the aquifer and the velocity of flow. Any incineration ought to be practiced when there is a wind velocity of at least $10 \mathrm{mph}$ and the prevailing direction away from site headquarters and nearby communities. A low rainfall area is preferable. Also areas where known inversions occur are to be avoided. The area should be chosen with a tight clay soil to inhibit ground water movement and maximize adsorption. The proposed site should be within 3 miles of a major highway and should have all-weather access road and railroad siding. Also the area should have an interlacing network of dirt and semi-improved roads for easy local transportation. The site should be located in the geographic center of the major waste producers. The cost of land burial may range from $\$ 1.52$ to $\$ 9.40 / \mathrm{cu}$ yd.

\section{SUBJECT CATEGORY: LLW}

ORIGIN: Commercial; Defense; Institutional
KEYWORDS: COST BENEFIT ANALYSIS; ENVIRONMENT; GEOLOGY; GROUND WATER; HYDRAULICS; HYDROLOGY; COMBUSTION; METEOROLOGY; SITE EVALUATION; SOILS; WASTE DISPOSAL; LOW-LEVEL RADIOACTIVE WASTES; RADIOACTIVE WASTES; SOLID WASTES; GROUND DISPOSAL

5

Ryan, E.S., and L.C. Farrell

COSTS INVOLVED IN THE OFFSITE DISPOSAL OF SOLID WASTES. TID-7517 (Part 1A); Sanitary Engineering Aspects of the Atumic Energy Industry, Proceedings of a Seminar held in Cincinnati; Ohio, December 6-9, 1955, (pp. 236-242), 609 pp. (TID-7517, Part 1A). (1955)

The costs of shipping contaminated solid wastes from the Rocky Flats installation to the AEC installation at Idaho Falls, Idaho. At first, the wastes were going to be shipped to San Francisco for sea burial but it proved to be too expensive. The wastes, paper, rags, and sludges, were placed in 55 gallon drums lined with polyethylene bags. Detailed steps are followed in record keeping and preparing the drums for shipment. From April 1954 to September 1955,41 trailers moved $1,450,000$ lbs or $41,900 \mathrm{cu} \mathrm{ft}$ of solid wastes. The total cost was $\$ 42,730$ or cost/Cwt was $\$ 2.95$. The cost/cu ft was $\$ 1.02$ and the cost/Ton-Mile (750 miles) was $\$ 0.08$.

SUBJECT CATEGORY: Transportation

ORIGIN: Defense

KEYWORDS: CONTAINERS; COST BENEFIT ANALYSIS; ECONOMICS; RADIOACTIVE WASTE DISPOSAL; WASTE TRANSPORTATION; LOW-LEVEL RADIOACTIVE WASTES; SOLID WASTES; SLUDGES; COST

\section{6}

\section{6}

Abee, H.H.; Oak Ridge National Laboratory, Oak Ridge, TN

PROBLEMS IN THE BURIAL OF SOLID WASTES AT OAK RIDGE NATIONAL LABO. RATORY. TID-7517 (Part 1A); Sanitary Engineering Aspects of the Atomic Energy Industry, Pro- 
ceedings of a Seminar, Cincinnati, $\mathrm{OH}$, December 6-9, 1955, (pp. 223-228). (1956)

This report is a dated discussion on safety, economy, and convenience of shallow land burial of radioactive waste.

In this report the general problems associated with shallow land burial of radioactive waste are discussed. The discussion includes information on personnel exposure to radiation and the contamination potential associated with the collection, handling, transportation, and burial of the waste. Waste material is currently buried in a Conasauga shale formation approximately $1500 \mathrm{ft}$ thick. This shale exhibits ion exchange capacities of from 5 to $25 \mathrm{meq} / 100 \mathrm{~g}$ of soil. Descriptions of solid waste receptacles, personnel protective apparel, health physics considerations, transport vehicle requirements, and decontamination procedures are provided. Typical burial operations, costs, land utilization rates, and records are briefly discussed.

\section{SUBJECI' CATEGORY: LLW}

ORIGIN: Commercial

KEYWORDS: CONTAMINATION; DECONTAMINATION; RADIATION DOSES; SHALES; ION EXCHANGE; RADIATION HAZARDS; RADIOACTIVE WASTE DISPOSAL; RADIOACTIVE WASTES; WASTE TRANSPORTATION; RADIOACTIVE WASTE STORAGE; RADIOACTIVE WASTE MANAGEMENT; ECONOMICS

\section{7}

Witkowski, E.J.; Oak Ridge National Laboratory, Oak Ridge, TN

OPERATING EXPERIENCE IN THE DISPOSAL OF RADIOACTIVE WASTES IN OPEN PITS. TID-7517 (Part 1A); Sanitary Engineering Aspects of the Atomic Energy Industry, Proceedings of a Seminar held in Cincinnati, Ohio, December 6-9, 1955, (pp. 105-115), 609 pp. (1956)

The evolution of the open pits and their use is presented. Originally waste disposal consisted of putting the liquid wastes in eight underground concrete storage tanks with a total capacity of 1.1 million gallons. Even using precipitation when the tanks could not handle the incoming effluents proved to be inadequate. The tanks were filling faster than could be emptied and the radwaste going into White Oak Lake could not be kept below the maximum permissible concentration (MPC) level.
In 1949 the storage tank precipitation procedure and discharge was discontinued and a steam evaporator was built. However, by 1951 this system became inadequate and economics forced the Laboratory to investigate using pits for the disposal of wastes. The first pit was in the Conasauga shale and was $100 \mathrm{ft}$ long, $20 \mathrm{ft}$ wide and $15 \mathrm{ft}$ deep with vertical walls. The capacity was 180,000 gallons. A total of 389 curies in 29,000 gallons of concentrated evaporator wastes and 94,000 gallons of waste containing high concentrations of salts were pumped into the pit. The soil around the pit allowed a breakthrough in 2.5 months about $150 \mathrm{ft}$ down the hill. No actual hazard developed because the activity leaking out was from Ru 106 which has a high MPC. With the success of the first pit, a million gallon pit, $15 \mathrm{ft}$ deep and $210 \mathrm{ft}$ by $100 \mathrm{ft}$ was dug. Instead of trucking in the liquid wastes they were now pumped in through a pipeline. More pits have also been added since the second one was excavated. To date, more than 2.7 million gallons containing 35,000 curies have been transferred to the waste pits. The disposal pits are considered satisfactory by the operating personnel because of the limited exposure to radiation. Radiation has been measured at $250 \mathrm{mr} / \mathrm{hr}$ at the edge of the pit and $1200 \mathrm{mr} / \mathrm{hr}$ in the center of the pit. Leakage of $\mathrm{Ru} 106$ is less than $1 / 1000$ MPC. It costs $\$ 78,000$ to build the million gallon pit and pipeline, while it saves $\$ 278,000$ for the evaporator project

\section{SUBJECT CATEGORY: LLW}

ORIGIN: Defense

KEYWORDS: CONTAINMENT; CONTAMINATION; COST BENEFIT ANALYSIS; DOSE RATES; EXCAVATION; FIELD TESTS; GEOLOGY; GROUND WATER; HAZARDS; MAXIMUM PERMISSIBLE CONCENTRATION; SHALES; SITE EVALUATION; LIQUID WASTES; RUTHENIUM 106; GROUND DISPOSAL; INVENTORIES; ORNL

\section{8}

De Laguna, W.

SOME GEOLOGIC FACTORS THAT INFLUENCE DISPOSAL OF RADIOACTIVE WASTES INTO PITS. TID-7517 (Part 1); Sanitary Engineering Aspects of the Atomic Energy Industry, Proceedings of a Seminar held in Cincinnati, Ohio, December 6-9, 1955, (pp. 426-456). (1956)

A generalized conceptual and philosophic discussion on waste disposal is presented. Site specific 
data of ORNL and Brookhaven National Laboratory are also presented.

A generalized conceptual discussion of the nature of ground water flow and how it relates to the proper selection of sites for radioactive waste disposal is presented. In addition, brief descriptions of the hydrogeology of the Brookhaven and Oak Ridge National Laboratories is presented. Brookhaven National Laboratory is composed of unconsolidated clay and clayey sand. Bottom sediment beds have a base-exchange capacity of about $18 \mathrm{meq} / 100 \mathrm{~g}$, as compared to 0.4 to $0.6 \mathrm{meq} / 100 \mathrm{~g}$ for the overlying, cleaner material. Initial considerations with respect to site selection include the cost consideration. Cost considerations must include both the disposal as well as the required monitoring costs since the halflives for many of the important waste radionuclides are long enough to require relative containment for centuries. The least expensive site is thus one that is cheapest and easiest to monitor. Advantageous hydrogeologic parameters for liquid waste disposal include large porosity, relatively large aquifer thickness, and large distance from hydrologic boundaries such as streams. Barriers to fluid movement such as faults or igneous intrusions are not necessarily as deleterious as linear features with high permeability such as gravel lenses, solution cavities, or joints. Homogeneity and high cation exchange capacity in the substrate are also favorable.

SUBJECT CATEGORY: Isolation; HLW

ORIGIN: Commercial

KEYWORDS: SORPTION; AQUIFERS; GROUND DISPOSAL; RADIOACTIVE WASTES; GEOLOGY; INTERMEDIATE-LEVEL RADIOACTIVE WASTES; LIQUID WASTES; ECONOMICS; RADIONUCLIDE MIGRATION; ION EXCHANGE; SHALES; SANDSTONES; COST BENEFIT ANALYSIS; RADIOACTIVE WASTE DISPOSAL; HYDROLOGY; RADIOACTIVE WASTE STORAGE

\section{9}

Granquist, D.P., and R.E. Tomlinson

ESTIMATED MAGNITUDE OF WASTE DISPOSAL PROBLEMS. TID-7517 (Part 1B); Sanitary Engineering Aspects of the Atomic Energy Industry, Proceedings of a Seminar, Cincinnati, Ohio, December 6-9, 1955, (pp. 400-405), 609 pp. (1956)
Disposal of fuel cycle radwastes are discussed. Also considered is magnitude of the problem and some criteria for problem evaluation. It is assumed that economics will require the irradiated fuel element be reprocessed for the recovery of fissile materials. For purposes of thi discussion, a unit block of power of 100 million kilowatts of heat energy, representing perhaps 10 to 20 million kilowatts of electrical energy is considered. Fission releases about 200 million electron volts of energy per atom fissioned. More than $99 \%$ of this energy is available as heat from the reactor on a continuing basis, while the rest is the decay energy as beta and gamma emissions. Assuming a constant rate of heat production at 100 million kilowatts and a fuel irradiation equivalent to 1 to 2 megawatts/kilogram of $U 235$ for 250 days, then this fission product decay would release heat at a rate of about 50 to 100 million Btu/hr. This heat will be dissipated from an aqueous solution in a tank, cast in concrete at the bottom of the ocean or fused into a glass in the middle of a desert. Assuming 100 million kilowatts of heat energy was produced by the irradiation of natural or slightly enriched uranium to about 2500 megawatt-days, 20,000 gallons of highly radioactive liquid waste would be produced per day. These wastes might be self-concentrated by a factor of three on a continuous operating basis. Selfconcentration would occur when the solution evaporated by the heat evolved from the fission product decay. The self-concentrated wastes would accunulate at about 2 million gallons/year and would be expected to boil for about 50 years. Storage of non-boiling wastes is in 500,000 to 1 million gallon tanks at about 20 to $25 \%$ gallon. Storage of boiling wastes costs about 40 to $50^{\prime} /$ gallon. The estimated costs of storing wastes from the reprocessing of fuel elements are 0.01 to $0.05 \mathrm{mils} / \mathrm{kilo}-$ watt-hr of electrical power produced. This cost amounts to less than $1 \%$ of the total cost of producing atomic power. At present, semipermanent storage in tanks is economically viable. An alternative method would be to extract Cs 137 and $\mathrm{Sr} 90$ and store the rest of the wastes in a soil with sufficient ion exchange capacity to retain them. Other methods under consideration are: calcination to a salt or oxide, preparation of a concrete or a glass and disposal in tanks or caverns, or burial in a desert or at sca. These all have drawbacks. The ideal solution would be to develop a market for these wastes.

SUBJECT CATEGORY: HLW; LLW; Spent Fuel

ORIGIN: Commercial

KEYWORDS: BETA PARTICLES; CALCINATION; CONCRETES; CONTAINMENT; COST 
BENEFIT ANALYSIS; EVAPORATION; FISSION PRODUCTS; FUEL CYCLE; REPROCESSING; GLASS; HAZARDS; HEAT SOURCES; ION EXCHANGE; PUREX PROCESS; RADIOACTIVE DECAY; RADIOACTIVE WASTE DISPOSAL; LIQUID WASTES; GAMMA RADIATION

10

Heatherton, R.C.

DISPOSAL OF FLUORIDE WASTES. TID7517 (Part 1A); Sanitary Engineering Aspects of the Atomic Energy Industry, Proceedings of a Seminar held in Cincinnati, Ohio, December 6-9, 1955, (pp. 275-285), 609 pp. (1956)

Generation, treatment, and disposal of fluoride wastes from uranium and thorium processing is discussed. Excess and process hydrofluoric acid and metal fluoride by-products are obtained from the processes. Hydrofluoric gas is condensed as either anhydrous or hydrous HF. The anhydrous $\mathrm{HF}$ is used in the UO2 to UF4 conversion and hydrous HF is sold. A KH scrub solution is used to clean HF from the off-gas and the KF solution is sold. Neutralized soluble fluorides are discharged with other treated waste liquors to the river. Insoluble fluorides are stored in the ground in a specially prepared pit on the site. Since the flow of the Miami River varies from 25,000 to $100 \mathrm{cfs}$ with an average of $1000 \mathrm{cfs}$ only additions that will add no more than $0.8 \mathrm{ppm}$ fluoride to the stream are permitted. Peak concentration of $1.5 \mathrm{ppm}$ are permitted if the average does not exceed $1.2 \mathrm{ppm}$. If the flow is $100 \mathrm{cfs}$, then 650 pounds of fluoride discharged in one day would raise the fluoride level above the maximum allowable concentration. In some months not more than 2,000 pounds could be discharged each day. The storrage pit has 500,000 cu ft capacity which holds the fluorides until the river can handle the load. In the first months of the year 15,000 pounds of $\mathrm{F} /$ month were discharged and contributed $0.1 \mathrm{ppm}$ to the river. Also, 90,000 gal of liquor/day was discharged. At no time did the amount of fluoride introduced raise the fluoride level above the maximum permissible concentration. The estimated cost of removal of HF from the condenser gas is $\$ 0.04$ pound of $\mathrm{HF}$ using lime scrub and $\$ 0.09$ /pound of $\mathrm{HF}$ using $\mathrm{KOH}$ scrub. Using the storage pit and the lime scrubber the cost is $\$ 0.05$ pound HF: In 2.5 years of operation there is no evidence of fluoride pickup in the groundwater.

SUBJECT CATEGORY: LLW

ORIGIN: Commercial
KEYWORDS: ACIDS; CALCIUM COMPOUNDS; CONTAMINATION; COST BENEFIT ANALYSIS; DOSE RATES; FLUORINE; GROUND WATER; MAXIMUM PERMISSIBLE CONCENTRATION; WASTE STORAGE; FLUORIDES

11

Hermann, E.R., and E.F. Gloyna

SUMMARY OF INVESTIGATIONS ON THE REMOVAL OF RADIOISOTOPES FROM WASTE WATER BY OXIDATION PONDS. TID-7517 (Part 1A); Sanitary Engineering Aspects of the Atomic Energy Industry, Proceedings of a Seminar held in Cincinnati, Ohio, December 6-9, 1955, (pp. 27-46), 609 pp. (1956)

Oxidation ponds were used in laboratory and pilotplant investigations to test the possibility of using these to concentrate certain radioactive isotopes and stabilize putrescible wastes. The value of using the oxidation ponds lies in the effects of biochemical processes, chemical precipitation and ion exchange in combination with relatively long detention periods. The radionuclides involved in the study were P 32, I 131, Cs 137, Sr 89, Sr 90, Ce 141, and an aged fission product. Biological activity and stable phosphorus controlled the amount of $\mathrm{P} 32$ removed. When the waste solution was free of silt and clay Cs 137 was readily removed. While the decontamination factor of $\mathrm{Sr} 89$ and $\mathrm{Sr} 90$ was 1.5, it is encouraging to note that the uptake is partly dependent on the biological population. For Ce 141 a decontamination factor of 20 is obtained and is dependent on the number of organisms and the rate of growth. The $\mathrm{pH}$ also affected the removal of $\mathrm{Ce}$ 141. A decontamination factor of 5 can be had in oxidation ponds for aged fission products when a dosing cycle is used on a period of once every 10 days. The primary advantage of using oxidation ponds as a storage and treatment device is to equalize the count in the effluent and also remove some radioisotopes. The most economical filter of the algae were the coarse grades of diatomaceous earth. Chemical coagulation was found to cost 3 cents $/ 1000$ gallons and the sludge concentrate still needing further filtration added 2 cents $/ 1000$ gallons to the cost. Tests were run to determine the operating criteria for the oxidation ponds: light, temperature, surface agitiation, depth, recirculation, and detention. Evaporation in hot, dry areas will increase the retention time of the wastes due to evaporation.

SUBJECT CATEGORY: LLW 
ORIGIN: Commercial

KEYWORDS: COST BENEFIT ANALYSIS; DECONTAMINATION; DIATOMACEOUS EARTH; AQUATIC ECOSYSTEMS; FILTRATION; FISSION PRODUCTS; ION EXCHANGE; MICROORGANISMS; OXYGEN; PH VALUE; PRECIPITATION; PONDS; EVAPORATION; RADIOACTIVE WASTE MANAGEMENT; UPTAKE; LIQUID WASTES; LOW-LEVEL RADIOACTIVE WASTES

\section{2}

SOLID RADIOACTIVE WASTE DISPOSAL AT THE NATIONAL REACTOR TESTING STATION. TID-7515(Part 1A); Sanitary Éngineering Aspects of the Atomic Energy Industry, Proceedings of a Seminar, Cincinnati, $\mathrm{OH}$, December 69, 1955, (pp. 250-263), 609 pp. (1956)

A number of factors are considered when providing facilities for solid radioactive waste disposal at the National Reactor Testing Station. In selecting a site the following are considered: 1) area not less than 10 acres; 2) accessibility; 3) not less than 15 and preferably 20 feet of unconsolidated sedimentary overburden on the bedrock; 4) appreciable amounts of clay in the burial sediment; 5) overburden sufficient to withstand vertical cuts; and 6) not directly up the ground water stream from existing or potential plant sites, or nearby populated areas. On July 8,1952 , a site meeting these criteria was fenced, posted and trenched. The soil is a sand gravel deposit exceeding 12 feet over a lava reef formation with the water table at a depth in excess of 300 feet in a lava-cinder formation. Slit burial trenches were dug and are about 1000 feet long, 11 feet deep, and about 5 feet wide. The bulk of the solid waste is low level, but some does have 2 to $150 \mathrm{R} / \mathrm{hr}$ at container suirfáce. Wastes with less than $2 \mathrm{R} / \mathrm{hr}$ are put in cardboard boxes, polyethylene bags, or large items into a dump truck. For those materials exceeding 2 $\mathrm{R} / \mathrm{hr}$ the light materials (200 to $300 \mathrm{lbs}$ ) are put into a burial cart and the larger, heavier are transported by means of charging coffins. Estimated unit cost of disposal is $\$ 9.11 /$ cu yd.

SUBJECT CATEGORY: LLW; Isolation

ORIGIN: Commercial

KEYWORDS: CONTAINERS; COST BENEFIT ANALYSIS; GEOLOGY; HAZARDS; HYDROL OGY; LINERS; OVERBURDEN; PACKAGING; RADIOACTIVE WASTE DISPOSAL; RADIOACTIVE WASTE MANAGEMENT; LOW-LEVEL
RADIOACTIVE WASTES; SOLID WASTES; COST; GROUND DISPOSAL; SITE SELECTION.

\section{7}

13

Culler, Floyd L. Jr.; Oak Ridge National Laboratory, Oak Ridge, TN; Argonne National Laboratory, Lemont, Ill.

STATUS REPORT ON THE DISPOSAL OF RADIOACTIVE WASTE. CF-57-3-114(Rev.); 232 pp. (1957)

Comprehensive survey of waste disposal techniques; from TID-3343, 1973

A comprehensive survey of waste disposal techniques, roquirements, costs, hazards, and longrange considerations is presented. The nature of high level wastes from reactors and chemical processes, in the form of fission product gases, waste solutions, solid wastes, and particulate solids in gas phase, is described. Growth predictions for nuclear reactor capacity and the associated fission product and transplutonic waste problem are made and discussed on the basis of present knowledge. Biological hazards from accumulated wastes and potential hazards from reactor accidents, ore and feed material processing, chemical reprocessing plants, and handling of fissionable and fertile material after irradiation and decontamination are surveyed. The waste transportation problem is considered from the standpoints of magnitude of the problem, present regulations, costs, and cooling periods. The possibilities for ultimate waste management and/or disposal are reviewed and discussed. The costs of disposal, evaporation, storage tanks, and drum-drying are considered.

SUBJECT CATEGORY: HLW; Isolation; Transportation

ORIGIN: Commercial

KEYWORDS: RADIOACTIVE WASTE DISPOSAL; ECONOMICS; RADIOACTIVE EFFLUENTS; REPROCESSING; LIQUID WASTES; SOLID WASTES; TRANSURANIUM ELEMENTS; PLUTONIUM; RADIOACTIVE AEROSOLS; RADIOACTIVE WASTE STORAGE; ORNL; ANL; HIGH-LEVEL RADIOACTIVE WASTES; FORECASTING; RADIOACTIVE WASTE MANAGEMENT; COST; RADIOACTIVE WASTE PROCESSING 


\section{8}

14

Summers, D.L., M.C. Gaske, and J.L. Dick; Kirtland Air Force Base, NM

MAXIMUM PERMISSIBLE ACTIVITY (MPA) OF FISSION PRODUCTS IN AIR AND WATER VERSUS THE AGE OF THE PRODUCTS. AFSWC-TN-58-30; 19 pp. (1958)

\section{2 figures, 4 tables, 7 references}

When mixed fission products are present in air and water, the maximum permissible activity (MPA) is dependent on the relative activity of the individual isotopes. This, in turn, is dependent on the age of the products. The MPA can be determined most accurately from measurements of the isotopic concentrations- however, the separation of mixed fission products into their constituent activities is extremely complicated and costly: In order to provide a simple method of evaluating the internal radiation hazard, the MPAs for ideal mixtures of fission products versus their ages were calculated and plotted. The resulting curves show that the MPAs change appreciably with time.

SUBJECT CATEGORY: Airborne

ORIGIN: Commercial; Defense

KEYWORDS: AIR; DRINKING WATER; FISSION PRODUCTS; MAXIMUM PERMISSIBLE LEVEL; TIME DEPENDENCE

15

Witkowski, E.J.; Oak Ridge National Laboratory, Oak Ridge, TN

RADIOACTIVE WASTE DISPOSAL AND DECONTAMINATION, ANNUAL REPORT FOR 1957. ORNL-CF-57-12-143; 11 pp. (1958)

Material possibly pertinent to preburial waste processing are presented. Nice diagrams of the waste treatment systems at Oak Ridge are included.

The main waste disposal facilities at Oak Ridge National Laboratory which are under the jurisdiction of the Operations Division, serve the laboratories and operating building located in the Bethel Valley area. This report covers the operation of these facilities in 1957, which include the hotchemical and the metal waste systems, the process waste system (frequently called the "semihot waste system") and the radioactive gas disposal system, which utilizes the $250 \mathrm{ft}$. stack located in the Radioisotope Area. The total 1957 operating cost, charged to research programs through monthly cost allocations, was $\$ 177,600$ with $\$ 116,600$, or $66 \%$, representing basic costs (labor and material). A total of 189 curies of activity was discharged into White Oak Creek in 1957, representing the lowest discharge since 1951 and a decrease of $31 \%$ under that of the previous year. The volume of waste was increased from. $260,710,000$ gal. in 1956 to $272,910,000 \mathrm{gal}$. in 1957 and was due entirely to an increase in large scale chemical processing. Construction of the Process Waste Treatment Plant, begun in August 1956, was completed and operation was started on August 8, 1957. The installation of automatic diversion equipment and the treatment of process wastes with materials other than lime and soda is expected to increase the efficiency of the plant and to further reduce the amount of activity released to the Creek. The disposal of all hot wastes to waste pits 2, 3, and 4 continued throughout 1957. There was no indication of a significant loss of pit seepage capacity or breakthrough of activity into White Oak creek. The neutralization of acid wastes (as they are collected in the stainless steel monitoring tanks) and the continuous agitation of wastes in W-5 were begun in January, 1957. The expression of the cell ventallation and off-gas facilities at the 3039 Stack Area is nearly complete. Preliminary engineering design is in progress for increasing the present off-gas capacity by $4000 \mathrm{ctm}$ to meet an anticipated increase in demand as a result of expanding Laboratory Programs.

SUBJECT CATEGORY: LLW

ORIGIN: Defense

KEYWORDS: COST BENEFIT ANALYSIS; RADIOACTIVE EFFLUENTS; RADIOACTIVE WASTE DISPOSAL; DECONTAMINATION; COST; INVENTORIES; GROUND WATER; OFFGAS SYSTEMS

16

Burns, R.H., and E. Glueckauf

DEVELOPMENT OF A SELF-CONTAINED SCHEME FOR LOW-ACTIVITY WASTES. A/CONF.15/P-308; Peaceful Uses of Atomic Energy, Proceedings of the 2nd United Nations International Conference held in Geneva, Switzer- 
land, September 1-13, 1958, Vol. 18, (pp. 150160). (1958)

The problem of storing large quantities of low-level wastes is considered. Ideally the two final components should be pure water and solid radwaste. However, to get pure water, evaporation must be used and this is a very expensive process. So, a multi-staged precipitation process is discussed. Prior to precipitation, filtration is used. It was found by earlier experiments that the higher the $\mathrm{pH}$ the greater efficiency of removal of alpha and betaemitters (alpha: $98.5 \%, 89.0 \%$; beta: $75 \%, 70 \%$ for $\mathrm{pH}$ : 9.4 and 8.0 , respectively). However, the $\mathrm{pH}$ was restricted to 9.5 or less so the waste could be discharged into rivers and the total dissolved solids would not be unacceptable. 'l'he best precipitator was found to be a calcium-iron-phosphate process in the sludge-blanket filters. The water to be treated is run through the sludge-blanket clarifiers and the sludge is removed at the bottom of the tank and frozen to better consolidate it. The mechanisms for this construction are electrolytes which cause coagulation. The sludge filters and settles well after the treatment. After flocculation, the water is run through an ion exchange process to remove the remaining $\mathrm{Cs}+1$ and $\mathrm{S}+2$. The decontamination factor using vermiculite is $5 \times 10(\mathrm{E}+3)$ to $10(\mathrm{E}+4)$ and the exchange capacity is $0.55-0.75 \mathrm{eq} / \mathrm{kg}$. Electrolytic de-ionization and fixation of activity in solid form also included in the discussion. The cost for using a precipitation and controlled disposal scheme is 123.25 Pounds Sterling/ 100,000 gallons of effluent. For precipitation and vermiculite columns is 117 and precipitation and electro-deionization is 144.1.

\section{SUBJECT CATEGORY: LLW}

ORIGIN: Foreign

KEYWORDS: CALCINATION; EVAPORATION; PRECIPITATION; RADIOACTIVE WASTE PROCESSING; LOW-LEVEL RADIOACTIVE WASTES; DECONTAMINATION; RADIOAC. TIVE WASTE DISPOSAL

17

Watson, C.D., A.J. Hoiberg, and G.A. West

ASPHALT LINING OF RADIOCHEMICAL WASTE STORAGE BASINS. Industrial and Engineering Chemistry 50(8):87A-91A. (1958)

One method of storing long-lived high-level radioactive wastes is to put them in an asphalt lined storage basin. Since such asphalts have softening points, it will be necessary to first neutralize and decay the wastes so the heating temperature does not exceed 150 degree $F$. When the temperatures are low, the membranes remain flexible and have high durability, especially when relieving internal stresses without failure. The asphalt will require more than 25 years to acquire a dose of $10(\mathrm{E}+9) \mathrm{r}$. It is noted that gamma irradiation of asphalts causes: evolution of hydrogen and carbon dioxide, resulting in 14 to $30 \%$ volume increase in honeycomb structure; increase in softening point, slight increase in inductility, and decrease in penetration; decrease in flash point, but no increase in "loss on heating" or solubility in carbon tetrachloride; and increase in asphaltenes and resins and decrease in oils. Cost of constructing a 1 million gallon basin would be $\$ 0.03 /$ gal, when a roof is required the cost would be $\$ 0.07 / \mathrm{gal}$. A 5 million gallon basin would cost $\$ 0.02 /$ gal. and with a roof $\$ 0.05 / \mathrm{gal}$. In 1956 an asphalt lined basin of 300 million gallons was constructed without a roof for about $1.5 \mathrm{mils} / \mathrm{gallon}$. It appears the use of either plant-type or membrane-type asphalt lined storage basins may be practical.

SUBJECT CATEGORY: HLW

ORIGIN: Defense; Commercial

KEYWORDS: ASPHALTS; COST BENEFIT ANALYSIS; DOSE RATES; HEAT TRANSFER; RADIOACTIVE WASTE STORAGE; HIGHLEVEL RADIOACTIVE WASTES; LIQUID WASTES; TRANSURANIUM ELEMENTS

\section{9}

\section{8}

Reisenauer, A.E.; Hanford Atomic Products Operation, Richland, WA

A PROCEDURE FOR ESTIMATING CAPACITY OF A GROUND DISPOSAL FACILITY FOR RADIOACTIVE WASTE. HW-57897; 16 pp. (1959)

3 figures, 3 tables, 11 references

Intermediate-level radioactive waste from chemical processing plants at Hanford are sent to the ground through a series of cribs. To estimate the maximum disposable volume of aqueous waste that may be discharged to a crib a series of laboratory tests that were designed to approximate field-disposal conditions were carried out. A graphical method for interpreting the results was evolved. 
SUBJECT CATEGORY: HLW

\author{
ORIGIN: Defense
}

KEYWORDS: CESIUM; NIOBIUM; RUTHENIUM; RADIONUCLIDE MIGRATION; STRONTIUM; ZIRCONIUM; FISSION PRODUCTS; LIQUID WASTES; UNDERGROUND DISPOSAL; RADIOACTIVE WASTE DISPOSAL; RADIOACTIVE WASTE MANAGEMENT; VOLUME

19

Browder, F.N. (Ed.); Oak Ridge National Laboratory, Oak Ridge, TN

\section{RADIOACTIVE WASTE MANAGEMENT AT OAK RIDGE NATIONAL LABORATORY. ORNL-2601; 57 pp. (1959)}

This report was previously issued as ORNL-cf-59-197.

The collection, treatment, disposal, and monitoring of radioactive wastes (solid, liquid, and gaseous) at Oak Ridge National Laboratory are described in detail. Mlustrations of facilities, maps, and tables of data on waste volumes and radionuclides discharged to the environment are included. The philosophy and history of waste management are discussed. The report constitutes an evaluation of waste management at $\mathrm{ORNL}$, concluding that the low degree of radioactive contamination of the air and water by ORNL does not represent a hazard to the local environment or population. At present a 7000-gallon/day liquid waste stream containing between 0.001 and $0.02 \mathrm{Ci} / \mathrm{gal}$ is produced. This waste is put through a series of tanks and finally stored in concrete storage tanks. Liquid uranium is produced at a rate of $100 \mathrm{gal} / \mathrm{wk}$ and is stored underground until there is a sufficient quantity to run the uranium recovery facility. Process waste water, produced at a rate of $700,000 \mathrm{gal} /$ day is sampled and ultimately discharged to the creek, with 172 to $498 \mathrm{Ci} / \mathrm{yr}$ of gross beta activity. Process water is treated as necessary. Low activity waste from the Low Intensity Test Reactor, Oak Ridge Research Reactor, Homogeneous Reactor Test, Aircraft Reactor Test, Tower Sheild Facility, ORNL Laundry, ORNI, Rolling Mill, and ORNL Gas Disposal Stock Fallout are held in retention ponds and finally released to nearby creeks. Gaseous wastes are filtered. Solid wastes from ORNL and other institutions such as Argonne National Laboratory, Knolls Atomic Power Laboratory, Mound Laboratories, Battelle Memorial Institute and
General Electric Company are buried in pits and trenches in the Conasauga Shale formation. Also included are surveys on the effectiveness of methods used. (Auth)

\section{SUBJECT CATEGORY: LLW}

ORIGIN: Defense; Commercial

KEYWORDS: SHALES; RADIOACTIVE WASTE DISPOSAL; RADIOACTIVE WASTE MANAGEMENT; RADIOACTIVE WASTE PROCESSING; RADIOACTIVE WASTE STORAGE; VOLUME; ORNL; GASEOUS WASTES; LIQUID WASTES; SOLID WASTES; GROUND DISPOSAL; URANIUM

\section{0}

Hoy, R.B., E.M. Kinderman, and R.R. Tarrice; Stanford Research Institute, Menlo Park, CA

AN ANALYSIS OF LAND DISPOSAL OF PACKAGED RADIOACTIVE WASTE IN SEVEN WESTERN STATES. SRIA-8-CFSTI; 120 pp. (1959)

A preliminary study was made of possible areas in western U.S., which might be used for future land burial of solid or packaged low-level radioactive wastes. The volume and nature of wastes generated in the seven western states were investigated. Fourteen areas in the states were selected as the best areas for further studies for disposal of packaged wastes. The costs of land disposal were also analyzed and compared with those for sea disposal.

SUBJECT CATEGORY: LLW

ORIGIN: Commercial

KEYWORDS: RADIOACTIVE WASTE DISPOSAL; MARINE DISPOSAL; ECONOMICS; GROUND DISPOSAL; SOLID WASTES; WASTE TRANSPORTATION

\section{1}

George, W.J., and L.R. Bacon; Wyandotte Chemicals Corporation, Wyandotte, MI

APPLICATION OF PRESENT WORTH TO WASTE-DISPOSAL ECONOMICS. Nucleonics 17(11):173-180. (1959)

5 Tables 
Using the present-worth concepts, which introduce the time value of money into cost calculations, it is apparent that either a combination tank-salt-cavity system or a cavity system alone leads to a lower cost for radioactive liquid-waste storage than tank storage alone.

\section{SUBJECT CATEGORY: HLW}

ORIGIN: Commercial

KEYWORDS: ECONOMICS; LIQUID WASTES; RADIOACTIVE WASTE MANAGEMENT; FISSION PRODUCTS; CONTAINERS; SALT DEPOSITS; RADIOACTIVE WASTE STORAGE; TANKS; UNDERGROUND DISPOSAL

22

Krawczynski, S.

VAPORIZATION AS A METHOD FOR THE DECONTAMINATION OF RADIOACTIVE WASTES. PART II. ORNL-tr-1030; 6 pp.; Kernechnik 1(2):60-66. (1959)

In German; 10 Figures, 20 References

In Part I a thin layer of steam from the evaporation of solidly enriched radioactive waste water was described. In Part II the following shall be discussed further, in practice previous to the inactivation of radioactive waste water. Applied types of evaporation as well as methods of management of the cost economy of the energy is treated.

SUBJECT CATEGORY: LLW

ORIGIN: Commercial

KEYWORDS: RADIOACTIVE WASTE DISPOSAL; LIQUID WASTES; RADIOACTIVE WASTE MANAGEMENT; EVAPORATION; EQUIP. MENT; DECONTAMINATION

\section{0}

23

Edison Electric Institute, New York, NY

RADIOACTIVE WASTE HANDLING IN THE NUCLEAR POWER INDUSTRY (A REPORT OF THE TECHNICAL APPRAISAL TASK FORCE ON NUCLEAR POWER TO THE BOARD OF DIRECTORS OF THE EDISON ELECTRIC INSTITUTE). EEI Publication No. $60-46$; 89 pp. (1960)
This report deals primarily with waste disposal (gas, liquid, solid) from power reactors. It presents projected schemes for various early reactors and economics of specific disposal schemes.

\section{SUBJECT CATEGORY: General}

ORIGIN: Commercial

KEYWORDS: BWR TYPE REACTORS; DRESDEN-1 REACTOR; ENRICO FERMI REACTOR; GRAPHITE MODERATED REACTORS; HNPF REACTOR; INDIAN POINT-1 REACTOR; SHIPPINGPORT REACTOR; RADIOACTIVE WASTE DISPOSAL; YANKEE ROWE REACTOR; POWER REACTORS; RADIOACTIVE WASTE MANAGEMENT; PWR TYPE REACTORS

24 Struxness, E.G., K.E. Cowser, W.:De Lagurn, D.G. Jacobs, R.J. Morton, and T. Tamura; Oak Ridge National Laboratory, Oak Ridge, TN

WASTE DISPOSAL RESEARCH AND DEVELOPMENT IN THE UNITED STATES OF AMERICA. Disposal of Radioactive Wastes, Proceedings of a Conference, Monaco, November 16-21, 1959, (pp. 481-498). (1960)

Treatment and disposal of low- and high-level liquid wastes are reviewed. At Oak Ridge low-level wastes are run through a plant which is specifically designed to reduce the concentration of radwastes to acceptable standards for disposal in the Clinch River. The water goe's to a flash mixer to be mixed with lime-soda and clay dosages. After mixing, the wastes are put into a coagulation basin, and finally a settling basin. The plant is capable of handling $350 \mathrm{gal} / \mathrm{min}$ with a detention time of over $2 \mathrm{hr}$. The sludge that is formed is then trucked to a disposal pit in the Conasauga formation. Efficiency of the process when Grundite (illite) is used is $86 \%$ and the cost per $1,000 \mathrm{gal}$ is 18 cents. More studies on improving the efficiency are underway. It was suggested that disposal pits would provide better decontamination if buried soil columns or lined plts were used. The layers would consist of vermiculite, rock phosphate, and graded gravel. This would permit a high exchange capacity for strontium and cesium and mechanical stability (sufficient flow rate with plugging). At Oak Ridge the soil column design would perhaps replace the pit system, now in use, for disposal of intermediate-level wastes. The cost is anticipated to be low. Geochemical studies are on going with respect to behavior of radionuclides in soil columns above the water table and in contact with the water table. Thermodynamics of 
ion sorption and sorption mechanisms are also briefly discussed. At present the best method for disosal of high-level wastes is to convert them to solids and then to store them in a salt mine. A number of methods exist for conversion to solid waste. At the Idaho Chemical Processing Plant aluminium nitrate waste is converted to solid oxide in a fluidized-bed calciner. Brookhaven National Laboratory fixes the waste on clay by heating in a kiln to 1700 degree F. Another process, now under study, is the evaporation of waste to a pumpable sludge to be sent into a pot calciner. Hanford Atomic Products Operations is evaluating the calcination of both Purex low-acid and neutralized Purex wastes. The Argonne National Laboratory is also conducting feasibility studies on the fluidized-bed calcination of Purex low-acid wastes. The ultimate disposal of high-level wastes in rock salt, mines in massive unfractured horizontal limestone beds, mines in granite or shale, deep well disposal, and disposal by fracturing the formation are discussed.

SUBJECT CATEGORY: HLW; LLW

ORIGIN: Commercial; Defense

KEYWORDS: BEDROCK; CALCINATION; CLAYS; CONTAINMENT; CONTAMINATION; COST BENEFIT ANALYSIS; DECONTAMINATION; EVAPORATION; FISSION PRODUCTS; FRACTURES; GEOLOGIC STRATA; GROUND WATER; REVIEWS; SALT DEPOSITS; SHALES; SOILS; RADIOACTIVE .WASTE DISPOSAL; RADIOACTIVE WASTE STORAGE; HIGHLEVEL RADIOACTIVE WASTES; INTERMEDIATE-LEVEL RADIOACTIVE WASTES; LIQUID WASTES; LOW-LEVEL RADIOACTIVE WASTES; INJECTION WELLS

25

Watkins, J.W., F.E. Armstrong, and R.J. Heemstra

FEASIBILITY OF RADIOACTIVE WASTE DISPOSAL IN SHALLOW SEDIMENTARY FORMATION. Nuclear Science and Engineering 7:133-143. (1960)

The feasibility of using shallow sedimentary formations is examined. As a working model for liquid radwaste disposal oil-field brines disposal is discussed. Brines have been disposed of by injecting them into subsurface formations. Some wells have been known to take 12,000 to 14,000 barrels daily at well-head pressures up to 100 psig. Brines, like radwastes, are toxic substances and the problems of injectivity, potential plugging, corrosion, and interformation communication are the same. Brine disposal costs between 0.014 to 0.033 cents/gallon of brine while radwaste disposal costs 0.20 to 8.20 cents/gallon of waste. So the cost is less and would probably be less with any special precautions. Shallow formations appear to be most suitable because the cost is $\$ 1.00$ to $\$ 2.25 / \mathrm{ft}$ whereas in deep formations it is about $\$ 51 / \mathrm{ft}$. The best shallow formations would be lenticular sandstones in the midcontinent oil-producing areas. In order to use these sandstones research must be done on ionexchange, adsorption, chemical and physical reactions, corrosivity, injectivity, determination of potential heat gradients generated, and instruments and techniques adaptable to monitoring disposal sites. A pilot plant study is also outlined. Transportation of the radwastes is another important consideration. Disposal of radwastes in shallow formations appears to be promising

SUBJECT CATEGORY: LLW; Isolation

ORIGIN: Defense; Commercial

KEYWORDS: ADSORPTION; AQUIFERS; BEDROCK; CONTAINMENT; COST BENEFIT ANALYSIS; GEOLOGIC STRATA; GEOLOGIC STRUCTURES; GROUND WATER; ION EXCHANGE; LITHOLOGY; MINERALS; OVERBURDEN; POROSITY; SANDSTONES; RADIOACTIVE WASTE DISPOSAL; INTERMEDIATE-LEVEL RADIOACTIVE WASTES; LIQUID WASTES; LOW-LEVEL RADIOACTIVE WASTES; HIGH-LEVEL RADIOACTIVE WASTES; INJECTION WELLS; BRINES; OIL FIELDS 


\section{THIS PAGE}

\section{WAS INTENTIONALLY \\ LEFT BLANK}




\section{1}

26

Argonne National Laboratory, Argonne, IL

WASTE DISPOSAL, SECTION IV. Reactor Fuel Processing 4(4):57-68. (1961)

46 references

Six committees of the National Academy of Sciences have prepared new summary reports bringing the findings of the committees up to date. As of 1.960, radioactive waste operations had not resulted in any significant effect on the public, its environment, or its natural resources. The cost of radioactive waste disposal does not appear to be a limiting factor in the development of nuclear power. Waste treatment and disposal methods being used and developed are reviewed including: waste packaging; low-level-activity liquid waste treatment by ion exchange; high-level-activity waste treatment and storage; reduction to solids by calcination, adsorption, conversion to glasses, and incorporation in ceramic sponges; ground disposal; disposal into salt; deep-well injection; and separation of specific isotopes.

SUBJECT CATEGORY: HLW; LLW; Isolation .

ORIGIN: Defense; Commercial

KEYWORDS: MARINE DISPOSAL; GROUND DISPOSAL; UNDERGROUND DISPOSAL; CAL CINATION; LIQUID WASTES; FISSION PRODUCTS; SEPARATION PROCESSES; INJECTION WELLS

27

Blomeke, J.O.; Oak Ridge National Laboratory, Oak Ridge, TN

SOME RECENT CONCEPTS IN NUCLEAR WASTE DISPOSAL. Nuclear Safety 2(3):50. 52. (1961)

Recent roncepts in nuclear waste disposal are discussed. Reduction of costs of waste disposal through use of fission products as a heat source is not economically feasible. Disposal of low-activity solid wastes presents a problem because of their quantity and diversity. In England, a volume reduction of solid waste of about 10 is attained by baling paper, glassware, and thin-walled metal tubing-a factor of about 80 is obtained by incineration of combustibles and melting of scrap metal in vacuo. New seepage pits at ORNL will employ copper compounds in an attempt to reduce movement of ruthenium.

\section{SUBJECT CATEGORY: LLW}

ORIGIN: Commercial

KEYWORDS: RADIOACTIVE WASTE DISPOSAL; RADIOACTIVE WASTE PROCESSING; RADIOACTIVE WASTE STORAGE; RUTHENIUM; COPPER COMPOUNDS; VOLUME

\section{8}

Bradshaw, R.L., J.J. Perona, J.T. Roberts, and J.O. Blomeke; Oak Ridge National Laboratory, Oak Ridge, TN

EVALUATION OF ULTIMATE DISPOSAL METHODS FOR LIQUID AND SOLID RADIOACTIVE WASTES. PART 1. INTERIM LIQUID STORAGE. ORNL-3128; 31 pp. (1961)

8 tables

Costs of interim liquid storage of acid and alkaline purex and thorex wastes were estimated for storage times of 0.5 to 30 years. A 6-ton/day plant was assumed, processing 1500 tonnes/year of uranium converter fuel at a burnup of $10,000 \mathrm{mwd} /$ tonne and 270 tonnes/year of thorium converter fuel at a burnup of 20,000 mwd/tonne. Tanks of Savannah river design were assumed, with stainless steel construction for acid wastes and mild steel construction for neutralized wastes. The operating cycle of each tank was assumed to consist of equal fllling and emptying periods plus a full period. Tank costs were minimum when full time was 40 to 70 percent of the interim storage time. Costs ranged from 0.0022 to $0.0095 \mathrm{mill} / \mathrm{kwh}$-electric for acid wastes and from 0.0017 to $0.0051 \mathrm{mill} / \mathrm{kwh}$-electric for neutralized wastes.

\section{SUBJECT CATEGORY: HLW}

ÖR̄IGIN: Commercial

KEYWORDS: RADIOACTIVE WASTE STORAGE; RADIOACTIVE WASTE DISPOSAL; ECONOMICS; RADIOACTIVE WASTE MANAGEMENT; COST; SPENT FUELS 
29

Cowser, K.E., T.F. Lomenick, and W.M. McMaster; Oak Ridge National Laboratory, Oak Ridge, TN

STATUS REPORT ON EVALUATION OF SOLID WASTE DISPOSAL AT ORNL.. ORNL 3035; 38 pp. (1961)

Solid waste is disposed of by burial at Oak Ridge National Laboratory (ORNL). New burial sites must meet the requirement of being useful for 4 to 5 years as well as meeting the geologic and hydrologic criteria. A field survey was done in Melton Valley to determine which of four sites was the best suited. Area A was the selected area and it is 20 to 25 acres on gently to moderately sloping land within the White Oak Lake drainage basin. The rock types at the site are shale, siltstone, and limestone. The siltstones become somewhat spongy and friable when the calcium carbonate is leached from the rock. Siltstone layers have well developed joints that usually open near the surface. Ground water circulation in the well-jointed layers is probably greater than in the layers which do not have the joints. These rocks are part of the Conasauga shale which is a structually incompetent unit between two competent units. The important zone of flow is the weathered zone. Water fluxuation ranges from 1.5 to 14 feet. The water table generally follows the surface topography. Ground water flows along the strike of the formation. Chemical analysis of the water showed a high calcium content. By analyzing solid waste burial records (beginning in 1957) the volumes of waste were estimated. For alpha contaminated waste the volume will be $1.1 \times 10(\mathrm{E}+6)$ and the beta-gamma waste, $9 \times 10(\mathrm{E}+5) \mathrm{cu} \mathrm{ft}$. Using $15 \mathrm{ft}$ as the maximum depth of trenches $21 \times 10(\mathrm{E}+6)$ cu $\mathrm{ft}$ are available. An area providing $1.4 \times 10(\mathrm{E}+6)$ will be ample for the alpha waste burial through 1964. In the same area $2.2 \times 10(\mathbf{E}+6)$ is available for beta-gamma waste. High-level wastes will be place in another site of 1.3 acres. A new trench design is recommended. 'The bottom should be covered with 6 in. of gravel, and sloped to an asphalt-lined sump. The sump meets a 6 in. perforated casing. Any liquid entering the trench would drain through the gravel and in to the sump where samples could be analyzed. Once the trench is filled it will be backfilled with shale and capped with asphalt. The total cost for such a trench is $\$ 1,000$. The trench was about $70 \mathrm{ft}$ long, $10 \mathrm{ft}$ wide, and $12 \mathrm{ft}$ deep containing a volume of $8,300 \mathrm{cu} \mathrm{ft}$. The cost was increased only by $\$ 0.02 / \mathrm{cu} \mathrm{ft}$ for the sump well, gravel underdrain, and asphalt cover. Cost of individual drum placement in the trench was $\$ 0.07 / \mathrm{cu} \mathrm{ft}$. A larger trench would afford cheaper monitoring costs. Additional studies on the vegetation prior to waste burial are planned for the area.
SUBJECT CATEGORY: Isolation

ORIGIN: Defense

KEYWORDS: ASPHALTS; RADIOACTIVE WASTE DISPOSAL; COST; ECONOMICS; RADI. OACTIVE WASTE MANAGEMENT; LIMESTONE; SHALES; HIGH-LEVEL RADIOACTIVE WASTES; INTERMEDIATE-LEVEL RADIOACTIVE WASTES; LOW-LEVEL RADIOACTIVE WASTES; SOLID WASTES

30

Perona, I.J., R.L. Bradshaw, J.T. Roberta, and J.O. Blomeke; Oak Ridge National Laboratory, Oak Ridge, TN

EVALUATION OF IITIMATE DISPOSAL METHODS FOR LIQUID AND SOLID RADIOACTIVE WASTES. PART II. CONVERSION OF SOLID BY POT CALCINATION. ORNL 3192 ; 46 pp. (1961)

13 figures, 14 tables, and 12 references

The costs of pot calcination of purex and thorex wastes were calculated. The wastes were assumed produced by a plant processing 1500 tonnes/year of uranium converter fuel at a burnup of 10,000 $\mathrm{mwd} /$ tonne and 270 tonnes/year of thorium converter fuel at $20,000 \mathrm{mwd} /$ tonne. Costs were calculated for processing purex waste in acidic and reacidified forms and for proccssing thorex wastes in acidic and reacidified forms and with constituents added for producing an acidic thorex glass. Costs were calculated for processing in 6-, 12-, and 24-in.-dia vessels with a fixed length of $10 \mathrm{ft}$. Costs were calculated for wastes decayed 120 days and $1,3,10$, and 30 years after reartor discharge prior to calcination. Aging had negligible effect on costs. The lowest cost was $0.87 \times 10.2 \mathrm{mill} / \mathrm{kwhe}$ for processing acidic purex and thorex wastes in 24-in.dia vessels, and the highest was $5.0 \times 10-2$ mill/kwhe for processing reacidified purex and thorex wastes in 6 -in.-dia vessels.

SUBJECT CATEGORY: HLW; Isolation

ORIGIN: Commercial

KEYWORDS: RADIOACTIVE WASTE STOR. AGE; CALCINATION; RADIOACTIVE WASTE DISPOSAL; ECONOMICS; RADIOACTIVE WASTE MANAGEMENT; COST; SOLID WASTES; LIQUID WASTES; URANIUM 
31

Linderoth, C.E., and D.W. Pearce

OPERATING PRACTICES AND EXPERIENCES AT HANFORD. Ground Disposal of Radioactive Wastes, W.J. Kaufman (Ed.), Proceedings of a Conference, Berkeley, CA, August 25-27, 1959. University of California, Berkeley, CA, (pp. 716), 168 pp. (1961)

Diagrams indicating the spread of the radionuclides are included.

Some of the operating practices and experiences at. Hanford are presented. Waste solutions are disposed of to the ground in naturally-occurring depressions, known as swamps. The largest volume of waste water comes from the cooling water streams and to mid 1959 a total of 139 million liters containing about 2,500 curies have been discharged to the swamps. Trenches are used at Hanford for wastes with a high salt or complexed radioisotope content. Before such waste is placed in the trenches it is put in underground storage tanks. The depleted uranium is recovered and $\mathrm{Sr} 90$ and $\mathrm{Cs} 137$ are scavenged and returned to the tanks as sludge. The solution placed in the trenches contains Co 60 and at the time of the report 106 million liters of waste containing $647,000 \mathrm{Ci}$ of fission products had been discharged. Process condensate wastes containing $1 \times 10(\mathrm{E}-1)$ to $1 \times 10(\mathrm{E}-3)$ uc beta emitters/cc are disposed of in sub-surface cribs. These wastes are allowed to percolate through the soils to be held by ion exchange. A total of 72 cribs have received 14.9 billion liters with 1.9 million $\mathrm{Ci}$ of fission products. It is estimated that $75 \%$ of the "gross beta-emitters" discharged have decayed to non-radioactive nuclides. Process engineering has reduced the amount of radwaste discharged each month from 18,000 to $180 \mathrm{Ci}$ without changing the waste volume discharged. A well study at one of the cribs indicated that Cs 137 was retained in the suils inmediately below the crib, Sr 90 was contained on the upper soils, and $\mathrm{Ru}$ was widely spread over the area. At present no demonstrable hazards have been created by the disposal of wastes to the ground at Hanford.

SUBJECT CATEGORY: LLW; HLW

ORIGIN: Defense

KEYWORDS: BETA PARTICLES; CONCENTRATION; CONTAINMENT; CONTAMINATION; GROUND DISPOSAL; ENVIRONMENT; FIELD TESTS; FISSION PRODUCTS; ION EXCHANGE; MONITORING; RADIONUCLIDE MIGRATION; SLUDGES; SOILS; RADIOACTIVE WASTE DISPOSAL; RADIOACTIVE WASTE
MANAGEMENT; LIQUID WASTES; INTERMEDIATE-LEVEL RADIOACTIVE WASTES; VOLUME; CESIUM 137; STRONTIUM 90; URA. NIUM

32

Ophel, I.L.

WASTE DISPOSAL OPERATIONS AT THE CHALK RIVER PROJECT OF ATOMIC ENERGY OF CANADA LIMITED. Ground Disposal of Radioactive Wastes, W.J. Kaufman (Ed.), Proceedings of a Conference, Berkeley, CA, August 25-27, 1959. University of California, Berkeley, CA, (pp. 40-46), 168 pp. (1961)

An overview of waste disposal operations at Chalk River is presented. Solid waste is handled in the usual manner. For liquid wastes there are several different pits used. Laundry and decontaminated waste are placed in a small open pit and only a few thousand gallons have been introduced. About 300,000 gallons/month of mildly acidic wastes have been pumped into the chemical waste pit for the past three years. After 20 months of operation the water level was stable at $8 \mathrm{ft}$. However, construction of a second pit disrupted the soil and the water level has not been as high since. Surface seepage from the pit was detected in a swamp $200 \mathrm{ft}$ away after 8 months of operations. The main nuclides were $\mathrm{Ru} 106$ and $\mathrm{Rh} 106$. Reactor pit 2 receives waste from the fuel storage bays at a rate of $3 \times 10(E+6)$ gallons/month. After 7 months of use radionuclides were detected in a swamp. The seepage contained S 35 and Ru $106 \mathrm{~A}$ sampling system; including dry monitoring boreholes, sampling boreholes, and soil samples, aids monitoring the movement of ground water.

SUBJECT CATEGORY: LLW

ORIGIN: Foreign

KEYWORDS: CONTAINMENT; RADIONUCLIDE MIGRATION; RUTHENIUM; RHODIUM; RADIOACTIVE WASTE DISPOSAL; RADIOACTIVE WASTE MANAGEMENT; VOLUME; LIQUID WASTES; LOW-LEVEL RADIOACTIVE WASTES; MONITORING; GROUND DISPOSAL

33

Peckham, A.E.

UNDERGROUND WASTE DISPOSAL STUDIES, CHEMICAL PROCESSING 
PLANT AREA. Ground Disposal of Radioactive Wastes, W.J. Kaufman (Ed.), Proceedings of a Conference, Berkeley, CA, August 25-27, 1959. University of California, Berkeley, CA, (pp. 157. 166), 168 pp. (1961)

Information collected during a series of well monitoring tests is presented. The Chemical Processing Plant (CPP) at the National Reactor Testing Station discharges 27 million gallons of liquid waste/month through a disposal well. The disposal well is about 600 feet deep, which is about 150 feet below the regional water table. The area is underlain by the Snake River basalt, which is overlain by sands and gravels up to 50 feet thick. These deposits are intermittent perched-stream sands and gravels and exhibit cross-bedding. Along with the sands and gravels are volcanic pillow lavas, cinders, or clinkers. As a result of the complex stratigraphy perched water beds exist. The water moves along the honzontal intertlow zones and cinder beds with a hydraulic gradient of 3 to 5 feet per mile. For the Snake River basalt the transmissivity and storage coefficient are $3.3 \times 10(\mathrm{E}+6) \cdot \mathrm{gal} / \mathrm{day} / \mathrm{ft}$ and 0.6 , respectively. From several series of test wells saline water has spread in all directions from the disposal well. Ruthenium 106 was detected recirculating from the disposal well through the production wells and passing through the basalt aquifer. At a distance of 700 feet from the disposal well the saline water occurs over an area at least 1,200 feet wide. The pumping of water from production wells and disposal of water has created mounds and depressions in the water table. Furthermore, band or bands of saline water at one or more horizons are moving southeast and southwest. The saline water is being diluted. Whether this is a result of mixing or interfingering was not determined. A lag in time between change in plant discharge to the disposal well and changes in chloride concentrations indicate straight-line ground water movement rate of 15 to $50 \mathrm{ft} /$ day. More tests are anticipated to further define the aquifer characteristics.

\section{SUBJECT CATEGORY: LLW}

ORIGIN: Defense

KEYWORDS: AQUIFERS; BASALT; CONTAINMENT; CONTAMINATION; UNDERGROUND DISPOSAL; RADIOACTIVE EFFLUENTS; GEOLOGIC STRUCTURES; GROUND WATER; HYDRODYNAMICS; MONITORING; RADIONUCLIDE MIGRATION; SAND; RADIOACTIVE WASTE DISPOSAL; VOLUME; LIQUID WASTES; RUTHENIUM 106; INJECTION WELLS

\section{2}

\section{4}

Gemmell, L., and S.G. Pearsall; Brookhaven National Laboratory, Upton, NY

\section{TRANSPORT OF FISSION PRODUCTS THROUGH THE SOIL FOLLOWING INJEC- TION FROM A WELL AND METHODS USED FOR REMOVAL. BNL-6554-OTS; 18 pp. (1962)}

In the summer of 1960 one of the wells on the Brookhaven National Laboratory site became accidentally contaminated with radioactive aterial. Procedures used in tracking the spread of the contamination through the soil are described. Data are presented on the radioactivity in water from test wells and soil samples taken over a 2-year period. In 1961 approximately $227,000 \mathrm{gal}$ of water were pumped from the test wells, decontaminated by means of an ion exchange column, and returned to the environment. The cost of this decontamination was approximately $1.06 \mathrm{mills} / \mathrm{gal}$.

\section{SUBJECT CATEGORY: LLW}

ORIGIN: Defense

KEYWORDS: DECONTAMINATION; RADIOACTIVE EFFLUENTS; GEOLOGY; GROUND WATER; SOILS; RADIONUCLIDE MIGRATION; RADIOACTIVE WASTE DISPOSAL; LIQUID WASTES; GROUND DISPOSAL; WELLS; COST

35

Gordillo, J.L.; Comision Nacional de Energia Nuclear, Mexico

CONSIDERATIONG REGARDING TREATMENT OF THE WATER OF A CONVERTIBLE NUCLEAR REACTOR. Peaceful Application of Nuclear Energy, Proceedings of the 4th InterAmerican Symposium, Vol. 1, Mexico City, April 913, 1962. Inter-American Nuclear Energy Commission, (pp. 143-152). (1962)

\section{Tables, 4 Figures, 8 References}

This paper is divided into three parts, as follows: 1 . generalities on the treatment of water for reactors, 2 . treatment of water in the subcritical phase of the convertible reactor, and 3 . treatment of the water in the critical phase. A system of treatment is proposed 
for heavy water as well as for the cationic resin (deuteration), endeavoring to make use of the equipment installed during the subcritical phase so far as possible, for reasons of economy. Consideration is given to the most advisable type of resin among those available on the market, along with an estimate of costs.

\section{SUBJECT CATEGORY: LLW}

ORIGIN: Foreign

KEYWORDS: LIQUID WASTES; ACTIVATION PRODUCTS; ION EXCHANGE; MEXICO; RADIOACTIVE WASTE PROCESSING; HEAVY WATER; DEUTERATION; COST; RESINS

36

International Atomic Energy. Agency, Vienna, Austria

DISPOSAL OF RADIOACTIVE WASTES INTO MARINE AND FRESH WATERS. STI/PUB/21/5; 365 pp. (1962)

The bibliography contains approximately 2,000 references to reports and to published literature from more than twenty countries on source and nature of wastes, treatment, engineered storage, disposal, monitoring, legal aspects, and economics.

SUBJECT CATEGORY: General; Isolation

ORIGIN: Foreign

KEYWORDS: BIBLIOGRAPHIES; IAEA; RADIOACTIVE WASTE DISPOSAL; MARINE DISPOSAL; RADIOACTIVE WASTE STORAGE; LEGAL ASPECTS; ECONOMICS

37

Beard, S.J., and W.L. Godfrey; Isochem Inc., Richland, Washington

WASTE DISPOSAL INTO THE GROUND A'T HANFORD. CONF-670512-1; ISO-SA-31; Disposal of Radioactive Wastes into the Ground, Proceedings of a joint IAEA/ENEA Symposium, Vienna, Austria, May 29-June 2, 1967. International Atomic Energy Agency, (19 pp.), 666 pp. (1962)

Large volumes of liquid waste are economically disposed of via artificial swamps when activity levels are favorable. As the activity levels increase or the compatibility of waste with soil decreases, other disposal methods such as cribs or trenches are used, with a corresponding increase in disposal costs. Typical disposal costs are $\$ 1.40, \$ 700$, and $\$ 7400$ per million liters for swamp, crib; and trench disposal, respectively. Solid wastes are disposed on in several ways, depending on their size, weight, and activity level. Costs vary from $\$ 15$ to $\$ 3000$ per cubic meter, depending on the difficulty in performing the burial. In no case have solids burials affected the ground water.

SUBJECT CATEGORY: LLW

ORIGIN: Defense; Commercial

KEYWORDS: RADIOACTIVE WASTE DISPOSAL; ECONOMICS; COST; HANFORD RESERVATION; GROUND DISPOSAL

38

Taylor, R.D., D.J. Kvam, and F.S. Smith; Lawrence Livermore Laboratory, Livermore, CA

HYDRAULIC PRESS FOR LOW-LEVEL RADIOACTIVE SOLID WASTE. UCRL 7254; Hazards Control Quarterly Report No. 11, OctoberDecember 1962, (pp. 34-39). (1962)

\section{3 figures}

At the Lawrence Radiation Laboratory, low-level radioactive solid waste is packaged in 55-gallon drums for land-burial disposal. At present, waste is shipped to Idaho Falls. Contents of the drum are loosely packed, as evidenced by net shipping weights of 25 to 75 pounds. A considerable portion of such material is compressible. It is obvious that lower handling and shipping charges would result from volume reduction. The following report describes a press (now in use) designed for this purpose.

SUBJECT CATEGORY: LLW

ORIGIN: Defense

KEYWORDS: SOLID WASTES; RADIOACTIVE WASTE MANAGEMENT; COMPACTING; VOLUME; COST; LOW-LEVEL RADIOACTIVE WASTES 
39

Perona, J.J., R.L. Bradshaw, J.O. Blomeke, and J.T. Roberts; Oak Ridge National Laboratory, Oak Ridge, TN

EVALUATION OF ULTIMATE DISPOSAL METHODS FOR LIQUID AND SOLID RADIOACTIVE WASTES. IV, SHIPMENT OFCALCINED SOLIDS. ORNL-3356-CFSTI; 23 pp. (1962)

10 figures, 3 tables, and 12 references

The costs of shipping calcined purex and thorex wastes were calculated. Calculations were made for purex waste calcined in acidic and reacidified (after alkaline storage) forms and for thorex waste calcined in acidic and reacidified forms with constituents added for producing an acidic thorex glass. Shipping casks of iron, lead and uranium were considered at $\$ 0.25,0.75$ and $\$ 5.0 \dot{0} / \mathrm{lb}$. Cask weights ranged up to 100 tons. The cask design did not include liquid coolants or mechanical cooling equipment, andcouriers were assumed not required. Rail freight rates of $\$ 24, \$ 44$ and $\$ 65 /$ ton were assumed for distances of 500,1000 and 1500 miles with rates 30 percent less for the return of the empty casks. Total costs were lowest in all cases for lead casks.

SUBJECT CATEGORY: Transportation; HLW

ORIGIN: Commercial

KEYWORDS: CALCINATION; LIQUID WASTES; SOLID WASTES; FISSION PRODUCTS; WASTE TRANSPORTATION; ECON. OMICS; GLASS; RADIOCHEMICAL ANALYSIS CAEKE

\section{0}

Belter, W.G.; U.S. Atomic Energy Commission, Division of Reactor Development

RADIOACTIVE EFFLUENT CONTROL IN A FUTURE NUCLEAR ENERGY INDUSTRY. Peaceful Application of Nuclear Energy. Proceedings of 4th Inter-American Symposium, Mexico City, April 9-13, 1962, Vol. 1. Inter-American Nuclear Energy Commission, (pp. 97-114). (1962)

2 tables, 10 figures

This discussion is focused on future requirements for more efficient waste management systems and the development of methods that minimize release of radioactivity to our environment. Present radioactive waste handling practices and experience in the United States for different types of waste are summarized. The effectiveness of various treatment systems for large-volume, low-activity wastes from laboratory and reactor operations is analyzed. Tank storage of smaller-volume, high-activity waste is briefly discussed. New developments in ion exchange, synthetic mineral exchange materials, and hydrofracluring are discussed as polential future methods for control of low and intermediate level waste. The possibilities of recycling and/or reusing processed waste streams in laboratory or reactor systems is also discussed. The present status of calcination and/or fixation of high activity waste from chemical reprocessing of irradiated reactor fuel is briefly described. Brief reference is made to economic considerations involved in the handling and disposal of radioactive wastes.

SUBJECT CATEGORY: HLW; LLW

ORIGIN: Defense; Commercial .

KEYWORDS: RADIOACTIVE WASTE DISPOSAL; RADIOACTIVE WASTE MANAGEMENT; RADIOACTIVE WASTE PROCESSING; RADIOACTIVE WASTE STORAGE; ECONOMICS

\section{3}

\section{1}

Fernandez, N.; Commissiariat a l'Energie Atomique, France

THE WASTE PROCESSING PLANT. ITS PROBLEMS, OPERATION, AND RESULTS. AEC-TR=0104, 25 pp., Dnergie Nucleäiré 5, p̈. 202$150,(1968)$. (1963)

1 table

The necessity for waste processing in a $\mathrm{Pu}$ extraction plant and the difficulties encountered in the chemical process chosen are described. The equipment used in the plant was not specially designed but was commercially available. The process is described. The results obtained are satisfactory, with removal of the most dangerous radioisotopes and $19 / 20$ of the total radioactivity received at the plant. A modification being made to the process (reduction of the volume to be treated by recirculation and coating of the sludge with bitumen) are discussed. 
SUBJECT CATEGORY: HLW; TRU

ORIGIN: Foreign

KEYWORDS: CERIUM; CESIUM; RUTHENIUM; STRONTIUM; ZIRCONIUM; RADIOACTIVE WASTE PROCESSING; PLUTONIUM; VOLUME; SLUDGES

42

Skarpelos, J.M.; Hanford Atomic Products Operation, Richland, WA

PROGRESS IN TREATMENT OF A RADIOACTIVE CONDENSATE WASTE. HW-79174; 80 pp. (1963)

9 figures, 10 tables, 8 references

Progress is reported on the development of an ion exchange process for treating condensate. waste from Hanford purex tanks. Results and conclusions of 35 pilot plant experiments is presented. Improvement in ruthenium decontamination is needed. Other isotopes were satisfactorily decontaminated from 10,000 to 20,000 column volumes. A costestimate of $\$ 7,50 / 1000 \mathrm{gal}$ based on a $2 \mathrm{~T} /$ day fuel reprocessing plant producing $30,000 \mathrm{gal} /$ day of condensate was abour $\$ 10 / 1000 \mathrm{gal}$ less than the estimated cost for reevaporation.

SUBJECT CATEGORY: LLW

ORIGIN: Commercial

KEYWORDS: RADIOACTIVE WASTE DISPOSAL; RADIOACTIVE WASTE STORAGE; ION EXCHANGE; FUEL REPRCESSING PLANTS; GROUND DISPOSAL; RUTHENIUM; CONDENSATES; LIQUID WASTES; RADIOACTIVE WASTE PROCESSING; COST

43

Yoder, R.E., and L. Silverman; Harvard University, Boston, MA

FOAM CONTAINMENT AND COLLECTION OF IODINE-131 AND PARTICULATES. Colloque International Sur La Pollution Radioactive Des Milieux Gazeus, (Radioactive Pollution of Gaseous Media), Book II, Saclay, November 12-16, 1963, (pp. 337-345). (1963)

9 figures, 3 tables, 3 references
A reliable, efficient and economical method is needed to remove radioactive halogens such as iodine, bromine and particulates from air in many atomic energy installations. One method we have developed which is particularly suited to reactor containment vessels or other large confined areas is foam containment. In this method an ether lauryl sulfate foam containing an iodine reactant is generated, rapidly filling the entire containment volume. This provides a tremendous surface area to which the encapsulated particles can diffuse and be removed.

SUBJECT CATEGORY: Airborne

ORIGIN: Commercial; Defense

KEYWORDS: DIFFUSION; FOAMS; IODINE 131; FISSION PRODUCTS; GASES; HALOGENS; REACTORS

\section{4}

Sakata, S., M.E. Ito, and N. Mitsuishi; Japan Atomic Energy Research Inst., Tokyo, Japan

TEST OPERATION AND COST ESTIMATION ON THE RADIOACTIVE WASTE TREATMENT PLANT AT JAERI. NSJ-TR-10 (JAERI-1048)- JCL. (1963)

Performance data on test operations conducted through April 1960 and treatment cost estimates concerning the radioactive waste treatment plant at JAERI are given. Test operations were first conducted with nonradioactive materials and then with real radioactive wastes from JAERI. The flocculation and ion exchange unit, evaporation unit, and incineration unit were examined. The performance data showed that the facilities fulfilled their specifications and functions expected from the initial planning. Considering that the plant is the first of its kind in Japan, some peculiarities and operational troubles were also pointed out from the view point of radioactive waste treatment. Brief cost estimates on each facility have been carried out with two purposes as follows: (1) to find out the optimum natures of wastes for each treatment process and, consequently, to serve as a reference of the selection of a suitable treatment process for a specified waste; (2) to suggest practical ways for realization of more economical waste treatment. For the liquid treatment, it is shown that solid content is one of the most important indices in this system. Some reasonable combinations of various ion exchanges and evaporations were examined to clarify their optimum regions in connection with 
solid content. For the solid processing, incineration is more favorable than direct storage.

SUBJECT CATEGORY: LLW

ORIGIN: Foreign

KEYWORDS: LIQUID WASTES; SOLID WASTES; ECONOMICS; EVAPORATION; COMBUSTION; ION EXCHANGE; RADIOACTIVE WASTE PROCESSING

45

Blomeke, J.O., J.J. Perona, R.L. Bradshaw, and J.'I. Roberts; Oak Ridge National Laboratory, Oak Ridge, TN

ESTIMATED COSTS FOR MANAGEMENT OF HIGH-ACTIVITY POWER REACTOR PROCESSING WASTES. ORNL TM-559; American Nuclear Society, Ninth Annual Meeting, Salt Lake City, June 17-19, 1963, 23 pp. (1963)

6 tables, 8 figures

Ëconomic and safety evaluations of alternative methods for management of high-activity wastes from power reactor fuel processing provide a means for deriving the optimum combination of operations and can indicate the most promising methods to be developed for a competitive nuclear power economy. Although the cost of long-term storage of these wastes as liquids is acceptable, the safety as a permanent disposal method is considered inadequate. A scheme believed to be acceptably safe consists of interim storage as liquids in tanks, followed by pot calcination of the wastes to produce relatively small volumes of stable solids, interim storage of the pots, and, finally, shipment of the pots to salt mines for permanent disposal. Total costs are estimated to range from $2.6 \times 10$ (E-2) to $4.8 \times 10$ (E-2) 2 mills/KWHE and are believed to represent an acceptable contribution to the cost of nuclear power.

SUBJECT CATEGORY: HLW

ORIGIN: Commercial

KEYWORDS: COST; ECONOMICS; SAFETY; HIGH-LEVEL RADIOACTIVE WASTES; RADIOACTIVE WASTE MANAGEMENT; REPROCESSING; RADIOACTIVE WASTE PROCESSING; SALT DEPOSITS; RADIOACTIVE WASTE STORAGE; CALCINATION
46

Perona, J.J., J.O. Blomeke, R.L. Bradshaw, and J.T. Roberts; Oak Ridge National Laboratory, Oak Ridge, TN

EVALUATION OF ULTIMATE DISPOSAL METHODS FOR LIQUID AND SOLID RADIOACTIVE WASTES. V. EFFECTS OF FISSION PRODUCT REMOVAL ON COSTS OF WASTE MANAGEMENT. ORNL_3357-CFSTI; 32 pp. (1963)

11 references, 11 figures, 8 tables

In a study based on optimistic expectations of waste composition from future fission product separations processes, estimated costs for management of wastes from which yu and $y y \%$ of all fission products had been removed werc from 70 to $80 \%$ of those for management of waste from which no fission products had been removed. This cost difference is not believed to be sufficient to pay for the separation and final disposal of the fission products, which was not included in the waste management costs, hence, separation does not represent an economic route for waste management unless a substantial market for the fission products exists to pay most of the costs.

SUBJECT CATEGORY: HLW; LLW

ORIGIN: Commercial

KEYWORDS: RADIOACTIVE WASTE STORAGE; CALCINATION; COST; LIQUID WASTES; SOLID WASTES; FISSION PRODUCTS; SEPARATION PROCFSSES; RADIOACTIVE WASTE MANAGEMENT; COST; ECONOMICS; RADIOCHEMICAL ANALYSIS

47

Dykes, J.W.; Phillips Petroleum Company, Idaho

MTR PROGRESS REPORT CYCLE NO. 190 APRIL 15, 1963 - MAY 6, 1963. IDO-16897; 37 pp. (1963)

Data is given on the volume and curie quantities of liquid and gaseous effluents released daily from MTR in the period April 15 to May 6, 1963.

SUBJECT CATEGORY: Airborne; LLW

ORIGIN: Commercial 
KEYWORDS: RADIOACTIVE EFFLUENTS; MTR REACTOR; RADIOACTIVE WASTE DISPOSAL; LIQUID WASTES; RADIOACTIVE AEROSOLS

\section{4}

48

Aerojet-General Corp., Azusa, CA

RADIOACTIVE MATERIALS COMPLEX DESIGN DATA AND STUDIES. RN-S-0012; 35 pp. (1964)

Declassified September 7, 1973

See Nuclear Science Abstracts 1975, 32(07) 18940

SUBJECT CATEGORY: Spent Fuel; General

ORIGIN: Commercial

KEYWORDS: DECONTAMINATION; DESIGN; FEASIBILITY STUDIES; NERVA REACTOR; RADIOACTIVE MATERIALS; RADIOACTIVE WASTE DISPOSAL; RADIOACTIVE WASTE FACILITIES; RADIOACTIVE WASTE STORAGE; SPENT FUEL STORAGE

49

CEA Centre d'Etudes Nucleaires de Saclay, 91 - Gifsur-Yvette, France

SUMMARY LIST OF CEA REPORTS PUBLISHED BY THE COMMISSION OF ATOMIC ENERGY - FIRST SERIES- ORIGINAL REPORTS. CEA-BIB-1004 (Addendum 1); 11 pp. (1964)

Reports from CEA for the last half of 1964 are listed under these headings: biology and medicine; chemistry; space studies; geophysics, geology, mineralogy, and meteorology; metals, ceramics and other materials; neutron physics and reactor technology; physics; theoretical physics and mathematics; radiation protection and control (effluents); technique; and economics.

SUBJECT CATEGORY: General

ORIGIN: Foreign
KEYWORDS: SPACE; SAFETY; BIBLIOGRAPHIES; GEOLOGY; PERSONNEL MONITORING; RADIOACTIVE EFFLUENTS

50

Backman, G.E.; General Electric Co., Hanford Atomic Products Operation, Richland, W.A

DISCUSSION OF RADIOACTIVE WASTE MANAGEMENT PRACTICES. HW-SA-3575; CONF-708-1; Lecture on Radioactive Waste Management, June 6, 1964, Portland, OR, 18 pp. (1964)

The main consideration in radioactive waste management is to prevent undue radiation exposure as economically as possible. The two disposal concepts of concentration-containment and dilution-dispersion are discussed for gaseous, liquid, and solid wastes, respectively.

SUBJECT CATEGORY: Isolation; LLW; HLW

ORIGIN: Defense; Commercial

KEYWORDS: RADIOACTIVE WASTE MANAGEMENT; RADIOACTIVE WASTE PROCESSING; ECONOMICS; DISPERSIONS; RADIATION DOSES; CONTAINMENT; DILUTION

51

Beard, S.J., and H.L. Caudill; General Electric Co., Hanford Atomic Products Operation, Richland, WA

TECHNETIUM RECOVERY AND STORAGE AT B-PLANT. HW-83348. (1964)

Declassified May 1973, Available from NTIS, PC A02/MF A01.

Results are presented of an engineering study of the requirements for providing Tc recovery, concentration, and storage as an incremental addition to BPlant Phase III processing activities. Approximately $600 \mathrm{~kg}$ of Tc could be recovered from the Purex tank farm supernatants in place as of January, 1967 as an incremental effort to the planned 5 to 7 year Waste Management Program in B-Plant. Equipment suitable for recovering Tc from the stored supernates at rates matching the waste management $\mathrm{Cs}$ removal process could be installed in either 224-B or 221-B assuming cell space needs are compatible with a possible Po separations 
program in 224-B and the planned fission product purification program in 221-B. An additional $370 \mathrm{~kg}$ of Tc could be recovered from the Redox supernates and Purex sludge wastes in place at the start of waste management processing in January, 1967, but recovery costs would be higher because of the lower Tc concentrations in the waste. Approximately $100 \mathrm{~kg}$ per year of $\mathrm{T} c$ would be available from current waste starting in January, 1967 and assuming three reactors are shut down. This Tc would go through B-Plant unextracted to the neutralized self-boiling waste stream; subsequently the supernate from these wastes would be processed through the proposed $\mathrm{Tc}$ recovery facility before going to in-tank solidification. An ion exchange process developed by Hanford Laboratories would be used for recovery of the technetium. Demonstration of this process was completed in 1963 with a plant scale test that recovered a kg of crude Tc from 'IK-103A supernate. F'or either a 224-B or 221 -B facility the equipment would consist of an ion exchange column, a concentrator, and associated feed, waste, and aqueous makeup tanks. The 224-B installation includes the addition of ventilation equipment and some additional shielding. Low radiation levels permit use of contact maintenance techniques in 224-B while 221-B is assumed to be a standard remote-type installation.

SUBJECT CATEGORY: HLW; LLW

ORIGIN: Defense

KEYWORDS: FISSION PRODUCTS; ION EXCHANGE; RADIOACTIVE WASTE MANAGEMENT; RECOVERY; SPENT FUELS; STORAGE; TECHNETIUM; RADIOACTIVE WASTE STORAGE; HANFORD RESERVATION; PUREX PROCESS

52

Rohrmann, C.A.; General Electric Co., Hanford Atomic Products Operation, Richland, WA

THE FISSION PRODUCTS. HW-SA-3080(Rev.); CONF-635-1; AEC Atomic Industrial Forum, Washington, DC, May 1964; 17 pp. (1964)

Radioisotopes as potential heat sources are discussed briefly. Of the usable radioisotopes, four are fission products: $\mathrm{Ce}-144, \mathrm{C}_{8}-137, \mathrm{Pm}-147$, and $\mathrm{Sr}-90$. The separation of these fission products from wastes at Hanford is discussed, and the results of an engineering study of the economics of such separation in the future are summarized. The processes for carrying out the separation and purification are described. Separation of other isotopes from power reactor fuel reprocessing is also considered.

SUBJECT CATEGORY: Spent Fuel

ORIGIN: Commercial

KEYWORDS: CERIUM; CESIUM; STRONTIUM; FISSION PRODUCTS; SEPARATION PROCESSES; REPROCESSING; PROMETHIUM: RADIOISOTOPES

53

Bradshaw, R.L., D.G. Jacobs, J.J. Perona, J.O. Blomeke, and K.E. Cowser; Oak Ridge National Laboratory, Oak Ridge, TN

ENGINEERING, ECONOMIC, AND SAFETY EVALUATIONS. ORNL 3697; Health Physics Division Annual Progress Report for Period Ending July 31, 1964, (pp. 54-61). (1964)

Costs of storage of calcined radioactive wastes in concrete vaults were five to seven times greater and costs for storage in rooms mined out of granite formations were twice those for storage in salt mines. Estimates were made of the movement of Strontium-90, Ruthenium-106, and Cesium-137 in Conasauga shale following a hypothetical release of reactor fuel-reprocessing waste from a tank. Strontium-90 would move quite rapidly in an acid waste system- movement in an alkaline waste solution would be much slower. Ruthenium-106 would move rapidly in either acid or neutralized waste systems. Movement of Cesium-137 would be slow because of its strong fixation by Ilite.

SUBJECT CATEGORY: Isolation

ORIGIN: Commercial

KEYWORDS: CESIUM 137; RUTHENIUM 106; STRONTIUM 90; RADIOACTIVE WASTE DISPOSAL; RADIOACTIVE WASTE STORAGE; ECONOMICS; RADIONUCLIDE MIGRATION; CONCRETES; SHALES; GRANITES; SAFETY ENGINEERING; COST

54

Parker, F.L., and R.E. Blanco; Oak Ridge Nátional Laboratory, Oak Ridge, TN

WASTE TREATMENT AND DISPOSAL PROGRESS REPORT, MAY-OCTOBER 1963. ORNL-TM-757; 189 pp. (1964) 
53 figures, 36 tables, 56 references

Progress of the research and development program at ORNL on waste treatment and waste disposal is reported. Subjects presented include calcination; low-level waste treatment by scavengingprecipitation ion exchange process and by foam separation; engineering, economic, and safety evaluations of waste management practices; disposal by hydrofracturing; disposal into natural salt formations; Clinch River studies; mineral exchange; and movement of radionuclides in the White Oak Creek Basin.

SUBJECT CATEGORY: LLW

ORIGIN: Defense

KEYWORDS: GROUND WATER; RADIOACTIVE WASTE DISPOSAL; RADIOACTIVE WASTE STORAGE; RADIONUCLIDE MIGRATION; ORNL; CALCINATION; LOW-LEVEL RADIOACTIVE WASTES; SEPARATION PROCESSES; SALT DEPOSITS

55

R.A. Taft Sanitary Engineering Center

ULTIMATE DISPOSAL OF ADVANCEDTREATMENT WASTE. PART 1. INJECTION. PART 2. PLACEMENT IN UNDERGROUND CAVITIES. PART 3. SPREADING. PHS-PUB999-WP-10; AWTR-8; 146 pp. (1964)

\section{3 figures, 3 tables, 21 references}

Cost estimates are made for ultimate disposal of the contaminants resulting from complete renovation of a municinal waste water plant. The processes investigated are: injection to underground formations, placement in underground cavities, and spreading. For injection, capability was the strongest determinant of conditioning and injecting costs. Injection is very much cheaper than wet oxidation, but may be limited by availability of injection sites. Disposal of advanced-treatment wastes in salt cavities created for such use is inapplicable because the difficulty of disposing of the salt removed greater than that of disposing of the waste. Feasibility depends upon geographical distribution. Injection is preferable to placement in cavities where possible. Spreading is by far the cheapest disposal method. The costs are 1 percent or less of those for any other disposal method investigated, but spreading is severely limited in application because of potential ground water pollution.
SUBJECT CATEGORY: LLW

ORIGIN: Commercial

KEYWORDS: UNDERGROUND DISPOSAL; ECONOMICS; LIQUID WASTES; WASTE MANAGEMENT; SALT DEPOSITS; INJECTION WELLS; COST

56

Christl, R.J., and F.H. (Ed.) Springer; Savannah River Laboratory, Aiken, SC

STORAGE OF RADIOACTIVE WASTES IN BASEMENT ROCK BENEATH THE SAVANNAH RIVER PLANT. DP-844; 106 pp. (1964)

Appendices contain the detailed data. Thorough coverage of the subject is given.

The geology, geophysics, and hydrology were studied in detail for a storage facility of radwastes in the basement rock beneath the Savannah River Plant. Also included was the conceptual design of the storage facility. The geologic formations are tabulated with their age, exposure, description, water content, and thickness. A hornblende gneiss, chlorite-hornblende schist with quartzite and saprolite characterize the basement rock series. The foliation and schistocity are parallel and dip at 55 degrees. The average compressive strength ranges from 9,000 to 16,000 psi and the modulus of elacticity. ranges from $9.0 \times 10(E+6)$ to $12 \times 10(E+6)$ on the average. The coefficient of thermal expansion, specific heat, thermal diffusivity, and thermal conductivity were also determined for the engineering design. Using both acidic and alkaline solutions it was found that only a few inches of rock would dissolve from the chamber walls. Extensive piezometer surveys were done to determine the water flow and water characteristics. Water from the basement rock was found to have a $6 \%$ helium content and it was calculated that 540,000 to 900,000 yrs were required for the helium to form. Hence, the water naturally present in the rock has different chemical properties which readily distinguishes it from water in overlying aquifers and indicates the rock water is not directly connected with the water above. Essentially there are two hydrologic systems shallow and deep, and the two have minimal if any contact. The permeability in the sound rock is 0.002 $\mathrm{gpd} / \mathrm{sq} \mathrm{ft}$ and the porosity is $0.01 \%$. A saprolite clay layer separates the two hydrologic systems and allows the head in the rock to be independent of that of the sediments above. Migration of liquid radwastes through the rock with no consideration of 
sorption would take 30,000 years to a point beneath the Savannah River. In the fractured rock migration would take 600 years to move 1,800 to $8,800 \mathrm{ft}$ without sorption. The design of the facility is 20 million gal at 1300 to 1700 feet and the cost would be $\$ 0.625$ per gallon of stored wastes.

SUBJECT CATEGORY: Isolation

ORIGIN: Defense; Commercial

KEYWORDS: AQUIFERS; RADIOACTIVE WASTE DISPOSAL; GEOLOGY; RADIONUCLIDE MIGRATION; RADIOACTIVE WASTE STORAGE; LIQUID WASTES; UNDERGROUND DISPOSAL; WATERTABLE; WELLS; ENVIRONMENTAL TRANSPORT; COST

57

Harper, J.A., and L. Jolly; Savannah River Laboratory, Aiken, SC

A METHOD FOR DISPOSAL OF LARGE QUANTITIES OF DEGRADED AND LOWLEVEL CONTAMINATED SOLVENT. DPSPU-64-30-8B; CONF-642-31; Annual Meeting of the Health Physics Society in Cincinnati, June 1964: 12 pp. (1964)

For publication in Health Physics

Solvent used in radiochemical separations processes is degraded during exposure to radiation and retains certain fission waste disposal problems of considerable magnitude. Of several disposal methods considered, controlled open-pan burning was selected as the safest and most economical. An extensive air-sampling program showed that more than 99 percent of all the solvent radioactivity, primarily fission products and plutonium, remained in a gummy residue. During two years, 80,000 gallons of solvent was burned which contained about 8 curies of gamma-emitting isotopes and about 60 millicuries of alpha-emitters. No adverse effect on the environment due to the burning operations was detected.

SUBJECT CATEGORY: LLW; TRU

ORIGIN: Defense

KEYWORDS: RADIOACTIVE WASTE DISPOSAL; COMBUSTION; SOLVENTS; PLUTO. NIUM; ALPHA-BEARING WASTES; GAMMA SOURCES; VOLUME
58

Prinz, W.H., and H. Huebner; Tieraerztliche Hochschule, Hanover

STRONTIUM DISTRIBUTION IN GOATS MILK AND MILK DECONTAMINATION. REPORT 2. Arch. Lebensmittelhyg 15:6266. (1964)

In German

After peroral administration of Sr-89 to goats, 20\% or less was found in milk of lactating goats, of which 75 to $80 \%$ was bound to the casein fraction, while 4 to $5 \%$ was in the fat fraction. After in vivo incorporation, $\mathrm{Sr}-89$ is bound more firmly by casein than is $\mathrm{Ca}$. It is not definitely established that $\mathrm{Sr}-89$ is quantitatively released from rasein hy shifting the $\mathrm{pH}$ of milk to 5.2 or 5.4. With large volumes of milk it is difficult to shift the $\mathrm{pH}$ to these values because the beta and gamma casein tend to be precipitated. These two forms of cascin make up more than $30 \%$ of the total casein. Ruminants have the capability of decreasing the $\mathrm{Sr}-89 / \mathrm{Ca}$ ratio in milk as compared to this ratio in feed. This ratio can be improved further by doubling the $\mathrm{Ca}$ concentration of the feed. The costs of decontamination of milk by means of ion exchange procedures might increase the price of milk 20 to $30 \%$.

SUBJECT CATEGORY: LLW

ORIGIN: Foreign

KEYWORDS: STRONTIUM; MILK; GERMANY; ION EXCHANGE; FOOD; ENVIRONMENTAL F.XPOSURF PATHWAY

59

Yamamoto, Y., T. Miyauchi, D. Kunii, and R. Kiyose; Tokyo University, Tokyo, Japan

CHEMICAL ENGINEERING STUDIES ON THE PROCESSING OF RADIOACTIVE LIQUID WASTES BY EVAPORATION. PROGRESS RFPORT JANUARY 1-JUNE 30, 1964. NP-15367; 24 pp. (1964)

The operational characteristics of fluidized-bed spray evaporation for processing radioactive liquid wastes were investigated. Although the principal idea of the process is almost the same as the doubleeffect evaporator, by using the spray evaporator for final evaporation and solidification, it becomes possible to get the product directly from the evaporator as solid particles and thus to minimize the cost of disposal of radioactive liquid wastes. 
SUBJECT CATEGORY: LLW

ORIGIN: Foreign

KEYWORDS: LIQUID WASTES; EVAPORATION; JAPAN; FLUIDIZED BED; ECONOMICS; RADIOACTIVE WASTE PROCESSING; SOLIDIFICATION

60

Belter, W.G.; U.S. Atomic Energy Commission

ADVANCES IN RADIOACTIVE WASTE MANAGEMENT TECHNOLOGY-ITS EFFECT ON THE FUTURE U.S. NUCLEAR POWER INDUSTRY. 28/P/868; Peaceful Uses of Atomic Energy, Proceedings of the United Nations Third International Conference, Geneva, August 31.September 9, 1964, 18 pp. (1964)

A discussion is presented on the advances in treatment and disposal of low- and high-level wastes, and their probable effects on the future nuclear power industry. Ion exchange and foam separation techniques are being applied to low-level wastes on an engineering pilot plant scale. The disposal of intermediate-level wastes into shale by hydraulic fracturing is being investigated. Calcination and fixation of high-level wastes are discussed. The feasibility of storing high-level wastes in salt mines and bedrock caverns is being studied. Engineering evaluation studies relative to the nuclear power economy in the future, indicate waste treatment and ultimate storage costs of approximately $0.03 \mathrm{mill} / \mathrm{kwh}$, less than $1 \%$ of the cost of nuclear power in a $4 \mathrm{mill} / \mathrm{kwh}$ economy.

SUBJECT CATEGORY: Isolation; HLW; LLW

ORIGIN: Defense

KEYWORDS: RADIOACTIVE WASTE MANAGEMENT; RADIOACTIVE WASTE DISPOSAL; RADIOACTIVE WASTE PROCESSING; COST; ECONOMICS; NUCLEAR POWER

61

Belter, W.G.; U.S. Atomic Energy Commission

U.S. OPERATIONAL EXPERIENCE IN RADIOACTIVE WASTE MANAGEMENT. 18/P/869; Peaceful Uses of Atomic Energy, Proceedings of the United Nations Third International Conference, Geneva, August 31-September 9, 1964, 16 pp. (1964)
Highlights of U.S. Waste Management experience in the past six years are summarized. The experiences include those of research laboratories, nuclear production facilities, and nuclear power plants. Among the methods of waste disposal discussed are tank storage, land burial, and sea disposal. The costs of radioactive waste management are described.

SUBJECT CATEGORY: Isolation; HLW; LLW

ORIGIN: Defense; Commercial

KEYWORDS: RADIOACTIVE WASTE DISPOSAL; ECONOMICS; RADIOACTIVE WASTE MANAGEMENT; COST; RADIOACTIVE WASTE STORAGE; MARINE DISPOSAL; UNDERGROUND DISPOSAL

\section{2}

Loysen, P.; U.S. Atomic Energy Commission, Health and Safety Laboratory, New York, NY

ECONOMICS OF BUILDING DECONTAMINATION. Surface Contamination, Proceedings of a Symposium in Gatlinburg, Tenn., June 1964, Pergamon Press, New York, (pp 361-671.). (1964)

2 tables

Describes the problems involved in decontaminating and/or dismantling contaminated buildings. The buildings had been used for processing, fabrication, research, dial painting, and warehousing operations involving uranium, thorium, plutonium, beryllium, and radium. Costs varied from $\$ 0.11$ per sq. $\mathrm{ft}$. to $\$ 2.54$ per sq. $\mathrm{ft}$.

SUBJECT CATEGORY: Remedial Action, FUSRAP; TRU

ORIGIN: Commercial

KEYWORDS: BERYLLIUM; ECONOMICS; PLUTONIUM; SURFACE GONTAMINATION; THORIUM; URANIUM; RADIUM; CONTAMINATION; DECONTAMINATION; BUILDINGS; COST

63

Pepper, D.; United Kingdom Atomic Energy Authority, Harwell, England

ION REMOVAL AND ITS APPLICATION TO RADIOACTIVE EFFLUENT TREATMENT. British Chemical Engineering 9(8):510-516. (1964) 
41 references, 8 figures, and 1 table

Techniques are surveyed for removal of ions from solution in regard to the degree of decontamination, volume reduction, and costs. Chemical treatment, ion exchange, dialysis, electrodialysis (or electrodeionization), reverse osmosis, foam separation, and ion flotation are discussed in regard to their application as methods for decontamination of radioactive effluents or for desalination of brackish waters.

\section{SUBJECT CATEGORY: LLW}

ORIGIN: Foreign

KEYWORDS: RADIOACTIVE EFFLUENTS; SEPARATION PROCESSES; VOLUME

64

Straub, C.P.

HANDLING AND TREATMENT OF SOLID WASTES. Low-Level Radioactive Wastes, Their Handling, Treatment, and Disposal, C.P. Straub, Chapter 14. U.S. Atomic Energy Commission, Washington, D.C., (pp. 313-328), 430 pp. (1964)

Brief discussion of solid waste sources, processing, and disposal.

Techniques used in handling and disposing of solid low-level radioactive wastes are described. Methods of collecting, packaging, monitoring, and transporting of untreated wastes are discussed, along with subsequent treatment of compressible or combustible waste by baling or incineration. Final disposal by land burial or ocean disposal is also described. Operational experience gained at specific sites and facilities is included in the discussions, and some cost data is given.

\section{SUBJECT CATEGORY: LLW}

ORIGIN: Commercial; Defense

KEYWORDS: SOLID WASTES; VOLUME; LOWLEVEL RADIOACTIVE WASTES; SAMPLING; GROUND DISPOSAL; MARINE DISPOSAL; CONTAINERS; PACKAGING; WASTE TRANSPORTATION; COMBUSTION; COST BENEFIT ANALYSIS

\section{5}

65

Aerojet-General Corp., Azusa, CA

CALIFORNIA WASTE MANAGEMENT STUDY. A REPORT TO THE STATE OF CALIFORNIA, DEPARTMENT OF HEALTH. AGC-3056; 500 pp. (1965)

Figures, tables, 39 references

The waste-handling methods presently used are discussed in considerable detail. Waste subsystems are evaluated which are based, in large measure, on state-uf-the-urt equipment. The results of tis study indicate that in this particular area, no major problem is anticipated in the waste system that cannot be adequately handled using present approaches. This assumes that regional considerations and requirements do not intrude severely on this area. However, more advanced equipment, combined with a fully integrated approach, might significantly reduce the system costs and increase system benefits. It is also recognized that the wastemanagement problem will increase many fold in the future years.

SUBJECT CATEGORY: Airborne; General

ORIGIN: Commercial

KEYWORDS: GASEOUS WASTES; INGESTION; ALPHA PARTICLES; MARINE DISPOSAL; RADIOACTIVE WASTE STORAGE; ECONOMICS; BETA PARTICLES; WASTE TRANSPORTATION; COSMIC RADIATION; NEUTRONS; WATER POLLUTION; CONCENTRATION; AQUATIC ORGANISMS; MAN; CALIFORNIA

66

Rastogi, R.C., J.D. Schgal, and K.T. Thomas; Atnmic. Fnergy Fstablishment, Trombay, Bombay, India

INVESTIGATION OF MATERLALS AND METHODS FOR FIXATION OF LOW AND MEDIUM LEVEL RADIOACTIVE WASTE IN STABLE SOLID MEDIA-PROGRESS REPORT, FEBRUARY 1, 1965- OCTOBER 31, 1965. TID-22531; 48 pp. (1965) 
In continuation of the first progress report, this report describes the results of the fusion studies on the incinerator ashes obtained from pilot incinerator and synthetic chemical treatment plant sludge obtained as secondary wastes in the treatment of radioactive liquid effluents. The leaching characteristic of the fused mass and volume reduction obtainable were studied. A method for evaluating loss on volatilization during firing, using stable cesium salt and application of flame photometry for the estimation of volatilized cesium is described. Results of volatilization loss of cesium during firing are presented. Details of pilot furnace under fabrication, proposed to be used for preparing 20-50 $\mathrm{kg}$ batches of glass using above type of inactive wastes, and suggestions for future work are presented.

SUBJECT CATEGORY: LLW; HLW

ORIGIN: Foreign

KEYWORDS: DOSE RATES; RADIOACTIVE WASTE DISPOSAL; INCINERATORS; COMBUSTION; INDIA; SOLID WASTES; LIQUID WASTES; RADIOACTIVE EFFLUENTS; VOLUME; SLUDGES; SOLIDIFICATION

67

Rastogi, R.C., J.D. Sehgal, and K.T. Thomas; Atomic Energy Establishment, Trombay, Bombay, India

INVESTIGATION OF MATERIALS AND METHODS FOR FIXATION OF LOW AND MEDIUM LEVEL RADIOACTIVE WASTE IN STABLE SOLID MEDIA - PROGRESS REPORT AUGUST 1, 1964 - JANUARY 31, 1965. TID-21882-CFSTI; 34 pp. (1965)

This report describes a proposal for fixation of spent vermiculite, incinerator ashes and chemical sludges in vitreous matrices. Results on the fusion studies of the mineral vermiculite, the leaching characteristics of the fused mass and the volume reduction ratios are given. The apparatus for studying volatilization loss is described. Suggestions for further work are presented.

SUBJECT CATEGORY: LLW; HLW

ORIGIN: Foreign

KEYWORDS: FISSION PRODUCTS; SLUDGES; VOLUME; SOLIDIFICATION; LIQUID WASTES; DESORPTION; GLASS
68

McQuade, D.W.; Atomic Energy of Canada Ltd., Chalk River, Ontario, Canada

CRNL ACTIVE WASTE INCINERATOR. AECL-2248; 39 pp. (1965)

20 figures, 2 references

At CRNL the daily collection of 1200 pounds of active combustible waste is burned in a refractory lined multichamber incinerator. Capacity is 500-550 pounds per hour-volume reduction $96 \%$. Combustion gases are cooled by air dilution an decontaminated by filtration through glass bags in a baghouse dust collector. This report includes a description of the incinerator plant, its operation, construction and operating costs, and recommendations for future designs.

\section{SUBJECT CATEGORY: LLW}

ORIGIN: Foreign

KEYWORDS: CANADA; RADIOACTIVE WASTE PROCESSING; SOLID WASTES; COMBUSTION; INCINERATORS

69

Coleman, L.F., and J.R. Eliason; Battelle Pacific Northwest Laboratory, Richland, WA

RUTHENIUM REMOVAL FROM INTERMEDIATE-LEVEL RADIOACTIVE WASTES BY ELECTRODIALYSIS METHODS. BNWL-72CFSTI; 27 pp. (1965)

References included

Electrodialysis was demonstrated to be capable of removing ruthenium from nitric acid wastes- the economics are not considered favorable. Electrodeionization through packed resin beds (a special application of electrodialysis) was shown to be a feasible and economical method for removing ruthenium from acid and alkaline process condensates containing on the order of $500 \mathrm{ppm}$ dissolved solids. Laboratory results show that 95 percent of the ruthenium can be removed from acidic and alkaline condensates at up to fiftyfold volume reductions.

SUBJECT CATEGORY: HLW

ORIGIN: Defense 
KEYWORDS: RUTHENIUM; LIQUID WASTES; ECONOMICS; RADIOACTIVE WASTE PROCESSING; VOLUME; INTERMEDIATE-LEVEL RADIOACTIVE WASTES; ELECTRODIALYSIS

70

Suchoza, B.P.; Bettis Atomic Power Laboratory, West Mifflin, PA

SHIPPINGPORT ATOMIC POWER STATION DISPOSITION OF RADIOACTIVE WASTE FROM UNDERGROUND STORAGE TANKS. WAPD-T-1851; CONF-651 101-52; Remote Systems Technology, Proceedings of the 13th Conference Washington, DC, November, 1965, 31 nn. (1.965)

12 figures, 3 tablos, referenoes

The design of a station for economically removing and disposing of radioactive wastes from the Shippingport Atomic Power Station is described. The design includes the capability of temporarily storing some $3100 \mathrm{cu}$. $\mathrm{ft}$ of wastes in two underground storage tanks. The waste is basically spent demineralizer resing with some incinerator ash resulting from plant operations. The design applies primarily to the removal of solid demineralizer resin. Any removal of incinerator ash is a consequence of the basic operation.

\section{SUBJECT CATEGORY: LLW}

ORIGIN: Commercial

KEYWORDS: SHIPPINGPORT REACTOR; WASTE TRANSPORTATION; RADIOACTIVE WASTE STORAGE; RADIOACTIVE WASTE DISPOSAL; LIQUID WASTES; SOLID WASTES; RESINS

\section{1}

Cerre, P., E. Mestre, S. Barral, and P. Lebrun; Centre d'Btudes Nucleaires de Saclay

NEW DEVICE FOR PROCESSING SOLID WASTE AT THE SACLAY NUCLEAR RESEARCH CENTER. Bulletin D Informations Scientifiques et Techniques 99:73-82. (1965)

The services that produce radioactive waste nearly always use drums for its storage and transportation to the processing installation. The large number of drums containing metals, screenings, and materials contaminated by fission products coming mainly from the dismantling of the Fontenay-AuxRoses Plutonium Plant led us to develop a press capable of compressing the drum and its contents. The article describes this installation which makes it possible to obtain a large reduction factor and to reduce considerably the cost of processing solid waste.

SUBJECT CATEGORY: LLW; Remedial Action, Surplus Facilities

ORIGIN: Foreign

KEYWORDS: RADIOACTIVE WASTE PROCESSING; SOLID WASTES; ECONOMICS; RADIOACTIVE WASTES; WASTE TRANSPORTATION

72

Stolzenbach, C.F.; Consolidated Edison Co., New York, NY

CURRENT PRACTICES IN THE DISPOSAL OF WASTE RADIOACTIVE GASES FROM NUCLEAR REACTORS. Nuclear Safety 6(4):436-440. (1965)

53 references

Nuoloar reactor waste, the report reviewed here, is one of three summaries completed under American Standards Assoctation (ABA) sponsurship. The work was co-ordinated by the ASA Nuclear Standards Board and was largely carried out by committees representing various phases of the nuclear industry. This review article is a condensation of the original document (review of current practices in disposal of waste radioactive gases from reactors, prepared by ASA aubcommittee N5.8, publizhed by American Institutc of Chemical Engineers, Novem. ber 1964), which reviews in detail the disposal of radioactive gases, including the sources of waste, means of disposal, limitations of disposal, and current practices. The first of the three summaries, which concerned radioactive-waste-disposal practices of uranium mines and mills, was reviewed in the previous issue of Nuclear Safety (Volume 6, No. 3 , pages 280-283). The membership of the group involved in preparation of the original documents was given in that review.

SUBJECT CATEGORY: Airborne 
ORIGIN: Commercial

KEYWORDS: BWR TYPE REACTORS; DILUTION; PWR TYPE REACTORS; RADIOACTIVE WASTE STORAGE; POWER REACTORS; RADIOACTIVE WASTE DISPOSAL; GASEOUS WASTES

73

Ramdohr, H.; Gesellschaft Fuer Kernforschung mbH, Karlsruhe, Germany, F.R.

SITING INVESTIGATIONS FOR A PROTOTYPE CAVITY FOR RADIOACTIVE WASTE STORAGE. BMWF-FBK-65-06; 40 pp. (1965)

\section{In German}

Saline formations in the subsoil of the Federal Republic of Germany offer many possibilities for ultimate storage of radioactive wastes. These types of rock, especially the pure halite rock, are practically impermeable, have a good thermal conductivity, and permit the excavation of large underground rooms at low cost. The storage of radioactive residues is possible either in accessible excavations (as in mines) or in inaccessible rooms (as in storage caverns), which are formed by the solution method.

SUBJECT CATEGORY: Isolation

ORIGIN: Foreign

KEYWORDS: RADIOACTIVE WASTE DISPOSAL; GERMAN FEDERAL REPUBLIC; SALT DEPOSITS; GEOLOGY; UNDERGROUND DISPOSAL

74

Thomas, H.A.; Harvard University, Boston, MA

OPERATIONS RESEARCH IN DISPOSAL OF LIQUID RADIOACTIVE WASTES IN STREAMS. NYO-10447; 202 pp. (1965)

A review and summary of the general principles of disposal of low-level radioactive wastes in streams is presented. A classification of physical and economic factors important in radioactive waste disposal in streams is included. A classification of rivers and other fresh-water bodies into four basic types was developed. A descriptive mathematical model is presented to show the logical structure of the scheme and to indicate the wide variety of wastedisposal environments that obtain in different streams. In some types of streams a potential exists for storage and sporadic release of activity from ben thal deposits and biomasses that may constitute a public health hazard. Various mechanisms of release are discussed. Three different models are also presented for economic and engineering analysis of stream disposal systems for radioactive wastes. Test results of model laboratory streams that were operated to supply information about the interaction of stream and radio-contaminant compounds and processes that could not readily be obtained from field studies on prototype streams are described.

\section{SUBJECT CATEGORY: LLW}

ORIGIN: Commercial

KEYWORDS: RIVERS; RADIOACTIVE WASTE DISPOSAL; SURFACE WATERS; SEDIMENTS; LIQUID WASTES; MATHEMATICAL MODELS; RADIONUCLIDE MIGRATION; ECONOMICS

\section{5}

Thompson, J.T., and J.M. Morgan, Jr.; Johns Hopkins University, Baltimore, MD

NUCLEAR TRANSPORTATION. TID-23390; 91 pp. (1965)

Part I. Research and Its Coordination. Part II. Problems Associated with Research

The scope and status of research in transportation of nuclear materials is covered as an evaluation of the overall program. Strengths and weaknesses of the research effort are highlighted. Problems associated with research are mentioned as - the importance of nuclear transportation, modes of transportation, the relation of safety versus cost, insurance, the interrelated weight-cost problem, standardization-interchangeability, specialized transportation services, criticality control, relation with toll and other transportation groups, and the development of regulations. Appendices discuss the possible role of a coordinator of transportation research and a data-bank information-retrieval system.

SUBJECT CATEGORY: Transportation

ORIGIN: Commercial; Defense 
KEYWORDS: ECONOMICS; WASTE TRANSPORTATION; NUCLEAR MATERIALS MANAGEMENT

76

Krause, H., and H. Ramdohr; Kernforschungszentrum, Karlsruhe, Germany, F.R.

S'YUDY GROŨP FOR DEEP STORAGE OF RADIOACTIVE WASTE. ANNUAL REPORT, 1964. KFK-357; ORNL-tr-1047; AEC-TR-6702; 26 pp. (1965)

In German

Studies on the development of safe and economic methods for the long-term removal of radioactive waste and for the design and construction of an installation for the final collection and processing of radioactive wastes are reported. The basic concepts used in the determination of the requirements for long-term storage of radioactive wastes are reported. Experimental work on the storage of radioactive wastes in salt caverns is described. The economic and safety factors to be considered in the disposal of waste under the sea were also consid. ered.

\section{SUBJECT CATEGORY: HLW}

ORIGIN: Foreign

KEYWORDS: RADIOACTIVE WASTE DISPOSAL; MARINE DISPOSAL; UNDERGROUND DISPOSAL; RADIOACTIVE WASTE STORAGE; ECONOMICS; GERMAN FEDERAL REPUBLIC; SALT DEPOSITS; ECONOMICS

77

Emelity, L.A., C.W. W. Christenson, and E.B. Fowler; Los Alamos Scientific Laboratory, Los Alamos, NM

DISPOSAL OF AMERICIUM 241 PLUTOONIUM 239 RAFFINATE SOLUTIONS BY FIXATION WITH CEMENT. LA-3150-MS; 20 pp. (1965)

In 1959 a raffinate waste containing $1 \mathrm{mg} /$ liter plutonium and 0.1 to $1.0 \mathrm{mg} /$ liter americium was delivered to the industrial waste section. Activity was too high to be handled by standard procedures. As a result, tests were carried out to determine feasibility of incorporating waste in cement.
A general review of the experimental procedures used and results obtained in determining the acceptable solidification procedures to be utilized for a raffinate waste containing $0.1-1.0 \mathrm{mg}$ of americium 241 per liter and $1.0 \mathrm{mg}$ of plutonium 239 per liter. High nitric acid content presented a problem in producing an acceptable grade mortar. Experiments indicate that a $50 \%$ caustic solution is required to neutralize the waste. Twenty gallons neutralized waste was put into 55 gallon steel hurial drums which were filled with Portland cement, 9 lbs. of exfoliated vermiculite, and 2 halves of a standard brick (added to improve mixing). The drums were tumbled for 15 minutes and allowed to "set" for 24 hours. The activity of the mortar ranged from $11.2 \mathrm{X}$ $10(E+6)$ w $2160 \times 10(E+6) \mathrm{cpm}$, with an average of $167 \mathrm{X} 10(\mathrm{E}+6) \mathrm{cpm}$. This mixture produccd on acceptable grade mortar. Leach test studies indicate a decreasing leach rate with respect to time. The total percent of the original leached within one year ranged from 0.001 to $0.2 \%$. Thtal material cost per gallon of delivered waste was $\$ 0.984$.

SUBJECT CATEGORY: TRU.

ORIGIN: Defense

KEYWORDS: RADIOACTIVE WASTES; SOLIDIFICATION; CEMENTS; VERMICULITE; MONTMORILLONITE; CRANDALLITE; RADIOACTIVE WASTE PROCESSING; AMERICIUM: PLUTTONIUM; RADIOACTIVE WASTE DISPO. SAL; COST; TRANSURANIUM ELEMENTS

78

Enders, J.W.; Los Alamos Scientific Laboratory, Los Alamos, NM

SOLID RADIOACTIVE WASTE DISPOSAL AT THE I.OS AI.AMOS SCIENTIFIC LABO. RATORY, LA-DC-8347; CONF-670512-5; Dispusal of Radioactive Wastes into the Ground, Proceedings of the Joint IAFA/ENEA Symposium, Vienna, Austria, 52 pp. (1965)

Figures included

Describes methods used at the Los Alamos Scientific Laboratory for the disposal of solid radioactive waste. Collection, transportation, and burial of waste, radiological safety of the disposal operations, and cost surveys covering a ten-year period are given.

SUBJECT CATEGORY: LLW; Isolation 
ORIGIN: Defense

KEYWORDS: RADIOACTIVE WASTE DISPOSAL; SOLID WASTES; WASTE TRANSPORTA. TION; COST; FORECASTING; GROUND DISPOSAL; SAFETY

79

Blomeke, J.O., E.J. Frederick, R. Salmon, and E.D. Arnold; Oak Ridge National Laboratory, Oak Ridge, TN

THE COSTS OF PERMANENT DISPOSAL OF POWER-REACTOR FUEL-PROCESSING WASTE IN TANKS. ORNL-2873; 106 pp. (1965)

\section{5 figures, 27 tables}

The costs of permanent storage of reactor fuel processing wastes are estimated for a $22,400-\mathrm{MWE}$ nuclear power economy. The wastes arise from chemical dissolution of the fuel cladding and solvent extraction purification of a combination of uranium and thorium converter fuels. It is assumed that a permanent tax-free fund is established during a 20-yr period of waste accumulation of auch size that the annual tax-free interest will be sufficient to provide for periodic replacement of tanks and for the annual operating expenses of the facility. Total costs for storing reaffinate waste, were least for storage of acid wastes in tanks of 75-yr life with government ownership, and greatest for storage of alkaline wastes in tanks of 25 -yr life with private ownership.

SUBJECT CATEGORY: HLW

ORIGIN: Commercial

KEYWORDS: RADIOACTIVE WASTE STORAGE; RADIOACTIVE WASTE DISPOSAL; ECONOMICS; RADIOACTIVE WASTE MANAGEMENT; COST; SPENT FUELS; REPROCESSING

80

Cux, J.A.; Oak Ridge National Laboratory, Oak Ridge, TN

PROBLEMS OF MOTHBALLING THE ORNL GRAPHITE REACTOR. American Nuclear Society Transactions 8(1):115-116. (1965)
1 table

Openings in the shield were sealed, and fuel slugs left in reactor with a slight exhaust airflow to hold a negative pressure. Heating the inleaking air keeps the fuel clad to $50 \mathrm{C}$ to prevent condensation and corrosion. The annual cost is $\$ 3000$, and fuel reprocessing would not pay. Spare control rods were inserted and the normal control rods welded in place. Demolition costs would be excessive - filling internal voids with grout is estimated at $\$ 70,000$, and decontamination of exhaust duct and filter house at $\$ 30,000$.

SUBJECT CATEGORY: Remedial Action, Surplus Facilities

ORIGIN: Defense

KEYWORDS: DECONTAMINATION; ECONOMICS; DECOMMISSIONING; COST; GRAPHITE MODERATED REACTORS; X-10 REACTOR

81

King, L.J., and M. Ichikawa; Oak Ridge National Laboratory, Oak Ridge, TN

PILOT PLANT DEMONSTRATION OF THE DECONTAMINATION OF LOW-LEVEL PROCESS WASTES BY A RECYCLE SCAVENGIN G - PRECIPITATION ION EXCHANGE PROCESS. ORNL-3863; 37 pp. (1965)

4 tables, 11 figures, 9 references

Low radioactivity-level waste ( $L L W$ ) can be treated by an improved scavenging-precipitation ionexchange process to reduce strontium and cesium activity levels, by factors of about 1000 at a cost of 74.6 cents per $1000 \mathrm{gal}$ in a 750,000 gal-per-day plant. The improved process was demonstrated in the ORNL pilot plant using ORNL LLW at a rate of $15,000 \mathrm{gal} /$ day.

SUBJECT CATEGORY: LLW

ORIGIN: Defense

KEYWORDS: CESIUM; COBALT; RUTHENIUM; STRONTIUM; LIQUID WASTES; ORNL; ECONOMICS; EQUIPMENT; DECONTAMINATION; SEPARATION PROCESSES; RADIOACTIVE WASTE PROCESSING 
82

Blanco, R.E., W. Davis, Jr., H.W. Godbee, L.J.King, J.T. Roberts, W.C. Yee, G.J. Alkire, E.R.I. Irish, and B.W. Mercer; Oak Ridge National Laboratory, Oak Ridge, TN; Battelle Pacific North west Laboratory, Richland, WA

RECENT DEVELOPMENTS IN TREATING LOW- AND INTERMEDIATE-LEVEL RADIOACTIVE WASTE IN THE UNITED STATES OF AMERICA. ORNL-TM-1289; STI-PUB-116; SM-71-26; 46 pp. (1965)

17 figures, 12 tables

Recent research and development work in the treatment of low-and intermediate-level radioactive. wastes is surveyed and brief economic evaluation of new treatment methods are included. A scavengingprecipitation ion-exchange process was developed for treating low-level waste which provides decontamination factors of greater than 1000 for strontium and cesium (for 2000 resin column volumes) and satisfactory decontamination of other activities. A scuvenging-precipitation foam-separation process was developed and tested on a laboratory and pilotplant scale as an alternative treatment method. A process was developed and tested on a small engineering scale for treating process condensate wastes containing ammonia and organic materials. A process for incorporating intermediate-level wastes in asphalt was developed in the laboratory, and design of a pllot plant is in progress.

SUBJECT CATEGORY: LLW; HLW

ORIGIN: Defense

KEYWORDS: RADIOACTIVE WASTE PROCESSING; RADIOACTIVE WASTE MANAGEMENT; ION EXCHANGE; PRECIPITATION; DECONTAMINATIOON: LOW-LEVEI RADIOAC:TIVE WASTES; INTERMEDIATE-LEVEL RADIOACTIVE WASTES

83

Blomeke, J.O., and L. Gemmell; Oak Ridge National Laboratory, Oak Ridge, TN; Brookhaven National Laboratory, Upton, NY

ECONOMICS OF RADIOACTIVE WASTE MANAGEMENT AT OAK RIDGE NATIONAL LABORATORY, ARGONNE NATIONAL LABORATORY, AND BROOKHAVEN NATIONAL LABORATORY. TID-25796; 59 pp. (1965)
This material was prepared for consideration by the panel on economics of radioactive waste management, sponsored by the International Atomic Energy Agency, Vienna, December 13-18, 1965. The information is presented separately for Oak Ridge National Laboratoy, Argonne National Laboratory, and Brookhaven National Laboratory, and is organized for each site to conform as nearly as possible to the outline of the I.A.E.A. questionnaire.

SUBJECT CATEGORY: General

ORIGIN: Commercial

KEYWORDS: ECONOMICS; RADIOACTIVE WASTE MANAGEMENT; ANL; ORNL; BNL

84

Cowser, K.E., L.C. Lasher, L. Gemmell, and S.G. Pearsall; Oak Ridge National Laboratory, Oak Ridge, TN; Brookhaven National Laboratory, Upton, NY

OPERATIONAL EXPERIENCE IN THE TREA'TMENT OF RADIOACTIVE WASTE AT OAK RIDGE NATIONAL LABORATORY AND BROOKHAVEN NATIONAL LABORA'TUKY. S'l'-PUB-116; SM-71-23; Practices in the Treatment of Low and Intermediate Level Kadioactive Wastes, Proceedings of a Symposium, Vienna, Austria, December 6-10, 1965, 25 pp. (1965)

26 references, 6 tables, 8 figures

Management of radioactive liquid and solid wastes (categorized as low-activity level and intermediateactivity level at this symposium) at the Oak Ridge National Laboratory and the Brookhaven National Laboratory are reviewed. Modifications of the original treatment technology have resulted from operational experience and the findings of research studies, and they are discussed in terms of their effect on effluent quality and operation cost.

SUBJECT CATEGORY: LLW; HLW

ORIGIN: Defense

KEYWORDS: ECONOMICS; RADIOACTIVE EF. FLUENTS; LIQUID WASTES; ORNL; SOLID WASTES; RADIOACTIVE WASTE MANAGE. MENT; LOW-LEVEL RADIOACTIVE WASTES; INTERMEDIATE-LEVEL RADIOACTIVE WASTES 
85

Girdler, R.M.; Savannah River Laboratory, Aiken, SC

HANDLING OF LOW AND MEDIUM LEVEL LIQUID WASTE AT SAVANNAH RIVER PLANT. DPSPU-65-30; CONF-651202-1; Practices in the Treatment of Low- and Intermediate-Level Radioactive Waste, Proceedings of a Symposium, Vienna, Austria, September, 1965, 18 pp. (1965)

Discusses the various means used to control the radioactivity in liquid wastes which may reach the environment by way of drainage to the Savannah River-seepage basins, distillation, ion exchange on synthetic zeolite, tank storage, and aging and settling. The cost of each method is given.

SUBJECT CATEGORY: HLW; LLW

ORIGIN: Defense

KEYWORDS: RADIOACTIVE WASTE STORAGE; RADIOACTIVE WASTE PROCESSING; RADIOACTIVE WASTE DISPOSAL; SAVANNAH RIVER; SURFACE WATERS; LIQUID WASTES; ECONOMICS; ION EXCHANGE

86

Hoffmann, E., J.M. Van Lint, and M. Vande Poel; Societe Belge Pour L Industrie Nucleaire, Brussels, Belgium

WASTE TREATMENT PLANT ACCOUNTING PROCEDURE, APPLICATION. TID22427; 37 pp. (1965)

Tables

Cost of running the MOL treatment plants on behalf of the C.E.N. is reported. All costs are quoted in Belgian francs. Two kinds of figures are quoted. In one table, actual figures of the December 1964 monthly running expenses are given. Although the other figures quoted are not considered as actual, they do give a very accurate idea of running expenses averaged over the last five years.

SUBJECT CATEGORY: LLW

ORIGIN: Foreign

KEYWORDS: RADIOACTIVE WASTE PROCESSING; LIQUID WASTES; BELGIUM; RADIOACTIVE WASTE MANAGEMENT; ECONOMICS; COST
87

Hoffmann, E., J.M. Van Lint, and M. Vande Poel; Societe Belge Pour L Industrie Nucleaire, Brussels, Belgium

WASTE TREATMENT PLANT MANAGEMENT AND ACCOUNTING PROCEDURE. TID-22428; 104 pp. (1965)

A waste treatment plant is described together with the way in which its accounting is carried out and yields the information required for efficient running and possible improvements. The information is given to show how a treatment cost is determined and understood.

SUBJECT CATEGORY: LLW

ORIGIN: Foreign

KEYWORDS: DECONTAMINATION; RADIOACTIVE WASTE DISPOSAL; LIQUID WASTES; BELGIUM; GASEOUS WASTES; SOLID WASTES; ECONOMICS; EQUIPMENT; RADIOACTIVE WASTE PROCESSING; COST

88

Yamamoto, Y., T. Miyauchi, D. Kunii, and R. Kiyose; Tokyo University, Tokyo, Japan

CHEMICAL ENGINEERING STUDIES ON THE PROCESSING OF RADIOACTIVE LIQUID WASTES BY EVAPORATION. FINAL REPORT JANUARY 1, 1964 - MARCH 31, 1965. NP-15371; 27 pp. (1965)

In studies on the use of the fluidized-bed spray-type evaporator for economical processing of radioactive liquid wastes, cold experiments were conducted to obtain fundamental data on evaporation and solidification processes of solutions aprayed and heated in superheated steam. Heat transfer rate in the preheating stage is quite rapid as the process is considered to be condensation heat transfer. In the vaporization process, sensible heat transfer through the film around the liquid drops is considered dominant and the process is somewhat slower than the preheating stage. Engineering data for the fluidized-bed are correlated. It was concluded that the selection of the position of injection point of the feed liquid is not a critical problem in this type of evaporator. Liquid drop size has, however, an important effect on the operation characteristics of the bed. From a bench scale experiment it was concluded that the minimum recycling of steam is necessary to maintain the good fluidizing condition. 
SUBJECT CATEGORY: LLW

ORIGIN: Foreign

KEYWORDS: HEAT TRANSFER; LIQUID WASTES; EVAPORATION; JAPAN; SOLIDIFICATION; ECONOMICS; FLUIDIZED BED; RADIOACTIVE WASTE PROCESSING

89

U.S. Atomic Energy Commission, Division of International Affairs, Washington, DC

AN ECONOMIC STUDY OF THE C. E. N. RADIOACTIVE WASTE TREATMENT PLANT. 'TID-21786-CFSTI; 68 pp. (1965)

Translated from French; available from NTIS

Operation of the C.E.N. waste treatment plant is described. Information is provided on the economics of the various processes used for waste decontamination.

SUBJECT CATEGORY: General

ORIGIN: Foreign

KEYWORDS: RADIOACTIVE EFFLUENTS; RADIOACTIVE WASTE DISPOSAL; RADIOACTIVE WASTE STORAGE; LIQUID WASTES; BELGIUM; SOLID WASTES; ECONOMICS; ION EXCHANGE; PRECIPITATION

90

Cordel, H.J.; Westinghouse Electric Corp., Pittsburgh, PA

LARGE CLOSED-CYCLE WATER REACTOR RESEARCH AND DEVELOPMENT PROGRAM - DEVELOPMENT OF AUXILIARY SYSTEMS. WCAP-3269-31. (1965)

23 figures, 10 tables, 8 references

Simple conceptual design description of systems and operations, no information on how or why designed. Chemical and volume control, water sampling, auxiliaries coolant, safety injection, waste disposal, and containment ventilation. Apparently common ancestry with San Onofre Reactor description. Contains information on coolant activities concentration, dilution cycles for Chem Shim reactor at $1350 \mathrm{mwth}$.

SUBJECT CATEGORY: General

ORIGIN: Commercial

KEYWORDS: RADIOACTIVE EFFLUENTS; PWR TYPE REACTORS; VOLUME; RADIOACTIVE AEROSOLS; RADIOACTIVE WASTE DISPOSAL; CONTAINMENT

91

Cerre, P., E. Mestre, J. Bourdrez, and S.D. Blalock, Jr. ('I'ranslator)

TREATMENT OF LOW-ACTIVITY WASTES BY CO-PRECIPITATION AT THE SACLAY NUCLEAR STUDIES CENTER. ORNL-tr-4422; CONF-651202; IAEA-SM-71; Practices in the Treatment of Low- and Intermediate-Level Radioactive Waste, Proceedings of a Symposium held in Vienna, Austria, December 6-10, 1965, (pp. 303-316). (1965)

Ten years' experience of operating the low-activity liquid effluent treatment plant at Saclay has led to improvements and modifications of the treatment cycle. Among these, the authors consider certain aspects of flocculation, and in particular techniques for solidifying sludge. The increasing specific activity and volume of effluent requiring processing made it necessary to perfect the techniques employed, to provide greater protection and, above all, to complete the effluent treatment cycle by devising a means of handling the sludge resulting from the treatment itsolf. Apart from ito increasing specific activity this sludge consists of $80 \%$ water. These two factors necessitate a reappraisal of the problem of handling and storing the concentrates, and the paper describes in detail modifications to the plant affecting principally: (1) remote control of the valves; (2) settling and filtration; and (3) solidification and final packaging of the sludge. The operating results are also analysed thus throwing light on the economic asperts of the problem. (Auth)

SUBJECT CATEGORY: LLW

ORIGIN: Foreign

KEYWORDS: PRECIPITATION; REPROCESSING; SAFETY; SLUDGES; SOLIDIFICATION; VOLUME; RADIOACTIVE WASTE PROCESSING; LIQUID WASTES; LOW-LEVEL RADIOACTIVE WASTES; RADIOACTIVE EFFLUENTS 
92

Sobolev, I.A., and L.M. Khomchik

COMBINED BURIAL OF SOLID AND LIQUID RADIOACTIVE WASTES. TT-6:51033/4-6; IPST-CAT.-1538-1540; Hygiene and Sanitation 30(4-6):92-94. (1965)

\section{2 figures, 1 reference}

In the USSR, the sanitary regulations for work with radioactive substances and sources of ionizing radiations no. 333-60 specify that such wastes must be buried in special underground vaults for liquid and solid wastes has been changed to use of one vault with solids and liquids incorporated into a solid mass. Combining liquids and solid wastes in concrete is a more efficient use of space and requires less ground area. Migration of radioactive substances into the environment is practically impossible. Cost of combined burial of liquid wastes in concrete is about 40 to $50 \%$ less than for liquid wastes alone.

SUBJECT CẠTEGORY: Isolation
ORIGIN: Foreign

KEYWORDS: RADIOACTIVE WASTE STORAGE; RADIOACTIVE WASTE DISPOSAL; LIQUID WASTES; SOLID WASTES; USSR; UNDERGROUND DISPOSAL; CONCRETES; COST

\section{3}

WASTE BURNING AT CHALK RIVER. Nuclear Engineering 10(115):472-473. (1965)

Operating experience at the low-activity waste incinerator is described. The incinerator and monitoring equipment are described, and operating data are given, along with the costs.

SUBJECT CATEGORY: LLW

ORIGIN: Foreign

KEYWORDS: CANADA; SOLID WASTES; ECONOMICS; CHALK RIVER; COMBUSTION; COST; INCINERATORS 
THIS PAGE

\section{WAS INTENTIONALLY \\ LEFT BLANK}




\section{6}

94

Hedlund, R., and A. Lindskog; Aktiebolaget Atomenergi, Stockholm

THE RADIOACTIVE WASTE MANAGEMENT AT STUDSVIK. AE-225; 14 pp. (1966)

The report was originally prepared as a contribution to the discussions in an IAEA panel on economics of radioactive waste management held in Vienna from 13-17 December 1965. It contains the answers and comments to the questions of a questionaire for the panel concerning the various operations associated with the management (collection, transport, treatment, discharge, storage, and operational monitoring) of radioactive liquid wastes, solid wastes, gaseous wastes, and equipment decontamination facilities and radioactive laundries.

\section{SUBJECT CATEGORY: LLW}

ORIGIN: Foreign

KEYWORDS: DECONTAMINATION; RADIOACTIVE WASTE STORAGE; RADIOACTIVE WASTE DISPOSAL; ECONOMICS; LIQUID WASTES; SOLID WASTES; WASTE TRANSPORTATION; RADIOACTIVE WASTE MANAGEMENT; SWEDEN; EQUIPMENT

95

Fineman, P.; Argonne National Laboratory, Idaho Falls, ID

WASTE DISPOSAL. SECTION IVTREATMENT OF LOW- AND INTERMEDIATE-LEVEL ACTIVITY WASTES. Reactor Fuel Processing 9(1):40-50. (1966)

7 Figures, 32 References

A survey of current work on waste disposul. Includes the following information - (1) ionexchange treatment of low-level waste water at Idaho Chemical Processing Plant, Pacific Northwest Laboratory, and Harwell, (2) fluidized-bed calcination and conversion to glass of high-level wastes, (3) economic studies of perpetical tank storage, and (4) fission-product recovery.

SUBJECT CATEGORY: LLW; HLW
ORIGIN: Defense

KEYWORDS: RADIOACTIVE WASTE DISPOSAL; RADIOACTIVE WASTE STORAGE; CALCINATION; ECONOMICS; LIQUID WASTES; FISSION PRODUCTS; ORNL; IDAHO CHEMICAL PROCESSING PLANT; BATTELLE PACIFIC NORTHWEST LABORATORIES; GLASS; ION EXCHANGE; MATERIALS RECOVERY; LOWLEVEL RADIOACTIVE WASTES; INTERMEDIATE-LEVEL RADIOACTIVE WASTES

96

Fineman, P.; Argonne National Laboratory, Idaho Falls, ID

WASTE DISPOSAL. SECTION IV. Reactor Fuel Processing 9(3):170-176. (1966)

36 References

This article reviews current work on waste disposal. Includes treatment of intermediate-level wastes by ion exchange electrodialysis, and incorporation in asphalt. Under conversion of high-level waste to solids, the economics of tank storage compared conversion to solids, fluidized-bed calcination, and conversion to glasses. Plans for the recovery of megacurie amounts of selected fission products from redox- and purex-plant waste are described.

SUBJECT CATEGORY: HLW; LLW

ORIGIN: Defense

KEYWORDS: RADIOACTIVE WASTE DISPOSAL; RADIOACTIVE WASTE STORAGE; CALCINATION; ECONOMICS; FISSION PRODUCTS; ORNL; RADIOACTIVE WASTE MANAGEMENT; IDAHO CHEMICAL PROCESSING PLANT; BATTELLE PACIFIC NORTHWEST LABORATORIES; GLASS; MATERIALS RECOVERY

97

Mawson, C.A., and K.E. Cowser; Atomic Energy of Canada Ltd., Chalk River, Ontario, Canada; Oak Ridge National Laboratory, Oak Ridge, TN

REVIEW OF HEALTH PHYSICS SOCIETY PAPERS ON ENVIRONMENTAL MONITORING, HAZARDS ANALYSIS, AND WASTE DISPOSAL. Nuclear Safety 7(3):370-374. (1966) 
23 references

A review is presented of papers on three topics discussed at the tenth annual meeting of the Health Physics Society (June 14 to 17, 1965, atLos Angeles, Calif.): environmental monitoring, hazards analysis, and waste disposal. In this review, papers on radiation exposures in the vicinities of nuclear operations at Oak Ridge, Hanford, and Savannah River, which were presented in the session on environmental monitoring, are discussed. Also, problems in environmental monitoring dealing with economy, practice and theory, cloud dispersion, dietary surveys, underground explosions, tritium in Japan, and the conversion of liquid waste to solids are covered. For the session on hazards analysis, several papers on internal and external dose estimates and exposures following the release of radionuclides are summarized. With regard to waste dispoisal, some recent tests concerning the ultimate disposal of liquid waste by the hydraulicfracturing technique are described briefly, and studies of liquid-waste disposal at Oak Ridge and Hanford are reviewed. A brief comment on U.S. and Soviet waste-disposal standards is also given.

SUBJECT CATEGORY: Isolation; HLW; LLW

ORIGIN: Defense; Foreign

KEYWORDS: DOSIMETRY; RADIOACTIVE WASTE DISPOSAL; RADIOACTIVE WASTE PROCESSING; RADIATION HAZARDS

98

Bonhote, P.A.; Australian Atomic Energy Commission

SOLAK EVAPORATION OF IOW-LEVEL RADIOACTIVE SLUDGE. Atomic Energy Australia 9(3):14-17. (1966)

\section{2 figures}

Studied solar evaporation as a method of further processing the sludge ( 3.5 to $5.0 \%$ solids, 0.01 microcurie/ml) produced from a scavenging/flocculation treatment of low-level effluent at Lucas Heights. Preliminary experiments showed that filters could be dispensed with and that the sludge could be dried in the open with little or no contamination spread. A full-size evaporator of 927 sq. $\mathrm{ft}$ area was designed to cope with the sludge production of $15,000 \mathrm{gal} / \mathrm{yr}$. The drying proceeds until the sludge can be cut into blocks, and, at the end of drying, the blocks are shoveled in to drums for burial. The performance in 16 months operation is described. The volume reduction factor averages 14 , and the moisture content of the dried sludge averages $27 \%$.

\section{SUBJECT CATEGORY: LLW}

ORIGIN: Foreign

KEYWORDS: RADIOACTIVE WASTE PROCESSING; RADIOACTIVE WASTE MANAGEMENT; EVAPORATION; VOLUME; LOWLEVEL RADIOACTIVE WASTES; RADIOACTIVE WASTE STORAGE

99

Bonhote, P.A., and E.D. Hespe; Australian Atnmic Energy Commission

LOW-LEVEL SLUDGE CONCENTRATION BY SOLAR EVAPORATION. CONF-651202; IAEA-SM-71/5; Practices in the Treatment of Lowand Intermediate-Level Radioactive Wastes, Proceedings of a Symposium, Vienna, Austria, December 6-10, 1965. International Atomic Energy Agency, Vienna, Austria, (pp. 439-447), 948 pp. (1966)

Solar-evaporation was developed as a method to treat low-level sludge at Lucas Heights in Australia. The low-level effluent generated by research done on a beryllia-moderated, high-temperature, gastunleri resctor system was used in developing the method. Once the effluent was collected into delay tanks it is pumped into a treatment plant for scavenging/flocculation using sodium carbonate to keep the $\mathrm{pH}$ between 6.0 and 6.5. The process is capable of producing $68 \mathrm{cu} \mathrm{m} / \mathrm{yr}$. Levels of contamination in the sludge are $10(\mathrm{E}-5)$ to $10(\mathrm{E}-3) \mathrm{uCi} / \mathrm{ml}$ gross alpha, $10(\mathrm{E}-3)$ to $10(\mathrm{E}-1) \mathrm{uCi} / \mathrm{m}$ gross beta, and 5 to $10 \mathrm{ppm}$ beryllium. Solar evaporation was thought feasible because the annual rainfall averages $122 \mathrm{~cm}$, and the sun shines for $6.7 \mathrm{~h} / \mathrm{d}$. For the initial experiment a drying bed with a $\sigma \mathrm{cm}$ thick gravel and sand filter and drain were used with a transparent cover. Ultimately the transparent covers were abandoned. The evaporation rates averaged 3.275 liters/sq $\mathrm{m}$ which compares favorably with the annual evaporation rate of 2.989 liters/sq $m$ d. A larger experimental design with $82 \%$ of the annual evaporation rate was tried next. The larger evaporation pan was designed to evaporate $15,000 \mathrm{gal}$ of sludge. The evaporation rate of $9,000 \mathrm{gal}$ of sludge was 3.43 liters/sq $\mathrm{m} \mathrm{d}$ with an average of 2.65 liters/sq $\mathrm{m} \mathrm{d}$. Overall volume reduction was 5.3 , and no significant airborne 
contamination or radiation fields were detected. Capital costs were initially \$A 5284 and over a 25 yr life span of the equipment the cost per gallon is 1.5 cent. The experience at Lucas Heights gives a favorable indication as to the viability of the method.

\section{SUBJECT CATEGORY: LLW}

ORIGIN: Foreign

KEYWORDS: EVAPORATION; RADIOACTIVE WASTE PROCESSING; VOLUME; RADIOACTIVE WASTE MANAGEMENT; LOW-LEVEL RADIOACTIVE WASTES; COST; ECONOMICS

100

Cooley, C.R., and A.M. Platt; Battelle Pacific Northwest Laboratory, Richland, WA

THE WASTE SOLIDIFICATION ENGINEERING PROTOTYPES TECHNICAL PROGRAM. BNWL-SA-467; CONF-660208-6; Solidification and Long-Term Storage of Highly Radioactive Wastes, Proceedings of a Symposium, Richland, WA, February 1, 1966; 25 pp. (1966)

The objectives and future plans for the waste solidifications engineering prototypes are discussed. The emphasis on specific safeguards, technical, and economic evaluations and the program steps to achieve demonstration of solidification methods are outlined for an Oak Ridge National Laboratory pot calcination and rising level glass process, a Pacific Northwest Laboratory spray solidification process, and a Brookhaven National Laboratory phosphate glass process. Plans for the first portion of the program are reviewed.

SUBJECT CATEGORY: Isolation; HLW

ORIGIN: Defense

KEYWORDS: RADIOACTIVE WASTE DISPOSAL; RADIOACTIVE WASTE PROCESSING; LIQUID WABTES; RADIOACTIVE WAETE MANAGEMENT; ECONOMICS; SOLIDIFICATION; CALCINATION; GLASS

101

Ray, J.W., R.O. Wooton, and R.H. Barnes; Battelle Pacific Northwest Laboratory, Richland, WA
INVESTIGATION OF TRITIUM GENERATION AND RELEASE IN PM NUCLEAR POWER PLANTS. BMI-1787; 121 pp. (1966)

The ternary fission process is the major source of tritium, following use of lithium-based resin in 1963 generated at the rate of $8.7 \times 10$ to the 5 th tritons per fission. The resultant tritium diffuses through the clad. Water samples were assayed, and a mathematical model describing tritium generation and movement throughout PM plants was developed. The resulting program, TRICON, was employed to calculate tritium concentrations at PM-3A during 1965. Agreement between calculated and measured concentrations was good. Potential health hazards from both airborne and waterborne tritium were calculated. The most economical solution at PM-1 appears to be the removal of tritiated effluent from the plant site at $\$ 1.40$ per gallon, and atPM-3A to be the expelling of tritiated effluent water to an isolated area where it will freeze and sublime in safe concentrations.

SUBJECT CATEGORY: Airborne; LLW

ORIGIN: Defense

KEYWORDS: COMPUTER CODES; PWR TYPE REACTORS; TRITIUM; RADIOACTIVE WASTE DISPOSAL; HAZARDS; PM-1 REACTOR; PM-3A REACTOR; LIQUID WASTES; MATHEMATICAL MODELS

\section{2}

Clelland, D.W., and A.D.W. Corbet; British Nuclear Fuels Ltd., London, England

THE TREATMENT OF INTERMEDIATELEVEL RADIOACTIVE WASTES BY EVAPORATION: THE DESIGN AND PERFORMANCE OF EVAPORATION SYSTEMS. CONF-651202; IAEA-SM-71/20; Practices in the Treatment of Low- and Intermediate-Level Radioactive Wastes, Proceedings of a Symposium, Vienna, Austria, December 6-10, 1965. International Atomic Energy Agency, Vienna, (pp. 497-515), 948 pp. (1966)

The design and performance of evaporation plants for the treatment of intermediate-level liquid radwastes is discussed. A number of factors must be considered before a satisfactory design can be established. These factors are: decontamination factor, concentration factor, corrosion, "steam stripping" of solvent, criticality, nitric acid rec- 
overy, and steam cost. The decontamination factor can vary enormously according to ultimate discharge strategy. If the waste is being discharged to a drinking water source then a factor of $10(E+9)$ is required. A high concentration factor is economically desirable in view of minimizing the size and cost of a storage structure. Higher concentration means higher activity must be considered. To minimize attack from corrosive materials such as nitric acid specially treated stainless steel is required. If the waste liquors contain organic solvents that may react violently then they must be "steam stripped" before evaporation can take place. If the wastes arise from processes involving significant amounts of fissile material then the possibility of criticality must be considered. Nitric acid recovery must considered for econnmic reasons and it may provide an additional activity decontamination factor before disposal. Finding an inexpensive source of steam isimportant to controlling a major cost of running an evaporation plant. With these factors in mind the plant should be designed so there is activity containment and ventilation, segregation of areas, sheilding, and maintenance. Several schemes of evaporative waste-treatment systems are given for a stated set of conditions. From the scenarios discussed, there are satisfactory and economic methods for treating intermediatelevel radwastes by evaporation.

SUBJECT CATEGORY: HLW

ORIGIN: Foreign

KEYWORDS: DECONTAMINATION: ECONOMICS; EVAPORATION; RADIOACTIVE WASTE PROCESSING; VOLUME; RADIOACTIVE WASTE MANAGEMENT; RADIOACTIVE WASTES; INTERMEDIATE-LEVEL RADIOACTIVE WASTES; LIQUID WASTES; REPROCESSING

\section{3}

Weth, G.G., G. Strickland, and E.J. Tuthill; Brooklurven Nutional Labörätory, Upton, NY

\section{PLATINUM FOR HIGH-TEMPERATURE CRUCIBLES USED IN PROCESSING RADI- OACTIVE WASTE. BNL-10132; CONF-660208- 17; Solidification and Long-Term Storage of Highly Radioactive Wastes, Proceedings of a Symposium, Kichland, WA (14 pp.). (1966)}

In the development of the phosphate-glass process for conversion of highly radioactive wastes to stable solids, platinum has been used successfully for the high temperature crucible. In this application a platinum crucible has been used at temperatures of 800-1200 C for a total of 8000 hours with no signs of deterioration. It was demonstrated that chemical reducing conditions must be avoided. Otherwise, rapid deterioration of platinum may take place in the presence of molten phosphate. Tests to determine the useful life of platinum included long-term creep measurements at $1250 \mathrm{C}$. The latest resillts of these tests, which are still in progress, are presented. Economic factors associated with the use of platinum in high level waste processing are discussed briefly.

\section{SUBJECT CATEGORY: HLW}

ORIGIN: Dcfense; Commercial

KEYWORDS: PHOSPHATE GLASS; PLATINUM; RADINACTTVE WASTE PROCESSING; CRUCIBLES; ECONOMICS

\section{4}

Brookhaven National Laboratory, Upton, NY

ULTIMATE WASTE DISPOSAL. BNL-50,023, (pp. 45-48) Brookhaven National Laboratory Annual Répiù l. (1988)

Figures included

Reports progress on a process for converting highly radioactive wastes to phosphate glass. Pilot-plant operations indicate that a critical factor is control of conditions in the evaporator. Phosphoric acid is mixed with the waste. The solution is then reduced in volume by evaporation of water and nitric acid and converted to glass by heating to $1200 \mathrm{C}$ in a platinum crucible.

SUBJECT CATEGORY: HLW

ORIGIN: Defense

KFYYWORDS: US NRC; SOIII WASTES; RADIOACTIVE WASTE MANAGEMENT; PHOSPHATE GLASS; EVAPORATORS; VOLUME; RADIOACTIVE WASTE PROCESSING

\section{5}

De Robien, E., J. Pomarola, and M. Brodsky; CEA Centre d'Etudes Nucleaires de Fontenay-aux-Roses, 92, France 
EXPERIENCE ACQUIRED IN REGARD TO EVAPORATING LIQUID RADIOACTIVE WASTE AND SOLIDIFYING EVAPORATION SLUDGE AT THE CENTRES D'ETUDES NUCLEAIRES DE FONTENAYAUX-ROSES AND DE GRENOBLE. ORNL-tr-4419; CONF-651202; Practices in the Treatment of Low-and Intermediate-Level Radioactive Wastes, Proceedings of a Symposium, Vienna, Austria, December 6-10, 1965, (pp. 279-290). (1966)

Very complete in its analysis of the topic. Translation by S.D. Blalock, Jr. from pp 279-290 of STI/PUB-116; Available from NTIS, PC A02/MF A01

A specific and complete analysis of the evaporators used at the radioactive effluent processing stations of the Grenoble and Fontenay-aux-Roses Centres. The reasons for selecting the evaporation method are given, reference being made to the regulations governing disposed of liquid effluents. After a comparative description of the characteristics of the two installations, the paper describes the experience gained in the course of operation, discussing; concentration factors; decontamination factors; precautions taken to avoid corrosion risks; and difficulties encountered, modifications and improvements made. Laboratory studies carried out on the solidification of sludges are described as well as the various stages leading to the completion of the present installations. Finally, the authors present an economic assessment. (Auth)

SUBJECT CATEGORY: HLW; LLW

ORIGIN: Foreign

KEYWORDS: EVAPORATION; LIQUID WASTES; SLUDGES; COST; SOLIDIFICATION; VOLUME; RADIOACTIVE WASTE PROCESSING; ECONOMICS

106

Orsenigo, G.; Comitato Nazionale per l'Energia Nucleare, Rome, Italy

THORIUM-URANIUM FUEL CYCLE IN ITALY. Technical Reports Series No. 52; Utilization of Thorium in Power Reactors, (pp. 127137). (1966)

The most recent evidence indicates that there is a trend for the reevaluation of the thorium-uranium cycle, but no one at the present time can anticipate any reactor experiment based on thorium-uranium fuel in Italy. The use of the thorium-uranium fuel cycle in Italian rector experiments is therefore mentioned here merely as a possibility. Much more realistic appears to be the future utilization of the PCUT (Programme Ciclo Uranio Thorio) facility to re-work thorium-uranium fuels, both in the form of oxide fuels from water reactors and in the form of carbide fuels from high-temperature, gas-cooled reactors, on the behalf of foreign customers interested in the development of these cycles. CNEN is prepared to accept any suggestion in this field and to plan the operation of the plant accordingly. Details of the construction status of the PCUT facility, specifically, civil work, chemical and mechanical equipment, analytical facility and laboratories, heating and ventilation system and utilities are given. Research and development in support of the facility is outlined as well as that on the sol-gel process and thorium-uranium carbides. The future program of PCUT facility use is outlined and fuel cycle costs discussed.

\section{SUBJECT CATEGORY: General}

ORIGIN: Foreign

KEYWORDS: THORIUM; URANIUM; FUEL CYCLE; EVALUATION; REVIEWS; REACTORS; SOL-GEL PROCESS; COST; REPROCESSING; URANIUM OXIDES; THORIUM OXIDES; FABRICATION; ITALY; ECONOMICS

107

Foster, R.S.; Dow Chemical Company, Golden, CO

INCINERATION OF PLUTONIUM CONTAMINATED WASTE MATERIALS. RFP-735; 27 pp. (1966)

1 Figure, 3 Tahles, 14 References

Present contaminated waste-incinerator design trends are presented along with references to recent incineration literature. Constant heat release is recommended as a basis for design of waste incinerators. Incineration costs were found to be only a small portion of overall costs associated with recovery of plutonium from combustible wastes.

SUBJECT CATEGORY: TRU

ORIGIN: Commercial

KEYWORDS: PLUTONIUM; ROCKY FLATS PLANT; RADIOACTIVE WASTE DISPOSAL; SOLID WASTES; COMBUSTION; INCINERATORS 
108

Cardozo, R.L., J. Vaccarezza, and S. Vanuzzi; European Atomic Energy Community, Ispra, Italy

SLUDGE CONCENTRATION WITH A CENTRIFUGAL SEPARATOR. EUR-3175E; 16 pp. (1966)

8 references

A description of a centrifugal separator for the volume reduction of sludges emanating from the decontamination: of radioactive waste water by coprecipitation is presented. Its main features are overall volume reduction factor of 500 , solids content of concentrated sludge of 11 to $16 \mathrm{wt} \%$, minimalization of radioactive hazards, ease of operation, and low cost of treatment.

SUBJECT CATEGORY: LLW

ORIGIN: Foreign

KEYWORDS: DECONTAMINATION;ECONOMICS; RADIOACTIVE WASTES; TRITIUM; PRECIPITATION; VOLUME; COST

109

Hild, W., E. Lopez-Menchero, and J.F. Lazzaretto; European Company for the Chemical Processing of Irradiated Fuels, Mol, Belgium

THE TREATMENT OF EUROCHEMIC MEDIUM LEVEL WASTE BY THE NEUTRALISATION SELF-SOLIDIFICATION PROCESS. PROGRESS REPORT NO. 1. NP-16597; ETR-194; 54 pp. (1966)

19 figures, 12 tables, 20 references

An assessment was made of eurochemics medium. level waste (MLW) produced in the period 1966-1970, including chemical compositions, activities, volumes, and storage situation. After a short description of the state of the work on MLW treatment in August, 1965, a detailed summary of recent experimental work is given, leading to the neutralisation self-solidification (NSS) process. The features of this very versatile process are described, and functional flowhseets are given.

SUBJECT CATEGORY: HLW

ORIGIN: Foreign
KEYWORDS: SOLIDIFICATION; FLOWSHEETS; LIQUID WASTES; ECONOMICS; EU. ROCHEMIC; INTERMEDIATE-LEVEL RADIOACTIVE WASTES; INVENTORIES

110

Marcus, F.R.; European Company for the Chemical Processing of Irradiated Fuels, Mol, Belgium

ROLE OF WASTE MANAGEMENT AT EUROCHEMIC. Atompraxis 12(1):50-53. (1966)

1 Figure, 1 Table

The Furochemic plant is located in a densely populated European inland area where released of radioactivity to the environment are extremely limited. Waste management at Eurochemic is designed to (1) reduce the amount of waste as far as practical, (2) segregate the different categories of waste at their origin, thus permitting individual treatment or utilization, (3) design methods of treatment to reduce the volumes of waste, (4) design safe storage installations, (5) provide for perpetual care of stored waste, (6) promote research into solidification methods, (7) prevent undue escape of activity in the waste released, (8) design wastehandling systems at minimum cost.

SUBJECT CATEGORY: LLW; HLW; TRU

ORIGIN: Foreign

KEYWORDS: RADIOACTIVE WASTE PROCESSING; LIQUID WASTES; SOLID WASTES; RADIOACTIVE WASTE MANAGEMENT; EUROCHEMIC

111

Federal Water Pollution Control Administration, Region VIII, Denver, CO

DISPOSITION AND CONTROL OF URANIUM MILL TAILINGS PILES IN THE COLORADO RIVER BASIN. NP-16094; 83 pp. (1966)

The radioactivity content of piles of uranium-mill tailings in the Colorado River Rasin and their radioactivity water pollution potential were evaluated. A cost analysis of suggested tailings-pile control measures at the mills is presented. Ra-226 
was demonstrated to be the major factor in causing radioactivity increases in streams. It is recommended that interim measures to prevent erosion and spread of tailings be undertaken. All distribution of tailings from either nonoperating or operating mills must be halted until proper and adequate review procedures can be instituted and agreements be reached on long-term public and private responsibility for maintenance of the tailings piles.

SUBJECT CATEGORY: Remedial Action, Mill Tailings

ORIGIN: Commercial

KEYWORDS: ECONOMICS; RADIUM 226; LIQUID WASTES; MILL TAILINGS; URANIUM; FEED MATERIALS PLANTS; RADIOACTIVE WASTE MANAGEMENT

\section{2}

Federal Water Pollution Control Administration, Region VIII, Denver, CO

COLORADO RIVER BASIN WATER QUALITY CONTROL PROJECT. PROGRAM REVIEW, DENVER, COLORADO, APRIL 25, 1966. PB-260047. (1966)

Available from NTIS, PC A07/MF A01; See also report dated Apr 1965, PB-260045

The Colorado River Basin Water Quality Control Project is reviewed. The bulk of this report deals with activities and accomplishments for FY 1966, including: radiological pollution; mineral pollution; municipal, industrial and related water pollution problems; laboratory activities; and STORET activities. Departures from FY 1966 plans are reviewed along with plans and schedules for work proposed for FY 1967. Details are also offered on the budget justification, technical backup requirements, and organization and management.

SUBJECT CATEGORY: General

ORIGIN: Commerrial

KEYWORDS: COLORADO RIVER BASIN; ECONOMICS; INDUSTRIAL WASTES; RADIOACTIVE WASTES; WATER QUALITY

\section{3}

International Atomic Energy Agency, Vienna, Austria
WASTE MANAGEMENT RESEARCH ABSTRACTS NO. 2. International Atomic Energy Agency Compilation; 90 pp. (1966)

Abstracts from eleven nations are included in this compilation. General areas include: gaseous wastes treatment and disposal, liquid wastes treatment, solid wastes treatment, storage and discharge studies, and economic studies.

SUBJECT CATEGORY: General

ORIGIN: Foreign

KEYWORDS: COBALT; IAEA; TRITIUM; RADIOACTIVE WASTE DISPOSAL; MARINE DISPOSAL; LEAD; POLONIUM; ZINC; LIQUID WASTES; SOLID WASTES; SOLIDS; WASTE MANAGEMENT; RADIOISOTOPES

114

Schulze-Rettmer, R.; Kernforschungsanlage Juelich GmbH, Germany, F.R.

PRACTICES IN THE TREATMENT OF RADIOACTIVE WASTES IN THE FEDERAL REPUBLIC OF GERMANY. Vom Wasser 33:211228. (1966)

In German

There are 34 nuclear reactors in operation or under construction, plus numerous users of radioisotopes in industry and medicine and processing installations for nuclear fuels. Each of these installation yields radioactive wastes. The characteristics of these wstes are summarized with respect to the installation of origin. The most common practices in the collection and treatment of radioactive wastes currently used in the Federal Republic are outlined. The treatment of concentrate-end precipitate is described. The cost of the waste processing is evaluated.

SUBJECT CATEGORY: General; LLW

ORIGIN: Foreign

KEYWORDS: LIQUID WASTES; POWER REACTORS; ECONOMICS; PRECIPITATION; RADIOISOTOPES; FUEL ELEMENTS; GERMAN FEDERAL REPUBLIC

115

Emelity, L.A., and C.W. Christenson; Los Alamos Scientific Laboratory, Los Alamos, NM 
PROGRAM AND PROCEDURES FOR CONTROL OF RADIOACTIVE WASTES AT LOS ALAMOS. LADC-7711; CONF660621; Health Physics Society 11th Annual Meeting held in Houston, Texas, June 27-30, 1966, (24 pp.). (1966)

Methods for handling radioactive wastes at the Los Alamos Laboratory are reviewed. All levels of radioactive waste are dealt with in varying quantities. The largest volume of material is the liquid lowlevel wastes. Also, relatively large amounts of intermediate-level wastes and occasionally highlevel wastes are handled. The waste management policy at Los Alamos is "concentrate and contain". The low-level wastes are collected by separate sewer systems and brought to a central point. If the liquid is acidic, it is neutralized. This system exists at both the Area 50 processing plant and at the Area 21 plant. The highly acidic americium and plutonium intermediate-level wastes are transferred in 270 gallon stainless steel tank trailers for delivery from Area 21. The high-level wastes are put in two liters plastic bottles and then placed in identified Dempster Dumpster. The processing plants concentrate alpha activity by using a ferric hydroxide floc at a high $\mathrm{pH}$. The floc is collected in sedimentation tanks, removed to separate storage for decantation of excess liquid, then further concentrated by vacuum filtraton. Intermediate-level wastes are incorporated in a cement-vermiculite mortar. The wastes are neutralized with a $50 \%$ sodium hydroxide solution, cooled and then added to the mortar. The solid wastes are packaged and buried in pits within the tuff rock strata of the Los Alamos area. Area 50 has a decontamination factor of 100 and Area 21 has a factor of 2000 . The volume is reduced by 300 at Area 21 and 800 at Area 50. The average cost for processing the various wastes at the facilities is about $\$ 23$.

SUBJECT CATEGORY: LLW; HLW; TRU

\section{ORIGIN: Defnse}

KEYWORDS: AMERICIUM; PLUTONIUM; CONTAINMENT; COST BENEFIT ANALYSIS; SOLIDIFICATION; RADIOACTIVE WASTE DISPOSAL; RADIOACTIVE WASTE MANAGEMENT; RADIOACTIVE WASTE PROCESSING; HIGH-LEVEL RADIOACTIVE WASTES; INTERMEDIATE-LEVEL RADIOACTIVE WASTES; LIQUID WASTES; LOW-LEVEL RADIOACTIVE WASTES; SOLID WASTES; VOLUME; COST

\section{6}

Emelity, L.A., C.W. Christenson, and W.H. Kline; Los Alamos Scientific Laboratory, Los Alamos, NM
OPERATIONAL PRACTICES IN THE TREATMENT OF LOW- AND INTERMEDIATE-LEVEL RADIOACTIVE WASTES: ARGONNE AND LOS ALAMOS LABORATORIES. SM-71/24; Practices in the Treatment of Low- and Intermediate-Level Radioactive Wastes, Proceedings of a Symposium, Vienna, Austria, December 6-10, 1965, (pp. 187-205), 948 pp. (1966)

Discusses waste treatment facilities. Brief discussion of packaging and burial at these sites, hence may be relevant to shallow land burial.

The "concentrate and contain" philosophy for treating radioactive wastes has heen adopted at both the Argonne and Los Alamos Laboratories. Whereas at Argonne solids are compacted, package and shipped off-site, at I.os Alamos a sparsely populated region permits on-site burial. All liquid radioactive-waste solutions at the Argonne National Laboratory are analyzed for radioactivity after collection in tanks. When the concentration of activity is below recognized international limits, wastes are discharged to the sanitary sewer. When the concentration is excessive, wastes are directed to the processing building. The annual output is about $1000 \mathrm{~m}(3)$. At the processing plant, methods including evaporation and concentration, filtration and ion exchange, filtration only, flocculation, absorption or entrainment in concrete are used. The evaporation-concentration system has been used to process the bulk of the liquid wastes. Treatment costs, encompassing all operations, vary from 3106 $5345 / \mathrm{m}(3)$. Low-level liquid wastes at the Los Alamos Scientific Laboratory are collected in separate sewer systems and delivered to two treatment sites. The volume prosessed is approximately $3800 \mathrm{~m}(3) /$ month at the principal facility and $760 \mathrm{~m}(3) /$ month at the outlying location. The main contaminant at both plants is $\mathrm{Pu} 230$ but the concentration of fission produces is increasing. Deslgn data for the recently completed main plant, which incorpurales cuagulation, cu-precipitation, and ion exchange for processing alpha, beta and gamma active solutions, are discussed. Treatment at this site results in a decontamination factor of 100 and a volume reduction factor of 800 . Respective factors for the smaller plant, at which the alpha activity is 50 to 100 times as high, are 2000 and 300 . Precipitated sludges are concentrated, vacuum dewatered and packaged for burial. Intermediate-level liquid wastes are treated batch-wise with the effort directed toward fixation in media. Which will resist leaching. Quantities up to $7.5 \mathrm{~m}(3) / \mathrm{month}$ of an acid americium-plutonium solution are incorporated in a cement-vermiculite monar. Brief mention is made of other batch methods used which include the gelling of contaminated soils and incineration of liquid organic wastes. Liquid-waste treatment costs vary from $\$ 7.00$ to $\$ 690 / \mathrm{m}(3)$. (Auth) 
SUBJECT CATEGORY: LLW; HLW; TRU

ORIGIN: Defense

KEYWORDS: RADIOACTIVE WASTES; RADIOACTIVE WASTE PROCESSING; LIQUID WASTES; EVAPORATION; SOLID WASTES; SOLIDIFICATION; VOLUME; ECONOMICS; LOW-LEVEL RADIOACTIVE WASTES; INTERMEDIATE-LEVEL RADIOACTIVE WASTES; COST; TRANSURANIUM ELEMENTS

117

Sanders, F.W.; Los Alamos Scientific Laboratory, Los Alamos, NM

DECONTAMINATION OF TEST CELL C AT THE NUCLEAR ROCKET DEVELOPMENT STATION AFTER A REACTOR ACCIDENT. LA-3633-MS; 58 pp. (1966)

29 figures, 1 table

Test cell C, a facility of the Los Alamos Scientific Laboratory at the nuclear rocket development station, was contaminated by fuel fragments during testing of the Phoebus IA Reactor, a prototype nuclear rocket reactor. About $10,000,000$ curies of radioactive materials, at $1 \mathrm{hr}$ post-test, was spread over about 5 acres. Decontamination of the test cell required 60 days. The cost of the cleanup was about $\$ 100,000$, and all participants combined received a total dose of 180 rems.

SUBJECT CATEGORY: Airborne

ORIGIN: Defense

KEYWORDS: DECONTAMINATION; RESEARCH AND TEST REACTORS; RADIATION DOSES; CONTAMINATION; COST; LASL; ACCIDENTS

\section{8}

Blanco, R.E., J.O. Blomeke, and J.T. Roberts; Oak Ridge National Laboratory, Oak Ridge, TN

FUTURE MAGNITUDE AND PROPOSED SOLUTIONS OF THE WASTE DISPOSAL PROBLEM. Solidification and Long-Term Storage of Highly Radioactive Wastes, Proceedings of a Symposium, Richland, WA, February 14-18, 1966; 12 pp. (1966)

2 tables, 1 figure
At the present time, high level radioactive wastes produced in all countries are stored in tanks and this practice will continue for an interim period until development of a safer or more economical disposal method is completed. The relative advan tages of the solidification of these wastes and their permanent storage in dry underground medium as a permanent disposal method as opposed to tank storage is discussed extensively. Both methods appear to be applicable in most countries.

SUBJECT CATEGORY: Isolation; HLW

ORIGIN: Commercial

KEYWORDS: RADIOACTIVE WASTE DISPOSAL; RADIOACTIVE WASTE STORAGE; ECONOMICS; RADIOACTIVE WASTE PROCESSING; RADIOACTIVE WASTE MANAGEMENT; HIGHLEVEL RADIOACTIVE WASTES

\section{9}

Blanco, R.E., and F.L. Parker; Oak Ridge National Laboratory, Oak Ridge, TN

WASTE TREATMENT AND DISPOSAL SEMIANNUAL PROGRESS REPORT JULY DECEMBE R, 1965. ORNL-TM-1465; 95 pp. (1966)

Figures and 22 tables

Reports progress in engineering and laboratory development of the solidification of high-level wastes on low- and intermediate-level waste treatment, on engineering, economics and safety evaluations, disposal by hydrofracturing, disposal in natural salt formations, soil studies, behavior of radionuclides in the ground, and disposal of gases into permeable formations.

SUBJECT CATEGORY: HLW; LLW

ORIGIN: Defense

KEYWORDS: CESIUM; RADIONUCLIDE MIGRATION; STRONTIUM; RADIOACTIVE WASTE DISPOSAL; RADIOACTIVE WASTE PROCESSING; ECONOMICS; HIGH-LEVEL RADIOACTIVE WASTES; LOW-LEVEL RADIOACTIVE WASTES; INTERMEDIATE-LEVEL RADIOACTIVE WASTES; SOLIDIFICATION; SOIL CHEMISTRY; SALT DEPOSITS; RADIOACTIVE AEROSOLS; HYDRAULIC FRACTURING; SAFETY ENGINEERING 
120

Blomeke, J.O., R. Salmon, J.T. Roberts, R.L. Bradshaw, and J.J. Perona; Oak Ridge National Laboratory, Oak Ridge, TN

ESTIMATED COSTS OF HIGH-LEVEL WASTE MANAGEMENT. ORNL-P-1926; CONF660208-1; Solidification and Long-Term Storage of Highly Radioactive Wastes, Proceedings of a Symposium, Richland, WA. February 14-18, 1966, 19 pp. (1966)

\section{8 figures, 5 tables}

The costs of perpetual tank storage of both acid and alkaline wastes were estimated as a function of tank size, tank life, and fission product concentration in the waste for three representative types of financing. For acid wastes, the optimum tank capacity is about a million gallons, and minimum total costs range from 0.0165 to $0.0272 \mathrm{mill} / \mathrm{KWHR}$. For alkaline wastes, the optimum tank capacity is 2.5 million gallons, and minimum total costs range. from 0.0177 to $0.0294 \mathrm{mill} / \mathrm{KWHR}$. Reducing the volume of wastes, as stored, by doubling the concentration of fission products reduces the total costs between 15 and $30 \%$. The minimum total costs for management by the series of operations consisting of interim liquid storage, pot calcination, interim solid storage, shipment, and disposal in salt mines, are estimated to range from 0.017 to 0.020 mill/KWHR when carried out over a 30-year period.

\section{SUBJECT CATEGORY: HLW}

ORIGIN: Commercial

KEYWORDS: RADIOACTIVE WASTE DISPOSAL; RADIOACTIVE WASTE STORAGE; RADIOACTIVE WASTE MANAGEMENT; ECONOMICS; COST; HIGH-LEVEL RADIOACTIVE WAS'IES: VOI.TIMF,

12.1

Boegly, W.J., F.L. Parker, and E.G. Struxness; Oak Ridge National Laboratory, Oak Ridge, TN

DISPOSAL OF RADIOACTIVE WASTES IN GEOLOGIC FORMATIONS. IRPA-92; International Radiation Protection Association, First International Congress, Rome, Italy, September 510, 1966, 10 pp. (1966)

The ultimate disposal of radioactive wastes into geologic formations has received increasing attention during the past 10 years. Due to the varying heat-generation rates of the different categories of wastes and the allowable costs, no single formation is capable of handling the entire spectrum of wastes produced. Therefore, three different methods of disposal have been investigated to handle the high-, intermediate-, and low-level wastes generated. High-level, small-volume wastes would be converted to solids and stored in a dry impermeable underground formation such as salt - intermediatevolume wastes would be slurried with cement and additives and injected into slightly permeable formations using the hydrofracturing technique and low-level, large-volume wastes would be injected into deep porous formations. The engineering-scale demonstration of hydrofracturing has been completed, and a demonstration of the disposal of radioactive solids in a salt mine is underway.

SUBJECT CATEGORY: Isolation; HLW; LLW

ORIGIN: General

KEYWORDS: HYDRAULIC FRACTURING; SALT DEPOSITS; RADIOACTIVE WASTE STORAGE; RADIOACTIVE WASTE DISPOSAL; HIGH-LEVEL RADIOACTIVE WASTES; LOWLEVEL RADIOACTIVE WASTES; INTERMEDIATE-LEVEL RADIOACTIVE WASTES; UNDERGROUND DISPOSAL

\section{2}

Clark, W.E., H.W. Godbee, and C.L. Filzyerald; Oak Ridge National Laboratory, Oak Ridge, TN

LABORATORY DEVELOPMENT OF POT PROCESSES FOR SOLIDIFICATION OF RADIOACTIVE WASTES. Solidification and Long-Term Storage of Highly Radioactive Wastes, Proceedings of a Symposium, Richland, WA, Fcbruary 14-18, 19GG, 26 pp. (1908)

8 tables, 8 figures, 19 references

Three pot processes for fixation of high level aqueous wastes have been developed at the Oak Ridge National Laboratory. All thre.e proiluce solddified waste in a cylindrical pipe pot suitable for permanent storage, and all three produce only dilute nitric acid as a sidestream. Since the off-gas volume is minimum in all three processes, capital costs for construction of the processing facility should be minimum. In all three processes the fixation vessel is connected to an evaporator in a loop, with the evaporator serving both to concentrate the feed to the pot and to give an extra decontamination factor from radionuclides, principally ruthenium. The 
evaporator was not operated as an integral part of the laboratory tests.

\section{SUBJECT CATEGORY: HLW}

ORIGIN: Defense

KEYWORDS: CALCINATION; RADIOACTIVE WASTE PROCESSING; HIGH-LEVEL RADIOACTIVE WASTES; ORNL; LIQUID WASTES; SOLID WASTES; RADIOACTIVE WASTE STORAGE; EVAPORATION; COST; ECONOMICS; SOLIDIFICATION

\section{3}

Roberts, J.T., L.M. Ferris, E.L. Nicholson, R.H. Rainey, and C.D. Watson; Oak Ridge National Laboratory, Oak Ridge, TN

REPROCESSING METHODS AND COSTS FOR SELECTED THORIUM-BEARING REACTOR FUEL TYPES. Technical Reports Series No. 52; Utilization of Thorium in Power Reactors, (pp. 343-352). (1966)

Developments in the chemical reprocessing of Th fuels from the most promising reactor types in the advanced converter reactor program are reviewed. Emphasis is on differences in methods and costs between $T h$ fuels and low-enrichment $U$ metal or oxide fuels clad in Al, $\mathrm{Zr}$, or stainless steel alloys. The relationship between reprocessing and the rest of the fuel cycle for proposed recycle schemes is discussed. Primary consideration is given to pyrolytic C-coated Th-U oxide or carbide microspheres contained in graphite fuel elements, i.e. fuels for high-temperature, gas cooled reactors and Th-U metal, oxide, or carbide clad with $\mathrm{Zr}$ or $\mathrm{Al}$ alloys, including fuels for heavy-water-cooled and moderated reactors, heavy-water-moderated, organiccooled reactors, and also spectral shift control reactors and light-water-cooled and moderated seedblanket reactors. Some aspects in which Th fuels are non-standard are given. Some differences can increase cost by 2 or more on a weight basis, or prevent processing of certain fuels in plants used for standard ones. Because of higher burn-up and/or thermal efficiency, some Th fuels can stand the cost, while others cannot. On the other hand, plants handling Th fuels with processes described in this paper, could have only slightly higher cost, allowing the Th-fuelled converters to take advantage of higher burn-up and/or thermal efficiency in achieving lower power costs. Thus, Th reprocessing problems are seen as temporary initial economic disadvantages for the early advanced converters; these problems will fade as the industry reaches a reasonable size.
SUBJECT CATEGORY: HLW; Spent Fuel

ORIGIN: Defense; Commercial

KEYWORDS: THORIUM; FUEL CYCLE; FUEL ELEMENTS; ECONOMICS; REPROCESSING; FUEL REPROCESSING PLANTS; WATER COOLED REACTORS; URANIUM; REVIEWS

\section{4}

Suddath, J.C., and J.O. Blomeke; Oak Ridge National Laboratory, Oak Ridge, TN

AN ECONOMIC ANALYSIS OF HIGHLEVEL WASTE MANAGEMENT FOR FLUIDIZED-BED VOLATILITY PROCESSING OF POWER REACTOR FUELS. ORNLTM-1441; 23 pp. (1966)

3 tables, 8 figures, 8 references

Costs are estimated for management of wastes from fluidized-bed volatility processing of zircaloy-and stainless-steel-clad UO-2 reactor fuels. Alternatives consist of encapsulating the wastes without additional treatment, encapsulation following preparation of glassy solids, and encapsulation of the fission products as a glass following their separation from the inerts by a phosphoric acid leach. In all cases, the final products are shipped to a salt mine for final disposal. There is not a clear-cut economic incentive to make glasses or to leach the fission products, but if these conversions are desirable for greater safety in handling and shipment, a substantial credit from cheaper management of the products can be applied against the cost of the treatment step. More economic waste management cannot be cited as an advantage of volatility over aqueous processing in the fluidizedbed method for low-enrichment fuel.

SUBJECT CATEGORY: HLW

ORIGIN: Commercial

KEYWORDS: RADIOACTIVE WASTE STORAGE; WASTE TRANSPORTATION; RADIOACTIVE WASTE MANAGEMENT; ECONOMICS; COST; ZIRCALOY; FISSION PRODUCTS; FLUIDIZED BED

\section{5}

Weeren, H.O.; Oak Ridge National Laboratory, Oak Ridge, TN

DISPOSAL OF RADIOACTIVE WASTES BY HYDRAULIC FRACTURING - PART II, 
DESIGN ORNL'S SHALE FRACTURING PLANT. Nuclear Engineering and Design 4(1):108117. (1966)

8 figures, 1 table, 8 references

The shale fracturing program has been concerned with the development of a technique for the safe and economic disposal of large batches of radioactive waste by mixing the waste with cement and injecting the mix into beds of shale at depths of about $1000 \mathrm{ft}$. A facility was built at ORNL to make a series of seven experimental injections. Large volumes of waste solution (up to 150,000 gallons per injection) were successfully injected. Precise control of the proportion of cement and waste solution remains a difficult problem. The facility is now scheduled for modification for regular disposal of laboratory waste.

SUBJECT CATEGORY: LLW

ORIGIN: Defense

KEYWORDS: ORNL; LIQUID WASTES; HYDRAULIC FRACTURING; GEOLOGY; CEMENTS; SHALES

\section{6}

Marshall, R.O., E.M. Sparling, and B.H. Heinemann; Producers Creamery Company, Springfield, MO

\section{REMOVING RADIONUCLIDES FROM FRESH MILK. PB-175709. (1966)}

Figures, references, tables

Laboratory investigations and full-scale tests showed the feasibility of full-scale processing of milk for continuous removal of iodine-131 and strontium-90 by a combined anion-cation fixedresin-bed system. The full-scale runs of nearly $1,000,000$ pounds of grade-A whole milk removed more than $99 \%$ of I-131 and 94.6 and $90.0 \%$ of Sr-85 and Sr-90, respectively. The data indicate the plant produced milk of acceptable quality at an estimated cost of 6.3 cents per quart, as compared with 2.3 cents per quart for $\mathrm{Sr}-90$ removal alone.

SUBJECT CATEGORY: LLW

ORIGIN: Institutional

KEYWORDS: FALLOUT; IODINE; STRON. TIUM; MILK; ION EXCHANGE; RADIOCHEMICAL ANALYSIS
127

Belter, W.G., and D.W. Pearce; U.S. Atomic Energy Commission, Division of Reactor Development and Technology, Pacific Northwest Laboratory

RADIOACTIVE WASTE MANAGEMENT. TID-8541; 100 pp.; Reactor Technology, Selected Reviews-1965, L.E. Link, (Ed.), Argonne National Laboratory, January 1966, (pp. 149-248). (1966)

19 tables, 24 figures

This review presents highlights in recent wastemanagement experience in the United States and abroad and summarizes advances in technology that have occurred during the past three to four years. Sections are included on treatment. storage and disposal, environmental studies, and evaluation and economics.

SUBJECT CATEGORY: HLW; LLW; TRU

ORIGIN: Defense; Commercial

KEYWORDS: RADIOACTIVE WASTE DISPOSAL; RADIOACTIVE WASTE MANAGEMENT; RADIOACTIVE WASTE PROCESSING; RADIOACTIVE WASTE STORAGE; ENVIRONMENTAL EFFEC'TS; ECONOMICS

128

Buinbridge, G.R.; United Kingdom Atomic Energy Authority, Harwell, England

UBSULETE NUĆLEAR POWER STATIONS. Atom 120:230-232. (1966)

Suggests that locations of obsolete stations will be needed because of the same features that made them attractive in the first place. Preliminary studies of razing the calder hall reactors indicate a few percent additional cost if site needed immediately, but less than 1 percent cost if $30-50$ years delay possible. Demolition of everything but the concrete pressure vessel and its earth coverage is suggested.

SUBJECT CATEGORY: Remedial Action, Surplus Facilities

ORIGIN: Foreign

KEYWORDS: ECONOMICS; DECOMMISSIONING; COST; NUCLEAR FACILITIESS

129

Wharton, J., and A.P. Thormhill; United Kingdom Atomic Energy Authority, Risley, England 
HTR FUEL DISPOSAL STUDY. DR-Report$450 ; 36$ pp. (1966)

The handling of fuel from a single dragon-type H.T.G.C. power reactor is considered. The study compares the relative costs of a selected number of alternative methods of storage of the feed and breed fuels discharged from a conceptual $532 \mathrm{MW}(\mathrm{e})$ reactor. The methods considered are storage of whole fuel elements and various processes to reduce the volume of the fuel before storage. It is found that the reduced volume schemes are less safe and cost more than any saving made in storage space. Interim cooling of the fuel within the reactor building for the first 200 days after discharge is recommended, followed by canning of whole fuel elements, and their transfer to a gas-cooled facility in a separate building for long-term storage.

SUBJECT CATEGORY: Spent Fuel

ORIGIN: Foreign

KEYWORDS: RADIOACTIVE WASTE DISPOSAL; RADIOACTIVE WASTE - STORAGE; POWER REACTORS; RADIOACTIVE WASTE MANAGEMENT; UKAEA; FUEL ELEMENTS; HTGR TYPE REACTORS; COST

\section{0}

Polan, M.; US Naval Radiological Defense Laboratory, San Francisco, California; Ford Instrument Company, Division of Sperry Rand Corporation; Long Island, New York

AN ANALYSIS OF THE FALLOUT PREDICTION MODELS, PRESENTED AT THE USNRDL-DASA FALLOUT SYMPOSIUM OF SEPTEMBER 1962, VOLUME I. ANALYSIS, COMPARISON, AND CLASSIFICATION OF MODELS. USNRDL-TRC-68; 157 pp. (1966)

15 figures, 13 tables, and 50 references

An analysis of the models, based on published and unpublished reports and on personal communications with those who developed or are currently responsible for them, is published in this volume. The models are classified according to use and implementation, and according to their physicomathematical structures. The basic characteristics of the models are compared and evaluated, and the conclusions drawn from this material are given.

SUBJECT CATEGORY: Airborne
ORIGIN: General

KEYWORDS: COMPUTER CODES; FALLOUT; PARTICLE SIZE; MATHEMATICAL MODELS; NUCLEAR EXPLOSIONS; METEOROLOGY; TOPOGRAPHY; MATHEMATICS

131

Barbour, R.A.

REVIEW OF NEW DEVELOPMENTS IN THE FIELD OF LOW AND INTERMEDIATE RADIOACTIVE WASTE DISPOSAL IN THE REPUBLIC OF SOUTH AFRICA. CONF. 651202; IAEA-SM-71/63B; Practices in the Treatment of Low- and Intermediate-Level Radioactive Wastes, Proceedings of a Symposium, Vienna, Austria, December 6-10, 1965. International Atomic Energy Agency, Vienna, Austria, (pp. 911-919), 948 pp. (1966)

Gives some description of solidified end product of waste treatment.

All radioactive material used in South Africa is under the statutory control of the Atomic Energy Board, and since 1957 a total of $1019 \mathrm{Ci}$ have been imported into the country. The disposal of radioactive waste produced by the use of this material has not presented a problem since the activity levels involved are very low. No national regulations covering the disposal of radioactive waste from isotope users have been promulgated but, in view of the rapid expansion and use of radioactive material, a National Committee of Control over Radioactive Waste Disposal has been appointed to assist and advise the Board with regard to the manner and conditions under which radioactive waste should be disposed of. The uranium industry, while producing fifty thousand tons of uranium oxide over the past thirteen years, has not presented a serious waste management problem. The only major development in radioactive waste disposal has taken place at Pelindaba, the National Nuclear Research Centre. Here liquid wastes are segregated at source and drained to a central waste-treatment facility. Intermediate-level waste of low volume $(45 \mathrm{cu}$ $\mathrm{m} /$ month) and high salinity is treated by a batch chemical blending or precipitation process followed by evaporation and mixed-bed ion exchange. Lowlevel waste (5-10 cu m/d), contaminated in excess of 10 (E-5) $\mathrm{pCi} / \mathrm{ml}$, is treated by an identical but separate process. It is expected that decontamination factors of the order of $10(E+4)-10(E+6)$ will be achieved by this combination of treatments. Con- 
centrates from the evaporators are collected in a central dump tank from where they are transferred to a batch solidification facility, utilizing a premixed blend of cement and exfoliated vermiculite. The solidified concentrate will be stored on-site in a structure designed to prevent penetration by underground water. The volume of low-level solid waste is reduced in a fully contained pneumatic baling press before permanent burial on site.

SUBJECT CATEGORY: LLW; HLW

ORIGIN: Foreign

KEYWORDS: RADIOACTIVE WASTE DISPOSAL; SOLIDIFICATION; RADIOACTIVE WASTE PROCESSING; LOW-LEVEL RADIOACTIVE WASTES; INTERMEDIATE-LEVEL RADIOACTIVE WASTES; VOLUME; RADIOACTIVE WASTE MANAGEMENT; GROUND DISPOSAL

132

Kvam, D.J.

WASTE MANAGEMENT PRACTICES AT LAWRENCE RADIATION LABORATORY, LIVERMORE. CONF651202; IAEA-SM-71/41; Practices in the Treatment of Low- and Intermediate-Level Radioactive Wastes, Proceedings of a Symposium held in Vienna, Austria, December 6-10, 1965, (pp. 3-16). (1966)

Relevant to shallow land burial only in terms of describing final packaging of waste to be shipped to land burial sites from Lawrence Livermore Laboratory.

This paper describes the facilities and practices currently involved in medium- and low-level radioactive waste management at the University of California, Lawrence Radiation Laboratory, Livermore. The research programes of the Lawrence Radiation Laboratory are such that waste disposal includes a complete variety of problems ranging from mixed fission products to transuranic elements. At a cost of $6-10 \% / \mathrm{gal}$, up to $200,000 \mathrm{gal}$ of liquid waste ranging from $10(E+4)-10(E+3) \mathrm{dpm} / 1$ $(5 \times 10(\mathrm{E}-6)$ to $5 \times 10(\mathrm{E}-2) \mathrm{uCl} / \mathrm{ml})$ are decontaminated annually in the $\$ 250,000$ coagulation facility. After breaking emulsions and centrifuging the waste when necessary, the $\mathrm{pH}$ is adjusted to 2.5 and an oxidizing environment is provided. Addition of $\mathrm{Fe}^{+++}$and evaluation of the $\mathrm{pH}$ to 9.0 results in a floc capable of enmeshing or combining with contaminants. Decontamination factors of 10,000 are obtained routinely in batch sizes ranging from 500 -
30,000 gal. Although most polyvalent cations respond favorably to co-precipitation, the presence of alkali metals, alkaline earths, and the complex, ninevalence states of ruthenium in the waste require further ion-exchange polishing. After precipitation, the hydroxide floc is partially de-watered with the aid of a rotary-drum filter, giving an overall volume reduction greater than $99.5 \%$. Other liquid disposal techniques in use at LRL, Livermore Laboratory, include phosphate and sulphide flocs, solidification, and solar evaporation. Over $25,000 \mathrm{cu}$ $\mathrm{ft}$ of packaged dry waste are cosigned to off-site land burial annually. Packages range from 55-gal drums to waste encapsulated in 20-t concrete coffins. A variety of special Livermore containers, utilizing wood, lead, steel, polyurethane and concrete, are described together with techniques for their use. A detailed account is offered of the design and operation of a 5-t hydraulic ram for compressing drummed dry waste. Costing only $\$ 1500$, the press achieves a four-to-one volume reduction and offers significant savings. (Auth)

SUBJEC'I CATEGORY: LLW; HLW; TRU

ORIGIN: Defense

KEYWORDS: RADIOACTIVE WASTE MANAGEMENT; ION EXCHANGE; FLOCCULATION; EVAPORATION; LOW-LEVEI RADIOACTIVE WASTES; INTERMEDIATE-LEVEL RADIOACTIVE WASTES; PRECIPITATION; LIQUID WASTES; COST BENEFIT ANALYSIS; SOLIDIFICATION; RADIOACTIVE WASTE DISPOSAL; SOLID WASTES; GROUND DISPOSAI; RADIOACTIVE WASTE PROCESSING

133

Osloond, J.H., and B.L. Schmalz

RADIOACTIVE WASTE DISPOSAL DATA FOR THE NATIONAL REACTOR TESTING STATION. IDO-12040(Suppl. 1); 11 pp. (1966)

A summary of the quantities, types and activities of radioactive wastes disposed of at NRTS.

During $19652.57 \times 10(\mathrm{E}+9)$ liters of radioactive liquids, containing $2,095 \mathrm{Ci}$ of activity were discharged. This was approximately $50 \%$ of the 1964 release. The major source of this volume was the ICPP (1.57 x 10(E+9)). Detailed monthly data on the volumes discharged to the seepage ponds and to the lithosphere are presenied. A total of $12.4 \times 10(\mathrm{E}+10)$ cu $\mathrm{ft}$ of gaseous radioactive wastes, containing $524,621 \mathrm{Ci}$, were discharged to the atmosphere. The 
major sources of this waste, with respect to activity, were the MTR and FCF (ANL) facilities. Data on the monthly releases to the atmosphere on a per facility basis are presented. Radioactive solid wastes buried at NRTS during 1965 totaled $7,529 \mathrm{cu} \mathrm{m}$ with an activity of $1.46 \times 10(\mathrm{E}+6) \mathrm{Ci}$. Of the volume disposed of the largest volume was $161,474 \mathrm{cu} \mathrm{ft}$ of low-level waste generated on site. Detailed semi-annual, solid waste disposal inventories for each facility are presented.

SUBJECT CATEGORY: HLW; LLW; Airborne

ORIGIN: Defense; Commercial

KEYWORDS: LIQUID WASTES; GASEOUS WASTES; SOLID WASTES; INVENTORIES; LOW-LEVEL RADIOACTIVE WASTES; VOLUME; RADIOISOTOPES; RADIOACTIVE EFFLUENTS;

134

Smeets, L., and B. Verkerk

LOW-LEVEL WASTE TREATMENT AT REACTOR CENTRUM NEDERLAND. CONF651202; IAEA-SM-71/10; Practices in the Treatment of Low- and Intermediate-Level Radioactive Wastes, Proceedings of a Symposium held in Vienna, Austria, December 6-10, 1965, (pp. 3141). (1966)

Describes waste treatment facilities.

The waste-treatment facilities on the site of RCN, Petten, were designed to serve a number of radiochemistry laboratories, where work on a millicurie level was foreseen. The facilities have been in operation for about five years at an increasing level, but still have a large over-capacity for low-level liquids. This will be taken up on a large scale next year when an isotope production facility will come into use. In the low-level liquid waste from this facility an amount of organic liquids will be present that may cause difficulties in treatment. Liquid wastes are first stored in a number of 50,100 and 200 cu $m$ ponds, analyzed for total alpha and beta activity and, if necessary, treated in a flocculation plant, also equipped with a sand filter and an ionexchange column. Sludges are concentrated by freezing and thawing. Final sludges contain about $25-30 \%$ solids. Effluents are again analyzed and disposed of in the North Sea through a 4-km long vulcathene pipeline. Our license allows for a discharge of $15 \mathrm{mCi} / \mathrm{d}$ of unspecified activity including alpha-emitters at a maximum concentration of $2 \times 10(\mathrm{E}-4) \mathrm{uCl} / \mathrm{ml}$. Design data of the semicontinuous flocculation plant are given and operational experience on a few different types of wastes, including liquids mixed with laundry effluent, are presented. A brief description is also given of the procedures for treating low-level solids where baling techniques are applied that result in five to ten-fold volume reduction. Operational experience of the Government-RCN waste-collecting service is also given. (Auth)

\section{SUBJECT CATEGORY: LLW}

ORIGIN: Foreign

KEYWORDS: FLOCCULATION; PACKAGING; LOW-LEVEL RADIOACTIVE WASTES; LIQUID WASTES; VOLUME; ION EXCHANGE; SLUDGES; COST BENEFIT ANALYSIS; RADIOACTIVE WASTE PROCESSING

135

Sugimoto, S.I., and T. Ishihara

TREATMENT PRACTICES OF LOW- AND INTERMEDIATE-LEVEL RADIOACTIVE WASTES AT THE JAPAN ATOMIC ENERGY RESEARCH INSTITUTE. CONF-651202; SM71/9; Practices in the Treatment of Low- and Intermediate-Level Radioactive Waste, Proceedings of a Symposium, Vienna, Austria, December 6-10, 1965, (pp. 207-222), 948 pp. (1966)

Gives brief description of processing of solid wastes, which are at present only stored. Requires interpretation.

The radioactive waste treatment plant, JAERI Tokai Research Establishment, has operated since 1958 , and various contaminated wastes that have been discharged by research laboratories, radioisotope processing facilities, and the five reactors in Tokai site, have been processed and removed. Most liquid wastes are intermediate-, low- and extremely low-level. Extremely low-level (less than 10(E-6) $\mathrm{uCl} / \mathrm{ml}$ ) liquid is discharged after dilution with ordinary effluent. Low.level liquid is processed by flocculators, ion-exchange columns with a membrane dialyzer and evaporators, with capacities of 1 cu $\mathrm{m} / \mathrm{h}$. Intermediate-level liquid is processed by small evaporators installed in a shielded cell. The resulting sludges are solidified with Portland cement into drums, and stored in concrete pits. In 1964,3700 cu m of low- and very low-level liquid were 
produced, the average volume per capita being $14 \mathrm{cu}$ $\mathrm{m} / \mathrm{yr}$. The average removal percent of activity is $99.7 \%$, and from 1959-1964 about $2.1 \mathrm{mCi}$ were discharged into the sea after decontamination. Most solid wastes are low-level and sent to the treatment plant in 20-litre cartons. Combustible wastes are incinerated at the rate of 3 cartons $/ h$, and non-combustible ones are compressed into drums with a volume reduction of one-fifth. In 1964, 11,000 cartons were processed by an incinerator or by a baling press, the average quantity per capita being 17 cartons a year. They were packaged in to 200-litre drums and stored in a semi-underground concrete pit. (Auth)

SUBJECT CATEGORY: HLW; LLW

ORIGIN: Fureign

KEYWORDS: FLOCCULATION; ION EXCHANGE; EVAPORATION; COMBUSTION; COMPACTING; SOLID WASTES; RADIOACTIVE WASTE STORAGE; LOW-LEVEL RADIOACTIVE WASTES; INTERMEDIATE-LEVEL RADIOACTIVE WASTES; VOLUME; DECONTAMINATION; SOLIDIFICATION; ENCAPSULA. TION; SLUDGES; INVENTORIES

\section{7}

130

Sachse, G., and H. Rosenberger; Centralinstitut Fuer Kernforschung, Rossendorf, Germany; Institut Fuer Angewandte Mineralogie, Dresden

SOLIDIFICATION OF RADIOACTIVE CONCENTRATES IN GLASSES OR CERAMICS. PART 1. SURVEY OF THE PAPERS PUBLISHED TILL 1965. Kemenergie 10:205. 210. (1967)

In German

Research in the field of safe storage of high-level radioactive concentrates by melting into glasses or ceramic materials is described. The accessible report literature as well as the results of the Conference on the Treatment and Storage of HighLevel Radioactive Wastes (Vienna, 1963) and the 3rd Conference on the Peaceful Uses of Atomic Energy (Geneva, 1964) were taken into consideration. Subjects covered include naturally occurring mineral raw materials, investigations of glass systems, technological studies, problems of the storage of vitrified high-level radioactive materials, and cost of the processes.

\section{SUBJECT CATEGORY: HLW}

ORIGIN: Foreign

KEYWORDS: CERAMICS; SOLIDIFICATION; GLASS; RADIOACTIVE WASTE STORAGE; COST

\section{7}

Baetsle, L.H., and J. Souffriau; Centre d Etude de IEnergie Nucleaire, Mol, Belgium

INSTALLATIŨN OH CHEMICAL BAKKIERS IN AQUIFERS AND THEIR SIGNIFICANCE IN ACCIDENTAL CONTAMINATION. CONF670512; STI/PUB-156; Disposal of Radioactive Wastes into the Ground, Proceedings of a Symposium, Vienna, Austria, 1967. International Atomic Energy Agency, Vienna, Austria, (pp. 229 . 240). (1967)

Principles of chemical barrier formation are re viewed and the principal results of laboratory research on the system silica-hf-antimonic acid are discussed in some detail. Field experiments have delineated the zone created by injecting reagents traced with $\mathrm{Br}-82$ into an aquifer. The economics of barrier formation are discussed in the conclusions. Finally a description is given of the most suitable experimental procedure for the injection of the reagents $\mathrm{HF}$ and $\mathrm{K} 2 \mathrm{H} 2 \mathrm{SB} 2 \mathrm{O} 7$ into the aquifer. The retention capacity of the installed barrier for $\mathrm{Sr}$ is also discussed in relation to its significance for environmental safety at reprocessing plants.

SUBJECT CATEGORY: Isolation

ORIGIN: Foreign

KEYWORDS: STRONTIUM; RADIOACTIVE WASTE DISPOSAI; RADIOACTIVE WASTE PROCESSING; BROMINE; REPROCESSING; TRACER TECHNIQUES; AQUIFERS; CONTAMINATION

138

Fontaine, G.; European Atomic Energy Community, Ispra, Italy

GROUND DISPOSAL METHODS FOR RADIOACTIVE SOLID WASTES AT THE ISPRA 
ESTABLISHMENT OF EURATOM. STI/PUB156; CONF-670512; Disposal of Radioactive Wastes into the Ground, Proceedings of a Symposium, Vienna, Austria, May 29-June 2, 1967. International Atomic Energy Agency, Vienna, Austria, (pp. 109. 121), 666 pp. (1967)

In French

Radioactive solid waste produced in the reactors and laboratories of the ISPRA establishment of EURATOM can be divided into highly contaminated but nonactivated waste (waste from laboratories, hot-cell decontamination, etc.), and highly activated but lightly contaminated waste (waste from in-pile loops and experiments). Ground disposal methods are used only if there is no material in the waste which can react with the cement. Various methods have been considered and utilized, underground wells being utilized in each case. A study of construction cost revealed an economical solution with respect to high-level activity and security, which also covers direct irradiation and the eventual transfer of contamination.

SUBJECT CATEGORY: HLW; LLW

ORIGIN: Foreign

KEYWORDS: CONCRETES; RADIOACTIVE WASTE DISPOSAL; ECONOMICS; SOLID WASTES; RADIOACTIVE WASTE MANAGEMENT; CONTAMINATION; HYDROLOGY; SAFETY; SOILS; GROUND DISPOSAL

139

Krause, H., H. Ramdohr, and M.C. Schuchardt; Gesellschaft Fuer Kernforschung mbH, Karlsruhe, Germany, F.R.

PROJECT FOR STORING RADIOACTIVE WASTES IN A SALT CAVITY. STI/PUB-156; CONF-670512; Disposal of Radioactive Wastes into the Ground, Proceedings of a Joint IAEA/ENEA Symposium, Vienna, Austria, May 29-June 2, 1967. International Atomic Energy Agency, Vienna, Austria, (pp. 479-494). (1967)

The solution method of creating a cavity in a salt dome is described. The mechanism for introduction of the radioactive waste into the cavity and the problems involved are explained (bore-hole diameter, method of introduction, etc). Economic consider: ations are presented for a cavity of $10,000 \mathrm{cu}$. meters, and the influence on the cost of parameters such as depth and diameter of the bore-hole and size of the cavity is investigated.
SUBJECT CATEGORY: HLW

ORIGIN: Foreign

KEYWORDS: RADIOACTIVE WASTE DISPOSAL; ECONOMICS; GERMAN FEDERAL REPUBLIC; SALT DEPOSITS; COST

140

Wheeler, B.R., B.R. Dickey, G.E. Lohse, D.E. Black, D.W. Rhodes, and J.A. Buckham; Idaho Nuclear Corp., Idaho Falls, ID

STORAGE OF RADIOACTIVE SOLIDS IN UNDERGROUND FACILITIES - CURRENT ICPP PRACTICES AND FUTURE CONCEPTS. STI/PUB-156; CONF-670512; Disposal of Radioactive Wastes Into the Ground, Proceedings of a Joint IAEA/ENEA Symposium, Vienna, Austria, May 29-June 2, 1967, (pp. 421-440). (1967)

High-activity granular solids are stored in stainless-steel bins inside a buried concrete vault at the Idaho Chemical Processing Plant for about $\$ 1500$ cu. meter. Laboratory work shows that no fission products will be released from the stored solids and safety aspects of storage at high temperatures are being studied to reduce further the expense of solids storage. An appreciable reduction in costs for solids storage facilities could be realized by omitting the concrete vault and burying bins directly in the soil.

SUBJECT CATEGORY: HLW; Isolation

ORIGIN: Commercial

KEYWORDS: RADIOACTIVE WASTE STORAGE; RADIOACTIVE WASTE MANAGEMENT; UNDERGROUND DISPOSAL; ECONOMICS; ICRP; SOILS; MATHEMATICS; FISSION PRODUCTS; SOLID WASTES; COST; IDAHO CHEMICAL PROCESSING PLANT

141

Malasek, E.; International Atomic Energy Agency, Vienna, Austria

TREATMENT OF RADIOACTIVE WASTES IN BULGARIA, CZECHOSLOVAKIA, THE GERMAN DEMOCRATIC REPUBLIC, HUNGARY, POLAND AND ROMANIA. Atomic Energy Review 5(4):151-167. (1967)

Tables, References 
Research work on decontamination and treatment of radioactive waste is directed towards improving existing methods of decontamination, treatment and storage, and also towards the discovery and use of progressive technological processes and new materials giving a number of advantages over those used at present. The purpose of the investigations is to increase the efficiency of decontamination, to concentrate the radioactivity in the solid phase, to reduce the volume of waste, and to lower the cost of its treatment and storage.

SUBJECT CATEGORY: LLW; HLW; TRU

ORIGIN: Foreign

KEYWORDS: DECONTAMINATION; RADIOACTIVE WASTE PROCESSING; SOLIDIFICATION; CZECHOSLOVAKLA; GERMAN DEMOCRATIC REPUBLIC; HUNGARY; POLAND; RADIOISOTOPES; BULGARIA; RUMANIA

\section{2}

International Atomic Energy Agency, Vienna, Austria

WASTE MANAGEMENT RESEARCH ABSTRACTS NO. 3. International Atomic Energy. Agency Compilations 103 pp. (1967)

This document is a compilation of abstracts of waste-management research completed in 1966 and forwarded to the IAEA. Includes contibutions from 10 countries. General areas convered are: gaseous wastes treatment and disposal, liquid waste treatment, solid waste treatment, storage and discharge studies, and economic studies.

\section{SUBJECT CATEGORY: General}

ORIGIN: Foreign

KEYWORDS: IAEA; MARINE DISPOSAL; RADIOACTIVE WASTE DISPOSAL; ECONOMICS; LIQUID WASTES; SOLID WASTES: GASEOUS WASTES; RADIOACTIVE WASTE MANAGEMENT; MONITORING

\section{3}

International Atomic Energy Agency, Vienna, Austria
OPERATION AND CONTROL OF IONEXCHANGE PROCESSES FOR TREATMENT OF RADIOACTIVE WASTES. STI/DOC/10/78; 147 pp. (1967)

Figures, tables, references

A manual dealing with the application of ionexchange materials to the treatment of radioactive wastes and reviewing the facilities currently using this method. This book is one of three commissioned by the IAEA on the three principal methods of concentrating radioactive wastes and was prepared by L.A. Emility. Contents: Introduction, historical review related to removal of radioactivity, principlen of ion exchange, ion-exchange materiälo, limilatiuns of ion exchangers, application of ion exchange to waste processing, operational procedures and experiences, costs of treatment by ion exchange, appendixes, glussary, tables, references, and bibliography.

\section{SUBJECT CATEGORY: LLW}

ORIGIN: Foreign

KEYWORDS: BIBLIOGRAPHIFS; DESIGN; IAEA; LIQUID WASTES; ECONOMICS; ION EXCHANGE; EQUIPMENT; MANUALS; RADIOACTIVE WASTE PROCESSING

\section{4}

Ramdohr, H.; Kernforschungszentrum, Karlsruhe, Germany, F.R.

WHITHER WITH ATOMIC WASTE. ORNL-tr1701; 17 pp.; Wiss. Tech. 67:219-224. (1967)

\section{Translated from UMSCH}

Describes the nature of radioactive waste and outlines past and current methods for disposal and containment. Forecasts waste quantities in West Germany and planned disposal practices.

SUBJECT CATEGORY: HLW; LLW; TRU

ORIGIN: Foreign

KEYWORDS: RADIOACTIVE WASTE DISPO. SAL; RADIOACTIVE WASTE STORAGE; RADIOACTIVE WASTE MANAGEMENT; GERMAN FEDERAL REPUBLIC; VOLUME; FORECASTING 
145

Blanco, R.E., J.O. Blomeke, and J.T. Roberts; Oak

Ridge National Laboratory, Oak Ridge, TN

SOLVING THE WASTE DISPOSAL PROBLEM. Nucleonics 25(2):58-61, 68. (1967)

2 tables

By the year 2000, U.S. Nuclear Power Plants will have accumulated over 5000 tons of fission products. Solidification of liquid waste from fuel reprocessing followed by storage in salt mines represents a safe and economical method of disposal. Cost of solidification, shipping 1000 miles, and ultimate disposal in salt is estimated at less than $1 \%$ of the total cost of 3 mills $/ \mathrm{Kw}$ hr nuclear power. Other advantages of the proposed method include low mobility of the solid waste, low surveillance requirements, low solubility, and safer heat removal.

SUBJECT CATEGORY: Spent Fuel

ORIGIN: Commercial

KEYWORDS: TRITIUM; RADIOACTIVE WASTE DISPOSAL; ECONOMICS; RADIOACTIVE WASTE PROCESSING; COST; TRANSPORT; RADIOACTIVE WASTE MANAGEMENT; SALT DEPOSITS; UNDERGROUND DISPOSAL; SPENT FUELS

\section{6}

Blanco, R.E., and F.L. Parker; Oak Ridge National Laboratory, Oak Ridge, TN

WASTE TREATMENT AND DISPOSAL SEMIANNUAL PROGRESS REPORT, JULYDECEMBER 1966. ORNL-TM-1887; 139 pp. (1967)

Figures and tables

Topics covered in this report are - treatment of high level radioactive waste, treatment of low- and intermediate-level radioactive waste, engineering, economics, and safety evaluations in connection with power-reactor waste management, separation of noble gases from air using permselective membranes, earthquakes and reactor plant design, disposal in natural salt formations, disposal by hydraulic fracturing, fate of radionuclides in terrestrial environment, application of mineral exchange, safety evaluations.
SUBJECT CATEGORY: HLW; LLW

ORIGIN: Defense

KEYWORDS: CESIUM; COBALT; KRYPTON; TRITIUM; RADIOACTIVE WASTE DISPOSAL; RADIOACTIVE WASTE STORAGE; RADIOACTIVE WASTE PROCESSING; RADIOACTIVE WASTE MANAGEMENT; RADIOACTIVE AEROSOLS; HYDRAULIC FRACTURING; RADIONUCLIDE MIGRATION; SOIL CHEMISTRY; ECONOMICS; HIGH-LEVEL RADIOACTIVE WASTES; LOW-LEVEL RADIOACTIVE WASTES; INTERMEDIATE-LEVEL RADIOACTIVE WASTES; SALT DEPOSITS; EARTHQUAKES; DESIGN; RARE GASES; SAFETY ENGINEERING

\section{7}

Brooksbank, R.E., and W.T. McDuffie; Oak Ridge National Laboratory, Oak Ridge, TN

CURRENT PRACTICES IN THE DISPOSAL OF RADIOACTIVE WASTES FROM FUELFABRICATION FACILITIES. Nuclear Safety 8(4):385-90. (1967)

2 tables, 15 references

Reviews current practices of typical commercial nuclear fuel-fabrication firms in the U.S. in storing and handling wastes. Both the sources and the types of waste generated in normal fuel fabrications by a 13-member group of firms surveyed by questionnaire and personal contact are described. Typical practices and techniques in handling, storage, and disposal of wastes, include baling and/or drumming of compressible wastes, incineration of combustible waste coupled with incorporation of the ash in concrete in steel drums equipped with heavy-duty forged closure rings, incorporation of both liquid and solid noncombustible wastes in concrete or concrete-vermiculite mixtures in steel drums, and the treatment and disposal of the largevolume wastes, such as ventilation air and cooling water. The health and safety aspects of these are discussed briefly, and applicable regulations are included in the list of references.

SUBJECT CATEGORY: LLW

ORIGIN: Commercial

KEYWORDS: RADIOACTIVE WASTE DISPOSAL; RADIOACTIVE WASTE STORAGE; RADI- 
OACTIVE WASTE PROCESSING; RADIOACTIVE . WASTE MANAGEMENT; FUEL FABRICATION PLANTS; LIQUID WASTES; SOLID WASTES; GASEOUS WASTES

148

McClain, W.C.; Oak Ridge National Laboratory, Oak Ridge, TN

HYDRAULIC FRACTURING AS A WASTE DISPOSAL METHOD. ORNL-P-3054; CONF. 670512-4; 20 pp. (1967)

See Also NSA 17:39297, 19:8674, 20:28856, 35175, 21:41191, 25:54971

A method is described for the subterranean disposal of radioactive waste. The method which is based on hydraulic fracturing consists of pumping a mixture of aqueous waste and cements into a nearly horizontal fracture located in a deep shale formation. After injection of the mixture, the cements serve as a confining seal for the radioactive waste. The most economic cement solution was found to consist of Portland cement (Type II), fly ash, attapulgite clay to present phase separation, illite (Grundite) to serve as retention of radiocesium, and a retarder (Delta Gluconolactone). Analysis of the stresses and deformations induced around the injected mixtures indicates that any failure of the rock barrier will cause a vertical fracture rather than an extended horizontal fracture. A method of calculating the maximum capacity of a fracture facility in terms of allowable stresses is presented. Data on cost analysis and evaluation procedures for possible sites are also presented.

SUBJECT CATEGORY: Isolation; LLW

ORIGIN: Defense

KEYWORDS: RADIOACTIVE WASTE DISPOSAL; HYDRAULIC FRACTURING; UNDERGROUND DISPOSAL; GEOLOGY; HYDROL OGY; GROUND WATER; CONCRETES; CEMENTS; CONTAINMENT; ECONOMICS; MONITORING; SITE SELECTION; CESIUM; ORNL;

149

Kom, A.M.; Oak Ridge National Laboratory, Oak Ridge, TN

INCORPORATION OF INTERMEDIATELEVEL WASTE IN ASPHALT. PRELIMI-
NARY DESIGN AND COST ESTIMATE OF A FULL-SCALE PLANT FOR ORNL. ORNL-TM$1697 ; 23$ pp. (1967)

Six figures, 3 tables, 17 references

The waste-asphalt process is an evaporation process. A wiped-film evaporator operating at $320 \mathrm{~F}$ mixes emulsified asphalt with concentrated intermediate-level waste from the ORNL waste evaporator, volatilizes the water, and yields a product (consisting of waste solids dispersed in asphalt) that, after being collected in 55-gal drums, is suitable for either long-term storage of burial. The total capital cost for building and equipment was estimated to be $\$ 330,500$. The unit. nperating cost. based on proncessing $400,000 \mathrm{gal}$ of LLW pcr ycar, was estimated at $\$ 0.34 / \mathrm{gal}$ assuming 20 -yeur amortization of capital without interest, or $\$ 0.37 /$ gal, assuming 20 -year a mortization with $1 \%$ interest. Estimates of possible reductions in operating costs through the direct discharge of the asphalt product into radial trenches from a semiportable unit, which would eliminate the need for individual barrels, are not available.

SUBJECT CATEGORY: HLW; LLW

ORIGIN: Defense

KEYWORDS: SOLIDIFICATION; RADIOACTIVE WASTE STORAGE; COST; ASPHALTS; LIQUID WASTES; SOLID WASTES; INTERMEDIATE-LEVEL RADIOACTIVE WASTES; EVAPORATION

160

Tadmor, J., and K.E. Cowser; Oak Ridge National Laboratory, Oak Ridge, TN

UNIERGROUND DISPOSAL OF KR-85 FROM NUCLEAR FUEL REPROCESSING PLANTS. ORNL-P-3246; 23 pp.; Nuclear Engineering and Design 6(3):243-250. (1967)

1 figure, 36 references

Evaluates the different methods for large-scale removal of $\mathrm{Kr}-85$ from the off-gas stream of a processing plant and the feasibility of underground disposal of $\mathrm{Kr} 85$. Although the apparent advan. tages of underground disposal are its relative simplicity and effectiveness, one severe require ment is that the disposal formation must be essentially free of vertical channels. The principal mechanisms by which $\mathrm{Kr}-85$ may be retarded or 
retained underground include adsorption and trapping. In the absence of convective transport, vertical underground movement is influenced by molecular diffusion. These mechanisms are evaluated for quantities of $\mathrm{Kr}-85$ and volumes of off-gas assumed to be produced at a 10 ton/day reprocessing plant.

SUBJECT CATEGORY: Isolation; Airborne

ORIGIN: Defense; Commercial

KEYWORDS: ADSORPTION; DIFFUSION; GEOLOGY; KRYPTON 85; CONTAINMENT; RADIOACTIVE WASTE DISPOSAL; FUEL REPROCESSING PLANTS; FUEL ELEMENTS; REPROCESSING; GASEOUS WASTES; UNDERGROUND DISPOSAL

151

Oak Ridge National Laboratory, Oak Ridge, TN

HEALTH PHYSICS DIVISION ANNUAL PROGRESS REPORT FOR PERIOD ENDING JULY 31, 1967. PART I. RADIOACTIVE WASTE DISPOSAL. ORNL $4168 ; 1-60$ pp. (1967)

33 figures, 8 tables, 99 references

Research is reported on: (1) fate of radionuclides in terrestrial environment, (2) disposal by hydraulic fracturing, (3) disposal in natural salt formations, (4) application of mineral exchange to reactor technology, (5) engineering, economic, and safety evaluations, (6) earthquakes and reactor design, (7) dose-estimation studies related to proposed construction of an Atlantic-Pacific interoceanic canal with nuclear explosives, and (8) related cooperative projects.

SUBJECT CATEGORY: General; LLW; HLW

ORIGIN: Defense

KEYWORDS: CESIUM; ECONOMICS; KRYP. TON; PLOWSHARE PROJECT; SOILS; RADIONUCLIDE MIGRATION; TRITIUM; RADIOACTIVE WASTE DISPOSAL; RADIOACTIVE WASTE STORAGE; ORNL; GASEOUS WASTES; RADIOACTIVE WASTE MANAGEMENT; CURIUM; MINERAL CYCLING; SORPTION; HYDRAULIC FRACTURING; SALT DEPOSITS; GEOLOGY; SAFETY; ROCK MECHANICS; PLANTS; CONCENTRATION
152

Philadelphia Electric Co., Philadelphia, PA

QUESTION 4.3-MAXIMUM RADIOACTIVE INVENTORY OF LIQUID WASTE. DOCKET50277; DOCKET-50278; Preliminary Safety Analy. sis Report, Peach Bottom Atomic Power Station Units 2 and 3, Supplement 1, 2 pp. (1967)

Provide the maximum radioactivity inventory of liquid wastes to be in storage tanks at the site at any one time. Include isotopic analysis, concentrations, and batch sizes. Discuss the potential for release of radioactive inventory from these tanks. (Answer) items listed total about 200 curies.

SUBJECT CATEGORY: TRU; HLW; LLW

ORIGIN: Commercial

KEYWORDS: BWR TYPE REACTORS; RADIOACTIVE WASTE DISPOSAL; RADIOACTIVE WASTE STORAGE; PEACH BOTTOM-2 REACTOR; US NRC; LIQUID WASTES; INVENTORIES

153

Trauth, C.A.; Sandia Laboratory, Albuquerque, NM

A SYSTEMS APPROACH TO CONTAMINATION CONTROL. SC-DC-67-2101; 51 pp. (1967)

13 references

Contamination control, in spite of its increasing importance, is still a subject suffering from a lack of cohesiveness. This situation obtains because there is no theory of contamination control which applies to all specific contamination control problems and encompasses all types of contamination control techniques. This paper represents an attempt to formulate a framework in which such a theory may be developed on a cost-effectiveness basis.

SUBJECT CATEGORY: General

ORIGIIN; Commercial

KEYWORDS: ECONOMICS; HUMAN POPULATIONS; COST; NUCLEAR MATERIALS MAN. AGEMENT; CONTAMINATION REGULATIONS; CONTAMINATION; ENVIRONMENT 
154

Kolychev, B.S., and V.M. Sedov; State Committee on the Utilization of Atomic Energy, Moscow

THE PRESENT STATE AND PROSPECTS OF DEVELOPMENT IN RADIOACTIVE WASTE MANAGEMENT IN THE USSR. Atomic Energy Review 5(4):123-150. (1967)

Figures, Tables, References

The development of commercial atomic energy, the use of radioisotopes in science, industry and medicine, the use of atomic energy in many types of human activities, in particular, for sea-water desalination, depend considerably on the rational and economical solution of the radioactive waste treatment and disposal problem. The significance of this problem is appreciated the the USSR, where great attention is therefore paid to the elaboration of new processing methods and the improvement of existing methods. Research and development are being carried out to improve the liquid waste decontamination, reduce the solid and liquid waste volumes, acheive their safe burial, decrease the operating costs and create new materials and apparatus for radioactive waste processing.

SUBJECT CATEGORY: General

ORIGIN: Foreign

KEYWORDS: CESIUM; DECONTAMINATION; GEOLOGY; STRONTIUM; RADIOACTIVE WASTE PROCESSING; RADIOACTIVE WASTE MANAGEMENT; CONTAMINATION; VOLUME; SOLID WASTES; LIQUID WASTES

155

Osloond, J.H.; U.S. Atomic Energy Commission, Health and Safety Division, Idaho Falls, ID

RADIOACTIVE WASTE DISPOSAL DATA FOR THE NATIONAL REACTOR TESTING STATION. IDO-12040; 36 pp. (1967)

Summarizes the data pertaining to the disposal of radioactive waste at the National Reactor Testing Station. The volumes of liquid, gaseous, and solid wastes are reported, with the concentration and total amounts of contained nuclides given. Detailed information is listed for the years 1962 through 1964. Yearly summary totals are listed for the years since 1955.

SUBJECT CATEGORY: HLW; LLW; TRU
ORIGIN: Defense

KEYWORDS: RADIOACTIVE WASTE DISPOSAL; LIQUID WASTES; SOLID WASTES; GASEOUS WASTES; RADIOACTIVE WASTE MANAGEMENT; VOLUME; INVENTORIES

156

Howells, H.; United Kingdom Atomic Energy Authority, Sellafield, England

TRENCH DISPOSAL OF SOLID RADIOACTIVE WASTE FROM THE WINDSCALE AND CALDER WORKS OF THE UKAEA. STI/PUB156; CONF-670512; Dispogal of Radioactive Wastes into the Ground, Proceedings of a Joint IAEA/E NEA Symposium, Vienna, Austria, May 29-June 2, 1967. International Atomic Energy Agency, Vienna, Austria, (pp. 3-13), 666 pp. (1967)

Windscale and calder works of the UKAEA is situated in Cumberland on the northwest coast of England. Large volumes of low-activity and suspect active solid wastes arise both from process and laboratory operations. The total quantity is about 1000 tons/yr, with an uncompressed volume of about $6000 \mathrm{cu}$. meters. It is impracticable to use monitoring as a method of segregation into active and inactive fractions. Consequently, all the material must be treated as radioactive waste and disposed of correspondingly. A study of the relative cost of disposal methods has emphasized the expense of pretreatment such as incineration or baling and shown that local burial without treatment is by far the cheapest method of disposal.

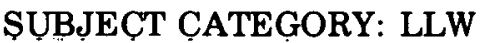

ORIGIN: Foreign

KEYWORDS: LIQUID WASTES; UNITED KINGDOM; CLIMATOLOGY; GROUND DISPOSAL; COST; SOLID WASTES; WASTE TRANSPORTATION; ECONOMICS; UKAEA; RADIOACTIVE WASTE DISPOSAL

157

Virginia Electric and Power Company

QUESTION 6.2 - AVERAGE GAS STRIPPING RATE AND AVERAGE ANNUAL LETDOWN FLOW RATE. DOCKET-50280; DOCKET50281; Amendment 4 (Supplement Volume 1) to the License Application for Surry 1 and 2, pp. S6.21-S6.2.2). (1967) 
To ascertain if the waste disposal system is adequately sited, discuss the basis for the assumptions made in determining the magnitude of the hydrogen stripping rate and the average annual letdown flow rate. To what extent have the large volumes of liquid waste associated with boron dilution or cooldown and subsequent heatup been consideed.

SUBJECT CATEGORY: General

ORIGIN: Commercial

KEYWORDS: HYDROGEN; PWR TYPE REACTORS; RADIOACTIVE WASTE DISPOSAL; US NRC; REPORTS; SURRY-1 REACTOR

158

Gailledreau, C., and C. Berlin

EXPERIMENTAL STORAGE OF RADIOACTIVE WASTE AT. SHALLOW. DEPTH. STI/PUB/156; CONF-670512; Disposal of Radioactive Wastes into the Ground, Proceedings of a Symposium, Vienna, Austria, May 29-June 2, 1967. International Atomic Energy Agency, Vienna, Austria, (pp. 251-259), 666 pp. (1967)

In French

Solid radioactive waste may be stored safely in the soil at shallow depths provided it lies above the water table and is protected from any significant infiltration by rainwater. A facility has been constructed whereby the buried waste is covered by a polyethylene umbrella with a surrounding drain. The walls and bottom of the waste pit itself are highly permeable and are made of large pebbles to catch any ground water diffusing laterally into the facility. Water from the drain surrounding the umbrella and from the bottom drain flows by gravity towards a nearby ravine, the the bottom drain passing into a monitoring sump. To reduce water condensation beneath the umbrella, the latter is covered by a mound of earth $30-50 \mathrm{~cm}$ thick with turf on top, which acts as a thermal screen. The amount of water in the area in which the waste is stored - $20 \mathrm{mCi}$ of fission products - and in the soil outside the facility is measured with a neutron moisture gauge, and the results of these measurements are given in the paper. It has been found that the volume filled by the waste constantly remains dry. The results of monitoring the drain sump are also quoted. Finally, an estimate of the cost price of such storage per unit volume is given. (Auth)
SUBJECT CATEGORY: LLW

ORIGIN: Foreign

KEYWORDS: RADIOACTIVE WASTES; SOLID WASTES; RADIOACTIVE WASTE STORAGE; RADIOACTIVE WASTE MANAGEMENT; GROUND DISPOSAL; COST; ECONOMICS; DIFFUSION

159

Halbouty, M.T.

SALT DOMES: GULF REGION, UNITED STATES AND MEXICO. Gulf Publishing Company, Houston, TX. (1967)

Chapters are devoted to: evaporite deposition in the Gulf Region, origin and growth of salt structures, configuration and composition, classification of salt structures, accumulation of gas and oil, factors affecting quantity of accumulation, economic significance of salt structures, and salt dome drilling and production problems. Extensive bibliography is included.

SUBJECT CATEGORY: Isolation

ORIGIN: Commercial

KEYWORDS: ALABAMA; CLASSIFICATION; DEPOSITION; ECONOMICS; GEOLOGY; LOUISIANA; MEXICO; MISSISSIPPI; NATURAL GAS DEPOSITS; ORIGIN; PETROLEUM DEPOSITS; RADIOACTIVE WASTE DISPOSAL; SALT DE. POSITS; TEXAS; UNDERGROUND DISPOSAL; UNDERGROUND STORAGE

160

Lenneman, W.L.

U.S. ATOMIC ENERGY COMMISSION INTERIM RADIOACTIVE WASTE BURIAL PROGRAM. STI/PUB/156; Disposal of Radioactive Wastes into the Ground, Proceedings of a Joint IAEA/ENEA Symposium, Vienna, Austria, May 29-June 2, 1967. International Atomic Energy Agency, Vienna, Austria, (pp. 261-300), 666 pp. (1967)

A general description of the waste management services including burial practices, costs, and packaging following the announcement that INEL and ORNL would accept waste from AEC licenses. 
Early in 1960, the U.S. Atomic Energy Commission (AEC) provided industry with radioactive waste disposal service in strategic locations within the United States. It announced that radioactive waste burial grounds at Oak Ridge, Tennessee, and the National Reactor Testing Station, Idaho, would be made available to AEC licenses for the disposal of solid radioactive wastes. For the next three years, the AEC had an interim radioactive waste burial program which was terminated when privately operated grounds, serving regional areas of the country, became available. The paper does not go into detail concerning the physical handling, treatment, or preparation of solid radioactive waste, per se, or the actual operations of a waste burial ground, but principally covers the administrative processes, treatment and procedures of a national radioactive waste burial program. All AEC radioactive waste burial grounds and operations were coordinated and a common reporting system and administrative controls were established for radioactive waste burials. Procedures were established for handling off-site and licensee waste shipments and deliveries to the interim burial grounds. Complete records were maintained of the disposition of the 7.2 million cu $\mathrm{ft}$ (203 thousand $\mathrm{cu} \mathrm{m}$ ) of AEC and licensee generated waste which was buried during the three-year period. Radioactive waste classification, handling procedures, reporting forms and sytems, administrative controls, and numerous problems and their resolutions are presented and discussed. Waste burial data and burial costs for the program are given. Post-1963 United States radioactive waste burial data and information through 1966 also are included. (Auth)

SIIRIECT CATFGORY: IIIW

ORIGIN: Cummercial

KEYWORDS: WASTE TRANSPORTATION; ECONOMICS; CONTAMINATION; SOLID WASTES; LOW-LEVEL RADIOACTIVE WASTES; HIGH-LEVEL RADIOACTIVE WASTES; INTERMEDIATE-LEVEL RADIOAC. TIVE WASTES; SOLIDIFICATION; COST; GROUND DISPOSAL; ORNL

161

Marter, W.L.

GROUND DISPOSAL PRACTICES AT THE SAVANNAH RIVER PLANT. STI/PUB/156; CONF-670512; Disposal of Radioactive Wastes into the Ground, Proceedings of a Joint IAEA/ENEA Symposium, Vienna, Austria, May 29-June 2, 1967, (pp. 95-105), 666 pp. (1967)
This report is chiefly a general summary without a great amount of hard data.

A description of the general ground waste disposal practices at SRP are detailed in this report. The discussion is based on experience in solid waste land burial since 1953 . The contaminated waste buried at the time of this report contained approximately 1.5 million curies of activation and fission product radionuclides along with 9,000 curies of transuranic elements. Low-level wastes which do not include transuranic activity exceeding 100 millicuries per waste container is buried in 6 meter deep trenches located 4 to 12 meters above the water table. Transuranic wastes are placed in concrete containers and then buried. Alpha waste is segregated from beta and gamma waste and the beta and gamma waste is further segregated into high and low level categories. The average cost for land burial was estimated to be 35 dollars per cu $m$. At the time this report was written, significant levels of activity resulting from migration had not been observed along the flood plains of the adjacent tributaries. The report also contains a discussion of the success of the seepage pit program at SRP including cost estimates, the observance of tritium breakthrough at the pits closest to the tributary, and the operational procedures adopted.

\section{SUBJECT CATEGORY: TRU; LLW; HLW}

ORIGIN: Defense

KEYWORDS: ADSORPTION; CLAYS; FISSION PRODUCTS; GEOLOGY; GROUND WATER: TRITIUM; RADIOACTIVE WASTE DISPOSAL; TRANSURANIUM ELEMENTS; GROUND RE LEASE; RADIOACTIVE WASTE STORAGE; LOW-LEVEL RADIOACTIVE WAS'IES; ECONOMICS

\section{2}

COS'T OF'TREATMENT OF ION EXCHANGE. Technical Report Series No. 78; Operation and Control of Ion-Exchange Processes for Treatment of Radioactive Wastes, Chapter 8, (pp. 78-84), 147 pp. (1967)

Cost analysis of ion exchange, pre-burial waste processing is discussed.

A large number of variables are involved in comparing costs of use of ion exchange for waste treatment among various sites. In addition to the normal variables such as differences in wage rates and costs of materials, few facilities are identical in their manner of employing ion exchange, the extent 
to which it is employed or the type of solution being processed. In many facilities ion exchange is established as a polishing operation to be used when effluent activities have not been reduced sufficiently by other means. Building and equipment costs are included in the capital cost items to be considered. The comparative costs of vertical storage tanks constructed of a number of materials increase with increasing capacity. The range of investments in existing ion-exchange facilities is provided in the 5 included test examples. Operating cost estimates for ion exchange should include: (1) labor (actual cost including benefits), (2) chemicals (cost of exchanger and regenerant chemicals), (3) utilities, services (costs of steam, gas, electricity, plus the costs of services specifically assigned to the ion exchange operation), (4) current maintenance (cost of maintaining the ion exchange facility in good repair), (5) direct or operating overheads (costs of supervisor, secretarial, and clerical staff, insurance, travel, etc.), (6) depreciation (the annual charge for amortization based on 20 year building life and $71 / 2$ year equipment life), and (7) total costs (this will not include cost of general overheads or applied research). The operating cost per cubic meter of waste treated ranged from $\$ 0.79$ to $\$ 36.50$ for several installations which vary widely in their application of ion exchange to waste processing. An equation is provided for calculation of total operating costs.

\section{SUBJECT CATEGORY: LLW}

ORIGIN: Defense; Commercial

KEYWORDS: COST BENEFIT ANALYSIS; ION EXCHANGE; RADIOACTIVE WASTE PROCESSING; COST; SOLIDIFICATION; EQUATIONS

\section{8}

\section{3}

Ramarathinam, K., A.A. Khan, K.G. Subramaniam, R.V. Amalraj, and K.T. Thomas; Bhabha Atomic Research Center, Trombay, Bombay, In dia

AIR-CLEANING OPERATIONAL EXPERIENCE IN THE BHABHA ATOMIC RESEARCH CENTER, TROMBAY.STI/PUB/195; SM-110/53; Operating and Developmental Experience in the Treatment of Airborne Radioactive Wastes, Proceedings of a Symposium, August 26-30,
1968. International Atomic Energy Agency, New York, New York, (pp. 683-893), 818 pp. (1968)

The details of the operational experience gathered in the Bhabha Atomic Research Center on various aspects of the problem associated with the control of pollutants from the operation of nuclear facilities housed therein are discussed. A short account of the standards for radioactive gaseous waste management and the general practices concerning the prevention and control of air contamination is given. Studies on airborne radioactivity and the operational experience of the ventilation systems connected with some of the installations at Trombay are reviewed. The cost aspects of a typical ventilation system of an operating plant are presented. (Auth)

SUBJECT CATEGORY: Airborne

ORIGIN: Foreign

KEYWORDS: AIR POLLUTION; GASES; ECONOMICS; NUCLEAR FACILITIES; CONTAMINA. TION; VENTILATION SYSTEMS

\section{4}

Seyfried, P.; Commissariat a l'Energie Atomique, Chusclan, France

SOME CRITERIA FOR CHOOSING PRESSES FOR THE COMPACTION OF RADIOACTIVE WASTE. CEA-R-3619; 27 pp. (1968)

7 references, figures; in French

The choice of a press for compacting low-activity radioactive waste depends on the possibility of recovering the collection containers and the final storage containers. These factors will determine the general organization of the machine and the possible limitations to the compacting pressures. The nature of the waste then makes it possible to determine the optimum pressure corresponding to the best compression power. It seems that it is possible to distinguish two types of waste according to their behaviour on compaction. The cost of the machines is related to the pressure chosen.

\section{SUBJECT CATEGORY: LLW}

ORIGIN: Foreign

KEYWORDS: SOLID WASTES; ECONOMICS; COMPACTING; CONTAINERS; RADIOACTIVE 
WASTE MANAGEMENT; LOW-LEVEL RADIOACTIVE WASTES

165

Warner, D.L.; Department of the Interior, Washington, DC

SUBSURFACE DISPOSAL OF LIQUID INDUSTRIAL WASTES BY DEEP-WELL INJECTION. Subsurface Disposal in Geologic Basins - A Study of Reservoir Strata, 1968, (pp 11-20). (1968)

\section{2 figures, references}

Dispusal of concentrated, unusable, relatively untreatable liquid wastes is an important problem in water-pollution control. Deep-well injection is nne. means for disposing of such wastes. The feasibility of deep-well injection depends on site suitability, waste characteristics, economics, and legal considerations. Geologic factors determine site suitahility and have an important influence on economics and the suitability of waste for injection. Thus, careful geologic evaluation is a prerequisite for deep-well waste injection.

SUBJECT CATEGORY: Isolation

ORIGIN: Defense; Commercial

KEYWORDS: ECONOMICS; GEOLOGY; LAWS; RADIOACTIVE WASTE DISPOSAL; LIQUID WASTES; INJECTION WELLS; UNDERGROUND DISPOSAL

166

Rickles, R.N.; Dorr-Oliver Inc., Stamford, CT

ENCAPSULATION OF HIGH-LEVEL NUCLEAR WASTES. CONF-641137; Disposal of Process Wastes, Proceedings of a Symposium, Frankfurt am Main, Germany, 1968. (pp. 107136). (1968)

The requirements for practical economic encapsula. tion systems for the long-term permanent storage of high-level nuclear wastes are discussed. The present status of research and development efforts in this area is reviewed. A logical application of those requirements to present development programs indicated that they do not recognize the overall requirements for safe and practical disposal of these wastes. Furthermore, these requirements indicate that certain directions should be followed in the development of optimum processes. Several new proposals for development efforts are presented together with defining technological and economic parameters.

SUBJECT CATEGORY: HLW; Isolation

ORIGIN: Commercial; Defense

KEYWORDS: RADIOACTIVE WASTE STORAGE; UNDERGROUND DISPOSAL; ENCAPSU. LATION

\section{7}

Hild, W., G.F. Lazzaretto, A. Hasler, and E. LopezMenchero; European Company for the Chemiral Processing of Irradiated Fuels, Mol, Belgium

THE NEUTRALIZATION SELF. SOLIDIFICATION PROCESS (NSSP) STA'TUS OF THE' DEVELOPMENT WORK. NP. 18306; 90 pp. (1968)

A preproject for an NSSP plant treating eurochemic MLW is described. This project is based on the results of development work carried out up to August 1967. An ernnnmic evaluation of this plant preproject shows that optimum working conditions are obtained for a plant capacity of 1 M3 MLW per hour. At this capacity the treatment costs amount to $434 \mathrm{M} 3$ or $0.0302 \mathrm{mill} / \mathrm{KW} \cdot \mathrm{hr}$ if the treatment costs are related to the electrical energy produced.

SUBJECT CATEGORY: HLW

ORIGIN: Foreign

KEYWORDS: RADIOACTIVE WASTE STORAGE; SOLIDIFICATION; RADIOAC'IIVE WASTE MANAGEMENT; ECONOMICS; COST; EUROCHEMIC; EQUIPMEN'

168

European Nuclear Energy Agency, Paris, France; Organization for Economic Co-Operation and Development, 75 - Paris, France

RADIOACTIVE WASTE DISPOSAL OPERA'TION INTO THE ATLANTIC 1967. ENEAOECD Report; 42 pp. (1968)

A disposal operation by five participating countries. 
A suitable solution for some types of solid waste is by disposal, under carefully controlled conditions, into selected areas of the deep oceans. However, such operations raise international administrative and political, as well as scientific, technological and economic questions. To deal with these and to establish on an international basis the required operational controls for sea disposal of packaged solid wastes, an experimental in ternational operation was carried out in the summer of 1967 under the aegis of the European Nuclear Energy Agency (ENEA). Five Member countries of ENEA took part in the operation, and some 11,000 tons of solid waste, with a total activity of approximately 8,000 Curies, were depositied at a depth of 5,000 metres in the eastern Atlantic Ocean. This report describes the planning and carrying-out of the operation.

SUBJECT CATEGORY: Isolation

ORIGIN: Foreign

KEYWORDS: RADIOACTIVE WASTE MANAGEMENT; SOLID WASTES; ATLANTIC OCEAN; HAZARDS; EVALUATION; CONTAIN. ERS; PACKAGING; REGULATIONS; TRANSPORT; SHIPS; ECONOMICS; DECONTAMINA. TION; OECD; MARINE DISPOSAL; .SITE SELECTION; INVENTORIES

169

Van den Bossche, A.; Ingenieurgemeinschaft Kemverfahrenstechnik Igk, Dortmund, Germany

EXTRACTION OF FISSION PRODUCTS FROM HIGHLY RADIOACTIVE WASTE. Atomwirt. Atomtech. 13:453-454. (1968)

\section{In German}

The separation of highly radioactive fission products eases considerably the problem of the storage and disposal of radioactive waste. Liquid highly active waste from reprocessing plants must be stored in containers which, because of the necessary cooling plants and filtered ventilation systems, entail high costs. Two radioisotopes from the waste fission produce solution are meeting a steadily growing demand - Cesium-137 and Strontium-90. Various precipitation processes, ion-exchange processes, and solvent extraction processes were carried out with both these radioactive substances.

SUBJECT CATEGORY: HLW

ORIGIN: Foreign
KEYWORDS: CESIUM 137; STRONTIUM 90; RADIOACTIVE WASTE DISPOSAL; RADIOACTIVE WASTE STORAGE; FISSION PRODUCTS; ION EXCHANGE; PRECIPITATION; SOLVENT EXTRACTION; REPROCESSING

\section{0}

Kepak, F.; Inst. of Nuclear Research, Rez, Czech.

DECONTAMINATION OF RADIORUTHENIUM FROM RADIOACTIVE WATERS BY SORPTION ON INORGANIC AND ORGANIC SORBENTS. Jad. Energ. 14:131-133. (1968)

In Czech

Economic aspects of treating radioactive wastes by sorption are discussed. A brief review is given of methods for decontamination of Ruthenium isotopes from radioactive waste water by adsorp. tion on inorganic absorbers such as unsoluble metal sulfides and hydrates, hydrated oxides, phosphates, powdered metals, and natural absorbers and on cellulose base or humic acid absorbers, and organic ion changers.

\section{SUBJECT CATEGORY: LLW}

ORIGIN: Foreign

KEYWORDS: ADSORPTION; DECONTAMINATION; METALS; OXIDES; RUTHENIUM; LIQUID WASTES; PHOSPHATES; ECONOMICS; ION EXCHANGE; SORPTION; RADIOACTIVE WASTE PROCESSING

\section{1}

International Atomic Energy Agency, Vienna, Austria

WASTE MANAGEMENT RESEARCH ABSTRACTS NO. 4. International Atomic Energy Agency Compilation; 136 pp. (1968)

Provides abstracts of waste management research concerning the following: (1) gaseous wastes treatment and disposal, (2) liquid wastes treatment, (3) solid wastes treatment, (4) storage and discharge studies, and (5) economic studies.

SUBJECT CATEGORY: General

ORIGIN: Foreign 
KEYWORDS: MARINE DISPOSAL; GROUND DISPOSAL; RADIOACTIVE WASTE STORAGE; LIQUID WASTES; . GASEOUS WASTES; SOLID WASTES; RADIOACTIVE WASTE MANAGEMENT; ECONOMICS

172

International Atomic Energy Agency, Vienna, Austria

ECONOMICS IN MANAGING RADIOACTIVE WASTES. STI/DOC-10-83; 45 pp. (1968)

1 table

'l'he purpose of this report is to recommend for uniform reporting purposes a costing system. The system should include all aspects of the costs of waste management in order to provide a sufficiently accurate assessment of the true costs and a common standard of reporting. The study, at the request of the agency, was confined to radioactive wastes produced at research and development centres. Because definitions of low, intermediate, and high levels of radioactivity vary from site to site, no specific upper limit was set on wastes to be included in the study except to exclude wastes from the first extraction cycle of chemical processing for recovery of reactor fuel.

SUBJECT CATEGORY: General

ORIGIN: Forcign

KEYWORDS: RADIOACTIVE WASTE DISPOSAL; RADIOACTIVE WASTE STORAGE; MONITORING; WASTE TRANSPORTATION; RADIOACTIVE WASTE MANAGEMENT; ECONOMICS; COST; STANDARDS

173

Christenson, C.W.; Los Alamos Scientific Laboratory, Los Alamos, NM

TREATMENT OF HIGHLY RADIOACTIVE WASTES. LA-DC-10006; 28 pp. (1968)

This report is confined to the waste generated and handled at Hanford, U.S.A., because they have been in uperation the longest and have perhaps generated more wastes than at any other site. Of the several methods of processing nuclear fuel, the purex process is the most widely used. The purex process involves solvent extraction from a nitric acid solution using a blend of tributyl phosphate and kerosene. With the current operating experience and success of this process and its economic attractiveness, initial power fuel reprocessing plants will probably continue to use the purex process with some minor variations, which are also discussed.

SUBJECT CATEGORY: HLW

ORIGIN: Defense

KEYWORDS: RADIOACTIVE WASTE STORAGE; CALCINATION; PUREX PROCESS; RADIOACTIVE WASTES; HIGH-LEVEL RADIOAC. TIVE WASTES; ECONOMICS; FUEL REPROCEESSING PLANTS; HAPO

\section{4}

Christenson, C.W.; Los Alamos Scientific Laboratory, Los Alamos, NM

GROUND DISPOSAL OF LIQUIDS. LA-DC$10004 ; 11$ pp. (1968)

The use of the ground for disposal operations is based on two fundamental properties. First, the minerals from which the subsoils are composed generally have a marked sorption capacity for most uranium fiogion products as well as fur many uther radioisotopes. Secondly, the mass of soil covering a disposal provides good radiation shielding and permunent physical protection to people ahove ground. Ground disposal is discussed relative to its most important criteria, i.e., soil ty pe, proximity to streams, volume of waste, siting, hydrology, geology, and deep injections.

SUBJECT CATEGORY: LLW

ORIGIN: Defense

KEYWORDS: KADIOACTIVE WASTE DISPOSAL; LIQUID WASTES; RADIOACTIVE WASTE MANAGEMENT; HYDKULUGY; ION EXCHANGE; IJNDFRRROINND DISPOSAL; RADIONUCLIDE MIGRATION; ENVIRONMENTAL TRANSPORT

175

Niagara Mohawk Power Corp., Syracuse, NY

RESPONSE TO QUESTION VI.5-PROVE CLAIMS ON PARTITION FACTORS. 
DOCKET-50220; Amendment 5, Exhibit D-3 to the Nine Mile Point FSAR, 5 pp. (1968)

1 figure, 2 references, 3 tables

To evaluate how the Dresden-I primary coolant activity correlates to stack-release rates, complete data on flow paths, flow rates, volumes, etc., should be provided. (See figure 9.1-1 in Vermont Yankee amendment 3). Similar data is required for Nine Mile Point to understand claims for the noble gases and iodine transport factors and correlation to radioactive gaseous release rates. Present effect of stopping primary system cleanup for various times. (Answer on pages VI-3 thru VI-7).

SUBJECT CATEGORY: General; Airborne

ORIGIN: Commercial

KEYWORDS: BWR TYPE REACTORS; DRESDEN-1 REACTOR; NINE MILE POINT-1 REACTOR; REPORTS; OFF-GAS SYSTEMS;COOLING SYSTEMS; GASEOUS WASTES; IODINE; PARTITION; GASES

\section{6}

Bradshaw, R.L., J.J. Perona, J.O. Blomeke, and W.J. Boegly; Oak Ridge National Laboratory, Oak Ridge, TN

EVALUATION OF ULTIMATE DISPOSAL METHODS FOR LIQUID AND SOLID RADIOACTIVE WASTES. VI. DISPOSAL OF SOLID WASTES IN SALT FORMATIONS. ORNL-3358; 90 pp. (1968)

This is a study of the cost of disposing of high-level solidified wastes in bedded salt formations. A conceptual design of a salt mine is developed for disposal of wastes from the recovery of spent uranium and thorium reactor fuels from a 15,000 . MW (Electrical) Nuclear Power Economy. The waste products are contained in pots 6,12 , and 24 in. in diameter by $10 \mathrm{ft}$ long and are buried in vertical holes in the floor of a mine $1 \mathrm{sq}$ mile in area and located $1000 \mathrm{ft}$ below the surface. The operating life of this mine and the costs of the mining and disposal operations are calculated, using rather conservative mine stability criteria, for various waste ages, pot sizes, and waste compositions.

SUBJECT CATEGORY: Isolation

ORIGIN: Commercial
KEYWORDS: RADIOACTIVE WASTE DISPOSAL; RADIOACTIVE WASTE STORAGE; COST; ECONOMICS; SALT DEPOSITS; SPENT FUELS; UNDERGROUND DISPOSAL

\section{7}

Godbee, H.W., and J.H. Goode; Oak Ridge National Laboratory, Oak Ridge, TN

DEVELOPMENT OF A PROCESS FOR INCORPORATION OF RADIOACTIVE WASTE SOLUTIONS AND SLURRIES IN EMULSIFIED ASPHALT. ORNL-P-3863; 20 pp. (1968)

Figures, Tables, 16 References

Incorporation in asphalt is a promising method for preparing alkaline solutions and slurries of intermediate-level radioactive wastes for storage or burial. The wastes are mixed with an asphalt-water emulsion, the water is volatilized by heating the mixture to $160 \mathrm{C}$, and the residue containing the radioactive solids is drained into the final disposal container. The volume of waste to be stored is reduced by a factor of about 2. Products containing $60 \mathrm{wt} \%$ waste solids were homogeneous and showed satisfactorily low leach rates in water, with no significant increase at radiation (external Co-60) doses as high 10(9th) rads. No evolution of gases or swelling was observed in products that contained up to 52 curies per gallon as radiation doses up to $7 x$ $10(7$ th) rads.

\section{SUBJECT CATEGORY: LLW}

ORIGIN: Commercial

KEYWORDS: RADIOACTIVE WASTE PROCESSING; SOLIDIFICATION; ASPHALTS; SLURRIES; VOLUME

\section{8}

McClain, W.C.; Oak Ridge National Laboratory, Oak Ridge, TN

DISPOSAL OF RADIOACTIVE WASTES BY HYDRAULIC FRACTURING. ORNL-P-4196; 32 pp. (1968)

15 references

Although hydraulic fracturing has been shown to be a safe and economical method of waste disposal 
at Oak Ridge National Laboratory, it will be necessary to carry out an extensive site examination program before the technique can be used at any other location. The most difficult part of this site examination is proving that the hydraulically induced fractures in the underground rocks are horizontal or nearly so. A site-testing program which utilizes several methods of remote determination of fracture orientation is discussed, but confirmatory core holes from the surface intersecting the test grout sheets will be required.

SUBJECT CATEGORY: Isolation; LLW

ORIGIN: Defense

KEYWORDS: GEOLOGY; SEISMOLOGY; STRESS ANALYSIS; RADIOACTIVE WASTE DISPOSAL; SITE SELECTION; ECONOMICS; ORNL; HYDRAULIC FRACTURING; ROCK MECHANICS; REPROCESSING

\section{9}

Parker, F.L.; Oak Ridge National Laboratory, Oak Ridge, TN

\section{RADIOACTIVE WASTES FROM FUSION REACTORS. Science 159:83-84. (1968)}

Tritium production from thermonuclear reactors (fusion).

Long-term future for nuclear power generation is in brecder-fission or fusion. Cost/kilowatt-hrelectrical for thermonuclear power less than 4 mill$\mathrm{kwhr}$. Major problem of fusion reactor will be tritium loss. 300 megawatt-electrical power production requires fusion of 228 grams of tritium/day. Major amts tritium released not at reactor site but during fuel reprocessing. Assuming 30\% thermal efficiency per 1000 megawatt-electrical and 1.15 tritium atoms per 10,000 fissions, and $200 \mathrm{Mev} / \mathrm{fis}$ sion, a fission reactor would generate 50 curies/day of tritium $/ 1000$ megawatt-electrical, whereas a fusion reactor would generate $1,000,000$ curies/da (20,000 times as much). Cowser (ORNL-400') calcd that overall increase in dose rate to the human population from nuclear fuel reprocessing would be $0.002 \mathrm{mrem} / \mathrm{yr}$ by the year $2000 \mathrm{~A}$.D. If release were to increase 20,000 times $(40 \mathrm{mrem} / \mathrm{yr})$ such an annual population dose rate would be unacceptable; however, thermonuclear reactors will need most of the tritium generated, and technology will be developed by then to contain and use the vast quantites of tritium envisioned as result of thermonuclear power production from D-T-type reactor.
SUBJECT CATEGORY: Airborne

ORIGIN: Defense; Commercial

KEYWORDS: TRITIUM; REACTORS; REPROCESSING; ECONOMICS; RADIOACTIVE WASTE MANAGEMENT; THERMONUCLEAR REACTORS; VOLUME; INVENTORIES

180

Oak Ridge National Laboratory, Oak Ridge, TN

HEALTH PHYSICS DIVISION ANNUAL PROCRESS REPORT FOR PERIOD END= ING JULY 31, 1868. ORNL 4816; 324 pp. (1968)

Progress of the Health Physics Division atORNLis reported as follows: Part I, radioactive waste disposal; (1) fate of trace elements and radionuclides in terrestrial environment, (2) disposal of hydraulic fracturing, (3) disposal in natural salt formations, (4) engineering, economic, and safety evaluations, (5) earthquake and reactor safety, (6) dose estimation studies related to peaceful uses of nuclear explosives, (7) related co-operative projects. Part II, radiation ecology. Part III, radiation physics. Part IV, radiation dosimetry research. Part V, internal dosimetry.

SUBJECT CATEGORY: General

ORIGIN: Defense

KEYWORDS: ECOLOGY; COMPUTER CODES; DOSIMETRY; TRITIUM; RADIOACTIVE WASTE DISPOSAL; ECONOMICS; DOSE RATES; RADIOACTIVE WASTE MANAGE. MENT; EARTHQUAKES; HYDRAULIC FRACTURING; SALT DEPOSITS; AQUATIC ORGANISMS

\section{1}

Saxton Nuclear Experimental Corp.

REQUEST TO EXTEND SAXTON OPERATING LICENSE TO 1972. DOCKET-50136; 1 p. (1968)

Letter to D.J. Skovholt; Available - NRC Public Document Room, 1717 H Street, Washington, DC 20545

Provides current corporate financial data on general public utilities, states SNEC contract will be 
extended to May 1974, and asks that license expiration date be entended to Dec. 31,1972.10 CFR 50 asks for estimate of shutdown costs. Plans have not been made, but assuming they are similar to those for CVTR, should not exceed $\$ 250,000$ with an annual maintenance cost of $\$ 5000$.

SUBJECT CATEGORY: Remedial Action, FUSRAP

ORIGIN: Commercial

KEYWORDS: CVTR REACTOR; ECONOMICS; PHWR TYPE REACTORS; REACTOR LICENSING; PWR TYPE REACTORS; SAXTON REACTOR; SPECIFICATIONS; REACTOR DECOMMISSIONING

\section{2}

Dagen, A., M. Alm, G. Sachse, and H. Haentzschel; Staatliche Zentrale Fuer Strahlenschutz, Berlin, Germany, D.R.

THE ECONOMY OF THE COLLECTION TREATMENT AND DISPOSAL OF RADIOACTIVF. WASTES IN THE GDR DECONTAMINATION OF RADIOACTIVE WASTES BY CONTACT PRECIPITATION. SZS-10/68; 42 pp. (1968)

In German

Solid and liquid radioactive wastes are exclusively collected by the Radiation Protection Centre and treated in a pilot plant by distillation, precipitation, ion exchange, or baling. The resulting concentrates are packed in 200-1 steel drums and stored in mine galleries. The parameters of the pilot plant as well as the treated wastes are described. To estimate the total costs of the disposal of the different wastes, a cost evaluation is performed of the single processes (collection, treatment, and disposal). The total costs per unit volume of waste are presented for the several kinds of waste.

SUBJECT CATEGORY: General; Isolation

ORIGIN: Foreign

KEYWORDS: RADIOACTIVE WASTE DISPOSAL; RADIOACTIVE WASTE STORAGE; ECONOMICS; RADIOACTIVE WASTE MANAGEMENT; RADIOACTIVE WASTE PROCESSING; GERMANY; COST; SOLID WASTES; LIQUID WASTES; DECONTAMINATION; PRECIPITATION
183

Yamamoto, Y., N. Mitsuishi, and S. Kadoya; University of Tokyo, Tokyo, Japan; University of Kyushu, Kyushu, Japan; Ebara Mfg. Co. Ltd., Tokyo, Japan

DESIGN AND OPERATION OF EVAPORATORS FOR RADIOACTIVE WASTES. STI/DOC/10/87; 115 pp. (1968)

Figures, Tables

A manual dealing with the application of evaporators to the treatment of radioactive wastes. This book is the second of three commissioned by the IAEA on the three principal techniques for concentrating radioactive wastes, namely chemical precipitation, evaporation, and ion-exchange. Contents introduction, design and description of evaporator types and associated equipment operational procedures, disposal of evaporator condensates and concentrates, costs, bibliography, appendices I, II, and III.

\section{SUBJECT CATEGORY: LLW}

ORIGIN: Foreign

KEYWORDS: BIBLIOGRAPHIES; DESIGN; IAEA; OPERATION; MANUALS; RADIOACTIVE WASTE DISPOSAL; LIQUID WASTES; CONDENSATION; ECONOMICS; EVAPORATORS; EQUIPMENT; RADIOACTIVE WASTE PROCESSING; ECONOMICS; COST; ION EXCHANGE

\section{4}

Fineman $P$.

PROGRESS IN WASTE-DISPOSAL RESEARCH AND DEVELOPMENT. Reactor and Fuel-Processing Technology 11(2):107-116. (1968)

5 Figures, 3 Tables, 52 References

At Pacific Northwest Laboratory (PNL), a program is in progress to demonstrate on an engineering scale the technical, economic, and safety aspects of various solidification processes for converting highlevel-activity wastes to solid form. Three processes have been selected for testin gin a multipurpose facility known as the waste-8olidification engineering prototypes (WESP). They are (1) the PNL spraysolidification process, (2) the ORNL (Oak Ridge National Laboratory) pot-calcination and risinglevel glass processes, and (3) the BNL (Brookhaven National Laboratory) phosphate-glass process. 
SUBJECT CATEGORY: HLW

ORIGIN: Defense

KEYWORDS: RADIOACTIVE WASTE STORAGE; CALCINATION; RADIOACTIVE WASTE DISPOSAL; ECONOMICS; LIQUID WASTES; PHOSPHATE GLASS; SOLID WASTES; ECONOMICS; GLASS; SOLIDIFICATION

185

Galley, J.E.

ECONOMIC AND INDUSTRIAL POTENTIAL OF GEOLOGIC BASINS AND RESERVOIR STRATA. Subsurface Disposal in Geologic Basins - A Study of Reservoir Strata, 1968, (pp. 110). (1968)

References included.

One potential value of subsurface strata in geologic basins is the available space for storage or disposal of industrial waste liquids and solids. Disposal methods which are being developed include the injection of liquids into deep permeable formations, the storage of solids in caverns constructed in salt beds, and the incorporation of liquids in cement slurries which are injected into artificially produced fractures in shale and allowed to harden. Six of the papers in this volume describe geologic basins where such disposal methods might be used successfully.

SUBJECT CATEGORY: Isolation

ORIGIN: Commercial

KEYWORDS: ECONOMICS; GEOLOGY; RADIOACTIVE WASTE DISPOSAL; RADIOACTIVE WASTE STORAGE; HYDRODYNAMICS; GEOLOGIC STRUCTURES; SALT DEPOSITS; CEMENTS

186

Morton, R.J.

LAND BURIAL OF SOLID RADIOACTIVE WASTES: STUDY OF COMMERCIAL OPERATIONS AND FACILITIES. WASH-1143; 133 pp. (1968)

The main text and each appendix has been abstracted separately. Disadvantage: continuous monitoring required (shallow burial)
The report includes a review of commercial waste burial operations, descriptions of health and safety considerations, and data pertaining to waste volumes and activity buried. Two appendices describing the geology and hydrology of the Sheffield and Beatty commercial sites are included.

SUBJECT CATEGORY: LLW

ORIGIN: Commercial

KEYWORDS: GEOLOGY; HYDROLOGY; RADIOACTIVE WASTE MANAGEMENT; ENVIRONMENT; VOLUME; RADIOACTIVE WASTE STORAGE; RADIOACTIVE WASTE FACILITIES; INVENTORIES; GROUND DISPOSAL

187

Yudin, F.P., M.K. Pimenov, A.I. Nazarov, S.I. Zakharov, S.V. Nikov, and V.M. Sedov

EXPERIENCE IN BURIAL OF LIQUID RADIOACTIVE WASTES IN DEEP GEOLOGICAL FORMATIONS. JPRS-46535; 10 pp. (1968)

2 figures, 10 references

Investigations were conducted on industrial scales on the disposal of liquid radioactive wastes into the plutonic formations of the earths crust. The equipment setup and the monitoring system assured the uninterrupted functioning of the installation. The accelerating ability of the pumping borehole, following the starting-adjustment period, was established as equalling $1.2 \mathrm{~m} 3 /$ day of excess pressure. The investigations indicate that under favorable hydrogeological conditions, the disposal of radioactive waters into the plutonic formations can be conducted on an industrial scale. Based on the technical-eronnmic calculations and the operat. ing experience, it was established that the underground burial of wastes has economic advantages vis a vis the evaporation technique.

SUBJECT CATEGORY: LLW

ORIGIN: Foreign

KEYWORDS: GEOLOGY; GROUND WATER; HYDRAULICS; RADIOACTIVE WASTE DISPOSAL; ECONOMICS; LIQUID WASTES; HYDROLOGY; . USSR; HYDRAULIC FRACTURING; MONITORING; UNDERGROUND DISPOSAL 
188

ION EXCHANGE PROPERTIES OF PINSTECH SOIL FOR THE DISPOSAL OF LIQUID RADIOACTIVE - WASTE DIRECTLY INTO THE GROUND. PINSTECH/HP-7; 30 pp. (1968)

12 figures, 9 tables, references

Concluded that the disposal of low-level liquid waste at Pinstech into shallow pits dug in the ground is a very economic and safe method of disposal. It is estimated that a total of about 8.5 million imperial gallons per year of low level liquid waste can be disposed of from a pit measuring $100 \mathrm{ft}$ x $50 \mathrm{ft} \times 5 \mathrm{ft}$ which would cost only $\$ 400$.

SUBJECT CATEGORY: LLW

ORIGIN: Foreign

KEYWORDS: ADSORPIION; RADIONUCLIDE MIGRATION; ECONOMICS; LIQUID WASTES; ION EXCHANGE; SOILS; RADIOACTIVE WASTE DISPOSAL; GROUND DISPOSAL; INVENTORIES

\section{9}

\section{9}

Evans, D.M.; American Institute of Mining, Metallurgical, and Petroleum Engineers, Inc., New York

PROPOSED INDUSTRY INVENTORY OF OUR FUEL RESOURCES. . (1969)

No Abstract

SUBJECT CATEGORY: General

ORIGIN: Commercial

KEYWORDS: COST; ENERGY SOURCES; ENVIRONMENTAL EFFECTS; FORECASTING; INVENTORIES; RADIOACTIVE WASTES

\section{0}

Carolina Power and Light Co., Raleigh, NC

RESPONSE TO QUESTION 9.2 - MAXIMUM INVENTORY OF RADIONUCLIDES IN LIQUID WASTE SYSTEM. DOCKET-50324-8;
DOCKET-50325; Amendment 4 to Brunswick 1 ana 2 License Application, pp. 9.1-1-9.2.2. (1969)

1 table

Provide an itemization of the maximum inventory of radionuclides expected in the liquid radwaste system. (Answer) An example of typical inventories of radioactive liquids are shows in table 9.2-1, based on a stack release level of 100,000 microcuries/sec from each unit. These inventories represent the maximum expected, however, they are not limits.

SUBJECT CATEGORY: General

ORIGIN: Commercial

KEYWORDS: BWR TYPE REACTORS; LIQUID WASTES; RADIOACTIVE WASTE MANAGEMENT; RADIOCHEMICAL ANALYSIS; BRUNSWICK-1 REACTOR; BRUNSWICK-2 REACTOR; INVENTORIES

191

Rodier, J., and G. Cohendy; Commissariat a l'Energie Atomique, Chusclan, France

THE USEFULNESS OF THE DECAY RATE IN THE MANAGEMENT OF RADIOACTIVE WASTE STOCKS. CEA-R-3731; 33 pp. (1969)

In French

Discussed usefulness of exploiting the natural decay rate of the radioactive element contaminating wastes. The storage of wastes under the best possible conditions in each case, was first of all favorable for the radiological safety point of view; it led, furthermore, to a marked reduction in the cost price since it made it possible to avoid employing protection means which would have proved to be excessively outsize after a few years. Finally, even when the half-life of the radioelements involved seemed to annul any possible advantages of this method, the temporary storage made it possible to develop treatment processes which were unknown at the time.

SUBJECT CATEGORY: HLW; LLW

ORIGIN: Foreign

KEYWORDS: ECONOMICS; RADIOACTIVE WASTE STORAGE; COST; DECAY 
192

Seyfried, P.; Commissariat a l'Energie Atomique, Chusclan, France

CHANGES IN THE PROCESSING OF HEAVY ALPHA-CONTAMINATED EQUIPMENT AT THE MARCOULE CENTER. CEA-R$3785 ; 17$ pp. (1969)

The processing of heavy alpha-contaminated equipment at the Marcoule Centre has been carried out by a rather expensive manual method. It is necessary to reduce these costs by using more automated methods. Two studies carried out have shown that when the amount of waste treated is large and composed mainly of plastic material, it is possible to design economic installations using cooling and shock demolition, conventional compaction leading to rather poor results. A cutting-up reservoir, used also for other purposes, makes it possible to solve these processing problems at Marcoule. The costs involved are lower than those previously required in the manual methods.

SUBJECT CATEGORY: LLW; TRU

ORIGIN: Foreign

KEYWORDS: ECONOMICS; RADIOACTIVE WASTE PROCESSING; COMPACTING; ALPHABEARING WASTES; COST

19.8

Dorr-Oliver, Inc., Stamford, CT

OPERATION RED DOG. A STUDY OF FLUID-BED COMBUSTION AND POTENTIAL USES OF ANTHRACITE CULM-BANK MATERIAL. FINAL REPORT, AUGUST 1966-APRIL 1969. PB-234512; OCR-42; pp.127. (1969)

See Nuclear.Science Abstracts 1975, 32(01) 00047

SUBJECT CATEGORY: General; Airborne

ORIGIN: Commercial

KEYWORDS: ALUMINIUM OXIDES; ANTHRACITE; BY-PRODUCTS; CALCINATION; CARBON DIOXIDE; ECONOMICS; FLY ASH; GASEOUS WASTES; GERMANIUM; LITHIUM; RECOVERY; SOLID WASTES; STACK DISPOSAL; SULFUR DIOXIDE; URANIUM; VANAD. IUM
194

Duquesne Light Company

RESPONSE TO QUESTION 11.4 - RADIOACTIVE EFFLUENTS, GASEOUS AND LIQUID - DECONTAMINATION FACTORS. DOCKET50334-7; Amendment to Beaver Valley 1 PSAR Vol. 4, (p. 9.4). (1969)

For figures 9.7.1-1 and 11.1.2.2-1, provide the following: (11.4.1) for each source (input to the system), volume of waste per day and activity concentration, (11.4.2) for each subsystem, state normal batches processed/day, volume/batch (gal), etc., (11.4.3) indicate the decontamination factors provided by filters, evaporators and demineralizers. (Answer) See section 11.1.2, amendment 4, BVPS PSAR.

SUBJECT CATEGORY: General; T.I.W

ORIGIN: Commercial

KEYWORDS: PWR TYPE REACIIORS; RADIOACTIVE WASTE MANAGEMEN'T; DECONTAMINATION; LIQUID WASTES; BEAVER VAL LEY-1 REACTOR; GASEOUS WASTES; VOLUME; INVENTORIES

195

Avenhaus, R., and D. Gupta; Kernforschungszentrum, Karloruhe, Germany, FR.

EFFECTIVITY AND COST OPTIMIZATION OF SAFEGUARDS SYSTEMS - PART 2. KFK$1101 ; 34$ pp. (1969)

A simplified numerical example is presented; 8 figures, 4 references

Optimization of safèguàid measures must interrelate economics and effectiveness. A method is presented fur defining and analyzing the system effectivity. In the new method all technical parameters which influence the probability of detection of a diversion can be expressed as equivalent random measuring variances. Generation of all variances is associated with costs. The main objective of these measurements is to make a statement on detection of a diversion.

SUBJECT CATEGORY: Isolation

ORIGIN: Foreign 
KEYWORDS: ECONOMICS; STATISTICS; MATHEMATICAL MODELS; REPROCESSING; SAFEGUARDS; RADIOACTIVE WASTES

\section{6}

Graf, P., and H. Zund; Motor-Columbus Ag, Baden, Switzerland

THE TREATMENT AND DISPOSAL OF RADIOACTIVE WASTE. Neue Technik 11(3):112127. (1969)

In German

Parallel to the construction of nuclear power stations in Switzerland there will be a growth in radioactive waste output. The crucial problem of waste management consists in finding appropriate methods of waste treatment and storage that ensure the safety of the population from ionizing radiation but are reasonably economic at the same time. The most important proved processes are reviewed and the possibilities of applying them in the peculiar situation of Switzerland are discussed.

SUBJECT CATEGORY: General

ORIGIN: Foreign

KEYWORDS: ECONOMICS; RADIOACTIVE WASTE DISPOSAL; RADIOACTIVE WASTE STORAGE; RADIOACTIVE WASTE MANAGEMENT; SWITZERLAND

197

Connolly, T.F.; Oak Ridge National Laboratory, Oak Ridge, TN

BIBLIOGRAPHY ON NUCLEAR REACTOR FUEL REPROCESSING AND WASTE DISPOSAL. ORNL-2971(Vol.8); 81 pp. (1969)

A bibliography of titles and abstracts treating the subject matter under the general topics of costs, decay storage, diepoeal methodo, plant and cquip ment, recovery or removal of materials, surveys and bibliographies, and volume reduction. j

SUBJECT CATEGORY: Spent Fuel; HLW; TRU

ORIGIN: Commercial; Defense
KEYWORDS: RADIOACTIVE WASTE DISPOSAL; RADIOACTIVE WASTE STORAGE; RADIOACTIVE WASTE PROCESSING; BIBLIOGRAPHIES; SPENT FUELS; REPROCESSING; ECONOMICS; COST; VOLUME

198

Spiewak, I.; Oak Ridge National Laboratory, Oak Ridge, TN

INVESTIGATION OF THE FEASIBILITY OF PURIFYING MUNICIPAL WASTE WATER BY DISTILLATION. ORNL-TM-2547; 43 pp. (1969)

9 figures, 1 table, 7 references

This investigation is one of a series sponsored by HUD to determine the feasibility of nuclear power plants for the provision of low cost thermal energy to urban areas. Distillation has two potential roles in municipal waste treatment, first as a means of purifying waste water for reuse and second as a step in the ultimate disposal of solids. The technical problems of waste water distillation, described in the literature, are summarized. Cost estimates are given for a number of possible systems using distillation to treat effluent from a city of 1 million. Distillation appears to be a promising method of waste treatment.

SUBJECT CATEGORY: General

ORIGIN: Commercial

KEYWORDS: THERMAL EFFLUENTS; SURFACE WATERS; LIQUID WASTES; CONDENSATES; DISTILLATION; RADIOACTIVE WASTE PROCESSING; RADIOACTIVE WASTE DISPOSAL; SOLID WASTES; MUNICIPAL WASTES; WASTE WATER; ENERGY SOURCES; ECONOMICS; WASTE HEAT; NUCLEAR POWER PLANTS

\section{9}

U.S. Atomic Energy Commission, Washington, DC

REQUEST FOR EXTENSION OF EXPIRATION DATE OF PROVISIONAL OPERATING LICENSE. DOCKET 50201; Extension of License Request, March 17, 1969, 7 pp. (1969) 
(License CSF-1.) Extension to Oct. 19, 1970, on the grounds that actual operating experience is needed with: (1) High-burnup fuels and fuels containing measurable radioiodine have not been processed. $22,000 \mathrm{mwd} / \mathrm{t}$ av burnup fuel will soon be processed. (2) Liquid waste can be confined at 10 to $15 \% \mathrm{mpc}$. AEC request for studies on lowering discharge levels may require substantial facility changes. Decommissioning costs estimated to be at $\$ 100,000$ yèr' week fü $4 \triangleleft 6$ weeks.

SUBJECT CATEGORY: Spent Fuel; General

ORIGIN: Defense

KEYWORDS: FISSION PRODUCTS; IODINE; RADIOACTIVE WASTE DISPOSAL; LIQUID WASTES; COST; REPROCESSING; DECOMMISSIONING

\section{0}

Haynes, C.D., and D.M. Grubbs; University of Alabama, Natural Resources Center, University, AL

DESIGN AND COST OF LIQUID-WASTE DISPOSAL SYSTEMS. REPORT 692. PB191535; 110 pp. (1969)

Figures, tables; Not concerned with radioactive wastes, but information might be useful.

The computer program LWSDAC offers a choice of four combinations of design procedures in the estimation of cost of deep-well liquid-waste disposal systems - (1) steady-state flow equation in combination with the Texas curve of average treatment plant costs, (2) pressure buildup subroutine (PBLDUP) in combination with the Texas curve to obtain plant cost, (3) steady-state flow equation combined with plant subroutine for treatment plant cost, and (4) PBLDUP subroutine combined with plant subroutine.

\section{SUBJECT CATEGORY: LLW}

ORIGIN: Commercial

KEYWORDS: COMPUTER CODES; ECONOMICS RADIOACTIVE WASTE DISPOSAL; LIQUID WASTES; WELLS; COST

201

Osloond, J.H., and D.L. Newcomb
RADIOACTIVE WASTE DISPOSAL DATA FOR THE NATIONAL REACTOR TESTING STATION, IDAHO. IDO-12040(Suppl. 4); 13 pp. (1969)

Several tables are given which summarize the radioactivity discharged to the environment.

Radioactive wastes associated with reactor nperations at the National Reactor Testing Station during 1968 are identified according to quantity, physical form, nuclide content, and installation or area originating the waste. For comparison similar data from the years. 1955 through 1967 is also presented. A volume of liquid radwastes totalling $5.5 \times 10(E+8)$ gallons and with a total activity of 2382 $\mathrm{Ci}$ was discharged to the lithusphere. Alpha activity was less than $0.3 \mathrm{Cl}$. The activity of the waste came mainly from the three reactors. The effect of decay is shown when the difference between gross activity and nuclide activity is 44,108 Ci. About 250,000 gallons of high-level liquid wastes were converted to granular solids. Nonradioactive waste water with a volume of 115 million gallons was discharged in a well. The total release to the atmosphere by all NRTS sites is $14.5 \times 10(E+10)$ cu ft containing $145,588 \mathrm{Ci}$. Almost all the atmospheric releases came from the fuel cycle facility and the transient Reactor Test Facility. The solid wastes are buried in trenches or pits in the regolith overlying the basalts. For 1968 both on and off-site low-level solid wastes had a volume of $479,000 \mathrm{cu} \mathrm{ft}$ with an activity of about $35,000 \mathrm{Ci}$. The radioactive levels of all solid wastes were on-site buried waste, $1.9 \mathrm{Ci} / \mathrm{cu} \mathrm{ft}$; on-site stored waste, $1063 \mathrm{Ci} / \mathrm{cu} \mathrm{ft}$; and off-site buried waste, $0.03 \mathrm{Ci} / \mathrm{cu} \mathrm{ft}$. The offsite wastes cume from the Dow Chemical Plant, Golden, Colorado, and Aerospace Corporation, Dallas, Texas. The cost for 1968 was 13 cents/cu ft.

SUBJECT CATEGORY: HLW; LLW; TRU

URIGIN: Defense

KEYWORDS: ALPHA PARTICLES; BETA PARTICLES; COST BENEFIT ANALYSISS; FUEL CYCLE; GAMMA RADIATION; RADIOACTIVE WASTE MANAGEMENT; GASEOUS WASTES; HIGH-LEVEL RADIOACTIVE WASTES; LIQUID WASTES; LOW-LEVEL RADIOACTIVE WASTES; SOLID WASTES; VOLUME; RADIOI SOTOPES; ALPHA SOURCES; INVENTORIES; VOLUME 
1970

202

Bush, D.E.; Aerojet Nuclear Systems Co., Sacramento, CA

AEROJET NUCLEAR SYSTEMS COMPANY PROPOSAL NR700059 FOR FUEL POOL SERVICE PLATFORM, NEW FUEL ELEVATORS, AND SPENT FUEL STORAGE RACKS. TID/SNA-100; 31 pp. (1970)

See Nuclear Science Abstracts 1975, 31(08) 21372

SUBJECT CATEGORY: Spent Fuel

ORIGIN: Commercial

KEYWORDS: SPENT FUELS; RADIOACTIVE WASTE STORAGE

203

Thompson, R.J., J.E. Mendel, C. Hampton, H.H. Irby, and J.H. Kleinpeter; Battelle Pacific Northwest Laboratory, Richland, WA

WASTE SOLIDIFICATION DEMONSTRATION PROGRAMS. EXPERIMENT TECHNIQUES FOR CHARACTERIZATION OF HIGH LEVEL RADIOACTIVE SOLIDIFIED WASTE: BNWL-1425; 75 pp. (1970)

Figures, tables, references

Objective of the program is to provide the technological basis which will enable industry to convert the high-level liquid waste from the reprnesessing of nuclear fuel to a safer solid form. The work has culminated in the operation of the waste solidification engineering prototypes by battelle-northwest, wherein engineering-scale radioactive demonstrations are being conducted with three alternative solidification systems - phosphate glass, spray solidification and pot calcination. Basic objectives of the program are to determine the characteristics of the solidified waste products and evaluate the safety and economic aspects of the product characteristics as related to the management of high level radioactive wastes.

SUBJECT CATEGORY: HLW

ORIGIN: Defense; Commercial
KEYWORDS: CALCINATION; LIQUID WASTES; ORNL; PHOSPHATE GLASS; RADIOACTIVE WASTE DISPOSAL; SOLID WASTES; SALT DEPOSITS; REPROCESSING; SOLIDIFICATION; RADIOACTIVE WASTE MANAGEMENT; ECONOMICS

204

Wilson, R.L., J.Y. Lee, and R. Stiens; Bechtel, Inc.; Sacramento Municipal Utility District, Sacramento, CA

RADWASTE DESIGN FOR NO PLANTORIGINATED RADIOACTIVE LIQUID DISCHARGE. Transactions of the American Nuclear Society 13(2):485-486. (1970)

Sacramento Municipal Utility District incorporated an objective in the design of Rancho Seco Nuclear Generating Station that there be no discharge of liquid effluents which contain radioactivity of plant origin. This objective was a result of selecting a dry site with no river, ocean, or other large body of water available as a discharge path. The additional costs and engineering efforts required to utilize such a site is offset by several advantages.

SUBJECT CATEGORY: General

ORIGIN: Commercial

KEYWORDS: PWR TYPE REACTORS; REGULATIONS; RADIOACTIVE WASTE. DISPOSAL; LIQUID WASTES; RADIOACTIVE WASTE MANAGEMENT; HYDROLOGY; RANCHO SECO-1 REACTOR

205

Sobolev, I.A., L.M. Khomchik, N.A. Mukhin, and B.D. Sokolov; Central Station of Radiation Shielding

THE TREATMENT OF SOLID RADIOACTIVE WASTES WITH A LOW-LEVEL OF ACTIVITY. SM-137/73; STI/PUB-264; CONF700905; Management of Low- and IntermediateLevel Radioactive Wastes, Proceedings of an IAEA Symposium, Aix-En-Provence, France, September 7-11, 1970; 22 pp. (1970)

The chief methods of reducing the volumes of solid radioactive wastes are preliminary burning and pressing. The use of these methods at the facilities of 
the central radiation safety station is discussed in this report.

\section{SUBJECT CATEGORY: LLW}

ORIGIN: Foreign

KEYWORDS: IAEA; SOLID WASTES; COMPACTING; COMBUSTION; USSR; VOLUME

\section{6}

Alexandre, D., and P. Pottier; Commissariat a l'Energie Atomique, Cadarache, France

ELIMINATION OF ORGANIC POLLUTANTS FROM RADIOACTIVE EFFLUENTS. SM-137/21; STI/PUB-264; CONF-700905; 18 pp.; Management of Low- and Intermediate-Level Wastes, Proceedings of a Symposium, Aix enProvence, France, September 7-11, 1970. (1970)

In French

Describes a procedure for treating effluents of a radioactive laundry. The economics are also discussed.

\section{SUBJECT CATEGORY: LLW}

ORIGIN: Foreign

KEYWORDS: DECONTAMINATION;ECONOMICS; RADIOACTIVE EFFLUENTS; FRANCE; RADIOACTIVE WASTE PROCESSING

\section{7}

Marque, Y., S. Barral, J. Belhomme, J. Bourdrez, H. Joffre, and P. Lebrun; Commissariat a L'Energie Atomique, Saclay, France

DEVELOPMENT OF THE MANAGEMENT OF SOLID WASTES OF INTERMEDIATE ACTIVITY AT THE CENTER OF NUCLEAR STUDIES AT SACLAY. SM-137/15; STİ PUUB264; CONF-700905; Management of Low- and Intermediate-Level Radioactive Wastes, Proceedings of a Symposium, Aix-en-Provence, France, September $7.11,1970$, International Atomic Energy Agency, Vienna, Austria. (1970)

7 figures, 6 references

Describes the new installation for storage - ponds in water-tight concrete, wells for storing wastes that take up little floor-space, holes for large elements. The means used for personnel protection are given as well as site protection against contamination. The elements of an economic balance-sheet relevant to the new mode of storage are given.

SUBJECT CATEGORY: HLW

ORIGIN: Foreign

KEYWORDS: ECONOMICS; IAEA; RADIOACTIVE WASTE MANAGEMENT; CONCRETES; RADIOACTIVE WASTE STORAGE

\section{8}

Commonwealth Edison Co., Chicago, IL; IowaIllinois Gus and Eleotrio Company

RESPONSE TO QUESTION 1.7 - ISOTOPIC INVENTORIES IN RADWASTE SYSTEM. DOCKE'I'-50254-016; Quad Cities 1 and 2 License Application, (p. 9-1). (1970)

Provide the expected average and maximum isotopic inventories during plant operation for each component of the liquid and solid radwaste system. Indicate what demineralizer decontaminaton factors are used in these predicted inventories. (Answer) This question is answered in section 9.3 of the FSAR.

SUBJECT CATEGORY: General

ORIGIN: Commercial

KEYWORDS: BWR TYPE REACTORS; RADIOACTIVE WASTE STORAGE; QUAD CITIES-1 REACTOR; QUAD CITIES-2 REACTOR; INVENTORIES; LIQUID WASTES; SOLID WASTES

\section{9}

Fontaine, G., G. Mosselmans, and J. Vaccarezza; European Atomic Energy Community, Ispra, Italy

THE MANAGEMENT OF RADIOACTIVE WASTES OF LOW ACTIVITY AND INTERMEDIATE ACTIVITY AT ISPRA. SM137/32; STI/PUB-264; CONF-700905; Management of Low- and Intermediate-Level Radioactive Wastes, Proceedings of a Symposium, Aix-enProvence, France, September 7-11, 1970. International Atomic Energy Agency, Vienna, Austria, 25 pp. (1970) 
The establishment at ISPRA of the common center of research of the European community treats radioactive wastes (solid and liquid products) from its laboratories and reactors. For economic reasons, the treated solid wastes are stored at the same site. The methods of treatment, storage, and burial are described for each category of waste.

SUBJECT CATEGORY: HLW; LLW

ORIGIN: Foreign

KEYWORDS: ECONOMICS; RADIOACTIVE WASTE STORAGE; RADIOACTIVE WASTE MANAGEMENT; ITALY; SOLID WASTES; GROUND DISPOSAL; LIQUID WASTES

210

Kent, C.E., S. Levy, and J.M. Smith; General Electric Co,, San Jose, CA

EFFLUENT CONTROL FOR BOILING WATER REACTORS. SM-146/21; CONF-700810-23; Environmental Aspects of Nuclear Power Stations, Proceedings of a Symposium, New York, August 1014, 1970, International Atomic Energy Agency, Vièná, Austria, 14 pp. (1970)

More than a decade of operating experience is available for reference from commercial boilingwater reactor nuclear power plants. Planned releases of radioactive materials to the environment have been based on a conservative design objective. Off-plant radiation doses are very small compared to permissible or natural background dose. The sources of wastes from the various portions of the plant are classified by physical and radioactive characteristics. Treatment processes are provided accordingly. The objective is to process and recycle these streams so as to minimize both volume and radioactivity of effluents.

SUBJECT CATEGORY: LLW

ORIGIN: Commercial

KEYWORDS: BWR TYPE REACTORS; DESIGN; RADIOACTIVE EFFLUENTS; IAEA; RADIOACTIVE WASTE DISPOSAL; LIQUID WASTES; POLLUTION CONTROL

\section{1}

Ryan, L.F., and L. Limon; Graver Water Conditioning Co., Ecodyne Corp., Union, NJ
CONDENSATE TREATMENT CONSIDERATIONS FOR BOILING-WATER REACTOR SYSTEMS. Proceedings of the American Power Conference, Chicago, IL, April 21-23, 1970, (pp. 757770). (1970)

Discusss considerations peculiar to boiling-water reactor systems that affect the evaluation and choice of condensate treatment systems. Economic evaluations, the effect of radioactive wastes on evaluations, and the burden or operating with condenser leaks are examined.

SUBJECT CATEGORY: LLW

ORIGIN: Commercial

KEYWORDS: BWR TYPE REACTORS; RADIOACTIVE EFFLUENTS; WATER TREATMENT; ECONOMICS; CONDENSERS

212

Slansky, C.M.; International Atomic Energy Agency, Vienna, Austria

FUTURE GOALS IN RADIOACTIVE WASTE MANAGEMENT. SM-137/67; STI/PUB-264; CONF-700905; Management of Low-and Intermediate-Level Radioactive Wastes; Proceedings of an IAEA Symposium, Aix-en-Provence, France, September $7-11,1970 ; 11$ pp. (1970)

Reviews possible reductions of radioactive waste discharged to the environment. Gives a few values for the quantity of radioactive materials produced and how the various disposal policies apply. Economics of waste disposal are discussed.

SUBJECT CATEGORY: HLW; LLW

ORIGIN: Foreign

KEYWORDS: ECONOMICS; IAEA; TRITIUM; RADIOACTIVE WASTE DISPOSAL; AUSTRIA; RADIOACTIVE WASTE MANAGEMENT; REPROCESSING; INVENTORIES

213

Ishihara, T., H. Amano, H. Nakamura, S. Kitani, and T. Segawa; Japan Atomic Energy Research Inst. Tokai, Japan

RECOVERY OF USEFUL RADIOISOTOPES FROM REPROCESSING WASTES AND 
THEIR APPLICATION. Ippon Genshiryoku Gakkaishi 12(10):597-610. (1970)

In Japanese

Reprocessed wastes are useful sources of radioisotopes because they contain high-level radioactive substances. Recovery of the radioisotopes from fission products is important, because it is helpful for the economics of fuel reprocessing. Separation of the fission products is carried out by ion exchange, solvent extraction, adsorption, etc. Development of useful applications has been carried out. A radioisotope power generator is illustrated as an example.

SUBJECT CATEGORY: HLW

ORIGIN: Foreign

KEYWORDS: ADSORPTION;ECONOMICS; FISSION PRODUCTS; ION EXCHANGE; JAPAN; RADIOISOTOPES; SOLVENT EXTRACTION; REPROCESSING; ABSORPTION; SEPARATION PROCESSES

\section{4}

Bahr, W., W. Hempelmann, H. Kraus, and D. Nentwich; Karlsruhe Nuclear Research Center, Germany, F.R.

EXPERIENCES IN THE TREATMENT OF LOW AND INTERMEDIATE RADIOACTIVE WASTES IN THE NUCLEAR RESEARCH CENTER KARLSRUHE. CONF-700905; SM137/12; STI/PUB-264; Management of Low- and Intermediate-Level Radioactive Wastes, Proceedings of a Symposium, Aix-en-Provence, France, September 7-11, 1970. International Atomic Energy Agency, Vienna, Austria. (1970)

15 figures, 1 lable

Only a part of the arising effluents can be decontaminated to the required low activity concen trations by chemical precipitation, so the new plant uses nearly exclusively vapour compression evaporation. Ion exchange proved to be uneconomical due to the high salt concentrations. The concentrates resulting from the evaporation are fixed in bitumen. This is reported on the experience in the operation of the pilot and industrial plant. Costs of the different methods are compared. Also deals with the treatment of low and intermediate radioactive solid waste.
SUBJECT CATEGORY: LEW; HLW

ORIGIN: Foreign

KEYWORDS: ECONOMICS; RADIOACTIVE WASTE PROCESSING; RADIOACTIVE WASTE MANAGEMENT; COST; LOW-LEVEL RADIOACTIVE WASTES; INTERMEDIATE-LEVEL RADIOACTIVE WASTES; EVAPORATION; BIT. UMENS

215

Nentwich, D., R. Kraemer, D. Gupta, and W. Hafele; Kernforschungszentrum, Karlsruhe, Germany, F.R.

DEVELOPMENT OF SAFEGUARDS PROCEDURES FOR A REPROCESSING PLANT SIMILAR TO THE WAK TYPE. KFK1102; 75 pp. (1970)

Figures and tables included

Detailed safeguards measures at strategic areas have been developed and the procedures for carrying out these measures have been laid out. 'The error propagation mechanism, both the random and the systematic components of mcasurcment error, has been anslysed and its influence on the estahlishment of a material balance has been shown. The costs for the safeguards system may be about 3 percent of the reprocessing costs from the plant. Chemical analyses from a major part of the total costs. Means of reducing these costs have been discussed. Possible improvements with regard to safeguards, methods, instruments, and techniques are discussed.

SUBJECT CATEGORY: Generul

ORIGIN: Foreign

KEYWORDS: GERMANY; RADIOCHEMICAL ANALYSIS; ECONOMICS; REPROCESSING; RESEARCH PROGRAMS; NUCLEAR MATERIALS; MANAGEMENT; MATERIAL BALANCE; FUEL REPROCESSING PLANTS

216

Dukat, A.J., J. Gonser, and D.B. James; Nuclear Materials and Equipment Corporation 
NONDESTRUCTIVE GAMMA ASSAY OF PLUTONIUM-CONTAMINATED SOLID WASTE IN DRUMS. Transactions of the American Nuclear Society 13(2):749-750. (1970)

Discusses the assay of PU-contaminated solid waste materials found in 55-gal steel drums. The assay of 27 drums at NUMEC found about 350 grams of PU-239. The 27 drums represented one sixteenth the inventory of drummed waste. Highresolution gamma-spectroscopic assay offers a rapid and convenient method for handling a large volume of contaminated material

SUBJECT CATEGORY: TRU

ORIGIN: General

KEYWORDS: PLUTONIUM; RADIOACTIVE WASTES; SOLID WASTES; GAMMA SPECTROSCOPY

\section{7}

Schlosser, K., F.O.P. Oszuszky, and A.A. Netwick; Oesterreichische Studiengelsellschaft Fuer Atomenergie GmbH, Seibersdorf, Institut Fuer Reaktortechnik

THE FUTURE MANAGEMENT OF RADIOACTIVE WASTES IN AUSTRIA. SM-137/52; STI/PUB-264; CONF-700905; Management of Lowand Intermediate-Level Radioactive Wastes, Proceedings of the IAEA Symposium, Aix en-Provence, France, September 7-11, 1970, 25 pp. (1970)

This report described how to ensure safe waste disposal to a river system without endangering its biological equilibrium while trying to compromise cost of waste management and high standard of safety. Furthermore it concentrates around the legal and economic aspects of waste management selecting the most suitable processes for waste treatment and its storage, the cooperation between waste producers and the national authorities and organizations responsible for a centralized service for waste collection, waste treatment and ultimate storage.

SUBJECT CATEGORY: LLW; HLW

ORIGIN: Foreign

KEYWORDS: ECONOMICS; IAEA; LAWS; RADIOACTIVE WASTE STORAGE; AUSTRIA; RADIOACTIVE WASTE DISPOSAL; RADIOACTIVE WASTE MANAGEMENT; RIVERS
218

Fischer, W., and G. Buhl; Staatliche Zentrale Fuer Strahlenschutz, Berlin, Germany, D.R.

ECONOMY OF THE DISPOSAL OF RADIOACTIVE WASTES FROM NUCLEAR POWER PLANTS AND THE REPROCESSING OF IRRADIATED NUCLEAR FUELS.. SZS-2/70; 24 pp. (1970)

\section{Figures, 14 References; In German}

The portion of current generating costs caused by the disposal of radioactive wastes from nuclear power plants and fuel reprocessing installations as well as the most important factors influencing the system of waste disposal are outlined. Different variants are formulated comgining the quantity of wastes of a supposed nuclear power application with the suitable technologies of the treatment and disposal of radioactive wastes. The boundary conditions and the evaluation criteria and the result of the evaluation of two variants with assumed investment and operation costs are presented.

SUBJECT CATEGORY: Spent Fuel; HLW

ORIGIN: Foreign

KEYWORDS: RADIOACTIVE WASTE DISPOSAL; ECONOMICS; POWER REACTORS; RADIOACTIVE WASTE MANAGEMENT; REPROCESSING; COST

\section{9}

Toledo Edison Co., Toledo, $\mathrm{OH}$

RESPONSE TO QUESTION 11.5 - GASEOUS WASTE (RADIOACTIVE). DOCKET-50346-7; Amendment to Davis-Besse PSAR. (1970)

1 table

Provide the following information regarding the radioactive gas waste system: (A) the maximum volume of primary coolant that will be bled and/or degassified each year for normal and refueling operations, (B) a list of the noble gas radionuclides and the maximum quantity of each that will be released from the primary coolant each year, (C) a list of the fractions and quantity of each noble gas radionuclide that will remain after 3,30 , and 60 days holdup in the waste tanks. Answer on pg 11.5-1 thru 11.5-3.

SUBJECT CATEGORY: Airborne; LLW 
ORIGIN: Commercial

KEYWORDS: RARE GASES; PWR TYPE REACTORS; RADIOACTIVE WASTE DISPOSAL; GASEOUS WASTES; REPORTS; DAVIS-BESSE1 REACTOR

220

Walter, P.D. (Chairman); U.S. Atomic Energy Commission, Washington, DC

COMPACTION OF RADIOACTIVE SOLID WASTE. WASH-1167; 38 pp. (1970)

As of 1969, the annual volume of solid, low-level, radioactive waste that was disposed of by shallow land burial was estimated at $1,700,000 \mathrm{cu} \mathrm{ft}$, of which $95 \%$ was disposed of at the federal sites at Idaho, Richland, Oak Ridge, Savannah River and Los Alamos. An additional $800,000 \mathrm{cu} \mathrm{ft}$ per year was buried at private facilities. In order to assess the means of reducing stored radioactive volumes and lengthening facility life, investigations were conducted into the applicability of sorting, incineration and compaction operations to the radwaste problem. This report summarizes the results of the investigation of the applicability of compaction to low-level radioactive waste volume reduction. The report concludes that (1) $50 \%$ or more of the solid radwaste generated at AEC facilities could be compacted and volume reduction factors achieved would range between 2 and 10, (2) compaction in Department of Transportation approved containers would result in cost savings, (3) airborne radioactivity is the primary health hazard, and (4) commercially available compaction units can be modified, cheaply. Compaction equipment should be contained in a chamber that has suitable off-gas treatment equipment and be remotely operable. Commercially available equipment is divided into four types; balers, compactors, baggers, and packers.

SUBJECT CATEGORY: LLW; TRU

ORIGIN: Defense; Commercial

KEYWORDS: SOLID WASTES; COMPACTING; RADIOACTIVE WASTE DISPOSAL; ECONOMICS; GASES; VOLUME; INVENTORIES; LOWLEVEL RADIOACTIVE WASTES; RADIOACTIVE WASTE MANAGEMENT; GROUND DISPOSAL; TRANSURANIUM ELEMENTS; PLUTONIUM
221

U.S. Atomic Energy Commission, Washington, DC

DISPOSAL OF SOLID RADIOACTIVE WASTES IN BEDDED SALT DEPOSITS. TID25576; 28 pp. (1970)

References

In June 1870, the AEC announced ito intention to initiate a demonstration project to provide technical data and experience on operational methods and costs of long-term storage of solidified wastes from the processing of spent nuclear power fuels. A site near Lyons, Kansas, has been selected tentatively us the locution of the demonstration project for a salt mine repository. To assist in the evaluation of the AEC plans, the committee reached the following conclusions: (1) the use of bedded salt for the disposal of radioactive wastes is satisfactory, and (2) the site near Lyons, Kansas, selected by the AEC is satisfactory.

SUBJECT CATEGORY: Isolation; HLW

ORIGIN: Defense; Commercial

KEYWORDS: DESIGN; HEAT TRANSFER; PLUTONIUM; RADIOACTIVE WASTE DISPOSAL; SOLID WASTES; RADIOACTIVE WASTE MANAGEMENT; HYDROLOGY; RADIATION PROTECTION; SHIELDING; SALT DEPOSITS; TRANSURANIUM ELEMENTS; GEOLOGY; PLASTICITY; REPROCESSING; UNDERGROUND DISPOSAL; KANSAS; US AEC

\section{2}

Kondrat'ev, A.N., I.L. Rybal'chenko, V.M. Sedov, and A.A. Konikevich; V. G. Khlopin Radiation Institute, USSR

ENGINEERING AND ECONOMIC ASPECTS OF' 'IHE 'THEA'I'MENT OF RADIOACTIVE WASTES OF RESEARCH CENTERS AND ATOMIC POWER PLANTS. SM-137/82; STI/PUR-264; CONF-700905; Managment of I $\Omega$ wand Intermediate-Level Radioactive Wastes, Pro. ceedings of a Symposium, Aix-en-Provence, France, September 7-11, 1970. International Atomic Energy Agency, Vienna, Austria, 21 pp. (1970)

This report contains a brief analysis of the technical and economic indices of three treatment methods and the cost of treatment for plants with capacities 
of 100,250 , and $500 \mathrm{M} 3 /$ day. The possibility of employing the three stated methods for desalinated waters and radioactive solutions with a total salinity of 0.5-7 $\mathrm{g} /$ liter, is examined. The technical and economic indices are taken on the basis of experience in the operation of working installations for the treatment of radioactive wastes at the scientific research institute of atomic reactors (NIIAR), Moscow decontamination and radiation safety stations, Leningrad disposal station, Beloyarsk and Novo-Voronezh atomic stations.

\section{SUBJECT CATEGORY: LLW}

\section{ORIGIN: Foreign}

KEYWORDS: ECONOMICS; IAEA; RADIOACTIVE WASTE PROCESSING; EVAPORATION; ION EXCHANGE; USSR; RADIOACTIVE WASTE DISPOSAL; HYDRAULIC FRACTURING

\section{3}

Virginia Electric and Power Company

RESPONSE TO QUESTION 11.5F - DESIGN BASIS OF RADWASTE SYSTEM. DOCKET. 50338-11; DOCKET-50339; Amendment 4 to North Anna 1 and 2 PSAR Supplement, Vol. 2, (2 pp.). (1970)

What is the design basis of the radwaste system (fission, corrosion and activation product source terms and decay heat loads on the demineralizers). (Answer) The liquid waste disposal system will be designed on a volume-processed basis. Sufficient processing operations, recycle, capability, sample procedures, and radiation monitoring, have been provided to ensure an effluent product which, with dilution, can readily meet the guidelines of $10 \mathrm{CFR}$ 20.

SUBJECT CATEGORY: General

ORIGIN: Commercial

KEYWORDS: AFTER-HEAT; DESIGN; PWR TYPE REACTORS; LIQUID WASTES; RADIOACTIVE WASTE MANAGEMENT; EVAPORATION; ION EXCHANGE; BLOWDOWN; REPORTS; NORTH ANNA-1 REACTOR

\section{4}

Albrecht, E., K. Kuhn, and F. Perzl
DISPOSAL OF RADIOACTIVE WASTES BY STORAGE IN A SALT MINE IN THE FEDERAL REPUBLIC OF GERMANY, PART 1. CONF-700905; STI/PUB/264; Developments in the Management of Low- and Intermediate-Level Radioactive Wastes, Proceedings of a Symposium, Aixen-Provence, France, September 7-11, 1970. International Atomic Energy Agency, Vienna, Austria, (pp. 753-759). (1970)

Data date 1967 - 1970

Disposal of low- and intermediate-level radioactive wastes in the Asse salt mine in Lower Saxony has been accomplished in an extensive program of scientific research and technical development. Twohundred litre drums of waste were emplaced in salt mine chambers in various configurations at a depth of 750 meters. Transportation and handling techniques within the mine were evaluated and safety monitoring of the operation was carried on at all times. Operations to date have not encountered any significant complications or radioactive contamination problems.

SUBJECT CATEGORY: Isolation; LLW; HLW

ORIGIN: Foreign

KEYWORDS: RADIOACTIVE WASTE STORAGE; RADIOACTIVE WASTES; RADIOACTIVE WASTE FACILITIES; RADIOACTIVE WASTE MANAGEMENT; LOW-LEVEL RADIOACTIVE WASTES; INTERMEDIATE-LEVEL RADIOACTIVE WASTES; SALT DEPOSITS

\section{5}

Grison, G.

LONG-TERM FORECASTS OF THE PRODUCTION OF RADIOACTIVE WASTE IN THE EUROPEAN COMMUNITY. EUR-4736 E; CONF-700452; Health Implications of the Storage of Radioactive Substances on and in the Ground, J. Smeets and R. Amavis (Eds.), Proceedings of a Symposium held in Cherbourgh-Le Hague, France, April 14-15, 1970, (pp. 17-50), 122 pp. (1970)

Estimates of the annual production of solid radioactive wastes for the European Community are presented, including low-level, intermediate-level, and high-level forms. The development of the nuclear power industry in Europe is discussed, and predictions of waste production by various nuclear facilities including research centers, industry, power reactors and reprocessing plants by the year 2000 are presented. 
SUBJECT CATEGORY: LLW; HLW

\author{
ORIGIN: Foreign
}

KEYWORDS: LOW-LEVEL RADIOACTIVE WASTES; INTERMEDIATE-LEVEL RADIOAC. TIVE WASTES; HIGH-LEVEL RADIOACTIVE WASTES; REACTORS; REPROCESSING; NUCLEAR FACILITIES; RADIOACTIVE WASTE STORAGE; REVIEWS; SOLID WASTES

\section{6}

Lenneman, W.L. (Chairman)

INCINERATION OF RADIOACTIVE SOLID WASTES. WASH-1168; 142 pp. (1970)

A review of the applicability of incineration of solid low-level radioactive wastes for the purpose of volume reduction.

In order to assess the feasibility of incinerating lowlevel radioactive waste, a study was conducted to evaluate (a) the decrease in volume and (b) the procedures and techniques used to safely handle and store radioactive solid wastes. Investigations into incineration experience at AEC facilities, e.g., Rocky Flats, Los Alamos Scientific Laboratory, and Argonne National Laboratory; non-AEC facilities, e.g., Bureau of Mines and Nuclear Materials and Equipment Corporation; and foreign facilities, e.g., Chalk River, Canada; Marcoule, France; and Hopewell, England, were conducted and summaries presented. The benefits associated with the incineration of combustible solid low-level radioactive waste including volume reduction (greater than $95 \%$ ), conversion of residue into a non-combustible form, retrievability and reduction of land requirements. The report concludes that (a) incineration techniques in the U.S. are still medieval, (b) incineration is cost-effective for large volumes of waste, (c) fire-box and rotary kiln type incinerators can be effectively modified to burn radioactive waste and (d) research and development for incineration of radioactive waste is required.

SUBJECT CATEGORY: LLW

ORIGIN: Commercial; Defense; Foreign.

KEYWORDS: SOLID WASTES; COMBUSTION; EQUIPMENT; COST BENEFIT ANALYSIS; FIL TERS; SCRUBBERS; VOLUME; AEROSOLS
227

Pradel, J., P.J. Parsons, and E. Malasek

THE VOLUME REDUCTION OF LOWACTIVITY SOLID WASTES. STI/DOC/10/106; Technical Reports Series No. 106; 44 pp. (1970)

Techniques for volume reduction of low-level radwastes are presented. Two categories of reduction are considered: fragmentation and compaction (mechanical) and incineration. The mechanical techniques reduce the volume whereas, incineration yields a reduction in both volume and weight. It is estimated that $70 \%$ of the wastes produced are compressible or combustible, while $20 \%$ are hard materials, and $10 \%$ debris from plant conversions. Low-level solid wastes are produced at a rate between 0.25 and $0.5 \mathrm{cu} \mathrm{m} / \mathrm{employee}$ annually. Waste sorting is essential to this kind of waste management because it will improve the efficiency of the chosen method. Decontamination of weakly contaminated scrap may be highly desirable in the overall efforts to reduce wastes from a plant. Compaction reduces waste volume by reducing the voids while fagmentation by reducing the size of large pieces, makes them easier to handle by other processes. Material easily compacted are paper, fragments of plastic or rubber, rags, glassware, and small metallic items. The compacting techniques, and experience are discussed in detail. Fragmen. table wastes are a result of dismantling and elimination of large items of equipment such as waste tanks, heat exchangers, ventilation hoods, glove boxes and fluid supply lines. Such wastes are cut apart in cutting rooms. Several different techniques are discussed along with practical experience. Packaging of the wastes depends on the final method of storage. A large proportion of lowlevel radwastes is combustible and the quantity of ash is such that the reduction factor is on the order of 100 by volume and 13 to 25 by weight. Combustible wastes are divided into three types: cellulose materials; plastics and rubber; and animal carcasses. Important characteristics such as physical state, chemical state and caloritic value also must be taken into account. The physical state affects the combustion rate with material compacted too tightly or powdered. The chemical state governs the degree of corrosion. 'l'he caloritic value determines the temperature in the furnace. Waste sorting is very important in combustion because it increases the homogeneity. Techniques and practical experience are included in the discussion. While the principal of incineration is simple, difficulties with gas clean-up pose a problem. Hence the method may 
not be as economical as for conventional wastes. Other techniques briefly considered are lead melting, ferrous materials and special steels melting, acid reduction, and mummification of animal carcasses. The disadvantages and advantages, choice of process, economic aspects, utilization of reduction facilities, influence of the storage possibilities, and importance of the choice of storage method are also covered.

\section{SUBJECT CATEGORY: LLW}

ORIGIN: Commercial; Defense; Institutional

KEYWORDS: COST BENEFIT ANALYSIS; COMBUSTION; PACKAGING; VOLUME; RADIOACTIVE WASTE MANAGEMENT; LOW. LEVEL RADIOACTIVE WASTES; SOLID WASTES

\section{8}

AEC AGAIN CONSIDERS BURYING ATOMIC MUCK. The Washington Star, Washington, DC, September 28, 1970. (1970)

Caught between pressure to save money and fear of another uproar over safety, AEC is taking second look at waste storage plan. Under project bedrock, millions of gallons of hot, highly radioactive muck would be poured into man-made caverns in the bedrock $1500 \mathrm{ft}$ below Savannah River Plant. Muck would be kept there for the 1000 yr or so that it would continue to emit radioactivity. Project was originally stalled due to Nat. Acad. of Sci. expressing concern that muck would ooze through fissures into Savannah River. Since salt mine storage of solidified wastes would cost 10 times more, AEC is spending $\$ 1.3$ million on further efforts to determine if bedrock project would provide safe long-term storage.

SUBJECT CATEGORY: HLW; Isolation

ORIGIN: Defense

KEYWORDS: ECONOMICS; FISSION PRODUCT RELEASE; GEOLOGY; RADIOACTIVE WASTE DISPOSAL; RADIOACTIVE WASTE MANAGEMENT; HYDRAULIC FRACTURING; SALT DEPOSITS; BEDROCK; UNDERGROUND DISPOSAL; US AEC
229

WESTINGHOUSE OFFERS SYSTEMS FOR ESSENTIALLY ZERO RELEASE OF RADWASTE. Nuclear Industry 40:1. (1970)

The company has announced that it is offering a new radwaste system that could add about $\$ 1 / \mathrm{kw}$ to the cost of a new plant. The system will enable krypton and tritium to be retained for long times and either stored on-site or shipped off periodically. The quantity involved yearly is enough to be contained in 5 normal-sized oxygen tanks such as used by welders. Discharge of nuclide gases would occur only when the containment structure is ventilated once a year during refueling, and these would be barely detectable above natural background. Release of tritium would be completely eliminated during normal operations (removed as tritium oxide), and off-site disposal required $1 / 2$ times during plants lifetime. System will be installed in the 2 zion units.

SUBJECT CATEGORY: Airborne; LLW

ORIGIN: Commercial

KEYWORDS: FISSION PRODUCT RELEASE; KRYPTON; TRITIUM; AIR POLLUTION; POWER REACTORS; RADIOACTIVE EFFLUENTS; ENVIRONMENT; ZION-1 REACTOR; EQUIPMENT; NUCLEAR INDUSTRY; CAPITAL

\section{0}

AEC COMMENTS ON ENVIRONMENTAL MONITORING USED BY VARIOUS FACILITIES. Atomic Energy Clearing House 16(34):3335. (1970)

At present there is substantial variation among older reactor facilities on effluent monitoring, in isotopic analysis, the choice of standards used, and the scope and depth of monitoring. Programs show that effluents are within permitted levels, but needs exist for more explicit and uniform monitoring procedures and record keeping. AEC has developed a tentative uniform monitoring, recording, and reporting guide to be used as a model for technical specifications. Eight older facilities were asked to comment on the impact this would have in their operations and costs. 


\section{SUBJECT CATEGORY: General}

ORIGIN: Defense; Commercial

KEYWORDS: FISSION PRODUCT RELEASE; REPORTS; RADIOACTIVE WASTE DISPOSAL; DATA PROCESSING; RADIOACTIVE WASTE MANAGEMENT; SPECIFICATIONS; RADIOACTIVE EFFLUENTS; MONITORING; ENVIRON. MENT; DATA COMPILATION; INFORMATION

231

Slansky, C.M.; Allied Chemical Corp., Idaho Falls, ID

ULTIMATE STORAGE OF RADIOACTIVE WASTE. CONF-711113-5; Radioactive Waste Management, Proceedings of a Regional Training Course, Tokyo, Japan, November 4, 1971; 12 pp. (1971)

The conditions for ultimate storage of radioactive waste are: periods of the order of a million years, inaccessabilty of the waste to man or his food chain, no surveillance or maintenance, and costs that would be commensurate with the benefits. Retrievability of the stored waste is not a necessary requirement although acceptable if convenient. Similarly, availability of the method to all nuclear nations would be a desirable characteristic. Two regions on the earth where wastes might be deposited and stored are the sea and the land, in trenches of ocean depths and in underground cavities (salt beds) or by hydrofracture: Two possible approaches to ultimate disposal of radioactive waste are transmutation of the radioisotopes to stable isotopes and shipment of the waste via rockets to other planets or to the sun.

SUBJECT CATEGUEYY: İsolation

ORIGIN: Commercial; Defense

KEYWUKUS: RADIUACIIVE WAS'I'E' S'IUKAGE; RADIOACTIVE WASTE DISPOSAI; RADIOACTIVE WASTE MANAGEMENT; HYDRAULIC FRACTURING; SALT DEPOSITS; SPACE; TRANSMUTATION 
1971

232

Kehler, L.H., and G.L. Miles; Australian Atomic Energy Commission, Nuclear Development Division, Sydney, Australia

THE NATURE AND DISPOSAL OF RADIOACTIVE WASTES. Solid Waste Treatment and Disposal, N.Y. Kirov, Ed., (p. 129-135), 204 pp. (1971)

Radioactive waste can be managed safely and economically without harm to the public, the environment, or natural resources. The quantities of waste arising from the predicted Australian nuclear power program to the year 2000 are relatively small. Estimates of the capital and operating costs of radioactive waste management are given. The nuclear power station is a "clean" source of energy which can, with safety and economy, significantly reduce the nations's overall environmental pollution problem. As a matter of policy all nuclear facilities should be operated as "closed systems" with a minimum release of radioactivity to the environment. Wherever possible liquid wastes containing radioactivity should be either insolubilized or converted to a solid form. Solid wastes should be disposed of at three types of disposal areas, all of which involve ground disposal: 1) very low level solid wastes should be disposed of at Municipal or State garbage dumps or at or near the sites of nuclear facilities, 2) low and intermediate level solid wastes should be disposed of at sites controlled by the Commonwealth or State Governments. Only a small number of sites will be needed, and 3) high level wastes should be stored indefinitely at a remote facility in a suitably dry geological forination. Only une facility is likely to be required for many years and it should be operated by the Commonweath Government. (Auth)

SUBJECT CATEGORY: LLW; HLW

ORIGIN: Foreign

KEYWORDS: FUEL REPROCESSING PLANTS; FUEL ELEMENTS; ECONOMICS; REACTORS; ENVIRONMENT; CONTAMINATION; NUCLEAR FACILITIES; RADIOACTIVE WASTE MANAGEMENT

233

Joyce, W.E.; Babcock and Wilcox, Lynchburg, VA
SODIUM THIOSULFATE SPRAY SYSTEM FOR RADIOIODINE REMOVAL. Nuclear Technology 10(4):444-448. (1971)

Radioiodine constitutes a radiological hazard to the public in the event of a loss-of-coolant accident (LOCA). The potential thyroid dose is normally the most restrictive factor in the siting requirements of nuclear power plants. When analysis of the LOCA shows that the thyroid dose limits are exceeded, an engineered safeguard system must be installed to reduce the dose to the allowable limits. At present, there are two ways to remove iodine from the containment atmosphere: filter-absorber systems and containment spray systems. The advantages of spray system are (a) the removal rate for radioiodine is faster, resulting in lower thyroid site doses, (b) an existing system could be modified, and (c) the cost of the system is less.

SUBJECT CATEGORY: Airborne

ORIGIN: Commercial

KEYWORDS: CONTAINMENT; FILTERS; IODINE; ACCIDENTS; LOSS OF COOLANT; SODIUM; THIOSULFATES; ADDITIVES; NUCLEAR FACILITIES; RADIATION DOSES

234

Commonwealth Edison Co., Chicago, IL

RESPONSE TO QUESTION 2 - RADIOACTIVE LIQUID WASTE TREATMENT. DOCKET-50254-36; DOCKET-50265; Amendment 23 to Quad Cities 1 and 2 License Application, 5p. (1971)

Provide your plans for maximum use of all radioactíve liquid waste treatment systems so that releases of radioactivity are very low. (Answer) A daily planning of radwaste operations will be intituted, whereby the operators are given instructions as to the various waste water movements to be made. Daily log sheets will provide data on waste volumes processed through the various subsystems. Charting of such data can show trends in station performance.

SUBJECT CATEGORY: General

ORIGIN: Commercial

KEYWORDS: BWR TYPE REACTORS; LIQUID WASTES; RADIOACTIVE WASTE DISPOSAL; RADIOACTIVE WASTE MANAGEMENT; QUAD CITIES-1 REACTOR; QUAD CITIES-2 REACTOR 
235

Schleicher, R.W.; Cornell Univ., Ithaca, NY

NUCLEAR INSURANCE: AN ESTIMATE OF THE COST OF THE NUCLEAR HAZARD. PB-228864; 21 pp. (1971)

See Nuclear Science Abstracts 1974, 30(07) 20440

SUBJECT CATEGORY: General

ORIGIN: Commercial

KEYWORDS: COST; NUCLEAR INSURANCE; NUCLEAR POWER PLANTS; RADIATION HAZARDS; RADIOACTIVE WAS'IES; REACTOR ACCIDFNTS

236

Detroit Edison Co., Detroit, MI

RESPONSE TO QUESTION 10.13 - HOLDUP TIMES FOR XENON AND KRYPTON. DOCKET-50341-25; Amendment 51 to Fermi 2 License Application, (p. 10.13-1). (1971)

Discuss the basis for establishing the 14-day delay for xenon and approximately a one-day delay for krypton and relate the bases to your criteria for maintaining off-gas effluent releases at values as low as practicable. (Answer) The studies concluded that the present state of recombiner - charcoal bed adsorption system technology is adequate to give reasonable assurance of operating reliability and safty and that such systems of reasonable size and cost could provide reductions in off-gas activity of about 100 , compared with earlier designs.

SUBJECT CATEGORY: Airborne

(JKICiIN: Commercial

KEYWORDS: KRYPTON; XENON; CHARCOAL; RADIOACTIVE WASTE DISPOSAL; RADIOACTIVE WASTE MANAGEMENT; GASEOUS WAETFI; NFF-CAS SYSTEMS

237

European Nuclear Energy Agency, Paris, France

RADIOACTIVE WASTE MANAGEMENT PRACTICES IN WESTERN EUROPE. European Nuclear Energy Agency Report; 126 pp. (1971)
The principles and practices applied to radioactive waste management in Western Europe are reviewed. The origin and different types of radioactive wastes are discussed, and data on the production of gaseous, liquid, and solid radioactive wastes in Western Europe during 1970 are presented. The general safety, technical, and economic aspects of waste management are reviewed. Specific treatment and storage practices at various European nuclear facilities and the outstanding waste management problems, notably safe permanent storage of high-level liquid wastes and the control of $\mathrm{Kr} 85$ and tritium releases to the atmosphere, are described.

SUBJECT CATEGORY: HLW; Airborne

ORIGIN: Foreign

KEYWORDS: KRYPTON 85; SAFETY; TRITIUM; RADIOACTIVE WASTE DISPOSAL; RADIOACTIVE WASTE STORAGE; ECONOMICS; RADIOACTIVE WASTE MANAGEMENT; GASEOUS WASTES; SOLID WASTES; LIQUID WASTES

\section{8}

International Atomic Energy Agency, Vienna, Austria

WASTE MANAGEMENT RESEARCH ABSTRACTS NO. 6. IAEA/HSW $/ 5 ; 130$ pp.; International Atomic Énergy Agency Compilation. (1971)

Publication by IAEA containing research abstracts of waste-treatment methods for gaseous wastes, liquid wastes, solid wastes storage and discharge studies, and economic studies.

SUBJECT CATEGORY: General

ORIGIN: Forelgn

KEYWORDS: RADIOACTIVE WASTE STORAGE; RADIOACTIVE WASTE MANAGEMENT; ECONOMICS; RADIOACTIVE WASTE PROCESSING; GASEOUS WASTES; SOLID WASTES; LIQUID WASTES

\section{9}

Cohen, J.J., A.E. Lewis, and R.L. Braun; Lawrence Livermore Laboratory, Livermore, CA

DISPOSAL OF RADIOACTIVE WASTE IN DEEP SILICATE ROCK. UCRL-73234; CONF- 
711111-10; Nuclear Science Symposium, San Francisco, CA, November 3, 1971, 11 pp. (1971)

A methods for disposing of nuclear-reactor wastes by in-situ incorporation in molten silicate rock is presented. In this method, liquid wastes are injected into a deep underground chimney and allowed to self-boil. The resulting steam is processed at the ground surface and recycled into a closed system. When waste addition is terminated, the chimney is allowed to boil dry, thereby solidifying the waste. The heat generated by the radioactive waste then melts the surrounding rock, which dissolves the waste. Finally, the rock refreezes, trapping the radioactivity in an insoluble rock matrix deep underground. This method has significant en vironmental and economic advantages over previously proposed methods.

SUBJECT CATEGORY: Isolation

ORIGIN: Defense; Commercial

KEYWORDS: UNDERGROUND DISPOSAL; PLOWSHARE PROJECT; RADIOACTIVE WASTE DISPOSAL; ECONOMICS; LIQUID WASTES; RADIOACTIVE WASTE MANAGEMENT

240

Dillon, R.S., J.J. Perona, and J.O. Blomeke; Oak Ridge National Laboratory, Oak Ridge, TN

MODEL FOR THE ECONOMIC ANALYSIS OF HIGH-LEVEL RADIOACTIVE WASTE MANAGEMENT. ORNL-4633; 79 pp. (1971)

11 figures, 1 table, 16 references

A computer program has been written to estimate costs of managing high-level radioactive waste from reprocessing power reactor fuels. The economic analysis encompasses interim liquid storage of the high-level fission product wastes, solidification (pot or fluidized-bed calcination), interim solid storage, shipment, and final storage in salt mines.

SUBJECT CATEGORY: HLW; Spent Fuel

ORIGIN: Commercial

KEYWORDS: COMPUTER CODES; ECONOMICS; RADIOACTIVE WASTE STORAGE; CALCINATION; WASTE TRANSPORTATION; RADI-
OACTIVE WASTE MANAGEMENT; SPENT FUELS; REPROCESSING; LIQUID WASTES; SOLIDIFICATION; SALT DEPOSITS; MATHEMATICAL MODELS; COST

241

Godbee, H.W., and J.P. Nichols; Oak Ridge National Laboratory, Oak Ridge, TN

SOURCES OF TRANSURANIUM SOLID WASTE AND THEIR INFLUENCE ON THE PROPOSED NATIONAL RADIOACTIVE WASTE REPOSITORY. ORNL-TM-3277; pp. 110. (1971)

See Nuclear Science Abstracts 1975, 31(08) 20552

SUBJECT CATEGORY: TRU

ORIGIN: Commercial; Defense

KEYWORDS: COST; FORECASTING; RADIOACTIVE WASTE DISPOSAL; SALT DEPOSITS TRANSURANIUM ELEMENTS; SOLID WASTES; WASTE TRANSPORTATION

242

U.S. Atomic Energy Commission, Washington, DC

ELK RIVER REACTOR DISMANTLING ENVIRONMENTAL STATEMENT. WASH1516; 43 pp. (1971)

The dismantling of the ERR is not expected to result in any significant adverse environmental impact. The proposed action is deemed to be beneficial in that it will remove from the ERR site all reactor originated radioactivity and permit alternative use of the site by RCPA. In assessing and balancing the benefits of the proposed action against the anticipated costs, and in considering the available alternatives, that AEC has concluded that the proposed action should be implemented.

SUBJECT CATEGORY: Remedial Action, FUS. RAP

ORIGIN: Commercial

KEYWORDS: ERR REACTOR; DECOMMISSIONING; REPORTS; REACTOR DISMANTLING 


\section{3}

U.S. Congress, Joint Committee on Atomic Energy, Washington, DC

AEC AUTHORIZING LEGISLATION, FISCAL YEAR 1972. Hearings, Part 31971, (pp. 1307 1405). (1971)

Fiscal years 1972 hearings to consider the AEC's authorization requests for its nuclear waste management program. AEC requested $\$ 27.5$ million in operating cost for this program and $\$ 10.8$ million for construction. Of the amount for construction, $\$ 3.5$ million was requested to proceed with plans for a national radioactivite waste repository near Lyons, Kansas. These funds will be used for acquisition of land and subsurface rights, to provide for title I and II architect-engineering services, and initiation of long leadtime detailed design efforts related to ronatrurtion

SUBJECT CATEGORY: Isolation; HLW

ORIGIN: Defense; Commercial

KEYWORDS: CONTAINMENT; DESIGN;GEOLOGY; SALT DEPOSITS; CONSTRUCTION; WASTE HEAT; PUBLIC RELATIONS; PLAN: NING; RADIOACTIVE WASTE MANAGEMENT; KANSAS; COST

\section{4}

U.S. Congress, Joint Committee on A tomic Energy, Washington, DC

AEC FACT SHEETS ON NATIONAL RADIOACTIVE WASTE REPOSITORY, LYONS, KANSAS. Hearing, Part 31971, (pp. 19081914). (1971)

The purpose of this repository is to provide for the perpetual storage of solidified high-level radioactive wastes and transuranium contaminated solid wastes such as plutonium generated at AEC installations. Additionally, this project will provide technical data and experience on operational methods and costs of long-term storage of solidified high-level wastes generated by commercial reprocessing plants. Additional data is given on origin of the proposal, design studies made, funding, contractors, site selection, criteria for selecting contractors, scheduling cost data, safety reviews, waste shipment and handling, size and capacity of mine, and the potential use of the surface land.

SUBJECT CATEGORY: HLW; TRU; Isolation
ORIGIN: Defense; Commercial

KEYWORDS: DESIGN; GEOLOGY; ALPHA PARTICLES; MINING; PLUTONIUM; SAFETY; RADIOACTIVE WASTE DISPOSAL; SOLID WASTES; COST; LAND USE; WASTE TRANSPORTATION; SALT DEPOSITS; TRANSURANIUM ELEMENTS; CONSTRUCTION; TRANSPORT

245

Fletcher, J.F., D.R. Hoffner, and W.E. Black; Wadco Corp.

A MODEL RELATING NUCLEAR POWER INDUSTRY GROWTH TO REGIONAL DOSE. Transactions of the American Nuclear Society $15(2): 457$. (1871)

A computer model has been developed that is capable of forecasting, on a regional basis, the growth of the nuclear power industry; modeling operation of the nuclear facilities and the release of radionuclides to the environment; and modeling the transport of these radionuclides throughout the region, and the pathways resulting in radiation dose to man. This model, known as the HERMES model (Hanford Engineering Regional Model for Environmental Studies), was designed in module form; it consists of several subsidiary. models designed to be used sequentially in the analysis of a region.

SUBJECT CATEGORY: General

ORIGIN: Commercial

KEYWORDS: COMPUTER CODES; DOSE RATES; FISSION PRODUCTS; FORECASTING; RADIOACTIVE EFFLUENTS

246

Cave, M.L.

DISPOSAL OF RADIOACTIVE WASTE IN GREAT BRITIAN. Journal of the British Nuclear Energy Society 10(3):165-166. (1971)

Provides an excellent review of the UK experience in this field, not only in terms of the technical problems which have arisen but also of the legislation necessary to control the disposal of these potentially hazardous wastes. In the discussion, the main topics of interest were, the relationship between the permissible levels of discharge and 
cost, the disposal of solid waste, the application of the critical-path concept in practice and the re-use of highly polluted water containing radioactive wastes.

SUBJECT CATEGORY: Isolation; HLW; LLW

ORIGIN: Foreign

KEYWORDS: RADIOACTIVE WASTE DISPOSAL; WATER POLLUTION; REPROCESSING; COST; ECONOMICS

247

Schneider, K.J.

SOLIDIFICATION AND DISPOSAL OF HIGH-LEVEL RADIOACTIVE WASTES IN THE UNITED STATES. Reactor Technology 13(4):387-415. (1971)

This article is a critical review and includes an extensive bibliography on the waste-disposal problem (liquid and solid wastes), including methods for converting liquid wastes to solids (calcines and glasses). Author also discusses transportation of wastes, storage methods, characteristics of wastes, and estimated costs for managing highly radioactive wastes.

SUBJECT CATEGORY: HLW; Transportation

ORIGIN: Commercial

KEYWORDS: BIBLIOGRAPHIES; RADIOAC TIVE WASTE DISPOSAL; MARINE DISPOSAL; RADIOACTIVE WASTE STORAGE; SOLIDIFI CATION; WASTE TRANSPORTATION; SOLID WASTES; LIQUID WASTES; ECONOMICS; SALT DEPOSITS; REVIEWS; FLUIDIZED BED; UNDERGROUND DISPOSAL; COST

248

Straub, C.P.

RADIOACTIVE WASTES. Journal of the Water Pollution Control Federation 43(6):10451068. (1971)

Literature Review; Figures, tables and references included

A new volume in the progress in nuclear energy series contains four chapters of interest - "Present
Status of Recommendations of the ICRP, National Committee on Radiation Protection, and Federal Research Council", by K.Z. Morgan; "Radiation Quantities and Units", by L.S. Taylor; "Problems of Highly Active Waste Management", by W.H. Hardwick and J.R. Goner; and "Consequences of Radioactive Disposals into the Ground", by C.A. Mawson.

SUBJECT CATEGORY: HLW; General

ORIGIN: Commercial

KEYWORDS: ECOLOGY; COLUMBIA RIVER; RADIOACTIVE WASTE MANAGEMENT; ION EXCHANGE; PRECIPITATION; RADIOACTIVE WASTE DISPOSAL; HYDRAULIC FRACTURING; GROUND DISPOSAL; SOLVENT EXTRACTION; REGULATIONS; TOXICITY

249

RESPONSE TO QUESTION 29, SECT. 9, AMEND. 17 - HANDLING OF SOLID WASTE. DOCKET-50254; DOCKET-50265; Amendment 17 to License Application for Quad Cities,(p. 29). (1971)

2 tables

Amplify your discussion on handling of the solid waste considering the increase amounts from powdex sources per section 50.34 of 10 CFR 50 . Including isotopic inventory of solids to be processed. (Answer) Table 4 indicates the estimated quantities of solidified waste; i.e., including cement and water added to achieve solidification. Quantities of solid wastes for Dresden 2 and 3 are also shown for comparison. Table 9.3.2 of the FSAR shows the anticipated isotopic composition of the various solid wastes.

SUBJECT CATEGORY: General

ORIGIN: Commercial

KEYWORDS: BWR TYPE REACTORS; REGU. LATIONS; RADIOACTIVE WASTE DISPOSAL; SOLID WASTES; QUAD CITIES-1 REACTOR; QUAD CITIES-2 REACTOR; SOLIDIFICATION; INVENTORIES

260

FIVE MILLIREM PLANTS PROPOSED BY THE AEC. Atomic Energy Clearing House 17(24):2-11. (1971) 
Proposed regulation amendment to limit radioactivity in effluents from light water reactors to exposures not exceeding $5 \mathrm{mrem} / \mathrm{yr}$ to individual of the public and average exposure to sizeable population groups to be less than $1 \mathrm{mrem} / \mathrm{yr}$ was published in federal register of $6 / 9 / 71$ (v.36, n.111) by AEC. This news release discusses and presents complete situation. AEC action followed meetings with over 100 federal, state, and regional organizations, environmental and conservation groups, electric power utilities, $\mathrm{N}$-power architech/engineers, consultants, and reactor suppliers. Added cost to $\mathrm{N}$ power plants will range from about $\$ 500,000$ for plants under design to maybe $\$ 1$ million for plant which have to backfit. Existing and applied-for plants have 3 years to meet new regulation.

SUBJECT CATEGORY: General

ORIGIN: Commercial

KEYWORDS: ECONOMICS; FISSION PRODUCT RELEASE; POWER REACTORS; REGULATIONS; STANDARDS; COST; US AEC; RADIOACTIVE EFFLUENTS 
1972

251

Allied-General Nuclear Services, Barnwell, SC

URANIUM HEXAFLUORIDE FACILITY. DRAFT ENVIRONMENTAL STATEMENT. DOCKET-701327-3; 107 pp. (1972)

See Nuclear Science Abstracts 1974, 30(03) 06567

SUBJECT CATEGORY: LLW

ORIGIN: Commercial

KEYWORDS: BARNWELL FUEL PROCESSING PLANT; CHEMICAL PREPARATION; CONSTRUCTION; CONTAMINATION; COST BENEFIT ANALYSIS; EARTH ATMOSPHERE; ECOLOGY ; ENVIRONMENT; GEOLOGY; HYDROLOGY; OPERATION; POLLUTION; RADIATION HAZARDS; RADIOACTIVE WASTES; SAFETY; SOILS; SURFACE WATERS; THERMAL EFFLUENTS; URANIUM HEXAFLUORIDE; URANYL NITRATES

252

Argonne National Laboratory, Argonne, $\amalg$

LFMBR: LIQUID METAL FAST BREEDER REACTOR PROGRAM PLAN. ELEMENT 8. FUEL RECYCLE. WASH-1108(2nd ed.); 232 pp. (1972)

See Nuclear Science Abstracts 1974, 29(11) 28671

SUBJECT CATEGORY: Spent Fuel

ORIGIN: Defense; Commercial

KEYWORDS: DESIGN; ECONOMICS; FABRICATION; FUEL ASSEMBLIES; FUEL CYCLE; LMFBR TYPE REACTORS; NUCLEAR MATERIALS MANAGEMENT; PLANNING; RADIOACTIVE WASTE PROCESSING; REPROCESSING; SAFETY; SPENT FUEL ELEMENTS; TRANSPORT; USA; WASTE MANAGEMENT; WASTE STORAGE

253

Martin, A., and H. Apsimon; Associated Nuclear. Services, London, England
THE FORECASTING OF RADIOACTIVE WASTES ARISING FROM NUCLEAR FUEL REPROCESSING. CONF-721107; Management of Radioactive Wastes from Fuel Reprocessing, Proceedings of a Symposium, Paris, November 27 Decem ber 1, 1972, 22 pp.; Nuclear Science Abstracts 1974, 29(04) 08392. (1972)

A mathematical model was developed to represent the generation and subsequent movements of radionuclides arising in a nuclear power program. The model was written into a computer program, NIMROD, by means of which estimates may be obtained of the inventories and throughputs of radionuclides in nuclear installations, including reprocessing plants and storage facilities. The operation and application of the model are illustrated by results obtained on the basis of a recent forecast of the nuclear power programme in the UK up to the year 2000 A.D.

SUBJECT CATEGORY: Spent Fuel; HLW; LLW

ORIGIN: Foreign

KEYWORDS: COMPUTER CODES; RADIOACTIVE WASTE STORAGE; THERMAL REACTORS; FBR TYPE REACTORS; MATHEMATICAL MODELS; REPROCESSING; FORECASTING; NUCLEAR FUELS; INVENTORIES

\section{4}

Heald, W.R.; Atlantic Richfield Hanford Co., Richland, WA

ATLANTIC RICHFIELD HANFORD COMPANY TRANSURANIC WASTE RETRIEVALE BURIAL. ARH-SA-139; CONF-721030-5; Pollution Control and Abatement at AEC Facilities, proceedings of a conference, Oak Ridge, TN, October 25, 1972, 10 pp. (1972)

Describes a prototype V-trench for retrievable burial of 55-gal drums in compliance with immediate action directive (IAD) 0511-21. The economics of the plan are discussed.

SUB.JECT C.ATEGSORY: TRU

ORIGIN: Defense

KEYWORDS: RADIOACTIVE WASTE DISPO. SAL; RADIOACTIVE WASTE STORAGE; CONTAINERS; TRANSURANIUM ELEMENTS; HANFORD RESERVATION; SAFETY; EVALUATION; ECONOMICS 
$\mathbf{2 5 5}$

Lewis, W.B.; Atomic Energy of Canada Ltd., Chalk River, Ontario, Canada

RADIOACTIVE WASTE MANAGEMENT IN THE LONG-TERM. DM-123; 11 pp. (1972)

A future is envisaged in which a world of 15,000 million people is supplied with energy from nuclear fission at an average of 50 thermal kilowatts per capita. The resulting radioactive wastes are managed permanently within the boundaries of plants that recover fuel for recycle and fabricate the new nuclear fuel. It is foreseen that a single plant would manage the fuel and wastes for 250 to 300 million kilowatts electric generating capacity. By the year 2000 about four such plants may be needed in North America. In the long-term future about 1,000 such plants would meet the envisaged world demand. An outline is sketched of the operations in such a plant on a near-breeding thorium-uranium fuel cycle. The operations are characterized by multiple parallel cycles for all materials and retrievable storage of radioactive wastes. (Auth)

SUBJECT CATEGORY: HLW; LLW

ORIGIN: Commercial

KEYWORDS: URANIUM; THORIUM; FUEL CYCLE; NUCLEAR FACILITIES; FORECASTING; NUCLEAR ENERGY

\section{6}

Platt, A.M., and R.W. Ramsey; Battelle Pacific Northwest Laboratory, Richland, WA; U.S. Atomic Energy. Commission, Germantown, MD

LONG-TERM WASTE MANAGEMENT METHODS. BNWL-SA-4450; CONF-721107; Management of Radioactive Wastes from Fuel Reprocessing, Proceedings of a Symposium held in Paris, France, November 27-December 1, 1972, (18 pp.). (1972)

See also Nuclear Science Abstracts 1974, 29(04) 08403

Battelle-Northwest has been conducting extensive evaluations of permanent of ultimate methods for storage and/or disposal of high-level radioactive wastes. Information pertinent to assessing the feasibility of various permanent approaches to thy problem is provided. The information includes identification of various candidate methods and assessment of the technical status, development requirements, development costs, development schedules and factors influencing public acceptability and overall feasibility. Specific information is presented on the potential usefulness of transmutation, extraterrestrial disposal and polar ice for management of nuclear wastes. The requirements of each option for modification in methods of reprocessing or subsequent waste treatment are discussed. The extraterrestrial disposal example shows the sensitivity of this concept to the definition of pay loads and selection of destination. The method appears favorable for disposal of at least a fraction of the longlived waste. However, extraterrestrial disposal as well as transmutation, depends a great deal upon the development of adequate partitioning methods to isolate long-lived radionuclides from the gross high-level waste. The innortance of a suitable energy balance and the economics of neutronics dominates the analysis of the trans mutation method and shows that considerable advantages could accrue from total recycle of actinides within the fuel cycle. Finally, the concept of Antarctic ice cap storage typifies considerations of long-term terrestrial storage methods although with special problems of transportation, placement and assessment of long-term stability. The critical importance of assessing public acceptance on an international scale and the necessity for modifying international agreements are other unique features of this concept.

SUBJECT CATEGORY: Isolation; HLW; TRU

ORIGIN: Defense

KFYWORDS: RADIOACTIVE WASTE STORAGE; RADIOACTIVE WASTE DISPOSAL; ECONOMICS; TRANSMUTATION; ICE; REPROCESSING; SEPARATION PROCESSES; ACTINIDES; WASTE TRANSPORTATION

257

Lagache, M.P., and J.D. Blatchford; Bechtel, Inc.

PWR PIANT LIMITED-RELEASE RADWASTE SYSTEM DESIGN. The American Power Conference, 34th Annual Meeting, Chicago, Illinois, April 18-20, 1972, 12 pp.; CEGB Digest 24(9):7. (1972)

\section{3 figures, 2 tables}

The radwaste system design briefly described illustrates a basic approach which presently appears to be most suitable for power plant applica- 
tion. It utilizes a relatively simple sequence of fieldproved processes to reduce costs and to provide reliable performance with low radioactive exposure to operating personnel. Yet it includes enough capability margin and flexibility to allow for possible off-design system operating conditions, and it is believed capable of reducing whole-body radiation exposure off-site to approximately $1 \%$ of natural background. This design can be readily adjusted to satisfy the particular requirements of a specific site, PWR type, and/or owner operating procedures.

SUBJECT CATEGORY: General

ORIGIN: Commercial

KEYWORDS: DESIGN; PWR TYPE REACTORS; TRITIUM; RADIOACTIVE WASTE DISPOSAL; LIQUID WASTES; SOLID WASTES; WASTE PROCESSING; EQUIPMENT

\section{8}

Warner, B.F., A.S. Davidson, and M.J. Larkin; British Nuclear Fuels, Ltd., Windscale Works, Seascale, England

OPERATIONAL EXPERIENCE IN THE EVAPORATION AND STORAGE OF HIGHLY ACTIVE FISSION PRODUCTS WASTES AT WINDSCALE.CONF-721107; Management of Radioactive Wastes from Fuel Reprocessing, Proceedings of a Symposium, Paris, November 27-December 1, 1972. International Atomic Energy Agency, Vienna, Austria, (pp. 339355). (1972)

3 figures; See also Nuclear Science Abstracts 1974, $29(04) 08401$

Concludes that both evaporators and tank form a reliable, simple system for safe concentration and storage of highly active fission product waste from the windscale reprocessing plants. The close similarity of design targets and operating performance up to concentrations of 40 liters/ton U is encourag. ing and the subsequent tanks, which will contain increasing quantities of oxide fuel wastes from the head end plant, will be operated on the same criteria of specific heal releuse, sulids concentration and nitrates solubility. On these grounds, there is every confidence in the current designs as a basis for the safe and economical storage of highly active waste. A study of the use of vitrification for the ultimate disposal of wastes and the interplay between the design of a vitrification plant and the liquor storage tanks is being assessed to achieve the optimum tank size and liquor concentration in the long term.

\section{SUBJECT CATEGORY: HLW}

ORIGIN: Foreign

KEYWORDS: CONTAINMENT; DESIGN; UNITED KINGDOM; RADIOACTIVE WASTE STORAGE; RADIOACTIVE WASTE DISPOSAL; SOLID WASTES; RADIOACTIVE WASTE MANAGEMENT; EVAPORATION; CONTAINERS; VITRIFICATION; REPROCESSING; FISSION PRODUCTS; FUEL REPROCESSING PLANTS

\section{9}

Boos, H., W. Vinck, and H. Baurer; Commission of the European Communities, Luxembourg

NUCLEAR POWER GENERATION IN WESTERN EUROPE - SAFETY AND ENVIRONMENTAL IMPLICATIONS. 2222/III/72-E; American Nuclear Society, Proceedings of an International Meeting, Washington, November 12 16, 1972, 97 pp. (1972)

Gives an outline of the current status of the future trends in nuclear power development in the six member states of the european community and in the frame of its enlargement to nine countries. The topics dealt with nuclear power forecasts, radioac. tive effluents from a growing nuclear industry, radioactive waste storage and accumulation - ore processing wastes, thermal waste from nuclear power production, accident potential, accident prevention and limitation of the possible consequences, and nuclear hazards in relation to other risks.

SUBJECT CATEGORY: General

ORIGIN: Foreign

KEYWORDS: RADIOACTIVE EFFLUENTS;RADIOACTIVE WASTE STORAGE; FORECASTING; RADIOACTIVE WASTE PROCESSING; SAFETY; ENVIRONMENT; RADIATION HAZARDS

\section{0}

Dornier System Gmbh, Friedrichshafen, Germany, F.R.

TRANSPORT OF RADIOACTIVE HIGH LEVEL WASTE TO THE SUN. DEU-76-35. (1972) 
Figures and tables; In German

First results on the feasibility of the disposal of high-level waste from reprocessing plants for LWR fuel elements are presented. The emphasis is on the transport of the waste to the sun by meams of existing and planned carrier systems and on a mission-specific upper stage (AMOS). The article discusses transition orbits earth-sun, gravitation losses, suitable carrier systems, design criteria, types of propulsion (radioisojet with hydrogen as propulsion gas), safety aspects and costs. It arrives at the conclusion that the transport of radioactive high-level waste to the sun by means of spacecraft technology appears feasible for the future and that the costs are not too high. It is pointed out that this project can only be carrie out in international cooperation.

SUBJECT CATEGORY: HLW; Isolation

ORIGIN: Foreign

KEYWORDS: COST; FEASIBILITY STUDIES; GRAVITATION; HYDROGEN; PLANNING; PROPULSION; RADIOACTIVE WASTE DISPOSAL; RADIOACTIVE WASTES; RADIOISOTOPES; ROCKETS; SAFETY; SPACE FLIGHT; SUN; TRANSPORT

261

Haekkinen, H.H.; Finnish Meteorological Institute, Helsinki, Finland

EFFECT OF LOVIISA NUCLEAR POWER STATION ON THE RADIOACTIVITY OF AIR AND RA DIATION DOSES UNDER NOR MAL CONDITIONS AND ACCIDENTS. NP-19743; 152 pp. (1972)

See Nuclear Science Abstracts 1974, 29(06) 14750

SUBJECI' CATEGORY: Airborne

ORIGIN: Foreign

KEYWORDS: CONTAMINATION; ECONOMICS; ELECTRIC POWER; ENVIRONMENT; FINLAND; GASEOUS WASTES; HUMAN POPULATIONS; LOVIISA REACTOR; METEOROLOGY; NUCLEAR POWER PLANTS; RADIATION DOSES; RADIOACTIVE WASTE DISPOSAL; REACTOR ACCIDENTS; REACTOR OPERATION; REACTOR SAFETY; REACTOR SITES; SAFETY ENGINEERING; STACK DISPOSAL; SURFACE AIR
262

Hittman Associates, Inc., Columbia, MD

RADIOACTIVE WASTE MANAGEMENT: A SURVEY. HIT-516; 429 pp. (1972)

See Nuclear Science Abstracts 1974, 30(05) 12407

SUBJECT CATEGORY: General

ORIGIN: Commercial

KEYWORDS: ADSORPTION; BIBLIOGRAPHIES; CENTRIFUGATION; CHEMICAL REACTIONS; COST; DIALYSIS; EVAPORATION; FILTERS; FILTRATION; FREEZING; FUEL REPROCESSING PLANTS; GASEOUS WASTES; ION EXCHANGE; LIQUID WASTES; MEMBRANES; NUCLEAR POWER PLANTS; PERFORMANCE; RADIOACTIVE WASTE PRO. CESSING; RADIOACTIVE WASTES; REVIEWS; SOLVENT EXTRACTION

\section{3}

Tuite, P.T., S.R. Zimmerman, and G.K. Boldt; Hittman Nuclear and Development Corporation, Columbia, MD; Baltimore Gas and Electric Company, Baltimore, $\mathrm{OH}$; Bechtel, Inc.

\section{A SYSTEM FOR SOLIDIFICATION AND PACKAGING OF RADIOACTIVE WASTE AT A PWR. American Power Conference, CEGB Digest 24(9):7; Proceedings of the 34th Annual Menting, Chirнyo, IJ, April 18-20, 1972, 15 pp. (1972)}

2 figures, 2 tables

Describes a solid radioactive waste processing, solidification, and pacleaging oyotem at a two unit 900-MW, pressurized-water-reactor site. The system described here differs from most such systems in that resins, filter cartridges, and cvaporator concentrates can be packaged in the same large disposable contriner (80.170 subic feet) within a shielded shipping cask. Details with regard to waste sources, process flow, equipment arrangement, operations and annual operating costs are discussed.

SUBJECT CATEGORY: LLW; HLW

ORIGIN: Commercial

KEYWORDS: ECONOMICS; PWR TYPE REACTORS; WASTE TRANSPORTATION; RADIOACTIVE WASTE DISPOSAL; SOLID WASTES; 
SOLIDIFICATION; RADIOACTIVE WASTE PROCESSING; COST

\section{4}

Rattay, K.H., M. Laser, and E. Merz; Institut Fuer Chemische Technologie, Kernforschungsanlage, Juelich, GmbH; Germany, F.R.

INTERIM STORAGE AND SOLIDIFICATION FOR THOREX-TYPE FISSION PRODUCT SOLUTIONS. CONF-721107; Management of Radioactive Wastes From Fuel Reprocessing, Paris, France, November 27-December 1, 1972; 24 pp. (1972)

Highly radioactive fission product solutions resulting from reprocessing of thorium-containing fuel elements (thorex-process) are interim stored in a special tank equipment at KFA Julich. Six cylindrical tanks ( $1 \mathrm{~m} 3$ volume each) are installed in cells built of concrete blocks. The tanks have a conical bottom, a coolant jacket and a lid in which all pipes are fixed. In the course of reprocessing spent HTGRfuel, a rather serious problem is the solidification and final disposal of the highly radioactive fission product waste solutions. A survey is given on the choice of a suitable process. Description of the proposed flowsheet as well as long-term storage and safety considerations are included.

SUBJECT CATEGORY: HLW; Spent Fuel

ORIGIN: Foreign

KEYWORDS: LIQUID WASTES; RADIOACTIVE WASTE DISPOSAL; FISSION PRODUCTS; THORIUM; SOLID WASTES; RADIOACTIVE WASTE MANAGEMENT; RADIOACTIVE WASTE STORAGE; CONTAINERS; SOLVENT EXTRACTION

\section{5}

Daiev, K.H.; International Atomic Energy Agency, Vienna, Austria

STUDY OF BULGARIAN BITUMENS AND NATURAL SORBENTS FOR USE IN THE PROCESSING AND DISPOSAL OF RADIOACTIVE WASTES. FINAL REPORT, 1 JUNE 1968-31 MARCH 1972. IAEA-R-610-F; 13 pp. (1972)

In Russian

See Nuclear Science Abstracts 1974, 30(03) 06171
SUBJECT CATEGORY: Isolation

ORIGIN: Foreign

KEYWORDS: SORPTION; BITUMENS; CAL CIUM 45; CESIUM 137; ECONOMICS; RADIOACTIVE WASTE DISPOSAL; RADIOACTIVE WASTE PROCESSING; SILVER 110; SOLIDIFICATION; STRONTIUM 90; THALLIUM 204; UNDERGROUND DISPOSAL

\section{6}

Jersey Central Power and Light Co.

RESPONSE TO QUESTION F19 - DECOMMISSIONING. DOCKET-50219-220; Amendment 2 to Oyster Creek Environmental Report, (p. F191). (1972)

Available from NTIS, Department of Commerce, Springfield, VA 22161

Decommissioning cost is estimated at a low of $\$ 4,635,000$ to a high of $\$ 25,215,000$, depending upon AEC regulations in force at the time of plant retirement. Details of cost estimates are shown in Tables F19-1 F19-2.

SUBJECT CATEGORY: Remedial Action, FUSRAP

ORIGIN: Commercial

KEYWORDS: BWR TYPE REACTORS; ECONOMICS; OYSTER CREEK-1 REACTOR; DECOMMISSIONING; REPORTS; COST; REACTOR DECOMMISSIONING; BWR TYPE REACTORS

267

Grathwohl, G.; Kernforschungszetnrum, Institut Fur Neutronenphysik and Reaktortechnic, Karlsruhe, Germany, F.R.

PRODUCTION AND RELEASE OFTRITIUM BY NUCLEAR POWER PLANTS AND REPROCESSING PLANTS AND THE EXPECTED RADIOLOGICAL BURDEN TILL THE YEAR 2000. KFK-EXT-4/73-36; 84 pp. (1972)

In German; 84 pages, 71 references

Natural tritium production is summarized as well as yields from nuclear weapons and nuclear facilities. 
An estimation of tritium inventory from fusion reactors is attempted. Production rates and global inventory for the year 2000 are calculated.

SUBJECT CATEGORY: HLW; LLW

ORIGIN: Foreign

KEYWORDS: TRITIUM; POWER REACTORS; FORECASTING; THERMONUCLEAR REACTORS; POLLUTION; NUCLEAR INDUSTRY; FUEL REPROCESSING PLANTS

268

Eno,. E., R.J. Walker, and .P. Salz; Lawrence Bcrkeley Laboratory, Berkeley, CA

A NEW METHOD OF CONTROLLING RADIOACTIVITY IN LABORATORY WASTE WATER. LBL-998; 20 pp. (1972)

9 figures, 2 references

A novel method of monitoring and controlling radioactive water from active waste sewers is presented. This method, developed to handle large flows, costs less, requires less space, and is more effective than the conventional 'holding tank' method. Advantages, equipment details, and comparative economics are discussed.

SUBJECT CATEGORY: LLW

ORIGTIN: General

KEYWORDS: LIQUID WASTES; ION EXCHANGE; RADIOACTIVE WASTES; COST; ECONOMICS

269

Louisiana Hower and Light Co.

RESPONSE TO QUESTION 11.1.3 - GASEOUS-WASTE DILUTION FACTORS. DÜ'KE"l 50382-15; Amendment 9 to Waterford Unit 33 PSAR, (p. Q11.1-5). (1972)

Provide an analysis of gaseous waste discharge. Answer - the gaseous waste effective dilution factor is $1.29 \mathrm{X} \mathrm{10}$ (9th) based upon an assumed maximum gaseous discharge flow of 5 SCFM and a X/Q of 3.3 $\mathrm{X}$ 10(-7th) sec/cu.m. The maximum batch discharge (4400 SCF) is equivalent to one gas-decay-tank volume at maximum operating pressure.
SUBJECT CATEGORY: Airborne

ORIGIN: Commercial

KEYWORDS: GASEOUS WASTES; DILUTION; PWR TYPE REACTORS; RADIOACTIVE WASTE MANAGEMENT; RADIOECOLOGICAL CONCENTRATION; WATERFORD-3 REACTOR

270

Fischer, W., W. Korner, and D. Richter; National Centre for Radiation Protection, Germany, D.R.

STUIJY OF VARIANTS FOR SELECTING A METHOD OF ULITMATE STORAGE OF RADIOACTIVE WASTES FRMM NITCL.FAR FACILITIES IN THE GDR. SZS-138; 10 pp. (1972)

4 figures, 12 references; In German

Starting from technological parameters influencing the disposal of radioactive wastes, as there are amounts and properties of wastes from nuclear power stations and plants of the nuclear fuel cycle, possible methods of treatment and final disposal of radioactive wastes are outlined. These methods are discussed from two points of view: safety and economy. The procedure chosen is explained and assessed considering the conditions in the GDR.

SUBJECT CATEGORY: HLW; LI.W; TRU

UKIGIN: F'orcign

KEYWORDS: ECONOMICS; RADIOACTIVE EFFLUENTS; RADIOACTIVE WASTE DISPOSAL; RADIOACTIVE WASTE STORAGE: ECONOMICS: POWER RADIOACTIVE WASTE STORAGE; ECOINOMICS; PÜWEK KEALIUUS; RADIOACTIVE WASTE MANAGEMENT; GERMAN FEDERAL REPUBLIC; SAFETY; EVALUATION

271

Srhulze, H.; National Centre for Radiation Protection, Germany, D.R.

STORAGE OF GASEOUS RADIOACTIVE WASTES IN GEOLOGICAL FORMATIONS. SZS-139; 30 pp. (1972)

In German

Possibilities of ultimate storage of gaseous radioactive wastes in the ground are presented taking into 
consideration safety, from a geological point of view, and the costs of the different types of storage. The geological tightness necessary for the safe underground storage of gaseous radioactive wastes as well as the assessment of the criteria of tightness are discussed. Besides the possible procedures for ultimate storage a method is proposed for interim storage of radioactive gases in the ground.

SUBJECT CATEGORY: Isolation

ORIGIN: Foreign

KEYWORDS: CONTAINMENT; GEOLOGY; RADIOACTIVE WASTE STORAGE; SAVANNAH RIVER PLANT; UNDERGROUND DISPOSAL; RADIOACTIVE WASTES; GASEOUS WASTES; RADIOACTIVE WASTE MANAGEMENT; SHIELDING; GERMAN FEDERAL REPUBLIC

272

Lurf, G.; Nuklear-Chemie und - Metallurgie GmbH (NUKEM), Hanau, Germany, F.R.

TECHNICAL AND ECONOMIC STATUS AND PROSPECTS FOR NUCLEAR ENERGY IN THE POWER ECONOMY OF THE FEDERAL REPUBLIC OF GERMANY. PART III. NUCLEAR FUEL CYCLE. AEC-TR-7445; 98 pp. (1972)

Translated from a German Report.

See Nuclear Science Abstracts 1975, 29(02) 04561

SUBJECT CATEGORY: Spent Fuel; TRU; HLW; LLW

ORIGIN: Foreign

KEYWORDS: ECONOMICS; ENERGY SOURCES; FABRICATION; FUEL CYCLE; FUEL ELEMENTS; GERMAN FEDERAL REPUBLIC; NUCLEAR FUELS; NUCLEAR POWER PLANTS; PLUTONIUM; RADIOACTIVE WASTE DISPOSAL; REPROCESSING; SPENT FUELS; STORAGE; TRANSPORT; URANIUM ORES; WATER COOLED REACTORS; WATER MODERATED REACTORS

\section{3}

Witte, H., J. Herzog, and R. Christ; Nuklear-Chemie und -Metallurgie GmbH (NUKEM), Hanau, Germany, F.R.; Transnuklear GmbH, Hanau, Germany, F.R.
REMOVAL OF RADIOACTIVE RESIDUES FROM NUCLEAR POWER PLANTS. PT. $1,2$. TEXT. APPENDICES. PERIOD: 1.1.7031.12.71. NUKEM-73. (1972)

With figures, tables and references. Availa ble from ZAED; in German

The radioactive residues deposited from the coolant purification and waste water processing of nuclear power plants are investigated regarding their quantity and specific activity. It is found in agreement with the safety specifications valid for the storage in the salt mine ASSE that it is partly necessary and partly, to a large extent, desirable to fix the residues to insoluble binders. There are also other methods besides the fixing process for conditioning the residues which only involve drying-up of the residues. The drying process in the nuclear power plant may be the most economical to carry out; however, an overall consideration of the process chain transport - conditioning - final storage shows that the fixing in a large central plant for the waste disposal of several nuclear power plants is technically the most economical and simultaneously the safest way of removing residues. Bituminization is the most economical process here.

SUBJECT CATEGORY: LLW

ORIGIN: Foreign

KEYWORDS: BITUMENS; COMPARATIVE EVALUATIONS; DECONTAMINATION; ECONOMICS; LIQUID WASTES; PURIFICATION; RADIOACTIVE WASTE PROCESSING; RADIOACTIVE WASTE STORAGE; REACTOR OPERATION; SALT DEPOSITS; SOLIDIFICATION; WATER

\section{4}

Blomeke, J.O., and J.J. Perona; Oak Ridge National Laboratory, Oak Ridge, TN

STORAGE, SHIPMENT, AND DISPOSAL OF SPENT FUEL CLADDING. ORNL-TM-3650; 20 pp. (1972)

Several hundredths of a percent of the plutonium in spent reactor fuels will be associated with the metal cladding, and this will probably necessitate the future storage of this waste material in a federal repository. A study of the design parameters for packaging, interim storage, shipment, and disposal of cladding in the proposed salt mine repository indicates that economics favor compacting the 
hulls as densely as possible, packaging them in 9 in.-diam cylindrical containers, and shipping them to the repository without interim storage at the reprocessing plant.

SUBJECT CATEGORY: Spent Fuel

ORIGIN: Commercial

KEYWORDS: ECONOMICS; PLUTONIUM; RADIOACTIVE WASTE DISPOSAL; SALT DEPOS. ITS; SPENT FUELS; TRANSPORT; RADIOACTIVE WASTE STORAGE

\section{5}

Braatz, R.J., and J.P. Jarvis; Oak Ridge National Laboratory, Oak Ridge, TN

CONCEPTUAL DESIGN REPORT FOR THE PROPOSED ORNL PROCESS WASTE TREATMENT PLANT. ORNL-TM-4004; 89 pp. (1972)

The ORNL low-level, or process, waste streams, averaging $150 \mathrm{gal} / \mathrm{min}$, contains about $0.3 \mathrm{microcu}$ rie/gal of beta-gamma activity. The present limesoda treatment facility achieves a decontamination factor of only 4-5. It is proposed to replace it with a much more efficient process using ion exchange following a head-end scavenging step. This report represents the conceptual design for this new facility, including a detailed description, justification, outline specifications, proposed schedule, and cost estimates, with design drawings.

SUBJECT CATEGORY: LLW

ORIGIN: Defense

KEYWORDS: RADIOACTIVE WASTE DISPOSAL; RADIOACTIVE WASTE PROCESSING; COST; ION EXCHANGE; ORNL; LOW-LEVEL RADIOACLIIVE WASTES

\section{6}

Organization for Economic Co-operation and Development, 75 - Paris, France

OECD NUCLEAR ENERGY AGENCY FIRST ACTIVITY REPORT. NP-19909; 79 pp. (1972)

See Nuclear Science Abstracts 1974, 29(07) 17945

SUBJECT CATEGORY: General
ORIGIN: Foreign

KEYWORDS: COMPUTERS; DIRECT ENERGY CONVERSION; DRAGON REACTOR; ECONOMICS; ENVIRONMENT; FAST REACTORS; GAS COOLED REACTORS; HBWR REACTOR; INFORMATION; LEGAL ASPECTS; NUCLEAR ENERGY; OECD; RADIATION PROTECTION; RADIOISOTOPE GENERATORS; REGULATIONS; RESEARCH PROGRAMS; RADIOACTIVE WASTES

\section{7}

Laser, M., H. Beahjean, J. Bohnenstingl, P. Filb, M. Heidendael, S. Maetora, E. Mers, and H. Vygen; Organization for Economic Co-Operation and Development, 75 - Paris, France; International Atomic Energy Agency, Paris, France

OFF-GAS TREATMENT AND KRYPTON DISPOSAL IN HTGR-FUEL ELEMENT REPROCESSING. CONF-721107-1; Management of Radioactive Wates from Fuel Reprocessing, Proceedings of a Symposium, Paris, France, November 27-December 1, 1972. International Atomic Energy Agency, Vienna, Austria, (pp. 77-98). (1972)

Krypton, tritium and iodine are separated from burner off-gas by $\mathrm{CO}(2)$-liquefaction and rectification at room temperature. Krypton is concentrated in the lower boiling fraction, while tritium and iodine are concentrated in the higher boiling fraction (AKUT-process). The dissolver off-gas is decontaminated by a cryogenic process. Based on safety and economy, the disposal of compressed kryplon cunfiuted in steel cyllnders by dumping in the deep sea is preferred to the long term overground bunker storage. The estimated costs are: $1.3 \times 10(-3)$ $\mathrm{Dpf} / \mathrm{kWh}$ for cleaning the burner off-gas; $1 \times 10(-4)$ $\mathrm{Dpf} / \mathrm{kWh}$ for dissolver off-gas cleanup; $2.8 \times 10(-5)$ $\mathrm{Dpf} / \mathrm{kWh}$ for krypton disposal ints the deep sea, and $2.4 \times 10(-4) \mathrm{Dpf} / \mathrm{kWh}$ for the long term over-ground krypton storage. (Auth)

SUBJECT CATEGORY: HI,W; Spent. Fuel .

ORIGIN: Foreign

KEYWORDS: RADIOACTIVE WASTE PROCESSING; OFF-GAS SYSTEMS; RADIOACTIVE WASTE DISPOSAL; KRYPTON; SPENT FUEL ELEMENTS; REPROCESSING; DISSOLUTION; CRYOGENICS; STORAGE FACILITIES; MARINE DISPOSAL; ECONOMICS; TRITIUM; IODINE; LIQUEFACTION 
278

Pacific Gas and Electric Company

RESPONSE TO QUESTION 6.1 - SITE PLANS AFTER OPERATION TERMINATES. DOCKET-50398-25; Amendment 15 to Mendocino 1 and 2 License Application, (pp. 6.1-1 - 6.1-2). (1972)

Available from NTIS, Department of Commerce, Springfield, VA 22161

PGE does not have firm plans at this time for the eventual decommissioning of the plant. If it were necessary to raze the plant and to restore a natural appearance for future regulatory or other unforeseen reasons, it is estimated that this might cost as much as $\$ 70,000,000$ (for two units at present labor costs and in present dollars).

SUBJECT CATEGORY: Remedial Action, FUSRAP

ORIGIN: Commercial

KEYWORDS: BWR TYPE REACTORS; ECONOMICS; COST; REACTOR DECOMMISSIONING; MENDOCINO-1 REACTOR; MENDOCINO2 REACTOR; REACTOR SITES

\section{9}

Brewer, S.T., and R.A. Livingston; U.S. Atomic Energy Commission, Washington, DC

ASSESSING THE EXTERNAL COSTS ASSOCIATED WITH COMPETING FUEL CYCLES. Transactions of the American Nuclear Society 15(2):661; American Nuclear Society, Transactions of the 1972 Winter Meeting, Washington, DC, November 12-17, 1972, (pp. 661). (1972)

The central task in this study is the assessment of external costs. These include the consumption of nonrenewable resources, environmental degradation through the emission of pollutants, and uncompensated human impact. The external costs must be assigned for each process throughout the competing fuel cycles and related to a common denominator, i.e., a unit of electrical energy. This is accomplished via the fuel cycle mass balances. A careful description of each fuel cycle process yields the source strengths of each waste stream and the accumulation of residuals with time.

\section{SUBJECT CATEGORY: General}

ORIGIN: General

KEYWORDS: ECONOMICS; ENVIRONMENTAL EFFECTS; FUEL CYCLE; RADIOACTIVE WASTES

\section{0}

Hollingsworth, R.E.; U.S. Atomic Energy Commission, Washington, DC

ENVIRONMENTAL STATEMENT, CONTAMINATED SOIL REMOVAL FACILITY, RICHLAND, WASHINGTON. WASH-1520; 36 pp. (1972)

The Environmental Statement was prepared in accordance with the National Environmental Policy Act and in support of the Atomic Energy Commission's proposal for legislative authorization and appropriations for the design, construction and operation of the Contaminated Soil Removal Facility at Richland, Washington. The U.S. Atomic Energy Commission plans to remove plutonium contaminated soil from the floor of an existing enclosed trench (Z-9) used between July 1955 and June 1962 as a subsurface disposal facility for plutonium contaminated liquids from the Plutonium Finishing Plant on the Hanford Reservation near Richland, Washington. It is estimated that the soil to be removed contains approximately 100 kilograms of plutonium in a volume of approximately 1800 cubic feet. It is believed that more than three-fourths of the plutonium in the soil (worth approximately $\$ 3,000,000$ ) can be economically recovered in the nearby Plutonium Finishing Plant. The proposed operation will permit extensive evaluation of soil dissolution and plutonium extraction techniques. Residues from the extraction operations and contaminated soil with insufficient plutonium to permit economical extraction will be packaged in plastic bags, placed in steel drums and stored in a new Underground Storage Vault. The proposed operation will also permit the extensive evaluation of techniques for contaminated soil removal, and for measuring the plutonium content of the contaminated soil. The Contaminated Soil Removal Facility and the Underground Storage Vault will discharge air through high efficiency filters which will release less than one $\mathrm{uCi}$ of plutonium per day to the atmosphere of a controlled area at a concentration estimated to be less than three percent of the concentration guide for a controlled area as defined in applicable federal standards. In assessing and balancing the benefits to be obtained from removing plutonium contaminuted soil from the Z-9 enclosed trench against the 
environmental and economic costs, and after considering the range of alternatives and their environmental impact, the A tomic Energy Commission has concluded that the proposed action should be undertaken.

\section{SUBJECT CATEGORY: TRU}

MRIFIN- Mefenge

KEYWORDS: LEGISLATION; DESIGN; RADIOACTIVE WASTE DISPOSAL; SOILS; PLUTONIUM; RECYCLING; CONTAMINATION; ECONOMICS; INDUSTRIAL PLANTS; STORAGE; SEPARATION PROCESSES; METHODS; ENVIRONMENT; COST BENEFIT ANALYSIS

\section{1}

U.S. Atomic Energy Commission, Washington, DC

DRAFT ENVIRONMENTAL STATEMENT, TRANSURANIUM SOLID WASTE DEVELOPMENT FACILITY, LOS ALAMOS SCIENTIFIC LABORATORY, NEW MEXICO. WASH1527,(Draft); 45 pp. (1972)

The environmental impact of constructing and operating a Transuranium Solid Waste Development Facility at the Los Alamos Scientific Laboratory (LASL) in New Mexico is estimated. The present annual generation of solid radioactivelycontaminated wastes is about 70,000 cubic feet, most of which is contaminated with transuranium radionuclides. A portion of this volume will be sent to the development facility; however, administrative procedures will limit the radioactive inventory in the facility at any one time to $100 \mathrm{~g}$ of $\mathrm{Pu} 239$ and $10 \mathrm{mCi}$ of mixed fission products. The proposed project provides for construction of a building with equipment for demonstrating solid waste volume reducing processes such as sorting, compaction and incineration. Improvements to land, filtration for airborne effluents, accidents such as fires and the eventual decontamination and removal of the buildings are considered. In assessing and balancing the anticipated benefits against the environmental and economic costs of the proposed facility, and after considering the range of alternatives and their environmental impacts, the AEC has concluded that the proposed solid radioactive waste volume reduction facility should be designed and constructed.

SUBJECT CATEGORY: TRU

ORIGIN: Defense
KEYWORDS: ENVIRONMENT; RADIOACTIVE WASTE DISPOSAL; TRANSURANIUM ELEMENTS; CONTAMINATION; SOLID WASTES; VOLUME; RADIOISOTOPES; PLUTONIUM 239; FISSION PRODUCTS; BUILDINGS; ECONOMICS; COST BENEFIT ANALYSIS

\section{2}

U.S. Atomic Energy Commission, Washington, DC

RADIOACTIVE WASTE EVAPORATOR AND AUXILIARIES, RICHLAND, WASHINGTON. WASH-1521(Draft); 66 pp. (1972)

Figuires, tables, references

Summarizes the need and purpose for the evaporator. The environmental impact resulting frnm its operation, including unavoidable adverse effects and alternates, is given. $\mathbf{A}$ cost-benefit analysis leads to conclusion that construction and operation of the evaporatory should proceed.

SUBJECT CATEGORY: General

ORIGIN: Commercial; Defense

KEYWORDS: CONCRETES; RADIOACTIVE WASTE STORAGE; CALCINATION; LIQUID WASTES; COST BENEFIT ANALYSIS; RADIOACTIVE WASTE MANAGEMENT; EVAPORATION; SHIELDING; SALT DEPOSITS; EVAPOR. ATORS

\section{3}

U.S. Atomic Energy Commission, Washington, DC

DRAFT ENVIRONMENTAL STATEMENT FUTURE HIGH LEVEL WASTE FACILITIES - SAVANNAH RIVER PLANT. WASH-1528; 70 pp. (1972)

The first proposed addition will consist of 1.3million-gallon high-activity waste tanks, an evaporator, and associated auxiliaries. Cost is 14-million dollars. About 20,000,000 gallons of radioactive liwuid waste, insoluble sludge, and crystallized salts are stored at the plant tank farms, and liquid waste continues to be generated at a rate of about $4,000,000$ gallons per year.

SUBJECT CATEGORY: HLW

ORIGIN: Defense 
KEYWORDS: RADIOACTIVE WASTE STORAGE; SAVANNAH RIVER PLANT; MODIFICATIONS; REPORTS; INVENTORIES; ENVIRONMENT; LICENSING; . LIQUID WASTES; SLUDGES; EVAPORATORS

\section{4}

Lewis, A.E., J.J. Cohen, and R.L. Braun; University of California, Livermore, CA

DISPOSAL OF NUCLEAR WASTE BY INSITU INCORPORATION IN DEEP MOLTEN SILICATE ROCK. CONF-711233; Underground Waste Management and Environmental Implications, Houston, TX, December 6, 1971. Amer. Assoc. Petr. Geol. 1972:280-286. (1972)

See Nuclear Science Abstracts 1975, 31(01) 01301

SUBJECT CATEGORY: HLW; Isolation

ORIGIN: Defense; Commercial

KEYWORDS: CAVITIES; COST; ENVIRONMENT; FUEL REPROCESSING PLANTS; LIQUID WASTES; MELTING; RADIOACTIVE WASTE DISPOSAL; RADIOACTIVE WASTE PROCESSING; RADIOACTIVE WASTES; ROCKS; SAFETY; SOLIDIFICATION; UNDERGROUND DISPOSAL

285

Spitzyn, V.I., A.A. Khonikevich, V.D. Balukova, L.M. Nosova, and N.A. Rakov; USSR State Committee on the Utilization of Atomic Energy, Moscow, USSR

TECHNICAL AND ECONOMIC ASPECTS OF HANDLING INTERMEDIATE AND HIGHACTIVITY LIQUID WASTES. CONF-721107; Management of Radioactive Wastes from Fuel Reporcessing, Proceedings of a OECD/IAEA Symposium, Paris, France, November 27-December 1, 1972. International Atomic Energy Agency, Vienna, Austria, (pp. 259-274). (1972)

The paper discusses the problems of handling intermediate- and high-level liquid wastes obtained during the reprocessing of fuel elements from waterpower reactors. Data on the chemical and radiochemical composition of these wastes are presented. When the waste is highly radioactive, it is ad visable to extract strontium and cesium, and possibly other isotopes. For the part remaining after extraction, the following handling procedures are considered: (1) Prolonged storage in special tanks in order to reduce the overall activity of the fission products contained in the waste; (2) Incorporation of highlevel wastes in solids by one of the well-known methods tested in pilot plants; (3) Burial of highlevel wastes in water-bearing geological horizonssimilar to the underground burial of intermediatelevel wastes as practised in the USSR. Also presented are some calculated technical and economic data on the storage of high-level liquid wastes, and on the underground burial of intermediate and high-level wastes. These methods are compared with other methods of storage and processing of radioactive wastes. (Auth)

SUBJECT CATEGORY: HLW; Spent Fuel; Isolation

ORIGIN: Foreign

KEYWORDS: RADIOACTIVE WASTE STORAGE; RADIOACTIVE WASTE DISPOSAL; IN. TERMEDIATE-LEVEL RADIOACTIVE WASTES; HIGH-LEVEL RADIOACTIVE WASTES; POWER REACTORS; REPROCESSING; RADIOCHEMICAL ANALYSIS; SOLVENT EXTRACTION; ECONOMICS; USSR; UNDERGROUND DISPOSAL; COMPARATIVE EVALU. ATIONS

286

Virginia Electric and Power Company

RESPONSE TO QUESTION 11.7 - SOLID WASTE MATERIAL. DOCKET-50404-18; DOCKET-50405; Amendment 5 to North Anna 3 and 4 License Application, (pp. 11.7.1 - 11.7. 3). (1972)

\section{1 figure}

The solid waste to be handled and ultimately disposed of includes bottoms from the chemical regeneration system evaporator, spent resins, spent filter cartridges and other miscellaneous solid materials resulting from station operation and maintenance, the concentrated liquid waste from the waste disposal evaporator, and the portion of concentrated bottoms from the boron recovery evaporator not reused in a primary coolant system. The volume and activity level estimated for each of these streams is shown. 


\section{SUBJECT CATEGORY: LLW}

ORIGIN: Commercial

KEYWORDS: PWR TYPE REACTORS; RADIOACTIVE WASTE DISPOSAL; SOLID WASTES; NORTH ANNA-3 REACTOR; NORTH ANNA-4 REACTOR; VOLUME; INVENTORIES; LIQUID WASTES

\section{7}

Blasewitz, A.G., G.L. Richardson, J.L. McElroy, J.E. Mendel, and K.J. Schneider; Westinghouse Hanford Co., Richland, WA; Battelle Pacific Northwest Laboratory, Richland, WA

THE HIGH-LEVEL WASTE SOLIDIFICATION DEMONSTRATION PROGRAM. CONF721107; Management of Radioactive Wastes from Fuel Reprocessing, Proceedings of a Symposium, Paris, France, November 27, 1972. OECD-LAEA, (pp. 615-654). (1972)

The High Level Waste Solidification Demonstration Program has involved pilot plant demonstrations with three alternative solidification systems: phosphate glass slidification, spray solidification, and pot calcination. The demonstrations have been performed with solutions having chemical compositions and radioactivity levels comparable to those which will exist in commercial fuel reprocessing plants. Extensive studies have also been conducted to determine the requirements for treating the effluents from the solidification processes and to evaluate the solidified waste products. The program data have been evaluated to provide a comparison of the processing parameters, product characteristics, industrial application potentialities, and economics associated with the solidification systems.

SUBJECT CATEGORY: HLW

ORIGIN: Commercial

KEYWORDS: HIGH-LEVEL RADIOACTIVE WASTES; GLASS; CALCINATION; FUEL REPROCESSING PLANTS; ECONOMICS; SOLIDIFICATION; RADIOACTIVE WASTE PROCESSING

\section{8}

Wisconsin Public Service Corporation
RESPONSE TO QUESTION 11.14 - RADIOACTIVITY RELEASES NOT GATHERED BY VENT HEADER. DOCKET-50305-33; Amendment 15 to Kewaunee License Application, (pp. Q11.14-1 - Q11.14-3). (1972)

Supplements table 11.1-6 in the FSAR with estimates of the release volumes and activities associated with steam-generator blowdown. pressure relief, containment purge, air ejectors, auxiliary building vent system, and other gaseous sources not gathered by the vent header and compressed. Provides all assumptions used for these estimates.

\section{SUBJECT CATEGORY: Airborne}

ORIGIN: Commercial

KEYWORDS: PWR TYPE REACTORS; RADIOACTIVE EFFLUENTS; GASEOUS WASTES; FORECASTING; KEWAUNEE REACTOR

\section{9}

Amalraj, R.V.

STORAGE TANKS FOR LIQUID RADIOACTIVE WASTES - THEIR DESIGN AND USE. CEGB Digest 24(9):7. (1972)

This book discusses the design criteria of radioactive waste storage systems. Chapter headings include - Nature of radioactive liquid wastes and their storage; Considerations for design of waste storage tanks; Design and construction of waste storage tanks; Operating techniques; Shielding of waste storage tanks; Environmental safeguards; Summary of experience and costs.

SUBJECT CATEGORY: Isolation; HLW

ORIGIN: Foreign

KEYWORDS: DESIGN; ECONOMICS; RADIOACTIVE WASTE STORAGE; RADIOACTIVE WASTE DISPOSAL

290

Pimenov, M.K.

STUDIES AND TECHNOLOGY OF THE SUBSURFACE DISPOSAL OF LIQUID RA- 
DIOACTIVE WASTES. ORNL-tr-2862; CONF7210129-2; Proceedings of a Science-Technical Conference, Kolobzheg, Poland, Oct 2 1972, 14 pp. (1972)

Translated from Russian.

See Nuclear Science Abstracts 1975, 31(03) 06777

SUBJECT CATEGORY: Isolation

ORIGIN: Foreign

KEYWORDS: ECONOMICS; LIQUID WASTES; RADIOACTIVE WASTE DISPOSAL; SAFETY; UNDERGROUND DISPOSAL

291

Schoeneich, K.

METHOD FOR THE DISPOSAL OF LIQUID RADIOACTIVE WASTE EFFLUENTS. Przem. Chem. 51(11):746. (1972)

It is proposed to dispose of radioactive waste liquids by means of hydrofracturing of rocks using the method tried with success in the oil and natural gas industry to enhance the yield. It involves drilling a hole with a diameter of a few centimeters and a depth of about $1000 \mathrm{~m}$, forcing the liquid into it under a pressure exceeding $160 \mathrm{~atm}$. This causes vertical or horizontal cracks, depending on the position, of several tens of meter diameter in the impermeable rock. Cement is added to the waste liquids and the grout is allowed to solidify in the cavity, creating layers of impervious rock-like concrete. Cost estimate of the process is given.

SUBJECT CATEGORY: LLW

ORIGIN: Foreign

KEYWORDS: CONCRETES; GEOLOGY; RADIOACTIVE WASTE DISPOSAL; LIQUID WASTES; POLAND; HYDRAULIC FRACTURING; ROCK MECHANICS

\section{2}

USE OF LOCAL MINERALS IN THE TREATMENT OF RADIOACTIVE WASTE. Technical Report Series No. 136; 113 pp. (1972)
Information pertinent to pre-burial waste processing is presented.

The decontamination of radioactive solutions by use of minerals are discussed. Included in the seven chapters are information on the kinds and properties of useful minerals, the possible mineral-waste solution reactions, mineral processing for waste treatment, plant scale applications, final product conditioning, and economic aspects of treatment. The three appendices include a list of natural materials useful in waste treatment, a section on the definition and determination of capacities of natural ion exchangers, and communications concerning national experience in various countries.

SUBJECT CATEGORY: LLW

ORIGIN: Foreign

KEYWORDS: MINERALS; ADSORPTION; ADSORBENTS; ION EXCHANGE; ZEOLITES; SILICATES; OXIDES; HALIDES; CARBONATES; PHOSPHATES; SULFATES; ECONOMICS; VOLUME; WASTE PROCESSING

293

NUCLEAR PLANTS - WPPSS REACTOR NO. 1; FERMI DECOMMISSIONING. Atomic En. ergy Clearing House 18(49): 1. (1972)

Washington Public Supply System negotiated a contract to construct a N-Power Generating unit and initial core loading for plant to be located at Hanford, Washington. Contract calls for expenditure of over $\$ 50$ million. The unit, WPPSS reactor project No. 1, will provide $1200 \mathrm{MWE}$ and is expected to be in operation by 1980 . The Power Development Co. reported its decision to decommission the Enrico Fermi LMFBR reactor. Lack of assured funding for further $R D$ associated with the installation of a more advanced fuel was given as reason.

SUBJECT CATEGORY: Remedial Action, FUSRAP

ORIGIN: Defense; Commercial

KEYWORDS: ECONOMICS; ENRICO FERMI-1 REACTOR; REACTOR DECOMMISSIONING; CONSTRUCTION; NUCLEAR INDUSTRY; ELECTRIC UTILITIES; NUCLEAR POWER PLANTS; FBR TYPE REACTORS; COST 
294

NUCLEAR LEGISLATION - INTERNATIONAL STUDY ON RADIOACTIVE WASTES. Atomic Energy Clearing House 18(9):1624. (1972)

Identical resolutions introduced in senate and house for international study on repositories for radioactive wastes to be set up under international treaties. Recommendation pertains to international commission recommending location of sites and acceptability by country in which site located. On completion of study, treaty be negotiated - including, but not limited to (1) procedures for transportation, methods of storage, compensation, and (2) establishment of international agency to administer. Senators Pearson, Baker, and Pastore comment - E.G., AEC has on hand at present time in accumulation of high-level, concentrated waste (40 million gallons) probably $8 X$ greater than that projected for burial at first federal repository. Worldwide, there is in existence perhaps 83.5 million gal from development of weapons and commercial reactors. No economic utility nor is any practical use envisionsed for this incredible concentration of deadly material. (Unquote).

\section{SUBJECT CATEGORY: HLW; Isolation}

ORIGIN: Defense; Foreign; Commercial

KEYWORDS: FRANCE; UNITED KINGDOM; RADIOACTIVE WASTE DISPOSAL; RADIOACTIVE WASTE STORAGE; WASTE TRANSPORTATION; RADIOACTIVE WASTE MANAGEMENT; GERMAN FEDERAL REPUBLIC; USSR; SALT DEPOSITS; USA

\section{5}

NEW COST DATA FOR INSTALLING ADDON RADWASTE CONTROL EQUIPMENT. Nuclear Industry 19(5):19-21. (1972)

Considerable new data was introduced during the recently concluded low-as-practicable public- rulemaking proceeding concerning the costs of installing additional equipment to nuclear power plants to reduce the amounts of radioactive effluents released to the environment. Costs for improved off-gas system for BWR's tabulated. Data for PWR's not tabulated, but cost for trapping iodine (low-as-practicable release) would be 500,000 dollars a year.

SUBJECT CATEGORY: Airborne

ORIGIN: Commercial

KEYWORDS: BWR TYPE REACTORS; RADIOACTIVE WASTE DISPOSAL; GASEOUS WASTFS; EQUIPMENT; COST; OFF-GAS SYST. EMS; CAPITAL; OPERATING COST; IODINE

\section{6}

TREATMENT AND STORAGE OF RADIOACTIVE SOLID WASTES DERIVED FROM THE NUCLEAR POWER STATIONS IN THE NETHERLANDS. Atoomenerg. Haar Toepass. 14:235-248. (1972)

Forecasts the amounts of radioactive wastes to arise from the operation of nuclear power stations in the nellierlunds. Vurious treatment and storage methods are compared and as the best solution for low and medium level solid wastes storage in a solutionmined cavity in rock salt is proposed. Possibilities for storage of high-level wastes are also indicated.

SUBJECT CATEGORY: LLW; HLW

ORIGIN: Fureign

KEYWORDS: RADIOACTIVE WASTE PROCESSING; RADIOACTIVE WASTE MANAGEMENT; FISSION PRODUCTS; NETHERLANDS; SALT DEPOSITS; FORECASTING; RADIOAC'IIVE' WAS'I'E S'IORAGE 
1973

297

Kubo, A.S., and D.J. Rose; Army Corps of Engineers, Fort Leavenworth, KS

DISPOSAL OF NUCLEAR WASTES. Science 182(4118):1205-1211. (1973)

See Nuclear Science Abstracts 1974, 29(06) 13271

SUBJECT CATEGORY: HLW; LLW

ORIGIN: Commercial; Defense

KEYWORDS: ARCTIC REGIONS; CONTAMINATION; COST; ENVIRONMENT; GEOLOGIC DEPOSITS; ICE; NUCLEAR POWER PLANTS; RADIOACTIVE WASTE DISPOSAL; RAOIOACTIVE WASTE PROCESSING; RADIOACTIVE WASTES; REVIEWS; SAFETY; UNDERGROUND DISPOSAL

\section{8}

Bruns, L.E.; Atlantic Richfield Hanford Co., Richland, WA

CRITICALITY PREVENTION BY CONTINUOUS NONDESTRUCTIVE INSTRUMENTATION ASSAY IN THE PLUTONIUM RECLAMATION FACILITY. Transactions of the American Nuclear Society 16(1):147-148; Proceedings of the ANS Annual Meeting, Chicago IL, June 10-14, 1973. (1973)

Criticality prevention is the number-one priority in the safe operation of the Plutonium Reclamation Facility (PRF), a plutonium scarp recovery facility operated by the Atlantic Richfield Hanford Company for the Atomic Energy Commission. The PRF uses geometrically favorable equipment wherever possible; however, added assurance is attained by monitoring the plutonium inputs, outputs, and inventories by continuous or semicontinuous instrumentation. Geometrically favorable equipment aided by instrumentation allows safe processing of large plutonium throughputs with attendant high plutonium inventories in the PRF.

SUBJECT CATEGORY: TRU; HLW

ORIGIN: Defense
KEYWORDS: CRITICALITY; SAFETY; PLUTONIUM; REPROCESSING; INVENTORIES; RADIOACTIVE WASTES; RADIOACTIVE WASTE PROCESSING; TRANSURANIUM ELEMENTS; HIGH-LEVEL RADIOACTIVE WASTES

\section{9}

Field, B.B., and C.K. Rosnick; Atlantic Richfield Hanford Co., Richland, WA

STORAGE FEE ANALYSIS FOR A RETRIEVABLE SURFACE STORAGE FACILITY. ARH-2960 (Vol. 2); 224 pp. (1973)

See Nuclear Science Abstracts 1975, 32(01) 01559

SUBJECT CATEGORY: HLW; Spent Fuel

ORIGIN: Commercial

KEYWORDS: COST; RADIOACTIVE WASTE FACILITIES; RADIOACTIVE - WASTE STORAGE

300

Field, B.B., and C.K. Rosnick; Atlantic Richfield Hanford Co., Richland, WA

STORAGE FEE ANALYSIS FOR A RETRIEVABLE SURFACE STORAGE FACILITY. ARH-2960 (Vol. 1); 115 pp. (1973)

See also Nuclear Science Abstracts 1975, 32(01) 01558

Conceptual design studies are in progress for a Water Basin Concept (WBC) and an alternative Sealed Storage Cask Concept (SSCC) of a Retrievable Surface Storage Facility (RSSF) intended as a Federal government facility for storing high-level radioactive wastes until a permanent disposal method is established. The RSSF will be a manmade facility with a design life of at least $100 \mathrm{y}$, and will have capacity to store all of the high-level waste from the reprocessing of nuclear power plant spent fuels generated by the industry through the year 2000. This report is a basic version of ARH-2746, "Retrievable Surface Storage Facility, Water Basin Concept, User Charge Analysis." It is concerned with the issue of establishing a fee to cover the cost of storing nuclear wastes both in the RSSF and at the subsequent disposal facility.

SUBJECT CATEGORY: HLW; Spent Fuel 
ORIGIN: Commercial

KEYWORDS: RADIOACTIVE WASTE STORAGE; COST; RADIOACTIVE WASTE FACILITIES; CASKS; GROUND DISPOSAL; HIGHLEVEL RADIOACTIVE WASTES; SPENT FUELS

301

Costello, J.M., and D.M. Levins; Australian Atomic Energy Commission, Coogee, New South Wales

REDUCTION IN CAPITAL COSTS OF FUEL REPROCESSING PLANTS. Transactions of the American Nuclear Society 17:320; CONF-731101; American Nuclear Society and the Atomic Industrial Forum and Nuclear Energy Exhibition Joint Meeting, San Francisco, CA, November 11, 1973. (1973)

See Nuclear Science Abstracts 1975, 29(03) 04997

SUBJECT CATEGORY: HLW; Spent Fuel

ORIGIN: Foreign

KEYWORDS: COST; FUEL REPROCESSING PLANTS; OPTIMIZATION; PLUTONIUM; PURIFICATION; SPENT FUEL STORAGE; URANIUM

302

Bartlett, J.W., L.A. Bray, L.L. Burger, R.E. Burns, and J.L. Ryan; Battelle Pacific Northwest Laboratory, Richland, WA

FEASIBILITY EVALUATION AND R $D$ PROGRAM PLAN FOR TRANSURANIC PARTITIONING OF HIGH-LEVEL REPROCESSING WASTE. BNWL-1776; 72 pp. (1973)

6 figures, 135 references; See.also Nuclear Science Abstracts, 1974, 29(06) 12638.

An approach to managing high-level radioactive waste is to separate it into fractions of different halflives. The objectives for this study were to review existing separations technologies and assess their potential for this application. The review concluded that, of all of the alternatives available, solvent extraction and ion exchange separations of the types already widely used in the nuclear industry offer the best prospects for a cost effective process.
Partitioning using these technologies to achieve transuranium element decontamination factors on the order of 100 is expected to be feasible. The $R D$ program to select and develop a partitioning process is expected to require five years for completion. Total estimated funding required is approximately 3.0 million dollars.

SUBJECT CATEGORY: TRU; HLW

ORIGIN: Defense

KEYWORDS: RADIOACTIVE WASTE DISPOSAL; RADIOACTIVE WASTE STORAGE; FISSION PRODUCTS; SEPARATION PROCESSES; TRANSURANIUM ELE MENTS;RADIOACTIVE WASTE MANAGEMENT; REPROCESSING; ECONOMICS; COST; DECONTAMINATION; RADIOACTIVE WASTES; SOLVENT EXTRACTION; ION EXCHANGE; HIGH-I.EVEL, RADIOACTIVE WASTES; PARTITION

\section{3}

Burger, L.L., and J.L. Ryan; Battelle Pacific Northwest Laboratory, Richland, WA

THE TECHNOLOGY OF TRITIUM FIXATION AND STORAGE. BNWL-1807; 34 pp. (1973)

Review of tritium fixation in solid form; 54 references

Criteria were estublished for narrowing the very wide possible choice of tritium fixation methods and the merits of various classes of tritium compounds are discussed. Current tritium fixation technology and fixation research is reviewed. The basic chemical and technical aspects of known and potential fixation methods and the applicability of these methods to specific sources or types of tritiated waste with some estimate of economics are given. These fixation methods are compared briefly to some other tritium disposal methods. Recommendations for further studies are made. Clays, Portland cement. and hydrides all appear to have merit, depending on the nature (principally degree of dilution) of the tritium waste. (Modified auth. abst.)

SUBJECT CATEGORY: LLW

ORIGIN: Commercial; Defense

KEYWORDS: TRITIUM; RADIOACTIVE WASTE MANAGEMENT; SOLIDIFICATION; RADIOACTIVE WASTE STORAGE; WASTE 
DISPOSAL; ECONOMICS; VOLUME; LOWLEVEL RADIOACTIVE WASTES

304

Boston Edison Co., Mass.

PILGRIM NUCLEAR POWER STATION, UNITS 2 AND 3. ENVIRONMENTAL REPORT, VOLUME 3. DOCKET-50471-14; DOCKET-50472-13; 475 pp. (1973)

See Nuclear Science Abstracts 1974, 29(06) 15002

SUBJECT CATEGORY: General

ORIGIN: Commercial

KEYWORDS: COST BENEFIT ANALYSIS; ENVIRONMENT; PILGRIM-2 REACTOR; PILGRIM3 REACTOR; POWER TRANSMISSION; RADIOACTIVE . WASTE DISPOSAL; RADIOACTIVITY; REACTOR ACCIDENTS; REACTOR COOLING SYSTEMS; WASTE MANAGEMENT

305

Kukacka, L.E., and R.J. Isler; Brookhaven National Laboratory, Upton, NY

COST ESTIMATE FOR REMEDIAL ACTION PROGRAM FOR RESIDENCES IN THE GRAND JUNCTION, COLORADO AREA. BNL-17433; 23 pp. (1973)

Cost estimates were made for remedial action in residences in the Grand Junction, Colorado area in which uranium mill tailings were used as a fill material under and around foundations. Gamma radiation profiles were analyzed and remedial action plans formulated for 226 residences. Removal of all uranium tailings under or within 5 -ft of the dwelling was stipulated for all residences in which the external gamma radiation (EGR) level was greater than or equal to $0.05 \mathrm{mR} / \mathrm{hr}$ above background, Level 1 of the Surgeon General's guidelines. For residences with an EGR greater than or equal to 0.001 and less than $0.05 \mathrm{mR} / \mathrm{hr}$ above background it was presumed that the radon daughter concentration (RDC) was greater than 0.01 Working Level (WL). In this case, the use of sealants and grouting materials in conjunction with appropriate tailing removal was assumed as an alternative to complete removal of tailings. Economic data were compiled for 226 homes. Fighty homes had an EGR less than
$0.001 \mathrm{mR} / \mathrm{hr}$ above background and therefore required no remedial action. For the other levels the cost estimates ranged from $\$ 2360$ to $\$ 6560$. The average for the 226 residences was $\$ 2110$. Based on the established radiation level criteria and the assumed remedial action plan, a total program cost of $\$ 10,000,000$ was estimated for the 4800 residences in Grand Junction that have tailings under or near the structure. This is approximately $33 \%$ lower than a previous estimate of $\$ 15,000,000$ which was based entirely on the removal of tailings from soil under or near areas in which the gamma radiation level was above background. Compared to the latter, the use of sealants and grouts results in an overall cost reduction of $\$ 1,900,000$ (approximately $13 \%$ ). The remainder of the saving $(\$ 3,100,000)$ is due to the deletion of any remedial action for residences with an EGR less tham $0.001 \mathrm{mR} / \mathrm{hr}$ above background and for limiting tailings removal to within $5-\mathrm{ft}$ of residences. (Auth)

SUBJECT CATEGORY: Remedial Action, Mill Tailings

ORIGIN: Commercial

KEYWORDS: ECONOMICS; URANIUM; MILL TAILINGS; RESIDENTIAL BUILDINGS; GAMMA RADIATION; RADIATION DOSES; RADON; DECAY PRODUCTS; RADIATION PROTECTION; DECONTAMINATION; COST

306

Bardet, G., and Y. Sousselier; CEA Centre d'Etudes Nucleaires de Saclay, 91 - Gif-sur-Yvette, France

RADIOACTIVE EFFLUENTS AND BYPRODUCTS RESULTING FROM THE PRODUCTION OF NUCLEAR ENERGY. CEACONF-2462; CONF-730983-2; Congress of the Society of Electrical, Electronic and Radio Engineers, Proceedings of a Meeting, Vittel, France, September 11, 1973, 22 pp. (1973)

In French

See Nuclear Science Abstracts, 1974, 29(09) 21627.

SUBJECT CATEGORY: Spent Fuel

ORIGIN: Foreign

KEYWORDS: ECONOMICS; REPROCESSING; RADIOACTIVE WASTE PROCESSING; RADIOACTIVE WASTES; SITE SELECTION; SPENT FUELS 
307

Bourgeois, M., M. Perrot, and Y. Rochedereux; CEA, Centre d'Etudes Nucleaires de Fontenay-aux-Roses, 92, France; Organization for Economic CoOperation and Development, 75 - Paris, France; International Atomic Energy Agency, Vienna, Austria

PROBLEM OF WASTES IN THE PROCESSING OF IRRADIATED FUELS BY THE DRY METHOD. CONF-721107-; Management of Radioactive Wastes from Fuel Reprocessing, Proceedings of a Symposium, Paris, France, November 27, 1972. OECD-IAEA. (1973)

In French

See Nuclear Science Abstracts 1974, 29(04) 07649.

SUBJECT CATEGORY: Spent Fuel; HLW

ORIGIN: Foreign

KEYWORDS: ECONOMICS; FISSION PRODUCTS; FLUORIDE VOLATILITY PROCESS; RADIOACTIVE WASTES; REPROCESSING; SPENT FUELS; RADIOACTIVE WASTE STORAGE

308

Bendell, F., R. Bonniaud, P. Michel, and L. Rozand; CEA, Paris, France

ECONOMIC EVALUATION OF PROCEDURES FOR STORING HIGH-ACTIVITY EFFLUENTS FROM FUELS FROM FAST NEUTRON REACTORS. CONF-721107; Management of Radioactive Wastes from Fuel Reprocessing, Proceedings of a Symposium, Paris, France, November 27, 1972. OECD-IAEA, (pp. 863$872)$. (1973)

In French

See Nuclear Science Abstracts, 1974, 29(04) 08407.

SUBJECT CATEGORY: Isolation; Spent Fuel; HLW

ORIGIN: Foreign

KEYWORDS: COST; ECONOMICS; FAST REACTORS; FUEL REPROCESSING PLANTS; GLASS; RADIOACTIVE WASTE PROCESSING; RADIOACTIVE WASTES; REPROCESSING; SPENT FUEL ELEMENTS; VITRIFICATION; RADIOACTIVE WASTE STORAGE
309

Clarke, R.H.; Central Electricity Generating Board, Berkeley, Eng. Berkeley, CA

WEERIE PROGRAM FOR ASSESSING THE RADIOLOGICAL CONSEQUENCES OF AIRBORNE EFFLUENTS FROM NUCLEAR INSTALLATIONS. Health Phys. 25(3):267. 280. (1973)

See Nuclear Science Abstracts 1974, 29(07) 15568

SUBJECT CATEGORY: Airborne

ORIGIN: Commercial

KEYWORDS: RADIOACTIVE AEROSOLS; COMPUTER CODES; INVENTORIES; MATHEMATICAL MODELS; NUCLEAR FACILITIES; RADIATION DOSES; RADIOACTIVE WASTES; W CODES

310

Roux, M.; Centre de Recherches en Physique des Plasmas; Lausanne, Switzerland

BIBLIOGRAPHIC COMPILATION AND TABULATION OF RESOURCES, OF THEIR CONSUMP'IION AND THEIR WASTE IN THE WORLD COMPILATION. LRP-63/73; 86 pp.; N-73-30975. (1973)

In Frensh; Availahle from N'I'IS

See Nuclear Science Abstracts 1975, 29(01)02311

SUBJECT CATEGORY: General

ORIGIN: Foreign

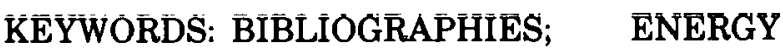
CONSUMPTION; ENERGY DEMAND; ENERGY SOIRCES; FORFCASTING; FOSSII. FUEI.S; HYDROELECTRIC POWER; NUCLEAR FUELS; POWER GENERATION; RADIOACTIVE WASTES; RESERVES; SOLAR ENERGY

311

Baba, T.; Chuguku Electric Power Co. Inc., Hiroshima, Japan

SHIMANE NUCLEAR POWER STATION. Genshiryoku Kogyo 19(3):9-32. (1973)

In Japanese 
See Nuclear Science Abstracts 1974, 29(09) 23412

SUBJECT CATEGORY: General

ORIGIN: Foreign

KEYWORDS: BUILDINGS; CONSTRUCTION; CONTAINMENT SPRAY SYSTEMS; COST; DESIGN; ENVIRONMENT; NUCLEAR MATERIALS MANAGEMENT; NUCLEAR POWER PLANTS; QUALITY CONTROL; RADIOACTIVE WASTE DISPOSAL; RADIOACTIVE WASTE PROCESSING; REACTOR COOLING SYSTEMS; REACTOR INSTRUMENTATION; REACTOR LICENSING; REACTOR SAFETY; REACTOR SITES; SHIMANE-1 REACTOR; SOLID FUELS; STEAM TURBINES; TRANSPORT

\section{2}

Cleveland Electric Illuminating Co., Cleveland, $\mathrm{OH}$

PERRY NUCLEAR POWER PLANT, UNITS 1 AND 2. USAEC DRAFT ENVIRONMENTAL S'TATEMEN'I. DOCKE'I'-50440-26; DOCKET50441-26; 231 pp. (1973)

See Nuclear Science Abstracts 1974, 29(05) 12292

SUBJECT CATEGORY: General

ORIGIN: Commercial

KEYWORDS: ARCHAEOLOGY; COST BENEFIT ANALYSIS; ECOLOGY; ECONOMICS; ENVIRONMENT; GEOLOGY; GROUND WATER; LAKE ERIE; METEOROLOGY; PERRY-1 REACTOR; PERRY-2 REACTOR; POWER; POWER TRANSMISSION; RADIATION MONITORING; RADIOACTIVE WASTES; REACTOR ACCIDENTS; REACTOR OPERATION; REACTOR SITES; SOCIOLOGY; SOILS; SURFACE WA. TERS; THERMAL POLLUTION

313

Kaufmann, F; Comision Nacional de Energia Atomica, Buenos Aires, Argentina

REPROCESSING, STORAGE, AND TRANSPORT COSTS OF IRRADIATED NATURAL URANIUM FUELS IN ARGENTINA. CNEAEN-37/110; 107 pp. (1973)

In Spanish

See Nuclear Science Abstracts 1974, 30(08) 20827
SUBJECT CATEGORY: Transportation; Spent Fuel

ORIGIN: Foreign

KEYWORDS: ARGENTINA; COST; ECONOMICS; REPROCESSING; SPENT FUEL ELEMENTS; SPENT FUEL STORAGE; WASTE TRANSPORTATION

314

Vinck, W., H. Maurer, and H. Boos; Commission of the European Communities, Directorate General for Industrial, Technological and Scientific Affairs, Luxenbourg

THE PRESENT AND FUTURE SITUATION OF NUCLEAR ENERGY - PRODUCTION AND ITS ASSOCIATED INDUSTRY. Report 2438/III/72-3; Nuclear Energy and the Environment, Proceedings of an International Colloquium, Lieg, Belgium, January 22-25, 1973, 101 pp. (1973)

Gives an outline of the current status of the future trends in nuclear power development in the six member states of the European community and in the frame of its enlargement to nine countries. The topics dealt with nuclear power forecasts, radioactive effluents from a growing nuclear industry, radioactive waste storage and accumulation, or processing wastes, thermal waste from nuclear power production, accident potential, accident prevention and limitation of the possible consequences, and nuclear hazards in relation to other risks.

SUBJECT CATEGORY: General

ORIGIN: Foreign

KEYWORDS: RADIOACTIVE EFFLUENTS; FRANCE; UNITED KINGDOM; RADIOACTIVE WASTE DISPOSAL; RADIOACTIVE WASTE STORAGE; BELGIUM; POWER REACTORS; FORECASTING; NUCLEAR POWER

315

Commonwealth Edison Co., Chicago, IL

DRESDEN NUCLEAR POWER STATION, UNITS 2 AND 3. FINAL ENVIRONMENTAL STATEMENT. DOCKET-50237-416; DOCKET50249-313; 431 pp. (1973)

See Nuclear Science Abstracts 1974, 29(04) 09556

SUBJECT CÁTEGORY: General 
ORIGIN: Commercial

KEYWORDS: COST BENEFIT ANALYSIS; DRESDEN-2 REACTOR; DRESDEN-3 REACTOR; ENVIRONMENT; RADIOACTIVE WASTES; REACTOR OPERATION; REACTOR SITES

316

Consolidated Edison Co., New York, NY

INDIAN POINT STATION, UNIT 3. DRAFT ENVIRONMENTAL STATEMENT. DOCKET. $50286-106 ; 546$ pp. (1973)

See Nuclear Science Abstracts 1975, 29(01) 02250

SUBJECT CATEGORY: General

ORIGIN: Commercial

KEYWORDS: CLIMATES; CONSTRUCTION; COST BENEFIT ANALYSIS; ECOLOGY; ENVIRONMENT; GEOGRAPHY; GEOLOGY; HYDROLOGY; INDIAN POINT-3 REACTOR; NONRADIOACTIVE WASTES; POWER; RADIOACTIVE WASTES; REACTOR OPERATION; REACTOR SITES; WATER

\section{7}

Reichert, R.G.; Dornier System Gmbh, Friedrichshafen, Germàny, F.R.

TRANSPORTATION OF HIGHLY ACTIVE NUCLEAR WASTE PRODUCTS TO THE SUN. Astronautik 10(2):157-160. (1973)

In German

See Nuclear Science Abstracts 1974, 30(07) 19450

SUBJECT CATEGORY: HLW; Transportation

ORIGIN: Foreign

KEYWORDS: COST; NUCLEAR POWER PLANTS; RADIOACTIVE WASTE DISPOSAL; SAFETY; SPACE FLIGHT; SPACE VEHICLES; SUN; WASTE TRANSPORTATION
LARGE VOLUMES OF RADWASTE BEING GENERATED AT OCONEE STATION. DOCKET-50269; DOCKET-50270; DOCKET-50287; Letter to Directorate of Licensing (AEC), October 26, 1973, 3 pp. (1973)

Liquid and gas waste-management systems are processing larger volumes of fluids than were estimated in the FSAR. Basic problems include: (1). Mixing of uncontaminated water with low-levelwaste water; (2) Boron and other chemicals add additional problems; (3) Nitrogen overblankets resulted in higher-than-predicted gaseous wastes; and (4) Waste-management systems are not operating at expected capacities to overcome these problems, interim waste-management facilities will be installed until additional permanent facilities can be provided. Studies to improve operation of present facilities are continuing.

SUBJECT CATEGORY: Airborne; LLW

ORIGIN: Commercial

KEYWORDS: PWR TYPE REACTORS; RADIOACTIVE WASTE MANAGEMENT; MODIFICA TIONS; DESIGN; OCONEE-1 REACTOR; EQUIP. MENT

319

Nomi, M.; Ebara Mfg. Co. Ltd., Tokyo, Japạn

SOLIDIFICATION OF INTERMEDIATEAND LOW-I.FVFI, RADIOACTIVE WASTES, Fapig 70:103-109. (1973)

In Japanese

See Nuclear Science Abstracts 1974, 30(05) 12410

SUBJECT CATEGORY: LLW; HLW

ORIGIN: Foreign

KEYWORDS: ASPHALTS; CEMENTS; CONCRETES; COST; LIQUID WASTES; MECHANICAL PRUPEKITES; RAUIUACTIVE WASI'E PROCESSING; RADIOACTIVE WASTES; SAFETY; SOLID WASTES; SOLIDIFICATION; HIGH-LEVEL RADIOACTIVE WASTES; INTERMEDIATE-LEVEL RADIOACTIVE WASTES

320

Ryan, L.F.; Graver Water Conditioning Co., Union, NJ 
IMPACT OF POWDERED ION-EXCHANGE RESINS FOR WATER TREATMENT ON BWR OPERATIONS. Proc. Amer. Power Conf. 35:864874; CONF-730582; American Power Conference, Chicago, ILlinois, May 8, 1973. (1973)

See Nuclear Science Abstracts 1974, 30(01) 01852

SUBJECT CATEGORY: General

ORIGIN: Commercial

KEYWORDS: BIG ROCK POINT REACTOR; BWR TYPE REACTORS; COST; DRESDEN-1 REACTOR; DRESDEN-2 REACTOR; DRESDEN-3 REACTOR; ECONOMICS; FEEDWATER; FIL TERS; ION EXCHANGE MATERIALS; LIQUID WASTES; MONTICELLO REACTOR; NINE MILE POINT-1 REACTOR; NINE MILE POINT-2 REACTOR; NUCLEAR POWER PLANTS; OPERATION; OYSTER CREEK-1 REACTOR; PERFORMANCE; PILGRIM-1 REACTOR; POWDERS; PURIFICATION; QUAD CITIES-1 REACTOR; QUAD CITIES-2 REACTOR; RADIOACTIVE WASTE DISPOSAL; RESINS; SPECIFICATIONS; VERMONT YANKEE REACTOR; WATER

321

Gulf United Nuclear Fuels Corp., Elsmford, NY

PRELIMINARY REPORT ON LIGHT WATER REACTOR DECOMMISSIONING COSTS. GU-5295; 69 pp. (1973)

Available from NTIS, Department of Commerce, Springfield, VA 22161

Cost estimates have been prepared for decommissioning of an 1100-mwe PWR nuclear power plant and a 1100-mwe BWR nuclear power plant. For both reactor types, complete removal and in-place entombment were considered. The estimates are based on costs incurred during decomissioning of the Bonus and Elk River reactors. The Bonus reactor was a 50-mwt plant located in Punta Higuera, Puerto Rico. It was decommissioned using an entombment concept following cessation of power operations in July 1967 . The Elk River reactor was a 58-mwt indirect cycle BWR plant located in Elk River, Minnesota.

SUBJECT CATEGORY: Remedial Action, FUSRAP

ORIGIN: Commercial
KEYWORDS: ECONOMICS; ERR REACTOR; REACTOR DECOMMISSIONING; REVIEWS; BWR TYPE REACTORS; COST

322

Lerch, R.E., C.R. Cooley, and J.M. Atwood; Hanford Engineering Development Laboratory, Richland, WA

ACID DIGESTION: A NEW METHOD FOR TREATMENT OF NUCLEAR WASTE. Westinghouse Eng. 33(5):146-149. (1973)

See Nuclear Science Abstracts 1974, 29(10) 24096

SUBJECT CATEGORY: LLW

ORIGIN: Commercial

KEYWORDS: CHEMICAL REACTIONS; COMBUSTION; CONTAMINATION REGULATIONS; DESIGN; DIGESTION; ECONOMICS; PLUTONIUM; RADIOACTIVE WASTE PROCESSING; RESIDUES; SAFETY; SOLID WASTES; SULFURIC ACID; RADIOACTIVE WASTE DISPOSAL; RADIOACTIVE WASTE STORAGE

323

International Atomic Energy Agency, Vienna, Austria

RADON IN URANIUM MINING. STI-PUB-391; Radon in Uranium Mining, Proceedings of a Panel, Washington, DC, September 4-7, 1973. International Atomic Energy Agency, Vienna Austria, 171 pp. (1973)

Presents the text of 9 papers covering the following subjects: Effects of radiological and wastemanagement legislative controls on uranium costs and ore reserves; technical problems of mine ventilation specifically related to the elimination of radon gas from underground and deep open-pit uranium mines; and the phenomenon of radon emanation and the mode of radon release by different types of ore body.

SUBJECT CATEGORY: Airborne

ORIGIN: Foreign

KEYWORDS: RADON; URANIUM; MINING; VENTILATION SYSTEMS; LEGISLATION; ECONOMICS; RADIOACTIVE WASTE MANAGEMENT; RADIOACTIVE EFFLUENTS 
324

Hiyama, T.; Japan Atomic Power Co., Tokyo, Japan

TREATMENT OF RADIOACTIVE WASTES. Karyoku Genshiryoku Hatsuden 24(5):553558. (1973)

In Japanese

See Nuclear Science Abstracts 1974, 30(09) 23727

SUBJECT CATEGORY: General

ORIGIN: Foreign

KEYWORDS: BWR TYPE REACTORS; CONTA. MINATION; ECONOMICS; ENVIRONMENT; GAS COOLED REACTORS; GASEOUS WASTES; LIQUID WASTES; NUCLEAR POWER PLANTS; PWR TYPE REACTORS; RADIOACTIVE WASTE DISPOSAL; RADIOACTIVE WASTE PROCESSING; RADIOACTIVE WASTES; SAFETY; SOLID WASTES

325

Kayser, J.; Kernforschungsanlage Juelich $\mathrm{GmbH}$ (F.R. Germany). Projekt Hochtemperaturreaktor Mit Heliumturbinen

SYSTEM ANALYSIS OF THE STUDY FOR CLOSING THE HHT FUEL CYCLE. Projekt Hochtemperaturreaktor Mit Heliumturbinen; Jul-1016-HT; 69 pp. (1973)

In German; 9 figures, 14 references, 1 table; with abstract

See Nuclear Science Abstracts 1974, 30(12) 31719

SUReIFCT C.ATFGORRY: Spont Fuel

ORIGIN: Foreign

KEYWORDS: COMPARATIVE EVALUATIONS; COMPUTER CALCULATIONS; COST; FUEL CYCLE; FUEL REPROCESSING PLANTS; HTGR 'I'YPE REACTORS; MARKET; O CODES; OPTIMIZATION; SPENT FUEL ELEMENTS; SPENT FUEL STORAGE; TRANSPORT; V CODES

\section{6}

Kerr-McGee Corporation
SUPPLEMENT 3 TO ENVIRONMENTAL REPORT FOR THE URANIUM HEXAFLUORIDE PLANT. DOCKET 50-8027; Letter With Attachment to Directorate of Licensing (AEC), August 1, 1973, 22 pp. (1973)

Presents a cost/benefit analysis of the alternative methods of raffinate disposal.

SUBJECT CATEGORY: LLW

ORIGIN: Commercial

KEYWORDS: RADIOACTIVE EFFLUENTS; LIQUID WASTES; RADIOACTIVE WASTE DISPOSAL; ENRICHMENT; COST BENEFIT ANALYSIS; REPORTS; URANIUM HEXAFLUORIDE

\section{7}

Rom, F.E.; Lewis Research Center, Cleveland. OH

SUMMARY OF THE STUDY OF DISPOSAL OF NUCLEAR WASTE INTO SPACE. NASATM-X-68235; Technology Today and Tomorrow, Proceedings of the 10th Space Congress, Cocoa Beach, FL, April 11-13, 1973. Canaveral Council of Technical Societies, Cocoa Beach, FL, (p. 7.197.26). (1973)

The National Aeronautic and Space Administration (NASA), at the request of the AEC, is conducting a preliminary study to determine the feasibility of disposing of nuclear waste material into space. The sindy has indicated that the Space Shuttlc together with expendable and non-expendable orbital stages such as the Space Tug or Centaur can safely dispose of waste material by ejecting it from the solar system. (No launching system that is under development or planned can deposit waste matcrial directly into the sun). The sufety problems associated with all phases of launching and operation (normal, emergency and accident) of such a system are being examined. From the preliminary study it appears that solutions can be found that should make the risks acceptable when compared to the benefits to be obtained from the disposal of the nuclear waste. The techniques proposed to make such a system acceptable need to be carefully verified by further study and experiment. Even though more than one hundred shuttle launches would be required per year by the year 2000 , the cost to the consumer would be less than five percent of his electric bill. Tests of models of waste packages impacted on reinforced concrete and soil have demonstrated the feasibility of safely containing 
waste material at impact speeds up to 1050 feet per second. (Auth)

\section{SUBJECT CATEGORY: Isolation}

ORIGIN: Defense

KEYWORDS: RADIOACTIVE WASTE DISPOSAL; SPACE VEHICLES; RADIATION HAZARDS; SOLAR SYSTEM; EVALUATION; ECONOMICS; CONCRETES; SOILS

\section{8}

Smith, D.B., and J.E. Foley; Los Alamos Scientific Laboratory, Los Alamos, NM

CRITICALITY PROBLEMS AND SOLUTIONS IN NUCLEAR SAFEGUARDS. Transactions of the American Nuclear Society 16(1): 146; ANS 1973 Annual Meeting, Chicago, IL, June 10-14, 1973, (p. 146). (1973)

Nondestructive assay (NDA) instrumentation which is routinely used for nuclear safeguards and accountability also is being used to increase the number of individual containers of scrap and waste that can be safely combined into a single batch for processing. This increase is due to the smaller uncertainty with which the fissile content of each container can be determined. The result is more efficient and therefore more economic processing.

SUBJECT CATEGORY: LLW

ORIGIN: Defense

KEYWORDS: RADIOACTIVE WASTE MAN. AGEMENT; SAFETY; RADIATION PROTECTION; MATERIALS MANAGEMENT; RADIATION MONITORING

\section{9}

Los Alamos Scientific Laboratory, Los Alamos, NM

NUCLEAR ANALYSIS RESEARCH AND DEVELOPMENT. PROGRAM STATUS REPORT, MAY-AUGUST 1973. LA-5431-PR; 32 pp. (1973)

See Nuclear Science Abstracts 1974, 29(06) 13244

SUBJECT CATEGORY: General
ORIGIN: Defense

KEYWORDS: ABUNDANCE; FAST NEUTRONS; FISSIONABLE MATERIALS; FUEL ELEMENTS; GAMMA DETECTION; GAMMA SPECTROMETERS; INVENTORIES; NEUTRON DETECTION; NUCLEAR FUELS; NUCLEAR MATERIALS MANAGEMENT; NUCLEAR REACTION ANALYSIS; PERFORMANCE; RADIOACTIVE WASTES; RADIOMETRIC ANALYSIS; RESEARCH PROGRAMS; SAFEGUARDS

330

Honea, F.I., and W.A. Bullerdiek; Mason and Hanger-Silas Mason Co., Inc., Amarillo, TX

DISPOSAL OF WASTE OR EXCESS HIGH EXPLOSIVES. PROGRESS REPORT, JULY-SEPTEMBER 1973. MHSMP-73-40; 20 pp. (1973)

See Nuclear Science Abstracts 1974, 30(01) 02283

SUBJECT CATEGORY: General

ORIGIN: Commercial

KEYWORDS: AIR POLLUTION; BIOCHEMISTRY; CHEMICAL EXPLOSIVES; COMBUSTION; DESIGN; ECONOMICS; ENVIRONMENT; INCINERATORS; LEGAL ASPECTS; WASTE DISPOSAL; WASTES

331

Honea, F.I., W.A. Bullerdiek, J.E. Wichmann, and T.K. Mehrhoff; Mason and Hanger-Silas Mason Co., Inc., Amarillo, TX

DISPOSAL OF WASTE OR EXCESS HIGH EXPLOSIVES. PROGRESS REPORT, APRIL-JUNE 1973. MHSMP-73-29; · 32 pp. (1973)

See Nuclear Science Abstracts 1974, 30(01) 02282

SUBJECT CATEGORY: General

ORIGIN: Cunmercial

KEYWORDS: AIR POLLUTION; BIOCHEMISTRY; CHEMICAL EXPLOSIVES; COMBUSTION; DESIGN; ECONOMICS; ENVIRONMENT; INCINERATORS; LEGAL ASPECTS; RESIDUES; WASTE DISPOSAL; WASTES 
332

Honea, F.I., and T.K. Mehrhoff; Mason and Hanger-

Silas Mason Co., Inc., Amarillo, TX

DISPOSAL OF WASTE OR EXCESS HIGH EXPLOSIVES. PROGRESS REPORT, OCTOBER-DECEMBER 1973. MHSMP-74-2; 67 pp. (1973)

See Nuclear Science Abstracts 1974, 30(01) 02284

SUBJECT CATEGORY: General

ORIGIN: Commercial

KEYWORDS: AIR POLLUTION; BIOCHEMIS. TRY; CHEMICAL EXPLOSIONS; COMBUSTION; DESIGN; ECONOMICS; ENVIRONMENT; INCINERATORS; LEGAL ASPECTS; WASTE DISPOSAL; WASTES

333

Millstone Point Company, Hartford, CT

MILLSTONE NUCLEAR POWER STATION, UNIT 3. LICENSE APPLICATION, ENVIRONMENTAL REPORT, CONSTRUCTION PERMIT STAGE. DOCKET-50423-54; 684 pp. (1973)

See Nuclear Science Abstracts 1974, 29(05) 12291

SUBJECT CATEGORY: General

ORIGIN: Commercial

KEYWORDS: COST BENEFIT ANALYSIS; ECOLOGY; ELECTRIC POWER; ENVIRONMENT; GEOLOGY; HEAT TRANSFER; HY. DROLOGY; METEOROLOGY; MILLSTONE-3 REACTOR; NONRADIOACTIVE WASTES; POWER TRANSMISSION; RADIATION MONITORING; RADIOACTIVE WASTE DISPOSAL; REACTOR ACCIDENTS; REACTOR SITES

\section{4}

Millstone Point Company, Hartford, CT

RESPONSE TO QUESTION 33 - HANDLING OF WASTE CONCENTRATE. DOCKET-5042341; Amendment 10 to Millstone Point 3 License Application. (1973)

The waste concentrate is placed in shipping containers for shipment offsite. An estimate of the volume and activity is presented.
SUBJECT CATEGORY: LLW; Transportation

ORIGIN: Commercial

KEYWORDS: PWR TYPE REACTORS; RADIOACTIVE WASTE DISPOSAL; SOLID WASTES; CONTAINERS; MILLSTONE-3 REACTOR; WASTE TRANSPORTATION; VOLUME

335

Millstone Point Company, Hartford, CT

RESPONSE TO QUESTION 34 - ANNUAL VOLUME OF DRY WASTE. DOCKET-50423-41; Amendment 10 to Millstone Point 3 License Application, p. ST-13. (1973)

Annual volume of dry waste expected is approximately 75 cubic feet. Curie content of each drum is unknown; however, it is expected that drum activity will be negligible.

\section{SUBJECT CATEGORY: LLW}

ORIGIN: Commercial

KEYWORDS: PWR TYPE RFACTORS; RADIOACTIVE WASTE DISPOSAL; VOLUME; INTERFACES; MILLSTONE-3 REACTOR

336

Mississippi Power and Light Co., Jackson, MS

GRAND GULF NUCLEAR STATION, UNITS 1 AND 2. DRAFT ENVIRONMENTAL STATEMENT. DOCKET-50416-59; DOCKET50417-59; 301 pp. (1973)

See Nuclear Science Abstracts 1974, 29(04) 09605

SUBJECT CATEGORY: General

ORIGIN: Commercial

KEYWORDS: CLIMATES; COST RENEFIT AN= ALYSIS; ECOLOGY; ENVIRONMENT; GEOGRAPHY; GEOLOGY; GRAND GULF-1 REACTOR; GRAND GULF-2 REACTOR; HYDROLOGY; POWER; RADIOACTIVE WASTES; REACTOR OPERATION; REACTOR SITES

337

Hyland, R.E., M.L. Wohl, and P.M. Finnegan; National Aeronautics and Space Administration, Lewis Research Center, Cleveland, $\mathrm{OH}$ 
STUDY OF EXTRATERRESTRIAL DISPOSAL OF RADIOACTIVE WASTES. PART 3. PRELIMINARY FEASIBILITY SCREENING STUDY OF SPACE DISPOSAL OF THE ACTINIDE RADIOACTIVE WASTES WITH 1 PERCENT AND 0.1 PERCENT FISSION PRODUCT CONTAMINATION. N-7321562;NASA-TM-X-68216; 41 pp. (1973)

See Nuclear Science Abstracts 1974, 29(07) 16412

SUBJECT CATEGORY: HLW; TRU; Isolation

ORIGIN: Commercial; Defense

KEYWORDS: ACTINIDES; CONTAINERS; COST; ORBITS; RADIOACTIVE WASTE DISPOSAL; SPACE

338

Zimmerman, A.V., R.L. Thompson, and R.J. Lubick; National Aeronautics and Space Administration, Lewis Research Center, Cleveland, $\mathrm{OH}$

SUMMARY REPORT OF SPACE TRANSPORTATION AND DESTINATION CONSIDERATIONS FOR EXTRATERRESTRIAL DISPOSAL OF RADIOACTIVE WASTE. NASA-TM-X-68211; 40 pp. (1973)

7 figures, 2 references; See also Nuclear Science Abstract 1974, 29(07) 16413

NASA has been conducting a feasibility study of extraterrestrial (space) disposal of radioactive waste. This report summarizes the initial work done on the evaluation and comparison of possible space destinations and launch vehicles. Only current or planned space transportation systems have been considered thus far. The currently planned space shuttle was found to be more cost effective than current expendable launch vehicles, by about a factor of two. The space shuttle will rquire a third stage to perform the disposal mission. Depending on the particular mission this could be either a reusable space tug or an expendable stage such as a centaur. Of the destinations considered, high earth orbits (between geostationary and lunar orbit altitudes), solar orbits (such as a $0.90 \mathrm{Au}$ circular solar orbit) or a direct injection to solar system escape appear to be the best candidates.

SUBJECT CATEGORY: Isolation

ORIGIN: Defense
KEYWORDS: ECONOMICS; RADIOACTIVE WASTE DISPOSAL; SPACE VEHICLES; SPACE; WASTE TRANSPORTATION; CONTAINERS; ORBITS; COST

\section{9}

National Aeronautics and Space Administration, Lewis Research Center, Cleveland, $\mathrm{OH}$

FEASIBILITY OF SPACE DISPOSAL OF RADIOACTIVE NUCLEAR WASTE. 1. EXECUTIVE SUMMARY. NASA-TM-X-2911; 18 pp. (1973)

See also NASA-TM-X-2912, Technical Summary.

The concept of disposing of radioactive waste into space was studied and found to be feasible. Tentative solutions are presented for technical problems of safely packaging the separated longlived actinide wastes. Disposal of these wastes is the primary concern because they will remain radioactive for extremely long times. The package design includes shielding to achieve reasonably low external levels of radiation. The logistics and potential hazards of launching these packages into either high Earth orbits or solar orbits or to escape the solar system have been evaluated. These destinations have been found to be the most promising. Although the solar system escape requires greater energy, it appears to be the most desirable for ultimate disposal. The total costs of a system for space disposal of radioactive waste are based on the rate of accumulation of fission products and uranium-free actinides in reprocessing plants serving the nuclear power industry and on the launch costs, the destinations, and the launch frequency. The number of waste packages to be launched per year depends on the degree of separation of the long-lived actinides. For example, a package containing about 200 kilograms of separated actinide wastes with about 0.1 percent residual fission products could be ejected out of the solar system for a cost of about $\$ 150,000$ per kilogram. Fifty to 100 Space Shuttle launches of such packages per year would be required in the 1990-1995 time period to handle the actinide waste. To this cost must be added the estimated cost of separating and encapsulating the actinide waste. Although the space transportation cost would be several billion dollars per year, the cost prorated over the nuclear electrical capacity is less than 0.1 cent per kilowatt-hour. A packaging design concept has been evolved that appears on a qualitative basis to provide protection against the radioactive waste in accident environments. The concept, however, 
does need a follow-up experimental program and safety assessment to establish a system design. (Auth)

SUBJECT CATEGORY: Isolation; TRU

ORIGIN: Defense

KEYWORDS: PACKAGING; DESIGN; ACTINIDES; COST; SITE SELECTION; HAZARDS; SAFETY; SOLAR SYSTEM; COST BENEFIT ANALYSIS; FISSION PRODUCTS; WASTE TRANSPORTATION; RADIOACTIVE WASTE DISPOSAL; SPACE

340

New South Wales University, Kensington, Australia

RADIATION HEALTH AND SAFETY ANNUAL REPORT FOR THE YEAR ENDED 31ST DECEMBER 1972. NP-19887; 17 pp. (1973)

See Nuclear Science Abstracts 1974, 29(06) 15082

SUBJECT CATEGORY: General

ORIGIN: Foreign

KEYWORDS: AUSTRALIA; INVENTORIES; MATERIAL BALANCE; PERSONNEL MONITORING; RADIATION HAZARDS; RADIATION PROTECTION; RADIATION SOURCES; RADIOACTIVE WASTE DISPOSAL; RADIOISOTOPDB; BAFDTY

341

Kelleher, W.J., and E.J. Michael; New York State Department of Environmental Conservation, New York, NY

LOW-LEVEL RADIOACTIVE WASTE BURIAL SITE INVENTORY FOR THE WEST VALLEY SITE, CATTARAUGUS COUNTY, NEW YORK. New York State Department of Environmental Conservation Report; 21 pp. (1973)

Directly applicable to shallow land burial. Data presented is specific to the nature and activity of waste buried at the NFS West Valley site.

A review of the radioactive materials buried at the disposal site at the West Valley facility. Burial operations were initiated in October 1963 and were continuing at the time of this inventory. Between October 1963 and December 1972, more than $1,700,000$ cubic feet of commercial radioactive waste was buried on site. In addition more than 87,000 cubic feet of radioactive waste from the N.F.S. fuel reprocessing facility were disposed of on site between 1966 and 1972. Review of inventory records indicates that nuclear power generating stations produced less than $10 \%$ of the waste buried on site. Burial of radioactive wastes was in trenches that were approximately $35 \mathrm{ft}$ wide, $20 \mathrm{ft}$ deep and $700 \mathrm{ft}$ in length. Trenches were filled to grade level and then covered with a minimum of 4' of backfill. Inventory records indicate that over $105,000 \mathrm{Ci} 3 \mathrm{H}$, 76,000 $\mathrm{Ci} \mathrm{Co} \mathrm{60,34,000} \mathrm{Ci} \mathrm{of} \mathrm{Pu} 235$ and 85,000 Ci of mixed fission products were buried on site. Included in an Appendix are diagrams of the burial sres snd trcnches, and radiometric analyses of trench water from trenches $1,3,4,5,8,0,10 \mathrm{~s}, 11$ and 12 .

SUBJECT CATEGORY: LLW

ORIGIN: Commercial

KEYWORDS: RADIOACTIVE WASTE - DISPOSAL; RADIOISOTOPES; FISSION PRODUCTS; LOW-LEVEL RADIOACTIVE WASTES; VOIUUME; WATER; NUCLEAR MATERIALS; METHODS; INVENTORIES; GROUND DISPOSAL

342

North, E.D., and R.L. Booth; Nuclear Fuel Services, Int., Rockville, MD

FISSION PRODUCT GAS RETENTION STUDY. FINAL REPORT. ORNL-TM-409; 119 pp. (1973)

See Nuclear Science Abstracts 1974, 29(05) 09983

SUBJECT CATEGORY: Airborne

ORIGIN: Defense; Commercial

KEYWORDS: CONTAINMENT; COST; FISSION PRODUCTS; GASEOUS WASTES; IODINE; KRYPTON; RADIOACTIVE WASTE PROCESSING; TRITIUM

343

Arnold, W.D., R. Salmon, and K.H. Lin, et. al.; Oak Ridge National Laboratory, Oak Ridge, TN 
PRELIMINARY EVALUATION OF METHODS FOR THE DISPOSAL OF TRITIATED WATER FROM NUCLEARLY STIMULATED NATURAL GAS WELLS. ORNL-TM-4024; 52 pp. (1973)

Large volumes of slightly tritiated water will be produced from natural gas fields developed via nuclear stimulation. Evaluations based on feasibility, safety, and cost indicate that injection into deep wells, evaporation into stacks, and evaporation from ponds are the best disposal methods. At this point, none of the three is clearly superior to the others. Each has potential advantages and disadvantages that can be evaluated in actural tests. These disposal tests can be made in conjunction with the production testing of the first Rio Blanco well. While unfavorable environmental effects would be expected from the tests, they can be monitored to ensure that this is the case and can be terminated if necessary.

\section{SUBJECT CATEGORY: LLW}

ORIGIN: Commercial

KEYWORDS: DECONTAMINATION; ECONOMICS; PLOWSHARE PROIFCT; TRITIUM; RADIOACTIVE WASTE DISPOSAL; RADIOACTIVE WASTE STORAGE; TRANSPORT; EVAPORATION; COST; NATURAL GAS WELLS; ENVIRONMENTAL EFFECTS; LOW-LEVEL RADIOACTIVE WASTES

\section{4}

Clark, W.E., and W.C. Ulrich; Oak Ridge National Laboratory, Oak Ridge, TN

PR.FGSITRIZTE AQUEEOUS COMBUSTION OF ALPHA-CONTAMINATED WASTE, FINAL PROGRAM STATUS REPORT. ORNL TM-4366; 42 pp. (1973)

This report describes the status of the Pressurized Aqueous Combustion of Alpha-Contaminated Waste Program (formerly called the Plutonium Burning Program) at the time it was canceled on June 1, 1973. Results of laboratory investigations involving reaction studies, liquid and gaseous effluent cleanup problems, and corrosion research are summarized. The status of the process flowsheet design, the equipment design and procurement, and the construction of an engineering-scale experiment capable of treating 0.1 ton of combustible waste per day on a continuous basis is discussed, and some equipment cost data are presented. Recommendations for further laboratory work and pilot-plant development are also included. (Auth)

SUBJECT CATEGORY: LLW; TRU

ORIGIN: Defense

KEYWORDS: ORNL; RADIOACTIVE WASTE PROCESSING; PLUTONIUM; LIQUID WASTES; GASEOUS WASTES; RADIOACTIVE AEROSOLS; GASEOUS WASTES; COST

\section{5}

Hirst, E.; Oak Ridge National Laboratory, Oak Ridge, TN

POLLUTION CONTROL ENERGY COSTS. CONF-731105-5; Winter Meeting of American Society of Mechanical Engineers, Detroit, MI, November 11, 1973; 28 pp. (1973)

See Nuclear Science Abstracts 1975, 29(01) 02309

SUB.JFCT CATFGORY: General

ORIGIN: Commercial

KEYWORDS: AIR POLLUTION; CONTROL; COST; ECONOMICS; ENERGY CONSUMPTION; ENERGY SOURCES; CONSERVATION; ENVIRONMENT; LIQUID WASTES; MONITORING; POLLUTION; SOLID WASTES; TRANSPORT; URBAN POPULATIONS; WASTE HEAT; WASTE MANAGEMENT; WASTE PROCESSING

\section{6}

Kasten, P.R.; Oak Ridge National Laboratory, Oak Ridge, TN

ENVIRONMENTAL AND ECONOMIC FACTORS ASSOCIATED WITH HIGH TEMPERATURE GAS-COOLED REACTORS. CONF-731203-2; Conference on Decision and Control, San Diego, California, December 5, 1973; 18 pp. (1973)

See Nuclear Science Abstracts 1974, 29(06) 14610

SUBJECT CATEGORY: HLW; LLW

ORIGIN: Commercial 
KEYWORDS: CONFIGURATION; DESIGN; ECONOMICS; ENVIRONMENT; FUEL REPROCESSING PLANTS; HTGR TYPE REACTORS; RADIOACTIVE WASTES; REACTOR OPERATION

347

Burch, W.D.; Oak Ridge National Laboratory, Oak Kidge, 'TN; Edgewood Arsenal, MD

NUCLEAR WASTE DISPOSAL. CONF-730417; Environmental Pollution, A.E. Hilsmeier, (Comp.), Proceedings of the Fourth Annual Symposium, Edgewood Arsenal, MD., September 1973, (pp. 119127). American Ordnance Association, Edgewood Arsenal, MD. (1973)

See Nuclear Science Abstracts 1975, 32(08) 19685

SUBJECT CATEGORY: Isolation; HLW; LLW; TRU

ORIGIN: Defense

KEYWORDS: ECONOMICS; FISSION PRODUCTS; FUEL REPROCESSING PLANTS; NUCLEAR POWER PLANTS; PLUTONIUM; RADIOACTIVE WASTE DISPOSAL; RADIOACTIVE WASTES; RESEARCH PROGRAMS; SALT DEPOSITS; UNDERGROUND DISPOSAL; RADIOACTIVE WASTE STORAGE

348

Philadelphia Electric Co., Philadelphia, PA

LIMERICK GENERATING STATION, UNITS 1 AND 2. FINAL ENVIRONMENTAL STATEMENT. DOCKET-50352-62; DOCKET50353-62; 692 pp. (1973)

See Nuclear Science Abstracts 1975, 29(03) 07322

SUBJECT CATEGORY: General

ORIGIN: Commercial

KEYWORDS: CLIMATES; CONSTRUCTION; COST BENEFIT ANALYSIS; ECOLOGY; ELECTRIC POWER; ENVIRONMENT; GEOGRAPHY; GEOLOGY; HYDROLOGY; LIMERICK-1 REACTOR; LIMERICK-2 REACTOR; RADIOACTIVE WASTE DISPOSAL; REACTOR OPERATION; REACTOR SITES; SITE SELECTION; THERMAL EFFLUENTS; WATER
349

Avenhaus, R., L. Gruenbaum, and D. Nentwich; Projekt Spaltstoffflusskontrolle, Institute Fuer Angewandte Systemtechnik und Reaktorphysik, Kernforschungszentrum, Karlsruhe, Germany

QUANTIFICATION OF CONTAINMENT MEASURES USED IN SAFEGUARDS. KFK-905; 38 pp. (1973)

No Abstract

SUBJECT CATEGORY: Isolation

ORIGIN: Foreign

K̄ĒŶWOORDSS: CONTAINMENT; COST; INSPEC'IION; MA'TERIAL BALANCE; MA'I'HEMA'I'I. CAL MODELS; OPTIMIZATION; PLUTONIUM; SAFEGUARDS; SAFETY; RADIOACTIVE WASTES

350

Kneese; A.V.; Resources for the Future, Inc., Environmental Law Institute

ARE WE MAKING A FAUSTIAN BARGAIN?. Kesources for the Future, September 1973, 9 pp. (1973)

Originally published as "Benefit-Cost Analysis and Unscheduled Events in the Nuclear Füel Cýclè"

In one of its documents the Atomic Linergy Ciommiss. sion noted that environmental statements for a power reactor shoüld conntâlin à cost-benefli analysis which "considers and balances the adverse environmental effects and the environmental, economic, technical and other benefits of the facility." 'I'his paper purports that benefit-cost analysis cannot answer policy questions connerning the desirability of developing a large-scale, fission-based economy because these questions are ethical in nature. Potential hazards from nuclear power plants are discussed, including those associated with the actual operation of the fuel cycle for power produc. tion (e.g., failure of the emergency core cooling equipment, transportation of spent fuel elements, fuel reprocessing, plutonium recycle, nuclear reactor accidents, and sabotage) and those associated with the long-term storage of radioactive wastes. Benefits from near-term development of fission power are also listec. 1) avoidance of certain environmental impacts from alternate energy sources, 2) possible economic advantages, 3) addi- 
tional energy supply during the current energy "crisis", and 4) a limitless supply of energy after the development of the breeder. It is suggested that present fission reactors be phased out, that large amounts of resources be put into dealing with environmental problems of fossil fuels, and that energy be priced at its full social cost in order to limit demand growth. Research work is encouraged on fusion, deep geothermal energy, solar energy, and on various types of breeders. It is felt that issues should be investigated before a committee of Congress having broad policy responsibilities. Then the entire Congress should make a decision as to whether the risks of fission are worth the benefits.

SUBJECT CATEGORY: General

ORIGIN: Commercial

KEYWORDS: HAZARDS; COST BENEFIT ANALYSIS; ENERGY POLICY; PLUTONIUM; RADIOACTIVE WASTES; RADIOACTIVE WASTE MANAGEMENT; WASTE TRANSPORTATION; FUEL CYCLE; ECONOMICS; ENVIRONMENTAL IMPACTS; NUCLEAR ENERGY

351

Southern California Edison Co., Rosemead, CA

SAN ONOFRE NUCLEAR GENERATING STATION, UNIT 1. FINAL ENVIRONMENTAL STATEMENT. DOCKET-50206-237; 330 pp. (1973)

See Nuclear Science Abstracts 1975, 29(01) 02113

SUBJECT CATEGORY: General

ORIGIN: Commercial

KEYWORDS: AQUATIC ECOSYSTEMS; COST BENEFIT ANALYSIS; ECOLOGY; ENVIRON. MENT; FISHES; NONRADIOACTIVE WASTES; POWER TRANSMISSION; RADIATION PROTECTION; RADIOACTIVE WASTES; REACTOR COOLING SYSTEMS; REACTOR SITES; SAN ONOFRE-1 REACTOR; THERMAL POLLUTION

\section{2}

Fisher, V., V. Kerner, and D. Richter; Staatliche Zentrale Fuer Strahlenschutz, Berlin, Germany, D.R.
INVESTIGATIONS OF VERSIONS FOR THE CHOICE OF FINAL RADIOACTIVE WASTE DISPOSAL METHOD FROM NUCLEAR FACILITIES OF GDR. INIS-MF-1639 (Vol. 1); pp. 44-52; Investigation Into Liquid, Solid and Gaseous Radioactive Waste Processing and Surface Decontamination, V. Chosnovska (Ed.), Proceedings of a Scientific and Technical Conference, Colobjeg, Poland, October 2, 1972. (1973)

In Russian

See Nuclear Science Abstracts 1975, 32(06) 15026

SUBJECT CATEGORY: HLW; LLW; TRU

ORIGIN: Foreign

KEYWORDS: ECONOMICS; GERMAN DEMOCRATIC REPUBLIC; NUCLEAR FACILITIES; RADIOACTIVE WASTE DISPOSAL; RADIOACTIVE WASTE PROCESSING; RADIOACTIVE WASTES; SAFETY

353

Bukina, I.G., V.M. Sedov, I.L. Rybal'chenko, A.A. Permyakov, and M.F. Yakushev; State Committee on the Utilization of Atomic Energy, Moscow

ECONOMICAL PROBLEMS OF RADIOACTIVE WASTES DECONTAMINATION AND DISPOSAL. Investigation into Liquid, Solid and Gaseous Radioactive Waste Processing and Surface Decontamination, Vol 1, V. Chosnovska (Ed.), Proceedings of a Scientific and Technical Conference, Colobjeg, Poland, October 2, 1972. (pp. 27-37); INIS-MF-1639(Vol. 1). (1973)

In Russian

See Nuclear Science Abstracts 1975, 32(06) 13906

SUBJECT CATEGORY: General

ORIGIN: Foreign

KEYWORDS: BITUMENS; CEMENTS; COST; ECONOMICS; LIQUID WASTES; RADIOACTIVE WASTE DISPOSAL; RADIOACTIVE WASTE PROCESSING; SOLIDIFICATION; DECONTAMINATION

\section{4}

U.S. Atomic Energy Commission, Technical Information Center, Oak Ridge, TN 
RADIOACTIVE WASTE MANAGEMENT - A BIBLIOGRAPHY OF PUBLICLY AVAILABLE LITERATURE PERTAINING TO THE USAEC'S NATIONAL REACTOR TESTING STATION, IDAHO. TID-3342; 56 pp. (1973)

Contains abstracts of 272 technical reports and journal articles which have appeared in 'Nuclear Science Abstracts' from January 1951 through July 1973 pertaining to radioactive waste management at the National Reactor Testing Station. The abstracts are grouped into ten categories, as indicated by the table of contents. Within the categories, they are arranged by NSA volume and abstract number.

SUBJECT CATEGORY: Spent Fuel; HLW; LLW; TRU

ORIGIN: Defense.

KEYWORDS: BIBLIOGRAPHIES; ECOLOGY; RADIOACTIVE EFFLUENTS; GEOLOGY; IDAHO NATIONAL ENGINEERING LABORATORY; RADIOACTIVE WASTE DISPOSAL; RADIOACTIVE WASTE STORAGE; STACKS; MONITORING; RADIOACTIVE WASTE MANAGEMENT; HYDROLOGY; SOILS; CONTAINERS; RADIOCHEMISTRY; REPORTS; RADIOACTIVE WASTE MANAGEMENT; METEOROLOGY; REPROCESSING; VITRIFICATION

\section{5}

U.S. Atomic Energy Commission, Technical Information Center, Oak Ridge, TN

RADIOACTIVE WASTE MANAGEMENT. A BIBLIOGRAPHY OF PUBLICLY AVAIL ABLE LITERATURE PERTAINING TO THE USAEC'S SAVANNAH RIVER, SOUTH CAROLINA, PRODUCTION SITE. TID 3341; 36 pp. (1973)

This bibliography contains abstracts of 197 technical reports and journal articles which have appeared in 'Nuclear Science Abstract' from January 1951 through July 1973 pertaining to radioactive waste management at the Savannah Riger site. The abstracts are grouped into ten categories as indicated by the table of contents. Within the categories, they are arranged by NSA volume and abstract number.

SUBJECT CATEGORY: General
ORIGIN: Defense

KEYWORDS: BIBLIOGRAPHIES; ECOLOGY; RADIOACTIVE EFFLUENTS; GEOLOGY; RADIOACTIVE WASTE STORAGE; STACKS; MONITORING; SAVANNAH RIVER PLANT; SOLID WASTES; CORROSION; RADIOACTIVE WASTE MANAGEMENT; HYDROLOGY; CONTAINERS; METEOROLOGY; RADIOACTIVE WASTE DISPOSAL

356

U.S. Atomic Energy Cómmissiun, Washingtun, DC

REPORT ON RELEASES OF RADIOACTIVITY IN EFFLUENTS AND SOLID WASTE FROM NUCLEAR POWER PLANTS FOR 1972. 64 pages, August 1973. (1973)

30 tables

Presents tabulations of radioactivity in effluents and solid waste from nuclear power plants in 1973. Tables include (1) the fission and activation products and of tritium released in liquid effluents, (2) the quantity of noble gases and of halogens and particulates released in effluents to the atmosphere, (3) comparison of these releases with the previous two years, (4) the gross thermal and net electrical power produced, (5) the total volumes and quantities of radioactivity in solid waste, and (6) summary data for each power reactor.

SUBJECT CATEGORY: Airborne; LLW

ORIGIN: Commercial

KEYWORDS: GASEOUS WASTES; BWR TYPE REACTORS; RADIOACTIVE EFFLUENTS; GCR TYPE REACTORS; PWR TYPE REACTORS; RADIOACTIVE WASTE DISPOSAL; POWER REACTORS; DATA; US AEC

357

Trice, V. G. Jr., and R. D. Walton, Jr.; U.S. Atomic Energy Commission, Washington, DC; Organization for Economic Co-Operation and Development, 75 - Paris, France; International Atomic Energy Agency, Vienna, Austria

PLANNING FOR THE MANAGEMENT OF RADIOACTIVE WASTE FROM REPRO CESSING OF FUEL IN AEC PROGRAMS. 
CONF-721107-; Management of Radioactive Wastes From Fuel Reprocessing, Proceedings of a Symposium, Paris, France, Novem ber 27, 1972, (pp. 275-284). (1973)

See Nuclear Science Abstracts 1974, 29(04) 08398

SUBJECT CATEGORY: Spent Fuel

ORIGIN: Defense

KEYWORDS: COST; FUEL REPROCESSING PLANTS; PLANNING; RADIOACTIVE WASTE DISPOSAL; RADIOACTIVE WASTES; REPROCESSING; SPENT FUEL ELEMENTS; US AEC; WASTE MANAGEMENT; WASTE STORAGE

358

Spitzyn, V.I., K.P. Zakharova, and L.D. Azamayefa; USSR State Committee on the Utilization of Atomic Energy, Moscow, USSR

DISPOSAL OF RADIOACTIVE WASTE. JPRS-58764; 71 pp. (1973)

Presents five IAEA papers dealing with the technical and economic aspects of handling liquid wastes with intermediate and high levels of radioactivity, the possibility of using bituminization for processing highly active wastes, a technical-economic comparison of the methods of solidification and tank storage for highly active liquid wastes from the processing of spent fuel elements of water-cooled water-moderated power reactors, scientific prerequisites for burying highly active liquid wastes in deep genlngical formations, and the development of methods for preparing the wastes from hexafluoride technology for burial.

SUBJECT CATEGORY: HLW; Isolation

ORIGIN: Foreign

KEYWORDS: LIQUID WASTES; BITUMINOUS MATERIALS; ECONOMICS; POWER REACTORS; RADIOACTTIVE WASTE MANAGEMENT; USSR; RADIOACTIVE WASTE DISPOSAL; RE. PROCESSING; UNDERGROUND DISPOSAL; HIGH-LEVEL RADIOACTIVE WASTES; SOLIDIFICATION; FUEL ELEMENTS; SALT DEPOS. ITS; GEOLOGIC STRUCTURES
359

Frieling, D.D., and C.H. Harris; Wisconsin Electric Power Co., Milwaukee, WI

DEMINERALIZER REGENERANT WASTE REDUCTION STUDIES: POINT BEACH NUCLEAR PLANT. Transactions of the American Nuclear Society 17:411-413; CONF-731101; American Nuclear Society and the Atomic Industrial Forum and Nuclear Energy Exhibition, Proceedings of a Joint Meeting, San Francisco, California, Nov. 11, 1973. (1973)

See Nuclear Science Abstracts 1975, 29(03) 05156

SUBJECT CATEGORY: General

ORIGIN: Commercial

KEYWORDS: COST; ION EXCHANGE; RADIOACTIVE WASTE DISPOSAL; POINT BEACH-1 REACTOR; RADIOACTIVE WASTE PROCESSING

360

Sachse, G., and G. Anders; Zentralinstitut Fuer Kernforschung, Rossendorf, Germany

RADIOACTIVE WASTE MATERIALS FROM AQUEOUS REPROCESSING OF SPENT NUCLEAR FUELS. Kernerergie 16(2):37-47. (1973)

In German

See Nuclear Science Abstracts 1974, 29(04) 07640

SUBJECT CATEGORY: Spent Fuel

ORIGIN: Foreign

KEYWORDS: COST; FUEL REPROCESSING PLANTS; GASEOUS WASTES; LIQUID WASTES; PUREX PROCESS; RADIOACTIVE WASTE DISPOSAL; RADIOACTIVE WASTE PROCESSING; RADIOACTIVE WASTES; REPROCESSING; SOLID WASTES; SPENT FUELS

361

Clark, D.T.

A HISTORY AND PRELIMINARY INVENTORY REPORT ON THE KENTUCKY RADI- 
OACTIVE WASTE DISPOSAL SITE. Radiation Data and Reports 14(10), 573-585. (1973)

Useful as an introduction to the waste contained in the Maxey Flats Disposal Site.

The Kentucky radioactive waste disposal site (Maxey Flats Disposal Site) has been in operation since March 1963. As of January 1, 1972, approximately 0.71 cubic kilometers of waste, containing 1.15 magacuries of by product material; 209 kilograms of special nuclear material, and 39,493 kilograms of source material, has been disposed of at this facility. Most of the solid wastes are buried in rectangular trenches approximately $110 \mathrm{~m}$ long, 21 $\mathrm{m}$ wide, and $6 \mathrm{~m}$ deep. The floor of the trench is to have a slope of approximately 1 degree to a pump and stand pipe positioned at the lowest level. Each completed trench is required to be backfilled with a minimum of $1 \mathrm{~m}$ of earth materials mounded and compacted to form and maintain an "umbrella" to seal out ground water to the greatest extent possible and to divert rain water away from the trench. A shallow rested crop is then planted to prevent erosion. Small volumes of high specific gamma activity sources are deposited in special hot wells constructed about $4.6 \mathrm{~m}$ deep with pipes of coated steel, concrete, or tile placed vertically in the ground and closed at the lower end and cupped at the upper end. Other high intensity sources of larger volumes are placed in individual pits approximately $9 \mathrm{~m}$ long by $3 \mathrm{~m}$ wide by $3 \mathrm{~m}$ deep. This report contains a brief history of the facility and a summary of the inventory results.

\section{SUBJECT CATEGORY: LLW}

ORIGIN: Commercial

KEYWORDS: LIQUID WASTES; SOLID WASTES; LOW-LEVEL RADIOACTIVE WASTES; RADIOACTIVE WASTE DISPOSAL; VOLUME; INVENTORIES; GROUND DISPOSAL; RADIOACTIVE WASTE STORAGE

362

Fisher, V., and G. Bul

DESIGNED MODEL FOR THE CHOICE OF THE RADIOACTIVE WASTE DISPOSAL VERSIONS FOR THE NUCLEAR POWER PLANTS AND FUEL REPROCESSING PLANTS. INIS-mf-1639 (Vol. 1), (pp. 38-43); Investigation Into Liquid, Solid and Gaseous
Radioactive Waste Processing and Surface Decontamination, V. Chosnovska (Ed.), Proceedings of a Scientific and Technical Conference, Colobjeg, Poland, October 2, 1972. (1973)

In Russian

See Nuclear Science Abstracts 1975, 32(06) 15025

SÜBJECT CATEGORY: HLW; LLW; TRU

ORIGIN: Foreign

KEYWORDS: COMPARATIVE EVALUATIONS; COST; ECONOMICS; FUEL REPROCESSING PLANTS; NUCLEAR POWER PLANTS; RADIOACTIVE WASTE DISPOSAL; SAFETY

\section{3}

Hentschel, G.

RADIOACTIVE WASTE MANAGEMENT SYSTEM. Brown Boveri Rev. 60(6):298-302. (1973)

See Nuclear Science Abstracts 1974, 29(09) 23602

SUBJECT CATEGORY: General

ORIGIN: Foreign

KEYWORDS: BWR TYPE REACTORS; COST; DESIGN; ENVIRONMENT; IN PILE LOOPS; NUCLEAR POWEK PLANTS; OFF-GAS SYSTEMS; POLIUTTION; PWR TYHE KEAC'TORS; RALIOAGIIVE WASTE PROCEEERNG; ILAUIOACTIVE WASTES; REGULATIONS; SAFETY; SWITZERLANI; WAS'I'E' MANAGE'MENT

\section{4}

Jammet. H.. D. Mechali, and G. I arnurly

ANALYSIS OF THE COSTS AND OF THE AUVANIAGES AND RELA'TION BETWEEN THE COST AND THE EFFICIENCY OF CONTROL SYSTEMS. CEA-CONF-2347; CONF-730462-1; IAEA Group for the Study of the Acceptance by the Environment of Radioactive Materials Meeting, Vienna, Austria, April 30, 1973, 17 pp. (1973)

In French

See Nuclear. Science Abstracts 1974, 29(06) 14732 
SUBJECT CATEGORY: General

ORIGIN: Foreign

KEYWORDS: COST BENEFIT ANALYSIS; NUCLEAR POWER PLANTS; PWR TYPE REACTORS; RADIATION HAZARDS; RADIOACTIVE WASTES; REACTOR OPERATION; REACTOR SAFETY

365

Richardson, J.J.

RADIOACTIVE WASTE QUANTITIES PRODUCED BY LIGHT WATER REACTORS AND METHODS OF STORAGE, TRANSPORTATION, AND DISPOSAL. (1973)

No Abstract

SUBJECT CATEGORY: Transportation; Spent Fuel; LLW; HLW

ORIGIN: Commercial

KEYWORDS: COST; GASEOUS WASTES; LIQUID WASTES; RADIOACTIVE WASTE DISPO-
SAL; RADIOACTIVE WASTE PROCESSING; RADIOACTIVE WASTES; SOLID WASTES; SPENT FUEL ELEMENTS; SPENT FUEL STORAGE; STORAGE; INVENTORIES; TRANSPORT REGULATIONS; USA; WATER MODERATED REACTORS

366

Rochford, R.S., and J.D: Walker

WASTE DISPOSAL: THE ALTERNATIVES OF COMBUSTION. Energy Int. 10(10):1516. (1973)

See Nuclear Science Abstracts 1975, 29(03) 07359

SUBJECT CATEGORY: LLW

ORIGIN: Commercial; Defense

KEYWORDS: COMBUSTION; DESIGN; ECONOMICS; ENERGY SOURCES; CONSERVATION; ENERGY SOURCES; INCINERATORS; INDUSTRIAL PLANTS; SOLID WASTES; URBAN POPULATIONS; WASTE DISPOSAL 
122

THIS PAGE

\section{WAS INTENTIONALLY \\ LEFT BLANK}




\section{4}

367

MacBeth, P.J., and W.W. Hickman; Aerojet Nuclear Co., Idaho Falls, ID

ITSA: ABOVE GROUND RETRIEVABLE STORAGE METHOD FOR LOW-LEVEL TRANSURANIC WASTES. CONF-740434-5; Waste Management Symposium, Tucson, Arizona, Apr 21, 1974, 29 pp. (1974)

See Nuclear Science Abstracts 1974, 30(07) 19449

SUBJECT CATEGORY: LLW

ORIGIN: Commercial

KEYWORDS: COST; RADIOACTIVE WASTE STORAGE; RADIOACTIVE WASTES; SAFETY; SOLID WASTES; TRANSURANIUM ELEMENTS; WASTE STORAGE; LOW-LEVEL RADIOACTIVE WASTES; IDAHO NATIONAL ENGINEERING LABORATORY

\section{8}

MacBeth, P.J., and W.W. Hickman; Aerojet Nuclear Co., Idaho Falls, ID

ITSA: ABOVE-GROUND RETRIEVABLE STORAGE METHOD FOR LOW-LEVEL TRANSURANIC WASTES. CONF-740434; Waste Management, Proceedings of a Symposium, Tucson, Arizona, April 21-24, 1974, (8 pp.); Nuclear Technology 24:383-390. (1974)

The Idaho Transuranic Storage Area (ITSA) consists of wastes packaged in fiberglass-coated wooden boxes or steel drums designed to retain their integrity for 20 years. Containers are stacked on sloped asphalt pads. The array is covered with plywood, nylon-reinforced polyvinyl sheeting, and 2 to $3 \mathrm{ft}$ of earth. The need for a safe and efficient method for storage of low-level transuranic wastes prompted the development of ITSA. Storage costs in 1973 for 208,000 cubic feet of waste containing $24,600 \mathrm{Ci}$ of transuranic activity average $\$ 1.04 / \mathrm{cu}$ bic feet. (Auth)

SUBJECT CATEGORY: LLW; TRU

ORIGIN: Commercial
KEYWORDS: TRANSURANIUM ELEMENTS; RADIOACTIVE WASTE STORAGE; RADIOACTIVE WASTE DISPOSAL; CONTAINERS; ECONOMICS; HAZARDS; SOILS; COST

369

Passmore, R.W.; Aerojet Nuclear Co., Idaho Falls, ID

EXPERIENCE AT THE NATIONAL REACTOR TESTING STATION IN SEGREGATION AND COMPACTION OF LOW-LEVEL SOLID WASTE. CONF-740406-20; Second AEC Pollution Control Conference, Albuquerque, New Mexico, April 16, 1974, 17 pp. (1974)

See Nuclear Science Abstracts 1974, 30(07) 18380

SUBJECT CATEGORY: LLW

ORIGIN: Defense

KEYWORDS: COMPACTING; RADIOACTIVE WASTE PROCESSING; SOLID WASTES; VOLUME; IDAHO NATIONAL ENGINEERING LABORATORY

370

Grant, C., J.C. Hite, and H.G. Shealy; Agricultural Experiment Station, Clemson, SC

ECONOMIC ANALYSIS OF FUNDING ARRANGEMENTS FOR MAINTENANCE, SURVEILLANCE, AND CONTINGENCY COSTS ASSOCIATED WITH BURIAL OF LOWLEVEL RADIOACTIVE WASTE IN SOUTH CAROLINA. Agricultural Experiment Station Report AE 379. (1974)

This study was commissioned by the South Carolina State Department of Health and Environmental Control to re-examine the funding arrangements for meeting the State's obligation relative to maintenance, surveillance and contingency costs associated with the operation of a burial site for low. level radioactive waste. The site for such burial facility is in Barnwell County adjacent to the Atomic Energy Commission's Savannah River Plant and the Allied-General Nuclear Services' Facility. Two major problems posed for consideration in the study: 1) What should be the charge per cubic foot of radioactive materials to assure that the 
sinking fund will, in perpetuity, adequately finance all routine and contingency costs associated with managing the Barnwell site so as to pose no threat to man or his environment, and 2) what funding arrangements are needed to protect the State of South Carolina in the event the license ceases operations before the expected decommissioning date.

SUBJECT CATEGORY: LLW

ORIGIN: Commercial

KEYWORDS: RADIOACTIVE WASTE DISPOSAL; ECONOMICS; ENVIRONMENT; COST; LOW-LEVEL RADIOACTIVE WASTES; GROUND DISPOSAL

\section{1}

Bentsen, B.A.; Air Force Systems Command, Wright-Patterson Air Force Base, $\mathrm{OH}$

RADIOACTIVE WASTE DISPOSAL: A SURVEY. CONF-7310101; Energy and the Environment, Annual AICHE Conference, A.J. Buonicore, (Ed.), Oxford, OH, October 25, 1973. American Institute of Chemical Engineers, (pp. 86-93). (1974)

See Nuclear Science Abstracts, 1975, 32(02) 04156.

SUBJECT CATEGORY: General

ORIGIN: Defense

KEYWORDS: RADIOACTIVE WASTE DISPOSAL; RADIOACTIVE WASTES; REVIEWS

\section{8}

Allied-Gulf Nuclear Services, Barn well, SC

BARNWELL NUCLEAR FUEL PLANT. AEC FINAL ENVIRONMENTAL STATEMENT. DOCKET-60332-37; 270 pp. (1974)

See Nuclear Science Abstracts 1974, 29(0y) 2u88y

SUBJECT CATEGORY: Spent Fuel

ORIGIN: Commercial

KEYWORDS: BARNWELL FUEL PROCESSING PLANT; CONTAMINATION; COST; EARTH ATMOSPHERE; ECOLOGY; ENVIRONMENT; GEOLOGY; HYDROLOGY; LIQUID WASTES;
POLLUTION; RADIATION HAZARDS; RADIOACTIVE WASTES; REPROCESSING; SAFETY; SOILS; SPENT FUEL ELEMENTS; SURFACE WATERS; THERMAL EFFLUENTS

373

Myers, W.G., and L.C. Oyen; American Society of Mechanical Engineers, New York, NY

NUCLEAR STATION LAUNDRY ALTERNATIVES. Winter Annual Meeting of the American Society of Mechanical Engineers, New York, NY, November 17, 1974, 11 pp. (1974)

See Nuclear Science Abstracts 1975, 31(11) 32216

SUBJECT CATEGORY: LLW

ORIGIN: Commercial

KEYWORDS: CLEANING; COST; LIQUID WASTES; NUCL.EAR POWER PLANTS; PERSONNEL; PROTECTIVE CLOTHING; RADIOACTIVE WASTES

374

Steindler, M.J., N.M. Levitz, W.J. Mecham, W.B. Seefeldt, L.E. Trevorrow, I.O. Winsch, T.J.Gerding, B.J. Kullen, D.S. Webster, and L. Burris; Argonne National Laboratory, Argonne, IL

WASTE MANAGEMENT FROGRAMЭ QUARTERLY REPORT, JULY-SEPTEMBER 1974. ANL-8152; 24 pp. (1974)

Experimentation in which chemical and mechanical process steps were explored and evaluated for a long-term management ochomo for a Ziroaloybased, plutonium-contaminated metal wяst. stream is presented. Two methods have been selected for initial review: hydrochlorination and reaction with molten zinc chloride. The design work for the hydrochlorination teats has haen finished and the apparatus will be built. Preliminary experiments reacting the molten zinc chloride and Zircaloy tubing segments were carried out at temperatures of about 510,370 , and 440 degrees $C$ for $1,1.5$, and $6 \mathrm{hrs}$, respectively. The reaction was 63,23 , and $69 \%$ complete in the respective tests. Appurently lemperature is the most significant factor, with the reaction at 510 degrees $C$ being the most vigorous. More tests will be done to monitor the distribution of the minor constituents in this system and determine whether heavy oxide coatings 
inhibit or interfere with the reaction. Another program is underway to determine methods for decontaminating metals that have been used with plutonium and salvage the metal. Acquisition of the equipment and set-up of an experimental facility is in progress. The facility consists of a glove box with an inert atmosphere feature, arc-melter and a furnace. The furnace will be able to achieve temperatures in excess of 2500 degrees C. A review of a system to concentrate tritium from low-level aqueous waste from fuel reprocessing was also discussed. The system employs an exchange column consisting of concentric tubes with the annulus serving as the reaction chamber. The cost for the system, including capital and operating costs, is a bout $0.01 \mathrm{mills} / \mathrm{kWh}$ of power generated by the nuclear fuel. The system used at Cluj, Rumania is described with equations and diagrams.

SUBJECT CATEGORY: TRU; Spent Fuel

ORIGIN: Defense; Commercial; Foreign

KEYWORDS: ACIDS; ALPHA PARTICLES; DECONTAMINATION; EQUATIONS; EQUIPMENT; ION EXCHANGE; PLUTONIUM; GLOVEBOXES; RADIOACTIVE WASTE MAN. AGEMFNT; RADIOACTIVE WASTE PROCESSING; LOW-LEVEL RADIOACTIVE WASTES; LIQUID WASTES; SOLID WASTES; ZIRCALOY; TRITIUM; COST BENEFIT ANALYSIS; CHEMICAL PROPERTIES; VOLUME; COST; CAPITAL; METALS

\section{5}

Steindler, M.J., N.M. Levitz, L.E. Trevorrow, T.J. Gerding, B.J. Kullen, D.S. Webster, and L. Burris; Argonne National Laboratory, Argonne, IL

CHEMICAL ENGINEERING DIVISION, WASTE MANAGEMENT PROGRAMS QUARTERLY REPORT, OCTOBER-DECEMBER 1973. ANL-8087; 41 pp. (1974)

Metal-compaction methods have been reviewed and information on the irradiation-induced property changes of Zircaloy surveyed as part of a study on the handling of fuel cladding hulls. Information orginating from AEC-site visits and from a review of the open literature concerning decontamination of plutonium-contaminated materials is presented. The technical and economic feasibility of adapting reverse osmosis to the concentration of tritium from tritiated fuel reprocessing wastes was briefly evaluated. Technical feasibility was assumed from literature reports of a difference of about $3 \%$ in the self-diffusion coefficients of $\mathrm{THO}$ and $\mathrm{T} 2 \mathrm{O}$, and possibly greater differences in transport rates in solution-diffusion membranes. The costs of such a process were calculated from 1) estimates for the single-stage separation factor, 2) the heads flow rate for assumed concentrations and volumes of feed, product, and waste in an ideal cascade of membranes, and 3) published costs for reverse osmosis equipment. The result ranged from $10(E-4)$ to 1 mill/kWh of nuclear power, depending on the assumed single-stage separation factor and whether tritium-depleted water was recycled to the reprocessing plant. (Auth)

SUBJECT CATEGORY: TRU; Spent Fuel

ORIGIN: Defense

KEYWORDS: REVIEWS; COMPACTING; METALS; STORAGE; RADIOACTIVE WASTE PROCESSING; DECONTAMINATION; GASES; PLUTONIUM; ALPHA PARTICLES; CLADDING; TRITIUM; WATER; REPROCESSING; DIFFUSION; MEMBRANES; ECONOMICS; SEPARATION PROCESSES; EQUATIONS; ALPHA PAR TICLES

376

Field, B.B.; Atlantic Richfield Hanford Co., Richland, WA

STORAGE FEE ANALYSIS FOR COMMERCIAL HIGH-LEVEL WASTES. Transaction of the American Nuclear Society 19:203; CONF. 741017; American Nuclear Society, Proceedings of a Meeting, Washington, DC, October 27, 1974. (1974)

See Nuclear Science Abstracts 1975, 31(03) 06780

SUBJECT CATEGORY: HLW

ORIGIN: Commercial

KEYWORDS: COST; RADIOACTIVE WASTE FACILITIES; RADIOACTIVE WASTE STORAGE; HIGH-LEVEL RADIOACTIVE WASTES

\section{7}

Guthrie, J.E., O.E. Acres, and G.I. Paul; Atomic Energy of Canada Ltd., Whiteshell Nuclear Research Establishment, Pinawa, Manitoba, Canada 
MONITORING OF EFFLUENT ENTERING THE WINNIPEG RIVER FROM THE WHITESHELL NUCLEAR RESEARCH ESTABLISHMENT IN THE PERIOD 1963-1972. CONF-731117-(Part 2); STI/PUB-353 (Vol.2); Environmental Surveillance Around Nuclear Installations, Vol. 2, Proceedings of a Symposium, Warsaw, Poland, November 5, 1973. International Atomic Energy Agency, Vienna, Austria, (pp. 353366). (1974)

See Nuclear Science Abstracts 1975, 31(06) 14045

SUBJECT CATEGORY: LLW

OKIGIN: Foreign

KEYWORDS: AIR; CANADA; COST; ENVIRONMENT; FISHES; FISSION PRODUCTS; LIQUID WASTES; NUCLEAR FACILITIES; RADIATION MONITORING; RADIOACTIVE WASTE DISPOSAL; RADIOACTIVE WASTE MANAGEMENT; RADIOACTIVE WASTES; RADIONUCLIDE KINETICS; RADIONUCLIDE MIGRATION; RIVERS; SAMPLING

\section{8}

Babcock and Wilcox, Lynchburg, VA

RESPONSE TO QUESTION 11.2 - LIQUID WASTE SYSTEM. DOCKET-STN-50481-6; Amendment 2 to B-SAR-241, (p. 11.2-1). (1974)

1 table

Presents an operational analysis for the waste management systems showing that the systems are capable of treating the volumes of wastes produced. The discharge volumes and activities from the solid, liquid, and gaseous waste systems are shown.

SUBJECT CATEGORY: LLW; Airborne; HLW

ORIGIN: Commercial

KEYWORDS: PWR TYPE REACTORS; LIQUID WASTES; GASEOUS WASTES; SOLID WASTES; RADIOACTIVE WASTE MANAGEMENT; B-SAR REACTOR; VOLUME; INVENTORIES

379

Flinn, J.E., and R.S. Reimers; Battelle Columbus Laboratory, Columbus, $\mathrm{OH}$
DEVELOPMENT OF PREDICTIONS OF FUTURE POLLUTION PROBLEMS. SOCIOECONOMIC ENVIRONMENTAL STUDIES SERIES. PB-245127. (1974)

Available from NTIS

The report describes the results of a program to identify, rank and project short- and intermediateterm future pollution problems. Identification was accomplished using three independent search approaches based on industrial production, environmental, and societal trends and activity. Primary emphasis was placed on the environmental trends as gleaned from EPA, Battelle, Literature, and other sources. An initial list of problems was compiled with specific slressurs identified with each. Nine ranking factors were devised to select ten most serious problems from the initial list. The factors included: persistence; mobility/pervasiveness; environmental, technological, social, and political complexity; physiological risk; research needs; and bulk or volume of the pollutant. The ten problems selected by this method were further ranked in order of relative importance. The ten selected problems in rank order are as follows: (1) Impacts of new energy initiatives; (2) Geophysical modifications of the earth; (3) Trace element (metal) contaminants; (4) Proliferating hazardous and toxic chemicals; (5) Emissions from new automobile fuels, additives, and control dovices; (6) Disposal of waste sludges, liquids, and solid residues; (7) Critical radiation problems; (8) Fine particulates; (9) Expanding drinking water contamination; (10) Irrigation (impoundment) practices. Five to ten year projections were imsle of the ten problems which resulted.

SUBJECT CATEGORY: General

ORIGIN: Commercial

KEYWORDS: AGRICULTURAL WASTES; AII POLLUTION; CONTAMINATION; DRINKING WATER; ENVIRONMENTAL EFFECTS; EXHAUST GASES; FORECASTING; INDUSTRIAL WASTES; LAND USE; LIQUID WASTES; RADIOACTIVE WASTE DISPOSAL; RADIOACTIVE WASTES; SOLID WASTES; WASTE DISPOSAL; WATER POLLUTION

380

Burnham, J.B.; Battelle Pacific Northwest Laboratory, Richland, WA 
HIGH-LEVEL RADIOACTIVE WASTE MANAGEMENT ALTERNATIVES - SUMMARY, BACKGROUND AND DATA BASE, AND EVALUATION METHODOLOGY. BNWL 1900; 441 pp. (1974)

Summarizes Methodologies; 42 figures, 48 tables, 131 references, 16 appendices

This section is a summary of a comprehensive overview study of potential alternatives for longterm management of high-level radioactive waste sponsored by the U.S. Atomic Energy Commission Div. of Waste Management and Transportation. The report describes the various waste management alternatives that have been studied by the Pacific Northwest Laboratory and outlines the methods being used for evaluation. The following objectives for each waste management alternative are reported: 1)Technical feasibility information; 2)Safety information and methodology for analysis; 3)Policy, environmental, and public response considerations; 4)Advantages and disadvantages; 5) Needed research and development; 6)Research and development costs; and 7) Schedules and capital and operating costs for implementation. (Auth)

\section{SUBJECT CATEGORY: HLW}

ORIGIN: Defense; Commercial

KEYWORDS: HIGH-LEVEL RADIOACTIVE WASTES; RADIOACTIVE WASTE MANAGEMENT; COST; ECONOMICS

\section{1}

Drumheller, K.; Battelle Pacific Northwest Laboratory, Richland, WA

EXTRATERRESTRIAL DISPOSAL OF NUCLEAR WASTES. Nuclear Technology 24(3):418424. (1974)

See Nuclear Science Abstracts 1975, 31(02) 04028

SUBJECT CATEGORY: General

ORIGIN: General

KEYWORDS: ECONOMICS; RADIOACTIVE WASTE DISPOSAL; SAFETY; SPACE

\section{2}

Jansen, G., Jr., K.J. Schneider, and V.L. Hammond; Battelle Pacific Northwest Laboratory, Richland, WA

CONCEPTUAL SYSTEM FOR HANDLING ALPHA-BEARING WASTES. BNWL-SA-5001 (Draft); CONF-741026-2; Management of Plutonium-Contaminated Solid Wastes, Proceedings of a Seminar Marcoule, France, October 14, 1974, 27 pp. (1974)

No Abstract

SUBJECT CATEGORY: TRU

ORIGIN: Defense

KEYWORDS: DESIGN; ECONOMICS; LIQUID WASTES; RADIOACTIVE WASTE FACILITIES; RADIOACTIVE WASTE STORAGE; RADIOACTIVE WASTE MANAGEMENT; SOLIDIFICATION; TOXICITY; ALPHA-BEARING WASTES; COST; RADIOACTIVE WASTE PROCESSING

383

Mudge, L.K.; Battelle Pacific Northwest Laboratory, Richland, WA

WASTE TREATMENT AND HANDLING PROCESSES. BNWL-1876; Nuclear Waste Management and Transportation Quarterly Progress Report, July-September 1974, Dau, G.J. (Comp.), (pp. 5-961). (1974)

See Nuclear Science Abstracts 1975, 31(10) 25336

SUBJECT CATEGORY: Transportation; Generảl

ORIGIN: Defense

KEYWORDS: ALPHA SOURCES; COMBUSTION; ECONOMICS; PYROLYSIS; RADIOACTIVE WASTE PROCESSING; SOLID WASTES

$\mathbf{3 8 4}$

Platt, A.M.; Battelle Pacific Northwest Laboratory, Richland, WA 
HIGH-LEVEL WASTE FIXATION AND MANAGEMENT. CONF-740319; BNWL-SA-4590; Uranium/Fuel Cycle, Proceedings of a Topical Symposium, New Orleans, Louisiana, March 17-20, 1974. Atomic Industrial Forum, 18 pp. (1974)

Several diagrams are included.

A general management overreview of the management of high-level nuclear wastes is presented. Discharged fuel is given a cooling time of one-half to one year, then is reprocessed to recover the $\mathrm{U}, \mathrm{Pu}$, and $\mathrm{Np}$. Primary removal of $\mathrm{U}$ and $\mathrm{Pu}$ is by solvent extraction with tributyl phosphate/kerosene from a nitric acid solution of the dissolved nuclear fuel. Methods of waste solidification by calcination and subsequent storage ànd disposal are described. Discussion of safety and costs are included.

SUBJECT CATEGORY: HLW; Isolation; TRU

ORIGIN: Defense

KEYWORDS: RADIOACTIVE WASTE MANAGEMENT; STORAGE; SOLIDIFICATION; URANIUM; PLUTONIUM; REPROCESSING; COST BENEFIT ANALYSIS; HAZARDS; CONTAINMENT; CONTAINERS COST; SOLVENT EXTRACTION; CALCINATION

385

Platt, A.M., and K.J. Schneider; Battelle Pacific Northwest Laboratory, Richland, WA

HIGH-LEVEL RADIOACTIVE WASTE MANAGEMENT ALTERNATIVES. SECTION 1: SUMMARY; SECTION 2: BACKGROUND AND DATA BASE; SECTION 3: EVALUATION METHODOLOGY. BNWL-1900 (VOL. 1); 400 pp.; Nuclear Science Abstracts 1974, 30(05) 13'inb. (19'/4)

Figures and references included

This report (one of four volumes) is a comprehensive overview study of potential alternative methods for long-term management of high-level radioactive waste. The study includes a compilation of in formation relevant to technical feasibility, safety, cost, environmental considerations, policy conflicts, public response and research and development needs for: (1) disposal in terrestrial locations - (a) in geologic settings on land, (b) in the seabed, (c) in ice sheets; (2) disposal into space; (3) elimination by transmutation (nuclear transformation of certain waste constituents into nuclides having less longterm toxicity).
SUBJECT CATEGORY: HLW; Isolation

ORIGIN: Defense

KEYWORDS: RADIOACTIVE WASTE DISPO SAL; ECONOMICS; RADIOACTIVE WASTE MANAGEMENT; REVIEWS; SAFETY; FORECASTING; COST; CAPITAL; PUBLIC RELATIONS; US EPA; MARINE DISPOSAL; SPACE; TRANSMUTATION

\section{6}

Schneider, K. J.; Battelle Pacific Northwcst Laboratory, Richland, WA

QITA RTERLY PROGRESS REPORT ., STUD. IES ON MANAGEMENT OF SELECTED WASTES, JANUARY - MARCH 1974.' RNWL 1825; 44 pp. (1974)

14 tables, 7 figures, 4 references

\begin{abstract}
A literature review of aqueous, molten salt, and melt flux decontamination processes has indicated that waste stream minimization, ease of operation, and decontamination efficiency can probably be optimized by a modified aqueous decontamination process followed by melting. The reuse of metal from decontamination would be possible after long cooling times but economicy are nul evaluated. Equipment required for the scoping studies on pyrolysis of wastes was fabricated and installed during the reporting period. Solvent extrartion oludies un tritium have ahown that competitive factors negate most of the separation which might be expected. A few studies are continuing using strongly basic solvents.
\end{abstract}

SUBJECT CATEGORY: General; HLW

ORIGIN: Defense

KEYWORDS: DECONTAMINATION; TRITIUM; ZIRCONIUM; STAINLESS STEELS; FISSION PRODUCTS; SEPARATION PROCESSES; LEACHING

\section{7}

Schneider, K.J.; Battelle Pacific Northwest Laboratory, Richland, WA

ADVANCED WASTE MANAGEMENT STUDIES. PROGRESS REPORT, JANUARY-MARCH 1974. BNWL-B-223-10; 80 pp. (1974)

See Nuclear Science Abstracts 1974, 30(05) 13300 
SUBJECT CATEGORY: General

ORIGIN: Defense; Commercial

KEYWORDS: COST; GEOLOGIC DEPOSITS; GLACIERS; RADIATION HAZARDS; RADIOACTIVE WASTE DISPOSAL; RADIOACTIVE WASTE PROCESSING; RADIOACTIVE WASTES; RADIOISOTOPES; RESEARCH PROGRAMS; SAFETY; SEAS; TRANSMUTATION; UNDERGROUND DISPOSAL

\section{8}

Schneider, K.J., and A.M. Platt; Battelle Pacific Northwest Laboratory, Richland, WA

HIGH-LEVEL RADIOACTIVE WASTE MANAGEMENT ALTERNATIVES. SECTION 5: ICE SHEET DISPOSAL, SECTION 6: SEABED DISPOSAL. BNWL-1900(Vol.3); 270 pp. (1974)

See also Nuclear Science Abstracts 1974, 30(05) 13297

This report (one of four volumes) is a comprehensive overview study of potential alternative methods for long-term management of high-level radioactive waste. The study includes a compilation of in formation relevant to technical feasibility, safety, cost, environmental considerations, policy conflicts, public response and research and development needs for: (1) disposal in terrestrial locations; (1) in geologic settings on land, (b) in the seabed, and (c) in ice sheets, (2) disposal into space and (3) elimination by transmutation (nuclear transformation of certain waste constituents into nuclides having less long-term toxicity).

\section{SUBJECT CATEGORY: HLW}

ORIGIN: Defense; Commercial

KEYWORDS: GEOLOGY; RADIOACTIVE WASTE DISPOSAL; MARINE DISPOSAL; RADIOACTIVE WASTE MANAGEMENT; CONTAINERS; SEDIMENTS; GROUND DISPOSAL; ICE; TRANSMUTATION

\section{9}

Schneider, K.J., and A.M. Platt; Battelle Pacific Northwest Laboratory, Richland, WA
HIGH-LEVEL RADIOACTIVE WASTE MANAGEMENT ALTERNATIVES. SECTION 4: GEOLOGIC DISPOSAL. BNWL-1900(Vol.2); 225 pp. (1974)

This report (one of four volumes) is a comprehensive overview study of potential alternative methods for long-term management of high-level radioactive waste. The study includes a compilation of in formation relevant to technical feasibilty, safety, cost, environmental considerations, policy conflicts, public response and research and development needs for: (1) disposal in terrestrial locations; (a) in geologic settings on land, (b) in the seabed, and (c) in ice sheets, (2) disposal into space, and (3) elimination by transmutation (nuclear transformation of certain waste constituents in to nuclides having less long-term toxicity).

\section{SUBJECT CATEGORY: HLW}

ORIGIN: Defense; Commercial

KEYWORDS: GEOLOGY; HEAT TRANSFER; RADIOACTIVE WASTE DISPOSAL; RADIOACTIVE WASTE MANAGEMENT; UNDERGROUND DISPOSAL; ICE; MARINE DISPOSAL; ROCK MECHANICS; FLUID FLOW; LEAKS; GROUND DISPOSAL

\section{0}

Schneider, K.J., and A.M. Platt; Battelle Pacific Northwest Laboratory, Richland, WA

HIGH-LEVEL RADIOACTIVE WASTE MANAGEMENT ALTERNATIVES, SECTION 7: WASTE PARTITIONING, SECTION 8: EXTRATERRESTRIAL DISPOSAL, SECTION 9: TRANSMUTATION PROCESSING. BNWL 1900(Vol.4); 420 pp. (1974)

This report (one of four volumes) is a comprehengive overview study of potential alternative method for long-term management of high-level radioactive waste. The study includes a compilation of in formation relevant to technical feasibility, safety, cost, environmental considerations, policy conflicts, public response and research and development needs for: (1) disposal in terrestrial locations; (a) in geologic settings on land, (b) in the seabed, (c) in ice sheets, (2) disposal into space, and (3) elimination by transmutation (nuclear transformation of cer. tain waste constituents into nuclides having less long-term toxicity). 


\section{SUBJECT CATEGORY: HLW}

ORIGIN: Defense; Commercial

KEYWORDS: DECAY HEAT; ISOTOPES; RADIOACTIVE WASTE DISPOSAL; FISSION PRODUCTS; COST; GROUND DISPOSAL; MARINE DISPOSAL; SPACE VEHICLES; STABLE ISOTOPES; RADIOACTIVE WASTE MANAGEMENT; TRANSMUTATIOON

\section{1}

Smith, T.H., W.K. Winegardner, and G. Jansen, Jr.; Battelle Pacific Northwest Laboratory, Richland, WA

METHODOLOGY FOR RISK ANALYSIS OF NUCLEAR WASTE MANAGEMENT SYSTEMS. BN̈ẄL-SA-4899; 25 pp. (1974)

4 figures, 36 references

Describes a methodology for risk assessment of nuclear waste management systems. The required information and calculations are discussed, along with computer codes used for inventory calcula. tions, fault tree evaluation, liquid and airborne transport, and dose to man.

SUBJECT CATEGORY: General

ORIGIN: Defense; Commercial

KEYWORDS: COMPUTER CODES; RADIOACTIVE WASTE DISPOSAL; HUMAN POPULATIONS; RADIOACTIVE WASTE MANAGEMEN'T; FAULT TREE ANALYSIS

392

Winegardner, W.K., and J.D. Kaser; Battelle Pacific Northwest Laboratory, Richland, WA

RADIOACTIVE WASTE MANAGEMENT FOR NUCLEAR ENERGY CENTER. BNWL B-334; 28 pp. (1974)

See Nuclear Science Abstracts 1974, 30(11) 30107

SUBJECT CATEGORY: HLW; LLW; TRU

ORIGIN: Commercial

KEYWORDS: ECONOMICS; FUEL FABRICATION PLANTS; FUEL REPROCESSING
PLANTS; NUCLEAR POWER PLANTS; PLANNING; RADIOACTIVE WASTE MANAGEMENT; NUCLEAR PARKS

\section{3}

Schneider, K.J., and R.C. Liikala; Battelle Pacific Northwest Laboratory, Richland, WA; Oklahoma State University, School of Electricul Engintering, Stillwater, OK

HIGH-LEVEL RADIOACTIVE WASTE MANAGEMENT. CONF-741070-; Frontiers of Power Technology, Proceedings of a Conference, Stillwater, OK, October 9, 1974, (pp. 4.1-4.38). (1974)

Revipw of genlngir, seahes, ice sheet, extraterrestrial, and transmutation methods

High-level radioactive waste in the U.S. will be converted to an encapsulated solid and shipped to a Federal repository for retrievable storage for ex. tended periods. Meanwhile the development of concepts for ultimate disposal of the waste which the Federal Government would manage is being actively pursued. A number of promising concepts have been proposed, for which there is high confidence that one or more will be suitable for long. term, ultimate disposal. Initial evaluations of technical (or theoretical) feasibilily fur lle variuus waste disposal concepts show that in the broad category, (i.e., geologic, seabed, ice sheet, extraterrestrial, and transmutation) all meet the criteria for judging feaslbllity, though a few alternatives within these categories do not. Preliminary cost estimates show that, although many millions of dollars may be required, the cost for even the most exotic concepts is small relative to the total cost of electric power generation. For example, the cost estimates for terrestrial disposal concepts are less than 1 percent of the total generating costs. 'I'he cost for actinide transmutation is estimated at around 1 percent of generation costs, while actinide element disposal in space is less than 5 percent of generating costs. Thus neither technical feasibility nor cost seems to be a no-go factor in selecting a waste management system. The seabed, ice shect, and space disposal concepts face international policy constraints. The information being developed currently in safety, environmental concern, and public response will be important factors in determining which concepts appear most promising for further development. (Auth)

\section{SUBJECT CATEGORY: HLW}

ORIGIN: Defense; Commercial 
KEYWORDS: COMPARATIVE EVALUATIONS; COST; DIAGRAMS; GEOLOGIC STRUCTURES; ICE; MARINE DISPOSAL; RADIOACTIVE WASTE DISPOSAL; RADIOACTIVE WASTE MANAGEMENT; RADIOACTIVE WASTE STORAGE; RESEARCH PROGRAMS; REVIEWS; SEA BED; SOLID WASTES; SPACE; TABLES; TRANSMUTATION

\section{4}

Schmidt-Kuester, W.J.; Bundesministerium fuer Forschung und Technologie, Bonn, Germany, F.R.

THE DISPOSAL SYSTEM IN THE NUCLEAR FUEL CYCLE. Atomwirt. Atomtech. 19(7):340345. (1974)

In German; 4 figures, 1 table. From reactor meeting, Berlin, F.R. Germany, 2 April 1974

See Nuclear Science Abstracts 1974, 30(11) 29147

SUBJECT CATEGORY: Spent Fuel

ORIGIN: Foreign

KEYWORDS: COST; FBR TYPE REACTORS; FORECASTING; FUEL CYCLE; GERMAN FEDERAL REPUBLIC; HTGR TYPE REACTORS; PLUTONIUM; RADIOACTIVE WASTE DISPOSAL; RADIOACTIVE WASTE MANAGEMENT; RADIOACTIVE WASTE STORAGE; REACTOR DISMANTLING; REPROCESSING; SPENT FUELS; WATER COOLED REACTORS; WATER MODERATED REACTORS

\section{5}

Bureau of Mines, Salt Lake City Metallurgy Research Center, Salt Lake City, UT

\section{METHODS AND COSTS FOR STABILIZING} FINE-SIZED MINERAL WASTES. BMRI-7896. (1974)

Available from Bureau of Mines, Washington, DC

Fine-sized mineral wastes discarded by ore milling plants require stabilization to prevent air and water pollution. Stabilization has been attained by physical, chemical, vegetative, and combination procedures. Vegetative reclamation is preferred to physical and chemical stabilization but is difficult to achieve because the wastes are sterile, contain deleterious inorganic salts, and lack the essential nutrients and physical characteristics required for sustaining vegetative growth. Methods now have been developed for attaining vegetative growth on all but excessively acidic, basic, or saline tailings at costs ranging from $\$ 120$ to $\$ 650$ per acre. The cost for stabilizing tailings requiring more intensive treatment techniques may range upward to $\$ 1,750$ per acre. This report summarizes procedures developed by the Bureau of Mines and industry for vegetating amenable tailings, lists costs for the various processes, and suggests procedures that may be applicable for stabilizing saline and pyritecontaining tailings. Ridged planting beds, drip irrigation, and deep-furrow planting techniques are suggested for stabilizing saline wastes. A combination of mill tailings and sewage sludge can be used for producing synthetic soils, and layers of sewage sludge buried under a layer of tailings offer promise of inhibiting acid formation from oxidation of sulfides in mineral wastes.

SUBJECT CATEGORY: Remedial Action, Mill Tailings

ORIGIN: Commercial

KEYWORDS: AIR POLLUTION CONTROL; COST; LAND RECLAMATION; MILL TAILINGS; MILLING; MINERALS; ORES; PARTICLE SIZE; RESIDUES; STABILIZATION; WATER POLLU. TION CONTROL

396

Richardson, J.A.; Burns and Roe Inc., New York, NY

RADIOACTIVE WASTE QUANTITIES PRODUCED BY LIGHT-WATER REACTORS. Nuclear Engineering International 19(212):31-37; Nuclear Science Abstracts 1974, 29(07) 19693. (1974)

Excellent general discussion on radioactive waste quantities generated at LWR's as well as information on costs of processing, transportation, and burial.

Operational statistics for radioactive liquids, gases, and solids from light water reactors up to $800 \mathrm{MW}(\mathrm{e})$ are tabulated together with projections for 1100 MWe reactors. Handling and transportation procedures for the radioactive wastes and spent fuel are described. Solidification and immobilization techniques employed at these LWR's or at commercial 
burial sites are also described. Waste processing, transportation and burial costs are outlined.

SUBJECT CATEGORY: Spent Fuel; HLW; LLW

ORIGIN: Commercial

KEYWORDS: RADIOACTIVE WASTE MAN. AGEMENT; RADIOACTIVE WASTE DISPOSAL; SOLIDIFICATION; FISSION PRODUCTS; COST BENEFIT ANALYSIS; SOLID WASTES; REACTORS

397

Carolina Power and Light Co., Raleigh, NC

SHEARON HARRIS NUCLEAR POWER PLANT, UNITS 1, 2, 3, AND 4. AECREVISED DRAFT ENVIRONMENTAL STATEMENT. DOCKET-5040061;DOCKET-50401-61;DOCKET50402-61; 241 pp. (1974)

See Nuclear Science Abstracts 1974, 29(07) 17876

SUBJECT CATEGORY: General

ORIGIN: Commercial

KEYWORDS: CLIMATES; CONSTRUCTION; COST BENEFIT ANALYSIS; ECOLOGY; ELECTRIC POWER;:ENVIRONMENT; GEOGRAPHY; HARRIS-1 REACTOR; HARRIS-2 REACTOR; HARRIS-3 REACTOR; HARRIS-4 REACTOR; HYDROLOGY; RADIOACTIVE WASTE DISPOSAL; REACTOR OPERATION; REACTOR SITES; THERMAL EFFLUENTS

398 .

Webster, B.H.; Carolina. Power and Light Co., Raleigh, NC; Oak Ridge National Laboratory, Oak Ridge, TN

WASTE PACKAGING AND COST ANALYSIS. CONF-740901; Packaging and Transportation of Radioactive Materials, Proceedings of the 4th International Symposium, Miami Beach, Florida, September 22-27, 1974, (pp. 483-489), 1047 pp.; Nuclear Science Abstracts 1974, 30(12) 32950. (1974)

A review of volumes of wastes generated at the H.B. Robinson Nuclear Plant, South Carolina and their associated costs. Data are limited to this one plant.
The H.B. Robinson Nuclear Plant is a pressurizedwater reactor located near Hartsville, South Caro. lina. The wastes generated during 1973 included 524 cubic feet of spent resins, 750 drums of evaporator concentrates and 750 drums of miscellaneous solid waste. The costs of packaging and disposal were $\$ 25.06$ per cubic foot for resins, $\$ 15.82$ per cubic foot for evaporator concentrates and $\$ 8.53$ per cubic foot for miscellaneous solid wastes.

SUBJECT CATEGORY: LLW; HLW

ORIGIN: Commercial

KEYWORDS: RESINS; SOLID WASTES; VO. LUME; COST BENEFIT ANALYSIS; PWR TYPE REACTORS; INVENTORIFS; COST

\section{9}

Ganivet, M., and G. Cousinou; CEA Centre d'Etudies Nucleaires de Cadarache, 13 - Saint-Paul-LesDurance, France

USE OF CRYOGENIC GRINDING AND LEACHING TO REDUCE THE VOLUME AND ACTIVITY OF SOLID WASTES CONTAMINATED BY ALPHA-ACTIVE MATERIALS. CONF-741026-8; Control of PlutoniumContaminated Solid Wastes, Proceedings of a Conference, Marcoule, France, October 14-16, 1974, 9 pp. (1974)

See Nuclear Science Abstracts 1975, 31(06) 13802

SUBJECT CATEGORY: TRU

ORIIGIN: Foreign

KEYWURDS: ALPHA SOURCES; CITRIC ACID; COST; CRYOGENICS; GRINDING; I.EACHING; PLUTONIUM; RADIOACTIVE WASTE PRO CESSING; RADIOACTIVE WASTE STORAGE; SOLID WASTES; SOLVENT EXTRACTION

400

Argiero, L., A. Lo Moro, and G. Panciatici; Centro Applicazioni Militari Energia Nucleare, S. Piero A Grado, Italy

A STORAGE SOLUTION FOR PRECONDITIONED SOLID RADIOACTIVE WASTES. Containment of Radioactivity and the Use of Nuclear Energy, H. Jarry (Ed.), Proceedings of the 
Seventh International Congress, Versailles, France, May 28-31, 1974. Societe Francaise de Radioprotection (pp. 763-768). (1974)

In French

See Nuclear Science Abstracts 1975, 31(11) 30359.

SUBJECT CATEGORY: Isolation; HLW

ORIGIN: Foreign

KEYWORDS: CONCRETES; COST; RADIOACTIVE WASTE STORAGE; SAFETY; RADIOACTIVE WASTE MANAGEMENT

401

Couture, J., T.G. Hughes, and P. Zeuhlke; COGEMA/Retraitment Service Commercial, Chatillon, France

PRESENT STATE AND FUTURE TRENDS IN NUCLEAR FUEI. REPROCESSING WITH A VIEW TO ECONOMIC POWER GENERATION AND RELIABLE WASTE DISPOSAL. CONF-740910-4; Ninth World Energy Conference, London, England, Paper 4.2-24, 9 pp. (1974)

See Nuclear Science Abstracts 1976, 33(08) 16714

SUBJECT CATEGORY: HLW; Spent Fuel

ORIGIN: Foreign

KEYWORDS: ECONOMICS; EUROPE; FUEL REPROCESSING PLANTS; NUCLEAR POWER PLANTS; RADIOACTIVE WASTE DISPOSAL; REPROCESSING; SAFETY; SPENT FUELS

402

Sousseler, Y.; Commissariat a l'Energie Atomique, Chatillon, France

RADIOACTIVE WASTES: LES DECHETS RADIOACTIFS. Annales des Mines 1:77. 86. (1974)

In French

The different sources of radioactive waste are reviewed together with the quantities of such materials that will be produced in the future. The processing of these wastes is discussed. In the processing, the volume of the wastes is reduced before they are stored. The storage must not exposue the present population or future generations to any risks. The storage is effected at the surface or inside appropriate geological formations depending on the activity and half-life of the waste considered. The cost of processing and storing radioactive wastes represents less than $1 \%$ of the price of the electricity produced by nuclear plants.

SUBJECT CATEGORY: General

ORIGIN: Foreign

KEYWORDS: RADIOACTIVE WASTE STORAGE; ECONOMICS; RADIOACTIVE WASTE PROCESSING; GEOLOGIC STRUCTURES; RADIOACTIVE WASTE DISPOSAL; VOLUME; COST; FORECASTING

403

Nomi, M.; Ebara Mfg. Co. Ltd., Tokyo, Japan

MEASURES TAKEN TO REDUCE THE RELEASE OF RADIOACTIVITY. Fapig 75:3746. (1974)

In Japanese

Minimizing the radioactivity released from nuclear power plants to the atmosphere is an urgent problem. A variety of the technological methods for the purpose are available. However, it is necessary to examine closely the relation of cost increase due to the measures taken and the decrease of radioactivity taking the exposure dose to human body into account. The need for technology assessment in advance thus arises to reduce danger. The following matters are described: regulations on the release of radioactivity; technological assessment for the reduction of radioactivity; cost effectiveness of the gaseous-waste treatment systems in PWRs and BWRs; WASH-1258 of the United States concerning the release of radioactivity; and reduction of the released radioactivity in spent-fuel processing plants.

SUBJECT CATEGORY: Airborne; Spent Fuel

ORIGIN: Foreign

KEYWORDS: BWR TYPE REACTORS; CONTA. MINATION; COST; KRYPTON 85; MAXIMUM PERMISSIBLE LEVEL; NUCLEAR POWER PLANTS; PWR TYPE REACTORS; RADIATION 
DOSES; RADIATION PROTECTION; RADIOACTIVE EFFLUENTS; RADIOACTIVE WASTE DISPOSAL; RADIOACTIVE WASTE PROCESSING; REPROCESSING; POLLUTION REGULATIONS; SPENT FUEL ELEMENTS

\section{4}

Rudman, R.L.; Electric Power Research Inst., Palo Alto, CA

COST/BENEFIT CONSIDERATIONS OF NUCLEAR POWER. Nuclear Technology 24(3):301-13; Nuclear Science Abstracts 1975, 31(02)04047. (1974)

3 seferentes

A cost/benefit analysis has been used in an attempt to place the societal costs associated with nuclear power in to perspective by comparing them with the costs associated with coal-fired plants. Generation of electricity from coal is assumed to represent an acceptable risk in our society. The results of this qualitative evaluation indicate that nuclear power compares favorably with coal for the following costs: resource depletion, environmental insult, cost of power generation, voluntary occupational health risks, and involuntary public health risks associated with routine plant operation.

SUBJECT CATEGORY: General

ORIGIN: Commercial

KEYWORDS: RADIOACTIVE WASTE MANAGEMENT; FOSSILFUEL POWER PLANTS; SAFEGUARDS; NUCLEAR MATERIALS MANAGEMENT; NUCLEAR POWER PLANTS; COST BENEFIT ANALYSIS

\section{5}

Environmental Protection Agency, Office of Solid Waste Management Programs, Washington, DC

REPORT TO CONGRESS: DISPOSAL OF HAZARDOUS WASTES. SW-115; 110 pp. (1974)

Table II of Appendix B shows potentially hazardous radionuclides and gives their source and half-life. Appendix A has been abstracted separately. It discusses the impact of improper hazardous waste management of the environment and includes lead and arsenic disposal, fish kill and Pu contamination at Rocky Flats. Appendix D gives a summary of Hazardous Waste Treatment and Disposal processes, e.g., physical, chemical, thermal and biological methods and disposal of residues.

The first section of the report discusses the congressional mandate and the U.S. Environmental Protection Agency's response to it. Next. the vublic health, technological and economic aspects of the problem of disposing of hazardous wastes are reviewed. A section detailing the case for hazardous waste regulation follows. The report concludes with a discussion of implementation issues and. a presentation of findings and recommendations. The conclusions of the study are that (1) a hazardous waote management problem existg and its magnilude is incieasing, (2) llet lechnitul means $w$ sulve the problem exist for most hazardous waste but are costly in comparison with present practices; (3) the legislative and economic incentives for using available technology are not sufficient to cause environmentally adequate treatment and disposal in most cases; (4) the most effective solution at least direct cost to the public is a program for the regulation of hazardous waste treatment and disposal. (5) a private hazardous waste management service industry exists and is capable of expensing under the stimulus of a regulatory program; (6) because of inherent uncertainties. private sector response cannot be definitely prescribed; (7) several other alternatives for Government action are available, but, based on analyses to date, EPA is not convinced that such actions are needed

SUBJECT CATEGORY: TRU

ORIGIN: Defense

KEYWORDS: REGUTLATIONS; ECONOMICS; RADIOACTIVE WASTE DISPOSAL; LEGAL ASPECTS; HAZARDS; RADIOISOTOPES; ENVIRONMENT; PLUTONIUM

406

O'Connell, M.F., and W.F. Holcomb; Environmental Protection Agency, Washington, DC

A SUMMARY OF LOW-LEVEL RADIOACTIVE WASTES BURIED AT COMMERCIAL SITES BETWEEN 1962-1973, WITH PROJECTIONS TO THE YEAR 2000. Radiation Data and Reports 15(12):759-767. (1974) 
Good review of commercial burial grounds. Tables with amounts and types of material buried at each site through 1973. See also Nucl. Sci. Abstr. (NSABA) 1975, 31(09) 23438.

A review of the six commercial shallow land burial sites is presented with tables showing types and amounts of radioactive material buried at each site since its inception. Projections of future waste production indicate that the current burial capacity of all six existing sites will be filled by 1998 .

SUBJECT CATEGORY: LLW

ORIGIN: Commercial

KEYWORDS: TRANSURANIUM ELEMENTS; RADIOACTIVE WASTE DISPOSAL; FORECASTING; LOW-LEVEL RADIOACTIVE WASTES; SOLID WASTES; VOLUME; LIQUID WASTES; SOLIDIFICATION; LOW-LEVEL RADIOACTIVE WASTES

407

Rowe, W.D., and W.F. Holcomb; Environmental Protection Agency, Washington, DC

HIDDEN COMMITMENT OF NUCLEAR WASTES. Nucl. Technol. 24(3):286-293. (1974)

See Nuclear Science Abstracts 1975, 31(02) 04024

SUBJECT CATEGORY: General

ORIGIN: Commercial; Defense

KEYWORDS: COST; FORECASTING; PLANNING; RADIOACTIVE WASTE DISPOSAL; RADIOACTIVE WASTE MANAGEMENT

408

Exxon Nuclear Co., Richland, WA

URANIUM OXIDE FUEL PLANT. DRAFT ENVIRONMENTAL STATEMENT. DOCKET701257-5; 140 pp. (1974)

See Nuclear Science Abstracts 1974, 29(09) 20890

SUBJECT CATEGORY: LLW

ORIGIN: Commercial
KEYWORDS: CONTAMINATION; COST; EARTH ATMOSPHERE; ECOLOGY; ENVIRONMENT; EXXON FUEL FABRICATION FACIL ITY; FABRICATION; FUEL ELEMENTS; FUEL FABRICATION PLANTS; GEOLOGY; HYDROLOGY; LIQUID WASTES; POLLUTION; RADIA: TION HAZARDS; RADIOACTIVE WASTES; SAFETY; SOILS; SURFACE WATERS; THERMAL EFFLUENTS

409

Exxon Nuclear Co., Richland, WA

URANIUM OXIDE FUEL PLANT. LICENSE APPLICATION, ENVIRONMENTAL REPORT, AMENDMENT 14. Docket-701257-7; 97 pp. (1974)

See Nuclear Science Abstracts 1974, 30(10) 26829

SUBJECT CATEGORY: LLW

ORIGIN: Commercial

KEYWORDS: ACCIDENTS; CONTAMINATION; COST BENEFIT ANALYSIS; ECONOMICS; ENVIRONMENT; FUEL FABRICATION PLANTS; GASEOUS WASTES; NONRADIOACTIVE WASTES; NUCLEAR INDUSTRY; POLLUTION; PRODUCTION; RADIATION MONITORING; RADIOACTIVE WASTES; REPROCESSING; RESIDUES; SAFETY; STACK DISPOSAL; URANIUM; WASHINGTON; RADIOACTIVE WASTE MANAGEMENT

410

Florida Power and Light Co., Tampa, FL

ST. LUCIE PLANT, UNIT 2. AEC DRAFT ENVIRONMENTAL STATEMENT. DOCKET50389-38; 208 pp. (1974)

See Nuclear Science Abstracts 1974, 29(09) 23725

SUBJECT CATEGORY: General

DRIGIN: Commernial

KEYWORDS: CLIMATES; CONSTRUCTION; COST BENEFIT ANALYSIS; ECOLOGY; ELECTRIC POWER; ENVIRONMENT; GEOGRAPHY; GEOLOGY; HYDROLOGY; LUCIE-2 REACTOR; 
NONRADIOACTIVE WASTES; RADIOACTIVE WASTES; REACTOR OPERATION; REACTOR SITES

411

Brown, P.E., and J.A. Garate; General Electric Co., Philadelphia, PA

REPORT ON THE AVAILABILITY AND COST OF CURIUM-244 FROM REACTOR FUEL REPROCESSING WASTE. General Electric Co., Space Division Report; 99 pp. (1974)

See Nuclear Science Abstracts 1974, 30(01) 00221

SUBJECT CATEGORY: Spent Fuel

ORIGIN: Commercial

KEYWORDS: COST; CURIUM 244; ISOTOPE PRODUCTION; RADIOACTIVE WASTE PROCESSING; RADIOACTIVE WASTES; REPROCESSING; SPENT FUELS

412

General Electric Company, Philadelphia, PA

RESPONSE TO QUESTION 11.18 - LIQUID WASTE VOLUMES AND ACTIVITY LEVELS. DOCKET-STN-50447-20; Amendment 9 to Gessar, 1 p. (1974)

The current activity levels and volumes are presented in the GESSAR chapter 11 revision (Amendment no. 9). These values were presented and justified in NEDO 10951 and subsequently by H.L. Loy of General Electric in public testimony on WASH-1'2b8 given during ALAP hearings on $12 / 4 / 73$.

\section{SUBJECT CATEGORY: LLW}

ORIGIN: Commercial

KEYWORDS: BWR TYPE REACTORS; RADIOACTIVE WASTE PROCESSING; LIQUID WASTES; VOLUME

\section{3}

Tarasova, N.V.; Gosudarstvennyj Komitet Po Ispol'Zovaniyu Atomnoj Ehnergii SSSR, Moscow, USSR
UNDERGROUND DISPOSAL OF RADIOACTIVE WASTES OF NUCLEAR POWER PLANTS ON THE TERRITORY OF THE EUROPEAN PART OF THE USSR. INISmf-1703; CONF-7406108-38; Nuclear Power Plant Operating Experience and Prospects of Nuclear Power Engineering, Vol. 2, Proceedings of the Jubilee Conference Dedicated to the Twentieth Anniversary of Nuclear Power Engineering, Obnisk, USSR, June 25, 1974, (pp. 332-342). (1974)

In Russian

See Nuclear Science Abstracts 1976, 33(01) 01410

SUBJECT CATEGORY: Isolation

ORIGIN: Foreign

KEYWORDS: ECONOMICS; GEOLOGIC DEPOSITS; LIQUID WASTES; NUCLEAR POWER PLANTS; RADIOACTIVE WASTE DISPOSAL; UNDERGROUND DISPOSAL; USSR

414

Gulf General Atomic Co., San Diego, CA

GULF YOUNGSVILLE NUCLEAR FACILITY. DRAFT ENVIRONMENTAL STATEMENT. DOCKET-701372-3; 195 pp. (1974)

See Nuclear Science Abstracts 1974, 29(09) 20891

SUBJĒCT CATEGORY: General

ORIGIN: Commercial

KEYWORDS: CONTAMINATION; COST; EARTH ATMOSPHERE; ECOLOGY; ENVIRONMEN'I'; FABKICA'IIUN; F'UEL ELEMENTS; FUEL FABRICATION PLANTS; GENERAL A'lOMIC FUEL FABRICATION FACILITY; GEAI r OGY; HYDROLOGY; LIQUID WASTES; POLLU. TION; RADIATION HAZARDS; RADIOACTIVE WASTES; SAFETY; SOILS; SURFACE WA'I'EKS; THERMAL EFFLUIFNTS

415

Wehmann, G., and W.W. Hickman; Idaho National Engineering Laboratory, National Engineering Laboratory, Idaho Falls, ID; Aerojet Nuclear Co., Idaho Falls, ID 
STORAGE OF TRANSURANIC CONTAMINATED SOLID WASTES AT THE IDAHO NATIONAL ENGINEERING LABORATORY. CONF-7410263; Management of Plutonium-Contaminated Solid Wastes, Proceedings of a Symposium, Marcoule, France, October 14, 1974 (pp 23), 250 pp. (1974)

Tables include a summarization of the volume and plutonium content of the waste in storage on Pad 1 of the transuranic storage area from 1970 to 1974 , and a summarization of the volume and plutonium content of the waste currently on Pad A of the transuranic disposal area from 1972 to 1974.

The storage method for low-level transuranic wastes employed at the Idaho National Engineering Laboratory is discussed in detail. The techniques used for wastes containing greater than ten (10) nanocuries of transuranic material per gram of waste as well as the technique for lesser concentrations of transuranic wastes are described. The safety, efficiency and adequacy of these storage methods are presented. (Auth)

SUBJECT CATEGORY: TRU; LLW

ORIGIN: Defense; Commercial

KEYWORDS: RADIOACTIVE WASTE DISPOSAL; PLUTONIUM; ECONOMICS; SITE EVALUATION; TRANSURANIUM ELEMENTS; VOLUME; INVENTORIES; RADIOACTIVE WASTE STORAGE; LOW-LEVEL RADIOACTIVE WASTES

\section{6}

Idaho Nuclear Corp., Idaho Falls, ID

HTGR FUELS REPROCESSING FACILITIES. ENVIRONMENTAL STATEMENT. WASH-1534; 189 pp. (1974)

See Nuclear Science Abstracts 1974, 29(09) 20897

SUBJECT CATEGORY; Spent Fuel

ORIGIN: Commercial

KKEYWORDS: ACCIDENTS; CONTAMINATION; COST BENEFIT ANALYSIS; EARTH ATMOSPHERE; ECOLOGY; ENVIRONMENT; FUEL REPROCESSING PLANTS; GASEOUS WASTES; GEOLOGY; HYDROLOGY; LIQUID WASTES; POLLUTION; RADIATION HA-
ZARDS; RADIATION MONITORING; RADIOACTIVE WASTES; REPROCESSING; SAFETY; SOILS; SOLID WASTES; SPENT FUELS; SURFACE WATERS; THERMAL EFFLUENTS; WASTE MANAGEMENT; IDAHO NATIONAL ENGINEERING LABORATORY

\section{7}

Schnez, H., M. Laser, and E. Merz; Institut Fuer Chemische Technologie, Kernforschungsanlage, Juelich, GmbH, Germany, F.R.

TRITIUM IN REPROCESSING PLANTS: A STUDY OF THE INVENTORY, BEHAVIOR, AND THE POSSIBILITIES OF SEPARATION OF THE TRITIUM ISOTOPE. GERHTR-139; Jul-1099-ct; pp. 85. (1974)

Work Performed Under United States-German High Temperature Reactor Research Exchange Program

See Nuclear Science Abstracts 1976, 33(07) 14365, and $1975,32(06) 13926$

SUBJECT CATEGORY: LLW

ORIGIN: Foreign

KEYWORDS: ECONOMICS; FLOWSHEETS; FUEL REPROCESSING PLANTS; PUREX PROCESS; RADIOACTIVE WASTE STORAGE; SEPARATION PROCESSES; SPENT FUEIS; THOREX PROCESS; TRANSPORT; TRITIUM

418

Eklund, S.; International Atomic Energy Agency, Vienna, Austria

NUCLEAR POWER, SAFETY, AND ENVIRONMENT. International Atomic Energy Agency, Bulletin 16(1/2):49-59. (1974)

See Nuclear Science Abstracts 1974, 30(03) 08921

SIJBIFCT CATEGORY: General

ORIGIN: Foreign

KEYWORDS: ENVIRONMENT; NUCLEAR INDUSTRY; RADIATION HAZARDS; RADIOACTIVE WASTES; SAFETY 
419

Emura, S., and H. Abe; Japan Atomic Energy Research Inst., Tokai, Japan

LATEST DEVELOPMENTS IN SOLIDIFICATION OF RADIOACTIVE WASTES. Genshiryoku Kogyo 20(1):25-32. (1974)

In Japanese

See Nuclear Science Abstracts 1974, 30(08) 20816

SUBJECT CATEGORY: Isolation

ORIGIN: Foreign

KEYWORDS: ASPHALTS; . CEMENTS; CONTAINERS; COST; EVAPORATION; LIQUID WASTES; PLASTICIZERS; POLYETHYLENES; RADIOACTIVE WASTE DISPOSAL; RADIOACTIVE WASTE PROCESSING; RADIOACTIVE WASTE STORAGE; SOLIDIFICATION

420

Murata, H.; Japan Atomic Energy Research Inst., Tokyo, Japan

NUCLEAR DEVELOPMENT UNDER ENERGY CRISIS. Genshiryoku Kogyo; 20(2):1316. (1974)

See Nuclear Science Abstracts 1975, 31(04) 10398

SUBJECT CATEGORY: General

ORIGIN: Foreign.

KEYWORDS: COST; . ECONOMICS; ENERGY SOURCES; ENVIRONMENT; FUEL CYCLE; JAPAN; NUCLEAR POWER PLANTS; PLANNING; POWER REACTORS; RADIOACTIVE WASTE PROCESSING

421

Japan Atomic Energy Research Inst., Tokyo, Japan

ANNUAL REPORT AND ACCOUNT, 1972/1973. NP-20117; 39 pp. (1974)

See Nuclear Science Abstracts 1974, 30(09) 26124

SUBJECT CATEGORY: General

ORIGIN: Foreign
KEYWORDS: ECONOMICS; EDUCATION; ENERGY POLICY; ENVIRONMENTAL EFFECTS; INTERNATIONAL COOPERATION; JAPANESE ORGANIZATIONS; MANAGEMENT; NUCLEAR ENERGY; OPERATION; POWER GENERATION; PRODUCTION; RADIOACTIVE WASTE DISPOSAL; RADIOACTIVE WASTES; RADIOISOTOPES; RESEARCH PROGRAMS; SAFETY; URANIUM

422

Von Baeckmann, A.; Kernforschungsanlage Juelich $\mathrm{GmbH}$, Zentralinstitut Fuer Analytische Cliemi, Gerimariy, F.R.; Kernforschungszentrum, Karlsruhe, Inst. Fuer Radiochemi, Germany, F.R.

ANALYTICAL CHEMISTRY OF NUCLEAR FUELS: AED-CONF-73-702-001; Workshop on Modern Analytical Methods. Vol. 1, Stoeppler, M. (Ed.), Juelich, Germany, F.R., October 15, 1973, (pp. 5-25). (1974)

In German; 1 figure, 1 table, 10 references; Available from ZAED.

See Nuclear Science Abstracts 1975, 32(09) 21855

SUBJECT CATEGORY: HLW; LLW; TRU

ORIGIN: Foreign

KEYWORDS: CHEMICAL STATE; COST; FABRICATION; FUEI, CYCLE; FUEI, EI.EMENTS; ISOTOPE RATIO; NUCLEAR FUELS; ORE COMPOSITION; ORE PROCESSING; PLUTONIUM; QUANTITATIVE CHEMICAL ANALYSIS; RADIOACTIVE WASTES; RELIABILITY; REPROCESSING; REVIEWS; SAFEGUARDS ; TABLES; THORIUM; URANIUM

\section{3}

Hilbert, F.; Kernforachungazentrum, Karlaruhe, Karlsruhe Univ., Germany, F.R.

PRODUCTION AND RELEASE OF RADIOACTIVE KRYPTON AND XENON ISOTOPES BY NUCLEAR POWER PLANTS AND REPROCESSING PLANTS AND THE EXPECTED RADIOLOGICAL BURDEN TILL THE YEAR 2000. NP-20111; 197 pp. (1974)

In German; figures included 
The natural production of radioactive Krypton- and Xenon-isotopes is summarized in this report together with the yields from nuclear facilities and nuclear weapons tests. Specific production rates in nuclear power reactors are calculated. The activity flow in the different plants are described and the consequent release rates, representative of time are evaluated. Estimated release rates from $1500 \mathrm{~T} / \mathrm{A}$ fuel reprocessing plants are also included. With the condition that a dose of $30 \mathrm{mRem} / \mathrm{a}$ should not be exceeded for any release, the requisite minimum decontamination factors and cooling times are specified. Based on the forecasted growth of nuclear facilities til the year 2000 , the time dependent global concentrations and radiation doses from $\mathrm{Kr}-85$ releases are calculated using different atmospheric models.

SUBJECT CATEGORY: Airborne

ORIGIN: Foreign

KEYWORDS: FISSION PRODUCTS; KRYPTON; AIR POLLUTION; XENON; POWER REACTORS; REPROCESSING; FORECASTING; RADIATION DOSES

\section{4}

Tsutsui, T., and K. Nishimaki; Kyoto University, Research Reactor Institute, Kumatori, Osaka, Japan

VOLUME EVALUATION OF SOLIDIFIED RADIOACTIVE WASTES WITH CEMENT. Hoken Butsuri 9(2):87-94. (1974)

In Japanese

See Nuclear Science Abstracts 1975, 31(12) 32655

SUBJECT CATEGORY: HLW; LLW

ORIGIN: Foreign

KEYWORDS: CEMENTS; COMPRESSION STRENGTH; ION EXCHANGE MATERIALS; RADIOACTIVE WASTE PROCESSING; RADIOACTIVE WASTE STORAGE; RADIOACTIVE WASTES; RESINS; SOLID WASTES; SOLIDIFICATION; VOLUME
425

Cohen, J.J., L.L. Schwartz, and H.A. Tewes; Lawrence Livermore Laboratory, Livermore, CA

ECONOMIC AND ENVIRONMENTAL EVALUATION OF NUCLEAR WASTE DISPOSAL BY UNDERGROUND IN-SITU MELTING. Transactions of the American Nuclear Society 18:194-195; UCRL-51713; 15 pp. (1974)

Basic premises of deep underground encapsulation in a rock matrix (DUERMIX) are presented. Originally, DUERMIX involved the direct disposal of liquid radioactive waste into nuclear chimneys formed by underground nuclear explosions. The waste would eventually evaporate to dryness from the heat produced by radioactive decay, melt the surrounding rock, dissolve in the molten rock, and ultimately resolidify and be incorporated in a solid rock matrix. Concept modifications are: use of underground cavities formed by conventional excavation methods; presolidification of waste and its addition in solid form; and self burial of wastes by rock-melting capsules. Potential environmental advantages of DUERMIX are: elimination or reduction of many processing operations and their attendant risks; potential for safe disposal of all levels of liquid waste; elimination of radioactive waste transportation and attendant risks; permanent binding of the radwaste in a rock matrix deep underground; and provision of a secure disposal method assuring permanent safety from effects of disasters such as floods, sabotage, or warfare. However, there are potential problem areas in using this method. They are: irretrievability of waste; increased number of disposal sites; ground water contamination; consequences of seismic activity; and geological alteration due to change of state of large volumes of rock. Considering all factors the advantages of the method outweigh the disadvantages. Cost comparison studies indicate DUERMIX would be the most economic method of waste disposal both in absolute terms and in cost effectiveness. Future research includes laboratory investigations on heat transfer and phase-change phenomenology, chemical studies on the properties of the resolidified waste-rock material, and engineering studies.

SUBJECT CATEGORY: Isolation

ORIGIN: Defense; Commercial 
KEYWORDS: EVAPORATION; RADIOACTIVE WASTE DISPOSAL; HIGH-LEVEL RADIOACTIVE WASTES; LIQUID WASTES; RADIOACTIVE WASTES; ECONOMICS; COST; ENVIRONMENTAL EFFECTS; UNDERGROUND DISPOSAL

\section{6}

Rose, D.J.; Massachusetts Inst. of Tech., Cambridge, MA

NUCLEAR ELECTRIC POWER. Science 184(4134):351-359. (1974)

See Nuclear Science Abstracts 1974, 29(12) 31508

SUBJECT CATEGORY: General

ORIGIN: Commercial

KEYWORDS: ACCIDENTS; COMPARATIVE EVALUATIONS; ECONOMICS; ELECTRIC POWER; ENVIRONMENT; FOSSIL-FUEL POWER PLANTS; NUCLEAR FUELS; NU. CLEAR POWER PLANTS; RADIOACTIVE WASTES; SOCIOLOGY; RADIOACTIVE WASTE DISPOSAL

427

Dever, E.A., and W.W. Rodenburg; Monsanto Research Corp., Miamisburg, $\mathrm{OH}$

MOUND LABORATORY: A LEADER IN NUCLEAR MATERIALS MANAGEMENT. Nuclear Materials Management 11(2):47-49. (1974)

See Nuclear Science Abstracts 1975, 31(02) 04014

SUBJECT CATEGORY Ý: General

ORIGIN: Commercial; Defense

KEYWORDS: INVENTORIES; MOUND LABORATORY; MANAGEMENT; RADIOACTIVE MATERIALS; RADIOACTIVE WASTE MANAGEMENT; SAFEGUARDS; WASTE TRANS. PORTATION

428

National Aeronautics and Space Administration, Lewis Research Center, Cleveland, $\mathrm{OH}$
FEASIBILITY OF SPACE DISPOSAL OF RADIOACTIVE NUCLEAR WASTE. 2. TECHNICAL SUMMARY. NASA-TM-X-2912; 119 pp.; Nuclear Science Abstracts 1974, 30(10) 27578. (1974)

See also NASA-TM-X-2911, Executive Summary.

The feasibility of transporting radioactive waste from nuolear power plants into space for ultimate disposal was investigated at the request of the Atomic Energy Commission (AEC) as a NASA inhouse effort. The investigation is part of a broad AEC study of various concepts for long-term storage or disposal of radioactive waste. Both expendable and reusable space vehicles were considered for the space disposal missions. The Space Shuttle in conjunction with either reusable or expendable space tugs provided the lowest cost per payload for delivery to the various destinations investigated. The choice of space destinations was narrowed to high Earth orbits, solar orbits, and solar system escape. The latter destination appears to be the most desirable and was found to be economically and technically feasible. The nuclear waste packages were designed to prevent loss of radioactive waste in accident environments. Several compositions of radioactive nuclear waste were considered: fission products, and actinides containing various percentages of fission products. The long-lived radioactive isotope group referred to as actinides (heavy isotopes, with atomic numbers above 89 ), which could be a scparate part of the waste, received the greatest attention. The disposal of only this relatively small quantity of the most dangerous components of nut!er The results of this exploratory study indicate that disposal into space of the long-lived actinides of nuclear waste appears feasible, from both the economic and safety viewpoints.' (Space disposal of all fission products does not appear practical.) The transportation costa for cjccting the actinidos out of the oolar oyotom would represent less thuse \& 5 . percent increase in the consumer bill for electric power generated by nuclear power plants. Such missions involve certuin risks, however small, which would have to be balanced against the benefits to be derived from removing the dangerous long-lived radioactive waste from man's environment and relieving future generations from the responsibility of protecting themselves against our radioactive waste. Firm plans for such nuclear disposal missions must be based on more study, development, and testing.

SUBJECT CATEGORY: Isolation; TRU

ORIGIN: Defense 
KEYWORDS: SPACE; SPACE VEHICLES; COST BENEFIT ANALYSIS; SOLAR SYSTEM; ACTINIDES; FISSION PRODUCTS; SAFETY; WASTE TRANSPORTATION; ACCIDENTS; FIRES; CONTAINERS; PACKAGING; SHIELDING; ECONOMICS; RADIOACTIVE WASTE DISPOSAL

\section{9}

Duckworth, J.P., M.J. Jump, and B.E. Knight; New York State Atomic and Space Development Authority, New York, NY

FINAL REPORT ON THE RADIOACTIVE WASTE MANAGEMENT PROJECT. Final Report; 59 pp. (1974)

The comparison of the advantages and disadvantages of cement and urea formaldehyde is useful. The waste characterization data are limited.

The results of a waste management research project funded by the New York State Atomic and Space Development Authority are presented in this report. The major tasks in the research project were a literature survey of waste characterization and immobilization alternatives, a description of the burial ground characteristics, and the development of disposal operation standards. The discussion on waste characteristics includes a summary of U.S. commercial low-level waste burial history, the historical use of the NFS burial site, and volume, activity and compositional data for spent resins and evaporator bottoms. A discussion of the results of a boring program of holes around the burial trenches is presented. Elevated tritium levels were detected in the soil zone above twenty feet, however, the extent of tritium migration at the time of this in vestigation was limited to within ten feet of the trenches. A comparison of immobilization methodologies is included with information on cement, urea formaldehyde, microcell, vermiculite and asphalt. Observations and suggestions for disposal criteria are also presented.

\section{SUBJECT CATEGORY: Isolation; LLW}

\section{ORIGIN: General}

KEYWORDS: RADIOACTIVE WASTES; SOLIDIFICATION; TRITIUM; RADIONUCLIDE MIGRATION; REVIEWS; LOW-LEVEL RADIOACTIVE WASTES; RADIOACTIVE WASTE DISPOSAL
430

Niagara Mohawk Power Corp., Syracuse, NY

NINE MILE POINT NUCLEAR STATION, UNIT 1. AEC FINAL ENVIRONMENTAL STATEMENT. DOCKET-50220227; 471 pp. (1974)

See Nuclear Science Abstracts 1974, 29(09) 23674

SUBJECT CATEGORY: General

ORIGIN: Commercial

KEYWORDS: COST; COST BENEFIT ANALYSIS; ECONOMICS; ENVIRONMENT; FISHES; NINE MILE POINT-1 REACTOR; NONRADIOACTIVE WASTES; POWER TRANSMISSION; RADIATION DOSES; RADIATION MONITORING, RADIOACTIVE WASTE DISPOSAL; REACTOR LICENSING; REACTOR OPERATION; THERMAL POLLUTION; WASTE MANAGEMENT

\section{1}

Haga, I., and P.I. Wethe; Norges Vassdrags if Elektrisitetsvesen, Oslo

NUCLEAR POWER: TAMED AND MATURE FOR A PLACE IN OUR ENERGY SUPPLY. Tek. Ukebl. 121(3):10-16. (1974)

See Nuclear Science Abstracts 1974, 29(10) 26308

SUBJECT CATEGORY: General

ORIGIN: Foreign

KEYWORDS: COST; ECONOMICS; FUEL CYCLE; HAZARDS; HUMAN POPULATIONS; NUCLEAR POWER PLANTS; RADIOACTIVE WASTES; REACTOR SAFETY; WASTE DISPOSAL

432

Rodger, W.A.; Nuclear Safety Associates, Bethesda, MD; California Univ., Berkeley, CA

RADIOACTIVE WASTE MANAGEMENT FOR REACTORS. Environmental 
Analysis and Environmental Monitoring for Nuclear Power Generation. California Univ., Berkeley; NP-20456; PP.VP PAPER 9. (1974)

See Nuclear Science Abstracts, 1975, 32(06) 15029

SUBJECT CATEGORY: General

ORIGIN: Commercial

KEYWORDS: BWR TYPE REACTORS; DIAGRAMS; ECONOMICS; PWR TYPE REACTORS; RADIOACTIVE WASTE MANAGEMENT; RADIOACTIVE WASTE PROCESSING; REVIEWS

\section{3}

NUKEM, Grossauheim, Germany, F.R.

\section{SYSTEM STUDY 'RADIOACTIVE WASTES IN THE FRG'. WORK PRO- GRAMME. PERIOD: 1.1.1974 - 30.6.1976. NUKEM Report. (1974)}

\section{2 figures; In German}

A working programme for a system study is set up having the following aims: a) to give predictions as precise as possible of the production site, amount and type of radioactive wastes in the FRG, b) to estimate the possible hazard to the environment under various aspects and requirements (environmental protection etc.), c) to analyze the state and potential of the technology as well as the current research and development work, d) to submit suggestions for an ordered research and development programme as well as for legal and administrative measures, e) to design alternative models for a waste disposal system with management and financing model and to propose an action programme to construct a waste disposal system, as well as f) to evaluate numerical determinable connections with the auxiliary help of mathematical part models. In a scheme model, the whole system is subdivided into single elements in order to distinguish a division of the working programme into subsequent phases and projects.

SUBJECT CATEGORY: General

ORIGIN: Foreign
KEYWORDS: COMPARATIVE EVALUATIONS; COST; ENVIRONMENT; FINANCING; FORECASTING; GERMAN FEDERAL REPUBLIC; HAZARDS; LEGISLATION; MANAGEMENT; MATHEMATICAL MODELS; RADIOACTIVE WASTES; RESEARCH PROGRAMS; SYSTEMS ANALYSIS

\section{4}

Blomeke, J.O., and W.D. Bond; Oak Ridge National Laboratory, Oak Ridge, TN

HIGH-LEVEL WASTE MANAGEMENT RESEARCH AND DEVELOPMENT PROGRAM AT OAK RIDGE NATIONAL LABORATORY. CONF-740428; American Chemical Society, Proceedings of the 1.67th National Sympnsium, Tos Angeles, California, April 1-5, 1974, (14 p.). (1974)

Three areas of major interest are being emphasized: projections of future radioactive wastes from the nuclear fuel cycle for use in planning, design, and environmental assessments; investigations of the technical feasibility of removing actinide elements from wastes to render the residuals more manageable in terms of hazards and storage requirements; and evaluations of geological formations in addition to bedded salt for use in the disposal of various kinds of radioactive wastes. Projections of wastes to be generated through the year 2000 portend a future management problem of impressive size and complexity but one which can be handled within the framework of current and planned investigative programs. Early results indicate that the actinides can be removed from wastes by the minimally desired factors of $10(E+2)$ to $10(E+4)$; however, demonstrations and engineering assessments of the most promising chemical flowsheets have yet to be made. Natural salt formations are believed to offer the best prospects for disposal of high-level wastes, and the current program is directed toward obtaining confirmation of this well as evaluating other promising geological formations for their suitahility for use in the disposal of wastes.

\section{SUBJECT CATEGORY: HLW}

ORIGIN: Commercial

KEYWORDS: FORECASTING; ENVIRONMENTAL EFFECTS; ACTINIDES; SEPARATION PROCESSES; RADIOACTIVE WASTE STORAGE; SALT DEPOSITS; RADIOACTIVE WASTE MANAGEMENT; HIGH-LEVEL RADIOACTIVE WASTES; UNDERGROUND DISPOSAL 
435

Blomeke, J.O., and C.W. Kee; Oak Ridge National Laboratory, Oak Ridge, TN

PROJECTIONS OF RADIOACTIVE WASTES FROM THE NUCLEAR FUEL CYCLE. CONF741018-2; Health Physics Society, Midyear Topical Symposium, Knoxville, Tennessee, October 21, 1974, 8 pp. (1974)

See Nuclear Science Abstracts 1974, 30(12) 32951.

SUBJECT CATEGORY: General

ORIGIN: Commercial

KEYWORDS: FORECASTING; FUEL CYCLE; RADIOACTIVE WASTES; VOLUME.

436

Blomeke, J.O., C.W. Kee, and R. Salmon; Oak Ridge National Laboratory, Oak Ridge, TN

PROJECTED SHIPMENTS OF SPECIAL NUCLEAR MATERIAL AND WASTES BY THE NUCLEAR POWER INDUSTRY. ORNL TM-4631; 67 pp. (1974)

See Nuclear Science Abstracts, 1974, 30(09) 24819.

SUBJECT CATEGORY: General

ORIGIN: Commercial

KEYWORDS: FORECASTING; RADIOACTIVE MATERIALS; RADIOACTIVE WASTES; SPENT FUELS; NUCLEAR FUELS; WASTE TRANSPORTATION

437

Boegly, W.J., I. Spiewak, D.G. Thomas, S.A. Reed, W.L. Griffith, A.L. Compere, and H.W. Wright; Oak Ridge National Laboratory, Oak Ridge, TN

MIUS TECHNOLOGY EVALUATION: COLLECTION, TREATMENT, AND DISPOSAL OF LIQUID WASTES, ORNL-HUD-MIUS-16; 170 pp. (1974)

See Nuclear Science Abstracts, 1975, 31(07) 19184. SUBJECT CATEGORY: General

ORIGTN: General
KEYWORDS: ECONOMICS; RADIOACTIVE WASTE MANAGEMENT; RADIOACTIVE WASTE PROCESSING; RADIOACTIVE WASTE DISPOSAL

\section{8}

Kibbey, A.H., and H.W. Godbee; Oak Ridge National Laboratory, Oak Ridge, TN

A CRITICAL REVIEW OF SOLID RADIOACTIVE WASTE PRACTICES AT NUCLEAR POWER PLANTS. ORNL 4924; 66 pp. (1974)

Tables, figures

A survey was made of solid radioactive waste (radwaste) practices at light-water-cooled nuclear power plants. Plant operating reports from initial criticality to December 31, 1972, were the main sources of information. A comparison of boiling water reactors (BWR's) and pressurized water reactors (PWR's) shows that BWR's consistently shipped a larger total volume of solid radwaste per thermal megawatt-hour than PWR's.

\section{SUBJECT CATEGORY: LLW}

ORIGIN: Commercial

KEYWORDS: BWR TYPE REACTORS; PWR TYPE REACTORS; RADIOACTIVE WASTE DISPOSAL; POWER REACTORS; SOLID WASTES; RADIOACTIVE WASTE MANAGEMENT; REVIEWS

439

McKay, L.R., and J.P. Witherspoon; Oak Ridge National Laboratory, Oak Ridge, TN

EFFECT OF ST ACK HEIGHT ON INDIVIDUAL AND POPULATION DOSES ATTRIBUTABLE TO GASEOUS EFFLUENTS FROM A MODEL FUEL REPROCESSING FACILITY. CONF-741018; Population Exposures, Proceedings of the Eighth Midyear Topical Symposium of the Health Physics Society. (pp. 223. 228). (1974)

Cost of increasing stack height from 20 to $100 \mathrm{~m}$ is $\$ 43,000 / \mathrm{m} \mathrm{rem} / \mathrm{yr}$ for $5 \mathrm{mrem} / \mathrm{yr}$ dose; 1 table, 10 references

Stack height is one of the more important parameters affecting atmospheric dilution of radioactive 
particles and gases. The effect of stack height on estimated radition doses from power reactors, and from fuel element fabrication and reprocessing facilities which serve the reactors, will become increasingly significant as more of these plants are built in response to the increased national need for energy. Fuel reprocessing plants are usually built with tall stacks in an attempt to decrease the "fenceline" dose to individuals. Effects of stack height on population and maximum individual dose are considered in this paper, along with considerations of the incremental cost, or benefit, associated with the selection of stacks. (Auth)

\section{SUBJECT CATEGORY: Airborne}

\section{ORIGIN: Defense}

KEYWORDS: RADIOACTIVE EFFLUENTS; RE PROCESSING; PUBLIC HEALTH; STACKS; KRYPTON; HEIGHT; GASEOUS WASTES; AIR POLLUTION; DILUTION; AEROSOLS; REAC. TOR SITES; COMPUTER CODES; TRITIUM; FORECASTING; FUEL REPROCESSING PLANTS; SITE SELECTION

\section{0}

Spiewak, I.; Oak Ridge National Laboratory, Oak Ridge, TN

RESEARCH AND DEVELOPMENT NEEDS OF NUCLEAR ENERGY CENTERS. CONF741086-2; Proceedings of the ANS National Meeting, Washington, DC, October 27, 1974, 9 pp. (1974)

See Nuclear Science Abstracts 1975, 31(07) 19117

SUBJECT CATEGORY: General

URIGIN: Commercial

KEYWORDS: COMMUNITIES; ECONOMICS; ELECTRIC POWER; ENVIRONMENTAL EFFECTS; FOSSIL-FUEL POWER PLANTS; INDUSTRIAL PLANTS; INFORMATION; NUCLEAR ENERGY; NUCLEAR FOWER; PERSONNEL; PLANNING; POWER REACTORS; RADIOACTIVE WASTES; RESEARCH PROGRAMS; SITE SELECTION
441

Oak Ridge National Laboratory, Oak Ridge, TN

HTGR FUEL REFABRICATION PILOT PLANT. ENVIRONMENTAL STATEMENT. WASH-1533; 153 pp. (1974)

See Nuclear Science Abstracts 1974, 29(09) 20896

SUBJECT CATEGORY: General

ORIGIN: Defense; Commercial

KEYWORDS: ACCIDENTS; CONSTRUCTION; CONTAMINATION; COST BENEFIT ANALYSIS; EARTH ATMOSPHERE; ECOLOGY; ENVIRONMENT; FABRICATION; FUEL ELLEMENTS; FUEL FABKICA'IION PLAN'IS; GASEOUS WASTES; HYDROLOGY; LIQUID WASTES; OPERATION; ORNL; PILOT PLANTS; FOLLUTION; RADIATION HAZARDS; RADIATION MONITORING; RADIOACTIVE WASTES; SAFETY; SEISMOLOGY; SITE SELECTION; SOILS; SOLID WASTES; SURFACE WATERS; THERMAL EFFLUENTS; URANIUM 233; WASTE DISPOSAI; WASTF MANAGEMFNT

442

Power Keactor Development Co., Detroit, MI

RETIREMENT OF THE ENRICO FERMI ATOMIC POWER PLANT. NP.20047; 340 pp. (1974)

Available from NTIS, Department of Commerce, Springfield, VA 22161

Presents the details of the activities to retire the Fermi-1 Power Plant. Decommissioning was initiated November $\overline{2} \overline{7}$. $19 \overline{9} \overline{2}$. The program was suhstantially completed by March of 1974 . The total cost of the program including disposition of the primary sodium and blanket fuel is estimated at about $\$ 7,000,000$.

SUDJECT CATEGORY: Remedial Action, FUSRAP

ORIGIN: Commercial; Defense 
KEYWORDS: ECONOMICS; ENRICO FERMI-1 REACTOR; DECOMMISSIONING; REVIEWS; FBR TYPE REACTORS; COST; REACTOR DECOMMISSIONING

443

Public Service Electric and Gas Co., Newark, NJ

HOPE CREEK GENERATING STATION, UNITS 1 AND 2. AEC FINAL ENVIRONMENTAL STATEMENT. DOCKET-50354100;DOCKET-50355-100; 460 pp. (1974)

See Nuclear Science Abstracts 1974, 29(10) 26353

SUBJECT CATEGORY: General

ORIGIN: Commercial

KEYWORDS: CLIMATES; CONSTRUCTION; COST BENEFIT ANALYSIS; ECOLOGY; ELECTRIC POWER; ENVIRONMENT; GEOGRAPHY; GEOLOGY; HOPE CREEK-1 REACTOR; HOPE CREEK-2 REACTOR; HYDROLOGY; NONRADIOACTIVE WASTE DISPOSAL; RADIOACTIVE WASTE DISPOSAL; REACTOR OPERATION; REACTOR SITES; THERMAL EFFLUENTS

\section{4}

Gileadi, A.E., and A. Musalem; Puerto Rico Nuclear Center, Mayaguez

COMPUTERIZED FISSION PRODUCT INVENTORY SYSTEM. CONF-740402-2; Health Physics Society Annual Meeting, Houston, Texas, July 7, 1974, 19 pp. (1974)

A computer code has been developed to generate fission product inventories for a given reactor with a given operating history. Future plans include the development of two computer codes: (1) one that will use computed fission and activation products' inventories in order to calculate atmospheric transport, diffusion and deposition of volatile radioactive effluents in the vicinity of a given nuclear facility; and (2) one that will compute gamma heating in reactur shields using the build-up factor method.

SUBJECT CATEGORY: HLW; LLW

ORIGIN: Foreign
KEYWORDS: COMPUTER CODES; FISSION PRODUCTS; DATA PROCESSING; MONITOR. ING; INVENTORIES; FORECASTING; VOLUME

\section{5}

Giraud, J.P., and G. LeBlaye; Saint-Gobain Techniques Nouvelles, Courbevoie, France

DESIGN OF AN INDUSTRIAL FACILITY FOR THE INCORPORATION INTO GLASS OF FISSION PRODUCTS AND THE STORAGE OF HIGHLY RADIOACTIVE GLASS. Management of Radioactive Wastes from Fuel Reprocessing, Proceedings of Symposium, Paris, France, November 27, 1972. OECD-LAEA, (pp. 813846). (1974)

Available from HPIS, 2507

The present document describes an industrial facility for incorporating fission products into glass (or vitrification) that was designed to be adapted for use in a plant treating $L W R$ type radioactive wastes. The main basic hypotheses and the principal stages of the process are defined. A description is given of the arrangements made for the temporary storage of the fission product solutions, the unit for the actual vitrification of the fission products, the treatment of gaseous and ruthenium effluents, the temporary storage of the glass on the site, and the utilities. The released activities are given and an analysis is made of the design of the facility from the safety point of view. Finally, a brief indication of the investment cost is given and an analysis is made of the possible applications of the process, with emphasis on its contribution to solving the safety problems invovled in the temporary or longterm storage of highly radioactive wastes. (Auth)

\section{SUBJECT CATEGORY: HLW}

ORIGIN: Foreign

KEYWORDS: GLASS; HIGH-LEVEL RADIOACTIVE WASTES; VITRIFICATION; FISSION PRODUCTS; RADIOACTIVE WASTE STORAGE; GASEOUS WASTES; RADIOACTIVE EFFLUENTS; SAFETY; COST BENEFIT ANALYSIS

446

Albenesius, E.L., and W.C. Reinig; Savannah River Laboratory, Aiken, SC 
LONG RANGE MANAGEMENT OF TRANSURANIUM-CONTAMINATED SOLID WASTES AT SAVANNAH RIVER. DP-MS-7426; 10 pp.; CONF-741026-1; Management of Plutonium-Contaminated Solid Wastes, Proceedings of a Seminar, Marcoule, France, October 14, 1974. (1974)

See Nuclear Science Abstracts 1975, 31(01) 01287

SUBJECT CATEGORY: Isolation; TRU; HLW

\section{ORIGIN: Defense}

KEYWORDS: CURIUM 244; PLUTONIUM 238; PLUTONIUM 239; RADIOACTIVE WASTE MANAGEMENT; RADIOACTIVE WASTE PROCESSING; RADIOACTIVE WASTE STORAGE; SAVANNAH RIVER PLANT; SOLIDIFICATION; TRANSURANIUM ELEMENTS; UNDERGROUND DISPOSAL; HIGH-LEVEL RADIOACTIVE WASTES

\section{7}

Crandall, J.L., and J.A. Porter; Savannah River Laboratory, Aiken, SC

ECONOMIC COMPARISONS OF ACID AND ALKALINE WASTE SYSTEMS AT SRP. DPST-74-95-37(Del.); 26 pp. (1974)

Declassified June 18, 1975

See Nuclear Science Abstracts 1975, 32(07) 16939

SUBJECT CATEGORY: Isolation

ORIGIN: Defense

KEYWORDS: CALCINATION; CONCRETES; ECONOMICS; GLASS; RADIOACTIVE WASTE DISPOSAL; RADIOACTIVE WASTE PROCESSING; SAVANNAH RIVER PLANT; SOLIDIFICATION

\section{8}

Folsom, T.R.; Scripps Institution of Oceanography, Soledad Laboratory, La Jolla, CA

RATIONAL REFERENCE LEVELS FOR PACIFIC COAST RADIOACTIVE POLLUTION STUDIES SUPPLIED BY SAMPLES FROM
NORTHERN BAJA CALIFORNIA. CONF7306121-1; Mexican Geophysical Union Annual Meeting, Ensenada, CA, June 1, 1973. (1974)

Available from NTIS

No Abstract

SUBJECT CATEGORY: General

ORIGIN: Commercial

KEYWORDS: AQUATIC ECOSYSTEMS; CALIFORNIA; COASTAL WATERS; DIFFUSION; DEPOSI'IS; FORLCAS'IING; NUCLEAR INDUSTRY; PACIFIC OCEAN; RADIOACTIVE EFFLU. ENTS; RADIOACTIVITY; RADIOISOTOPES; RADIONUCLIDE MIGRA'TION; S'I'ANDARDS

449

Richter, D.; Staatliches Amt Fuer Atomsicherheit Und Strahlenschutz, Berlin, Germany, D.R.

CRITERIA FOR THE ASSESSMENT OF POSSIBLE METHODS FOR LONG-TERM STORAGE OF RADIOACTIVE WASTES IN THE GDR. The Containment of Radioactivity and the Use of Nuclear Energy. Proceedings of the Seven th International Congress, French Society for Radioprotection, Versailles, France, 28-31 May 1974, Jarry, H. (Ed.). Montrouge, France, (pp. 679 . 702). (1974)

See Nuclear Science Abstracts 1975, 31(11) 30358

SUBJECT CATEGORY: General

ORIGIN: Foreign

KEYWORDS: COST; ENVIRONMENT; GASEOUS WASTES; GERMAN DEMOCRATIC REPU. BLIC; LIQUID WASTES; RADIATION HAZARDS; RADIATION PROTECTION; RADIOACTIVE WASTE STORAGE; SAFETY; SALT DEPOSITS; SOLID WASTES; UNDERGROUND DISPUSAL

450

Azamaeva, L.G., Z.G. Llinu, A.N. Kolusov, A.N. Kondrat'ev, M.A. Khodos, and A.A. Khonikevich; State Coimmittee on the Utilization of Atomic Energy, Moscow 
TECHNICAL AND ECONOMIC COMPARISON OF METHODS FOR SOLIDIFYING AND STORING HIGH-ACTIVITY LIQUID WASTE ARISING IN THE REPROCESSING OF IRRADIATED FUEL ELEMENTS FROM WATER-COOLED AND WATER MODERATED REACTORS. CONF-721107; Management of Radioactive Wastes from Fuel Reprocessing, Proceedings of a Symposium, Paris, France, November 27, 1972. OECD-IAEA, (pp. 847-861). (1974)

In the Soviet Union work on the vitrification of high-level radioactive solutions is being pursued in two directions, one involving the use of a two-stage process and the other a single-stage process. In the two-stage process, drying and calcining are performed in a fluidized bed apparatus whilst the conversion of the calcined product in to glass takes place in a disposable concrete or ceramic crucible (single application), in which it is then sent to the burial ground for storage; in the single-stage process, drying, calcining and melting are all performed in the same apparatus. The glass melt is poured directly from the apparatus into the burial ground, situated beneath it, or into a special container, which is then transported to a burial ground. Both processes have been used in tests with model solutions on experimental-industrial installations with a throughput of $50-1001 / \mathrm{hr}$, referred to the initial unfluxed solution. In the course of these tests the main technological parameters - were obtained, the performance of the basic equipment and the gas purification system were checked and data were obtained for a planned experimentalindustrial installation. The specific capital costs, the operating costs and the optimal conditions for long-term storage of the vitrified mass in special burial grounds were determined on the basis of technical and economic calculations. In addition, a comparative study is made of the technical and economic characteristics of an optimal variant of the vitrification method in which high-level wastes are stored as solutions in stainless steel containers provided with coil pipes for heat removal.

SUBJECT CATEGORY: Isolation; HLW; Spent Fuel

ORIGIN: Foreign

KEYWORDS: VITRIFICATION; HIGH-LEVEL RADIOACTIVE WASTES; CALCINATION; GLASS; RADIOACTIVE WASTE STORAGE; ECONOMICS; RADIOACTIVE WASTE PROCESSING; SPENT FUELS; RADIOACTIVE WASTE DISPOSAL
451

Van der Horst, J.M.A., and R.E. Hartman; Surface Research, Inc., Olean; N.Y.; Saint Bonaventure Univ., N.Y.

ECONOMIC PROCESS FOR THE REMOVAL OF SR-90 AND CS-137 FROM INDUSTRIAL WASTE WATERS. Metalloberflaeche- Angew. Elektrochem. 28(5):170-173. (1974)

In German; 4 figures, 40 references

See Nuclear Science Abstracts 1975, 31(03) 05701

SUBJECT CATEGORY: LLW

ORIGIN: Commercial

KEYWORDS: BIBLIOGRAPHIES; BRICKS; CEMENTS; CESIUM 137; CLAYS; COST; DECONTAMINATION; EFFICIENCY; INDUSTRIAL PLANTS; ION EXCHANGE; LIQUID WASTES; RADIOACTIVE WASTE PROCESSING; RADIOACTIVE WASTES; STRONTIUM 90; ECONOMICS

452

Tennessee Valley Authority, Chattanooga, TN

BELLEFONTE NUCLEAR PLANT, UNITS 1 AND 2. AEC DRAFT ENVIRONMENTAL STATEMENT. DOCKET-50438-27;DOCKET50439-27; 250 pp. (1974)

See Nuclear Science Abstracts 1974, 29(09) 23738

SUBJECT CATEGORY: General

ORIGIN: Commercial

KEYWORDS: BELLEFONTE-1 REACTOR; BELLEFONTE-2 REACTOR; CONSTRUCTION; COST BENEFIT ANALYSIS; ENVIRONMENT; RADIOACTIVE WASTES; REACTOR OPERATION; REACTOR SITES; THERMAL EFFLU. ENTS

453

Texas Utilities Generating Co., Dallas, TX

COMANCHE PEAK STEAM ELECTRICSTATION, UNITS 1 AND 2. AEC DRAFT ENVI- 
RONMENTAL STATEMENT. DOCKET-5044532;DOCKET-50446-32; 319 pp. (1974)

See Nuclear Science Abstracts 1974, 29(09) 23739

SUBJECT CATEGORY: General

ORIGIN: Commercial

KEYWORDS: COMANCHE PEAK-1 REACTOR; COMANCHE PEAK-2 REACTOR; CONSTRUCTION; COST BENEFIT ANALYSIS; ENVIRONMENT; RADIOACTIVE WASTES; REACTOR OPERATION; REACTOR SITES; THERMAL EFF'LUE'N'I'S

\section{4}

Peeters, K., and N. Van de Voorde; TO Societe Belge Pour L'Industrie Nucleaire, Brussels

DECONTAMINATION PROCEDURE FOR RA DIOACTIVE LIQUIDS. Patent 2,242,412/A/; 6 pp. (1974)

In German

See Nuclear Science Abstracts 1975, 31(12) 32656

SUBJECT CATEGORY: HLW; LLW

ORIGIN: Foreign

KEYWORDS: ADSORBENTS; ADSORPTION; ANTIMONY; BARIUM CARBONATES; BINARY MIXTURES; CESIUM; CHEMISORPTION; COBALT; COPPER COMPOUNDS; COST; DECONT. AMINATION; EFFICIENCY; FERROCYANIDES; LIQUID WASTES; PRECIPITATION; RADIOACTIVE WASTE PROCESSING; RUTHENITIM; STRONTIUM

\section{5}

Toledo Edison Co., Toledo, $\mathrm{OH}$

RESPONSE TO QUESTION 15.3.3(10/4/74) LIQUID RADWASTE COMPONENT FAILURE ANALYSIS. DOCKET-50346-95; Amendment 24 to Davis-Besse 1 License Application, (pp. 15.3-3.1 - 15.5.3.5). (1974)

Provides an anlysis indicating the radionuclide concentrations which could occur in both (1) the nearest potable water supply, and (2) the nearest surface water in an unrestricted area as a result of leakage based on single failures of components located outside reactor containment containing radioactive liquids. Assumes 1\% of the operating fission product inventory is released to the primary coolant, failed tanks release $80 \%$ of their design capacity, and all liquids from failed components enter the groundwater.

\section{SUBJECT CATEGORY: LLW}

ORIGIN: Commercial

KEYWORDS: ACCIDENTS; PWR TYPE REACTORS; FISSIONABLE MATERIALS; RADIONUCLIDE MIGRATION; LIQUID WASTES; DAVIS-RFSSF-1 R.ACETOR: RATIOACTIVF FIFFI ITFNTF

\section{6}

U.S. Atomic Energy Commission, Directorate of Licensing, Fuels and Materials, Washington, DC

COST BENEFIT ANALYSIS OF ALTERNATIVE DISPOSITIONS OF PLUTONIUM. WASH-1327 (Vol. 4); Generic Environmental Statement Mixed Oxide Fuel (Recycle Plutonium in Light Water-Cooled Reactors), Chapter 11, (p. XI-3 XI-60), 824 pp. (1974)

Tables include: Materials processed in fuel cycles of alternative dispositions of $\mathrm{Pu}$, Summary of en vironmental factors for alternative dispositions of $\mathrm{Pu}$. Capital investment of fuel cycle operations, Projected costs for materials and services, and Fuel cycle costs about 1990 .

Recycle and recovery disposition alternatives for uranium and plutonium are economically analyzed. The effects of alternative dispositions of $\mathrm{Pu}$ on the LWR fuel cycle operations (mining, milling, VF6, conversion, uranium enrichment, uranium fuel fabrication, transportation, reprocessing, $\mathrm{Pu}$. storage, MOX fabrication, opent fucl storage, and waste management) are compared. Environmental considerations such as the utilization of natural resources, energy requirements, effluents and radiological exposure are economically analyzed. Fuel cycle costs and materials and plant protection considerations are given.

SUBJECT CATEGORY: TRU

ORIGIN: Defense; Commercial

KEYWORDS: ECONOMICS; PLUTONIUM; RADIOACTIVE WASTE DISPOSAL; MINING; 
MILLING; ENRICHMENT; URANIUM; FUEL ELEMENTS; REPROCESSING; RADIOACTIVE WASTE STORAGE; RADIOACTIVE EFFLUENTS; ENVIRONMENT; FUEL CYCLE;

\section{7}

U.S. Atomic Energy Commission, Directorate of Licensing, Fuels and Materials, Washington, DC

GENERIC ENVIRONMENTAL STATEMENT MIXED OXIDE FUEL (RECYCLE PLUTONIUM IN LIGHT WATER-COOLED REACTORS). WASH-1327 (Vols. 1-4); 824 pp. (1974)

The findings and conclusions of the four volumes on the use of mixed oxide fuel in light water reactors (LWR's) are summarized. Issues evaluated in the four volumes are: environmental assessment, reactor safety, safeguards considerations, process alternatives and cost-benefits. Environmental as sessment includes the radiobiological characteris tics of $\mathrm{Pu}$, radiological health assessment of $\mathrm{Pu}$ recycle, impact of $\mathrm{Pu}$ recycle on $\mathrm{Pu}$ storage requirements, and influence of the alternative dispositions of $\mathrm{Pu}$ on the environment (land, water, radioactive and non-radioactive effluents and solid wastes, and population exposure). From the standpoint of environmental, safety and economic factors, the prompt reprocessing of spent fuel with recycle of both $\mathrm{U}$ and $\mathrm{Pu}$ in LWR's was determined to be the most advantageous disposition alternative. Eleven selections have been inpute separately.

SUBJECT CATEGORY: TRU; Spent Fuel

ORIGIN: Commercial

KEYWORDS: REACTORS; SPENT FUEL ELEMENTS; FABRICATION; FUEL REPROCESSING PLANTS; RADIOACTIVE WASTE DISPOSAL; ECONOMICS; ENVIRONMENT; LUNGS; LIVER; RADIATION EFFECTS; PLUTONIUM; URANIUM; RADIOACTIVE WASTE STORAGE; MINING; MILLING; ENRICHMENT; RADIOAC TIVE EFFLUENTS; RESIDUAL FUELS; ACCIDENTS; BONES; THYROID; PLUTONIUM OXIDES; SKIN; GASTROINTESTINAL TRACT; FALLOUT; DEPOSITION; ABSORPTION; RETENTION; BLOOD; INGESTION; INHALATION; ANIMALS; PLANTS; UPTAKE;

458

U.S. Atomic Energy Commission, Directorate of Liscensing, Fuels and Materials, Washington, DC -
ALTERNATIVE DISPOSITIONS OF PLUTONIUM. WASH-1327 (Vol. 4); Generic Environmental Statement Mixed Oxide Fuel (Recycle Plutonium in Light Water-Cooled Reactors), Chapter 8, (pp. VIII-5 - VIII-87), 824 pp. (1974)

Uranium and plutonium values in LWR spent fuel, and Effect of $\mathrm{Pu}$ recycle in large LWR's are tabulated. Appendix A contains tables of environmental factors (natural resource use, water balance, energy requirements, emissions and effluents, radiological emissions and effluents, plutonium storage, and radiological exposure) for each alternative.

Various alternative dispositions of plutonium are identified and analyzed. Environmental, economic and materials and plant protection considerations are discussed for six possible alternatives based upon storing plutonium for future use, immediate use of plutonium, and never using the plutonium. The following six alternatives were analyzed: (1) temporary storage of recovered plutonium with prompt recycle of the recovered uranium in LWR's, (2) temporary storage of spent fuel elements for later recovery of plutonium and uranium values, (3) prompt recovery and recycle of plutonium and uranium in LWR's, (4) prompt recovery and recycle of plutonium and uranium in LWR's utilizing an upgraded materials and plant protection program, (5) prompt recovery and recycling of uranium while storing plutonium without considerations for later use, and (6) permanent storage of spent fuel elements without consideration for later use. Alternative 1 is the existing LWR-UO2 industry and serves as the reference or base case from which all other alternatives are compared.

SUBJECT CATEGORY: Spent Fuel; TRU

ORIGIN: Defense; Commercial

KEYWORDS: PLUTONIUM; RADIOACTIVE WASTE DISPOSAL; REACTORS; RADIOACTIVE WASTE STORAGE; MINING; MILLING; ENRICHMENT; SPENT FUEL ELEMENTS; REPROCESSING; ECONOMICS; FUEL CYCLE; URANIUM

\section{9}

Pittman, F.K.; U.S. Atomic Energy Commission, Div. of Waste Management and Transportation, Washington, DC

HIGH-LEVEL RADIOACTIVE WASTE MANAGEMENT ALTERNATIVES. WASH-1297; 105 pp. (1974) 
Summary of alternative methods of waste management; 24 figures, 14 tables, 5 references, 1 bibliography

This report is the summary of a comprehensive overview study of potential alternative methods for long-term management of high-level radioactive waste. The study includes a compilation of in formation relevant to technical feasibility, safety, cost, environmental considerations, policy conflicts, public response and research and development needs for: 1 . Disposal in terrestrial locations (a) in geologic settings on land; (b) in the seabed; (c) in ice sheets. 2. Disposal into space. 3. Elimination by transmutation (nuclear transformation of certain waste constituents into nuclides having less long. term toxicity). The study is limited to the management of high-level radioactive waste from nuclear power by variations of these alternatives. Consideration of alternative types of electrical power generation are not within the scope of the study. In addition, evaluation of interim storage of radioactive waste in retrievable surface storage facilities is not part of this study. Disposal of waste in bedded salt deposits was studied extensively in other AEC programs, and the concept is included here as part of the overall matrix of geologic disposal techniques. (Auth)

SUBJECT CATEGORY: HLW

ORIGIN: Defense; Commercial

KEYWORDS: RADIOACTIVE WASTE DISPOSAL; EVALUATION; SAFETY; ECONOMICS; GEOLOGY; SALT DEPOSITS; MARINE DISPOSAL; TRANSMUTATION; HIGHLEVEL RADIOACTIVE WASTES; ENVIRONMENT; US AEC; RADIOACTIVE WASTE MANAGEMENT; COST

\section{0}

Eister, W.K., and R.H. Kennedy; U.S. Atomic Energy Commission, Germantown, MD

NUCLEAR INDUSTRY. Riegel's Handbook of Industrial Chemistry, Kent, J.A. (Ed.). Van Nostrand Reinhold Co., New York, pp. 719-771. (1974)

See Nuclear Science Abstracts 1974, 30(02) 05705

SUBJECT CATEGORY: General

ORIGIN: Commercial

KEYWORDS: ECONOMICS; NUCLEAR ENERGY; NUCLEAR INDUSTRY; RADIOACTIVE WASTE PROCESSING; REVIEWS
461

U.S. Atomic Energy Commission, Office of Planning and Analysis, Washington, D.C.

NUCLEAR POWER GROWTH, 1974 - 2000. WASH-1139(74); 74 pp. (1974)

Summary tables are given of nuclear electrical capacity, separative work requirements, enrichment plant natural uranium feed requirements and uranium requirements. Appendices $C$ and $D$ list operating nuclear power plants and those under construction and planned or announced.

The forecast of the growth of nuclear power in the United States and the rest of the world represents a current evaluation of domcotic and foreign trends in , the growth of nuclear power, the future capability of foreign nations to supply uranium enrichment services to reantor nperators, the timing and application of plutonium recycle technology, and the timing and rate of introduction of the fastbreeder reactor. A total of seven cases has been prepared, four for the United States and three for the rest of the world. These cases are not intended to specify precise future situations but rather to provide a reasonable range of estimates of the growth of nuclear power and the concomitant range of requirements for separative work, uranium and related materials and services. Forecasts for the next decade are based on an analysis and evaluation of nuclear power plants already operating, those under construction, and those planned. Forecasts beyond this period and to the year 2000 are bascd on extrapolations of near-term growth trends together with differing assumptions about future trends in energy consumption and electricity generating capacity. The ranges of nuclear power capacity installed by the end of 1980 will be 85,000 MWe to $112,000 \mathrm{MWe}$ in the United States and 113,000 to $157,000 \mathrm{MWe}$ in forejgn countries. There will be 231,000 to $275,000 \mathrm{MWe}$ in the United States and 290,000 to $420,000 \mathrm{MWe}$ abroud by the end of 1985 , and there will be 850,000 to $1,400,000 \mathrm{MWe}$ and $1,600,000$ to $2,550,000$ MWe by the end of 2000 . The forecast for the next few years is somewhat lower than that presented in a previous forecast. In the United States, this reduction is the result of continuing long project schedules which have a multiplicity of causes such as late equipment delivery, construction delays, strikes, poor labor productivity, and regulatory problems.

SUBJECT CATEGORY: TRU

ORIGIN: Commercial

KEYWORDS: NUCLEAR POWER PLANTS; FORECASTING; EVALUATION; URANIUM; 
PLUTONIUM; FABRICATION; FUEL REPROCESSING PLANTS; SEPARATION PROCESSES; BREEDER REACTORS

462

Kluk, A.F., and D.T. Wong; U.S. Atomic Energy Commission, Washington, DC

MANAGEMENT OF RADIOACTIVE WASTES. Chemical Engineering Progress 70(4):85-86. (1974)

See also Nuclear Science Abstracts 1974, 30(03) 07464

Recent improvements in the management of radioactive solid wastes by the United State Atomic Energy Commission may be helpful to others having this responsibility in the expanding nuclear industry. This article describes current waste handling practices; waste treatment, burial ground stabilization programs, pilot experiences, and it provides cost information. (Auth)

SUBJECT CATEGORY: HLW; LLW

ORIGIN: Commercial; Defense

KEYWORDS: SOLID WASTES; RADIOACTIVE WASTE DISPOSAL; ECONOMICS; CONTAMINATION; FISSION PRODUCTS; URANIUM; TRANSURANIUM ELEMENTS; RADIOACTIVE WASTE PROCESSING; RADIOACTIVE WASTE MANAGEMENT; COST; US AEC

463

Pittman, F.K.; U.S. Atomic Energy Commission, Washington, DC

AEC EVALUATION OF PROGRAMS FOR MANAGEMENT OF COMMERCIAL RADIOACTIVE WASTE. CONF-740697; Land Use Planning, Proceedings of a Conference, San Francisco, California, June 16, 1974. Atomic Industrial Forum, Inc, NY, (pp. VP). (1974)

See Nuclear Science Abstracts 1975, 32(05) 11532

SUBJECT CATEGORY: HLW; LLW; TRU

ORIGIN: Commercial

KEYWORDS: ECONOMICS; FABRICATION; NUCLEAR FUELS; NUCLEAR POWER
PLANTS; PLUTONIUM; RADIOACTIVE WASTE MANAGEMENT; RADIOACTIVE WASTE STORAGE; RADIOACTIVE WASTES; REVIEWS; STORAGE

464

Salmon, R., J.O. Blomeke, and J.P. Nichols; U.S. Atomic Energy Commission, Washington, DC

TRENDS AND PROJECTED SHIPMENTS IN THE NUCLEAR FUEL CYCLE INDUSTRY TO THE YEAR 2000. CONF-740901 (Part 1); Packaging and Transportation of Radioactive Materials, Proceedings of the 4th International Symposium, Miami Beach, Florida, September 2227, 1974, (pp. 349-364), 1195 pp. (1974)

Projections of the production, shipment, and accumulation of nuclear fuel, plutonium, and radioactive waste from 1974 to 2000 are presented. The nuclear power reactor complex is assumed to consist of LWRs using enriched uranium and plutonium recycle fueling, HTGRs, and LMFBRs. Installed nuclear electric capacity is taken as 102,500 , and $1200 \mathrm{GW}(\mathrm{e})$ at the ends of calendar years 1980,1990 , and 2000, respectively, with an LMFBR capacity of $200 \mathrm{GW}(\mathrm{e})$ at the end of year 2000 . Trends seen in fuel and waste shipping are more stringent recovery of radioisotopes from the effluents of all types of nuclear installations; more emphasis on shipping various types of waste to federal repositories, rather than to burial grounds; continued development of improved shipping concepts; shipment of a greater proportion of spent fuel by rail rather than by truck; and shipment of $\mathrm{Pu}$ in the solid oxide form rather than as the nitrate solution.

SUBJECT CATEGORY: TRU; Transportation; Spent Fuel

ORIGIN: Commercial

KEYWORDS: PLUTONIUM; URANIUM; FUEL CYCLE; WASTE TRANSPORTATION; FORECASTING; INDUSTRIAL PLANTS; NUCLEAR POWER PLANTS; REACTORS; IODINE; TRITIUM; GASES

465

U.S. Atomic Energy Commission, Washington, DC

LIQUID METAL FAST BREEDER REACTOR PROGRAM. ENVIRONMENTAL STATEMENT. AEC Report 1535, Volume IV; 556 pp.; 
Nuclear Science Abstracts 1975, 32(03) 08245. (1974)

\section{Available from NTIS}

A broad overview is presented of the many implications of LMFBR program implementation, up to and encompassing a fully developed LMFBR power plant economy, including the secondary impacts, the unavoidable adverse environmental impacts, cumulative environmental impacts, and costbenefit analyses, and alternative energy strategies. Under the heading of secondary impacts, the national implications of the availability of electricity from LMFBRs, and the specific economic im pacts of the LMFBR program are examined. The currently feasible alternatives and potential future alternatives for mitigating adverse environmental impacts of the LMFBR fuel cycle are described. The problems of safeguarding special nuclear material from potential diversion to unauthorized purposes are analyzed. The cumulative environmental effects of LMFBR operation to the Year 2020, the decommissioning of LMFBRs and fuel cycle facilities upon the completion of their useful life, the irreversible and irretrievable commitments of resources that will accompany implementation of an LMFBR economy, and an analysis of the costs and benefits of implementing the LMFBR Program are included.

SUBJECT CATEGORY: Remedial Action, FUSR.AP; TRII; Spẹnt Fuel

ORIGIN: Commercial

KEYWORDS: USA; LMFBR TYPE REACTORS; ENVIRONMENTAL EFFECTS; COST BENEFIT ANALYSIS; ECONOMICS; ENVIRONMENT; ENVIRONMENTAL IMPACT STATEMENTS; FUEL CYCLE; NUCLEAR MATERIALS MANAGEMENT; REACTOR DECOMMISSIONING; SAFEGUARD3

\section{6}

U.S. Atomic Energy Commission, Washington, DC

LIQUID METAL FAST BREEDER REACTOR PROGRAM. VOLUME III. IMPLICATION OF LMFBR PROGRAM IMPLEMENTATION. ENVIRONMENTAL STATEMENT. WASH-1535-DR(Vol.3); 526 pp. (1974)

See Nuclear Science Abstracts 1974, 30(04) 11963

SUBJECT CATEGORY: TRU; Spent Fuel
ORIGIN: Commercial

KEYWORDS: COST BENEFIT ANALYSIS; ECOLOGY; ECONOMICS; ELECTRIC POWER; ENVIRONMENT; FUEL CYCLE; FUEL FABRICATION PLANTS; FUEL REPROCESSING PLANTS; LMFBR TYPE REACTORS; RADIOACTIVE WASTES; REACTOR DECOMMISSIONING; SOCIOLOGY; TRANSPORT; USA; WASTE MANAGEMENT

467

U.S. Atomic Energy Commission, Washington, DC

HTGR FUEL REFARRICATION PILOT PLANT, OAK RIDGE NATIONAL LABORATORY, OAK RIDGE, TENNESSEE. FINAL ENVIRONMENTAL STATEMENT. WASH-1533; 159 pp. (1974)

See Nuclear Science. Abstracts 1974, 30(09) 24013

SUBJECT CATEGORY: General

ORIGIN: Defense

KEYWORDS: ACCIDENTS; COST BENEFIT ANALYSIS; ENVIRONMENT; FABRICATION; FUEL ELEMENTS; FUEL FABRICATION PLANTS; IIEALTII IIAZARDS; HOT CELLS; H'TGR TYPE REACTORS; ORNL; PILOT PLANTS; RADIOACTIVE WASTE MANAGEMENT; RADIUAC'IIIVE WAS'I'ES; KHPKUCESSSING; SAFETY; SPENT FUEL ELEMENTS; TEN. NESSEE

468

U.S. Atomic E'nergy Commission, Washington, $\bar{D} C$

WASTE MANAGEMFNT OPFRATIONS, HANFORD RESERVATION-RICHLAND, WASHINGTON: ENVIRONMENTAL STATEMENT. VOLUME 1. WASH-1538(Vol. 1)(Draft); $645 \mathrm{pn}$. (1974)

See Nuclear Science Abstracts 1975, 31(01) 01291

SUBJECT CATEGORY: Isolation; HLW

ORIGIN: Defense

KEYWORDS: CONTAMINATION; COST BENEFIT ANALYSIS; ENVIRONMENT; FUEL RE- 
PROCESSING PLANTS; GASEOUS WASTES; HAPO; LIQUID WASTES; RADIATION HAZARDS; RADIOACTIVE WASTE MANAGEMENT; RADIOACTIVE WASTE PROCESSING; RADIOACTIVE WASTES; SAFETY; SOLID WASTES; UNDERGROUND DISPOSAL

469

U.S. Atomic Energy Commission, Washington, DC

NUCLEAR INDUSTRY, 1974. WASH-1174; 115 pp. (1974)

See Nuclear Science Abstracts 1975, 31(08) 21864

SUBJECT CATEGORY: General

ORIGIN: Commercial

KEYWORDS: COST; DATA; ECONOMICS; FABRICATION; FORECASTING; FUEL CYCLE; NUCLEAR FUELS; NUCLEAR INDUSTRY; NU. CLEAR POWER PLANTS; OPERATION; PLANNING; RADIOACTIVE WASTES; REACTOR COMPONENTS; REACTOR SAFETY; REACTORS; US AEC; USA; WASTE MANAGEMENT

\section{0}

U.S. Atomic Energy Commission, Washington, DC

EVALUATION OF NUCLEAR ENERGY CENTERS. VOLUME 2. APPENDICES. WASH-1288(Vol. 2)(App.); V pp. (1974)

See Nuclear Science Abstracts 1975, 31(09) 25043

SUBJECT CATEGORY: Fuel Cycle Centers

ORIGIN: Defense; Commercial

KEYWORDS: ECONOMICS; EFFICIENCY; ENVIRONMENTAL EFFECTS; FEASIBILITY STUDIES; LEGAL ASPECTS; NUCLEAR INDUSTRY; NUCLEAR PARKS; NUCLEAR POWER PLANTS; POWER TRANSMISSION; RADIOACTIVE WASTE MANAGEMENT; REACTOR SITES; SITE SELECTION

471

U.S. Atomic Energy Commission, Washington, DC
HIGH-LEVEL RADIOACTIVE WASTE MANAGEMENT ALTERNATIVES. WASH-1297; 97 pp: (1974)

14 tables, 24 figures

This report is the summary of a comprehensive overview study of potential alternative methods for long-term management of high-level radioactive waste. The study includes a compilation of information relevant to technical feasibility, safety, cost, environmental considerations, policy conflicts, public response and research and development needs for: (1) Disposal in terrestrial locations, (a) in geologic settings on land, (b) in the seabed, (c) in ice sheets, (2) Disposal into space, (3) Elimination by transmutation (nuclear transformation of certain waste constituents into nuclides having less longterm toxicity).

SUBJECT CATEGORY: HLW; Isolation

ORIGIN: Defense; Commercial

KEYWORDS: BIBLIOGRAPHIES; RADIOACTIVE WASTE DISPOSAL; ACCIDENTS; SOLID WASTES; RADIOACTIVE WASTE MANAGEMENT; MARINE DISPOSAL; UNDERGROUND DISPOSAL; TRANSMUTATION; SPACE

472

United Power Association, Elk River, MN

FINAL ELK RIVER REACTOR PROGRAM REPORT. COO-651-93; 123 pp. (1974)

See Nuclear Science Abstracts 1975, 31(11) 31747

SUBJECT CATEGORY: Remedial Action, FUSRAP

ORIGIN: Commercial

KEYWORDS: COST; ERR REACTOR; REACTOR DECOMMISSIONING; REACTOR DISMANT. I.ING; SPECIFICATIONS

473

Westinghouse Electric Corp., Pittsburgh, PA

WESTINGHOUSE RECYCLE FUEL PLANTS. LICENSE APPLICATION, ENVI- 
RONMENTAL REPORT, SUPPLEMENT 1. DOCKET-701432-5; 30 pp. (1974)

See Nuclear Science Abstracts 1974, 30(09) 24005

SUBJECT CATEGORY: Spent Fuel; TRU

ORIGIN: Commercial

KEYWORDS: AQUATIC ECOSYSTEMS; CONSTRUCTION; ECONOMICS; ENVIRONMENT; GASEOUS WASTES; GROUND WATER; LIQUID WASTES; PLANTS; SURFACE WATERS; THERMAL EFFLUENTS; WASTE DISPOSAL; WESTINGHOUSE RECYCLE FUELS PLANT

\section{4}

Blasewitz, A.G., C.R. Cooley, and G.L. Richardson; Westinghouse Hanford Co., Richland, WA

QUANTITIES AND CHARACTERISTICS OF COMMERCIAL ALPHA CONTAMINATED SOLID WASTES IN THE U.S.. HEDLSA-705; CONF-741026-3; Management of PlutoniumContaminated Solid Wastes, Proceedings of a Seminar, Marcoule, France, October 14, 1974, 12 pp. (1974)

See Nuclear Science Abstracts, 1975, 31(02) 04016.

SUBJECT CATEGORY: HLW

ORIGIN: Defense; Commercial

KEYWORDS: FORECASTING; RADIOACTIVE WASTE PROCESSING; RADIOACTIVE WASTES; INVENTORIES; ALPHA DECAY RADIOISOTOPES

\section{5}

Alven, $\mathrm{H}$.

FISSION ENERGY AND OTHER SOURCES OF ENERGY. Bulletin of the Atomic Scientists 30(1):4-8. (1974)

See Nuclear Science Abstracts 1974, 29(08) 20461

SUBJECT CATEGORY: General

ORIGIN: General

KEYWORDS: ECONOMICS ; ENERGY SOURCES; FISSION; GEOTHERMAL ENERGY;
NUCLEAR ENERGY; PLANNING; RADIOACTIVE WASTES; REACTOR SAFETY; SOLAR ENERGY

476

Alonso Santos, A.

ENVIRONMENTAL ASPECTS AND SAFETY IN THE USE OF NUCLEAR ENERGY. Energ. Nucl. 18(89):137-155. (1974)

In Spanish

See Nuclear Science Abstracts 1975, 31(04) 08886

פUDJECT CATEGORY. Gunurul

ORIGIN: Foreign

KEYWORDS: COST; ENVIRONMENT; FUEL CYCLE; NUCLEAR ENERGY; RADIATION HAZARDS; RADIOACTIVE WASTE DISPOSAL; RADIOACTIVE WASTES; SAFETY

477

Conlon, F.B., and G.L. Pettigrew

SUMMARY OF FEDERAL REGULATIONS FOR PACKAGING AND TRANSPORTATION OF RADIOACTIVE MATERIALS. CONF-711193; Environmental Impact of Nuclcar Power Plants, Proceedings of a Conference, Atlanta, Georgia, November 26-30, 1974, (pp. 201-230), 546 pp. (1974)

Report contains tabular data with no text.

This paper consists entirely of tabular data on Department of Traneportation regulations, projected amounts of radioactive material to be transported, the amounts and types of radioactive materials present in the projected transport materials, external radiation fields on containers, container specifications, transport vehicle specifications, and population dose factors

SUBJECT CATEGORY: Transportation

ORIGIN: Commercial

KEYWORDS: WASTE TRANSPORTATION; RADIOACTIVE WASTE DISPOSAL; VOLUME; FORECASTING 
478

Coplan, B.V., P.J. Mayo, and L. Rutland

A COST-BENEFIT ANALYSIS OF DISPOSABLE AND REUSABLE RADWASTE SHIPPING CONTAINERS. CONF-740901; Packaging and Transportation of Radioactive Materials, Proceedings of the 4th International Symposium, Miami Beach, Florida, September 22-27, 1974, (pp. 504-516), 1047 pp. (1974)

The paper evaluates the feasability of utilizing large disposable containers for other than high-level wastes generated at nuclear power stations.

A cost benefit comparison was made between disposable and reusable shipping container concepts for handling radwaste from nuclear power generating plants. For this study, reinforced concrete containers were used to typify the disposable container concept, and thin shell steel containers with lead and steel auxiliary shields were used to typify the reusable container scheme. Concrete containers were found for this example to be economically competitive and could represent a significant savings in overall waste disposal costs. Other equally significant advantages which may also result from the use of disposable concrete containers include reduced shield inventories, maintenance, or rental costs for the utility; fewer scheduling problems associated with availability of sheilding for radwaste transportation; more convenient and safer handling at the power station and the burial site; potential longterm durability and ease of retrievability at the burial site. (Auth)

SUBJECT CATEGORY: Transportation; LLW

ORIGIN: Commercial

KEYWORDS: CONTAINERS; COST BENEFIT ANALYSIS; CONCRETES; STEELS; WASTE TRANSPORTATION; LOW-LEVEL RADIOACTIVE WASTES; NUCLEAR POWER PLANTS

\section{9}

Gey, A.

FORMATION OF GASEOUS EFFLUIENTS IN NUCLEAR REACTORS. The Containment of Radioactivity and the Use of Nuclear Energy: Proceedings of the Seventh International Congress, French Society for Radioprotection, Versailles, 2831 May 1974, Jarry, H. (Ed.). Societe Francaise de Radioprotection, Montrouge, France, pp. 1532. (1974)
In French

See Nuclear Science Abstracts 1975, 31(11) 32222

SUBJECT CATEGORY: Airborne

ORIGIN: Foreign

KEYWORDS: CONTAINMENT; FAST REACTORS; FISSION PRODUCTS; GASEOUS WASTES; INVENTORIES; IODINE; KRYPTON; RADIOACTIVE WASTES; THERMAL REAC. TORS; TRITIUM; XENON

\section{0}

Heacock, H.W., and J.W. Riches

WASTE SOLIDIFICATION CEMENT OR UREA FORMALDEHYDE. CONF-741104; American Society of Mechanical Engineers, Proceedings of the Winter Meeting held in New York, New York, November 17-21, 1974, (8 pp.). (1974)

Good cursory review of general physical properties and operational costs for cement and urea formalde. hyde solidification systems.

The advantages and disadvantages of the two major radioactive waste solidification systems are presented. The report describes the operations of these type systems and presents figures to illustrate the general procedures. Operational data on radioactive waste volumes for recent PWR's, projected design volumes for older PWR's and BWR is presented in tabular form. The physical properties of Portland cement, Portland cement with sodium silicate additives and urea formaldehyde are compared in tabular form. The comparisons include tolerance for variations in mixing proportions, the resultant amounts of residual water, shelf life, and shipping efficiency. Estimates of annual operating costs for the Portland cement, Portland cement with sodium silicate, and urea formaldehyde are presented for high and low waste volume PWR's as well as BWR's.

SUBJECT CATEGORY: LLW

ORIGIN: Commercial; Defense

KEYWORDS: CEMENTS; GROUTING; UREA FORMALDEHYDE; RADIOACTIVE WASTE DISPOSAL; SOLIDIFICATION; LOW-LEVEL RADIOACTIVE WASTES; WASTE TRANSPOR: TATION; COST BENEFIT ANALYSIS; VOLUME 
481

Khonikevich, A.A.

DECONTAMINATION OF RADIOACTIVELY CONTAMINATED WATER OF LABORATORIES AND RESEARCH REACTORS. Moscow Atomizdat 312 pp. (1974)

See Nuclear Science Abstracts 1974, 30(12) 31698

SUBJECT CATEGORY: LLW

ORIGIN: Foreign

KEYWORDS: DECONTAMINATION;ECONOMICS; EFFICIENCY; LIQUID WASTES; RADIOACTIVE WASTE PROCESSING; WATER

482

Rauzen, F.V., and V.V. Aleshnya

COMPARING COSTS OF TREATING LOWLEVEL RADIOACTIVE WASTES WITH IONEXCHANGE MATERIALS. At. Energ.37(4):322325. (1974)

In Russian

See Nuclear Science Abstracts 1975, 31(05) 10826

SUBJECT CATEGORY: LLW

ORIGIN. Fü eiğ

KEYWORDS: COST; ION EXCHANGE; ION EXCHANGE MATERIALS; RADIOACTIVE WASTE PROCESSING; SEPARATION PROCESSES

483

Rublevskii, V.P., A.S. Zykova, and A.D. Turkin

ATOMIC POWER STATIONS AS A SOURCE OF C 14 DISCHARGE. CONF-730907-26; ORNLtr-2976; International Radiation Protection Association, Proceedings of the Third International Congress, Washington, DC, September 9, 1973. (1974)

Prediction of content of $\mathrm{C} 14$ in biosphere by year 2010

See Nuclear Science Abstracts 1975, 32(11) 25904
SUBJECT CATEGORY: Airborne

ORIGIN: Foreign

KEYWORDS: BIOSPHERE; CARBON 14; CONTAMINATION; DIFFUSION; ENVIRONMENT; FORECASTING; GASEOUS WASTES; NU. CLEAR POWER PLANTS; RADIOACTIVE WASTE DISPOSAL; RADIOACTIVITY; RADIONUCLIDE MIGRATION, TERREGTRIAL ECO. SYSTEMS; TIME DEPENDENCE

484

Wolf, J. Schmidt, and Kuester

WASTE DISPOSAL SYSTEM IN TIIE NUCLEAR FUEL CYCLE. AEC-TR-7573; CONF740468-1; 18 pp. (1974)

Translated from Reactor Conference of the German Atom Forum, Berlin, April 2-5, 1974.

See Nuclear Science Abstracts 1975, 31(01) 01286

SUBJECT CATEGORY: HLW; LLW; TRU

ORIGIN: Foreign

KEYWORDS: CONTAMINATION; COST; ENVI RONMENT; FUEL REPROCESSING PIAANTS; GERMAN FEDERAL REPUBLIC; INTERNATIONAL COOPERATION; NUCLEAR POWER PLANTS; RADIOACTIVE WASTE DISPOSAL; RADIOACTIVE WAS'I'E YKUL'E'SSING; KAUIOACTIVE WASTE STORAGE; RADIOACTIVE WASTES; REVIEWS; SAFETY; FUEL CYCLE

485

Wrighl, J.H.

ENVIRONMENTAL ASPECI'S UF 'IHE' CLINCH KIVEK BKE'EUEK KEAC"IÜR PRŌJECT. Nucl. Eng. Int. 19(221):851-854. (1974)

See Nuclear Science Abstracts 1975, 31(04) 10329

SUBJECT CATEGORY: General; TRU

ORIGIN: Commercial

KEYWORDS: CLINCH RIVER BREEDER REACTOR; COST BENEFIT ANALYSIS; ENVIRON. MENT; REACTOR SITES; SAFETY; SPECIFICATIONS; RADIOACTIVE WASTE DISPOSAL; RADIOACTIVE WASTE PROCESSING 
486

PERSPECTIVES ON THE ENVIRONMENT: ENVIRONMENTAL QUALITY. THE FIFTH ANNUAL REPORT OF THE COUNCIL ON ENVIRONMENTAL QUALITY. NP-23192, (pp. 93238). (1974)

The following topics are discussed: energy; air quality; solid waste; water quality; hazardous polutants; radiation; noise, pollution control at federal facilities; costs of pollution abatement; protection of wildlife and wilderness; and forest resources.
SUBJECT CATEGORY: General

ORIGIN: Commercial

KEYWORDS: AIR QUALITY; COST; ENERGY CONSERVATION; ENERGY SOURCES; ENVIRONMENTAL EFFECTS; EXHAUST GASES; FORESTS; HAZARDS; NOISE POLLUTION; POLLUTION; POLLUTION CONTROL; RADIA TION ACCIDENTS; RADIOACTIVE WASTES; SOLID WASTES; WATER QUALITY; WILD ANIMALS 


\section{THIS PAGE}

\section{WAS INTENTIONALLY}

LEFT BLANK 
1975

487

Roth, B.F.; Abt. Kernkraftwerke, Badenwerk A.G., Karlsruhe, Germany, F.R.

REPROCESSING OF BWR FUEL ELEMENTS. A SITUATION REPORT FOR THE FEDERAL REPUBLIC OF GERMANY. . (1975)

6 figures; in German; available from the British Library Lending Div., Yorkshire, England

The present state of reprocessing and the reprocessing capacities required in the future for the FRG and West Europe are described. The currently and in the near future available capacities of the URG (United Reprocessors $\mathrm{GmbH}$ ), the only European reprocessing society formed of the BNFL, CEA and KEWA, essentially guarantee under contract the removal of fuel elements from German nuclear power plants only until 1976. At the latest from $1978 / 79$ onwards, in view of the nuclear power development (for the FRG up to $198020,000 \mathrm{MW}, 1985$ 45,000 MW), a bottleneck in reprocessing will occur as the two large plants in Windscale (BNFL) or La Hague (CEA) have made contracts for 1978 with Japan, and as the expansion and conversion of the available plants can only take place stepwise. This bottleneck until the commissioning of the planned large plant of $1,500 \mathrm{t} / \mathrm{a}$ in the FRG can be bridged by the building of 2 intermediate storage tanks each of $1,500 \mathrm{tU}$ one of which should be available by 1980 . The KEWA, GWR, GfRC in the framework of the reprocessing project and waste treatment (PWA), the electric supply undertaking and the state are involved in the planning of the development work, the financing and building of the large plant, where lastly the covering of the risks regarding the licensing conditions and of the transfer of the radioactive waste to the end storage is essentially done at the expense of the instigator. The required decisions, schedules, development works and cost problems connected with the $1,500 \mathrm{t} / \mathrm{a}$ plants are illustrated in several pictures.

SUBJECT CATEGORY: Spent Fuel

ORIGIN: Foreign

KEYWORDS: BWR TYPE REACTORS; COST; ENERGY POLICY; FUEL CYCLE; FUEL REPROCESSING PLANTS; GERMAN FEDERAL REPUBLIC; NUCLEAR POWER PLANTS; PLANNING;
PWR TYPE REACTORS; REPROCESSING; REVIEWS; SPENT FUEL ELEMENTS; SPENT FUEL STORAGE

\section{8}

White, L.E., and R. Garcia; Aerojet Energy Conversion Co., Sacramento, CA

USE AND ECONOMIC ADVANTAGES OF FLUID BED CALCINERS FOR VOLUME REDUCTION OF LIQUID RADWASTE. Energ. Nucl. 22(4):195-209; American Society of Mechanical Engineers, Proceedings of the Winter Annual Meeting, New York, NY, November 17, 1974. (1975)

See Nuclear Science Abstracts 1975, 32(03) 06095 and Nuclear Science Abstracts 1975, 31(09) 22156

SUBJECT CATEGORY: LLW; HLW

ORIGIN: Commercial

KEYWORDS: BWR TYPE REACTORS; CALCINATION; ECONOMICS; LIQUID WASTES; NUCLEAR POWER PLANTS; PWR TYPE REACTORS; RADIOACTIVE WASTE PROCESSING; SOLIDIFICATION

\section{9}

Zalogin, N.G., and L.I. Kropp; All-Union Heat Engineering Inst., Moscow

OPERATION OF POWER STATIONS AND PROTECTION OF THE ENVIRONMENT. Therm. Eng. 22(4):1-3; Teploenergetika; 22:(4, 5, 6, 7). (1975)

Fossil-fuel power plants and nuclear power plants are compared in terms of material exchange with the environment, thermal effluents, economic aspects of air pollution, and performance characteristics. The emission and control of sulfur oxides, nitrogen oxides, ash, and radioactive materials are discussed.

SUBJECT CATEGORY: Airborne

ORIGIN: Foreign

KEYWORDS: AIR POLLUTION; ASHES; COMPARATIVE EVALUATIONS; ECONOMICS; ENVIRONMENTAL EFFECTS; FOSSILFUEL 
POWER PLANTS; NITROGEN OXIDES; NU. CLEAR POWER PLANTS; PERFORMANCE; RADIOACTIVE WASTES; SULFUR OXIDES; THERMAL POLLUTION

490

Levitz, N.M., T.H. Gerding, I.O. Winsch, T.F. Cannon, and M.J. Steindler; Argonne National Laboratory, Argonne, IL

VOLUME REDUCTION AND SALVAGE CONSIDERATIONS FOR PLUTONIUMCONTAMINATED FERROUS METAL. CONF750902-9; Eightieth National Meeting of the American Institute of Chemical Engineers, Boston, Massachusetts, September 71975,23 pp. (1975)

See Nuclear Science Abstracts 1976, 32(12) 27681

SUBJECT CATEGORY: TRU

ORIGIN: Defense; Commercial

KEYWORDS: DECONTAMINATION; PLUTONIUM; QUALITATIVE CHEMICAL ANALYSIS; RADIOACTIVE WASTE PROCESSING; RADIOACTIVE WASTES; REMOVAL; RESEARCH PROGRAMS; REVIEWS; SCINTILLATION COUNTING; STEELS; VOLUME

\section{9)}

Steindler, M.J., N.M. Levitz, W.J. Mecham, W.B. Seefeldt, L.E. Trevorrow, I.O. Winsch, T.F.Cannon, T.J. Gerding, B.J. Kullen, D.S. Webster, and L. Burris; Argonne National Laboratory, Argonne, IL

CHEMICAL ENGINEERING DIVISION WASTE MANAGEMENT PROGRAMSQUARTERLY REPORT, APRIL-JUNE 1975. ANL 75-63; 32 pp. (1975)

6 tables, 4 figures, 17 references

Consolidation techniques for zircaloy fuel-cladding hulls were studied including (1) further work on a pyrochemical-volatility scheme for separating the zirconium as the volatile tetrachloride and (2) ignition tests and shock-ignition tests on several zircaloy materials to further characterize the pyrophoric behavior of zircaloy and the impact on hulls management. Examination of existing information on deep-well injection of industrial wastes and on low-level aqueous wastes from fuel reprocessing led to the conclusions that the technology is generally available from industrial practice, that costs are of the order of $10(\exp -4) \mathrm{mill} / \mathrm{kwh}$, that environmental effects could be insignificant in normal operation.

SUBJECT CATEGORY: LLW; Spent Fuel

ORIGIN: Commercial

KEYWORDS: CLADDING; PYROLYSIS; STEELS; TRITIUM; RADIOACTIVE WASTE MANAGEMENT; ZIRCALOY; REPROCESSING; RADIOACTIVE WASTE DISPOSAL; COST; SOLID WASTES; LIQUID WASTES; INJECTION WELLS; SEPARATION PROCESSES

492

Metz, W.P., and W.E. Ogren; Atlantic Richfield Hanford Co., Richland, WA

ENGINEERING STUDY: DISPOSITION OF TERMINAL LIQUORS FOR INTERIM STORAGE. ARH-CD-231. (1975)

Eight alternative processes; available from NTIS

Eight alternative processes were chosen as being technologically feasible within the time frame dictated by budgeting procedures and terminal liqunr a vailability. Solidified waste producte accept. able for single-shell tank storage were assumed to bo placed in available single-shell tanks. Douhle-shell tanks were used only for the inure mubile lerminal liquors or semi-solid mush products. The mush, chemical neutralization, and clay in-tank processes offer potential savings of tens of millions of dollars over double-shell tank storage of terminal liquors. In order to achieve this cost savings, the process development and demonstration must be completed prior to the beginning of double-shell tank construction (Dec. 1976) expected to be funded from a fiscal year 1977 line item. Budgeting for these additional double-shell tanks must proceed since the processing options discussed here are not yet available and may not pruve $t w$ be available at the required time. This study indicates the following topics for additional study: Process technology development to achieve interim storage of terminal liquor products receives the greatest emphasis as a means of reducing capital expenditures. Interim storage product criteria, waste inventory, and conversion to final form require definition to allow comparison of the alternatives for disposition of terminal liquors. The pseudotechnical nature of product acceptability criteria is important to the evaluation of the partial neutralization and aluminum removal alternatives. 
More accurate estimates of terminal liquor quantity and composition are required to give a sound technical basis for choosing the appropriate processing alternative. Retrieval and reprocessing operations may affect the comparisons presented by this study

SUBJECT CATEGÓRY: HLW

ORIGIN: Defense

KEYWORDS: CLAYS; COMPARATIVE EVALUATIONS; COST; LIQUID WASTES; PH VALUE; RADIOACTIVE WASTE PROCESSING; RADIOACTIVE WASTE STORAGE; TANKS

493

Schulz, W.W:, and L.D. McIsaac; Atlantic Richfield Hanford Co., Richland, WA

REMOVAL OF ACTINIDES FROM NUCLEAR FUEL REPROCESSING WASTE SOLUTIONS WITH BIDENTATE ORGANOPHOSPHORUS EXTRACTANTS. ARH-SA-217;CONF-750913-13; Transplutonium Elements, Proceedings of the 4th International Symposium, Baden-Baden, Germany, F.R., September 13, 1975; 32 pp. (1975)

See Nuclear Science Abstracts 1976, 32(12) 27680

SUBJECT CATEGORY: TRU; Spent Fuel

ORIGIN: Defense

KEYWORDS: AMERICIUM; CARBON TETRACHLORIDE; COST; FUEL REPROCESSING PLANTS; LIQUID WASTES; NEPTUNIUM; ORGANIC PHOSPHORUS COMPOUNDS; PLUTONIUM; PURIFICATION; RADIOACTIVE WASTE PROCESSING; REPROCESSING; SOLVENT EXTRACTION; SPENT FUELS; URANIUM

494

Atlantic Richfield Hanford Co., Rịchland, WA

CALCINE CONVERSION FACILITY ALTERNATIVE CONCEPTS ENGINEERING STUDIES. ARH-LD-108; 77 pp. (1975)

See Nuclear Science Abstracts 1976, 33(02) 02701
SUBJECT CATEGORY: General; HLW

ORIGIN: Defense

KEYWORDS: CALCINATION; COMPARATIVE EVALUATIONS; COST; DESIGN; GLASS; HAPO; RADIOACTIVE WASTE FACILITIES; RADIOACTIVE WASTE PROCESSING; RADIOACTIVE WASTES; SOLIDIFICATION

\section{5}

Dyne, P.J.; Atomic Energy of Canada Ltd., Whiteshell Nuclear Research Establishment, Pinawa, Manitoba, Canada

AECL'S RESPONSIBILITIES AND PROGRAMS FOR MANAGEMENT OF HIGHLEVEL RADIOACTIVE WASTES. AECL-5111; 19 pp. (1975)

See Nuclear Science Abstracts 1975, 32(05) 12244

SUBJECT CATEGORY: HLW

ORIGIN: Foreign

KEYWORDS: CANADA; ECONOMICS; RADIATION HAZARDS; RADIOACTIVE WASTE DISPOSAL; RADIOACTIVE WASTE MANAGE. MENT; RADIOACTIVE WASTE PROCESSING; SAFETY; WASTE TRANSPORTATION; UNDERGROUND DISPOSAL; HIGH-LEVEL RADIOACTIVE WASTES

\section{6}

Dyne, P.J.; Atomic Energy of Canada Ltd., Whiteshell Nuclear Research Establishment, Pinawa, Manitoba, Canada

MANAGING NUCLEAR WASTES. AECL-5136; 19 pp. (1975)

See Nuclear Science Abstracts 1975, 32(11) 26313

SUBJECT CATEGORY: General

ORIGIN: Foreign

KEYWORDS: CANADA; ECONOMICS; RADIOACTIVE WASTE MANAGEMENT; RADIOACTIVE WASTE PROCESSING; RADIOACTIVE WASTE STORAGE; SAFETY 
497

McKenzie, D.E., L.F. Grantham, R.B. Paulson, W.L. Richards, and R.B. Rennick; Atomics International, Canoga Park, CA

DISPOSAL OF TRANSURANIC SOLID WASTE USING ATOMICS INTERNATIONAL MOLTEN SALT COMBUSTION PROCESS. AI-ERDA-13151; 68 pp. (1975)

17 tables, 9 figures

The process for disposal of transuranic solid waste utilizes a molten salt to combust organic materials, to trap inorganic substances including transuranics, and to react chemically with acidicgases formed during combustion. Subsequent processing of the melt in an aqueous system produces three products: (1) ash, (2) salt, and (3) solid sodium chloride for disposal. The transuranics are readily leached from the ash and separated via ion exchange techniques. No liquid wastes are produced. The reductions in weight and volume are 82 and $98 \%$.

\section{SUBJECT CATEGORY: TRU}

ORIGIN: Commercial; Defense

KEYWORDS: RADIOACTIVE WASTE PRO CESSING; RADIOACTIVE WASTE DISPOSAL; SOLID WASTES; MOLTEN SALT COAL GASIFICATION PROCESS; COMBUSTION; TRANSURANIUM ELEMENTS

498

Welch, F.H., and O.P.Steele; Atomics International, Canoga Yark, CA

PROCESS FLUID REGENERATION AND WASTE DISPOSAL FOR ALCOHOLSODIUM REMOVAL SYSTEMS. Transactions of the American Nuclear Society 22:600-60; Proceed. ings of the ANS Winter Meeting, San Francisco; CA, November 16, 1975. (1975)

See Nuclear Science Abstracts 1976, 33(09) 20924

SUBJECT CATEGORY: LLW

ORIGIN: Commercial

KEYW ORDS: CEMENTS; ECONOMICS ETHANOL; RADIOACTIVE WASTE DISPOSAL; RADIOACTIVE WASTE PROCESSING; RADIOACTIVE WASTE STORAGE; REMOVAL; SOD IUM; SOLIDIFICATION
499

Basham, S.J. Jr., and K.D. Kok; Battelle Columbus Laboratory, Columbus, $\mathrm{OH}$

RESEARCH REACTOR DISMANTLING: A CASE HISTORY. Transactions of the American Nuclear Society 22:636-637. (1975)

No Abstract

SUBJECT CATEGORY: Remedial Action, Surplus Facilities

ORIGIN: Defense

KEYWORDS: BRR REACTOR; COST; REACTOR DISMANTLING; REACTOR DECOMMISSIONING; NUCLEAR FACILITIES

500

Bartlett, J.W.; Battelle Pacific Northwest Laboratory, Richland, WA

ALTERNATIVES FOR RADIOACTIVE WASTE MANAGEMENT. BNWL-SA-5507; CONF-751044-1; Proceedings of the ANS Topical Meeting on Nuclear Safety, Tucson, Arizona, October 5, 1975, 21 pp. (1975)

See Nuclear Science Abstracts, 1976, 33(03) 06074

SUBJECT CATEGORY: Isolation

ORIGIN: Defense

KEYWORDS: COST BENEFIT ANALYSIS; GEOLOGIC DEPOSITS; RADIOACTTVE WASTTE DISPOSAL; RADIOACTIVE WASTE MANAGEMENT: RADIOACTIVE WASTES: SAFETY: SPENT FUELS

501

Burns, R.E., J.N. Hartley, D.H. Lester, F.P. Roberts, J.L. Swanson, and E.J. Wheelwright; Battelle Pacific Northwest Laboratory, Richland, WA

TECHNICAL AND ECONOMIC FEASIBILITY OF PARTITIONING HANFORD PUREX PROCESS AND WASTE. BNWL-1907; 48 pp. (1.975)

13 tables, 14 references

Summarizes a study on the technical and economic feasibility of applying the concept of partitioning 
(removal of long-lived radionuclides, primarily actinides) to Hanford purex process acidic high level radioactive waste. Discusses the amount and composition of such waste which may be produced, the actinide element separation factors required to attain given concentrations of actinide elements in the short-lived residual waste and separations schemes which have potential for achieveing the desired removal of actinide elements. Preliminary cost estimates are given.

SUBJECT CATEGORY: HLW; TRU

ORIGIN: Defense

KEYWORDS: RADIOACTIVE WASTE DISPOSAL; RADIOACTIVE WASTE MANAGEMENT; HIGH-LEVEL RADIOACTIVE WASTES; COST; PUREX PROCESS; ECONOMICS; ACTINIDES; RADIOACTIVE WASTE PROCESSING; VOLUME

502

Harmon, K.M.; Battelle Pacific Northwest Laboratory, Richland, WA

PNL STUDIES OF D AND D AT HANFORD. BNWL-SA-5514; CONF-750822-8; Low Temperature Physics, Proceedings of the International Conference, Otaniemi, Finland, August 14, 1975; 20 pp. (1975)

See also Nuclear Science Abstracts 1976, 32(12) 27644

The PNL decontamination and decommissioning program at Hanford involves (1) the preparation of a long-term plan for a systematic approach to the extensive and varied programs of decommissioning retired facilities at Hanford and (2) a D and D demonstration project, the decommissioning of a grossly contaminated plutonium processing facility.

SUBJECT CATEGORY: Remedial Action, Surplus Facilities

ORIGIN: Defense

KEYWORDS: DECOMMISSIONING; DECONTAMINATION; ECONOMICS; HAPO; NUCLEAR FACILITIES; RADIOACTIVE WASTE DISPO. SAL; RADIONUCLIDE MIGRATION; SAFETY
503

Litchfield, J.W., J.V. Hansen, and L.C. Beck; Battelle Pacific Northwest Laboratory, Richland, WA

DECISION MODEL INCORPORATING UTILITY THEORY AND MEASUREMENT OF SOCIAL VALUES APPLIED TO NUCLEAR WASTE MANAGEMENT. BNWLB-424; 58 pp. (1975)

See Nuclear Science Abstracts 1975, 32(10) 24710

SUBJECT CATEGORY: General

ORIGIN: Commercial

KEYWORDS: COST; DECISION TREE ANALY. SIS; DIAGRAMS; MAN; RADIATION PROTECTION; RADIOACTIVE WASTE DISPOSAL; RADIOACTIVE WASTE MANAGEMENT

504

Platt, A.M.; Battelle Pacific Northwest Laboratory, Richland, WA

NUCLEAR WASTE MANAGEMENT AND TRANSPORTATION QUATERLY PROGRESS REPORT JULY - SEPTEMBER 1975. BNWL-1952; 51 pp. (1975)

7 tables, 15 figures

A conceptual plan was developed for management of high-level waste for purposes of recovery and use of economic values. Work on radionuclide migration from nonsalt formations was completed. Analysis of data from the survey of public attitudes toward nuclear waste management is near completion. The study of alternatives for management of iodine and technetium was completed. The assessment of risk of transporting plutonium by rail and truck was made.

SUBJECT CATEGORY: HLW; Transportation; TRU

ORIGIN: Defense

KEYWORDS: DECONTAMINATION; PLUTONIUM; RADIOACTIVE WASTE DISPOSAL; WASTE TRANSPORTATION; RADIOACTIVE WASTE MANAGEMENT; HIGH-LEVEL RADI- 
OACTIVE WASTES; RADIONUCLIDE MIGRATION; IODINE; TECHNETIUM

505

Smith, T.H., and W.K. Winegardner; Battelle Pacific Northwest Laboratory, Richland, WA

RISK ANALYSIS OF NUCLEAR WASTE MANAGEMENT SYSTEMS. Power Engineering 79(2):35-37. (1975)

The safety of nuclear waste management systems is being addressed by the quantitative risk analysis study conducted by Battelle Pacific Northwest Laboratories. This study is sponsored by the AEC's division of waste management and transportation. The results will help guide research and development efforts, and will be used in the formulation of waste product criteria and for comparisons of alternative waste management procedures. Evaluating proposed waste management systems is a complicated process. It includes assessments of technical feasibility, $\mathrm{R} D$ needs, costs, environmental impacts, and both the calculated and the publicly perceived safety. The method selected for safety assessment of proposed year-2000 waste management systems is quantitative risk analysis. It considers both the consequences of material and the estimated probabilities of such events. This is a departure from the traditional 'maximum credible accident' approach which deals only with the consequences of maximum-release accidents.

SUBJECI CA'I'EGORY: General

ORIGIN: Defense; Commercial

KEYWORDS: RADIOACTIVE WASTE MANAGEMENT; DESIGN; RADIATION ·HAZARDS; RADIATION PROTECTION; COST

\section{6}

Thomas, C.W.; Battelle Pacific Northwest Laboratory, Richland, WA

RADIONUCLIDES FROM NUCLEAR POWER REACTORS. BNWL-1950. (Part 3); Pacific Northwest Laboratory Annual Report for 1974 to the USAEC Division of Biomedical and Environmental Research, Part III, Atmospheric Sciences, C.L. Simpson, (pp. 22-24). (1975)

See Nuclear Science Abstracts 1975, 32(06) 14273
SUBJECT CATEGORY: TRU; Airborne; LLW

ORIGIN: Commercial; Defense; Institutional

KEYWORDS: AMERICIUM ISOTOPES; CARBON 14; CESIUM 135; COBALT 60; CURIUM ISOTOPES; ENVIRONMENT; FISSION PRODUCTS; FORECASTING; IODINE 129; IRON 55; MANGANESE 54; NICKEL 63; NIOBIUM 93; NUCLEAR INDUSTRY; NUCLEAR POWER PLANTS; PLUTONIUM 238; PLUTONIUM 239; SAMARIUM 151; SELENIUM 79; TECHNETIUM 99; TIN 126; TRITIUM; ZIRCONIUM 93 .

507

Thomas, C.W., and R.W. Perkins; Battelle Pacific Northwest Laboratory, Richland, WA; Energy Research and Development Administration, Health and Safety Laboratory, New York, NY

TRANSURANIUM ELEMENTS IN THE ATMOSPHERE. HASL-291; Health and Safety Laboratory Environmental Quarterly, December 1, 1974 through March 1, 1975, E.P. Hardy, Jr., (pp. I.80-I.103), 227 pp. (1975)

See Nuclear Science Abstracts 1975, 31(12) 33127

KEYWOR̄DS: ĀMĒRICIUM 241; CESIUM 137; CONTAMINATION; DIFFUSION; ENVIRONMENTAL EFFECTS; FORECASTING; NUCLEAR EXPLOSIONS; NUCLEAR POWER PLANTS; PLUTONIUM 238; PLUTONIUM 238; PLUTONIUM 240; PLUTONIUM 241; RADIATION MONITORING; RADIOACTIVE WASTES; SATELLI'I'ES; SURFACE AIR; TRANSURANIUTM ELEMENTS

\section{8}

Murphy, P.H., and N.S. Anderton; Baylor Univ., Huiston, TX

INEXPENSIVE, CONVENIENT XFNON DISPOSAL. Health Phys. 29(5):779-780. (1975)

See Nuclear Science Abstracts 1976, 33(06) 11791

SUBJECT CATEGORY: Airborne

ORIGIN: Commercial

KEYWORDS: ACTIVATED CARBON; CHARCOAL; COST; FILTERS; FILTRATION; GASEOUS WASTES; LOW TEMPERATURE; PERFOR- 
MANCE; RADIOACTIVE WASTE DISPOSAL; RADIOACTIVE WASTE STORAGE; XENON 133

509

Columbo, P.; Brookhaven National Laboratory, Upton, NY

TRITIUM STORAGE DEVELOPMENT. PROGRESS REPORT NO. 4, APRIL-JUNE 1975. BNL-20421; 33 pp. (1975)

See Nuclear Science Abstracts 1976, 32(12) 28728

SUBJECT CATEGORY: LLW; Airborne

ORIGIN: Defense

KEYWORDS: CEMENTS; COST; RADIOACTIVE WASTE STORAGE; RESEARCH PROGRAMS; SOLIDIFICATION; TRITIUM

510

Barbreau, A., J. Marcaillou, J. Mery, D. Pinto, and D. Rancon; Commissariat a l'Energie Atomique, Cadarache, France

DEVELOPMENT OF THE MANAGEMENT OF WASTES OF LOW AND INTERMEDIATE ACTIVITY AT THE CADARACHE LABORATORY. CONF-700905; SM-137/16; STI/PUB-264; Management of Low- and Intermediate-Level Radioactive Wastes, Proceedings of a Symposium, Aixen-Provence, France, September 7-11;1970. International Atomic Energy Agency, Vienna, Austria. (1975)

The various aspects of collection, handling, treatment and disposal of wastes are discussed. The problems of retention of nuclides in the soil and their movements are pointed out. A time-table of movement is given for strontium. Discusses economic consideration.

SUBJECT CATEGORY: Isolation; LLW; HLW

ORIGIN: Foreign

KEYWORDS: RADIOACTIVE WASTE DISPOSAL; RADIOACTIVE WASTE PROCESSING; RADIOACTIVE WASTE MANAGEMENT; STRONTIUM; RADIONUCLIDE MIGRATION; LOW-LEVEL RADIOACTIVE WASTES; INTERMEDIATE-LEVEL RADIOACTIVE WASTES; RADIUAC"ITVE WASTES
511

Ditterich, K., and J. Schneider; Commission of the European Communities, Joint Research Centre, Ispra, Italy

SYSTEMS ANALYSIS AS A TOOL FOR OPTIMAL PROCESS STRATEGY. EUR-5372E; 36 pp. (1975)

See Nuclear Science Abstracts 1976, 33(07) 16576

SUBJECT CATEGORY: General

ORIGIN: Foreign

KEYWORDS: COST; RADIOACTIVE WASTE MANAGEMENT; SAFETY; SYSTEMS ANALYSIS

\section{2}

Du Pont de Nemours (E.I.) and Co., Engineering Dept., Wilmington, DE

WASTE SOLIDIFICATION AND RETRIEVABLE STORAGE, 200S AREA. SAVANNAH RIVER PLANT, WORK REQUEST 860447. DPE-3410(Vol.1). (1975)

Portions of document are illegible; Available from NTIS, PC A17/MF A01.

A Scope of Work and a Current Appraisal of Cost for venture guidance were prepared for a conceptual process for the solidification and long-term storage of radioactive wastes removed from underground storage tanks in the Separations Areas (200 F and $\mathrm{H})$ at the Savannah River Plant. The Scopes of Work describe facilities for removing liquid wastes from Buildng $241 \mathrm{~F}$ and $\mathrm{H}$ waste tank farms, separation of sludge from the supernate by physical processes, removal of radioactive cesium from the supernate, incorporation of sludge and cesium into concrete, and packaging and storage of the concrete form waste. Decontaminated supernate is to be evaporated and the resulting salt cake packaged and separately stored. Operations are to be located in a new area, designated 200S, and the scope also describes a full complement of auxiliary power, service, and general facilities consistent with development of a new plant area. The Current Appraisal of Cost is $\$ 2,400,000,000$ and is suitable only for venture guidance and planning.

SUBJECT CATEGORY: HLW

ORIGIN: Defense 
KEYWORDS: COST; DESIGN; HIGH-LEVEL RADIOACTIVE WASTES; LIQUID WASTES; RADIOACTIVE WASTE FACILITIES; RADIOACTIVE WASTE PROCESSING; RADIOACTIVE WASTE STORAGE; SAVANNAH RIVER PLANT; SOLIDIFICATION

\section{3}

Du Pont de Nemours (E.I.) and Co., Engineering Dept., Wilmington, DE

WASTE SOLIDIFICATION AND RETRIEVABLE STORAGE FACILITIES. SAVANNAH RIVER PLANT, WORK REQUEST 860447. VOLUME 2. DRAWING SUPPLEMENT.. DPE-3410(Vol.2). (1975)

Portions of document are illegible; No text; available from NTIS, MF/A01.

Volume 2 contains the drawings for the waste solidification and retrievable storage facilities at the Savannah River Plant.

SUBJECT CATEGORY: HLW

ORIGIN: Defense

KEYWORDS: COST; DESIGN; HIGH-LEVEL RADIOACTIVE WASTES; RADIOACTIVE WASTE FACILITIES; RADIOACTIVE WASTE PROCESSING; SAVANNAH RIVER PLANT; SOLIDIFICATION

\section{4}

Johnson, E.R.; E. R. Johnson Associates, Inc., Vienna, VA

PROPOSED INDEPENDENT SPENT-FUEL STORAGE PROJECT. Transactions of the American Nuclear Society 22:308 American Nuclear Society 1975 Winter Meeting, San Francisco, CA, November 16, 1975. (1975)

See Nuclear Science Abstracts 1976, 33(09) 22634

SUBJECT CATEGORY: Spent Fuel

ORIGIN: Commercial

KEYWORDS: COST; DESIGN; ECONOMICS; NUCLEAR FACILITIES; NUCLEAR POWER PLANTS; SPENT FUEL STORAGE
515

Creswell, J.S., and L.E. Katonak; Ebasco Services, Inc., Norcross, GA

DESCRIPTION AND USAGE OF RADWASTE-DIS POSAL COST COMPUTER PROGRAM, RWECONO. Transactions of the American Nuclear Society 21:444-445; Proceedings of the ANS Annual Meeting, New Orleans, LA, June 8, 1975. (1975)

See Nuclear Science Abstracts 1975, 32(05) 13670

SUBJECT CATEGORY: Isolation

ORIGIN: Commercial

KEYWORDS: COMPUTER CODES; COST; NUCLEAR POWER PLANTS; R CODES; RADIOACTIVE WASTE DISPOSAL

516

Fairchild, P.D., and R.A. Benfield; Ebasco Services, Inc., Norcross, GA

EVALUATION OF RADWASTE VOLUME REDUCTION. Transactions of the American Nuclear Society 21:445; Transactions of the American Nuclear Society 1975 Annual Meeting, New Orleans, LA, June 8 1975: (1975)

See Nuclear Science Abstracts 1975, 32(05) 13042

SURJECT CATEGORY: General

ORIGIN: Commercial

KEYWORDS: BWR TYPE REACTORS; ECONDMICS; EFFICIENCY; PWR TYPE REACTORS; RADIOACTIVF WASTIE DISPOSAL; RADIOAC.TIVE WASTE PROCESSING; VOLUME

517

Bell, D.D.; Eldorado Nuclear Limited, Ottawa, Ontario

EFFECTS OF RADIOLOGICAL AND WASTE-MANAGEMENT LEGISLATIVE CONTROLS ON URANIUM PRODUCTION COSTS WITH SPECIFIC REFERENCE TO THE BEAVERLODGE OPERATION OF ELDORADO NUCLEAR LIMITED. CONF7309134; STI/PUB-391; Radon in Uranium Mining, 
Proceedings of a Panel, Washington, District of Columbia, September 4, 1973. International Atomic Energy Agency, Vienna, Austria, (pp.37-48). (1975)

See Nuclear Science Abstracts, 1975, 32(11) 25887

SUBJECT CATEGORY: General

ORIGIN: Foreign

KEYWORDS: ECONOMICS; COST; MINERS; MINING; PRODUCTION; RADIATION HAZARDS; RADIATION MONITORING; RADIOACTIVE WASTE DISPOSAL; RADON; URANIUM MINES; URANIUM ORES

518

Starr, C. , and R.P. Hammond; Electric Power Research Inst., Palo Alto, CA

NUCLEAR WASTE PROBLEM IN PERSPECTIVE. Aware 58:pp. 14-15. (1975)

No Abstract

SUBJECT CATEGORY: General

ORIGIN: Commercial

KEYWORDS: CONTAINERS; CONTAINMENT SYSTEMS; ECONOMICS; ENGINEERED SAFETY SYSTEMS; ENVIRONMENT; ENVIRONMENTAL EFFECTS; FISSION PRODUCTS; RADIOACTIVE WASTE MANAGEMENT; RADIOACTIVE WASTE STORAGE; SAFETY; STORAGE; VOLUME; WASTE DISPOSAL

519

Nemzek, T.A., and T.F.P. (Ed.) Sullivan; Energy Research and Development Administration, Division of Reactor Research and Development, Washington, DC

REACTOR RESEARCH AND DEVELOPMENT; ENERGY TECHNOLOGY II. Proceedings of 2nd Energy Technology Conference, Washington, DC, May 12, 1975. Government Institutes, Inc., Washington, DC. (1975)

No Abstract

SUBJECT CATEGORY: HLW; TRU; LLW

ORIGIN: Commercial; Defense
KEYWORDS: BREEDER REACTORS; FORECASTING; INVESTMENT; PLUTONIUM; RADIOACTIVE WASTE DISPOSAL; REACTORS; RESEARCH PROGRAMS; URANIUM; US ERDA

520

Energy Research and Development Administration, Washington, DC

\section{RADIOACTIVE WASTE PROCESSING AND} DISPOSAL. TID-3311-S6; 280 pp. (1975)

References to 2140 publications related to radioactive waste, announced in Nuclear Science Abstracts (NSA) volumes 28 (July-Dec. 1973), 29 (Jan.June 1974), and 30 (July-Dec. 1974), are contained in this bibliography. The references are arranged by the oriinal NSA abstract number, which approximately places them in chronological order. Sequence numbers appear beside each reference and the NSA volume and abstract numbers appear at the end of the citations. Three indexes are provided: personal author, subject, and report number. These indexes refer to the sequence numbers for the references.

SUBJECT CATEGORY: General

ORIGIN: Commercial; Institutional; Defense

KEYWORDS: BIBLIOGRAPHIES; RADIOACTIVE WASTE DISPOSAL; RADIOACTIVE WASTE PROCESSING; RADIOACTIVE WASTE MANAGEMENT

521

Energy Research and Development Administration, Washington, DS,

NUCLEAR FUEL CYCLE.. ERDA Report; 107 pp. (1975)

A detailed analysis of the commercial nuclear fuel cycle including exploration, mining, enrichment, fabrication, reactor use, spent fuel storage, reprocessing, waste disposal, transportation, and plutonium recycle is presented.

SUBJECT CATEGORY: TRU; Spent Fuel; Transportation

ORIGIN: Commercial

KEYWORDS: POWER REACTORS; FUEL CYCLE ; ECONOMICS; FABRICATION; ISOTOPE 
SEPARATION; MINING; ORE PROCESSING; PLUTONIUM RECYCLE; RADIOACTIVE WASTE DISPOSAL; REPROCESSING; RE. VIEWS; URANIUM RESERVES; SPENT FUEL STORAGE

\section{2}

Energy Research and Development Administration, Washington, DC

NUCLEAR FUEL CYCLE. ERDA-33; 107 pp. (1975)

See Nuclear Science Abstracts 1975, 32(03) 08391

SUBJECT CATEGORY: Spent Fuel; TRU

ORIGIN: Commercial; Defense

KEYWORDS: ECONOMICS; FABRICATION; FUEL CYCLE; ISOTOPE SEPARATION; MIN. ING; ORE PROCESSING; PLUTONIUM RECY. CLE; POWER REACTORS; RADIOACTIVE WASTE DISPOSAL; REPROCESSING; RE. VIEWS; URANIUM RESERVES

\section{3}

Energy Research and Development Administration, Washington, DC

ENVIRONMENTAL STATEMENT: EXPANSION OF U.S. URANIUM ENRICHMENT CAPACITY. ERDA-1543(Draft); 449 pp. (1975)

See Nuclear Science Abstracts 1975, 32(19) 24439

SUBJE'C"I' CA'TEGORY: Airborne

ORIGIN: Commerçiali: Defense

KEYWORDS: CHEMICAL EFFLUENTS; COST BENEFIT ANALYSIS; ENRICHED URANIUM; ENVIRONMENTAL EFFECTS; ENVIRONMENTAL IMPACT STATEMENTS; GAS CENTRIFUGATION; GAS CENTRIFUGES; GASE. OUS DIFFUSION PLANTS; GASEOUS DIFFUSION PROCESS; GASEOUS WASTES; RADIOACTIVE EFFLUENTS; SITE SEI.ECTION; URANIUM ISOTOPES
524

Environmental Protection Agency, Washington, DC

PROCEEDINGS OF PUBLIC HEARINGS: PLUTONIUM AND THE OTHER TRANSURANIUM ELEMENTS, VOLUME 1. ORP/CSD-5-1; 866 pp. (1975)

Meeting Held in Washington, D.C., December 10, 1974.

This volume contains the proceedings of the hearing held in Washington, D.C. The hearings present information regarding the public and social implications of plutonium utilization; the factors involved in the balancing of costs vo. benefits; dosimetry, health, and environmental effects; environmental levels and pathways; application using plutonium: and control and cleanup tes.hnn.ogy.

\section{SUBJECT CATEGORY: TRU}

ORIGIN: Commercial

KEYWORDS: DOSIMETRY; FALLOUT; PLUTONIUM; RADIOACTIVE WASTE MANAGEMENT; ' ENVIRONMENT; TRANSURANIUM ELEMENTS; REPROCESSING; RADIONUCLIUE KINETICS; PUBLIC OPINION; COST BENEFIT ANALYSIS; FUEL CYCLE

525

Food and Drug Administration, Rockville, MD

'IASK FORCE REPORT ON BONDING AND PERPETUAL CARE OF NUCLEAR LICENSEDD AC'IIVITIES. CONF-75ח4107-; nHFW/FDA-76-8026; Radiation Control, Prooeedings of the 7th Annual National Conference, Hyennis, MA, April 27, 1975, (pp. 254-271). (1875)

Potential issues which should be considered prior to the adoption and implementation of a bonding or perpetual care program are examined. The following topics are discussed: problem definition; major processors; factors in setting the amount of a bond; waste handling licensees; ore refineries and mills; former AEC licensed facilities; other specific licenses; authority; states where it is deemed that amendment of existing statutes is necessary to 
authorize imposition of a bonding requirement for licenses; administration; and recommendations. The following appendices are included: summary of cost estimate to decontaminate the American Nuclear Company; report on 1974 national conference on radiation control workshop no. 3; suggested changes to state regulations; and suggested legislation for licensee bonding and perpetual care trust funds.

SUBJECT CATEGORY: Remedial Action, FUSRAP

ORIGIN: Commercial

KEYWORDS: COST; LEGAL ASPECTS; LEGISLATION; LICENSING; ORE PROCESSING; RADIOACTIVE MATERIALS; RADIOACTIVE WASTE DISPOSAL; RECOMMENDATIONS; REFINING; REGULATIONS; UNDERGROUND DISPOSAL; WASTE PROCESSING

\section{6}

Maul, K.H.; Frankfurt Univ., Juristische Fakultaet, Germany, F.R.

THE BALANCING TREATMENT OF DECONTAMINATION COSTS OF NUCLEAR POWE R PLANTS. Atomwirtsch. Atomtech. 20(1):43-46. (1975)

In German; 2 Tables; 20 References

See Nuclear Science Abstracts 1975, 32(01) 02699

SUBJECT CATEGORY: Remedial Action, Surplus Facilities

ORIGIN: Foreign

KEYWORDS: BUDGETS; COST; DECONTAMINATION; ECONOMICS; NUCLEAR MATERIALS MANAGEMENT; NUCLEAR POWER PLANTS; RADIATION PROTECTION; REACTOR DECOMMISSIONING; REACTOR OPERATION

\section{7}

Carney, H.C. (Ed.); General Atomic Co., San Diego, CA

CURIUM-244/NEPTUNIUM-237 RECOVERY FROM THE BARNWELL NUCLEAR FUEL PLANT. GA-A-13348; 366 pp. (1975)
See Nuclear Science Abstracts 1976, 33(09) 19772

SUBJECT CATEGORY: TRU

ORIGIN: Commercial

KEYWORDS: BARNWELL FUEL PROCESSING PLANT; CENTRIFUGATION; CURIUM 244; ECONOMICS; FLOWSHEETS; ION EXCHANGE; ISOTOPE PRODUCTION; LIQUID WASTES; NEPTUNIUM 237; PLUTONIUM; PURIFICATION; RADIATION HAZARDS; RADIOACTIVE WASTE DISPOSAL; RADIOACTIVE WASTE PROCESSING; SOLVENT EXTRACTION; URA. NIUM; REPROCESSING

528

Clarke, R.H., H.F. MacDonald, J. Fitzpatrick, and A.J.H. Goddard; General Electricity Generating. Board, Berkeley, England

WASTE DISPOSAL ASPECTS OFTHE LONG TERM COOLING CHARACTERISTICS OF IRRADIATED NUCLEAR FUELS. Annals Nuclear Energy 2(6):451-466. (1975)

See Nuclear Science Abstracts 1976, 33(06) 12689

SUBJECT CATEGORY: Spent Fuel

ORIGIN: Commercial

KEYWORDS: HTGR TYPE REACTORS; INVENTORIES; PLUTONIUM; RADIATION HAZARDS; RADIOACTIVE WASTE DISPOSAL; RADIOACTIVE WASTE MANAGEMENT; RADIOACTIVE WASTE STORAGE; SPENT FUELS; THORIUM

\section{9}

Schueller, W.; Gesellschaft zur Wiederaufarbeitung von Kernbrennstoffen mbH, Karlsruhe, Germany, F.R.; American Nuclear Society, Hinsdale, IL; Canadian Nuclear Association, Toronto, Ontario, Canada

REPROCESSING IN EUROPE: PROCEEDINGS OF JOINT TOPICAL MEETING ON COMMERCIAL NUCLEAR FUEL TECHNOLOGY TODA Y. SESSIONS 3, 4, AND 5. INIS-mf3193; Commercial Nuclear Fuel Technology Today, Proceedings of a Joint Topical Meeting, Toronto, Ontario, Canada, April 28, 1975, (pp. 60-86). (1975) 


\begin{abstract}
A brief history of the purposes for fuel processing is given. Current European technology, especially head-end treatment and dissolution, extraction, plutonium purification, solvent and diluent treatment, and waste treatment, is described. Supply and demand for reprocessing is analyzed. The status of the European plants is explained.
\end{abstract}

SUBJECT CATEGORY: TRU; Spent Fuel

ORIGIN: Foreign

KEYWORDS: ECONOMICS; EUROPE; HEAD END PROCESSES; PRODUCTION; RADIOACTIVE WASTE PROCESSING; REPROCESSING; SOLVENT EXTRACTION; SPENT FUELS

\section{0}

Bentley, B.W., and D.R. Haffner; Hanford Engineering Development Laboratory, Richland, WA

ECONOMIC INCENTIVES OF SHORT OUTOF-REACTOR TIME FOR FAST BREEDER REACTOR FUEL. Transactions of the Nuclear Society 22:329-330; Proceedings of the ANS 1975 Winter Meeting, San Francisco, CA, November 16, 1975. (1975)

See Nuclear Science Abstracts, 1976, 33(09) 22138.

SURJECT CATEGORY: Spent Fuel

ORIGIN: Commercial

KEYWORDS: ECONOMICS; LMFBR TYPE REACTORS; REPROCESSING; SPENT FUEL STORAGE; SPENT FUELS

631

Cooley, C.R.; Hanford Engineering Development Laboratory, Richland, WA

COMMERCIAL ALPHA WASTE PROGRAM QUARTERLY PROGRESS REPORT, OCTOBER-DECEMBER 1974. HEDL-TME-75-41; 40 pp. (1975)

13 tables, 9 figures, 13 references

Data on waste generation during commercial fabrication of FFTF fuel are discussed. Expected volumes and activity levels of waste generated during commercial fuel reprocessing operations are also discussed. Progress to date on development of the acid digestion process for treating combustible wastes is discussed as well as work on product storage and disposal of wastes. Date on compaction and incineration of hepa filters are presented.

SUBJECT CATEGORY: LLW

ORIGIN: Commercial

KEYWORDS: RADIOACTIVE WASTE DISPOSAL; RADIOACTIVE WASTE STORAGE; RADIOACTIVE WASTE PROCESSING; VOLUME; LOW-LEVEL RADIOACTIVE WASTES; RADIOACTIVE WASTE MANAGEMENT; REPROCESSING; FUEL ELEMENTS; COMPACIIING; (.)MHIISIIUN; FURECASTIVG: ALPHA. BEAKING WASI'ES; FILTERS

\section{2}

Trevorrow, L.E.; Harvard University, Air Cleaning Laboratory, Boston, MA; Lawrence Berkeley Laboratory, Berkeley, CA; Argonne National Laboratory, Argonne, IL; U.S. Atomic Energy Commission, Washington, DC

GOVERNMENT-INDUSTRY CONFERENCE ON CONTROL OF TRITIUM EFFLUENTS. CONF-740807; AEC Air Cleaning Conference, M.W. First, (Ed.), Proceedings of the Thirteen th Amnurl Conference, (pp. 1113-1115). (1975)

Sep Nuclear Srience Ahstracts 1975, 32(07) 169:37

SUBJECT CATEGORY: LLW; Airborne

ORIGIN: Defense; Commercial

KEYWORDS: COST; DISTILLATION; ELEC. TROT.YSIS; FITFI, REPROCESSING PLANTS; ISOTOPIC EXCHANGE; MEMBRANES; RADIOACTIVE EFFLUENTS; RADIOACTIVE WASTE DISPOSAL; RADIOACTIVE WASTE PROCESSING; SOLIDIFICATION; TRITIUM; WATER COOLED REACTORS

533

Reiber, M., S.L. Soo, and J. Stukel; Illinois Univ., Center for Advanced Computation, Urbana. IL

COAL FUTURE: ECONOMIC AND TECHNOLOGICAL ANAL YSIS OF INITIATIVES AND INNOVATIONS TO SECURE FUEL SUPPLY 
INDEPENDENCE. APPENDIX B. FINAL REP OR T. UIUC-CA C-DN-75-163B; PB-247679. (1975)

\section{Available from NTIS}

Energy costs of mining, preparing, reprocessing, and disposing of fuel for an average $1000 \mathrm{MWe}$ nuclear power plant are discussed. This model plant is assumed to average one boiling water reactor (BWR) and two pressurized water reactors (PWR). The energy cost of materials needed to construct a boiling water reactor plant is also discussed.

SUBJECT CATEGORY: HLW; LLW; Spent Fuel

ORIGIN: Commercial

KEYWORDS: BWR TYPE REACTORS; COST; ENERGY DEMAND; MINING; NUCLEAR FUELS; NUCLEAR INDUSTRY; NUCLEAR POWER PLANTS; PWR TYPE REACTORS; RADIOACTIVE WASTE DISPOSAL; REPROCESSING; URANIUM ORES; CAPIIAL

\section{4}

Gasteiger, R., and G. Hochlein; Inst. Fuer Angewandte Systemtechnik und Reaktorphysik, Abt. Dekontaminationsbetriebe, Kernforschungszentrum Karlsruhe, Germany, F.R.

TREATMENT OF RADIOACTIVE WASTES FROM REPROCESSING PLANTS. Atomwirtsch. Atomtech. 20(7):349-353. (1975)

In German; 3 figures, 4 tables, 17 references

See Nuclear Science Abstracts 1976, 33(05) 09004

SUBJECT CATEGORY: HLW; TRU

ORIGIN: Foreign

KEYWORDS: CHEMICAL PROPERTIES; DATA; FISSION PRODUCTS; FLOWSHEETS; FUEL REPROCESSING PLANTS; GASEOUS WASTES; GERMAN FEDERAL REPUBLIC; LIQUID WASTES; RADIOACTIVE WASTE PROCESSING; RADIOACTIVE WASTE STORAGE; RADIOACTIVE WASTES; REVIEWS; SEPARATION PROCESSES; SOLID WASTES; SOLIDIFICATION; SOLVENTS; SPENT FUEL ELEMENTS; VITRIFICATION; VOLUME
535

Seidler, H., and M. Naertig; Institut Fuer Ernaehrung, Potsdam-Rehbruecke, Germany

THE REMOVAL OF SR-90 FROM MILK. PART I. SURVEY OF LITERATURE AND EXPERIMENTS ON THE USE OF BONE PREPARATIONS AS ADSORBENTS.. Nahrung 9:735-43. (1975)

\section{In German}

Reviews previous reports (55) relating to hazards of fallout Sr-90 in dairy products and its removal from milk. Discusses factors that must be considered relative to the necessity for decontaminating restricted quantities of milk in case of a nuclear disaster. Also deals with the distribution of $\mathrm{Sr}-90$ in milk and the reduction of the Sr-90 activity in milk and milk products that can be obtained by simple procedures. A survey is given of the results of investigations on the efficiency of bone preparations in removing $\mathrm{Sr}-90$ from milk. Surveys publications dealing with the decontamination of milk by means of resin ion exchangers. The cost of Sr-90 removal by various methods is also estimated.

SUBJECT CATEGORY: LLW; Airborne

ORIGIN: Foreign

KEYWORDS: ADSORPTION; STRONTIUM; MILK; ION EXCHANGE; FOOD; ADSORBENTS; COST; FALLOUT

\section{6}

Haug, H.O., and E.G. (Translator) Silver; Institut fuer Heisse Chemie, Kernforschungszentrum, Karloruhe, Germany, F.R.

PRODUCTION, DISPOSAL, AND RELATIVE TOXICITY OF LONG-LIVED FISSION PRODUCTS AND ACTINIDES IN THE RADIOACTIVE WASTES FROM NUCLEAR FUEL CYCLES. ORNL-tr-4302; 190 pp.; KFK2022; 190 pp. (1975)

This report concerns long-term problems related to radioactive wastes in the German Federal Republic and Western Europe. Future development of nuclear energy, specifically, contributions of nuclear power plants, various types of reactors and fuel fabrication and reprocessing, is discussed. Fuel cycle 
variations and production of fission products and actinides in waste from reprocessed nuclear fuels is the subject of one chapter. The discussion includes U-Pu cycles and Th-U cycles. Other chapters cover the following subjects: long-lived fission products and actinides in the waste streams from the reprocessing of nuclear fuels; relative toxicity index; presently preferred waste-management concepts; alternative concepts for the elimination of highlevel wastes. Appendices include: A prognosis of the development of nuclear power plants in the German Federal Republic and Western Europe; build-up of the transuranium elements in the U-Pu fuel cycle; notes on the Th- $U$ fuel cycle with coated-particle fuel. The report does not include discussion of the hazards associated with radioactive wastes during production, temporary storage, treatment, transportation. or placement into their final resting place.

SUBJECT CATEGORY: TRU; HLW; LLW

ORIGIN: Foreign

KEYWORDS: NUCLEAR FACILITIES; NUCLEAR POWER; FORECASTING; URANIUM 233; URANIUM 235; PLUTONIUM; THORIUM 232; URANIUM 238; LWR TYPE REACTORS; LMFBR TYPE REACTORS; HTGR TYPE REACTORS; REPROCESSING; FUEL CYCLE; FUEL ELEMENTS; HAZARDS; RADIOACTIVE WASTE DISPOSAL; SEPARATION PRO. CESSES; SPACE; UNDERGROUND DISPOSAL; ACTININFIS

637

Weinberg, A.M.; Institute for Energy Analysis, Oak Ridge, TN

IS NUCLEAR ENERGY ACCEPTABLE. Institute on National Affairs, Proceedings of a Meeting Iowa State University, Ames, IA, January 24, 1975. (1975)

Available from Institute for Energy Analysis, P.O. Dü̃ 117, Oak Ridge, TN 97830.

No Abstract

SUBJECT CATEGORY: General; TRU

ORIGIN: Defense; Commercial

KEYWORDS: ACTINIDES; COAL; ECONOMICS; ENVIRONMENTAL EFFECTS; FOSSILFUEL POWER PLANTS; GOVERNMENT POLICIES; HAZARDS; MINING; NUCLEAR
ENERGY; NUCLEAR EXPLOSIVES; NUCLEAR PARKS; NUCLEAR POWER PLANTS; PLUTONIUM; RADIATION HAZARDS; RADIOACTIVE WASTE DISPOSAL; REACTOR ACCIDENTS; REACTOR SAFETY; SABOTAGE; SEPARATION PROCESSES; THERMAL POLLUTION; TOXICITY; URANIUM;. WASTE HEAT

\section{8}

De Floh, B., J.A. Araujo, and H.T. Matsuda; Instituto de Energia Atomica, Divisao de Engenharia Quimica, Sao Paulo, Brazil

INTRODUCTION TO THE STUDY OF THE T'REATMENT OF SPENT NUCLEAR FUEL. IEA-TI-41 . (1975)

In Portuguese; available from NTIS (US Sales Only), PC A08/MF A01.

An introduction is made to the study of the treatment of spent nuclear fuels. Main topics discussed are: basic information, volatilization processes, treatment of thorium based fuels (Thorex process), analytical chemistry of spent nuclear fuel and design of industrial facilities.

SUBJECT CATEGORY: Spent Fuel

ORIGIN: Foreign

KEYWORDS: AUTOMATION; CHEMICAL ANALYSIS; CRITICALITY; ECONOMICS; FISSION PRODUCTS; FUEL CYCLE; NUCLEAR FŨELS; RADIOACTIVE WASTES; REPROCESSING; SAFETY; SEPARATION PROCESSES; SPENT FUELY, TIIOREX FROCESB

\section{$\mathbf{5} \mathbf{3 9}$}

Interdepartementale Commissie voor de Kernenergie, Leidschendam, Netherlands

RADIOACTIVE WASTES IN THE NETHER= LANDS AS A CONSEQUENCE OF THE INSTALLATION OF NUCLEAR POWER PLANTS UP TO A CAPACITY OF 3500MWE. INIS-mf-3055. (1975)

RCN-75-040 used as appendix (75 p.); In Dutch

The report analyzes the risks involved in radioactive waste management of possible nuclear power plants of the capacity of $3500 \mathrm{MW}(\mathrm{e})$ to be installed in the Netherlands. The basis of the analysis is the 
fuel cycle as far as it takes place in the Netherlands. As a solution, dumping radioactive material in the ocean as well as temporary and definitive storage is discussed. For definitive storage, the use of salt deposits is proposed and some judicial and economic aspects are discussed.

SUBJECT CATEGORY: General

ORIGIN: Foreign

KEYWORDS: ECONOMICS; FUEL CYCLE; LEGAL ASPECTS; MARINE DISPOSAL; NETHERLANDS; NUCLEAR POWER PLANTS; RADIATION HAZARDS; RADIOACTIVE WASTE DISPOSAL; RADIOACTIVE WASTE STORAGE; RADIOACTIVE WASTES; SALT DEPOSITS

\section{0}

International Atomic Energy Agency, Vienna, Austria

DECOMMISSIONING OF NUCLEAR FACILITIES. International Atomic Energy Agency Technical Committee Meeting, Vienna, October 224, 1975. (1975)

Available from INIS

Present concepts on stages of, designing for, and costs of decommissioning, together with criteria for site release, are described. Recent operations and studies and assessments in progress are summarized. Wastes from decommissioning are characterized.

SUBJECT CATEGORY: Remedial Action, Surplus Facilities

ORIGIN: Foreign

KEYWORDS: COST; IAEA; NUCLEAR FACILITIES; RADIOACTIVITY; REACTOR DECOMMISSIONING; REACTOR SITES; REGULATIONS; RADIOACTIVE WASTE MANAGEMENT

541

International Atomic Energy Agency, Vienna, Austria

DECOMMISSIONING OF NUCLEAR FACILITIES. REPORT OF A TECHNICAL COMMITTEE MEETING ORGANIZED BY THE
IAEA AND HELD IN VIENNA, 20-24 OCTOBER 1975. IAEA-179. (1975)

Available from INIS

Present concepts on stages of, designing for, and costs of decommissioning, together with criteria for site release, are described. Recent operations and studies and assessments in progress are summarized. Wastes from decommissioning are characterized.

SUBJECT CATEGORY: Remedial Action, Surplus Facilities

ORIGIN: Foreign

KEYWORDS: COST; IAEA; NUCLEAR FACILITIES; RADIOACTIVITY; REACTOR DECOMMISSIONING; REACTOR SITES; REGULATIONS; WASTE MANAGEMENT; WASTES

542

Levin. I.; Israel Nuclear Society, Yavne, Israel

REPROCESSING OF FUELS. INIS-mf-1966/8; Nuclear Fuel, Proceedings of a Symposium, Israel, Rehovot, Israel, July 11975,5 pp. (1975)

In Hebrew

See Nuclear Science Abstracts 1976, 33(12) 28652

SUBJECT CATEGORY: Spent Fuel

ORIGIN: Foreign

KEYWORDS: CONTROL; COST; ECONOMICS; FUEL CYCLE; NUCLEAR FUELS; PERSONNEL MONITORING; PLUTONIUM; PURIFICATION; PWR TYPE REACTORS; RADIOACTIVE WASTE DISPOSAL; RADIOACTIVE WASTE STORAGE; RADIOACTIVITY; REPROCESSING; SPENT FUELS; URANIUM

543

Machida, C., and M. Suzuki; Japan Atomic Energy Research Inst., Tokai, Japan

MATERIAL COMPOSITION OF THE LOWLEVEL RADIOACTIVE SOLID WASTE. Hoken Butsuri 10(1):17-21. (1975) 
Various combustible and noncombustible components; In Japanese

The survey of material composition of the low level radioactive solid waste was performed in connection with the design work of the new incinerator in Tokai Establishment, JAERI. Five large facilities were selected as the representation of more than 20 facilities, and 500 packages were chosen out of 2,189 packages discharged during 2 months, June and July 1973. They consisted of the combustible and compressible waste but not included filters and contaminated equipments. The survey showed following result; plastics $33 \%$, waste cloth $24 \%$, paper $18 \%$, rubber $9 \%$, clothes $5 \%$, timber $1 \%$ (total of above mentioned materials $89 \%$ ), metal $7 \%$, glass $2 \%$, concrete and sand $2 \%$. Eighty-nine $\%$ of thetotal quantity is combustible material in principle, then it will be expected that the incineration treatment get a wider application to reduce the volume of final disposal.

SUBJECT CATEGORY: LLW

ORIGIN: Foreign

KEYWORDS: CALCINATION; COMBUSTION; CONCRETES; GLASS; METALS; PAPER; PLASTICS; RADIOACTIVE WASTE PROCESSING; RADIOACTIVE WASTES; RUBBERS; SAND; SOLID WASTES; TABLES; TEXTILES; VOLUME; WEIGHT; WOOD

\section{4}

Wadachi, Y., and K. Kojima; Japan Atomic Energy Research Inst., Tokyo, Japan

REVERSE OSMOSIS TREATMENT OF THE LAUNDRY WASTE FROM A NUCLEAR FACILITY, LABORATORY-SCALE TEST. JAERT-M-6337. (1975)

In Japanese

For treatment of the laundry waste occurring in a nuclear facility, the reverse osmosis with a cellulose acetate semipermeable membrane has been studied in the laboratory. A synthetic detergent, sodium dodecylbenzene sulfonate (DBS), and radioactivity, Co 60 and Ce 144, can both effectively be removed simultaneously; only slight radioactive contamination occurs to the membrane. Decrease in the decontamination factor of radionuclides and in. crease in radioactive contamination of the mem. brane are small regardless of frequency of the treatment. The optimum $\mathrm{pH}$ for the treatment is about 5. If the DBS concentration is $1,000 \mathrm{ppM}$ initially, the volume reduction approximately can be $1 / 100$. The method may be feasible for the intended purpose.

\section{SUBJECT CATEGORY: LLW}

ORIGIN: Foreign

KEYWORDS: CELLULOSE ESTERS; CERIUM 144; CLEANING; COBALT 60; DECONTAMINATION; DETERGENTS; EFFICIENCY; LIQUID WASTES; MEMBRANES; OSMOSIS; PERFORMANCE TESTING; PH VALUE; PROTECTIVE CLOTHING; RADIOACTIVE WASTE FACILITIES; RADIOACTIVE WASTE PROCESSING; VOLUME

545

Shultis, J.K., N.D. Eckhoff, and S. Wilcox; Kansas State Univ., Manhattan, KS

PERSPECTIVES ON POWER PRODUCTION: 1975. Kansas State Univ. Report. (1975)

16 papers on all aspects of energy

The sixteen lectures presented are intended to serve as a current information source for facts on many aspects of energy supply, consumption, and electrical power generation. Among the lecture topics are prínciples of nuclear reactors, radiation hazards, radioactivity, and energ.y resources. Most of the lectures included referencos:

SUBJECT CATEGORY: General

ORIGIN: Commercial

KEYWORDS: BIOLOGICAL EFFECTS; COAL; COMPARATIVE EVALUATIONS; COST; DF. SIGN; ELECTRIC POWER; ENERGY CONSER. VATION; ENERGY CONGUMPTION; ENERGY SOURCES; ENERGY SUPPLIES; ENVIRONMENTAL EFFECTS; FINANCIAL DATA; GASFOUS WASTES; GEOLOGIC STRUCTURES; GEOTHERMAL ENERGY; HEALTH HAZARDS; HYDROELECTRIC POWER PLANTS; LICENSING; NUCLEAR ENERGY; NUCLEAR FUELS; NUCLEAR POWER PLANTS; PETROLEUM; PLANNING; POWER DISTRIBUTION; POWER GENERATION; POWER PLANTS; REACTOR COMPONENTS; SOLAR ENERGY; THERMAL POLLUTION; THERMODYNAMICS; TIDAL POWER; RADIOACTIVE WASTE MANAGEMENT; WIND POWER 
546

Schlitt, A.; Kernbrennst off-

Wiederaufarbeitungsgesellschaft $\mathrm{mbH}$, Leopoldshafen Germany, F.R.

EUROPEAN REPROCESSING SCENE. Atomwirtsch. Atomtech. 20(7):335-338. (1975)

In German; 1 Figure

See Nuclear Science Abstracts 1976, 33(05) 09003

SUBJECT CATEGORY: Spent Fuel

ORIGIN: Foreign

KEYWORDS: COST; EUROPE; FUEL REPROCESSING PLANTS; NUCLEAR INDUSTRY; PLANNING; SITE SELECTION; SPENT FUEL ELEMENTS; SPENT FUEL STORAGE; WAK

547

Schnez, H.; Kernforschungsanlage Juelich GmbH, Inst. fuer Chemische Technologie, Germany, F.R.; Technische Hochschule Aachen, Germany, F.R.

TREATMENT AND SEPARATION OF THE RADIOACTIVE FISSION PRODUCTS TRITIUM, NOBLE GASES, AND IODINE IN NUCLEAR FUEL REPROCESSING PLANTS. Juel-1223; GERHTR-158. '(1975)

In German; 19 figs.; 27 tabs.; 88 refs.; with app. Thesis; available from INIS; NTIS, PC A07/MF A01; Work performance under United States German High Temperature Reactor Research Exchange Program

The plant concept, the physical and chemical properties of the fission products $\mathrm{T}, \mathrm{Kr} 85$, I 129, I 131 and $\mathrm{Xe} 133$, and the resulting behaviour and path of these nuclides in the plant are discussed. On the basis of a detailed analysis of the paths of emission, the emissions from large plants are estimated by consideration of these data and measures suggested to reduce these emissions. Several separation methods are compured, and cost estimates are made for the methods and plants which enable an evaluation of the various alterna. tives.

SUBJECT CATEGORY: LLW; Airborne

ORIGIN: Foreign
KEYWORDS: COMPARATIVE EVALUATIONS; COST; ECONOMICS; FISSION PRODUCT RELEASE; FUEL REPROCESSING PLANTS; GASEOUS WASTES; IODINE 129; IODINE 131; KRYPTON 85; RADIOACTIVE WASTE DISPOSAL; RADIONUCLIDE MIGRATION; REVIEWS; SEPARATION PROCESSES; STACK DISPOSAL; TRITIUM; XENON 133

\section{8}

Bonka, H., R. Schulten, K. Bruessermann, G. Schwarz, R. Bieselt, P. Winske, D. Brenk, K.J. Vogt, $J$. Darvas, and M. Laser; Kernforschungsanlage Juelich $\mathrm{GmbH}$, Inst. fuer Reaktorentwicklung, Germany, F.R.; Technische Hochschule Aachen, Lehrstuhl fuer Reaktortechnik, Germany, F.R.

FUTURE RADIOACTIVE ENVIRONMENTAL POLLUTION IN THE FEDERAL REPUBLIC OF GERMANY BY RADIONUCLIDES FROM NUCLEAR FACILITIES IN NORMAL OPERATION. IST REPORT. Juel-1220. (1975)

In German

Based on important gaseous and liquid radioactive effluents, mainly $\mathrm{T}, \mathrm{Kr} 85$, I 129, I 131, and Xe 133, from modern nuclear power plants and corresponding reprocessing plants and on a prediction of the nuclear power plant capacity expansion over a period of approximately 100 years, future radiation exposure is examined. Local and regional radiation exposure due to waste air as well as the potential radiation exposure due to liquid effluent in running waters and their use for drinking water are studied. The global effects are dealt with. The results are compared with the variation of the natural radiation exposure of the population in the FRG. There is evidence that the future additional radiation dose will be within the limits of the fluctuation of the natural radiation exposure if it is possible to retain the nuclides $\mathrm{T}$ and $\mathrm{Kr} 85$ at a rate of about $99 \%$ to $99.8 \%$ in the first large reprocessing plants.

\section{SUBJECT CATEGORY: Airborne; LLW}

ORIGIN: Foreign

KEYWORDS: AIR; CONTAMINATION; ENVIRONMENT; FISSION PRODUCTS; FORECAST. ING; FUEL REPROCESSING PLANTS; IODINE 129; IODINE 131; KRYPTON 85; NUCLEAR FACILITIES; NUCLEAR POWER PLANTS; OP. 
ERATION; RADIATION DOSES; RADIOACTIVE EFFLUENTS; SURFACE WATERS; TRITIUM; XENON 133; RADIOACTIVE AEROSOLS

549

Schiesser, D.; Kernforschungszentrum, Karlsruhe, Germany, F.R.

PRODUCTION AND RELEASE OF SR-89, SR-90, RU-103, RU-106, CS-134, CS-135, CS137, CE-141, AND CE-144 BY NUCLEAR POWER PLANTS AND REPROCESSING PLANTS AND THE EXPECTED RADIOLOGICAL BURDEN UNTIL THE YEAR 2000. KFF-2153; 167 pp. (1975)

In German; 260 references; with figures and tables

The natural production of long-lived radioisotopes of the elements strontium, rutherium, cesium and cerium is summarized in this report together with the yields from nuclear weapons tests and nuclear facilities. Specific production rates and the consequent release reates, representative of time are evaluated for the different types of nuclear power plants and fuel reprocessing plants. Estimated release rates from fuel reprocessing plants are also included, based on attainable decontamination factors at present. Local radiological burdens are specified resulting from the releases of radionuclides by nuclear power plants and reprocessing plants. Based on the forecasted onset of nuclear facilities, the global accumulated activity of singlenuclides released from these facilities until the year 2000 is calculated.

SUBJECT CATEGORY: HLW; LLW; Spent Fuel

ORIGIN: Foreign

KEYWORDS: BIBLIOGRAPHIES; CERIUM 141; CERIUM 144; CESIUM 134; CESIUM 135; CESIUM 137; DATA; FISSION PRODUCT RELEASE; FORECASTING; FUEL REPROCESS. ING PLANTS; NUCLEAR POWER PLANTS; RADIATION DOSES; RADIOACTIVE EFFLUENTS; RUTHENIUM 103; RUTHENIUM 106; STRONTIUM 89; STRONTIUM 90

\section{0}

Inoue, Y., and S. Morisawa; Kyoto Univ., Japan

COSMIC DISPOSAL OF RADIOACTIVE WASTE. Genshiryoku Kogyo 21(3):31-41. (1975)

\section{In Japanese}

The technical and economical possibility and safety of the disposal of highly radioactive waste into cosmos are reviewed. The disposal of highly radioactive waste is serious problem to be solved in the near future, because it is produced in large amounts by the reprocessing of spent fuel. The promising methods proposed are (i) underground disposal, (ii) ocean disposal, (iii) cosmic disposal and (iv) extinguishing disposal. The final disposal method is not yet decided internationally. The radioactive waste contains very long life nuclides, for example transuranic elements and actinide elements. The author thinks the most perfect and safe disposal method for these very long life nuclides is the disposal into cosmos. The space vehicle carrying radioactive waste will be launched safely into outer space with recent space technology. The selection of orbit for vehicles (earth satellite or orbit around planets) or escape from solar system, selection of launching rocket type pretreatment of waste, launching weight, and the cost of cosmic disposal were investigated roughly and quantitatively. Safety problems of cosmic disposal should be examined from the reliable safety study data in the future.

SUBJECT CATEGORY: TRU; Isolation

ORIGIN: Foreign

KEYWORDS: ACTINIDES; COST; INTERSTELLAR SPACE; ORBITS; RADIOACTIVE WASTE DISPOSAL; RADIOACTIVE WASTE PROCESSING; ROCKETS; SAFETY; SATELLITES; SHIELDING; SPACE

551

Ang. K.P.: Lawrence Berkeley I.ahoratnry, Rerkeley, CA

QUANTITIES OF ACTINIDES IN NUCLEAR REACTOR FUEL CYCLES. LBL-3682; Thesis; 198 pp. (1975)

Seee Nuclear Science Abstracts 19'75, 32(05) 13676.

SUBJECT CATEGORY: Spent Fuel; HLW

ORIGIN: Commercial

KEYWORDS: ACTINIDES; ACTIVITY LEVELS; BWR TYPE REACTORS; ECONOMICS; FORECASTING; FUEL CYCLE; HTGR TYPE REACTORS; LMFBR TYPE REACTORS; NUCLEAR 
FUELS; NUCLEAR POWER PLANTS; PLUTONIUM; PRODUCTION; PWR TYPE REACTORS; RADIOACTIVE WASTES

\section{2}

Carr, R.B. (Ed.), J.M. (Ed.) Barnett, R.C. (Ed.) Berlo, C.S. (Ed.) McCaleb, and J.K. (Ed.) Prono; Lawrence Livermore Laboratory, Livermore, CA

LAWRENCE LIVERMORE LABORATORY ENERGY AND TECHNOLOGY REVIEW. UCRL-52000-75-8; 24 pp. (1975)

See Nuclear Science Abstracts 1976, 33(03) 05604

SUBJECT CATEGORY: General

ORIGIN: Defense

KEYWORDS: AIR POLLUTION; DATA ACQUISITION SYSTEMS; DIFFUSION; GEOTHERMAL ENERGY CONVERSION; INVENTORIES; LAWRENCE LIVERMORE LABORATORY; MONITORING; NUCLEAR MATERIALS MANAGEMENT; PLUTONIUM; RADIATION MONITORING; RADIOACTIVE EFFLUENTS; RESEARCH PROGRAMS; URANIUM

\section{3}

Dickerson, M.H., and R.C. Orphan; Lawrence Livermore Laboratory, Livermore, CA

\section{ATMOSPHERIC RELEASE ADVISORY CAPABILITY (ARAC): DEVELOPMENT AND PLANS FOR IMPLEMENTATION. UCRL-51839; 19 pp. (1975)}

See Nuclear Science Abstracts 1975, 32(07) 17187

SUBJECT CATEGORY: Airborne

ORIGIN: Defense

KEYWORDS: AIR POLLUTION; ENVIRONMENT; FORECASTING; HEALTH HAZARDS; NUCLEAR PARKS; RADIOACTIVE EFFLUENTS; RADIOACTIVITY

\section{4}

Cohen, J.J.; Lawrence Livermore Laboratory, Livermore, CA; Inleruational Atomic Energy Agency, Vienna, Aùstria
COST EFFECTIVENESS OF RELEASE PREVENTION CONTROLS FOR TRITIUM AND KRYPTON-85. CONF-7506117; STI/PUB-404; Combined Effects of Radioactive, Chemical, and Thermal Releases to the Environment, Proceedings of a Symposium, Stockholm, Sweden, June 2, 1975. International Atomic Energy Agency, Vienna, Austria, (pp. 285-298). (1975)

See Nuclear Science Abstracts 1976, 33(12) 29128

SÜBJECT CATEGORY: Airborne; LLW

ORIGIN: Foreign

KEYWORDS: ENVIRONMENTAL EFFECTS; KRYPTON 85; RADIATION HAZARDS; RADIOACTIVE EFFLUENTS; TRITIUM; COST

555

Long Island Lighting Co., Hicksville, NY

RESPONSE TO QUESTION 2 - BLOWDOWN SYSTEM AND EQUIPMENT OPERATION. DOCKET-STN-50516-107; DOCKET-STN-50517; Amendment 8 to Jarnesport 1 and 2 License Application, (pp. 11.2A-5 - 11.2A-6). (1975)

Provides the following information: (1) Expected blowdown rate and method of processing blowdown. (2) Number and type of condensate demineralizers and flow rate of condensate through polishing demineralizers. (3) Expected frequency of resin regeneration or replacement, volumes and radioactivity of regenerant and rinse solutions, sluice water or backwash water per batch of resin regenerated or replaced. (4) Method of collection, processing and disposal of liquid wastes, including decontamination factors assumed for process operations. (5) PID's and process flow diagrams for the steam generator blowdown system and condensate polishing system.

SUBJECT CATEGORY: LLW

ORIGIN: Commercial

KEYWORDS: JAMESPORT-1 REACTOR; JAMESPORT-2 REACTOR; PWR TYPE REACTORS; BLOWDOWN; EQUIPMENT; DEMINERALIZERS; RADIOACTIVE WASTE DISPOSAL; LIQUID WASTES

556

Herzog, W.; Ministerium fuer Wirtschaft, Mittelstand und Verkehr, Duesseldorf, Germany, F.R. 
LIQUID WASTE DECONTAMINATION IN NUCLEAR POWER PLANTS. STATE AND PROSPECTS; ENERGIEPOLITIK IN NORDRHEIN-WESTFALEN. Report. (1975)

The study presented deals with the status of liquid waste decontamination in nuclear power stations and nuclear research centres and describes the methods of liquid waste processing and their possibilities of development. The following decontamination methods are examined and discussed regarding their applicability and effectiveness: 1 ) chemical precipitation; 2) ion exchange; 3 ) evaporation; 4) electrodialysis; 5) reversed osmosis. Two new methods seem to be technically applicable today, but are very expensive; a) bithermal $\mathrm{H} 2 \mathrm{O}-\mathrm{H} 2$ exchange (600/cbm processed wasle water); b) fractionated destillation of liquid hydrogen $(1,000$ /cmb)

\section{SUBJECT CATEGORY: LLW}

ORIGIN: Foreign

KEYWORDS: COST; DECONTAMINATION; DIALYSIS; DISTILLATION; EFFICIENCY; EVAPORATION; ION EXCHANGE; LIQUID WASTES; NUCLEAR POWER PLANTS; OSMOSIS; PRECIPITATION; RADIOACTIVE EFFLUENTS; RADIOACTIVE WASTE PROCESSING; REACTOR OPERATION; REVIEWS

557

Bernardi, R., and B. Burku; Mitre Corp., McLean, VA

QUANTITATIVE ENVIRONMENTAL COMPARISON OF COAL AND NUCLEAR GENERATION WORKSHOP SUMMARY. MTR7004; 100 pp. (1975)

A summary of presentations and discussions at a workshop held by the Mitre Corp., McLean, VA, May 27-28, 1.975.

A summary is presented of a two-day Environmental Workshop, which examined the public risks arising from coal and nuclear fuel cycles. Comparison of a light water reactor and a coal-fired plant indicates that in the next 10 to 15 years nuclear fission and coal combustion will be the principal energy sources for electric power generation, with high capital and environmental costs for both. Cost benefit analyses project economic costs for coal by 1980 (1975 dollars) will be $24.2 \mathrm{mills} / \mathrm{kWh}$, and for nuclear, $22.7 \mathrm{mills} / \mathrm{kWh}$. Social costs for coal (excluding sulfur oxide emissions) are projected at $0.56 \mathrm{mills} / \mathrm{kWh}$, and for nuclear, $0.06 \mathrm{mills} / \mathrm{kWh}$. Included in the analyses are considerations of employee and public health and safety, environmental and climate damage, waste management, and potential for sabotage. Recommendations are made to develop National energy production stategies for building and siting coal and/or nuclear electric power facilities and to encourage greater participation of public interest groups in the decision process.

SUBJECT CATEGORY: General

ORIGIN: Commercial

KEYWORDS: COAL; NUICLEAR POWFR; FI.F,CTRIC POWER; COST; ECONOMICS; ENVIRONMENTAL EFFECTS; FOSSILFUEL POWER PLANTS: NUCLEAR POWER PLANTS; RADI. OACTIVE WASTES; RADIOACTIVE WASTE MANAGEMENT

\section{8}

Tomes, S.A., and T.C. Bishop; Monsanto Research Corp., Miamisburg, $\mathrm{OH}$

MOUND LABORATORY CONTAMINATED WASTE INVENTORY SYSTEM. Nuclear Materials Manugemenl 4(3):522-534; Sixteenth Annual Meeting of the Institute of Nuclear Materials Management, Inc., New Orleans, LA, June 18, 1.975. (1975)

See Nuclear Science Abstracts 1976, 33(10) 23866

SUBJECLII LA'IEGUKY: HLW; LLW; TRU

ORIGIN: Commercial

KEYWORDS: ACCOUNTING; CON'IAINERS; INVENTORIES; MOUND LABORATORY; RADIOACTIVE WASTE MANAGEMENT; NUCLEAR MATERIALS MANAGEMENT

\section{9}

Kirkby, R.W., J.V. Happ, and I.R.W. (Ed.) Johnston; Mount Isa Mines Ltd., Australia

UTILIZATION OF WASTE MATERIAL AS FILL IN A LARGE SCALE MINING OPERATION: TREATMEN', RECYCLE, AND DISPOSAL OF WASTES. CONF-750897; Third National Chemical Engineering Conference, Mildura, 
Victoria, Australia, August 20, 1975. Monash University, Clayton; Australia. (1975)

The generation of solid wastes in all stages of the mineral extraction process is discussed, and the desirability and economics of using stabilized fill produced by cementing coarse fractions of mill tailings and rocks for stopping and backfill operations in underground mining are described.

SUBJECT CATEGORY: General

ORIGIN: Foreign

KEYWORDS: AUSTRALIA; ECONOMICS; FEASIBILITY STUDIES; INDUSTRIAL WASTES; MILL TAILINGS; MINERAL WASTES; SANITARY LANDFILLS; SOLID WASTES; SOLIDIFICATION; MINING; USES; WASTE PRODUCT UTILIZATION

560

National Academy of Sciences, Washington, DC

INTERIM STORAGE OF SOLIDIFIED HIGHLEVEL RADIOACTIVE WASTES. TID-27915; 82 pp. (1975)

The feasibility, safety, and estimated costs of several concepts for the interim surface storage of solidified high-level radioactive wastes that result from the civilian nuclear power program were reviewed and evaluated. The panel concluded that, in principle, high-level wastes can be stored safely and economically in sealed storage casks, in a water basin, or in an air-cooled vault, but they recommend an optimized version of the sealed storage cask concept.

SUBJECT CATEGORY: HLW

ORIGIN: Commercial

KEYWORDS: CASKS; COST; FEASIBILITY STUDIES; FUEL CYCLE; GEOLOGY; HYDROLOGY; RADIOACTIVE WASTE PROCESSING; RADIOAC'LIVE WASTE STORAGE; REPROCESSING; SAFETY; SOLID WASTES; SOLIDIFICATION; SPENT FUELS

561

National Academy of Sciences, Washington, DC

INTERIM STORAGE OF SOLIDIFIED HIGHLEVEL RADIOACTIVE WASTES. TID-27189; 90 pp. (1975)
Available from NTIS; EPA citation 02:015982

The feasibility, safety, and technological aspects of storage of high-level solidified wastes in an engineered storage facility at or near the earth's surface for an interim period of up to 100 years are reviewed and evaluated. Several methods of providing surface storage are considered: the use of sealed storage casks, water basins, and air-cooled vaults are assessed with regard to the advantages of each in terms of technology, public safety, resources for production, cost estimates, and land requirements. Other topics include fuel reprocessing and waste solidification, segregation of transuranic elements, determination of optimum construction materials and integrity of waste containers, and safeguarding.

SUBJECT CATEGORY: HLW; Isolation; TRU

ORIGIN: Commercial; Defense

KEYWORDS: CASKS; COST; FEASIBILITY STUDIES; GEOLOGY; HYDROLOGY; RADIOACTIVE WASTE STORAGE; RADIOACTIVE WASTES; REPROCESSING; SAFETY; SOLID WASTES; SOLIDIFICATION; SPENT FUELS; UNDERGROUND STORAGE; TRANSURANIUM ELEMENTS

562

Dunster, H.J.; National Radiological Protection Board, Harwell, England

EPA REQUIREMENTS FOR THE URANIUM FUEL CYCLE. Radiol. Prot. Bull. 13:10-11. (1975)

See Nuclear Science Abstracts 1976, 33(06) 12381

SUBJECT CATEGORY: General

ORIGIN: General

KEYWORDS: COST; ENVIRONMENT; NUCLEAR POWER PLANTS; RADIATION HAZARDS; RADIOACTIVE WASTE MANAGEMENT

663

Kelly, G.N., J.A. Jones, P.M. Bryant, and F. Morley; National Radiological Protection Board, Harwell, England; Commission of the European Communities, Luxembourg

THE PREDICTED RADIATION EXPOSURE OF THE POPULATION OF THE EUROPEAN 
COMMUNITY RESULTING FROM DISCHARGES OF KRYPTON-85, TRITIUM, CARBON-14 AND IODINE-129 FROM THE NUCLEAR POWER INDUSTRY TO THE YEAR 2000. DOC. V/2676/75; 14 pp. (1975)

These nuclides, owing to their relatively long halflives and their widespread dispersion, accumulate in the environment and represent long term sources of radiation to essentially the whole world population. Consideration is given to the exposure of individuals and the community population as a whole from each of the 4 nuclides; the relative significance of each nuclide in this context is evaluated. The levels of exposure are compared with ICRP recommended dose limits and with exposure from nther sources such as natural background radiation. A comparison is also made between the natural inventories of these nuclides in the environment and those arising from discharges from the nuclear power programs.

SUBJECT CATEGORY: Airborne; LLW

ORIGIN: Foreign

KEYWORDS: TRITIUM; CARBON 14; IODINE 129; FORECASTING; RADIATION DOSES; RADIOACTIVE WASTE MANAGEMENT; KRYPTON; IDAHO CHEMICAL PROCESSING PLAN'I'; KKYY'IUN \& 8

b64

Netherland, Sewell anḋ Associates, Inc., Dallas, TX

PRELIMINARY STUDY OF THE OIL SHALES OF THE GREEN RIVER FORMATION IN THE TRI-STATE AREA OF COLORADO, UTAH, AND WYOMING TO INVESTIGATE THEIR UTILITY FOR DISPOSAL OF RADIOACTIVE WASTE. ORNL. /SUB-75/70345. (1975)

Available from NTIS, PC A06/MF A01.

Results are presented of a preliminary study of the oil shales of the Green River formation in the tristate area of Colorado, Utah, and Wyoming to investigate their utility for possible disposal of radioactive waste material. The objective of this study was to make a preliminary investigation and to obtain a broad overview of the physical and economic factors which would have an effect on the suitability of the oil shale formations for possible disposal of radioactive waste material. These physical and economic factors are discussed in sections on magnitude of the oil shales, waste disposal relations with oil mining, cavities requirements, hydrological aspects, and study requirements.

SUBJECT CATEGORY: LLW; HLW

ORIGIN: Commercial

KEYWORDD: DECOMPOSITION; FEASIBILITY STUDIES; GEOLOGIC STRUCTURES; GREEN RIVER FORMATION; GROUND WATER; HYDROLOGY; KEROGEN; MECHANICAL PROPERTIES; OIL SHALE DEPOSITS; PICEANCE CREEK BASIN; RADIOACTIVE WASTE DISPOSAL; STRATIGRAPHY; TIME DEPENDENCE

\section{5}

Nuclear Regulatury Cummissiun, Office of Standards Development, Washington, DC

PREPARATION OF ENVIRONMENTAL REPORTS FOR COMMERCIAL URANIUM ENRICHMENT FACILITIES. REG/G-4,9(Rev. 1); 32 pp. (1975)

See Nuclear Science Abstracts 1976, 33(07) 14831

SUBJECT CATEGORY: Gonoral

ORIGIN: Commercial

KEYWORDS: COST BENEFIT ANALYSIS; ENVIRUNMEN'TAL EFFECTS; ENVIRON. MENTAL IMPACT STATEMENTS; GASEOUS DIFFUSION PLANTS; INDUSTRIIÁl. PLANTS; ISOTOPE SEPARATION; MANUALS; RADIATION ACCIDENTS; RADIATION MONITORING; RADIOACTIVE EFFLUENTS; REGULATORY GUIDES; SITE SELECTION; URANIUM; URANIUM ISU'IUPES

\section{6}

Booth, H.R., R.D. Ehrlich, F.J. Keneshea, P.D. Knecht, H. Lawroski, R.L. Naymark, A.G. Silvester, and W.R. Thompson; Nuclear Service Corp., Campbell, CA

NUCLEAR POWER TODAY. Chemical Engineering 82(22):102-118. (1975)

The fission process, the suclear fuel cycle, uranium ore resources and mining, the fuel element in the reactor, fuel reprocessing, nuclear waste handling. 
current reactor design in the U.S., a cost comparison between nuclear and fossil fuels, and, the various types of reactors are discussed.

\section{SUBJECT CATEGORY: General}

ORIGIN: Commercial

KEYWORDS: BREEDER REACTORS; BWR TYPE REACTORS; COST; DESIGN; ENERGY SUPPLIES; FISSION; FUEL CONSUMPTION; FUEL ELEMENTS; GCFR TYPE REACTORS; GCR TYPE REACTORS; ISOTOPE SEPARATION; LMFBR TYPE REACTORS; LWBR TYPE REACTORS; MILLING; MOLTEN SALT REACTORS; NUCLEAR ENERGY; NUCLEAR FUEL CONVERSION; NUCLEAR FUELS; NUCLEAR INDUSTRY; NUCLEAR POWER PLANTS; PWR TYPE REACTORS; RADIOACTIVE WASTE DISPOSAL; REGULATIONS; REPROCESSING; REVIEWS; THERMONUCLEAR REACTORS; URANIUM MINES; URANIUM ORES; URANIUM RESERVES

567

Ledford, S.G., and E.H. Gift; Oak Ridge Gaseous Diffusion Plant, Oak Ridge, TN

ECONOMICS OF PWR SPENT FUEL RECOVERY. K-OP-185, (Rev. 1); 30 pp. (1975)

The results are presented of an analysis of the economics of spent PWR fuel recovery. The plutonium indifference value, the associated breakeven reprocessing cost and overall fuel cycle costs were estimated as functions of the price of $\mathrm{U} 3 \mathrm{O} 8$, the price of uranium enrichment, and the increased cost of fabricating mixed oxide fuel assemblies (relative to UO2 fabrication). The impacts of spent fuel storage costs on fuel cycle costs and breakeven reprocessing costs were also investigated. Plutonium "indifference" values were calculated in the traditional manner; i.e., they represent the values at which the reactor operator is indifferent either to recovery and reuse of the plutonium (and uranium) or to recovery and sale of the uranium and plutonium. The "breakeven" reprocessing cost represents the price that the reactor operator could afford to pay for reprocessing and waste management (combined) such that his total fuel cycle cost is the same with or without fuel recovery.

SUBJECT CATEGORY: TRU; Spent Fuel

ORIGIN: Commercial; Defense
KEYWORDS: ECONOMICS; EFFICIENCY; FUEL CYCLE; PWR TYPE REACTORS; REPROCESSING; SPENT FUEL ELEMENTS

568

Blomeke, J.O., C.W. Kee, and R. Salmon; Oak Ridge National Laboratory, Oak Ridge, TN

SHIPMENTS IN THE NUCLEAR FUEL CYCLE PROJECTED TO THE YEAR 2000. Nuclear News 18(8):62-65. (1975)

See Nuclear Science Abstracts, 1975, 32(04) 09632.

SUBJECT CATEGORY: General

ORIGIN: Commercial

KEYWORDS: FORECASTING; NUCLEAR FUELS; PLUTONIUM; RADIOACTIVE WASTES; WASTE TRANSPORTATION

569

Compere, E.L., S.S. Kirslis, E.G. Bohlmann, F.F. Blankenship, and W.R. Grimes; Oak Ridge National Laboratory, Oak Ridge, TN

FISSION PRODUCT BEHAVIOR IN THE MOLTEN SALT REACTOR EXPERIMENT. ORNL-4856; 143 pp. (1975)

See Nuclear Science Abstracts 1976, 33(07) 16370

SUBJECT CATEGORY: General

ORIGIN: Defense

KEYWORDS: FISSION PRODUCTS; GASEOUS WASTES; INVENTORIES; MOLTEN SALT FU. ELS; MOLTEN SALT REACTORS; REACTOR COMPONENTS; REACTOR OPERATION

570

Gat, U., J.D. Thomas, and D.T. Clark; Oak Ridge National Laboratory, Oak Ridge, TN

MAXEY FLATS NUCLEAR WASTE BURIAL SITE: INVENTORY. Transactions of the American Nuclear Society 21:265-266; American Nuclear Society 1975 Annual Meeting, New Orleans, LA, June 8, 1975. (1975) 
See Nuclear Science Abstracts 1975, 32(05) 12256

SUBJECT CATEGORY: LLW

ORIGIN: Commercial

KEYWORDS: INVENTORIES; RADIOACTIVE WASTE DISPOSAL; RADIOACTIVITY; GROUND DISPOSAL; VOLUME

571

Groenier, W.S., R.E. Blanco, R.C. Dahlman, B.C. Finney, A.H. Kibbey, and J.P. Witherspoon; Oak Ridge National Laboratory, Oak Ridge, TN

CORRELATION OF RADIOACTIVE WASTE TREATMENT COSTS AND THE ENVIRONMENTAL IMPACT OF WASTE EFFLUENTS IN THE NUCLEAR FUEL CYCLE FOR USE IN ESTABLISHING "AS LOW AS PRACTICABLE" GUIDES-FABRICATION OF LIGHT-WATER REACTOR FUELS CONTAINING PLUTONIUM. ORNL-TM-4904; 140 pp.; Nuclear Science Abstracts 1975, 32(06) 13910. (1975)

Table 7.9 shows percent contributions of inhaled and injested radionuclids from the gaseous effluent of a model mixed-oxide fuel fabrication plant to individual organ (bone, kidney, lung, liver) doses. Table 7.8 shows major radionuclides ( $\mathrm{Pu}$ 238, $\mathrm{Pu}$ 239, $\mathrm{Pu} 240, \mathrm{Pu} 241, \mathrm{Am} 241$ ) contributing to dose to individuals from gaseous effluents via terrestrial path ways at 0.5 mile from a model mixed-oxide fuel fahrication plant.

A cost-benefit study was made to determine the cost and effectiveness of radioactive waste (radwaste) treatment systems for decreasing the release of radioactive materials from a model light-water plutonium recycle reactor fuel fabrication plant, and to determine the radiological impact (dose commitment) of the released materials on the environment. The study is designed to assist in defining the term "as low as practicable" in relation to limiting the release of radioactive materials from nuclear facilities. The base case model plant is representative of current plant technology and has an annual capacity of 300 metric tons of LWR plutonium recycle fuel. Additional radwaste treatment equipment is added to the base case plants in a series of case studies to decrease the amounts of radioactive materials released and to reduce the radiological dose commitment to the population in the surrounding area. The cost for the added waste treatment operations and the corresponding dose commitment are calculated for each case. In the final analysis, radiological dose is plotted vs the annual cost for treatment of the radwastes. The status of the radwaste treatment methods used in the case studies is discussed. Some of the technology used in the advanced cases is in an early stage of development and is not suitable for immediate use. The methodology used in estimating the costs and the radiological doses, detailed calculations, and tabulations are presented in appendices A and B. (Auth)

SUBJECT CATEGORY: TRU; Airborne

ORIGIN: Commercial

KE'YWURDS: CUS'I BENEFIT ANALYSIS; FUEL FABRICATION PLANTS; PWR TYPE REACTORS; ENVIRONMENT; RADIOACTIVE WAS'I'E PKOCESSING; POPULATIONS; PLUTONIUM 238; PLUTONIUM 239; PLUTONIUM 240; PLUTONIUM 241; AMERICIUM 241; NUCLEAR FUELS; CALCULATION METHODS; GASEOUS WASTES; DOSE COMMITMENTS

\section{2}

Lampton, R.E., R.A. Robinson, and H.O. Werren; Oak Ridge National Laboratory, Oak Ridge, TN

CONCEPTUAL DESIGN REPORT: NEW HY DROFRACTURE FACILITY. ORNLTM-4826; 101 pp. (1975)

Sep Nuclear Srience Ahstrasts 1975, 32(05) 12248

SUBJECT CATEGORY: LLW

ORIGIN: Commercial

KEYWORDS: CONSTRUCTION; COST; DESIGN; ENVIRONMENTAL EFFECTS; FRACTURES; HYDRAULIC FRACTURING; LIQUID WASTES; OPERATION; PLANNING; RADIA. TION MONITORING; RADIOACTIVE WASTE DISPPOSAL; RADIOACTIVE WASTE FACILITIES; RADIOACTIVE WASTE PROCESSING; SAFETY; SHALES; UNDERGROUND DISPOSAL

673

McWherter, J.R.; Oak Ridge National Laboratory, Oak Ridge, TN 
ENVIRONMENTAL ANALYSIS OF THE OPERATION OF THE ERDA FACILITIES IN OAK RIDGE. CONF-750967-11; ERDA Environmental Protection Conference, Proceedings, Chicago, IL, September 23, 1975. 7 pp. (1975)

See Nuclear Science Abstracts 1976, 33(02) 03021

SUBJECT CATEGORY: General; LLW

ORIGIN: Defense

KEYWORDS: ENVIRONMENTAL EFFECTS; WASTE DISPOSAL; NUCLEAR FACILITIES; ORGDP; ORNL; RADIOACTIVE WASTES; REGIONAL ANALYSIS; SOCIOLOGY; URBAN AREAS; US ERDA; WASTE MANAGEMENT; Y12 PLANT

574

Pechin, W.H., R.E. Blanco, R.C. Dahlman, B.C. Finney, R.B. Lindauer, and J.P. Witherspoon; Oak Ridge National Laboratory, Oak Ridge, TN

CORRELATION OF RADIOACTIVE WASTE TREATMENT COSTS AND THE ENVIRONMENTAL IMPACT OF WASTE EFFLUENTS IN THE NUCLEAR FUEL CYCLE FOR USE IN ESTABLISHING "AS LOW AS PRACTICABLE" GUIDES - FABRICATION OF LIGHT-WATER REACTOR FUEL FROM ENRICHED URANIUM DIOXIDE. ORNL-TM4902; 208 pp.; Nuclear Science Abstracts 1975, 32(06) 13909. (1975)

Methodology used in estimating costs and radiological doses, detailed calculations, and tabulations are presented in Appendix A and ORNL-4992.

A study was made to determine the cost and effectiveness of radwaste and chemwaste treatment systems for 2 model enriched-uranium, light-water reactor fuel fabrication plants, and to determine the dose commitment of released radionuclides to the environment. One model plant uses the wet ammon. ium diuranate (ADU) process, the other the dry direct conversion (DC) process. The plants are assumed to each process 1500 metric Tons of $U$ per year (5 tons/day for 300 days). Th 231, Th 234, and $\mathrm{Pa} 234$ daughters are in equilibrium with the UF6 feed (4\% U 235). Four conceptual cases were modeled: a base case representing the lowest cost and technology used in some current plants, and successive cases in which treatment equipment is added. In advanced case studies, treated water, recovered nitrogen oxides (as nitric acid), and ammonia are recycled in the plants; in all cases, solid radwastes and chemwastes are stored on-site or shipped to commercial burial grounds. Model plants are evaluated for a midwestern site and a southeastern coastal site, using typical meteorological patterns and population densities for each. The annual amounts of radioactive materials released (the source term), the capital, annual and contribution to power costs, and the radiological impact are calcualted for each case. The annual radwaste treatment costs are compared with the dose commitment from released radionuclides; comparison with commitments from liquid effluents are on two bases: 1) annual individual total body dose from aquatic pathways after dilution in a $15 \mathrm{cfs}$ stream, and 2) after the $15 \mathrm{cfs}$ stream flows into a $1300 \mathrm{cfs}$ stream (at the midwestern site) or into an estuary (at the coastal site). Estimated maximum total body doses do not exceed $1 \mathrm{mrem} / \mathrm{yr}$ within 0.5-1 mi. of the Case 1 plant at either site. Average individual dose is lower at the midwestern site due to meteorological factors, but the population dose is higher due to the denser population. Capital costs of the treatment systems modeled range from $\$ 0.586$ million for DC Case 1 to $\$ 4.99$ million for ADU Case 4, or up to about $14 \%$ of the $\$ 36$ million which is taken as the cost for the base plant. Annual costs are $\$ 202,000$ $\$ 2,515,000 / \mathrm{hr}$, corresponding to contribution to power costs of $5.5 \times 10(\mathrm{E}-4)$ and $6.4 \times 10(\mathrm{E}-3)$ mills $\mathrm{kWhr}$, respectively. These values are less than $0.1 \%$ of an estimated total power generation cost of 7-10 mills/kWhr.

SUBJECT CATEGORY: LLW; Airborne

ORIGIN: Commercial

KEYWORDS: COST BENEFIT ANALYSIS; FUEL FABRICATION PLANTS; DOSE COMMITMENTS; MATHEMATICAL MODELS; RECYCLING; RADIOACTIVE EFFLUENTS; STREAMS; METEOROLOGY; FUEL CYCLE; EVALUATION; GASEOUS WASTES

\section{5}

Ryon, A.D., and R.E. Blanco; Oak Ridge National Laboratory, Oak Ridge, TN

CORRELATION OF RADIOACTIVE WASTE TREATMENT COSTS AND THE ENVIRONMENTAL IMPACT OF WASTE EFFLUENTS IN THE NUCLEAR FUEL CYCLE FOR USE IN ESTABLISHING "AS LOW AS PRACTICABLE” GUIDES - APPENDIX A PREPARATION OF COST ESTIMATES FOR VOLUME 
I, MILLING OF URANIUM ORES. ORNL-TM4903, Vol. 2; 255 pp. (1975)

Cross Ref.: ORNL/NUREG/TM-6; ORNL-TM-4902; ORNL-TM-4903, Vol. 1; ORNL-TM-4904; See Nuclear Science Abstracts 1975, 32(10) 24165

This appendix presents the methodology and detailed calculations used in estimating the costs for treating the radwastes at the model uranium mills. (Auth)

SUBJECT CATEGORY: Remedial Action, Mill Tailings

ORIGIN: Commercial

KEYWORDS: POLLUTION REGULATIONS; CONTROL; SAFETY; RADIOACTIVE EFFLUENTS; FUEL CYCLE; URANIUM; MILLING; ECONOMICS; COST; MILL TAILINGS

576

Sears, M.B., R.E. Blanco, R.C. Dahlman, G.S. Hill, A.D. Ryon, and J.P. Witherspoon; Oak Ridge National Laboratory, Oak Ridge, TN

CORRELATION OF RADIOACTIVE WASTE TREATMENT COSTS AND THE ENVIRONMENTAL IMPACT OF WASTE EFFLUENTS IN THE NUCLEAR FUEL CYCLE FOR USE IN ESTABLISHING "AS LOW AS PRACTICABLE" GUIDES - MILLING OF URANIUM ORES.. ORNL-TM-4903, (Vol. 1) 291 pp.; Nuclear Science Abstracts 1975, 32(06) 13836. (1975)

Cross Reference: ORNL-4992; ORNL/NUREG/TM6; ORNL-TM-4902; ORNL-TM-4903. Vol. 2; ORNLTM-4904; 95 Tables, 34 Figures, 106 References

A Cost-benefit study was made to determine the cost and effectiveness of radioactive waste (radwaste) treatment systems for decreasing the release of radioactive materials from model uranium ore processing mills, and to determine the radiological impact (dose commitment) of the released materials on the environment. The study is designed to assist in defining the term "as low as practicable" in relation to release of radioactive materials from nuclear facilities. The base case model mills are representative of mills which will process a major fraction of the ore in the next 20 years. Each mill processes 2,000 short tons of ore per day. Additional radwaste treatment techniques are applied to the base case mill and the waste tailings area in a series of case studies to decrease the amounts of radioactive materials released and to reduce the radiological dose commitment to the population in the surrounding area. The cost for the added waste treatment operations and the corresponding commitment are calculated for each case. In the final analysis, radiological dose is plotted vs the annual cost for treatment of the radwastes. The status of the radwaste treatment methods used in the case studies is discussed. Much of the technology used in the advanced cases will require development and demonstration and is not suitable for immediate use. The methodology used in estimating the costs, detailed calculations, and tabulations are presented in ORNL-TM-4903, Volume 2. The methodology and assumptions for the radiological doses are found in ORNL-4992. (Auth)

SUBJECT CATEGORY: Remedial Action, Mill Tailings

ORIGIN: Commercial

KEYWORDS: ECONOMICS; COST BENEFIT ANALYSIS; MILL TAILINGS; DOSE COMMITMENTS; HUMAN POPULATIONS; RADIOACTIVE EFFLUENTS; DOSIMETRY; URANIUM ORES

\section{7}

Tamura, T., F.S. Brinkley, J.O. Duguid, D.T. Farrar, C.W. Francis, C.D. Malone, and O.M. Sealand; Oak Ridge National Laboratory, Oak Ridge, TN

WASTE MANAGEMENT ANALYSES AND APPLICATIONS. ORNL-5016; Environmental Sciences Division Annual Progress Report for Period Ending September 30, 1974, Taylor, C.E. (Ed.). Oak Ridge National Laboratory, Oak Ridge, TN, (pp. 26-36). (1975)

See Nuclear Science Abstracts 1975, 31(12) 33096

SUBJECT CATEGORY: LLW; HLW

ORIGIN: Defense

KEYWORDS: DENITRIFICATION; FORECASTING; GROUND WATER; NITRATES; NITROGEN; POLLUTION; RADIOACTIVE WASTE DISPOSAL; RADIOACTIVE WASTE MANAGEMENT; RADIOACTIVE WASTES; RADIONUCLIDE MIGRATION; RESEARCH PROGRAMS; SOILS; SOLID WASTES; STRONTIUM 90; UN. DERGROUND DISPOSAL 
578

Oak Ridge National Laboratory, Oak Ridge, TN

PROGRAM FOR IMPROVED WASTE MANAGEMENT IN COMMERCIAL NUCLEAR FUEL REPROCESSING FACILITIES. ORNLTM-4783;.24 pp. (1975)

The principal objective of the program proposed in the report is to decrease the long-term (more than 1000 years) hazards of radioactive wastes from commercial nuclear fuel reprocessing facilities. This is to be accomplished by modifying reprocessing methods currently in use to increase actinide recoveries and to produce waste streams that are amenable to recycle or further treatment; all wastes should be treated so as to achieve separaton into a solid, fission-product-containing fraction with low concentrations of long-lived actinides and a semipure concentrated fraction containing the actinides. After sufficient information has been accumulated from laboratory-scale studies to allow preparation of overall, detailed flowsheets and to permit making a lechnical evaluation, a detailed review. will be made to determine if the program should be continued through construction and operation of a large-scale demonstration plant that will satisfactorily treat all waste streams from a modified nuclear fuel reprocessing facility. There is a listing and brief summary of the tasks required to carry out this program. Also included are estimates of the manpower, costs, and time required to complete the program. (Auth)

SUBJECT CATEGORY: TRU; HLW; LLW

ORIGIN: Commercial

KEYWORDS: FUEL REPROCESSING PLANTS; EVALUATION; HAZARDS; ACTINIDES; RADIOACTIVE WASTE PROCESSING; SEPARATION PROCESSES; FISSION PRODUCTS; NEPTUNIUM; PLUTONIUM; AMERICIUM; CURIUM; PROTACTINIUM; THORIUM; URANIUM; IODINE 129; ZIRCONIUM 93; TECHNETIUM 99; CESIUM 135; ECONOMICS

\section{9}

Olivier, J.P.; OECD Nuclear Energy Agency, Paris, France

MANAGEMENT OF FISSION PRODUCTS AND LONG-LIVED ALPHA WASTES. Advan. Nucl. Sci. Technol. 8:141-172. (1975)

See Nuclear Science Abstracts 1975, 31(11) 29175
SUBJECT CATEGORY: TRU

ORIGIN: Foreign

KEYWORDS: ALPHA SOURCES; ECONOMICS; EUROPE; FISSION PRODUCTS; RADIOACTIVE WASTE DISPOSAL; RADIOACTIVE WASTE MANAGEMENT; RADIOACTIVE WASTE PROCESSING; RADIOACTIVE WASTE STORAGE; SOLIDIFICATION; UNDERGROUND DISPOSAL; USA; VITRIFICATION; ALPHA-BEARING WASTES

580

Woodhead, L.W., and L.J. Ingolfsrud; Ontario Hydro, Toronto, Canada; Canadian Nuclear Association, Toronto, Ontario, Canada

PERFORMANCE OF CANADIAN COMMERCIAL NUCLEAR UNITS AND HEAVY WATER PLANTS: VOLUME 2: DEVEIOPMENTS IN CANADA AND ABROAD. CONF-750699 (Part 2); Proceedings of the 15th Annual International Conference held in Ottawa, Canada, June 15-18, 1975, (pp. 39-54). (1975)

The operating history of Canadian commercial CANDU type reactors, i.e. Pickering generating station-A, is described. Capacity factors and unit energy costs are analyzed in detail. Equipment performance highlights are given. The performance of the two Canadian heavy water plants is described and five more are under construction or planned.

SUBJECT CATEGORY: General

ORIGIN: Foreign

KEYWORDS: CANDU TYPE REACTORS; DUAL TEMPERATURE PROCESS; ECONOMICS; FUEL ELEMENTS; HEAVY WATER; PERFORMANCE; PRESSURE TUBES; PRODUCTION; PUMPS; RADIOACTIVE EFFLUENTS; RELIABILITY; STEAM GENERATORS; STEAM TURBINES; COST

\section{1}

Anno, G.H., and H. Montgomery; Pacific-Seirra Research Corp., Santa Monica, CA

FACILITY FIELD MONITORING COST/BENEFIT ANALYSIS. Transactions of the American Nuclear Society 21:89-90, Transactions of the 
1975 Annual Meeting, New Orleans, LA, June 8, 1975. (1975)

See Nuclear Science Abstracts 1975, 32(05) 11537.

SUBJECT CATEGORY: General

ORIGIN: Commercial

KEYWORDS: COST BENEFIT ANALYSIS; ENVIRONMENT; NUCLEAR POWER PLANTS; RADIATION MONITORING; RADIOACTIVE EFFLUENTS

582

Project Management Corp., IL

RESPONSE TO QUESTION 010.2 (SECTION 3.5) - RADWASTE SYSTEM. DOCKET-50537-9; Amendment 1 to Clinch River Breeder Reactor License Application,(p. A1-5). (1975)

2 Tables

Lists the capacities and volumes for the components in the radwaste systems.

SUBJECT CATEGORY: General

ORIGIN: Commercial

KEYWORDS: RADIOACTIVE WASTE MANAGEMENT; LMFBR TYPE REACTORS; CAPAC. ITY; CLINCH RIVER BREEDER REACTOR

583

Safonov, G., and R.G. (Ed.) Post; R and D Associates, Yacific Yalisades, LA

NICLEAR WASTE STEAM PLANT CONCEPT: WASTE MANAGEMENT'75. University of Arizona, Tucson, AZ. (1975)

A feasibility study was conducted on the design of a military 5-MW plant which would produce 350 degrees F. saturated steam from canisters of solidified radioactive waste. Such a 5-MW plant could be built for a cost of approximately $\$ 1.8 \mathrm{M}$ and would save approximately 1.5 million gallons of fuel oil per year.

\section{SUBJECT CATEGORY: HLW}

ORIGIN: Defense
KEYWORDS: BOILER FUEL; DESIGN; FEASIBILITY STUDIES; RADIOACTIVE WASTES; SOLIDIFICATION; STEAM; THERMAL POWER PLANTS; USES; COST

584

Gregory, W.D., and H.D. Maillie; Rochester Univ., Rochester, NY

INCINERATION OF ANIMAL RADIOACTIVE WASTE. A COMPARATIVE COST ANALYSIS. Health Phys. 29(3):389-392; Nuclear Science Abstracts 1976, 33(04) 07909. (1975)

No Abstract

SUBJECT CATEGORY: LLW

ORIGIN: Institutional

KEYWORDS: ANIMALS; BIOLOGICAL WASTES; COMBUSTION; COMPARATIVE EVALUATIONS; COST BENEFIT ANALYSIS; ENVIRONMENT; INCINERATORS; MAXIMUM PERMISSIBLE CONCENTRATION; RADIOACTIVE WASTE DISPOSAL; RADIOACTIVE WASTE PROCESSING; RADIOACTIVE WASTES; UNDERGROUND DISPOSAL

585

Paschall, R.K.; Rockwell International, Atomics International Division, Canoga Park, CA

DECONTAMINATION AND DECOMMISGIONING CRITERIA FOR USE IN DESIGN OF NEW-PLUTONIUM FACILITIES. A1ERDA-13156; 123 pp. (1975)

12 references

Several plutonium facilities were decontaminated and decommissioned $(\mathrm{DD})$ during the past several yearrs; others are currenlly undergoing $D D$. This report assembles, investigates, and resnmmends design considerations for new plutonium facilities which will help to minimize the eventual $D D$ costs and time, and will help to leave the site for unrestricted future use. In addition to savings of cost and time, improved designs will reduce hazards and enhance safety during $D D$ operations. The investigations included literature searches and visits to many existing plutonium facilities around the country. The purposes of the visits were to: 1 ) view various types of facilities, 2) have discussions 
with experienced personnel, and 3) obtain applicable internal reports and letters of information.

SUBJECT CATEGORY: Remedial Action, Surplus Facilities; Remedial Action, FUSRAP; TRU

ORIGIN: Commercial

KEYWORDS: DECONTAMINATION; DECOMMISSIONING; PLUTONIUM; NUCLEAR FACILITIES; DESIGN; COST BENEFIT ANALYSIS

\section{6}

Field, F.R.; Savannah River Laboratory, Aiken, SC

DECOMMISSIONING PLAN FOR THE HEAVY WATER COMPONENTS TEST REACTOR. DP-MS-75-61; CONF750822-3;Decontamination and Decommissioning of ERDA Facilities, Proceedings of a Conference, Idaho Falls, ID, 1975, 23 pp. (1975)

Three alternatives to decommission the Heavy Water Components Test Reactor (HWCTR) have been analyzed. No final choice has been made between alternatives, and all are feasible. Selection of a plan for decommissioning will depend on criteria that are presently being formulated within ERDA and other regulatory bodies.

See Nuclear Science Abstracts 1975, 32(09) 23662

SUBJECT CATEGORY: Remedial Action, Surplus Facilities

ORIGIN: Defense

KEYWORDS: COMPARATIVE EVALUATIONS; COST; HWCTR REACTOR; RADIATION HAZARDS; REACTOR DECOMMISSIUNING; SAFETY

\section{$\mathbf{5 8 7}$}

Kelley, J.A., W.H. Hale, J.A. Stone, and J.R. Wiley; Savannah River Laboratory, Aiken, SC

SOLIDIFICATION AND STORAGE OF SAVANNAH RIVER PLANT RADIOACIIVE WASTE. DP-MS-75-19; CONF-751107-5; Sixtyeighth Annual Meeting of American Institute of Chemical Engineering, Los Angeles, California, 16 Nov 1975, 17 pp. (1975)

See Nuclear Science Abstracts 1976, 33(02) 02707
SUBJECT CATEGORY: HLW; LLW

ORIGIN: Defense; Commercial

KEYWORDS: CONCRETES; COST BENEFIT ANALYSIS; GLASS; LIQUID WASTES; RADIOACTIVE WASTE PROCESSING; RADIOACTIVE WASTE STORAGE; RADIOACTIVE WASTES; RUTHENIUM 106; SAVANNAH RIVER PLANT; SLURRIES; SOLIDIFICATION; ZEOLITES

588

Savannah River Laboratory, Aiken, SC

LWR SPENT FUEL DISPOSITION CAPABILITIES, 1975-1984.. ERDA-25; SRL Report. (1975).

The new spent fuel storage facilities are expected to be operational by the end of May 1976.

SUBJECT CATEGORY: Spent Fuel

ORIGIN: Commercial

KEYWORDS: LWR TYPE REACTORS; SPENT FUEL STORAGE; FORECASTING

589

Savannah River Laboratory, Aiken, SC

WASTE MANAGEMENT. SAVANNAH RIVER LABORATORY QUARTERLY REPORT, OCTOBER-DECEMBER 1975. DPST-75-125-4. (1975)

Available from NTIS

A conceptual process description for solidification of Savannah River Plant liquid wastes to glass monoliths in double-walled containers for retrievable surface storage was prepared and submitted to the Plant for design and cost studies. Initial results of long-term heating tests of six candidate container alloys indicate that all are compatible with glass or concrete waste forms. Equipment for obtaining 40-liter samples of plant waste supernate was constructed and used successfully to provide large volumes of supernate for tests of the conceptual waste solidification process. Dried, unwashed subsurface sludge from Tank $16 \mathrm{H}$ was analyzed for elemental composition and radionuclide content in support of sludge removal demonstrations scheduled for 1977. A computer program was developed 
to simulate steady-state operation of -wiped-film evaporators for the concentration of typical plant waste solutions during storage in waste tanks. Charges that would apply to storage of waste from MTR-type fuel were calculated. A study of the SSP was completed to determine the possible utility of the SSP at Savannah River; based on this study, application to Savannah River waste is not recommended.

\section{SUBJECT CATEGORY: HLW}

\section{ORIGIN: Defense}

KEYWORDS: COMPUTER CODES; CONTAINERS; COST; GLASS; LIQUID WASTES; MATERIAIS; RADIOACTIVE WASTE MANAGEMEN'T; RADIOACTIVE WASTE PROCESSING; RADIOACTIVE WASTE STORAGE; RESEARCH PROGRAMS; SAMPLERS; SAVANNAH RIVER PLAN'T; SOLIDIFICATION

590

Southern California Edison Co., Rosemead, CA

RESPONSE TO ITEM 2 - ESTIMATED DECOMMISSIONING COSTS. DOCKET-50206-368; Amendment 43 to San Onofre 1 License Application, (1 p.). (1975)

Available from - Magnagard, Inc., P.O. Box 3501, Oak Ridge, TN 37830

The estimated cost of permanently shutting down San Onofre Unit 1 is $\$ 26,000,000$. This cost represents the difference between the dismantling labor cost and material salvage value where: (1) the dismantling labor cost is estimated to be one-third of the original labor cost escalated to the year 2005 using $8 \%$ compound interest, and (2) the total material salvage value is estimated to be one-tenth of the original total material cost escalated to the year 2005 using $8 \%$ compound interest.

SUBJECT CATEGORY: Remedial Action, FUSRAP

ORIGIN: Commercial

KEYWORDS: ECONOMICS; PWR TYPE REACTORS; SAN ONOFRE-1 REACTOR; REACTOR DECOMMISSIONING; OPERATING LICENSES; OPERATING COST; COST
591

Southern California Edison Co., Rosemead, CA

RESPONSE TO ITEM 3 - ESTIMATED ANNUAL COST TO MAINTAIN THE SHUTDOWN FAILITY. DOCKET-50206-368; Amendment 43. to San Onofre 1 License Application, (1 p.). (1975)

Available from Magnagard, Inc., P.O. Box 3501, Oak Ridge, TN 37830

The estimated annual cost to maintain San Onofre Unit 1, once permanently shut down, in a safe condition is 910,000 . This cost represents the annual cost of security personnel escalated to the year 2005 using $8 \%$ compound interest. The costs associated with routine maintenance to ensure the physical integrity of the shutdown facility and the annual easement charges are comparatively negligible. The funds necessary to cover this annual cost could be obtained from system-wide operating revenues.

SUBJECT CATEGORY: Remedial Action, FUSRAP

ORIGIN: Commercial

KEYWORDS: PWR TYPE REACTORS; SAN ONOFRE-1 REACTOR; REACTOR DECOMMISSIONING; OPERATING LICENSES; OPERAT. ING COST

502

Pelser, J.; Stichting Reactor Centrum Nederland, The Hague

URANIUM ENRICHMENT. Atoomenerg. Haar 'I'oepass. 1'/:134-139. (1975')

In Dutch

See Nuclear Science Abstracts 1976, 32(12) 28109

SURBIECT CATEGORY: LLW

ORIGIN: Foreign

KEYWORDS: COST; ENRICHED URANIUM; GAS CENTRIFUGATION; GAS CENTRIFUGES; ISOTOPE SEPARATION; URANIUM ISOTOPES; URANIUM 235; WASTES 
593

Strickmann, G., and G. Modemann; Technische Hochschule Aachen, Inst. fuer Elektrische Anlagen und Energiewirtschaft, Germany, F.R.

INVESTIGATION FOR AN ECONOMICALLY OPTIMUM STRATEGY IN DISPOSING HIGHLY RADIOACTIVE WASTES. DEU-76-34. (1975)

26 figures; 17 tables; 37 references; In German

The free parameters for the total disposal process as well as for alternative plans are determined in this study by means of the minimum costs criterion. The individual steps of the disposal process are: storage of the liquid highly radioactive waste, glassing, storage of the glass blocks, transport of the glass blocks to the ultimate storage and embedding the glass blocks in the salt. The essential free paramters are the storage times in liquid and/or intermediate storage, the concentration of the fission products in the glass block and their measurements. The cost structure and influence of the process variables for the individual process stages are firstly described. A program system is then set up with whose help the optimum-cost parameters are determined even for alternative process strategies.

\section{SUBJECT CATEGORY: HLW}

ORIGIN: Foreign

KEYWORDS: COST; ECONOMICS; FISSION PRODUCTS; FUEL CYCLE; GLASS; OPTIMIZATION; RADIOACTIVE WASTE DISPOSAL; RADIOACTIVE WASTE PROCESSING; SALT DEPOSITS; SOLIDIFICATION; SYSTEMS ANALYSIS; RADIOACTIVE WASTE MANAGEMENT; RADIOACTIVE WASTE STORAGE

\section{4}

Greco, J., and J.L. Ingwersen; Tennessee Valley Authority, Chattanooga, TN

RADIOACTIVE WASTE: PLANT TO DISPOSAL. Proceedings of the American Power Association 37:205-212; CONF-750469; Annual American Power Conference, Chicago, IL, April 21, 1975. (1975)

See Nuclear Science Abstracts 1976, 33(10) 23883

SUBJECT CATEGORY: Transportation

ORIGIN: Commercial
KEYWORDS: CASKS; COST; DESIGN; FILTERS; LINERS; OPERATION; RADIOACTIVE WASTE DISPOSAL; RADIOACTIVE WASTE FACILITIES; TRUCKS; WASTE TRANSPORTATION

\section{5}

Toledo Edison Co., Toledo, $\mathrm{OH}$

RESPONSE TO QUESTION 010.7 - SOLID WASTE STORAGE AND RETENTION TIME. DOCKET 50500-32; Amendment 6 to Davis-Besse 2 3 License Application, (pp. 010.7-1 - 010.7-2). (1975)

The expected solid waste volumes and on-site storage capabilities will result in storage of two weeks for the expected quantities of waste. The storage time proposed is sufficient to provide for decay or short-lived radionuclides prior to shipment to ensure that doses to operators and handlers are ALAP.

\section{SUBJECT CATEGORY: LLW}

ORIGIN: Commercial

KEYWORDS: PWR TYPE REACTORS; SOLID WASTES; RADIOACTIVE WASTE MANAGEMENT; RADIOACTIVE WASTE STORAGE; CONTAINERS; DAVIS-BESSE-2 REACTOR; DAVIS-BESSE-3 REACTOR

\section{6}

Larson, H.J.; U.S. Atomic Energy Commission, Washington, DC

NUCLEAR FUEL CYCLE. CONF-7410119; AIF Public Affairs Workshop on Plutonium, Safeguards, and the Breeder, Plutonium, Safeguards, and the Breeder, Knoxville, Tennessee, October 8 1974. Atomic Industrial Forum, Inc., New York, NY, (pp. VP). (1975)

See Nuclear Science Abstracts 1975, 32(09) 24053

SUBJECT CATEGORY: Spent Fuel; TRU; HLW; LLW

ORIGIN: Defense; Commercial

KEYWORDS: ECONOMICS; FORECASTING; FUEL CYCLE; NUCLEAR POWER PLANTS; PLUTONIUM RECYCLE; RADIOACTIVE WASTE MANAGEMENT; REPROCESSING; 
SPENT FUEL STORAGE; SPENT FUELS; TRANSPORT

$\mathbf{5 9 7}$

U.S. Congress, Joint Committee on Atomic Energy, Washington, DC

NAVAL NUCLEAR PROPULSION PROGRAM, 1974. HEARING BEFORE THE JOINT COMMITTEE ON ATOMIC ENERGY CONGRESS OF THE UNITED STATES, NINETY-THIRD CONGRESS, SECOND SESSION. Hearing, February 25, 1974; 84 pp. (1975)

See Nuclear Science Abstracts 1975, 32(01) 02667

SUBJECT CATEGORY: General

ORIGIN: Defense

KEYWORDS: CONSTRUCTION; COST;EDUCATION; FOSSIL FUELS; HEARINGS; NUCLEAR FUELS; PERSONNEL; RADIOACTIVE WASTE DISPOSAL; REACTOR CORES; SHIP PROPULSION REACTORS; USA; USSR

598

Cohen, J.J., and R.G. (Ed.) Post; University of California, Livermore, CA; University of Arizona, Tucson, A7

SYSTEMS ANALYSIS APPROACH TO NUCLEAR WASTE MANAGEMENT PROBLEMS: WASTE MANAGEMENT' '75. . (1975)

4 tables, 6 figures

This paper discusses the application of systems analysis to the problem of risk assessment in nuclear waste management, specifically to off-gas treatment. Kr 85 causes more damage per curie than tritium, and therefore $\mathrm{Kr} 85$ control should be more costeffective than tritium control, yet most research is on tritium exposure. The fact that $\mathrm{Kr} 85$ release control is not presently required at fuel reprocessing plants shows the need for better guidelines.

SUBJECT CATEGORY: Mirborne

ORIGIN: Defense; Commercial

KEYWORDS: COST BENEFIT ANALYSIS; HAZARDS; HUMAN POPULATIONS; KRYPTON 85;
OFF-GAS SYSTEMS; RADIATION PROTEC. TION; RADIOACTIVE WASTE MANAGEMENT; SYSTEMS ANALYSIS; TRITIUM; RADIOAC TIVE AEROSOLS

599

Carter, R.L.; University of Missouri, Colu mbia, MO

NUCLEAR ENERGY: A PROTOTYPE FOR RESOURCE SALVAGE. Transactions of the American Nuclear Society 21:88-89; American Nuclear Society 1975 Annual Meeting, Transactions, New Orleans, LA, June 8, 1975. (1975)

See Nuclear Science Abstracts 1975, 32(5) 13697

SUBJECT CATEGORY: General

ORIGIN: Commercial; Defense

KEYWORDS: COST; ECONOMICS; RESEARCH PROGRAMS; RADIOACTIVE WASTE PROCESSING

600

Davidson, J.W., and E.L. Draper, Jr.; University of Texas, Austin, TX

COSTS FOR PARTITIONING STRATEGIES INVOLVED IN HIGH-LEVEL NUCLEAR WASTE MANAGEMENT. Transactions of the American Nuclear Society 22:348=350; American Nuclear Socicty 1975 Winter Mecting, San Francisco, CA, November 16, 1975. (1975)

See Nuclear Science Abstracts 1976, 33(09) 20896

SUBJECT CATEGORY: HLW

ORIGIN: General

KEYWORDS: COST; RADIOACTIVE WASTE MANAGEMENT; TRANSMUTATION; HIGHLEVEL RADIOACTIVE WASTES; ECONOMICS; RADIOACTIVE WASTE PROCESSING; REACTORS

601

US Nuclear Regulatory Commission, Washington, DC

NRC ISSUES DECISION IN 'AS LOW AS PRACTICABLE' RULEMAKING. NRC Pressure Release $75-108 ; 1$ p. (1975) 
The new regulation involves both design objectives and a cost-benefit analysis requirement to determine the point at which the costs of further reductions of radioactive emissions are not justified.

\section{SUBJECT CATEGORY: LLW}

ORIGIN: Commercial

KEYWORDS: ECONOMICS; RADIOACTIVE EFFLUENTS; COST BENEFIT ANALYSIS; REGULATIONS; US NRC

602

Mattila, L.J., and J.O. Stengard; Valtion Teknillinen Tutkimuskeskus, Ydinvoimatekniikan Lab., Otaniemi, Finland

INVENTORIES OF STABLE FISSION GASES AND RADIOLOGICALLY MOST IMPORTANT RADIOACTIVE FISSION PRODUCTS IN THE CORE OF A PRESSURIZED WATER REACTOR. VTT.YDI-15; 18 pp. (1975)

See Nuclear Science Abstracts 1976, 33(01) 02295

SUBJECT CATEGORY: HLW; LLW; Airborne

ORIGINः Foreign

KEYWORDS: BURNUP; FISSION PRODUCTS; GASEOUS WASTES; GASES; INVENTORIES; LOSS OF COOLANT; PWR TYPE REACTORS; RADIOACTIVE EFFLUENTS; REACTOR CORES

\section{3}

Larkin, D.L.; Washington Public Power Supply System, Richland, WA

ECONOMIC ANALYSIS OF SPENT-FUEL DISPOSITION ALTERNATIVES. Transactions of the American Nuclear Society 22:326; American Nuclear Society 1975 Winter Meeting, San Francisco, CA November 16, 197.5. (1975)

See Nuclear Science Abstracts 1976, 33(09) 19776

SUBJECT CATEGORY: Spent Fuel

ORIGIN: Commercial

KEYWORDS: COST; ECONOMICS; FUEL CY. CLE; REPROCESSING; SPENT FUEL STORAGE; SPENT FUELS
604

Seyfferth, L.; Zentralstelle fuer AtomkernenergieDokumentation (ZAED), EggensteinLeopoldshafen, Germany, F.R.

PLANNING FOR DECOMMISSIONING. CONF-7509129-61; AED-CONF-75-769-120; Nuclear Power Plant Project Planning and Implementation, Proceedings of a Meeting, Karlsruhe, Germany, F.R., September 17, 1975. (1975)

Available from NTIS (US Sales Only); With figs.

The following conclusions can be drawn: decommissioning of large commercial nuclear power plants is technically feasible. It can be done within the frame of licensing regulations. Costs for decommissioning will be high; however the overall economic advantages of nuclear power are not considerably influenced. Search for suitable storage facilities and transport methods for large quantities and large dimensions should be started in an early stage. Tools and processes for cutting and conditioning of large radioactive components are still to be developed in detail.

SUBJECT CATEGORY: Remedial Action, Surplus Facilities

ORIGIN: Foreign

KEYWORDS: COST; FEASIBILITY STUDIES; NUCLEAR POWER PLANTS; PLANNING; REACTOR DECOMMISSIONING; REACTOR DISMANTLING; REACTOR LICENSING; REGU. LATIONS

605

Borrowman, S.R., and P.T. Brooks

RADIUM REMOVAL FROM URANIUM ORES AND MILL TAILINGS. RI-8099. (1975)

Methods were investigated for removing radium from uranium mill tailings included sand-slimes separation and leaching with solutions of either hydrochloric acid or EDTA. Although a maximum permissible concentration of radium in mill tailings allowing unrestricted usage has not been promulgated in the United States, a value of about 10 picocuries of radium per gram appears not particularly hazardous. None of the radium removal methods tested were able to produce tailings meeting this value, and their cost were considerable. A method was devised for leaching both uranium and radium from several uranium ores using hydrochloric acid; however, sulfur contained in the 
ores apparently prevented complete radium extraction.

SUBJECT CATEGORY: Remedial Action, Mịll Tailings

ORIGIN: Commercial

KEYWORDS: RADIUM; MILL TAILINGS; RADIOACTIVE WASTE PROCESSING; RADIOACTIVE WASTES; COST; ECONOMICS

606

Commoner, B. (Ed.), H. (Ed.) Boksenbaum, and M. (Ed) Corr

ENERGY AND HUMAN WELFARE: A CRITICAL ANALYSIS. VOLUME I. THE SOCIAL COSTS OF POWER PRODUCTION. MacMillan Information, New York, NY. (1975)

Statements are presented of the Board of Directors of the American Association for the Advancement of Science and the Committee on Environmental Alterations. Following the Preface by Barry Commoner, eighteen papers are presented: Thermal Pollution and Its Control by Christopher T. Hill; Biologic Effects of Air Pollution by Robert Frank; Acid Rain by Gene E. Likens, F. Herbert Bormann, and Noye M. Johnson; Environmental Consequences of Extracting Coal by Michael Fortune; Reclamation of Strip Mine Spoil Banks in Wyoming by Morton May, Robert Lang, Leandro Lujan, Peter Jacoby, and Wesley 'Thompson; Oil Spills by Max Blumer, Howard L. Sanders, J. Fred Grassle, and George R. Hampson; Nuclear Power: Its Promise and Its Problems by Milton Shaw; Radioactivity from Fossil-Fuel and Nuclear Power Plants by J. E. Martin, E. D. Harward, D. T. Oakley, J. M. Smith, and P. H. Bedrosion; A Reevaluation of Reactor Safety by Daniel F. Ford; Management of Radioactive Wastes from the Use of Nuclear Fuel by George Berg; Storage of High Level Radioactive Wastes by William W. Hambleton; Plutonium and Public Health by Donald P. Geesaman; Radiation: The Invisible Casualties by John W. Gofman and Arthur R. Tamplin; The Need for National and International Systems to Provide Physical Security for Fissionable Materials by Theodore B. Taylor; and Nuclear Electric Power by Sheldon Novick.

SUBJECT CATEGORY: HLW; LLW; TRU

ORIGIN: Commercial; Defense
KEYWORDS: COAL MINING; CONSUMPTION RATES; CONTROL; ENERGY POLICY; ENERGY SOURCES; ENVIRONMENTAL EFFECTS; FOSSILFUEL POWER PLANTS; LAND RECLAMATION; NUCLEAR POWER PLANTS; OIL SPILLS; POLLUTION; POWER GENERATION; POWER PLANTS; PUBLIC HEALTH; RADIATION EFFECTS; RADIOACTIVE WASTE MANAGEMENT; RADIOACTIVE WASTE STORAGE; RADIOACTIVE WASTES; RADIOACTIVITY; SAFETY; SECURITY; SOCIO-ECONOMIC FACTORS; SOCIOLOGY

607

Daly, G.H., and A.F. Kluk

TRANSÜRANIÜM NUCLIDES IN THE ENVIRONMENT FROM MANAGEMENT OF SOLID RADIOACTIVE WASTE. HASL-291; Health and Safety Laboratory Environmental Quarterly, December 1, 1974 through March 1, 1975, E.P. Hardy, Jr., (pp. I-110 - I-126), 227 pp. CONF741017; CONF-741086; Proceedings of the ANS Winter Meeting, Washington, DC, October 27. November 1, 1974, 17 pp. (1975)

The volumes of transuranic waste produced and modes of disposal (including shallow land burial) as of 1974 are discussed.

Up to 20 percent of solid radioactive wastes which have been generated at ERDA sites may be contaminated with TRU nuclides. Prior to the requirement for 20-year retrievable storage in March 1970, solid waste contaminated with TRU nuclides was buried with other radioactive waste at carefully selected locations. A total of about $900 \mathrm{~kg}$ of TRU nuclides are contained in just over 1 million cubic meters of radioactive waste at these locations. Approximately $760 \mathrm{~kg}$ of TRU nuclides are contained in the buried waste, while the remainder is contained in the stored waste. Another $80 \mathrm{~kg}$ of TRU nuclides are contained at the five (5) commercial burial sites. All evidence to date indicates that TRU nuclides have not migrated significantly from their burial location. (Auth)

SUBJECT CATEGORY: TRU; Isolation

ORIGIN: Defense

KEYWORDS: RADIOACTIVE WASTE MANAGEMENT; PLUTONIUM; RADIOACTIVE WASTE STORAGE; RADIOACTIVE WASTE 
DISPOSAL; SOLID WASTES; TRANSURANIUM ELEMENTS; VOLUME; UNDERGROUND DISPOSAL; RADIONUCLIDE MIGRATION

608

Dlouhy, Z., J. Napravnik, and O. Safar

RADIOACTIVE WASTE MANAGEMENT IN NUCLEAR POWER PLANTS WITH WWERTYPE REACTORS. Nukleon 1:8-13. (1975)

In Czech

The possibilities of radioactive waste solidification in nuclear power plants with LWR reactors (of the WWER type) and the problems of their safe storage in Czechoslovakia are discussed. The most suitable method for the treatment of emitted sorbents and concentrates seems to be their incorporation in bitumen or concrete. In the disposal of solidified blocks all requirements should be met including the selection of suitable sites and of convenient methods of transportation. A preliminary economic estimate shows that the storage of bitumenincorporated wastes in trenches seems to be less expensive from the point of view of exploitation of the storage facility as well as from the point of view of investment.

SUBJECT CATEGORY: Isolation

ORIGIN: Foreign

KEYWORDS: BITUMENS; CEMENTS; COST; LIQUID WASTES; RADIOACTIVE WASTE DISPOSAL; RADIOACTIVE WASTE MANAGEMENT; RADIOACTIVE WASTE PROCESSING; RADIOACTIVE WASTE STORAGE; RADIOACTIVE WASTES; SOLIDIFICATION; UNDERGROUND DISPOSAL; WWER TYPE REACTORS

609

Farb, D., and S. Ward

\section{INFORMATION ABOUT HAZARDOUS WASTE MANAGEMENT FACILITIES. EPA/530/SW-145; 130 pp. (1975)}

Useful information for hazardous waste generators.

This compilation includes information concerning 64 known hazardous waste management facilities. Data are presented in a standard resume form under general categories of toxic chemical, flammable, radioactive, explosive and biological wastes. Information supplied in resumes include general background, wastes streams, waste handling and economics as well as comments and description of sources of information.

SUBJECT CATEGORY: General

ORIGIN: General

KEYWORDS: HAZARDS; RADIOACTIVE WASTE MANAGEMENT; ECONOMICS; WASTES; RADIOACTIVE WASTES

610

Finney, B.C., R.E. Blanko (Proj. Dr.), R.C. Dahlman, F.G. Kitts, and J.P. Witherspoon

CORRELATION OF RADIOACTIVE WASTE TREATMENT COSTS AND THE ENVIRONMENTAL IMPACT OF WASTE EFFLUENTS IN THE NUCLEAR FUEL CYCLE FOR USE IN ESTABLISHING “AS LOW AS PRACTICABLE" GUIDES-NUCLEAR FUEL REPROCESSING. ORNLTM-4901; 174 pp. (1975)

Numerous diagrams and graphical and tabular data are included. See also Nuclear Science Abstract 1975, 32(06) 13927; Cross Reference - ORNL 4922; ORNL-TM-4902; ORNL-TM-4903; Vol. 1; ORNL-TM-4903, Vol. 2; ORNL-TM-4904

A cost-benefit study was made to determine the cost and effectiveness of radioactive waste (radwaste) treatment systems for decreasing the release of radioactive materials from a model nuclear fuel reprocessing plant which processes lightwater reactor (LWR) fuels, and to determine the radiological impact (dose commitment) of the released materials on the environment. The study is designed to assist in defining the term "as low as practicable" in relation to limiting the release of radioactive materials from nuclear facilities. The base case model plant is representative of current plant technology and has an annual capacity of 1500 metric tons of LWR fuel. Additional radwaste treatment systems are added to the base case plant in a series of case studies to decrease the amounts of radioactive materials released and to reduce the radiological dose commitment to the population in the surrounding area. The cost for the added waste treatment operations and the corresponding dose commitments are calculated for each case. In the final analysis, radiological dose is ploted vs the annual cost for treatment of the radwastes. The status of the radwaste treatment methods used in 
the case studies is discussed. Much of the technology used in the advanced cases is in an early stage of development and is not suitable for immediate use. The methodology used in estimating the costs and the radiological doses, detailed calculations, and tabulations are presented in Appendix $A$ and ORNL-4992. (Auth)

SUBJECT CATEGORY: LLW; Airborne

ORIGIN: Commercial

KEYWORDS: COST BENEFIT ANALYSIS; FUEL REPROCESSING PLANTS; NUCLEAR FACILITIES; FILTERS; EVAYURATION; ADSORPTION; RADIOCHEMISTRY; SILVER; 'ZEOLITES; IODINE; GASES; LIQUID WASTES; SOLID WASTES; EVALUATION; THYROID; BONES; POPULATIONS; WHOLE BODY IRRADIATION; LWR TYPE REACTORS; DECONTAMINATION; GASEOUS WASTES; POWER REACTORS; DOSE COMMITMENTS

611

Franz, J.A., and L.L. Burger

POLYMERIC MEDIA FOR TRITIUM FIXATION. BNWL-B-430; 24 pp. (1975)

Report is geared mostly towards process descriptions. The leach data are not reported in IAEA standard format. 3 tables, 3 figures, 31 references. See also Nuclear Science Abstract 1976, 33(02) 03680

The synthesis and leach testing of bakelite, polyacrylonitrile and polystyrene for the fixation of tritium are presented in this report. In order to study the synthesis scheme and to study the properties of the polymers to be used for fixation, samples of phenolic resins, polyacrylonitrile, and hydrogenated polystyrene were prepared. The results of leach tests run using tracer quantities of tritium showed negligible release quantities after preliminary rinsing. The tests performed for this study indicate that only polystyrene and the phenolic resins warrant study in view of process feusibility, product properties, and cost. The thermal and radiation stability of the polymers is also discussed. Cost estimates for use of the polymeric media is compared in tabular form with other fixation and storage alternativcs.

SUBJECT CATEGORY: LLW

ORIGIN: Commercial
KEYWORDS: SOLIDIFICATION; TRITIUM; POLYMERS; POLYSTYRENE; RESINS; POLYACRYLATES; CONCRETES; COST BENEFIT ANALYSIS; BAKELITE; ENCAPSULATION; RADIOACTIVE WASTE PROCESSING; SYNTHESIS

612

Kirkpatrick, M.H.

TRITIUM FROM NUCLEAR REACTORS. EPRI-NP-3; 4 pp. (1975)

1 table, 1 figure, 1 references

Current estimates indicate that U.S. nuclear power reactors will discharge 1.5 million curies per yeur of tritium into the environment by 1980 and that reactor-produced tritium will exceed the natural global tritium inventory by the year 2000. Despite these seemingly large quantities, the resulting impact on the environment is negligible, and any proposed process or mechanism for concentrating tritium and disposing of it should be considered with this in mind.

\section{SUBJECT CATEGORY: LLW}

ÜRIGIN: Cōmmercial

KEYWORDS: RADIOACTIVE EFFLUENTS; TRITIUM; POWER REACTORS; REVIEWS; FORECASTING; VOLUME

\section{3}

Kochenov, A.S., and P. Gitsesku

THE COST OF NEUTRON IRRADIATION IN A RESEARCH REACTOR. Soviet Atomic Energy 37(6):1260-1261. (1975)

In order to minimize the cost of neutron irradiation, it is necessary to know the effect of the puwer level of a reactor on the amortization, operational, and fuel components of the costs. Those reactors in which one can obtain a high flux of thermal neutrons are of particular interest. Two types of reactor vessel are considered: light-water (with a light-water moderator and a beryllium reflector) and heavy-water (with a heavy-water moderator and reflector). The capital costs (including the costs of the reactor and the building) are shown. 
SUBJECT CATEGORY: LLW

ORIGIN: Foreign

KEYWORDS: RESEARCH AND TEST REACTORS; IRRADIATION PROCEDURES; NEUTRONS; COST BENEFIT ANALYSIS; COST; CAPITAL; OPERATING COST

614

Olivier, J.P.

SEA DISPOSAL OF PACKAGED RADIOACTIVE WASTES. Transactions of the American Nuclear Society 20:693-695; Proceedings of a European Nuclear Conference, Paris, France, Apr 21, 1975. (1975)

See Nuclear Science Abstracts 1975, 32(01) 01567

SUBJECT CATEGORY: General; Isolation

ORIGIN: Foreign

KEYWORDS: ECONOMICS; MARINE DISPOSAL; RADIOACTIVE WASTE DISPOSAL; SAFETY

615

Puechl, K.H.

NUCLEAR WASTE PROBLEM IN PERSPECTIVE. Nucl. Eng. Int. 20(236):950-954. (1975)

Dilution

In this paper, a quantitative assessment of radioactivity levels in nuclear wastes is presented. The author suggests that radioactive material be diluted with innocuous material as part of the waste treatment process.

SUBJECT CATEGORY: LLW; HLW; TRU

ORIGIN: Commercial

KEYWORDS: COST; FISSION PRODUCTS; MATHEMATICAL MODELS; NUCLEAR FU. ELS; NUCLEAR POWER PLANTS; PLUTONIUM 239; RADIOACTIVE WASTE DISPOSAL; RADIOACTIVE WASTE PROCESSING; RADIOACTIVE WASTES; URANIUM 235: URANIUM 238
616

Stewart, J.E., and M.K. Khandhar

RADWASTE REDUCTION TECHNIQUES FOR LWR GASEOUS EFFLUENTS. Transactions of the American Nuclear Society 20:649-654; Proceedings of the European Nuclear Conference, Paris, France, April 21, 1975. (1975)

See Nuclear Science Abstracts 1975, 32(01) 02215

SUBJECT CATEGORY: Airborne

ORIGIN: Defense; Commercial

KEYWORDS: BWR TYPE REACTORS; CONFIGURATION; COST; DESIGN; GASEOUS WASTES; OFF-GAS SYSTEMS; PWR TYPE REACTORS; RADIOACTIVE WASTE PROCESSING; SEPARATION PROCESSES

617

RSA JOINS 20-NATION NUCLEAR 'CLUB'. To the Point, (pp. 7-9). (1975)

See Nuclear Science Abstracts 1976, 33(12) 32224

SUBJECT CATEGORY: General

ORIGIN: Foreign

KEYWORDS: COST; ENRICHED URANIUM; KOEBERG-1 REACTOR; NUCLEAR POWER; RADIOACTIVE WASTE DISPOSAL; SOUTH AFRICA

\section{8}

NUCLEAR FUEL CYCLE: U.S. CAPITAL AND CAPACITY REQUIREMENTS, 19751985. Atomic Industrial Forum, Inc., New York, NY. (1975)

The capital needed to increase nuclear fuel cycle capacity during the next decade is estimated for four projected nuclear growth rates. These growth rates include the Presidential program for 200 additional nuclear power plants by 1985 , one growth rate which is larger than the Presidential program, and two smaller. This report also calculates the collateral capital required for initiating capacity needed after 1985 . Three areas of the fuel cycle will need 
substantial capital for expansion-mining and milling, enrichment, and reprocessing. Relatively modest capital investment will be necessary for the other steps in the nuclear fuel cycle (UF6 production, fuel fabrication, transportation, and waste management). It is concluded that over $\$ 12$ billion in capital investment may be needed for the nuclear fuel cycle in the 1975-1985 decade.

SUBJECT CATEGORY: General

ORIGIN: Commercial

KEYWORDS: CAPITAL; ECONOMICS; ENRICHMENT; FABRICATION; FORECASTING; FUEL CYCLE; INVESTMENT; MILLING; MINING; NUCLEAR FUELS; NUCLEAR POWER PLANTS; PRODUCTION; RADIOACTIVE WASTE MANAGEMENT; REPROCESSING; SPENT FUELS; TABLES; TRANSPORT; TRANSPORTATION SYSTEMS; URANIUM FLUORIDES; URANIUM ORES

\section{9}

URANIUM, PLUTONIUM AND THE GROWTH OF NUCLEAR POWER 1975 TO 2000. Roskill Information Services Ltd, London. (1975)
The contents cover: world uranium production, by countries (including information on exploration, development, reserves); refining and conversion; enrichment, fabrication; reprocessing; nuclear wastes; plutonium; estimated future demand for electricity and the growth of capacity in nuclear power stations; future demand for uranium fuel for power reactors; other uses; prices.

SUBJECT CATEGORY: TRU

ORIGIN: Foreign

KEYWORDS: CHARGES; ENRICHED URANIUM; EXPLORATION; FABRICATION; FORECASTING; ISOTOPE SEPARATION; NUCLEAR FUELS; NUCLEAR POWER; NUCLEAR POWER PLAN'I'S; UKE PKUL'ESSING; PLUTTUNIUM; PRODUCTION; RADIOACTIVE WASTES; REPROCESSING; URANIUM; URANIUM ORES; URANIUM RESERVES 


\section{6}

620

Koch, H., and A. Schober; Akademie der Wissenschaften der DDR, Zentralinstitut fuer Isotopen- und Strahlenforschung, Leipzig, Germany, F.R.

POSSIBILITIES OF THE EXTRACTION AND APPLICATION OF LOW-ACTIVITY FISSION PRODUCTS FROM HIGHACTIVITY NUCLEAR FUEL WASTES. Isotopenpraxis 12(2):49-56. (1976)

In German

The possibilities of an economical extraction and technical application of low-activity fission products (krypton, xenon, rhodium, palladium, ruthenium, technetium) from radioactive wastes are shown. A survey is presented on the production, properties and quantities of fission products in nuclear fuel, on their application, the demand to be expected by the year 2000 , and the supply from natural resources, as well as the economic prospects of pilot plants producing fission products.

SUBJECT CATEGORY: LLW; HLW

ORIGIN: Commercial

KEYWORDS: COST; ECONOMICS; FISSION PRODUCTS; FORECASTING; KRYPTON; PALLADIUM; QUANTITY RATIO; RADIOACTIVE WASTES; RHODIUM; RUTHENIUM; SEPARATION PROCESSES; SPENT FUELS; TECHNETIUM; XENON

\section{1}

Bingham, G.E., and T.K. Evans; Allied Chemical Corp., Idaho Chemical Programs - Operations Office, Idaho Falls, ID

FINAL SAFETY ANALYSIS REPORT FOR THE IRRADIATED FUELS STORAGE FACILITY. ICP-1052; 169 pp. (1976)

See Nuclear Science Abstracts 1976, 33(09) 19791.

SUBJECT CATEGORY: Spent Fuel

ORIGIN: Commercial
KEYWORDS: COST; IDAHO CHEMICAL PROCESSING PLANT; PEACH BOTTOM-1 REACTOR; RADIATION MONITORING; SPENT FUEL ELEMENTS; SPENT FUEL STORAGE; VRAIN REACTOR; SPENT FUELS; SAFETY

\section{2}

Allied-General Nuclear Services, Barnwell, SC

FUEL RECEIVING AND STORAGE STATION. NUCLEAR REGULATORY COMMISSION'S FINAL ENVIRONMENTAL STATEMENT. DOCKET-701729-7; NUREG-0008; 189 pp. (1976)

See Nuclear Science Abstracts 1976, 33(11) 25558

SUBJECT CATEGORY: General; Spent Fuel

ORIGIN: Commercial

KEYWORDS: BARNWELL FUEL PROCESSING PLANT; CHEMICAL EFFLUENTS; COST BENEFIT ANALYSIS; ENVIRONMENTAL EFFECTS; ENVIRONMENTAL IMPACT STATEMENTS; LICENSING; RADIATION MONITORING; RADIOACTIVE WASTES; REPROCESSING; SPENT FUEL STORAGE; SPENT FUELS

\section{3}

American Nuclear Society, Hinsdale, IL

NUCLEAR POWER AND THE ENVIRONMENT: QUESTIONS AND ANSWERS. Revised edition; American Nuclear Society Publication. (1976)

\section{2 references}

The purpose of this book is to present information and answers to questions about nuclear power and the environment, e.g., questions on its effects on public health, safety, and welfare. Information on the overall U.S. energy outlook, with emphasis on nuclear power generation, is provided. Although proponents of nuclear power, the authors have attempted to present factual information and to maintain objectivity. Included are answers to questions on these aspects of nuclear power: the energy situation and nuclear power; economics and reliability; alternative technologies; radioactivity; 
biological effects of radiation; transportation in the nuclear fuel cycle; fuel reprocessing and nuclear waste disposal; plutonium toxicity; nuclear plant security; thermal pollution; nuclear power plant siting-earthquakes; nuclear reactor safety; public risk and benefits; nuclear liability and insurance; breeder reactors; and thermonuclear fusion.

SUBJECT CATEGORY: General

ORIGIN: Commercial

KEYWORDS: BIOLOGICAL EFFECTS; BREEDER REACTORS; ECONOMICS; ENVIRONMENTAL EFFECTS; FUEL CYCLE; HAZARDS; INFORMATION; NUCLEAR ENERGY; NUCLEAR POWER PLANTS; PLUTONIUM; RADIOACTIVE WASTE DISPOSAL; RADIOACTIVITY; REACTOR LICENSING; REACTOR SAFETY; RELIABILITY; SECURITY; THERMAL POLLUTION; THERMONUCLEAR REACTIONS; TOXICITY; TRANSPORT

\section{4}

Vilks, G.; Atlantic Geoscience Centre, Bedford Institute of Oceanography, Dartmouth, Nova Scotia

THE DISPOSAL OF HIGH-LEVEL NUCLEAR WASTE IN THE OCEANS. Geoscience C'anada 3(4):295-298. (1976)

An international workshop on the feasibility of sea disposal of high-level waste was held at Woods Hole, MA, February 16-20, 1976. Areas of discussion covered current knowledge on disposal technology, what needs to be known and with what certainty, potential criteria for disposal decisions, and programs needed. Most criteria discussed at the workshop point to the centers of mid-latitude gyres as the safest disposal sites; they are regions of relative geologic statility, low organic productivity, and essentially homogeneous sediments. It is suggested that future studies include in situ experiments on the transfer of organic matter through marine ecosystems, studies of chemical and physical responses of sediments to heat and radioactivity, of interstitial fluid behavior and ion exchange in the sediments, mass fluidization by heat, and viscoelastic properties of the sediments. Sandia Laboratories and other institutions in the US have been conducting research to identify barriers to radionuclide migration in solidified waste, walls of containers, basement rock, sediment, the benthic boundary layer, and seawater. Waste emplacement schemes considered include use of a free-falling or winch-controlled penetrometer in unconsolidated sediments, and construction of boreholes accomodating up to 400 waste canisters and sealed with grout in bedrock. In the UK, British Nuclear Fuels, Ltd. is working with problems of solidification and emplacement of high-level waste, and has proposed dumping it at sea in containers within a few years of release from the reactor, letting it cool by contact with seawater; archaeological artifacts are being studied to identify materials with long-term resistance to seawater for use in containers. A model developed by the National Radiological Protection Board predicts that by $2000 \mathrm{AD}$ there will be about $400,000 \mathrm{~T}$ of waste worldwide, yielding $10(\mathrm{E}+9) \mathrm{Ci}$ of actinides and $10(\mathrm{E}+10) \mathrm{Ci}$ of fission products. Assuming all waste is vitrified and sea disposed, leaching immediately at $10(\mathrm{E}-5) \mathrm{g} / \mathrm{sq} \mathrm{m} /$ day, calculated ratios of the estimated annual intake of each radionuclude by man vs. the maximum permissable intake should be in the range of $10(\mathrm{E}-2)$ - $3 \times 10$ (E-6). Japan is conducting an intensive . feasibility study on the sea disposal of high-level waste, particularly liquid waste-impregnated concrete in drums. A brief statement of Canadian waste policy and of factors precluding the disposal of wastes in the Arctic Ocean or Canadian Arctic Archipelago was presented. Canadian participation in sea disposal research is strongly advocated.

SUBJECT CATEGORY: HI.W

ÓRİGIN: Foreign

KEYWORDS: MARINE DISPOSAL; HIGHLEVEL RADIOACTIVE WASTES: SEDIMENTS: CHEMICAL PROPERTIES; PHYSICAL PROPERTIES; RADIATION EFFECTS; RADIOACTIVE WASTE STORAGE: RADIOACTIVE WASTE MANAGEMENT; CONTAINMENT; FORECASTING; DOSE RATES; RECOMMENDATIONS; FEASIBILITY STUDIES; RADIOACTIVE WASTE DISPOSAI.

625

Burton, G.; Atlantic Richfield Hanford Co., Richland, WA

INTERIM PROGRAM FOR THE MANAGEMENT OF HIGH-LEVEL RADIOACTIVE LIQUID WASTE. ARH-SA-268; CONF-760684-1; Radioactive Waste Management National Academy of Sciences Committee Meeting, Richland, WA, June 24, 1976, 26 pp. (1976) 
Radioactive wastes have accumulated at Hanford since 1944 when the first reactor fuel was processed for plutonium recovery. These solutions containing primarily sodium, iron, zirconium, aluminum, carbonates, and nitrates were neutralized by the addition of caustic and placed in underground storage tanks. The fission product concentration of the solutions ranged from 0.4 to 20,000 curies per gallon. The corresponding average heat generation rates range from negligible to $10 \mathrm{btu} / \mathrm{hr} / \mathrm{gal}$. By mid-1977, this stored liquid waste inventory is projected to be essentially solidified except for: the volume of terminal liquid which is planned to be entirely stored in double-shell tanks.

SUBJECT CATEGORY: HLW

ORIGIN: Defense; Commercial

KEYWORDS: RADIOACTIVE WASTE MANAGEMENT; ENVIRONMENT; RADIOACTIVE WASTE STORAGE; INVENTORIES; RADIOACTIVE WASTES; LIQUID WASTES; RADIOAC'I'IVE WAS'IE PROCESSING; INVENTORIES

\section{6}

Geier, R.G.; Atlantic Richfield Hanford Co., Richland, WA

ESTIMATED HANFORD LIQUID WASTE CHEMICAL INVENTORY AS OF MARCH 31, 1976. ARH-CD-717. (1976)

Available from NTIS; 10 tables

The dilute liquid wastes at Hanford comprise a volume of 4.4 million gallons. The liquid contains $51.8 \times 10(E+6)$ gram moles $(8.8 \times 10(E+6)$ pounds) of sodium salts and 3.2 megacuries of $\mathrm{Cs} 137$.

SUBJECT CATEGORY: HLW; LLW

ORIGIN: Defense; Commercial

KEYWORDS: CESIUM 137; CHEMICAL COMPOSITION; HAPO; INVENTORIES; LIQUID WASTES; RADIOACTIVE WASTES; SODIUM COMPOUNDS; VOLUME

\section{7}

Tammemagi, H.Y.; Atomic Energy of Canada Ltd., Whiteshell Nuclear Research Establishment, Pinawa, Manitoba, Canada
GEOLOGICAL DISPOSAL OF RADIOACTIVE WASTES - THE CANADIAN DEVELOPMENT PROGRAM. AECL-5392. (1976)

Available from NTIS (US Sales Only); 8 references

The objective of the program described is to demonstrate the use of a mined cavity as a facility for the ultimate disposal of high-level radioactive wastes. Since the wastes will have to be safely contained for very lengthy periods, thorough and extensive field work is planned to search for a site and investigate the host rock. Laboratory research will also be performed to study the response of the host medium and the engineered cavity to the radiation and heat produced by the wastes. Potential hosts are plutonic crystalline rock, bedded salt, and serpentinite; the program places emphasis on the development of plutonic rock within the Precambrian Canadian Shield.

\section{SUBJECT CATEGORY: Isolation; HLW}

ORIGIN: Foreign

KEYWORDS: CANADA; COST; MINES; RADIOACTIVE WASTE DISPOSAL; RADIOACTIVE WASTE STORAGE; UNDERGROUND DISPOSAL

\section{8}

Manion, W.J., T.S. LaGuardia, and P. Garrett; Atomic Industrial Forum Inc., New York, NY; Automation Industries Inc.

AN ENGINEERING EVALUATION OF NUCLEAR POWER REACTOR DECOMMISSIONING ALTERNATIVES - SUMMARY REPORT. AIF/NESP-009SR; 35 pp. (1976)

Available From - Atomic Industrial Forum Inc., Public Affairs Information Program, 7101 Wisconsin Ave., Washington, DC

The purpose of this generic study is to provide detailed engineering information that will permit utilities to evaluate reactor decommissioning. This study addressed PWRS, BWRS, and HTGRS looking at 3 primary decommissioning alternatives and 2 combination alternatives - mothballing; entombing; prompt removal/dismantling; mothballing-delayed removal/dismantling combination; and entombing-delayed/dismantling combination. For each of the 3 primary alternatives, the objectives of the study were: detailed descriptions of 
work procedures and end products; estimates of costs including sensitivity and reliability analyses; estimates of occupational exposures; identification of generic environmental effects, and identification of regulations and guidelines.

SUBJECT CATEGORY: Remedial Action, Surplus Facilities

ORIGIN: Commercial

KEYWORDS: DECOMMISSIONING; BWR TYPE REACTORS; PWR TYPE. REACTORS; HTGR TYPE REACTORS; ECONOMICS; ENVIRONMENT; REGULATIONS; RELIABILITY; SENSITIVITY

629

Mullarkey, T.B., T.L. Jentz, J.M. Connelly, and J.P. Kane; Atomic Industrial Forum, Inc., National Environmental Studies Project, New York, NY

ALTERNATIVE RADWASTE TREATMENT METHODS AND PROJECTIONS. AIF/NESP008; A Survey and Evaluation of Handling and Disposal of Solid Low-Level Nuclear Fuel Cycle Wastes, Section 2, (pp. 19-29), 143 pp. (1976)

Tables and figures included

Processes for reducing the volume of current wastes and improving the processing of liquids are identified and evaluated using the $1000 \mathrm{MWe}$ reactor plant as a standard. The processes include incineration, horizontal wiped-film evaporators, vertical thin-film dryer, crystallizer, extruder-evaporator, calciner, acid digestion, improved compaction, and improved solidification. Incineration, vertical thinfilm dryer, extruder-evaporator, and acid digestion are not considered economically feasible at this time. Those not listed above are economically feasible now or should be incorporated with the newer plants. As an alternative to new process methods the waste systems should be designed with the "worst case" in mind for expansion. Operations minimizing waste generation, maximum waste packaging, and segregation of contaminated materials should be practiced.

SUBJECT CATEGORY: LLW

URIGIN: Commercial

KEYWORDS: CALCINATION; CEMENTS; CONCRETES; CONTAINERS; COST BENEFIT AN-
ALYSIS; EVAPORATION; EVAPORATORS; FIL TERS; COMBUSTION; SOLIDIFICATION; RADIOACTIVE WASTE PROCESSING; NUCLEAR FACILITIES; NUCLEAR POWER; RESINS; REACTORS; VOLUME; RADIOACTIVE WASTE MANAGEMENT; LIQUID WASTES; LOW-LEVEL RADIOACTIVE WASTES; SOLID WASTES

630

Buttedahl, O.I., and K. Terada; Atomics International, Rocky Flats Plant, Golden, CO

VOLUME REDUCTION OF CONTAMINATED FILTER WASTES. Fourteenth ERDA Air Cleaning Conference, Paper 2-1, Sun Valley, ID, August 2-4, 1976, 6 pp. (1976)

Reported are details of a pilot project to design and construct a compactor to reduce the handling of high efficiency particulate air (HEPA) filters used in air filtration systems at facilities where radioactive materials are processed. In such systems at Rocky Flats Plant, filters require frequent change and removal. Large quantities are used and will be increased for future operations. With the completion of the pilot model, it has been demonstrated that volume reduction of more than 80 percent can be achieved and cost savingo will be realized also.

\section{SUBJECT CATEGORY: LLW}

ORIGIN: Defense

KEYWORDS: AIR CLEANING; RADIOACTIVE WASTE PROCESSING; ROCKY FLATS PLANT; FUEL REPROCESSING PLANTS; COST; VOLUME; RADIOACTIVE MATERIALS; GASEOUS WASTES

631

Babcock and Wilcox, Lymchburg, VA

RESPONSE TO QUESTION 010.3 - QUANTITIES CONCENTRATION OF RADIOACTIVE MATERIAL DURING OPERATIONS. DOCKET-STN-50561-11; Amendment 1 to Babcock and Wilcox B-SAR-205 License Application, (p. 010.3-1). (1976)

Concentrations and certain batch volumes from the NSS are specified or referenced in section 5.7.16; 6.3.6, item 16; 9.3.4.1.4, item 16; 9.3.4.2.2, item 16; 
and 9.3.6.6.16. The maximum relief valve discharge during anticipated operational occurrences is given in section 5.5.11. Leakage to the reactor building and auxiliary building is specified in section 11.1.5.

\section{SUBJECT CATEGORY: LLW}

ORIGIN: Commercial

KEYWORDS: B-SAR REACTOR; PWR TYPE REACTORS; RADIOACTIVE WASTE MANAGEMENT; RADIOACTIVE EFFLUENTS

\section{2}

Finnigan, J.W.; Battelle Pacific Northwest Laboratory, Richland, WA

U.S. DOMESTIC HIGH LEVEL WASTE MANAGEMENT SYSTEM. CONF-760341-1; BNWLSA-5725; Fuel Cycle Conference, Phoenix, AZ, March 21, 1976. (1976)

Spray solidification and fluidized-bed calcination; Available from NTIS

The following aspects of radioactive waste management are discussed: techniques for solidifying or fixing the high-level waste; transport of the fixed waste to a federal repository; the characteristics of the solidified waste; an interim storage technique for these wastes at the federal repository; and a rough estimate of costs.

\section{SUBJECT CATEGORY: HLW}

ORIGIN: Commercial; Defense

KEYWORDS: CALCINATION; COST; FLUID. IZED BED; RADIOACTIVE WASTE MANAGEMEN'I; RADIOACTIVE WASTE PROCESSING; RADIOACTIVE WASTE STORAGE; SOLIDIFICATION; HIGH-LEVEL RADIOACTIVE WASTES

633

Franz, J.A., and L.L. Burger; Battelle Pacific Northwest Laboratory, Richland, WA

POLYMERIC MEDIA FOR TRITIUM FIXATION. BNWL-B-430(Suppl.1); 8 pp. (1976)

1 table, 13 references
Procedures for the fixation of tritium as Th or Tho in two different polymeric media are described. The complete procedure for $\mathrm{ThO}$ fixation in a polyureylene-polyurethane polymer, including polymer molding procedures and leach tests is presented. The catalytic tritiation of polystyrene under very mild conditions using a rhodium catalyst is also described. Thermal stabilities and cost estimates for the polymers examined under this program are discussed. Organic polymers were found to have attractive features for the fixation and storage of concentrated tritium wastes due to the convenience of fixation procedures and favorable properties of the resulting media.

\section{SUBJECT CATEGORY: LLW}

ORIGIN: Commercial; Defense

KEYWORDS: TRITIUM; RADIOACTIVE WASTE DISPOSAL; RADIOACTIVE WASTE PROCESSING; COST; .SOLIDIFICATION; POLYMERS

634

King, R.R., V.C. Asmund, and H.L. Butts; Battelle Pacific Northwest Laboratory, Richland, WA

DETAILED PLAN FOR THE DECONTAMINATION AND RESTORATION OF THE 231Z FACILITY. BNWL-B-479. (1976)

Available from NTIS

The detailed plan, special considerations, and time schedule and cost estimate are given for the decontamination and restoration of the 231-Z facility for use as a nonplutonium ERDA laboratory,

SUBJECT CATEGORY: Remedial Action, Surplus Facilities

ORIGIN: Defense

KEYWORDS: COST; DECONTAMINATION; GLOVEBOXES; NUCLEAR FACILITIES; NUCLEAR MATERIALS MANAGEMENT; RADIATION PROTECTION; VENTII.ATION

635

Platt, A.M.; Battelle Pacific Northwest Laboratory, Richland, WA 
NUCLEAR WASTE MANAGEMENT AND TRANSPORTATION QUARTERLY PROGRESS REPORT JANUARY - MARCH 1976. BNWL-2029; 55 pp. (1976)

\section{1 tables, 25 figures}

This is one of a series. Topics reported are: (1) alternative waste management systems; (2) decontamination and densification of chop-leach cladding residues; (3) tritium separation and fixiation; (4) disposition (DD) of retired contaminated facilities at Hanford; (5) transportation safety studies; (6) transport problems, 1976-2000; (7) safety and economic study of special trains and (8) development of high-level waste shipping cask models.

SUBJECT CATEGORY: Remedial Action, Surplus Facilities; Transportation; HLW; Airborne

ORIGIN: Defense

KEYWORDS: DECONTAMINATION; CONTAINERS; TRITIUM; TRANSPORT; RADIOACTIVE WASTE MANAGEMENT; ECONOMICS; FUEL DENSIFICATION; CASKS; HIGH-LEVEL RADIOACTIVE WASTES; DECOMMISSIONING

\section{6}

Platt, A.M.; Battelle Pacific Northwest Laboratory, Richland, WA

NUCLEAR WASTE MANAGEMENT AND TRANSPORTATION QUARTERLY PROGRESS REPORT, OCTOBER-DECEMBER 1975. BNWL-1978. (1976)

Available from NTIS

Research is reported on advanced methods for waste management and disposal, decontamination and densification of chop-leach cladding residues, pyrolysis-incineration of combustible alpha wastes, tritium separation and fixation, disposition of retired contaminated facilities at Hanford, transportation safety studies, safety and economics of special trains, and high-level waste shipping cask models.

SUBJECT CATEGORY: Remedial Action, Surplus Facilities; Transportation; HLW

ORIGIN: Defense
KEYWORDS: CASKS; COMBUSTION; DECONTAMINATION; ECONOMICS; EQUIPMENT; PYROLYSIS; RADIOACTIVE WASTE MANAGEMENT; RESEARCH PROGRAMS; SAFETY; SEPARATION PROCESSES; SOLIDIFICATION; SPENT FUELS; TRAINS; TRANSPORT; TRITIUM; WASTE TRANSPORTATION

\section{7}

Platt, A.M.; Battelle Pacific Northwest Laboratory, Richland, WA

ALTERNATIVES FOR MANAGING POST LWR REACTOR NUCLEAR WASTES. CONF760310-6; BNWL-SA-5737; Management of Radioactive Wastes, Proceedings of the IAEA Symposium, Vienna, Austria, March 22, 1976. International Atomic Energy Agency, Vienna, Austria: (1976)

Available from NTIS

The two extremes in the LWR fuel cycle are discarding the spent fuel and recycling the $U$ and $\mathrm{Pu}$ to the maximum extent possible. The waste volumes frum lle lwo allernatives are compared. A preliminary evaluation is made of the technology available for handling wastes from each step of the fuel cycle. The wastes considered are fuel materials, high-level wastes, other liquids, combustible and noncombustible solids, and non-high-level wastes. Evaluation of processing gaseous wastes indicates that technology is available for capture of $\mathrm{Kr}$ and I 2 , bui furllier develupurenl is needed för T2. Technology for interim storage and geological isolation is considered adequate. An outline is given of the steps in the selection of a final storage site.

SUBJECT CATEGORY: HLW; LLW; Airborne; Spent Fuel; 'I'RU

ORIGIN: Defense

KEYWORDS: BWR TYPE REACTORS; FEASIBILITY STUDIES; GASEOUS WASTES; IODINE; KRYPTON; LIQUID WASTES; RADIOACTIVE WASTE DISPOSAL; RADIOACTIVE WASTE MANAGEMENT; RADIOACTIVE WASTE PROCESSING; RADIUAC'IIVE WASTE STORAGE; SOLID WASTES; TRITIUM 
638

Platt, A.M.; Battelle Pacific Northwest Laboratory, Richland, WA

NUCLEAR WASTE MANAGEMENT AND TRANSPORTATION QUARTERLY PROGRESS REPORT, JANUARY-MARCH 1976. BNWL-2029. (1976)

Available from NTIS

Progress is reported in the following areas: Alternative waste management systems; decontamination and densification of chop-leach cladding residues; tritium separation and fixation; disposition of retired contaminated facilities at Hanford; transportation safety studies; transport problems, 1976 2000; safety and economic study of special trains; and development of high-level waste shipping cask models.

SUBJECT CATEGORY: HLW; Remedial Action, Surplus Facilities; Transportation

ORIGIN: Defense

KEYWORDS: BATTELLE PACIFIC NORTHWEST LABORATORIES; CASKS; DECONTAMINATION; ECONOMICS; FUEL CYCLE; GEO. LOGIC DEPOSITS; RADIOACTIVE WASTE MANAGEMENT; RADIOACTIVE WASTE PROCESSING; RADIOACTIVE WASTES; RADIONUCLIDE MIGRATION; RESEARCH PROGRAMS; SAFETY; TRAINS; TRITIUM; WASTE TRANSPORTATION

\section{9}

Platt, A.M.; Battelle Pacific Northwest Laboratory, Rlchland, WA

NUCLEAR WASTE MANAGEMENT AND TRANSPORTATION QUARTERLY PROGRESS REPORT, APRIL-JUNE 1976. BNWL-2126. (1976)

Available from NTIS

Status of the following programs is reported: Alternative waste management systems; decontamination and densification of chop-leach cladding residues; disposition of retired contaminated facilities at Hanford; transportation safety studies; transport problems, 1976-2000; safety and economic study of special trains; and development of highlevel waste shipping cask models.
SUBJECT CATEGORY: Remedial Action, Surplus Facilities; HLW; Transportation

ORIGIN: Defense

KEYWORDS: CASKS; DECONTAMINATION; DESIGN; ECONOMICS; RADIOACTIVE WASTE MANAGEMENT; RADIOACTIVE WASTES; RESEARCH PROGRAMS; SAFETY; TRAINS; TRANSPORT; WASTE TRANSPORTATION

\section{0}

Scheele, R.D., and L.L. Burger; Battelle Pacific Northwest Laboratory, Richland, WA

ZIRCONIUM HYDRIDE AS A STORAGE MEDIUM FOR TRITIUM. BNWL-2083; 22 pp. (1976)

7 figures, 21 references

Two alternate sets of conditions were found to produce a hydride of suitable physical integrity for tritium storage, one of which produced an essentially crack-free hydride. Small amounts of air in the hydrogen were found to have a deleterious effect. The cost of zirconium is a disadvantage, but the use of scrap or irradiated zircaloy cladding hulls would lessen the disadvantage. Leach testing and pyrophoricity studies on the hydride should be carried out.

SUBJECT CATEGORY: LLW

ORIGIN: Defense

KEYWORDS: HYDROGEN; TRITIUM; RADIOACTIVE WASTE STORAGE; ZIRCONIUM; HYDRIDES; ZIRCALOY; ZIRCONIUM HY. DRIDES

641

Zima, G.E.; Battelle Pacific Northwest Laboratory, Richland, WA

A BRIEF ASSESSMENT OF SOME TECHNICAL AND RADIOLOGICAL HAZARD FAC. TORS AFFECTING CLAD WASTE MANAGEMENT. BNWL-2104; 39 pp. (1976)

This report addresses primarily high-level and clad wastes. Applicable to shallow land burial in that some facilities, e.g. Nuclear Fuel Services, have disposed of clad wastes by shallow land burial. 
For the clad waste, two fuel models are used for the volume comparison, namely, the reference fuel assembly (RFA) and the Diablo Canyon reference fuel model (DC). The more extensive data available for the Diablo Canyon model of radioactivity and thermal power are used in the comparison of these indices. Most of this review pertains to a burnup of $33 \mathrm{GWD} / \mathrm{MT}$ because of the predominance of this particular burnup in waste management literature. Comparison of the projected total volume of clad waste generated between 1979 and 1999 , as projected by the 2 models, showed a range of $61.0 \mathrm{cu} \mathrm{m}$ $64.4 \mathrm{cu} \mathrm{m}$. A brief analysis is given on the effect of burnup and fuel model on certain clad waste characteristics.

SUBJECT CATEGORY: Spent Fuel; HLW

ORIGIN: Commercial; Defense

KEYWORDS: LWR TYPE REACTORS; DIABLO CANYON-1 REACTOR; RADIOACTIVE WASTE MANAGEMENT; CLADDING; VOLUME; BURNUP

\section{2}

Battelle Pacific Northwest Laboratory, Richland, WA

GEOLOGIC STORAGE ALTERNATIVES. BURIAL GROUNDS. ERDA-76-43; Alternatives for Managing Wastes from Reactors and PostFission Operations in the LWR Fuel Cycle, Vol. 4, (pp. 24.1-24.49). (1976)

Tables containing commercial burial ground operations, waste inventories, licensing of commercial sites, site characteristics; ERDA burial ground operations, waste inventories, and site characteristics are included. Monitoring programs are also tabulated.

Current disposal practices at the 6 commercial facilities and 5 ERDA sites for burial of wastes are brefly discussed. Burial in this instance is understood to mean "placement of waste at relatively shallow depths in earth materials, with no intent or provision for ready retriveability at a later date. Chem-Nuclear Systems, Inc. operates a commercial site at Barnwell, SC while Nuclear Fuel Services operates one at West Valley, NY. The rest of the commercial sites are run by Nuclear Engineering Company at Sheffield, IL; Beatty, NV; Richland, WA; and Morehead, KY. The wastes generally accepted at these sites are low-level and come from the nuclear fuel cycle, educational institutions, hopitals, government installations, industrial research and production facilities, pharmaceutical manufacturers and waste disposal and decontamination companies. The exact wastes accepted, waste packaging required, waste treatment, burial procedures, special burial techniques, disposal location markings and records, burial site inventory, burial charges, licensing, and hydrologic characteristics are outlined in detail. A similar discussion of the wastes disposed of in the 5 ERUA sites is also presented. The ERDA sites are: Savannah River Laboratory, SC; Idaho National Engineering Laboratory, ID; Oak Ridge National Laboratory, TN; Hanford, WA; and Los Alamos Scientific Laboratory, NM. Decommissioning, perpetual care, and resource commitments are also included in the topio lists. Although no hazards have been found as a result of leakage from the above burial grounds better retention can be had by improved: engineered containment, administrative measures and decommissioning. Finally, increased containment of radwastes by a burial site may be had by a better understanding of the geology and hydrology of the area and in what region the site is to be located.

SUBJECT CATEGORY: Isolation; LLW

ORIGIN: Commercial; Defense; Institutional

KEYWURDS: BIUSPHERE; CEMENTS; CLAYS; CONTAINMENT; CONTAMINANTS; COST BENEFIT ANALYSIS; DECOMMISSIONING; DOSE RATES; ECONOMICS; ENVIRONMENT; GEOLOGY; GROUND WATER; HAZARDS; HY. DROI.OGY; MONITORING; RADIONUCLIDE MIGRATION; SOILS; RADIOACTIVE WASTE DISPOSAL; RADIOACTIVE WASTE MANAGEMENT; LOW-LEVEL RADIOACIIVE WASTES; PACKAGING; VOLUME; INVENTORIES; GROUND DISPOSAL

643

Battelle Pacific Northwest Laboratory, Richland, WA

ALTERNATIVE PROCESSES FOR MANAGING EXISTING COMMERCIAL HIGHLEVEL RADIOACTIVE WASTES. NU. REG-0043. (1976)

Available from NTIS

A number of alternatives are discussed for managing high-level radioactive waste presently stored at 
the West Valley, New York, plant owned by Nuclear Fuel Services, Inc. These alternatives (liquid storage, conversion to cement, shale fracturing, shale cement, calcination, aqueous silicate, conversion to glass, and salt cake) are limited to concepts presently under active investigation by ERDA. Each waste management option is described and examined regarding the status of the technology; its applications to managing NFS waste; its advantages and disadvantages; the research and development needed to implement the option; safety considerations; and estimated costs and time to implement the process.

\section{SUBJECT CATEGORY: HLW}

ORIGIN: Commercial

KEYWORDS: CALCINATION; CEMENTS; COST; GLASS; LEACHING; RADIOACTIVE WASTE MANAGEMENT; RADIOACTIVE WASTE PROCESSING; SAFETY; SALT DEPOSITS; SILICATES; SOLIDIFICATION; VOLATIL ITY; WEST VALLEY PROCESSING PLANT

\section{4}

Battelle Pacific Northwest Laboratory, Richland, WA

ALTERNATIVES FOR MANAGING WASTES FROM REACTORS AND POST-FISSION OPERATIONS IN THE LWR FUEL CYCLE. VOLUME 1. SUMMARY: ALTERNATIVES FOR THE BACK OF THE LWR FUEL CYCLE TYPES AND PROPERTIES OF LWR FUEL CYCLE WASTES PROJECTIONS OF WASTE QUANTITIES; SELECTED GLOSSARY. ERDA-76-43(Vol.1). (1976)

Available from NTIS

Volume I of the five-volume report contains executive and technical summaries of the entire report, background information of the LWR fuel cycle alternatives, descriptions of waste types, and projections of waste quantities. Overview characterizations of alternative LWR fuel cycle modes are also included.

SUBJECT CATEGORY: LLW; HLW; Spent Fuel

ORIGIN: Commercial

KEYWORDS: BWR TYPE - REACTORS; DIAGRAMS; FABRICATION; FISSION PRODUCTS;
FORECASTING; FUEL CYCLE; LIQUID WASTES; NUCLEAR FUELS; PWR TYPE REACTORS; RADIOACTIVE WASTE MANAGEMENT; RADIOACTIVE WASTE PROCESSING; RADIOACTIVE WASTES; REPROCESSING; REVIEWS; SOLID WASTES; SPENT FUELS; TABLES

\section{5}

Burger, L.L., and L.E. Trevorrow; Battelle Pacific Northwest Laboratory, Richland, WA; Argonne National Laboratory, Argonne, IL

RELEASE OF TRITIUM FROM FUEL AND COLLECTION FOR STORAGE. CONF. 760806-3; BNWL-SA-5778; Controlling Airborne Effluents from Fuel Cycle Plants, Proceedings of a Meeting, Sun Valley, ID, August 5, 1976. (1976)

Recent work is reviewed on the technology that has been suggested as applicable to collection and storage of tritium in anticipation of the necessity of that course of action. Collection technology and procedures must be adapted to the tritium-bearing effluent and to the facility from which it emerges. Therefore, this discussion of tritium collection technology includes some information on the processes from which release is expected to occur, the amounts, the nature of the effluent media, and the form in which tritium appears. Recent work on collection and storage concepts has explored, both by experimentation and by feasibility analyses, the operations generally aimed at producing recycle, collection, or storage of tritium from these streams. Storage concepts aimed specifically at tritium involve plans to store volumes ranging from that of the entire effluent stream to only that of a small volume of a concentrate. Decisions between storage of unconcentrated streams and storage of concentrates are expected to be made largely by weighing the cost of storage space against the cost of concentration. The storage of tritium concentrate requires the selection of a form of tritium possessing physical and chemical properties appropriate for the expected storage conditions. This selection of an appropriate storage form has occupied a major portion of recent work concerned with tritium storage concepts. In summary, within the context of present regulations and expected amounts of waste tritium; this waste can be disposed of by dilution and dispersal to the environment. In the future, however, more restrictive regulations might be introduced that could be satisfied only by some collection and storage operations. Technology for this practice is not now available, and the present 
discussion reviews recent activities devoted to its development.

\section{SUBJECT CATEGORY: LLW}

\section{ORIGIN: Defense}

KEYWORDS: AIR POLLUTION; COST; ENVIRONMENTAL EFFECTS; FUELS; RADIOACTIVE WASTES; REGULATIONS; SURFACE WATERS; TRITIUM; RADIOACTIVE WASTE STORAGE; WATER POLLUTION; LOW-LEVEL RADIOACTIVE WASTES

\section{6}

Sunder Rajān, N.S., V. Ravindranath, M.S. Kumra, M.K. Sinha Ray, and K.T. Thomas; Bhabha Atomicic Research Center, Trombay, Bombay, India

LONG-TERM PLANNING FOR MANAGEMENT OF AQUEOUS WASTES FROM FUEL REPROCESSING PLANTS. CONF-760310; STI/PUB/433; IAEA-SM-207/47; Management of Radioactive Wastes from the Nuclear Fuel Cycle, Proceedings of an Symposium, Vol. 1, Vienna, Austria, March 22-26, 1976. International Atomic Energy Agency, Vienna, Austria, (pp. 15-22), 397 pp. (1976)

This paper reviews Indian policy regarding management of high-and intermediate-level liquid wastes from fuel reprocessing plants, and attempts to estimate the generation of such wastes over the next 25 years. Methods for treatment and disposal of wastes are discussed, including interim storage, incorporation of waste salts in bitumen, solidification of high-level wastes, and ultimately geologic storage/disposal. As reported in an earlier paper, experimental solidification of high-level waste oxides in borosilicate matrices has yielded products with melting ranges of 1000 to 1100 degrees $C$. and leach rates of $10(\mathrm{E}-5)$ to $10(\mathrm{E}-6) \mathrm{g} \mathrm{cm}(\mathrm{E}-2) \mathrm{d}(\mathrm{E}-1)$. Waste oxide incorporation is approximately $25 \%$. Long term studies of the behavior of these melts under intense radiation and thermal stresses are ongoing. Another major consideration has been the management of actinide-bearing wastes. Research is continuing on separation of actinides before waste solidification, or, alternatively, conversion of actinide-bearing wastes into insoluble aluminosilicates.

SUBJECT CATEGORY: HLW

ORIGIN: Foreign
KEYWORDS: CONCENTRATION; CONTAINMENT; EVAPORATION; FUEL REPROCESSING PLANTS; BREEDER REACTORS; REPROCESSING; SOLIDIFICATION; RADIOACTIVE WASTE STORAGE; RADIOACTIVE WASTE MANAGEMENT; HIGH-LEVEL RADIOACTIVE WASTES; INTERMEDIATE-LEVEL RADIOACTIVE WASTES; LIQUID WASTES; SOLID WASTES; ACTINIDES; THORIUM; URANIUM; PLUTONIUM

\section{7}

Allday, C.; British Nuclear Fuels Ltd., London, England

NUCLEAR FUEL OPER̃ATIONS: NUCLEAR POWER AND THE PUBLIC INTEREST: THE IMPIICATION FOR BUSINESS. Financial Times July 8, 1976. (1976)

The operations of the British Nuclear Fuels Limited are discussed against the background of the title of the Conference. The subject is treated under the following heads: economics of nuclear power; nuclear fuel cycle (uranium, uranium ore concentrate to uranium hexafluoride conversion, enrichment, fuel fabrication, reprocessing); environmental issues (fission product storage, plutonium).

SUBJECT CATEGORY: General; TRU; HLW

ORIGIN: Foreign

KEYWORDS: ECONOMICS; ENVIRONMENT; FABRICATION; FUEL CYCLE; HAZARDS; ISOTOPE SEPARATION; NUCLEAR FUELS; NUCLEAR INDUSTRY; NUCLEAR POWER; PLUTONIUM; RADIOACTIVE WASTE STORAGE; REPROCESSING; URANIUM

\section{8}

Gangwer, T.; Brookhaven National Laboratory, Upton, NY

PARTITIONING OF ACTINIDE ELEMENTS FROM HIGH-LEVEL WASTE USING LASER PHOTOCHEMICAL METHODS. CONF760642-3; BNL-21456; Nuclear Regulatory Commission Partitioning Workshop, Seattle, WA, June 8, 1976. (1976)

Available from NTIS 
The feasibility of photochemically fractionating the actinides in nuclear waste processing has been evaluated on a preliminary basis. The data indicate that there are potentially useful photo-redox reactions. However, there is a serious lack of data on photochemical parameters for the solutions conditions which exist in nuclear waste processing. The problem areas relevant to photochemical processing are identified. The experimental areas which must be investigated in order to further evaluate the photochemistry are defined. A research and development program is required to determine whether these photochemical reactions can be successfully modified and adapted into a functional actinide fractionating process.

\section{SUBJECT CATEGORY: TRU}

ORIGIN: Defense

KEYWORDS: ACTINIDES; AMERICIUM; CURIUM; FEASIBILITY STUDIES; LASER RADIATION; LIQUID WASTES; NEPTUNIUM; PHOTOCHEMISTRY; PLUTONIUM; RADIOACTIVE WASTE PROCESSING; SEPARATION PROCESSES; URANIUM

\section{9}

Dyroff, H., and F.K. Fleischmann; Bundesministerium fuer Forschung und Technologie, Bonn, Germany, F.R.

RADIOACTIVE WASTE IN THE FEDERAL REPUBLIC OF GERMANY. SYSTEMS STUDY. VOLUME 1. THE AMOUNT OF RADIOACTIVE WASTE PRODUCED IN THE FRG. DEU-76-19. (1976)

In German; 23 figures, 32 tables, 14 references; Available from NTIS

Taking the probable developments in the fields of nuclear technology, and the data specific for the wastes of certain plants, the overall rate of radioactive wastes in the FRG from 1975 till 1990 is estimated and some prognostications are made up till the year 2000 . The analysis of the waste rate in the FRG from 1975 till 1990 shows that the wastes of nuclear power plants, compared with those of the reprocessing plants, predominate quantitatively, but looking at it from the radiological properties it becomes obvious that almost all radioactivity released in nuclear technology is contained in reprocessing wastes. With regard to the fuel cycle industry, those substances from the $\mathrm{U} / \mathrm{Pu}$ fuel production which emit alpha radiation present a special problem. Radioactive wastes from large research centres, from industry research, collecting depots of the Laender, and isotope technology are of no significance, neither with regard to the quantity nor from the point of view of radioactivity.

SUBJECT CATEGORY: General

ORIGIN: Foreign

KEYWORDS: DIAGRAMS; DOSE RATES; FORECASTING; FUEL CYCLE; FUEL REPROCESSING PLANTS; GASEOUS WASTES; GERMAN FEDERAL REPUBLIC; LIQUID WASTES; NUCLEAR INDUSTRY; PRODUCTION; RADIOACTIVE WASTES; RADIOACTIVITY; REACTORS; SOLID WASTES; TABLES; VOLUME

650

Laporte, T., D. Metlay, and P. Windham; California Univ., Berkeley, CA.

SPACE DISPOSAL OF NUCLEAR WASTES: SOCIO-POLITICAL ASPECTS. VOLUME 2. NASA-CR-153054; N-77-23914. (1976)

Available from NTIS PC A09/MF A01.

The character and scope of the secondary impacts of a space disposal program on the daily lives of people are estimated. These include public health and safety, environmental concerns, socioeconomic benefits and costs, civil liberties, and psychological effects. The types of accidents that might occur during space disposal operations and their indirect as well as direct consequences are discussed as well as the difficulties involved in constructing a management and operational organization that maintains the required high level of vigilance and performance over many years of routine operation.

SUBJECT CATEGORY: HLW; LLW

ORIGIN: Commercial; Defense

KEYWORDS: ACCIDENTS; COST; ENVIRONMENTAL IMPACTS; PUBLIC HEALTH; PUBLIC RELATIONS; RADIOACTIVE WASTE DISPOSAL; SAFETY; SOCIAL IMPACT; SOCIOECONOMIC FACTORS; SPACE 
651

Lefillatre, G.; CEA Centre d'Etudes Nucleaires de Cadarache, 13 - Saint-Paul-les-Durance, France

ADVANCES IN TECHNIQUES FOR BITUMINIZING LIQUID WASTE FROM PRESSURIZED WATER NUCLEAR POWER REACTORS: MANAGMENT OF RADIOACTIVE WASTES FROM THE NUCLEAR FUEL CY CLE. VOL. 2. CONF-760310; STI/PUB-433 (Vol. 2); Management of Radioactive Waste, Proceedings of a Symposium, Vienna, Austria, March 22, 1976. International Atomic Energy Agency, Vienna, Austria. (1976)

\section{In French}

'l'he author gives an account of recent progress in the technique of direct bituminization (without preconcentration) of spent effluents from a nuclear power station with a light-water reactor (PWR). Direct bituminization involves complete dehydration in a vertical evaporator with a thin layer of dilute emulsion formed by the on-line mixing of bituminous emulsion and effluents at $\mathrm{pH}$ 9.6. The bituminized material containing 40 to $50 \%$ salts and less than $1 \%$ water flows by gravity into a drum, where it solidifies. There is complete decontamination of the distillates by passage over activated charcoal and ion-exchange resin columns. The process was developed at the pilot plant of the Cadarache Nuclear Research Centre, which is equipped with an LUWA L150 evaporator that can treat $601 / \mathrm{h}$ of effluents with an activity of the order of $1 \mathrm{Ci} / \mathrm{cu} \mathrm{m}$. The decontamination factors for the equipment range from $10(E+3)$ to $10(E+5)$, and the actual concentration factor attains 290 with effluents containing $2 \mathrm{~g} / \mathrm{l}$. The characterisitcs of the solidified waste, i.e. density, bitumen content, softening point, leaching rate, and thermal stability, are given. Finally, from the example of an industrial direct bituminization plant with a capacity of $3 \mathrm{cu} \mathrm{m} / \mathrm{h}$, the author estimates the annual cost of treating spent effluents from two $900 \mathrm{MW}(e)$ power plants (PWR) at 1.5 million francs. A comparison of a number of drums treated with bitumen and with cement suggests that, in terms of the solidified waste to be stored, there is a gain in volume of 2.7 in favour of hitumen.

SUBJECT CATEGORY: Spent Fuel; LLW

ORIGIN: Foreign

KEYYWORDS: BITUMENS; COMPARATIVE EVALUATIONS; COST; LIQUID WASTES; PWR TYPE REACTORS; RADIOACTIVE WASTE PRO. CESSING; SOLIDIFICATION
652

Johnson, C.D.; Chem Nuclear Systems, Inc., Bellevue, WA

MODERN RADWASTE SYSTEMS: AN OVERVIEW. Chem. Eng. Prog. 72(3):43-46. (1976)

Design of subsystems

Systematic diagrams for early and present designs for solid and liquid radiowaste subsystems were presented. The trend toward automation was noted. Problems causing excessive maintenance were described, and the difficulty of excessive waste generation was discussed. Radioactive waste transportation considerations included a cost comparison for different type containers.

SUBJECT CATEGORY: LLW; HLW

ORIGIN: Commercial

KEYWORDS: CONTAINERS; COST BENEFIT ANALYSIS; MAINTENANCE; OPERATION; RADIOACTIVE WASTE FACILITIES; RADIOACTIVE WASTE PROCESSING; RADIOACTIVE WASTES; WASTE TRANSPORTATION

\section{3}

Arenz, H.J., and E. Van der Stijl; Commission of the European Communities, Directorate for Safeguards and Controls and Property Rights, Luxenbourg

EURATOM EXPERIENCE OF VERIFICATION METHODS IN REPROCESSING FACILITIES: SAFEGUARDING NUCLEAR MATERIALS. VOLUME 2. Safeguarding of Nuclear Materials, Proceedings of a Symposium, Vienna, Austria, October 20, 1975. International Atomic Energy Agency, Vienna, Austria. (1976)

The start of safeguards inspection of a reprocessing plant is briefly reviewed and the changeover from intermittent inspection to continuous inspection is outlined. The methods, which are subdivided into safeguards implementation before startup, during operation, aud after ohulduwn of the facility arc described. The step-by-step procedure of approval based on the Euratom Treaty guarantees a good knowledge of both process and facility by the inspectors before startup. The description of the inspectors' manual stresses the following points: Accounting procedures used for flow and inventory measurement; verification and independent measurements to be performed by the inspectors; and surveillance measures applied during inspection. 
The theoretical assumptions for a conceptual inspection plan for a model reprocessing plant have had to be modified in the light of difficulties encountered in actual operating conditions. A wide range of examples is given, discussing inventorytaking with detection of hidden inventory, input and output measurement comparing results of control laboratories with plant results, waste management and measurements with nondestructive devices and various practical problems encountered during inspection. Surveillance and containment measures are also briefly discussed. The necessity of an independent material balance made by the Safeguards Authority is discussed. Attention is paid to the material balance as a whole and to its components, and the extent to which the degree of independence may be improved by surveillance and containment measures. The necessity of further development work in particular for input measurements is pointed out.

SUBJECT CATEGORY: Spent Fuel

ORIGIN: Foreign

KEYWORDS: ACCOUNTING; FUEL REPROCESSING PLANTS; INSPECTION; INVENTO. RIES; MATERIAL BALANCE; MATERIAL UN. ACCOUNTED FOR; PLUTONIUM; RADIOACTIVE WASTES; SAFEGUARDS; URANIUM

\section{4}

Baron, Moneyron, Thepot, Aupetit, Boussard, Bernard, Cherruau, Couture, Mustelier, and Sousselier; Compagnie de Produits Chimiques et Electrometallurgiques Pechiney-Ugine Kuhlmann, 75 Paris, France

NUCLEAR FUEL CYCLE. Rev. Gen. Nucl. 1:3766. (1976)

In French; different steps in the cycle are reviewed.

The different steps of the nuclear fuel cycle are reviewed: uranium concentrates and UF6 production; uranium enrichment; fuel manufacture for water reactors; plutonium fuel elements; reprocessing; strategy for plutonium use; effluents and wastes; transport of nuclear materials; economy of fuel cycle in the case of water reactors.

SUBJECT CATEGORY: HLW; LLW; TRU

ORIGIN: Foreign
KEYWORDS: COST; ENRICHED URANIUM; FRANCE; FUEL CYCLE; FUEL ELEMENTS; PLUTONIUM; RADIOACTIVE WASTES; REPROCESSING; TRANSPORT; URANIUM 235; URANIUM CONCENTRATES

655

Detroit Edison Co., Detroit, MI

RESPONSE TO QUESTION 5A(2) - LIQUID WASTE PROCESSING SYSTEM HOLDUP TIME. Docket 50341-215; A-4 of Amendment 6 to Fermi 2 License Application. (1976)

In calculating the releases of radionuclides reported in the FERMI 2 FSAR and ER, no credit was taken for decay resulting from holdup with the process system. Holdup times based on the data presented in table 1 have been calculated per RG 1.112 and are shown in the table 3 of this annex. Holdup times based on RG 1.112 expected source volumes (table 2) have also been calculated and are also presented in table 3 .

SUBJECT CATEGORY: General

ORIGIN: Commercial

KEYWORDS: ENRICO FERMI-2 REACTOR; BWR TYPE REACTORS; REPORTS; LIQUID WASTES; VOLUME

656

Edison Electric Institute, New York, NY

APPENDICES TO THE REPORT OF THE EDISON ELECTRIC INSTITUTE ON NUCLEAR FUELS SUPPLY. Edison Electric Institute Report. (1976)

Nine appendices are included: estimates of demand, supply, financial requirements, and cost and price estimates for major components of the fuel cycle; uranium supply; enrichment services supply; spent fuel temporary storage; spent fuel transportation; reprocessing and recycle of $\mathrm{Pu}$ and $\mathrm{U}$; radioactive waste management; HTGR fuel cycle; and impact of LWR fuel performance on fuel cycle planning.

SUBJECT CATEGORY: TRU; Spent Fuel; Transportation; HLW; LLW

ORIGIN: Commercial 
KEYWORDS: COST; ECONOMICS; ENRICHED URANIUM; FUEL CYCLE; FUEL MANAGEMENT; HTGR TYPE REACTORS; ISOTOPE SEPARATION; NUCLEAR POWER; RADIOACTIVE WASTE MANAGEMENT; REPROCESSING; SPENT FUEL STORAGE; SPENT FUELS; WASTE TRANSPORTATION; URANIUM ISOTOPES; URANIUM RESERVES; WATER COOLED REACTORS

\section{7}

Francioni, W.M.; Eidgenoessisches Inst. fuèr Reaktorforschung, Wuerenlingen, Switzerland

PILOT INCINERATION PLANT FOR SOLID, COMBUSTIBLE, AND LOW-LEVEL WASTES. ORNL-tr-4510; EIR-299. (1976)

Portions of document are illegible; Available from NTIS, MF A01; Translation by J.W. Crabbs

Radioactively contaminated wastes are formed in the handling of radioactive materials at the Federal Institute for Reactor Research (FIRR) and in other facilities, hospitals, sanitoria, industry, and nuclear power plants. A large part of the wastes are combustible and only very slightly radioactive. Incineration of these wastes is obvious. A pilot incineration plant, henceforth called the PIP, for radioactive combustible wastes of the FIRR is surveyed. The plant and its individual components are described. The production costs of the plant and experience gained in operation available at present are reviewed. Solid combustible radioactive waste can be incinerated in the PIP. The maximum possible reduction in volume of these wastes is achieved by incineration. Subsequently the chemically sterile ashes can be consolidated in a stable block suitable for long-term storage mixing with cement.

\section{SUBJECT CATEGORY: LLW}

ORIGIN: Foreign

KEYWORDS: COMBUSTION; COST; INCINERATORS; LOW-LEVEL RADIOACTIVE WASTES; OPERATION; PERFORMANCE; PILOT PLANTS; PYROLYSIS; RADIOACTIVE WASTE PROCESSING
658

Zolotar, B.A., and R.A. (Ed.) Karam; Electric Power Research Inst., Palo Alto, CA

PLUTONIUM RECYCLE. CONF-750697; Energy and the Environment - Cost Benefit Analysis, Proceedings of a Conference, Atlanta, GA, June 23, 1975. Pergamon Press, Inc., Elmsford, NY. (1976)

Plutonium recycle is discussed in terms of the potential of conservation of nuclear fuel resources, reduction in fuel costs and minimization of environmental effects. However, it is concluded that commercial implementation requires a clarification of the regulatory situation. Fuel performance experience and the potential for accidents are also examined. It is indicaled that while plutunium is a highly toxic material if introduced into the human body, its basic properties tend to greatly reduce the potential danger.

\section{SUBJECT CATEGORY: TRU}

OKIGIN: Commercial

KEYWORDS: CHEMICAL EFFLUENTS; COMPARATIVE EVALUATIONS; ECONOMICS; ENVIRONMENTAL EFFECTS; FUEL REPROCESSING PLANTS; HEALTH HAZARDS; NUCLEAR FUELSS; PLUTONIUM; PLUTONIUM RECYCLE; RADIATION PROTECTION; RADIOACTIVE EFFLUENTS; REPROCESSING; RESOURCE CONSERVATION; SOCIO-ECONOMIC FACTORS; THERMAL EFFLUENTS; TOXICITY

\section{9}

Energy Research and Development Administration, Oak Ridge, Tenn.

\section{RADIOACTIVE WASTE PROCESSING AND DISPOSAL. TID-3311-S7; 300 pp. (1976)}

References in 1841 publications related to radioactive waste, announced in Nuclear Science Abstracts (NSA) volumes 31 (Jan.-June 1975), 32 (July-Dec. 1975), and 33 (Jan.-June 1976), are cumulated in this bibliography. The references are arranged by the original NSA abstract number, which approximately places them in chronological order. A listing of the subject descriptors used to describe each reference for machine storage and retrieval is shown. Four indexes are provided: corporate author, personal author, subject, and report number. These 
indexes refer to the sequence numbers for the references.

SUBJECT CATEGORY: General

ORIGIN: Defense; Commercial; Institutional

KEYWORDS: BIBLIOGRAPHIES; RADIOACTIVE WASTE DISPOSAL; RADIOACTIVE WASTE MANAGEMENT

660

Energy Research and Development Administration, Savannah River Operations Office, Aiken, SC

LWR SPENT FUEL DISPOSITION CAPABILITIES, 1976-1985. 1976 EDITION. ERDA-76-25; 27 pp. (1976)

\section{Available from NTIS}

The data indicate the need for added LWR spent fuel storage capacity. Such capacity could be obtained by capacity additions at the reactor sites, or by additional Away From Reactor (AFR) construction. A few such additions appear necessary in the near term. The data show that the extent of additional storage capacity required for the long term depends strongly on the timing of reprocessing plant startups and the capacity these plants can sustain. The industry recognizes the situation and appears to be coping by proposed (1) expansion of fuel storage capacity (2) intra-site shuffling and/or (3) off-site storage. The increase in additional storage capacity requirements clearly intensifies from 1981 onward, and it is apparent that increasingly widespread reliance on the full core reserve capacity, at least on an interim basis, has already begun. Additions have nearly doubled available AFR storage capacity in the past year.

SUBJECT CATEGORY: Spent Fuel

ORIGIN: Commercial; Defense

KEYWORDS: BWR TYPE REACTORS; EVALUATION; FORECASTING; FUEL CYCLE; PWR TYPE REACTORS; SPENT FUEL STORAGE; SPENT FUELS; WATER COOLED REACTORS

\section{1}

Energy Research and Development Administration, Washington, DC
BENEFIT ANALYSIS OF REPROCESSING AND RECYCLING LIGHT WATER REACTOR FUEL. ERDA-76/121; 27 pp. (1976)

4 tables, 8 figures

Examines the macro-economic impact of reprocessing and recycling fuel for nuclear power reactors and assesses the impact of reprocessing on the conservation of uranium resources. The approach used compares the costs of an energy resource throwaway fuel cycle with a mode which closes the fuel cycle by recycling the fuel. In the throwaway cycle, fuel discharged from reactors is eventually transferred to a federal repository for long term storage. The benefits and penalties of reprocessing and recycle are compared with the throwaway cycle from an economic standpoint. Discusses the availability of natural uranium resources needed to meet projected growth. Examines the importance of the LWR reprocessing and recycle industry in meeting the future plutonium needs of commercial breeder reactors.

SUBJECT CATEGORY: Spent Fuel; HLW

ORIGIN: Commercial

KEYWORDS: US ERDA; COST BENEFIT ANAL YSIS; FUEL CYCLE; REPROCESSING; ECONOMICS; SPENT FUEL STORAGE; URANIUM; PLUTONIUM; BREEDER REACTORS; BWR TYPE REACTORS; PWR TYPE REACTORS

\section{2}

Energy Research and Development Administration, Washington, DC

INTENSE NEUTRON SOURCE FACILITY, LOS ALAMOS SCIENTIFIC LABORATORY, LOS ALAMOS, NEW MEXICO. FINAL ENVIRONMENTAL STATEMENT.

ERDA-1548. (1976)

Available from NTIS; Experimental neutron irradiation facility simulating the neutronic environment of a fusion power reactor

A final environmental statement is presented which was prepared toward compliance with the National Environmental Policy Act and in support of the Energy Research and Development Administration's proposed actions to construct and operate a deuterium-tritium gas target intense neutron source at the Los Alamos Scientific Laboratory (LASL) in 
Los Alamos, Los Alamos County, New Mexico. The purpose of the proposed facility is to provide an experimental neutron irradiation facility providing a neutronic environment similar to that anticipated in a fusion power reactor. In addition, the facility will provide prototypic testing of tritium pumping, purification, containment, and cleanup systems necessary for future experimental power reactors. The benefits of developing radiation resistant structural materials, insulators, and tritium handling systems suitable for use in fusion reactors would be substantial and far outweigh the nominal environmental impacts associated with construction and operation of this facility. The principal environmental impacts of the proposed facility result from routine construction activities including clearing approximately six acres of land for the building, parking areas and an access road. Liquid waste discharges consist primarily of cooling tower blowdown during operations. Significantly contaminated liquid and solid waste will be disposed at the existing LASL waste disposal area. Very small quantities (less than 100 curies per year) of tritium and traces of other radioactivity will result in site boundary doses not exceeding 5 mrem per year, or less than 5 percent of applicable radiation protection guidelines and less than 5 percent of the natural radiation background from naturally occurring radioactivity. Alternatives considered included abandoning or postponing the project, selecting alternative designs, and selecting alternative locations for the facility.

\section{SUBJECT CATEGORY: LLW}

ORIGIPJ. Defense

KEYWORDS: BUILDINGS; DEUTERIUM; ENVIRONMENTAL IMPACT STATEMENTS; ION SOURCES; IRRADIATION DEVICES; LIQUID WASTES; MATERIALS TESTING; NEUTRON SOURCES; PHYSICAL RADIATION EFFECTS; RADIOACTIVE WASTES; SAFETY; SHIELDING; SIMULATION; SITE SELECTION; SOCIOECONOMIC FACTORS; TEST FACILITIES; THERMONUCLEAR REACTORS; TRITIUM

\section{3}

Environmental Protection Agency, Office of Radiation Programs, Washington, DC

ENVIRONMENTAL ANALYSIS OF THE URANIUM FUEL CYCLE. PART IV. SUPPLEMENTARY ANALYSIS: 1976. EPA-520/4. 76/017; PB-259857. (1976)
See also PB-235806; available from NTIS, PC A07/MF A01.

The EPA recently completed a technical review of the uranium milling industry as part of an overall analysis of the uranium fuel cycle. This review included a description of the milling process, estimations of radioactive effluent releases, radiological impact, health effects impact, and the costs and effectiveness of control technologies for mills. An analysis of the tailings piles associated with mills was also included. This review was prepared in support of EPA's proposed standards for the nuclear fuel cycle. This report contains an extensive review of the costs and the effectiveness of various control technology systems for uranium mills and mill tailings piles.

SUBJECT CATEGORY: Remedial Action, Mill Tailings

ORIGIN: Commercial

KEYWORDS: COST; ENVIRONMENTAL IMPACTS; MILLING; ORE PROCESSING; RADIATION HAZARDS; RADIOACTIVE EFFLUENTS; RADIOACTIVE WASTE MANAGEMENT; URANIUM ORES

\section{4}

Wong, H.W., and L. Abraham; General Atomic Co., San Diego, CA

IITGR GPENT REFLECTOR BI,OCK DIGPOSAL STUDY. GA-A-13860; 37 pp. (1976)

Burial or Crush-burn processing; 12 tables, 11 figures

A preliminary evaluation of alternative concepts and associated costs for the disposal of irradiated HTGR reflector blocks has been completed. The alternative methods considered in the study are: (1) burial of the reflector blocks as contaminated waste, and (2) dispossl of blocks by a crush-burn process in a reprocessing facility. The primary objective of the study is to evaluate the relative economics of the two disposal methods.

\section{SUBJECT CATEGORY: LLW}

ORIGIN: Commercial

KEYWORDS: ECONOMICS; GRAPHITE; RADIOACTIVE WASTE DISPOSAL; HTGR TYPE 
REACTORS; GROUND DISPOSAL; COMBUSTION; CRUSHING; REPROCESSING; NUCIEAAR MATERIAISS MANAGEMENT

665

Williamson, H.E.; General Electric Co., San Jose, CA

APPRAISAL OF BWR PLUTONIUM BURNERS FOR ENERGY CENTERS. GEAP-11367; 70 pp. (1976)

36 tables, 52 figures

The design of BWR cores with plutonium loadings beyond the self-generation recycle (SGR) level is investigated with regard to their possible role as plutonium burners in a nuclear energy center. Alternative plutonium burner approaches are also examined including the substitution of thorium for uranium as fertile material in the BWR and the use of a high-temperature gas reactor (HTGR) as a plutonium burner. Effects un core design, fuel cycle facility requirements, economics, and actinide residue are considered. Differences in net fissile material consumption among the various plutonium-burning systems examined were small in comparison to uncertainties in HTGR, thorium cycle, and high plutonium-loaded LWR technology. Variation in the actinide content of high-level wastes is not likely to be a significant factor in determining the feasibility of alternate systems of plutonium utilization. It was found that after 10,000 years the toxicity of actinide high-level wastes from the plutonium-burning fuel cycles was less than would have existed if the processed natural ores had not been used for nuclear fuel. The implications of plutonium burning and possible future fuel cycle options on uranium resource conservation are examined in the framework of current ERDA estimates of minable uranium resources.

SUBJECT CATEGORY: TRU

ORIGIN: Commercial

KEYWORDS: BWR TYPE REACTORS; PLUTONIUM RECYCLE; PLUTONIUM; HTGR TYPE REACTORS; COST; FUEL CYCLE; THORIUM; ACTINIDES; NUCLEAR PARKS; RESOURCE CONSERVATION
666

General Electric Co., San Jose, CA

RESPONSE TO QUESTION 010.5 - LIQUID RADWASTE SYSTEM. DOCKET-STN-50550; Amendment 2 to 238 NSSS Gessar License Application, p. 010.5-1. (1976)

Provides long-term average flow rates and the volumes of large quantities of waste that originate from the NSSS over a short period of time (E.G., RHR system flushes prior to initiating normal reactor cooldown). Liquid radwaste inputs to the system are identified.

\section{SUBJECT CATEGORY: LLW}

ORIGIN: Commercial

KEYWORDS: BWR TYPE REACTORS; LIQUID WASTES; GESSAR REACTOR

\section{7}

Eichholz, G.G., and W.C. Evans; Georgia Institute of Technology, Atlanta, GA

COST-EFFECTIVENESS OF ENVIRONMENTAL SURVEILLANCE PROGRAMS. Transactions of the American Nuclear Society 24:103; American Nuclear Society 1976 International Conference, Washington DC, November 14, 1976. (1976)

None

SUBJECT CATEGORY: General

ORIGIN: General

KEYWORDS: COST; EFFICIENCY; NUCLEAR POWER PLANTS; RADIATION MONITORING; RADIOACTIVE EFFLUENTS

\section{8}

Karam, R.A., and K.Z. Morgan; Georgia Institute of Technology, Atlanta, GA

ENVIRONMENTAL IMPACT OF NUCLEAR POWER PLANTS. PROCEEDINGS OF A CONFERENCE HELD NOVEMBER 26-30, 
1974, IN ATlanta, GEORgIA. Pergamon Press Inc., Elmsford, NY. (1976)

Book, ISBN 0-08-019956-9.

This conference served as a forum for experts, power industry executives and engineers, and Federal and state agencies' representatives to discuss and exchange information on the environmental effects of nuclear power plants. An objective of this meeting was to identify the necessary elements and legal requirements for environmental impact statements. Twenty-three papers were presented in six sessions: Plant Site Selection; Ecology; Radioactive Waste and Thermal Pollution; Standards and Guidelines in the Preparation of Environmental Impact Statements; Cost-Benefit Analysis; and Environmental Impact Studies of Various Power Reactors.

SUBJECT CATEGORY: General

ORIGIN: Commerciàl

KEYWORDS: COST BENEFIT ANALYSIS; ECOLOGY; ENVIRONMENTAL EFFECTS; ENVIRONMENTAL IMPACT STATEMENTS; MEETINGS; NUCLEAR POWER PLANTS; RADIOACTIVE WASTE MANAGEMENT; REACTOR SITES; STANDARDS; THERMAL POLLUTION

\section{9}

Duerr, K., H. Feddersen, K. Klarr, K. Kuehn, R. Proske, K. Schneider, G. Staupendahl, E.P. Uerpmann, E. Albrecht, and N. Jockwer; Gesellschaft fuer Strahlen- und Umweltforschung $\mathrm{mbH}$, Neuherberg/Muenchen, Germany, F.R.; Kernforschungszentrum, Karlsruhe, Germany, F.R., Abt. zur Behandlung Radioaktiver Abfaelle

DISPOSAL OF RADIOACTIVE WASTES. ANNUAL REPORT 1975. KFK-2309; GSFT-60. (1976)

In German; Available from NTIS (US Sales Only), PC A04/MF A01.

This report is a joint effort of Gesellschaft fuer Strahlen- und Umweltforschung $\mathrm{mbH}$ Muenchen and Gesellschaft fuer Kernforschung mbH Karlsruhe, presenting a survey of the work performed in 1975 in the field of disposal of radiactive waste. The mining and construction work is discussed, which was carried out both underground and above at the ASSE Salt Mine near Remlingen and which was done for repair, maintenance and expansion of operation in accordance with its future purpose. The disposal of low-level wastes on the $750-\mathrm{m}$-level and the experimental disposal of intermediate-level wastes on the $490-\mathrm{m}$-level were continued in the period under review. Furthermore the construction of a reloading container and the operation of the single shielded container E2 are reported. The preparations for the single disposal of spent fuel elements of the AVR-reactor were continued so that at the end of the reported year preparations could be done to install the charging equipment. The drilled shaft Asse 4 was finished up to the 750-m-level and preparatory work was done to continue the sinking. Moreover, the report gives information on the present status of research and of its results, especially from work done in the field of disposal of high level waste, rock mechanics and safety studies.

SUBJECT CATEGORY: Isolatiọn; LLW

ORIGIN: Forcign

KEYWORDS: RADIOACTIVE WASTE DISPOSAL; RADIOACTIVE WASTE MANAGEMENT; RADIOACTIVE WASTE STORAGE; SALT DEPOSITS; LOW-LEVEL RADIOACTIVE WASTES; INTERMEDIATE-LEVEL RADIOACTIVE WASTES

\section{0}

Baer, A., A. Traxler. A. Limongi. and D. Thiery; Groupement pour les Activites Atomiques et Avancees (GAAA), 92 - Le Plessis-Robinson, France; Service de Protection et des Etudes d'Environnement, CEA Centre d'Etudes Nucleaires de Grenoble, 38, France.

EMBEDDING OF RADIOACTIVE WASTES BY THERMOSETTING RESINS, CONF. 760310-17; IAEA-SM-207/32; BNWL-tr-203; Management of Radioactive Waste, Proceedings of a Symposium, Vienna, Austria, March 22, 1976. International Atomic Energy Agency, Vienna, Austria. (1976)

May be titled "Incorporation of Radioactive Wastes into Heat-Hardened Resins" in other translations.

The process for embedding radioactive wastes in thermosetting resins perfected and applied at the Grenoble Nuclear Research Center and its applica. tion to the treatment of radioactive wastes from Light-Water Nuclear Power Plants (PWR and BWR) are presented. The various types of wastes are 
enumerated and their activities and quantities are estimated: evaporator concentrates, ion exchange resins, filtration sludges, filters, various solid wastes, etc. The authors review the orientations of the research performed and indicate, for each type of waste considered, the cycle of treatment operations from rendering the radioelements insoluble to drying the concentrates to final embedding. The operational safety of the process and the safety of transport and storage of the embedded wastes are investigated. The essential technical features concerning the safety of the installation and of the final product obtained are presented. In particular, results are presented from tests of resistance to fire, irradiation, leaching, etc., these being characteristics which represent safety criteria. The economic aspects of the process are considered by presenting the influences of the reduction of volume and weight of wastes to be stored, simplicity of installations and cost of primary materials.

SUBJECT CATEGORY: LLW

ORIGIN: Foreign

KEYWORDS: BWR TYPE REACTORS; ECONOMICS; PWR TYPE REACTORS; RADIOACTIVE WASTE PROCESSING; RESINS; SAFETY; SOLIDIFICATION; RADIOACTIVE WASTES

671

Bayer, A., R. Kalckbrenner, and M. Schueckler; Inst. fuer Neutronenphysik und Reaktortechnik, Kernforschungszentrum, Karlsruhe, Germany, F.R.

FUTURE RADIOLOGICAL LOADS DUE TO NUCLEAR FACILITIES IN THE CATCHMENT-BASIN OFTHE UPPER RHINE. PT. 1. LOADS BY AIR. AED-CONF-76-013-182; Reactor Meeting, Section 3: Design, Construction and Operation of Nuclear Power Plants and Their Components, Duesseldorf, Germany, F.R., March 30, 1976. ZAED, Eggenstein-Leopoldshafen, Germany, F.R. (1976)

In German, 3 figures, 2 tables, Short communication only

No Abstract

SUBJECT CATEGORY: General

ORIGIN: Foreign
KEYWORDS: ENVIRONMENTAL EXPOSURE PATHWAY; FORECASTING; NUCLEAR FACIL ITIES; RADIATION DOSES; RADIOACTIVE WASTE DISPOSAL; RADIOACTIVE AEROSOLS

672

Schmieder, H.; Institut fuer Heisse Chemie, Kernforschungszentrum, Karlsruhe, Germany, F.R.

\section{WASTE REMOVAL IN NUCLEAR ENGINEERING. ENERGY ECONOMICS AND TECHNICAL ASPECTS. Brennst.- Waerme-Kraft 28(5):212-215; Waste Disposal in Nuclear Engineering, Proceedings of a Symposium, Mainz, FR Germany, Jan 19, 1976. (1976)}

In German; 1 reference

Report on those papers of the DAtF Symposium concerning the topics 'Energy Economics and Technical Aspects'.

SUBJECT CATEGORY: General

ORIGIN: Foreign

KEYWORDS: ECONOMICS; ' FUEL REPROCESSING PLANTS; MEETINGS; NUCLEAR ENGINEERING; RADIOACTIVE WASTE DISPOSAL; RADIOACTIVE WASTE FACILITIES; RADIOACTIVE WASTE STORAGE; REACTOR DECOMMISSIONING; REVIEWS

673

Schmieder, H.; Institut fuer Heisse Chemie, Kernforschungszentrum, Karlsruhe, Germany, F.R.

PROBLEMS IN WASTE MANAGEMENT. Atomwirtsch. Atomtech. 21(5):267; Waste Disposal in Nuclear Engineering, Proceedings of a Symposium, Mainz, Germany, F.R., January 19, 1976. (1976)

\section{In German}

A survey is given on the problems arising in managing the waste of nuclear engineering which were discussed at a symposium of the German Atomic Forum. One of the main problems is the licensing procedure with its close connection to the publicity problem. The requirements in the licensing of reprocessing plants (tritium and krypton 85 
retention, iodine separation) and in waste conditioning and storage are indicated. $\mathbf{A}$ further main problem are the financial problems as, e.g., the 1,500 tons/year reprocessing plants planned in the FRG will cost approximately $2-2.5$ thousand million DM. The technical problems in the main stages of the Purex process are basically solved, also the techniques for removing radioactive wastes and in transporting irradiated fuel elements can be taken as well tested. Individual problems such as reduction of emission, scale-up questions, minimization of wastes and their conditioning, or increasing systems availability, are part of the world-wide research and development programme.

SUBJECT CATEGORY: Spent Fuel

ORIGIN: Foreign

KEYWORDS: COST; FUEL CYCLE; FUEL REPROCESSING PLANTS; LICENSING; NUCLEAR MATERIALS MANAGEMENT; RADIOACTIVE WASTE DISPOSAL; RADIOACTIVE WASTE MANAGEMENT; RADIOACTIVE WASTE PROCESSING; RADIOACTIVE WASTES; REPROCESSING; RESEARCH PROGRAMS; REVIEWS

\section{4}

Sawakuchi, R.S., and G.A.A. Sordi; Instituto de Energia Atomica, Divisao de Protecao Radiologica e Dosimetria, Sao Paulo, Brazil

EVALUATION OF THE INCREASING OF RADIOACTIVE WASTES PRODUCTION AT THE INSTITUTO DE ENERGIA ATOMICA, BRAZIL. IEA-421. (1976)

Available from NTIS (US Sales Only, PC A02/MF A01.

This evaluation has the purpose of selecting a new method for radioactive waste disposal at the IEA (Brazil). A production growth pattern for radioactive waste was established. The growth of radioactive wastes produced at the IEA was estimated for the next ten years.

SUBJECT CATEGORY: General

ORIGIN: Foreign

KEYWORDS: FISSION PRODUCT RELEASE; FORECASTING; IEAR-1 REACTOR; RADIOACTIVE WASTE DISPOSAL; RADIOACTIVE
WASTE PROCESSING; RADIOACTIVE WASTE STORAGE; RADIOACTIVE WASTES

675

Kotte, U., H. Bueker, and G. Stein; International Atomic Energy Agency, Vienna, Austria

PROCEDURES FOR THE ACCOUNTING AND CONTROL OF NUCLEAR MATERIALS IN LARGE RESEARCH CENTRES, AS RELATED TO THE NEEDS OF INTERNATIONAL SAFEGUARDS. FINAL REPORT FOR THE PERIOD 15 DECEMBER 1974 - 30 APRIL 1976. IAEA-R-1574-F. (1976)

Available from NTIS (US Sales Only), PC A01/MF A01.

In signatory states of the Non-Proliferation Treaty nuclear material is subject to the supervision of the International Atomic Energy Agency. The IAEA safeguards concept intended for nuclear material has, so far, been predominantly applied to nuclear facilities of the nuclear fuel cycle. It is the aim of this report to consider the applicability of these control measures to a nuclear research centre. The report refers to the concrete example of the Juelich Nuclear Research Centre (KFA). The particular features of a nuclear research centre and the handling of nuclear material in the KFA are described. A review is given of the various licence areas and permitted handling quantities as well as of the inventories and flow of nuclear material. The concept of a control system for a nuclear research centre setisfying the operator's requirements, national requirement and international obligations at the same time is developed along these lines. The essential characteristic of the concept is a far-reaching clarity of the distribution of nuclear material items within the Nuclear Research Centre. The clarity desired will be achieved by means of an integrated accountancy system processing all necessary data with the aid of a central computer and remote terminals. The availability of information is based on differentiated material acountancy in conjunction with adequate measurement of nuclear material data. In the case of the KFA two groups are formed by research reactors and critical assemblies. Research institutes and central departments the permitted handling quantities of which do not exceed 5 eff.kg constitute a further group. Two further groups are formed for casea where the permitted handling quantities are above or below 1 eff.kg. The report shows the safeguards measures that can be applied in certain circumstances and conditions in a nuclear research centre. 
SUBJECT CATEGORY: General; LLW

ORIGIN: Foreign

KEYWORDS: ACCOUNTING; CONTAINMENT; DATA ACQUISITION; FISSILE MATERIALS; FISSIONABLE MATERIALS; IAEA; SAFEGUARDS; INVENTORIES; KERNFORSCHUNGSANLAGE JUELICH; LICENSING; ; MATERIAL BALANCE; NUCLEAR MATERIALS DIVERSION; NUCLEAR MATERIALS MANAGEMENT; PHYSICAL PROTECTION DEVICES; RECOMMENDATIONS; RESEARCH PROGRAMS; RADIOACTIVE WASTE MANAGEMENT

\section{6}

International Atomic Energy Agency, Vienna, Austria

ECONOMIC EVALUATION OF BIDS FOR NUCLEAR POWER PLANTS.. Technical Reports Series Guidebook. (1976)

The purpose of the guidebook is to assist an organisation responsible for a nuclear power project in evaluating and establishing an economic order of merit among competing bids. An approximate overall time schedule for a first nuclear power plant project is provided. A schematic outline of technical bid evaluation is given. The basic procedure of economic bid evaluation is outlined, e.g. evaluation of the present worth of all cost items of plant capital investment, of the nuclear cycle, of $O$ and $M$ costs (operation and maintenance costs), and of economic corrections. All these cost items are evaluated for the economic life of the plant and corrected for escalation where applicable.

\section{SUBJECT CATEGORY: General}

ORIGIN: Foreign

KEYWORDS: BIDS; CAPITAL; COMPARATIVE EVALUATIONS; CONSTRUCTION; COST; COST BENEFIT ANALYSIS; DECOMMISSION. ING; ECONOMICS; FUEL CYCLE; INVESTMENT; MAINTENANCE; MANUALS; NUCLEAR INDUSTRY; NUCLEAR POWER PLANTS; OPERATION; PERSONNEL; RECOMMENDATIONS
677

Machida, C.; Japan Atomic Energy Research Inst., Tokai, Japan

VOLUME REDUCTION RATIO OF RADIOACTIVE SOLID WASTE. Hoken Butsuri 11(3):211-215. (1976)

In Japanese

A theoretical explanation and the experimental results of the volume reduction ratio in incineration and compression are presented for low level solid waste treatments. The volume reduction ratio of the combustibles by incineration can be expressed as the product of the weight reduction ratio and the reverse ratio of bulk densities before and after treatment. The weight reduction ratio is the most important factor in the process. The volume reduction ratio by compression is represented only by the reverse ratio of the two bulk densities, because the weight reduction is not involved. The bulk density of a compressed waste decreases due to its elasticity when the mechanical compression is removed. The preventive measures against volume restoration should be taken to retain the effect of volume reduction.

SUBJECT CATEGORY: LLW

ORIGIN: Foreign

KEYWORDS: ASHES; COMBUSTION; COMPARATIVE EVALUATIONS; COMPRESSION; COST; DENSITY; RADIOACTIVE WASTE PROCESSING; RADIOACTIVE WASTE STORAGE; SOLID WASTES; VOLUME

\section{8}

Turikai, K., Y. Endo, and T. Wajima; Japan Atomic Energy Research Inst., Tokai, Japan

STATUS OF DECOMMISSIONING OF NUCLEAR POWER FACILITIES. Genshiryoku Kogyo 22(4):15-25. (1976)

\section{In Japanese}

Present status of nuclear facility decommissioning is widely reviewed on the basis of the discussions in IAEA meeting held in October 1975. The first part of this report defines three stages of decommissioning. 
Namely, the physical states of plants and components and the required surveillance, inspections and tests are defined for each stage. The second part recommends principally some regulatory guides for both restricted and unrestricted site release on the basis of ICRP recommendations. The third part reviews studies and evaluations being performed in each member country. The fourth part explains the necessity of taking into account the decommissioning of facilities at the design stage. The key points are discussed from the viewpoints of component arrangement, construction, deconstruction during operation and dismantling, and the recording of plant history. The fifth part discusses the development of tools and technology for decommissioning from the viewpoints of decontamination, dismantling, conditioning, transportation and disposal, and exposure prevention. The remaining parts of this report treat problems of waste disposal, the methods of estimating decommissioning costs, and the role of IAEA for international cooperation. 'l'he present status and future problems of Japanese atomic industry are also discuissed. In the final part, the decommissionings of JRR-1 and Fermi reactor are reviewed as examples.

SUBJECT CATEGORY: Remedial Action, Surplus Facilities

\section{ORIGIN: Foreign}

KEYWORDS: COST; ENRICO FERMI-1 REACTOR; JRR-1 REACTOR; MAXIMUM PERMISSIBLE DOSE; NUCLEAR FACILITIES; NUCLEAR POWER PLANTS; PLANNING; RADIATION DOSES; RADIATION PROTECTION; RADIOACTIVE WASTE DISPOSAL; REACTOR COMPONENTS; REACTOR DECOMMISSIONING; REACTOR DISMANTLING; SAFETY STANDARDS; SPECIFICATIONS

\section{9}

Mori, M.; Kansai Electric Power Company, Inc., Osaka, Japan

DECOMMISSIONING OF NUCLEAR POWER PLANTS. Genshiryoku Kogyo 22(4): 26-28. (1976)

\section{In Japanese}

It is preferable to grasp the possible selection of disposing methods and the extent of expense in decommissioning nuclear power plants after their durable years have expired, and also to establish countermeasures if necessary. The following discus- sion is mainly on light water reactors. As the measures for the reactors after the durable years have expired, (1) mothballing, (2) in-place entombment, and (3) dismantling are considered in the Regulatory Guide 1.86 of US AEC. Mothballing is advantageous in the case that the administration of a reactor is not a heavy burden after mothballing as, for example, other reactor facilities are still in operation at that site. In-place entombment is superior in the point that the dismantling of a pressure vessel and biological shields is avoidable, which is most difficult in the whole station dismantling. Dismantling is the most satisfactory method but most expensive. More than 10,000 million yen will be needed in the complete dismantling of a large light water reactor. The dismantling techniques for in-reactor construction, a pressure vessel and biological shields are instructed together with the disposal of waste material and radiation exposure by dismantling works. However, exposure is supposed to be the same as that in normal reactor operation or less.

SUBJECT CATEGORY: Remedial Action, Surplus Facilities

ORIGIN: Foreign

KEYWORDS: BIOLOGICAL SHIEIDS; BWR TYPE REACTORS; COST; PRESSURE VESSELS; PWR TYPE REACTORS; RADIOACTIVE WASTE DIISPOSAL; REACTOR COMPONEN'S; KEACTOR DECOMMISSIONING; REACTOR DISMANTLING

\section{0}

Krause, H.; Kernforschungszentrum Karlsruhe, Germany, F.R.

TREATMENT OF RADIOACTIVE WASTE IN THE FEDERAL REPUBLIC OF GERMANY. Atomwirtsch. Atomtech. 21(7):343-346. (1976)

In German; 4 figures; 3 tables.

In the Federal Republic of Germany a nuclear generating capacity of approximately $65 \mathrm{GWe}$ is anticipated by 1990 which, together with the fuel cycle industry and a reprocessing plant, will produce approximately 18,000 cubic $m$ of preconcentrated liquids and 16,000 cubic $m$ of solid waste with a total activity of sume $3 \times 10(\mathrm{E}+7) \mathrm{Ci}$. The contribution to the total amount and activity of waste made by the individual types of waste in various nuclear installations differs widely. Waste 
from reprocessing plants contains some $99.9 \%$ of the radionuclides contained in liquid waste and $86 \%$ of those contained in solid waste. Waste from the rest of the fuel cycle, th nuclear power stations and the large research centers together contains only some $0.01 \%$ of the total activity of the solid waste. In terms of volume, most of the radioactive waste is low level waste.

\section{SUBJECT CATEGORY: LLW}

ORIGIN: Foreign

KEYWORDS: ALPHA DECAY RADIOISOTOPES; FISSION PRODUCTS; FORECASTING; FUEL CYCLE; GERMAN FEDERAL REPUBLIC; LIQUID WASTES; NUCLEAR FACILITIES; RADIOACTIVE WASTE DISPOSAL; RADIOACTIVE WASTE PROCESSING; REVIEWS; SOLIDIFICATION; WASTE MANAGEMENT

681

Kondrat'ev, A.N., Y.P. Martynov, and M.V. Strakhov; Kernforschungszentrum, Karlsruhe, Internationales Buero/Uebersetzergruppe, Germany, F.R.

TREATMENT OF HIGHLY ACTIVE AND ALPHA-LEAVING WASTES IN THE USSR: A RUSSIAN: OBRASCHENIE S VYSOKOAKTIVNYMI I AL'FAIZLUCHAYUSHCHIMI OTKHODAMI V SSSR. AEDCONF-76-355-001; KFK-tr-481; High-Level and Alpha-Bearing Wastes, Proceedings of a Technical Meeting, Vienna, Austria, May 10, 1976. (1976)

In German; 2 figures, 3 tables, 12 references. Available from AZED and NTIS

A three-year cooling period is planned for the fuel elements coming out of boiling or pressurized water reactors in order to simplify the reprocessing and treatment of radioactive wastes. Regarding the potential value of the transuranium elements and their large lifetime, one tries to separate these from the fission products such as $\mathrm{Sr}$ and Cs. Several methods for the vitrification of highly radioactive liquid wastes are worked out in the USSR which are technically and apparatively different, but which however may be summarized into two groups: Onestage and two-stage processes. The two-stage process consists in the calcination in a fluidized bed and the subsequent melting of the calcinate. Test results are given. The storage of highly active wastes after a cooling period of $10-20$ years in gquifer storage is thought possible. A comparison of different methods of treatment of highly active wastes: storage in stainless steel tanks, vitrification and pressing in underground layers, has shown that pressing involves the least expenditure.

SUBJECT CATEGORY: HLW; Spent Fuel; TRU

ORIGIN: Foreign

KEYWORDS: AMERICIUM; CALCINATION; COST; CURIUM; LIQUID WASTES; PILOT PLANTS; PLUTONIUM; RADIOACTIVE WASTE PROCESSING; RADIOACTIVE WASTE STORAGE; SPENT FUEL ELEMENTS; USSR; VITRIFICATION.

682

Kulichenko, V.V., F.S. Dukhovich, O.I. Volkova, M.V. Boyarinova, I.A. Sobolev, L.M. Khomchik, and Yu.M. Bazhenov; Kernforschungszentrum, Karlsruhe, Internationales Buero/Uebersetzergruppe, Germany, F.R.

FIXATION OF RADIOACTIVE WASTES IN CEMENT: A RUSSIAN: $K$ VOPROSU O TSEMENTIROVANII RADIOAKTIVNYKH OTKHODOV. KFK-tr-490; Russian" title "K Voprosu O Tsementirovanii Radioaktivnykh Otkhodov". (1976)

In German; 6 figures; 3 tables; 11 references. Available from INIS

The authors study the leaching behavior of the main long-lived fission products $\mathrm{Sr} 90$ and $\mathrm{Cs} 137$. It is found that $\mathrm{Sr} 90$ and $\mathrm{Cs} 137$ have high elution values, namely (2-12) x 10(E-2) resp. (2-6) x 10(E-2) $\mathrm{g} / \mathrm{square} \mathrm{cm} / 24 \mathrm{~h}$, independently of the type of waste. On the basis of these results, maximum concentrations for the solutions in the cement/solution mixtures are proposed. Further studies relate to the formation of radiolysis gas in the waste fixed to cement. Experiments are described to make use of the empty space in the containers, filled with solid waste by filling them with mixtures of cement and liquid radioactive waste of $10(\mathrm{E}-4)$ to $1(\mathrm{E}-6) \mathrm{Ci}$. The ratio solution/cement should amount to 0.5 . The containers are then buried underground. This method of combined waste storage helped to reduce the cost for the storage of liquid waste by about 40 $50 \%$.

SUBJECT CATEGORY: HLW

ORIGIN: Foreign 
KEYWORDS: ADDITIVES; BENTONITE; CEMENTS; CESIUM 137; COST; GASES; LEACHING; LIQUID WASTES; RADIOACTIVE WASTE PROCESSING; RADIOACTIVE WASTE STORAGE; RADIOLYSIS; REACTION KINETICS; SOLID WASTES; SOLIDIFICATION; STRONTIUM 90

\section{3}

Rublevskii, V.P., A.S. Zykova, and A.D. Turkin; Kernforschungszentrum, Karlsruhe, Internationales Buero/Uebersetzergruppe, Germany, F.R.

NUCLEAR POWER STATIONS AS SOURCES OF $C$ 14 EMISSION. CONF. 730907-27; KFK-tr-458; International Radiation Protection Association, Proceedings of the Third International Congress, Washington DC, September 9, 1973, (pp. 296-300). (1976)

3 tabs.; 13 refs. Transl. from Russian: Atomnye elektrostantsii kak istochnik vybrosa ugleroda-14. Available from ZAED; In German

Nuclear reactors produce $\mathrm{C} 14$ by neutron reactions in $\mathrm{N} \mathrm{14,} \mathrm{O} 17$, and $\mathrm{C} 13$. The expanding use of nuclear reactors for power production will contribute additional amounts of C 14 to the existing natural production by neutrons in the upper atmosphere. The report considers the problem of environmental C 14 contamination from the increasing use of nuclear reactors for power production. The experimental data on the production of $\mathrm{C} 14$ at different types of nuclear power stations in the USSR are presented in the report. The future production of $\mathrm{C} 14$ from nuclear power stations will be approximately $12,000 \mathrm{Ci}$ /day to 2010 . The $\mathrm{C} 14$ concentration in the terrestrial biosphere will reach 1,050 per cent of its natural level by this year. These estimates are compared with existing equilibrium levels of naturally occuring C 14 and with the decreasing inventory of $\mathrm{C} 14$ from atmospheric nuclear tests.

\section{SUBJECT CATEGORY: Airborne}

\section{ORIGIN: Foreign}

KEYWORDS: BIOSPHERE; CARBON 14; CONTAMINATION; EARTH ATMOSPHERE; ENVIRONMENTAL EFFECTS; FORECASTING; NUCLEAR POWER PLANTS; RADIOACTIVATION; RADIOACTIVE AEROSOLS; RADIOACTIVE EFFLUENTS; STACK DISPOSAL
684

Newkirk, H.W.; Lawrence Livermore Laboratory, Livermore, CA

ENVIRONMENTAL EFFECTS OF ENERGY PRODUCTION AND UTILIZATION IN THE U.S. VOLUME 3. TECHNIQUES FOR CONTROLLING EMISSIONS. UCRL-51930(Vol.3). (1976)

Available from NTIS

Technological, social, economic and political techniques for controlling emission are summarized for environmental pollutants introduced into air, water and land resources. Chemical, radiological and physical factors are discussed.

SUBJECT CATEGORY: Airborne; LLW

ORIGIN: Commercial

KEYWORDS: AIR POLLUTION; BIBLIOGRAPHIES; CHEMICAL EFFLUENTS; CONTROL; ENERGY; ENVIRONMENTAL EFFECTS; LAND POLLUTION; RADIOACTIVE EFFLUENTS; SOCIO-ECONOMIC FACTORS; THERMAL EFFLUENTS; WATER POLLUTION

\section{5}

Volk, E.E., and R.D. Partridge; Lawrence Livermore Laboratory, Livermore, CA

DECONTAMINATING GLOVED BOXES. Health Phys. 31(2):178-179. (1976)

An acid wash method for the decontamination of gloved boxes, which had been used for handling $\mathrm{Pu}$ 239 and $U 233$ is described. The costs of packaging contaminated gloved boxes as against the much reduced cost for the packaging of the materials removed during such decontamination procedures, which is necessary to meet ERDA requirements for storage in inlerim isulation, are compared.

SUB.JECT CATEGORY: LLW

ORIGIN: Commercial

KEYWORDS: COST; DECONTAMINATION; GLOVEBOXES; PACKAGING; PLUTONIUM 239; RADIOACTIVE WASTE STORAGE; SAFETY STANDARDS; URANIUM 233 
686

Boorboor, F.; Long Island Lighting Co., Hicksville, NY

WHY 10CFR100 IS NOT COST EFFECTIVE. Transactions of the American Nuclear Society 23:450-451; American Nuclear Society, Transactions of the 1976 Annual Meeting, Toronto, Canada, June 13, 1976. (1976)

No Abstract

SUBJECT CATEGORY: General

ORIGIN: General

KEYWORDS: CONTAMINATION REGULATIONS; COST; NUCLEAR POWER PLANTS; RADIOACTIVE EFFLUENTS; RECOMMENDATIONS; ECONOMICS

687

Khristova, M.D.; Meditsinska Akademiya, Nauchen Inst. po Rentgenoloiya i Radiobiologia, Sofia, Bulgaria

PREDICTION OF ENVIRONMENTAL RADIOACTIVE CONTAMINATION LEVELS TO FOLLOW THE COMMISSIONING OF "KOZLODUJ" NUCLEAR POWER STATION. INISmf-3431; Thesis. (1976)

In Bulgarian; Available from NTIS (US Sales Only), PC A03/MF A01.

The primary objective of the dissertation work was the prediction of radiological situations to be expected after commissioning the Kozloduj NPS, for specific weather, terrain relief, and soil properties. To this end, a pre-operational analysis was carried out of natural background radiation and airborne radioactivity. Based on pre-operational estimates of radionuclide releases, predictions were elaborated for expected radioactivity levels in air, the earth's surface, soils, plants, and some food types with regard to both total radioactivity and selected isotopes of biological interest, namely strontium 90 , indine 131, and cesium 137. As a criterion of radiation safety, computations were made of absorbed doses from external exposure to airborne or surface-deposited man-made radionuclides and from internal exposure to nuclides inhaled or ingested. Human exposure was evaluated in terms of "health effect". Environmental iodine 131 levels from accidental releases were predicted for a number of release rates and weather conditions.
Thyroid doses from iodine 131 inhaled or ingested with contaminated milk were claculated. The general conclusion was that normal operation of the Kozloduj NPS should have no deleterious effects on the population. The expected impact on man and his environment was found to be comparable to that of global radioactive fallout.

SUBJECT CATEGORY: Airborne

ORIGIN: Foreign

KEYWORDS: BACKGROUND RADIATION; BULGARIA; CESIUM 137; CONTAMINATION; ENVIRONMENT; FORECASTING; HEALTH HAZARDS; IODINE 131; KOZLODUY-1 REACTOR; KOZLODUY-2 REACTOR; MAN; MILK; RADIATION DOSES; RADIOACTIVE EFFLUENTS; RADIOACTIVITY; REGIONAL ANALYSIS; STRONTIUM 90; THYROID

\section{8}

Bendersky, D., R.E. Gustafson, C.E. Mumma, K.R. Walker, and D. Costello; Midwest Research Institute, Kansas City, MO

STUDY OF WASTE GENERATION, TREATMENT, AND DISPOSAL IN THE METALS MINING INDUSTRY. FINAL REPORT, JUNE 1974-JULY 1976. PB-261052. (1976)

The primary objective of the program was to provide EPA with detailed information concerning the generation, treatment, and disposal of potentially hazardous wastes in the metals mining and concentrating industries. The metals mining and concentrating industries covered in this study were categorized by the following Bureau of the Census Standard Industrial Classification Numbers: 1021 Copper Ores; 1031 - Lead-Zinc Ores; 1092 - Mercury Ores; 1094 - Uranium, Radium and Vanadium Ores; and 1099 - Metal Ores-not elsewhere classified . antimony, beryllium, platinum, rare earths, tin, titanium, and zirconium. Waste disposal and treatment practices are discussed, and estimates are given for the cost of hazardous waste treatment and disposal at typical facilities.

SUBJECT CATEGORY: General

ORIGIN: Commercial

KEYWORDS: COST; ECONOMICS; MILL TAIL INGS; MINING; RADIOACTIVE WASTE DISPOSAL; URANIUM ORES; VANADIUM ORES; RADIOACTIVE WASTE PROCESSING 


\section{9}

Giraud, B., and P. Candes; Ministere de l'Industrie et de la Recherche, 75 Service Central de Surete des Installations Paris, France

RADIOACTIVE WASTES. Ann. Mines 182(3):45162. (1976)

\section{In French}

A classification of radioactive wastes is proposed and an inventory of the wastes produced by the different lines is made. The possible storage solutions as well for high activity wastes (according to their characteristics) as for medium and low activity wastes are described. Finally, the problems of wastes together with dismantling of definitively shut down nuclear installations are recalled.

SUBJECT CATEGORY: General

ORIGIN: Foreign

KEYWORDS: CLASSIFICATION; FRANCE; GLOBAL ASPECTS; INVENTORIES; RADIOACTIVE WASTE DISPOSAL; RADIOACTIVE WASTE PROCESSING; RADIOACTIVE WASTE STORAGE; RADIOACTIVE WASTES; REACTOR DECOMMISSIONING; SAFETY

690

Bixel, J.C., and C.J. Kershner; Mound Laboratory, Miamisburg, $\mathrm{OH}$

TRITIUM WASTE CONTROL PROJECT PROGRESS REPORT: APRIL-JUNE 1976. MLM-2382. (1976)

Tritiated Liquid Waste Decontamination (Molecular Excitation): A preliminary economic study of water detritiation by laser isotope separation indicates possible advantages over the catalytic exchange process. The electric power requirements are a factor of 5 lower, resulting in a 50-percent reduction in operating costs. Capital costs for the two methods appear comparable. Additional attempts were made to determine the IR spectrum of HTO around the nu $(E+1)$ band. However, carbon dioxide impurity obscured the HTO absorption around $2265 \mathrm{~cm}$ (E-2) making it impossible to obtain a high quality spectrum for use in the LIS experiments. Electrolysis of High Level Tritiated Water: In an experiment using a regenerative cell on water containing approximately $0.3 \mathrm{~g}$ tritium, about $21 \mathrm{ml}$ of water was electrolyzed but the solid polymer electrolyte ruptured and cell components were damaged beyond repair. Tritium Monitor Development and Calibration: The calibration system design was modified to allow procurement and fabrication of the major components during FY1976. Shipping Container Development for Tritiated Liquid Waste: The bourbon tube pressure gage was replaced with a pressure transducer for double containment. A calorimeter was completed for tritium assay of contents. Catalytic Exchange Detritiation Studies: The Englehard hydrophobic, catalyst for $\mathrm{HT} / \mathrm{H} 2 \mathrm{O}$ exchange is being tested. An experiment to establish the height of one equilibrium plate was completed.

\section{SUBJECT CATEGORY: LLW}

ORIGIN: Defense

KEYWORDS: CALORIMETERS; CATALYSIS; CATALYSTS; CHEMICAL REACTION KINETICS; COMPARATIVE' EVALUA'TIONS; CONTAINERS; COST; DECONTAMINATION; DISSOCIATION; ECONOMICS; ELECTROLYSIS; FUEL REPROCESSING PLANTS; GASEOUS WASTES; INFRARED SPECTRA; ISOTOPIC EXCHANGE; LASER ISOTOPE SEPARATION; PHOTOLYSIS; RADIATION MONITORS; RADIOACTIVE EFFLUENTS; RADIOACTIVE WASTE PROCESSING; REGENERATIVE FUEL CELLS; TESTING; TRANSPORT; TRITIUM; TRITIUM COMPOUNDS; TRITIUM RECOVERY; MOUND LABORATORY

691

Gilbert, K.V., E.M. Wright, and R.D. Madding; Mound Laboratory, Miamisburg, $\mathrm{OH}$

A REPORT ON THE DECONTAMINATION AND DECOMMISSIONING OF THE TECHNICAL (T) BUILDING AT MOUND LABORATORY. MLM-2239; 24 pp. (1976)

Available from NTIS, Springfield, Va

'The technical ('I') building was used for separation and purification of polonium-210 isotope. A total of 32,400 sq. $\mathrm{ft}$. was affected by the termination effort. This area housed 439 lin $\mathrm{ft}$ of gloveboxes, 236 of which were radioactively contaminated. Throughout the project span, six to eight skilled tradesmen were assigned to the termination effort. Total cost of the project, including standby maintenance of both restored and awaiting-restoration space was $\$ 2.157$ million. Permanent walls, ceilings, and service 
areas were decontaminated to $2000 \mathrm{cpm}$ before painting over was permitted.

SUBJECT CATEGORY: Remedial Action, Surplus Facilities

ORIGIN: Defense

KEYWORDS: DECONTAMINATION; PERSON. NEL MONITORING; BUILDINGS; RADIOCHEMISTRY; DECOMMISSIONING; COST; POLONIUM 210; MOUND LABORATORY

\section{2}

Cavendish, J.H. (Ed.); National Lead Co. of Ohio, Cincinnati, $\mathrm{OH}$

FEASIBILITY STUDY OF A PORTABLE SMELTER FOR SCRAP METALS. NLCO-1132. (1976)

\section{Available from NTIS}

The use of a portable smelter to process uraniumcontaminated scrap metals was studied. Objectives were to convert scrap metal located at many diverse sites into a form which would be suitable for unlicensed sale and reduce the problems associated with storing the scrap. The Foundry Design Company study indicated the portable smelter concept was feasible from an equipment and transportation standpoint. Capital costs for a 5ton/hour (steel) nominal capacity unit were estimated to be $\$ 2,349,000$. Technical evaluation indicates that all the common metals considered, i.e., iron, nickel, copper, and aluminum, are amenable to uranium decontamination by smelting except aluminum. An economic evaluation of the processing of the 30,000 tons of steel scrap to be generated by the Cascade Improvement Program by a portable smelter was made based upon information supplied by Foundry Design Company, plus the assumption that the product metal could be sold for $\$ 120.00$ per ton. This evaluation indicated a net return of $\$ 2,424,000$ to the government could be realized. The Health and Safety study indicated no major problems of this nature would be encountered in operating a portable smelter. The legal review indicated the proposed operation fell within the authority of existing regulations. Consideration of possible conflicts with regard to competition with the private sector was suggested.

SUBJECT CATEGORY: LLW
ORIGIN: Commercial

KEYWORDS: DECONTAMINATION; ECONOMICS; FEASIBILITY STUDIES; GASEOUS DIFFUSION PLANTS; LEGAL ASPECTS; METALS; RADIOACTIVE WASTE PROCESSING; SAFETY; SMELTING; URANIUM

\section{3}

Blomeke, J.O.; Nuclear Regulatory Commission, Office of Nuclear Material Safety and Safeguards, Washington, DC

PROGRAM TO ESTABLISH THE TECHNICAL FEASIBILITY AND INCENTIVES FOR PARTITIONING. PB-254737; Management of Radioactive Waste: Waste Paritioning as an Altern. ative, Proceedings of a Conference, (pp. 38. 52). (1976)

ORNL has proposed to ERDA a program for the cost-risk-benefit analysis of actinide partitioning and transmutation as a waste management concept. The program is divided into two groups of tasks: experimental work on separations process flowsheet, and nonpartitioning aspects. These tasks and expected results in FY 1979 are described.

SUBJECT CATEGORY: TRU

ORIGIN: Commercial

KEYWORDS: COST . BENEFIT ANALYSIS; FLOWSHEETS; PARTITION; PLANNING; RADIOACTIVE WASTE MANAGEMENT; RADIOACTIVE WASTE PROCESSING; RESEARCH PROGRAMS; SEPARATION PROCESSES; TRANSMUTATION; ACTINIDES; TRANSURANIUM ELEMENTS

\section{4}

Cohen, B.L.; Nuclear Regulatory Commission, Office of Nuclear Material Safety and Safeguards, Washington, DC,

ENVIRONMENTAL HAZARDS FROM HIGH-LEVEL WASTE: PROCEEDINGS OF THE CONFERENCE ON THE MANAGEMENT OF RADIOACTIVE WASTE: WASTE PARTITIONING AS AN ALTERNATIVE. PB-254737; 107-131 pp. (1976) 
This paper presents methods for quantifying the hazards from high-level waste to put them into perspective with other hazards we experience and draws conclusions on the value of partitioning the waste and of maintaining surveillance on a waste repository.

SUBJECT CATEGORY: HLW

ORIGIN: Defense; Commercial

KEYWORDS: COMPARATIVE EVALUATIONS; COST BENEFIT ANALYSIS; HIGH-LEVEL RADIOACTIVE WASTES; NEOPLASMS; PARTITION; POWER REACTORS; RADIATION HAZARDS; RADIOACTIVE WASTE DISPOSAL; RADIOACTIVE WASTES; SOILS; TOXIC MATERIALS; UNDERGROUND DISFOSAL; WATER COOLED REACTORS; ENVIRONMENT

695

Nuclear Regulatory Commission, Office of Nuclear Material Safety and Safeguards, Washington, DC

FINAL GENERIC ENVIRONMENTAL STATEMENT ON THE USE OF RECYCLE PLUTONIUM IN MIXED OXIDE FUEL IN LIGHT WATER COOLED REACTORS. VOLUME 3. NUREG-0002(Vol.3); 651 pp. (1976)

Available from NTIS

An assessment is presented of the health, safety and environmental effects of the entire light water reactor fuel cycle, considering the comparative effects of three major alternatives: no recycle, recycle of uranium only, and recycle of both uranium and plutonium. The assessment covers the period from 1975 through the year 2000 and includes the cumulative offects for the entire poriod as well as projections for specific years. Topics discussed include: the light water reactor with plutonium recycle; mixed oxide fuel fabrication; reprocessing plant operations; supporting uranium fuel cycle; transportation of radioactive materials; radioactive waste management; storage of plutonium; radiological health assessment; extended spent fuel storage; and blending of plutonium and uranium at reprocessing plants.

SUBJECT CATEGORY: TRU; Spent Fuel

ORIGIN: Commercial

KEYWORDS: BWR TYPE REACTORS; COST; COST BENEFIT ANALYSIS; ECONOMICS; EN.
VIRONMENTAL EFFECTS; ENVIRONMENTAL IMPACT STATEMENTS; FABRICATION; FUEL ELEMENTS; PLUTONIUM DIOXIDE; PLUTONIUM RECYCLE; PWR TYPE REACTORS; REPROCESSING; SPENT FUEL STORAGE; URANIUM DIOXIDE

696

Nuclear Regulatory Commission, Office of Special Studies, Washington, DC

NUCLEAR ENERGY CENTER SITE SURVEY, 1975. PART I. SUMMARY AND CONCLUSIONS. NUREG-0001(Part 1 of V); 215 pp. (1976)

Available from NTIS; 13 tables, 13 figures

The Nuclear Energy Center Site Survey is a study of a potential siting approach for projected power and fuel-cycle facilities that would cluster sizable groups of such facilities on a relatively small number of sites, as contrasted with current dispersed siting practices. Three basic types of nuclear energy centers (NECs) are considered: power-plant centers, involving ten to forty units of 1200-megawatt electric capacity each; fuel-cycle centers, involving fuel reprocessing plants, mixed-oxide fuel fabrication facilities, and high-level and transuranic radioactive waste management facilities, with a capacity corresponding to the fuel throughput of power plants with a total capacity of approximately 50,000 to $300,000 \mathrm{MWe}$; and combined centers, containing both power plants and fuel cycle facilities in representative possible combinations. Included among the principal issues considered in evaluation of feasibility of nuclear energy centers are dissipation of the waste heat from the powergenerating facilities; transmission system design, reliability, and oconomics; radiological impact; and environmental impact.

\section{SUBJECT CATEGORY: Fuel Cycle Centers}

ORIGIN: Commercial

KEYWORDS: ECONOMICS; ELECTRIC POWER; ENVIRONMENTAL EFFECTS; FEASIBILITY STUDIES; FUEL FABRICATION PLANTS; FUEL REPROCESSING PLANTS; LAND USE; NUCLEAR PARKS; NUCLEAR POWER PLANTS; POWER SUPPLIES; RADIOACTIVE EFFLUENTS; SITE SELECTION; TECHNOLOGY ASSESSMENT; US NRC; USA; WASTE DISPOSAL; WASTE HEAT; WATER RESOURCES 
697

Nuclear Regulatory Commission, Office of Special Studies, Washington, DC

NUCLEAR ENERGY CENTER SITE SURVEY, 1975. PART III. TECHNICAL CONSIDERATIONS. NUREG-0001(Part 3). (1976)

Available from NTIS

Studies of the technical feasibility of nuclear energy centers (NECs) and the comparison between NEC technical feasibility and that of nuclear facilities on dispersed sites are reviewed. The conclusions related to technical feasibility of NEC are summarized. Technical feasibility was found to rest mainly on five major issues: heat dissipation, transmission, facility construction, radiological impact, and environmental impact. Although general conclusions can be reached in these five areas, it is recognized that they are interdependent, and detailed site-by-site analysis will be necessary. Some general conclusions on technical feasibility of $\mathrm{NECs}$ are presented, then detailed conclusions derived from the technical evaluation of NECs compared to dispersed site facilities are presented. The findings of this study on each of the five major feasibility issues are then discussed in sequence. The study concludes that nuclear energy centers, as defined herein, are technically feasible.

SUBJECT CATEGORY: Fuel Cycle Centers

ORIGIN: Commercial

KEYWORDS: ENVIRONMENTAL EFFECTS; FEASIBILITY STUDIES; HUMAN POPULATIONS; NUCLEAR PARKS; POWER TRANSMISSION; RADIATION PROTECTION; RADIOACTIVE EFFLUENTS; SAFETY ENGINEERING; SITE SELECTION; TECHNOLOGY ASSESSMENT; US NRC; USA; WASTE DISPOSAL; WASTE HEAT

\section{8}

Bell, M.J., and W.M. Hewitt; Nuclear Regulatory Commission, Washington, DC

COST/BENEFIT ASPECTS OF APPENDIX I TO 10 CFR PART 50. Transactions of the American Nuclear Society 23:425. (1976)

None

SUBJECT CATEGORY: General
ORIGIN: Commercial; Defense

KEYWORDS: BWR TYPE REACTORS; COST BENEFIT ANALYSIS; ECONOMICS; MAXIMUM ACCEPTABLE CONTAMINATION; POL LUTION REGULATIONS; PWR TYPE REACTORS; RADIOACTIVE EFFLUENTS

699

Richter, D., and W. Korner; Nuclear Safety and Radiation Protection Board, Berlin, Germany, D.R.

DISPOSAL OF RADIOACTIVE WASTES PRODUCED IN NUCLEAR INSTALLATIONS IN THE GERMAN DEMOCRATIC REPUBLIC. CONF-760310; STI/PUB/433; IAEASM-207/44; Management of Radioactive Wastes from the Nuclear Fuel Cycle, Vol. 2, Proceedings of an IAEA Symposium, Vienna, Austria, March 2226, 1976. International Atomic Energy Agency, Vienna, Austria, (pp. 271-286), 424 pp. (1976)

As conventional energy sources have decreased in availability, the GDR has been developing its nuclear power production. Studies have been conducted to establish the best methods for disposal of radioactive wastes from the nuclear fuel cycle. Methods investigated included storage above ground, shallow burial, storage in salt mines and formations, and injection into porous bedrock. All types of radioactive waste were considered in the study and the various aspects compared from the standpoints of economics and nuclear safety. As a result, the solution chosen was the secondary usage of abandoned salt mines. Construction of such a repository is currently underway in the Bartensleben mine, located in the cleft salt diapir of the upper Aller Valley. Volume of the storage area is about $5 \times 10(E+6)$ cu $\mathrm{m}$.

SUBJECT CATEGORY: LLW; HLW; Isolation

ORIGIN: Foreign

KEYWORDS: GEOLOGIC STRATA; SALT DEPOSITS; SITE SELECTION; UNDERGROUND DISPOSAL; RADIOACTIVE WASTE DISPOSAL; RADIOACTIVE WASTE STORAGE; COST BENEFIT ANALYSIS; LOW-LEVEL RADIOACTIVE WASTES; HIGH-LEVEL RADIOACTIVE WASTES; INTERMEDIATE-LEVEL RADIOACTIVE WASTES; 
700

Rodger, W.A.; Nuclear Safety Associates, Bethesda, MD

CRITICAL EVALUATION OF THE LIMIT OF TRANSURANIC CONTAMINATION OF LOW LEVEL WASTE. AIChE Symp. Ser. 72(154):3341. (1976)

Four references

The suggested limit for transuranics of 10 nanocuries/gram as a break point at which wastes should go to a national repository is seriously questioned. It is shown that insofar as protection of water supplies is concerned, the key to the problem is $\mathrm{Sr} 90$, not transuranics, and in any case, the limit should be based on a site-determined inventory, not on concentration. Concentration is only important as a protection for future stumblers who might dig into the waste. Calculations are presented to show that for this purpose the limit should be higher by several orders of magnitude. The 10 nanocurie/gram should be used as a definition of complete innocuousness.

SUBJECT CATEGORY: LLW; TRU

ORIGIN: Commercial; Defense

KEYWORDS: CALCULATION METHODS; CLASSIFICATION; COST BENEFIT ANALYSIS; FUEL REPROCESSING PLANTS; NUCLEAR POWER PLANTS; QUANTITY RATIO; RADIOACTIVE WASTE DISPOSAL; RADIOACTIVE WASTES; SOLID WASTES; SPENT FUEL ELEMENTS; STRONTIUM 90; WATER POLLUTION

701

Bachmann, R., J. Herzog, and H. Witte; NuklearChemie und -Metallurgie GmbH (NUKEM), Hanau, Germany, F.R.

FUEL ELEMENTS, FUEL CYCLE AND ISOTOPE TECHNIQUE: STATE AND POSSIBLE DEVELOPMENT OF THE REPROCESSING OF RADIOACTIVE WASTES FROM NUCLEAR POWER STATIONS IN THE FRG. AED-CONF-76-013-099; Reactor Meeting, Dusseldorf, Germany, F.R., March 30, 1976. ZAED, Eggenstein-Leopoldshafen, Germany, F.R. (1976)

In German; 1 table

Estimation of the annual and cumulated amount of radioactive wastes from nuclear power stations in the Federal Republic of Germany until the year
1990 , and present practice and thoughts on the future practice of waste management are presented.

SUBJECT CATEGORY: Spent Fuel; HLW

ORIGIN: Foreign

KEYWORDS: FORECASTING; RADIOACTIVE WASTE MANAGEMENT; RADIOACTIVE WASTE PROCESSING; RADIOACTIVE WASTES; SPENT FUELS; REPROCESSING; VOLUME

702

Jelinek-Fink, $Y_{\text {.; }}$ Nuklear-Chemie und -Metallurgle

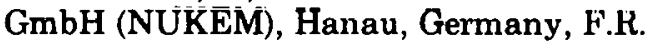

RADIOACTIVE WASTE FROM NUCLEAR PUWER STATIONS AND OTHEK NUCLEAR FACILITIES. CONF-760139-7; AED-CONF-76004-004; Waste Disposal in Nuclear Engineering, Proceedings of a Symposium, Mainz, Germany F.R., January 19, 1976. (1976)

In German; 8 figures; 1 table. Available from INIS

After estimating the amounts of liquid and solid radioactive wastes that will be produced in nuclear power plants, reprocessing plants, by the fuel cycle industry, and in the nuclear research centers in the FRG until 1990, the state of technology and the tendencies in the development of processing radioactive waste are reported. The paper also describes how waste disposal is managed by those producing radioactive waste and discusses the future development of the complex of waste disposal from the industry's point of view.

SUBJECT CATEGORY: HLW; LLW; TRU

ORIGIN: Foreign

KEYWORDS: DIAGRAMMS; FORECASTING; GERMAN FEDERAL REPUBLIC; LIQUID WASTES; NUCLEAR INDUSTRY; RADIOACTIVE WASTE DISPOSAL; RADIOACTIVE WASTE MANAGEMENT; RADIIOACTIVE WASTE PROCESSING; RADIOACTIVE WASTES; SOLID WASTES; SOLIDIFICATION

703

Dyroff, H., F.K. Fleischmann, and H. Witte; Nuklear-Chemie und Metallurgie GmbH (NUKEM), Hanau, Germany, F.R. 
RADIOACTIVE WASTE MANAGEMENT. Atomwirtsch., Atomtech. 21(7):340-342. (1976)

In German; 4 figures, 1 table

The Federal Ministry of Research and Technology in early 1974 commissioned a systems study on 'Radioactive Waste in the Federal Republic of Germany', which is being written by industry and the government-financed research centers and is due to be completed by late 1976 . The systems study will assess the amounts of radioactive waste expected to be generated by nuclear technology, nuclear research and isotope application, analyze current $\mathrm{R}+\mathrm{D}$ work, the processing technology adopted, the present waste management practice and the underlying legal principles, suggest a waste management system with satisfactory safety characteristics, an accompanying $R+D$ program and the necessary basic legal principles and launch an action program to set up this waste management system. The study covers the years until 1990 and will also indicate some trends up to 2000 .

SUBJECT CATEGORY: General

ORIGIN: Foreign

KEYWORDS: FISSION PRODUCTS; FORECASTING; GERMAN FEDERAL REPUBLIC; PLANNING; RADIOACTIVE WASTE MANAGEMENT; RADIOACTIVE WASTES; SALT DEPOSITS; SOLIDIFICATION; SYSTEMS ANALYSIS; VOLUME

\section{4.}

Schwarzwaelder, R.; Nuklear-Ingenieur Service GmbH, Hanau, Germany, F.R.

\section{DECOMMISSIONING OF NUCLEAR POWER} STATIONS. Energiewirtsch. Tagesfragen 26(7):358-363; Nuclear Energy, Proceedings of the 3rd RWE Workshop, Frankenthal, F.R. Germany, November 12, 1975. (1976)

In German; 6 figures

The essential findings about the decommissioning of mainly commercial LWR reactors are: 1) It can said that the decommissioning of the commercial nuclear plants in the Federal Republic which are being built or are already in operation will not bring any insurmountable technical problems. 2) The decommissioning will be carried out within the frame of the safety prescriptions already existing.
The personnel carrying out the decommissioning won't be subject to an inadmissible exposure. An increased emission of activity to the environment during the decommissioning is not expected. 3) The costs of the total dismantling of a nuclear plant are rather high in absolute values, but the cost advantage of the nuclear plants compared with other fossile power plants is only negligibly influenced by the decommissioning costs. 4) It is necessary to find a storage site for bulky radioactive waste in the Federal Republic. Transport containers of large volume are to be developed at the same time. 5) The progress of procedures and devices already known for grinding and conditioning of active heavy reactor components, especially of the reactor pressure vessel, should be hastened. 6) The decommissioning of nuclear test plants in the FRG to be carried out during the next years should be used to collect more experience both concerning the technical procedures, costs and concerning the permittance process for later decommissioning of commercial nuclear plants.

SUBJECT CATEGORY: Remedial Action, Surplus Facilities

ORIGIN: Foreign

KEYWORDS: COST; GERMAN FEDERAL REPUBLIC; NUCLEAR ENGINEERING; NUCLEAR POWER PLANTS; REACTOR DECOMMISSIONING; REACTOR DISMANTLING

705

Englehart, R.W., D.E. Martin, R.A. Martineit, J.F. Pang, B.J. Reckman, and E.R. Smith; NUS Corp., Rockville, MD

TECHNICAL ASSESSMENT OF SPECIFIC ASPECTS OF EPA PROPOSED ENVIRONMENTAL RADIATION STANDARD FOR THE URANIUM FUEL CYCLE (40CFR190) AND ITS ASSOCIATED DOCUMENTATION. AIF/NESP-011; 179 pp. (1976)

This report is a detailed review of the technical basis of the environmental radiation protection standards for the uranium fuel cycle (40CFR190) pro: posed by the U.S. Environmental Protection Agency. The study examines in detail the draft environmental impact statements and the associated documentation supporting the proposed standard in three specific areas: dose models and calculations; effluent control cost effectiveness; and radio-biological effects. This evaluation will be used 
by the Atomic Industrial Forum and its supporting members as a basis for evaluating the impact of the proposed standard on the nuclear power industry, and in providing testimony during the public hearing conducted by the Environmental Protection Agency. General conclusions drawn from specific results are the following: population dose considerations are not limiting with respect to effluent control design criteria; the curie limitations on $\mathrm{Kr} 85$, I 129, and transuranics are unnecessarily low, based on the potential health effect related cost effectiveness criterion of EPA; maximum individual dose considerations are the controlling factor for effluent control system design and release limitations. Neither this study nor EPA has investigated in detail the practicality of meeting a specific maximum individual dose limit for elements of the fuel cycle other than reactors. Since the determination of what level of effluent control technology represents "as low as practicable" or "as low as reasonably achievable" for elements of the uranium fuel cycle other than reactors is still underway by NRC and since much of the effluent control technology being considered has not been demonstrated in full scale operating conditions, it appears premature to set generally applicable standards to the whole fuel cycle.

\section{SUBJECII CA'TEGORY: General}

ORIGIN: Gencral

KEYWORDS: URANIUM; FUEL CYCLE; RADIOACTIVE EFFLUENTS; FUEL REPROCESSING PLANTS; IODINE 129; TRITIUM; KRYPTON 85; TRANSURANIUM ELEMENTS; DECONTAMINATION; FORECASTING; ENVIRON. MENTAL EFFECTS

\section{8}

Mullarkey, T.B., T.L. Jentz, J.M. Connelly, and J.P. Kane; NUS Corp., Rockville, MD

A SURVEY AND EVALUATION OF HANDLING AND DISPOSING OF SOLID LOWLEVEL NUCLEAR FUEL CYCLE WASTES. AIF/NESP-008; 143 pp. (1976)

Tables and figures included

The purpose of the study was to provide engineering economic and environmental data and analyses to aid in establishing a technical basis for the sound management of solid radioactive wastes. One objective of the study was to provide the information needed to help individuals in all phases of the industry understand the impact of solid waste generation. The study includes the characterization of current waste management techniques and the evaluation of alternatives to current practices. Data were obatined from 8 fuel fabrication facilities, 39 reactor sites, and 6 commercial waste disposal sites.

SUBJECT CATEGORY: LLW

ORIGIN: Commercial

KEYWORDS: RADIOACTIVE WASTE DISPOSAL; TERRESTRIAL ECOSYSTEMS; REPROCESSING; RADIOACTIVE WASTE MANAGEMENT; SOLID WASTES; LOW-LEVEL RADIOACTIVE WASTES

\section{7}

Ledford, S.G., and E.H. Gift; Oak Ridge Gaseous Diffusion Plant, Oak Ridge, TN

BWK FUEL RECUVEKY ECUNUMICS. K-UP. 207; 20 pp. (1976)

The purpose of the study is to gain insight into the incontivoo for rocovory of the fiseilo values in spent I.WR fuel. The plutonium "indifference value." associated "breakeven" reprocessing cost, and overall fuel cycle costs have been estimated as functions of the price of U308, the price of uranium enrichment, and of the cost of fabricating mixed oxide fuel assemblies relative to UO2 fabrication. The effects of spent fuel storage costs on fuel cycle and broakrovon roproooeoing oote havo aleo been calculated. The plutonium indifference value represents the value at which a reactor operator is indifferenl eillıer lu secuver y and 1 euse of plütonium (and uranium) or to recovery and sale of plutonium and uranium. The breakeven reprocessing costs represent the price that a reactor operator could afford to pay for reprocessing and waste management (combined), such that his total fuel cycle cost is the same with or without recovery.

SUBJECT CATEGORY: Spent Fuel; TRU

ORIGIN: Defense; Commercial

KEYWORDS: BWR TYPE REACTORS; ECONOMICS; FUEL CYCLE; PLUTONIUM; REPRO. CESSING; SPENT FUELS; COST 
708

Blanco, R.E.; Oak Ridge National Laboratory, Oak Ridge, TN

CONTROLLING THE RADIOLOGICAL IMPACT IN THE NUCLEAR FUEL CYCLE: A COST/BENEFIT ANALYSIS. CONF-760826-5; American Chemical Society Meeting, San Francisco, CA, August 29, 1976. (1976)

Methods that are used to control the radiological impact of the nuclear fuel cycle are discussed. This control is exercised through the application of a series of Federal laws and regulations that are used as the basis for licensing nuclear facilities. These licenses contain technical specifications which define the limits for the release of radioactive materials. The control is exercised more directly in a technical sense by the use of radwaste treatment equipment at the nuclear facilities to limit the release of radioactive materials. The first part of this paper contains a summary of the principal Federal laws and regulations that apply to nuclear fuel cycle facilities and a description of how they are applied in licensing procedures. A detailed discussion is presented of the amounts of radioactive materials that may be released from licensed facilities, and the radiological doses that individuals and populations surrounding these facilities would receive from these releases. These doses are then compared with the radiological doses received from natural background radiation to put them in perspective. Cost/benefit engineering surveys which are being made to determine the cost (in dollars) and the effectiveness of radwaste systems for decreasing the release of radioactive materials from model fuel cycle facilities, and to determine the benefits in terms of reduction in dose commitment to individuals and populations in surrounding areas are described.

\section{SUBJECT CATEGORY: General}

ORIGIN: Commercial

KEYWORDS: COST BENEFIT ANALYSIS; ENVIRONMENTAL EFFECTS; FEED MATERIALS PLANTS; FUEL FABRIC $\triangle$ TION PLANTS; FUEL REPROCESSING PLANTS; HUMAN POPULATIONS; LEGAL ASPECTS; LICENSING; MAXIMUM PERMISSIBLE ACTIVITY; NUCLEAR FACILITIES; NUCLEAR FUELS; NUCLEAR POWER PLANTS; RADIATION PROTECTION; RADIOACTIVE EFFLUENTS; RADIOACTIVE WASTE FACILITIES; RADIOACTIVE WASTE MANAGEMENT; RADIOACTIVE WASTE PROCESSING; RECOMMENDATIONS; SAFETY ENGINEERING
709

Blomeke, J.O., and W.D. Bond; Oak Ridge National Laboratory, Oak Ridge, TN

HIGH-LEVEL WASTE MANAGEMENT RESEARCH AND DEVELOPMENT PROGRAM AT OAK RIDGE NATIONAL LABORATORY. CONF-740346; Advances in Chemistry Series 153; High-Level Radioactive Waste Management, M.H. Campbell (Ed.), American Chemical Society, Proceedings of the 167th Meeting, Los Angeles, California, April 1-2, 1974, Chapter 6, (pp. 84-92), 166 pp. (1976)

Projections of wastes to be generated through the year 2000 present a problem of impressive size and complexity. It is estimated that the metric tons of spent fuels to be reprocessed annually will increase from 1700 in 1980 to 22,000 in the year 2000 . Generation of concentrated high-level liquid waste will increase from $170,000 \mathrm{gal} /$ year to 2.2 million gal/year in 2000. It is assumed that the actinide elements in the waste consist of $0.5 \%$ of the uranium and plutonium originally in the spent fuels plus all other heavy elements formed by transmutation of the uranium and plutonium in the reactors. Investigations of the technical feasibility of removing actinide elements from wastes to render the residuals more manageable in terms of hazards and storage requirements indicate that they can be removed from wastes by the minimally desired factors of $10(E+2)$ to $10(E+4)$. Natural salt formations are believed to offer the best prospects for disposal of high-level wastes, although other geologic formations, such as shales, granite, and limestone are also being studied.

SUBJECT CATEGORY: HLW

ORIGIN: Commercial

KEYWORDS: RADIOACTIVE WASTES; HIGHLEVEL RADIOACTIVE WASTES; ACTINIDES; FORECASTING; RADIOACTIVE WASTE STORAGE; SALT DEPOSITS; SHALES; GRANITES; LIMESTONE; RADIOACTIVE WASTE MANAGEMENT; VOLUME; RADIOACTIVE WASTE DISPOSAL

\section{0}

Blomeke, J.O., and C.W. Kee; Oak Ridge National Laboratory, Oak Ridge, TN

PROJECTIONS OF WASTES TO BE GENERATED: PROCEEDINGS OF THE INTERNATIONAL SYMPOSIUM ON THE MANAGEMENT OF WASTES FROM LWR FUEL 
CYCLE. CONF-760701; Management of Waste from the LWR Fuel Cycle, Proceedings of a Symposium, Denver, CO, July 11, 1976, (pp. 96 117). (1976)

Projections of commercial fuel-cycle wastes are based on ERDA's "low-growth" forecast of February 1975 (revised) for nuclear power in the United States. In this case, the installed nuclear electric capacity rises from $70 \mathrm{GW}$ in 1980 to $625 \mathrm{GW}$ in the year 2000. Most of the power is generated by LWRs through the end of this century. Commercial liquidmetal fast breeder reactors are introduced in 1993 and account for about $10 \%$ of the total installed capacity by 2000 . Plutonium recycle as fuel in LWRs begins in 1981 and is used in about 75\% of LWRs by 1983. Fuel reprocessing is assumed to begin in 19'78, with reprocessing capability increasing at such a rate that the spent-fuel backlog is worked off by 1988. Eleven principal fuel-cycle wastes are identified, and their rates of generation, shipment, and total accumulated inventories are calculated. These estimates assume the satisfactory completion of selected research and development programs that are under way on separation techniques, fixation processes, packaging and transportaton systems, and repositories for long-term storage and terminal isolation of the wastes. Results are presented on three bases: for $1 \mathrm{GW}$-yr of electricity generated; for a fuel fabrication and reprocessing throughput of 1500 metric tons per year; and for the total U.S. nuclcar economy.

SUBJECT CATEGORY: Spent Fuel

ORIGIN. Cómmercial

KEYWORDS: FORECASTING; LMFBR TYPE REACTORS; RADIOACTIVE WASTES; WATER COOLED REACTORS; VOLUME

711

Blomeke, J.O., and J.J. Perona; Oak Ridge National Laburalury, Oak Ridge, TN

SOURCE TERMS FOR AIRBORNE ĒFFLU. ENTS. CONF-760806; Airborne Effluents from Fuel Cycle Plants, Proceedings of the ANS-AIChE Symposium, Sun Valley, Idaho, August 5-6, 1976, (pp. 1-16). (1976)

Reactor fuel cycles are discussed and the sources of radioactive wastes are pointed out. The amounts and general characteristics of all significant radioactive wastes from the fuel cycle are presented in an attempt to clarify the relative position of airborne wastes with respect to the other kinds. Included in the discussion are high-level wastes, cladding, noble gases, iodine, tritium, carbon 14 , low-level and intermediate-level transuranic wastes, ore tailings, LWR fuel reprocessing, and HTGR fuel reprocessing. Projections of nuclear power generation and accumulation of gaseous wastes are presented with much tabular data. The impact of nuclear fuel cycle centers and the global buildup of airborne effluents are considered. Lowlevel transuranic wastes are defined as solid materials with alpha concentrations greater than $10 \mathrm{uci} / \mathrm{kg}$, but with a surface dose rate of less than 10 $\mathrm{mrem} / \mathrm{hr}$. Intermediate-level transuranic wastes are solid materials, other than high-level and cladding wastes with alpha activities grealer than $10 \mathrm{u} \mathrm{ci} / \mathrm{kg}$ and surface dose rates between 10 and $1000 \mathrm{mrem} / \mathrm{hr}$.

SUBJECT CA'TEGOKY: Airborne; Fuel Cycle Centers; HLW; LLW

ORIGIN: Commercial

KEYWORDS: RADIOACTIVE AEROSOLS; HIGH-LEVEL RADIOACTIVE WASTES; LOWLEVEL RADIOACTIVE WASTES; INTERMEDIATE-LEVEL RADIOACTIVE WASTES; RARE GASES; KRYPTON; XENON; IODINE; FUEL REPROCESSING PLANTS; TRITIUM; CARBON 14; URANIUM OXIDES; MILL TAILINGS; FORECASTING; FUEL CYCLE

\section{2}

Blomeke, J.O., J.H. Kust (Ed.), and L.E. Weaver (Ed.); Oak Ridge National Laboratory, Oak Ridge, TN

MANAGEMENT OF RADIOACTIVE WASTESi NUCLEAR POWER gAFETY. Per gamon Press Inc., New York. (1976)

The nature and characteristics of the wastes, the otatuo of the work that has been done, the options that are available in waste management, and ORNL's plans and expectations for the near future are reviewed.

SUBJECT CATEGORY: General

ORIGIN: Cümmercial

KEYWORDS: ACTINIDES; FORECASTING; GEOLOGIC DEPOSITS; HIGH-LEVEL RADIOACTIVE WASTES; RADIOACTIVE WASTE 
DISPOSAL; RADIOACTIVE WASTE MANAGEMENT; RADIOACTIVE WASTES; SALT DEPOSITS; SPACE

\section{3}

Croff, A.G.; Oak Ridge National Laboratory, Oak Ridge, TN

\section{AN EVALUATION OF OPTIONS RELATIVE TO THE FIXATION AND DISPOSAL OF 14C- CONTAMINATED CO2 AS CACO3. ORNL/TM-5171; 57 pp. (1976)}

Tables and references included

The least expensive disposal options which are likely to be acceptable appear to be the shallow-land burial of either drummed $\mathrm{CaCO} 3$ solid (total cost = $\$ 18.47 / \mathrm{kg}$ heavy metal) or drummed $\mathrm{CaCO} 3$ concreted with cement (total cost $=\$ 43.33 / \mathrm{kg}$ heavy metal). Neither placing the $\mathrm{CO} 2$ fixation process before the $\mathrm{Kr}$ removal process nor separating the bulk of the graphite fuel block from the fuel particles is attractive on both technical and economic grounds. However, reduction of the HTGR fuel nitrogen content appears to be a more attractive method of reducing the $\mathrm{C} 14$ release rate.

SUBJECT CATEGORY: LLW

ORIGIN: Defense

KEYWORDS: CARBON 14; CARBON DIOXIDE; RADIOACTIVE WASTE DISPOSAL; CALCIUM CARBONATES; LOW-LEVEL RADIOACTIVE WASTES; ECONOMICS

\section{4}

Davis, W., Jr.; Oak Ridge National Laboratory, Oak Ridge, TN

COSTS AND THE ENVIRONMENTAL IMPACT OF RADIOACTIVE WASTE TREATMENT IN REPROCESSING HIGHTEMPERATURE GAS-COOLED REACTOR FUEL. CONF-761103-17; American Nuclear Society Winter Meeting, Washington, DC, November 15, 1976; 17 pp. (1976)

The model plant is sized to process fuel from about fifty $1000 \mathrm{MW}(\mathrm{E})$ reactors, corresponding to 450 metric tons of uranium plus thorium (MTHM) annually charged to these reactors and to the same energy production, namely $45 \mathrm{gw}(\mathrm{e})$-yrs, as from the $1500 \mathrm{MT} / \mathrm{yr}$ capacity of the barnwell LWR fuel reprocessing plant. The cost of the plant was assumed to be 400 million 1973 dollars.

SUBJECT CATEGORY: Spent Fuel

ORIGIN: Commercial

KEYWORDS: FUEL REPROCESSING PLANTS; COST; ENVIRONMENTAL EFFECTS; SPENT FUELS; URANIUM; THORIUM; VOLUME; RADIOACTIVE WASTE PROCESSING

715

Davis, W., Jr., R.E. Blanco, B.C. Finney, G.S. Hill, R.E. Moore, and J.P. Witherspoon; Oak Ridge National Laboratory, Oak Ridge, TN

CORRELATION OF RADIOACTIVE WASTE TREATMENT COSTS AND THE ENVIRONMENTAL IMPACT OF WASTE EFFLUENTS IN THE NUCLEAR FUEL CYCLE - REPROCESSING OF HIGH-TEMPERATURE GASCOOLED REACTOR FUEL CONTAINING URANIUM 233 AND THORIUM. ORNL/NUREG/TM-4; 182 pp. (1976)

A cost/benefit study was made to determine the cost and effectiveness of various radioactive waste (radwaste) treatment systems for decreasing the release of radioactive materials from a model hightemperature gas-cooled reactor (HTGR) fuel reprocessing plant and to determine the radiological impact (dose commitment) of the released materials on the environment. The study is designed to assist the U.S. Nuclear Regulatory Commission in defining the term "as low as reasonable achievable" as it applies to this nuclear facility. The base case is representative of conceptual, developing technology of head-end graphite-burning operations and of extensions of solvent-extraction technology of current designs for light-water-reactor (LWR) fuel reprocessing plants. The model plant has an annual capacity of $\mathbf{4 5 0}$ metric tons of heavy metal (MTHM, where heavy metal is uranium plus thorium), as charged to about fity 1000-MW(e) HTGRs. Additional radwaste treatment systems are added to the base-case plant in a series of case studies to decrease the amounts of radioactive materials released and to reduce the radiological dose commitment to the population in the surrounding area. The capital and annual costs for the added waste treatment operations and the corresponding reductions in dose commitments are calculated for each case. In the 
final analysis, the cost/benefit of each case, calculated as additional cost of radwaste system divided by the reduction in dose commitment, is tabulated or the dose commitment is plotted with cost as the variable. The status of each of the radwaste treatment methods used in the case studies is discussed. Much of the technology used in the advanced cases is in an early stage of development and is not suitable for immediate use in detailed designs of an HTGR fuel reprocessing plant. However, the radwaste treatment methods are believed to be reducible to practice. The methodology used in estimating the costs is presented in Appendix A. (Auth)

\section{SUBJECT CATEGORY: Airborne}

ORIGIN: Commercial

KEYWORDS: RADIOACTIVE WASTE PROCESSING; URANIUM 233; THORIUM; COST BENEFIT ANALYSIS; COST; SPENT FUELS; HTGR TYPE REACTORS; VOLUME; FUEL REPROCESSING PLANTS; GASEOUS WASTES; DOSE COMMITMENTS

\section{6}

Finney, B.C.; Oak Ridge National Laboratory, Oak Ridge, TN

\section{RADIOACTIVE WASTE TREATMENT COSTS AND ENVIRONMENTAL IMPACT FOR REPROCESSING LIGHT-WATER REACTOR FUEL. Transactions of the American Nuclear Society 24:96; American Nuclear Society 1976 International Meeting, Washington DC, No- vember 14,1976 . (1976)}

\section{No Abstract}

SUBJECI CATEGUKY: Airborne

\section{ORIGIN: Commercial}

KEYWORDS: BWR TYPE REACTORS; COST BENEFIT ANALYSIS; ENVIRONMENTAL EF. FECTS; FLOWSHEETS; HUMAN POPULATIONS; P.WR TYPE REACTORS; RADIATION DOSES; RADIOACTIVE WASTE PROCESSING; REPROCESSING; SPENT FUELS; DOSE COMMITMENTS; GASEOUS WASTES

\section{7}

Finney, B.C., R.E. Blanco, R.C. Dahlman, G.S. Hill, F.G. Kitts, R.E. Moore, and J.P. Witherspoon; Oak Ridge National Laboratory, Oak Ridge, TN
CORRELATION OF RADIOACTIVE WASTE TREATMENT COSTS AND THE ENVIRONMENTAL IMPACT OF WASTE EFFLUENTS IN THE NUCLEAR FUEL CYCLE - REPROCESSING LIGHT-WATER REACTOR FUEL. ORNL/NUREG/TM-6; 153 pp. (1976)

Cross References - ORNL-4922; ORNL-TM-4901; ORNL-TM-4902; ORNL-TM-4903, Vol. 1; ORNLTM-4903, Vol. 2; ORNLTM-4904; 42 tables, 28 figures, references

A cost/benefit study was made to determine the cost and effectiveness of radioactive waste (radwaste) treatment systems for decreasing the release of radioactive materials from a model nuclear fuel reprocessing plant which processes light-water reactor (LWR) fuels, and to determine the radiological impact (dose cormmitment) of the releassed materials on the environment. The study is designed to assist in defining the term "as low as reasonably achievable" in relation to limiting the release of radioactive materials from nuclear facilities. The base case model plant is representative of current plant technology and has an annual capacity of 1500 metric tons of LWR fuel. Additional radwaste treatment systems are added to the base case plant in a series of case studies to decrease the amounts of radioactive materials released and to reduce the radiological dose commitment to the population in the surrounding area. The cost for the added waste treatment operations and the corresponding dose commitments are calculated for each case. In the final analysis, radiological dose is plotted vs the annual cost for treatment of the radwastes. The status of the radwaste treatment methods used in the case studies is discussed. Much of the technology used in the advanced cases is in an early stage of development and is not suitable for immediate use. The methodology used in estimating the costs and the radiological doses, detailed calculations, and tahulations are presented in Appendix $A$ and ORNL 4892 ,

SUBJECT CATEGORY: LILW; Airborne

ORIGIN: Commercial

KEYWORUS: COST BENETIT ANALYSIS; DOSIMETRY; FUEL CYCLE; RADIATION PROTECTION; DOSE COMMITMENTS; ECONOMICS; RECOMMENDATIONS; COST; REPROCESSING; RADIOACTIVE WASTE PROCESSING; GASEOUS WAS'IES

\section{8}

Groenier, W.S.; Oak Ridge National Laboratory, Oak Ridge, TN 
WASTE TREATMENT COST/BENEFIT ANALYSIS FOR FABRICATION OF LIGHTWATER REACTOR FUEL CONTAINING PLUTONIUM. Transactions of the American Nuclear Society 24:95; Transactions of the American Nuclear Society 1976 International Meeting, Washington, DC, November 14, 1976. (1976)

No Abstract

SUBJECT CATEGORY: TRU

ORIGIN: Commercial

KEYWORDS: BWR TYPE REACTORS; COST BENEFIT ANALYSIS; FABRICATION; FLOWSHEETS; FUEL PELLETS; HUMAN POPULATIONS; NUCLEAR FUELS; PLUTONIUM OXIDES; PWR TYPE REACTORS; RADIATION DOSES; RADIOACTIVE WASTE PROCESSING; URANIUM OXIDES

719

Lotts, A.L., and P.R. Kasten; Oak Ridge National Laboratory, Oak Ridge, TN

\section{GAS-COOLED REACTOR PROGRAMS - THORIUM UTILIZATION PROGRAM PROGRESS REPORT, JAN. 1, 1974 THROUGH JUNE 30, 1975. ORNL-5128; 335 pp. (1976)}

Figures, references

Overall HTGR fuel recycle involves shipment and storage, reprocessing, refabrication, and waste disposal. Reprocessing deals with the chemical reprocessing of spent fuel to recover useful fuel values - bolh residual U-235 and U-233 converted from Th-232 - and also to isolate and convert the fission products and other wastes into forms suitable for disposal. These chemical processing steps are conveniently grouped into four areas: head end, solvent extraction, off-gas cleanup, and waste processing and isolation. For HTGR recycle, the product is in the form of uranyl nitrate solution, which will be the feed for a refabrication plant.

SUBJECT CATEGORY: Spent Fuel; HLW

ORIGIN: Commercial

KEYWORDS: BREEDER REACTORS; CARBON; ECONOMICS; HOT CELLS; THORIUM; DESIGN; ENVIRONMENT; OFF.GAS SYSTEMS;
RESINS; SOLVENT EXTRACTION; REPROCESSING; HTGR TYPE REACTORS; SAFEGUARDS; NUCLEAR MATERIALS; RADIOACTIVE WASTE PROCESSING; GAS COOLED REACTORS; THORIUM 232; THORIUM CYCLE

\section{0}

Roddy, J.W., R.E. Blanco, G.S. Hill, R.E. Moore, R.D. Seagren, and J.P. Witherspoon; Oak Ridge National Laboratory, Oak Ridge, TN

CORRELATION OF RADIOACTIVE WASTE TREATMENT COSTS AND THE ENVIRONMENTAL IMPACT OF WASTE EFFLUENTS IN THE NUCLEAR FUEL CYCLE - FABRICATION OF HIGH-TEMPERATURE GASCOOLED REACTOR FUEL CONTAINING URANIUM 233 AND THORIUM. ORNL/NUREG/TM-5; 217 pp. (1976)

Forty-eight figures, 74 tables

A cost/benefit study was made to determine the cost and effectiveness of various radioactive waste (radwaste) treatment systems for decreasing the release of radioactive materials from model HighTemperature Gas-Cooled (HTGR) fuel fabrication plants and to determine the radiological impact (dose commitment) of the released materials on the environment. The study is designed to assist the U.S. Nuclear Regulatory Commission in defining the term "as low as reasonable achievable" as it applies to these nuclear facilities. The base cases of the two model plants, a fresh fuel fabrication plant and a refabrication plant, are representative of current proposed commercial designs or are based on technology that is being developed to fabricate uranium, thorium, and graphite into fuel elements. The annual capacities of the fresh fuel plant and the refabrication plant are 450 and 245 metric tons of heavy metal (where heavy metal is uranium plus thorium), as charged to about fifty 1000-MW(e) HTGRs. Additional radwaste treatment systems are added to the base case plants in a series of case studies to decrease the amounts of radioactive materials released and to reduce the radiological dose commitment to the population in the surrounding area. The capital and annual costs for the added waste treatment operations and the corresponding reductions in dose commitments are calculated for each case. In the final analysis, the cost/benefit of each case, calculated as additional cost of radwaste system divided by the reduction in dose commitment, is tabulated or the dose commitment is plotted with cost as the variable. The status of each of the radwaste treatment methods used in the case 
studies is discussed. Much of the technology included in the advanced case studies has been utilized in either pilot-plant or industrial-scale operations, although no existing fabrication plant has used all of the treatment methods. The methodology used in estimating the costs is presented in Appendix A. (Auth)

\section{SUBJECT CATEGORY: LLW}

ORIGIN: Commcrcial

KEYWORDS: COST BENEFIT ANALYSIS; FUEL CYCLE; FUEL ELEMENTS; HTGR TYPE REACTORS; RADIOACTIVE WASTE MANAGEMENT; URANIUM 233; THORIUM; DOSE COMMITMENTS; FUEL FABRICATION PLANTS; POPULATIONS; COST; EVALUATION; FABRICATION; GASTROINTESTINAL TRACT; BONES; THYROID; LUNGS; MUSCLES; KIDNEYS; SPLEEN; LIVER; TESTES; OVARIES; RADIOACTIVE EFFLUENTS

\section{1}

Sears, M.B.; Oak Ridge National Laboratory, Oak Ridge, TN

\section{AIRBORNE EFFLUENT CONTROL AT URA- NIUM MILLS. CONF-760806-4; Controlling Air- borne Effluents from Fuel Cycle Plants, Proceed- ings of a Meeting, Sun Valley, ID, August 5, 1976. American Nuclear Society, Hinsdale, IL. (1976)}

Available from N'IIS; 8 tables, 3 figures

The Oak Ridge National Laboratory has made an engineering cost-environmental benefit study of radioactive waste treatment systems for decreasing the amount of radioactive materials released from uranium ore processing mills (ORNL/TM-4903). 'I'his paper summarizes the results of the studyy which pertain to the control and/or abatement of airborne radioactive materials from the mill processes. The tailings area is not included. Present practices in the uranium milling industry, with particular emphasis on effluent control and waste management, have been surveyed. A questionnaire was distributed to each active mill in the United States. Replies were received from about 75 percent of the mill operators. Visits were made to six operating uranium mills that were selected because they represented the different processes in use today and the newest, most modern in mill designs. Discussions were held with members of the Region IV Office of NRC and the Grand Junction Office of ERDA. Nuclear Science Abstracts, as well as other sources, were searched for literature pertinent to uranium mill processes, effluent control, and waste management.

SUBJECT CATEGORY: Airborne

ORIGIN: Commercial

KEYWORDS: AEROSOLS; AIR POLLUTION; CONTROL, COGT BENEFIT ANALYSIS; MILL ING; ORNL; RADIATION MONITORING; RADIOACTIVE WASTES; URANIUM; URANIUM ORES; RADIOACTIVE WASTE MANAGEMENT; RADIOACTIVE EFFLUENTS; GASEOUS WASTES

\section{2}

Sears, M.B.; Oak Ridge National Laboratory, Oak Ridge, TN

RADIOACTIVE WASTE TREATMENT COSTS AND ENVIRONMENTAL IMPACT FOR MILLING OF URANIUM ORES. Transactions of the American Nuclear Society 24:94-95; From Transactions of the American Nuclear Society 1976 International Meeting, Washington, DC, November 14, 1976. (1976)

None

\section{SUBJECT CATEGORY: LLW}

ORIGIN: Commercial

KEYWORDS: COST' BENEFIT ANALYSIS; ENVIRONNMĒNTAL EFFECTS; HUMAN POPULATIONS; MILLING; RADIATION DOSES; RADIOACTIVE WASTE PROCESSING; URANIUM ORES; COST; ENVIRONMENT

\section{3}

Tamura, T., F.S. Brinkley, D.A. Crerar, J.O. Duguid, E.R. Eastwood, C.W. Francis, J.L. Means, and O.M. Sealand; Oak Ridge National Laboratory, Oak Ridge, 'I'N

WASTE MANAGEMENT ANALYSES AND APPLICATIONS: ENVIRONMENTAL SCIENCES DIVISION ANNUAL PROGRESS REPORT FOR PERIOD ENDING SEPTEMBER 30, 1975. ORNL-5193, (pp. 173-180). (1976)

Land use for waste management and disposal has been practiced extensively in the nuclear industry. 
To prevent and mitigate adverse effects of this utilization of our resource, research on the geohydrologic characteristics of the formations and on the waste solutions is essential. An active program is being pursued in the waste disposal area of White Oak Drainage Basin of ORNL. In addition to the radioactive elements of nuclear waste, nonradioactive nitrates pose a particular problem in some of the nuclear processes. The studies reported in this section utilize soil microbes to decompose the nitrate; the particular emphasis is on engineering feasibility and parametric relationship for optimum decomposition. Of increasing concern in the nuclear industry is the increasing generation and utilization of plutonium and its potential hazard in the environment. Its release in the environment is associated with bomb testing, fuel reprocessing, and processes related to fuel fabrication. Plutonium from these sources may behave differently in the environment, and understanding of its characteristics and properties will be invaluable in utilizing this valuable resource. Studies related to plutonium characterization from several contaminated sites are described in this section.

SUBJECT CATEGORY: LLW; TRU

ORIGIN: Defense

KEYWORDS: BIODEGRADATION; DECOMPOSITION; FEASIBILITY STUDIES; LAND USE; NITRATES; NONRADIOACTIVE WASTES; PLUTONIUM; RADIOACTIVE WASTE MANAGEMENT; RADIOACTIVE WASTES; SOILS; RADIOACTIVE WASTE DISPOSAL

724

Weeren, H.O.; Oak Ridge National Laboratory, Oak Ridge, TN

AN EVALUATION OF WASTE DISPOSAL BY SHALE FRACTURING. ORNLTM-5209; 52 pp. (1976)

See also Nuclear Science Abstract 1976, 33(09) 20920

The shale fracturing process is evaluated as a means for permanent disposal of radioactive intermediate level liquid waste generated at the Oak Ridge National Laboratory. The estimated capital operating and development costs of a proposed disposal facility are compared with equivalent estimated costs for alternative methods of waste fixation. (Auth)
SUBJECT CATEGORY: HLW; LLW

ORIGIN: Defense

KEYWORDS: RADIOACTIVE WASTE DISPOSAL; LIQUID WASTES; ECONOMICS; INTERMEDIATE-LEVEL RADIOACTIVE WASTES; SHALES; COST; RADIOACTIVE WASTE PROCESSING; HYDRAULIC FRACTURING

\section{5}

Weeren, H.O., F.T. Binford, and J.O. Blomeke; Oak Ridge National Laboratory, Oak Ridge, TN

STUDY OF ALTERNATIVE METHODS FOR THE MANAGEMENT OF WASTE SOLUTION AND SLUDGE AT OAK RIDGE NATIONAL LABORATORY. ORNL-TM-5208. (1976)

Alternative methods seem to be much more expensive than by the hydrofractive method

Several methods for solidifying and storing radioactive intermediate level liquid wastes generated at the Oak Ridge National Laboratory are considered. Three methods, shale-cement fixation, ion exchange, and glass fixation, are evaluated in greater detail and cost estimates are given. (Auth)

SUBJECT CATEGORY: HLW

ORIGIN: Commercial

KEYWORDS: RADIOACTIVE WASTE DISPOSAL; LIQUID WASTES; ORNL; EVAPORATION; ECONOMICS; HYDRAULIC FRACTURING; INTERMEDIATE-LEVEL RADIOACTIVE WASTES; SHALES; CEMENTS; ION EXCHANGE; GLASS; SOLIDIFICATION; SLUDGES

726

Lowman, F.G., and R.A. (Ed.) Karam; Puerto Rico Nuclear Ceniler, Mayaguez

RADIOACTIVE WASTE IN THE MARINE ENVIRONMENT: ENERGY AND THE ENVIRONMENT COST-BENEFIT ANALYSIS. CONF-750697; Energy and the Environment - Cost Benefit Analysis, Proceedings of a Conference, Atlanta, GA, June 23, 1975. Pergamon Press, Inc., Elsmford, NY. (1976) 
The introduction of radionuclides into near-shore marine areas is considered in relation to Federal Regulations and to the hazards posed to man and to marine organisms living near the site of introduction of the contaminants. The use of the critical pathway concept for evaluating hazards to man from radionuclides in his food is discussed, and the specific activity concept is applied to demonstrate the degree of hazard to man which could result from normal reactor operation using seawater for the coolant. The relative hazards to marine organisms from naturally occurring and reactor-produced radionuclides are also evaluated.

\section{SUBJECT CATEGORY: LLW}

ORIGIN: Foreign

KEYWORDS: AQUATIC ORGANISMS; BIOLOGICAL EFFECTS; COMPARATIVE EVALUATIONS; COOLING; COST BENEFIT ANALYSIS; ENVIRONMENTAL EFFECTS; ENVIRONMENTAL EXPOSURE PATHWAY; ESTUARIES; FOOD CHAINS; HEALTH HAZARDS; MAN; MARINE DISPOSAL; NUCLEAR ENERGY; NUCLEAR POWER PLANTS; POLLUTION; RADIOACTIVE WASTE DISPOSAL; RADIOECOLOGICAL CONCENTRATION; RADIOISOTOPES; RADIONUCLIDE MIGRATION; REACYIOR COOLING SYSTEMS; SEAWATER; TABLES

\section{7}

Mandel, H.; Rheinisch-Westfaelisches Elektrizitaetswerk A.G., Essen, Germany, F.R.

IMPORTANCE OF WASTE MANAGEMENT IN ENERGY POLICY. CONF-760139-10; AECCONF-76-004-008; Waste Disposal in Nuclear Engineering, Proceedings of a Symposium, Mainz, Germany, F.R., January 19, 1976. (1976)

In German; 9 figures; available from INIS

Waste management in nuclear power plants must be given the same economic significance as the other sections of the nuclear fuel cycle, because the proportional costs for reprocessing, conditioning, and final storage of radioactive wastes have increased considerably in comparison with the overall fuel costs. A further increase in waste management costs is to be prevented. The need for accelerated creation of reprocessing capacity as well as the need for the making storage capacity available for irradiated fuel elements in good time is pointed out. In addition, the increased demand for uranium there is a delay in the recycling of uranium and plutonium from reprocessing.

SUBJECT CATEGORY: General

ORIGIN: Foreign

KEYWORDS: DIAGRAMS; ECONOMICS; ENERGY POLICY; FORECASTING; FUEL CYCLE; PLANNING; RADIOACTIVE WASTE DISPOSAL; RADIOACTIVE WASTE MANAGEMENT; REPROCESSING; SPENT FUEL STORAGE

\section{8}

Bradley, R.F., and J.C. Corey; Savannah River Laboratory, Aiken, SC

TECHNICAL ASSESSMENT OF BEDROCK WASTE STORAGE AT THE SAVANNAH RIVER PLANT. DP-1438; 287 pp. (1976)

This study indicates that a cavern with an excavated volume of 130 million gallons could contain 80 million gallons of concentrated radioactive SRP wastes with minimal risks if the cavern is located in the impermeable Triassic basin underlying the Savannah River site. The cavern could be placed so that it would lie wholly within the boundaries of the plantsite. Summarizes the general geological, hydrological, and chemical knowledge of the geological structures beneath the plantsite; develops evaluation guidelines; and utilizes mathematical models to conduct risk analyses.

SU'BJECT CATEGORY: Isolation

ORIGIN: Defense

KEYWORDB: RADIOACTIVD WAGTE ETORAGE; FADIO DERGROUND DISPOSAL; TRIASSIC PERIOD; SAVANNAH RIVER PLANT; MATHEMATICAL MUOUELS

\section{9}

Bradley, R.F., and J.C. Corey; Savannah River Laburatory, Aiken, SC

EVALUA'IIUN GUIDELINES. DP-1438; Tèchnical Assessment of Bedrock Waste Storage at the Savannah River Plant, R.F. Bradley, et.al., (pp. II-3. II-27), 287 pp. (1976) 
Assessment of bedrock storage and a preliminary cost-benefit-risk analysis are the main themes of this section. Although the section deals with highlevel waste the principals would seem to apply as well to low-level waste.

The two basic criteria to be met for assessing the feasibility of bedrock storage are that radioactive and stable constituents entering the biosphere should: 1) have a negligible effect on a single individual and 2) produce a minimum effect on the entire population over extended time periods. Drinking water is the principal means of ingesting toxic waste. In order to satisfy the first criterion the net concentration of all toxic species, both radioactive and stable, must be well below (less than $1 \%$ of) presently accepted MPC values in public water. The second criterion requires that the total quantities of activity released should not exceed certain limits. Proper evaluation of bedrock storage necessitates a comparison with alternate means of storing waste on a risk-cost-benefit basis which, in turn, is dependent upon an evaluation of the risk of longlived radionuclides. However, at present, there is no acceptable method for risk evaluation. Once this is achieved, potential biomedical costs resulting from radionuclide release to the environment can be readily calculated and equated with costs of reducing these releases by alternative waste storage methods. Biomedical cost estimates of various radionuclide releases are given in terms of: 1) uptake of nuclides of $1 \%$ MPC, 2) ingestion of I-129, Cs-135, and $\mathrm{Pu}-239,3$ ) failure of waste tanks assuming the same drinking water pathway and 4) alternative pathways to drinking water. Besides radionuclides, toxic stable chemical species also occur in the waste and it is assumed that they will all be released into the biosphere over a period of millions of years. Relaxation of the two criteria required for assessing feasibility of bedrock storage may be necessary when considering toxic stable compounds although relaxation is not condoned. This preliminary costbenefit-risk analysis indicates that: (1) The potential net biomedical cost of abandoning unaltered Savannah River radioactive waste in existing tanks is estimated to be about $\$ 300,000,000$. The expected $\$ 100,000,000$ cost of a bedrock storage facility for unaltered waste appears justified on this basis. (2) The potential biomedical cost (at $\$ 100 /$ man-rem) of a bedrock storage facility that releases all of the I129 and Cs-135 but essentially none of the Pu-239 may be only a few million dollars distributed over many centuries (ca. $\$ 130,000$ for I-129 and ca. $\$ 2,200,000$ for Cs-135 for the drinking water pathway); however, other potential pathways should be investigated. (3) Additional bedrock facility costs to prevent the entry of most of the Pu-239 into the biosphere are justified, if necessary, based on the estimated potential biomedical cost of $\$ 66,000,000$ for releasing all of the Pu-239 from a bedrock cavern. The final assessment of bedrock storage will require identification and analysis of all potential exposure pathways for all of the isotopes, with special emphasis on the extremely long-lived isostopes such as I-239, Cs-135, and Pu-239 as well as the stable toxic chemical constituents such as mercury, and comparison on a cost-benefit-risk basis with alternative waste management techniques.

SUBJECT CATEGORY: Isolation; HLW

ORIGIN: Defense

KEYWORDS: RADIOACTIVE WASTE STORAGE; RADIOACTIVE WASTE DISPOSAL; UNDERGROUND DISPOSAL; ECONOMICS; COST; COST BENEFIT ANALYSIS

730

Hardt, H.A.; Savannah River Laboratory, Aiken, SC

REDUCTION OF ENVIRONMENTAL POLLUTION FROM FUEL AND TARGET MANUFACTURING PROCESSES. MET-E-18; DPSPU-76-11-14. (1976)

\section{Available from NTIS}

Nuclear fuel and target manufacturing processes in the 300 Area generate potential environmental pollutants. Efforts to eliminate or reduce their harmful effects have been pursued for many years by the Raw Materials and Raw Materials Technology departments with assistance from other groups, primarily the Project and Health Physics departments. This report documents: methods adopted to reduce pollution; cost of these methods; amount of pollution reduction achieved; and other benefits in cost savings or quality improvement for January 1968 through December 1975. Capital funds totaling $\$ 915,000$ were spent on these programs. Annual cost savings of $\$ 65,000$ were realized, and incidental but significant improvements in product quality were obtained. In no case was product quality degraded. Reductions in releases of pollutants are summarized for water pollution, air pollution, and land pollution. In addition to these reductions, intangible benefits were realized including reduced corrosion of structures and equipment; improved working conditions for personnel; energy savings, both on and offplant; improved utilization of natural resources; and reduced impact to environment, both on and offplant. 
SUBJECT CATEGORY: LLW; HLW

\section{ORIGIN: Defense}

KEYWORDS: AIR POLLUTION; AIR POLLUTION ABATEMENT; ALUMINIUM; ECONOMICS; ENERGY CONSERVATION; ENVIRONMENTAL EFFECTS; FUEL FABRICATION PLANTS; INORGANIC ACIDS; LAND POLLUTION; LAND POLLUTION ABATEMENT; LIQUID WASTES; MATERLALS RECOVERY; NUCLEAR FUELS; ORGANIC ACIDS; ORGANIC COMPOUNDS; PROCESS CONTROL; PRODUCTION; QUALITY CONTROL; RADIOACTIVE EFFLUENTS; TARGETS; URANIUM; WATER POLLUTION; WATER POLLUTION ABATEMENT

731

King, F.D., and W.H. Baker; Savannah River Laboratory, Aiken, SC

INTERIM STORAGE OF SPENT FUEL ASSEMBLIES. DP-MS-76-39; CONF-760701; Management of Waste from the LWR Fuel Cycle, Proceedings of an International Symposium, Denver, Colorado, July 11-16, 1976, (22 pp.). (1976)

Spent fuel discharged from light water reactors (LWR) is cooled at the reactor sites for at least 5 months to allow short-lived radioactive isotopes to decay. After this decay, fuel could be shipped to a chemical reprocessing plant for recovery of uranium and plutonium. Accordingly, storage facilities at LWR sites were originally intended for only shortterm storage of spent fuel. More recently, spent fuel has been considered as a possible waste form suitable for interim storage or even ultimate disposal. Several alternatives have been demonstrated or proposed for retrievable storage of spent fuel for periods of up to 100 years. "These include storage in water-cooled basins, air-cooled vaults, concrete surface silos, geologic formations, or nearsurface heat sinks. The fuel cladding is usually considered the initial barrier for confinement of fuel core material for all storage concepts. The storage facility is designed to protect this cladding against mechanical, chemical, or thermal damage and to provide a safe, subcritical arrangement with adequate shielding under normal operating conditions or during extreme natural phenomena. Additional confinement is provided by a container if the fuel has been packaged or by cleanup of the coolant if bare fuel is stored. In all concepts, leaking fuel must be packaged in sealed containers to minimize radioactive releases. Water-cooled storage of spent fuel in near-surface cells of heavily reinforced concrete lined with stainless steel has been proven by about 30 years of operating experience at reactor sites and fuel reprocessing plants. Near-surface storage with forced-draft air cooling of HTGR (High Temperature Gas Reactor) fuels is being used by INEL (Idaho National Engineering Laboratory) and is feasible for unpackaged LWR fuel that has been out of the reactor at least 3 to 4 years. Naturaldraft cooling of spent fuel has also been proposed, and demonstration programs are in progress for CANDU (Canada Deuterium Uranium) fuel. Spent fuel assemblies are sealed in thick low-carbon steel containers and placed in large cylindrical concrete housings (silos) located outdoors. The cooling is completely passive, requiring little maintenance and only minimal surveillance. Recent studies comparing the econnmics of interim storage of spent. fuel (throwaway fuel cycle) to prompt chemical reprocessing conclude that disposal as fuel decreases the Nation's natural resources significantly and is not cost justified if both plutonium and uranium are recycled in the nuclear fuel cycle. (Auth)

SUBJECT CATEGORY: Spent Fuel

ORIGIN: Defense; Commercial

KEYWORDS: SPENT FUELS; LWRTYPE REACTORS; RADIOACTIVE DECAY; REPROCESSING; URANIUM; PLUTONIUM; RADIOACTIVE WASTE STORAGE; RADIOACTIVE WASTE DISPOSAL; RADIOACTIVE WASTE STORAGE; COOLANTS; WATER; AIR; CLADDING; SAFETY; SHIELDING; CONTAINERS; PACKAGING; LEAKS; CONCRETES; STEEISS; HTGR TYPE REACTORS; CANDU TYPE REACTORS; ECONOMICS; FUEL CYCLE; COST BENEFIT ANALYSIS

\section{2}

Wallace, R.M.; W.H. Hale, R.F. Bradley, H.L. Hull, J.A. Kelley, J.A. Stone, and G.H. Thompson; Savannah River Laboratory, Aiken, SC

SOLID FORMS FOR SAVANNAH RIVER PLANT RADIOACTIVE WASTES. CONF740346; Advances in Chemistry Series 153, HighLevel Radioactive Waste Management, Chapter 2, M.H. Campbell (Ed.), Proceedings of the 167th Meeting of the American Chemical Society, Los Angeles, California, April 1-2, 1974. American Chemical Society, Washington, DC, (pp. 9-30), 166 pp. (1976) 
The radioactive wastes from plant operations at the Savannah River Laboratory are stored as liquids or slurries in double-walled carbon steel tanks. Until recently, the only alternative under serious consideration was storage as a liquid in a deep mined cavern under the plantsite, but in November of 1972 , the AEC deferred further study of that project in favor of an investigation of the solidification of SRL waste and storage in a Retrievable Surface Storage facility. Methods are now being developed to immoblize these wastes in solid forms such as cement, asphalt, or glass. Cs 137 and Sr 90 are the major biological hazards and heat producers in the alkaline wastes produced at SRL. In the conceptual processes studied, Cs 137 removed from alkaline supernates, together with insoluble sludges that contain $\mathrm{Sr} 90$, will be incorporated into solid forms of high integrity and low volume suitable for storage in a retrievable surface storage facility for about 100 years, and for eventual shipment to an offsite repository. Mineralization of Cs 137, or its fixation on zeolite prior to incorporation into solid forms, is also being studied. Economic analyses to reduce costs and fault-tree analyses to minimize risks are being conducted. Methods are being studied for removal of sludge from (and final decontamination of) waste tanks.

SUBJECT CATEGORY: HLW; LLW

ORIGIN: Defense

KEYWORDS: RADIOACTIVE WASTE MANAGEMENT; CESIUM; STRONTIUM; HAZARDS; SOLIDIFICATION; CEMENTS; GLASS; ASPHALTS; RADIOACTIVE WASTE STORAGE; TANKS; CHEMICAL PROPERTIES; SLUDGES; ION EXCHANGE; RETRIEVAL SYSTEMS; COST BENEFIT ANALYSIS

733

Savannah River Laboratory, Aiken, SC

LIGHT WATER REACTOR FUEL RECYCLE. SAVANNAH RIVER LABORATORY QUARTERLY REPORT, JANUARY-MARCH 1976. DPST-LWR-76-1-1; 35 pj. (1976)

Available from NTIS; ERA Citation 02:002466

A preliminary economic assessment indicates that the cost advantage of closing the LWR fuel cycle becomes more pronounced as uranium ore reserves are depleted. A study showed that a recycle plant with a capacity of 10 metric tons per day of uranium and plutonium would best suit industry requirements for the mid-1980's. Evaluation of tank storage technology indicates the feasibility of tank storage of high-activity liquid waste from processing LWR fuel. Calculations showed that a 4500 . MTU/year separations plant for LWR fuel would generate annually 5 million pounds $(80,00$ cubic $\mathrm{ft})$ of Zircaloy hulls containing $1.4 \times 10(\mathrm{E}+8) \mathrm{Ci}$ of activation products, $2.1 \times 10(\mathrm{E}+7) \mathrm{Ci}$ of fission products, and $2.1 \times 10(\mathrm{E}+4) \mathrm{Ci}$ of transuranium nuclides with half-lives greater than 85 years.

SUBJECT CATEGORY: TRU; HLW

ORIGIN: Defense; Commercial

KEYWORDS: ECONOMICS; FUEL CYCLE; HEAD END PROCESSES; RADIOACTIVE WASTE MANAGEMENT; RADIOACTIVE WASTE STORAGE; REPROCESSING; RESEARCH PROGRAMS; SAVANNAH RIVER PLANT; SPENT FUELS; TANKS; WATER COOLED REACTORS; WATER MODERATED REACTORS

734

Savannah River Laboratory, Aiken, SC

LIGHT WATER REACTOR FUEL RECYCLE. COMPOSITE QUARTERLY REPORT, APRIL-JUNE 1976. DPST-LWR-76-2-2. (1976)

\section{Available from N'TIS}

This document summarizes $R$ and $D$ studies by participating ERDA sites to produce information needed by industry to close the back end of the commercial LWR fuel cycle. Topics covered include economics, environmental effects, spent fuel characterization, head-end processes, off-gas treatment, Purex process; finishing processes, and waste management.

SUBJECT CATEGORY: HLW; TRU; LLW; Spent Fuel

ORIGIN: Commercial

KEYWORDS: ECONOMICS; ENVIRON. MENTAL EFFECTS; FUEL CYCLE; HEAD END PROCESSES; OFF-GAS SYSTEMS; PLUTONIUM; POWER REACTORS; PUREX PROCESS; RADIOACTIVE WASTE MANAGEMENT; REPROCESSING; RESEARCH PROGRAMS; SPENT FUELS; US ERDA; US ORGANIZATIONS; WATER COOLED REACTORS 
735

Savannah River Laboratory, Aiken, SC

LIGHT WATER REACTOR FUEL RECYCLE. SAVANNAH RIVER LABORATORY QUARTERLY REPORT, JULY-SEPTEMBER 1976. DPST-LWR-76-1-3; 88 pp. (1976)

Head end processes, Purex Process; available from NTIS; ERA citation 02:019371

A calculational study of the impact of a new reprocessing facility was completed. A computer model is being developed to forecast storage basin inventories and the consequences of limited storage capacity based on projections of fuel discharges and reprocessing schedules. An economic analysis shows that a receiving basin with a capacity of 800 MTU (metric tons of uranium) is adequate to service a 10-MTU/day LWR fuel reprocessing plant. An economic study indicates that LWR fuel from foreign reactors can be stored in water basins in the U. S. at a cost of approximately $\$ 10 / ;(\mathrm{kg})(\mathrm{yr})$. A draft environmental statement on the LWR reprocessing and recycle industry was prepared. Dissolution tests began with irradiated UO2 fuel from the H. B. Robinson 2 reactor, to prepare feed for solventextraction studies and to define technical problems associated with fuel dissolution. The advantages and disadvantages of reprocessing. LWR fuel without partitioning of uranium and plutonium were evaluated. A new method was developed in the laboratory to prepare uranous nitrate solutions. A process for fixation of LWR high-level liquid waste (HLLW) was outlined for use in design and cost studies of the back end of the commercial nuclear fuel cycle. A rapid, quantitative ion-exchange technique was developed to remove radioactive fission products and actinides from dissolved, irradiated LWR fuel to permit determination of tritium by liquid scintillation counting. Results of nuclear criticality calculations for mixed uranium and plutonium oxides outside reactors are summarized. The various correlations of the calculational methods with critical experiments made to support the calculations are described.

SUBJECT CATEGORY: HLW; TRU; Spent Fuel

ORIGIN: Commercial; Defense

KEYWORDS: BWR TYPE REACTORS; DISSOLUTION; ECONOMICS; FUEL CYCLE; HEAD END PROCESSES; ION EXCHANGE; PUREX PROCESS; PWR TYPE REACTORS; RADIOACTIVE WASTE PROCESSING; REPROCESSING; RESEARCH PROGRAMS; SPENT FUELS; INVENTORIES; COMPUTER CODES; COST
736

Savannah River Laboratory, Aiken, SC

LIGHT WATER REACTOR FUEI RECYCLE. COMPOSITE QUARTERLY REPORT, JULY-SEPTEMBER 1976. DPST-LWR-76-2-3; 122 pp. (1976)

Available from NTIS; ERA Citation 02:024066

This report summarizes studies by participating ERDA sites to produce information needed to close the back end of the commercial LWR fuel cycle. These studies are directed primarily at reprocessing and recycle of uranium and plutonium from spent LWR fuel. Processing areas under study in this program are head-end treatment of the spent fuel, treatment of off-gas from various parts of the reprocessing system, recovery and purification of uranium and plutonium by the Purex solventextraction process. mixed-oxide fuel fahrication, and waste management (evaporation storage). Additional information is being provided by economic and environmental studies of the LWR fuel cycle, and by general support activities such as corrosion and shielding studies and development of improved on-line process-control methods.

SUBJECT CATEGORY: HLW; Spent Fuel; TRU

ORIGIN: Commercial; Defense

KEYWORDS: ECONOMICS; ENVIRONMENTAL EFFECTS; FUEL CYCLE; HEAD END PROCESSES; OFF-GAS SYSTEMS; PUREX PROCFAS; RADIOACTIVF WASTF, MANAGEMENT; REPROCESSING; RESEARCH PROGRAMS; SPENT FUELS; WATER COOLED REACTORS

\section{7}

Savannah River I ahoratory, Aiken, SC

LIGHT WATER REACTOR FUEL RECYCIE. COMPOSITE QUARTERLY REPORT, OCTOBER-DECEMBER 1976. DPST-LWR-76-2-4; 127 pp. (1976)

Available from NTIS, PC A07/MF A01.

Progress in the following areas is reported: economic studies; environmental studies; fuel receipt; head-end processes; off-gas treatment; Purex Process; finishing processes; waste management; environmental effects; and safeguards. The economics of seven alternatives for the back end of the nuclear fuel cycle has been evaluated. Average 
storage time for spent fuel was calculated, and current storage history was studied. Recovery of iodine from an off-gas stream by silver-loaded sorbents continued to be investigated. Chemical studies of LWR off-gas contaminants include CH3I distribution between refrigerant liquid and vapor phases, nitrogen oxide solubility in R-12, and corrosion of stainless steel by CH3I. Solvent extraction flowsheets for the Purex Process are being developed. The critical nuclides of primary environmental interest that would be released from a fuel reprocessing plant have been identified. The design basis incidents have been defined in the development of safeguards required against materials theft or sabotage for a $10 \mathrm{MTU} /$ day fuel reprocessing plant.

SUBJECT CATEGORY: Spent Fuel; HLW

ORIGIN: Commercial

KEYWORDS: BWR TYPE REACTORS; ECONOMICS; ENVIRONMENTAL EFFECTS; FUEL CYCLE; HEAD END PROCESSES; OFF-GAS SYSTEMS; PUREX PROCESS; PWR TYPE REACTORS; RESEARCH PROGRAMS; SAFEGUARDS; SPENT FUEL STORAGE; SPENT FUELS; WATER COOLED REACTORS; FUEL REPROCESSING PLANTS

738

Science Applications, Inc., Oak Ridge, TN

STORAGE FEE ANALYSIS FOR A NUCLEAR WASTE TERMINAL STORAGE FACILITY. FINAL REPORT. Y/OWI/SUB-76/16503; 61 pp. (1976)

Available from NTIS, PC A04/MF A01; ERA citation 02:041142

A model was developed for determining a pricing schedule designed to recover federal government costs incurred in the development, design, construction, operation, decommissioning, and surveillance of a federal repository for high-level waste generated by the commercial nuclear power industry. As currently constructed, the model computes current dollar prices on a yearly basis for a single unit charge or a split fee based upon two user-provided quantity flows. Over the period of facility operation, the computed-cost schedule shows variability on a year-to-year basis only within specified ranges. The model uses as basic input data: cost schedule for the federal repository; quantity flow schedule for each factor to be charged; schedule for escalation rate, discount rate, and interest rate; and fraction of costs to be recovered on each quantity flow if the split-fee option is used. The model allows testing of these variables in order to determine the relative significance of each component with regard to cost to, and impact on, the nuclear power industry. Another feature of the model is its versatility. Not only is the user able to specify the percent of total costs to be covered by each method of fee assessment listed above but also the user can specify a revenue-cost ratio, an option that would prove useful in trying to assess the general uncertainty involved when dealing in the future. In addition, the model accepts either current-dollar or constant-dollar cost measures, and in the case of the latter escalates the costs with user-provided assumptions.

\section{SUBJECT CATEGORY: HLW}

ORIGIN: Defense; Commercial

KEYWORDS: CHARGES; COMPUTER CODES; ECONOMICS; RADIOACTIVE WASTE STORAGE

\section{9}

Rajcok, M.; Slovenska Vysoka Skola Technicka, Bratislava, Czechoslovakia

INCINERATION AS A METHOD OF RADIOACTIVE WASTE DISPOSAL. Jad. Energ. 22(1):8-12. (1976)

The method is discussed of the disposal of low-level radioactive wastes from nuclear power plants by incinerating in special incinerator plants. A design is submitted of an incinerator plant equipped with Czechoslovak engineering equipment featuring a high decontamination factor. The economic advantages are shown of the plant as against capital expenditure invested in waste storage.

\section{SUBJECT CATEGORY: LLW}

ORIGIN: Foreign

KEYWORDS: COMBUSTION; COST; DECONTAMINATION; EFFICIENCY; INCINERATORS; RADIOACTIVE WASTE DISPOSAL; RADIOACTIVE WASTE FACILITIES; RADIOACTIVE WASTE PROCESSING; RADIOACTIVE WASTES; SPECIFICATIONS 
740

Chamberlin, W.E.; Society of Manufacturing Engineers, Dearborn, MI

NUCLEAR CONTRIBUTION-TO SOLVING OUR ENERGY PROBLEM: SME TECHNICAL PAPER EM76-111. NP-22070; SME Technical Paper EM76-111. (1976)

A look at the general energy situation in the United States, a descriptive example of one type of reactor, some background on radioactivity and some information on waste are presented.

SUBJECT CATEGORY: General

ORIGIN: Commercial

KEYWORDS: BWR TYPE REACTORS; COST; NUCLEAR POWER PLANTS; POWER DEMAND; RADIATION HAZARDS; RADIOACTIVE WASTES; REACTOR SAFETY; SPECIFICATIONS; USA

741

Harwood, S., K. May, M. Resnikoff, B. Schlenger, and P. Tames; State Univ. of New York, Buffalo, NY

COST OF TURNING IT OFF. Environment 18(10):17-20, 25-26. (1976)

Dismantling nuclear reactors

The cost of nuclear power must include the as-yetuncalculated cost of dismantling a commercial power plant. New calculations show that hazardous levels of radioactive nickel will continue for as much as a million years after a power plant ceases to operate. Attention has been concentrated on waste disposal, overlooking disposal of the activation products such as steel and concrete structures. So far only eight small plants have been shut down, but these show considerable variation in the buildup of activation products depending on the number of megawatt-years the reactor was exposed. Commercial reactors with greater amounts of stainless steel and core structure can be expected to develop larger proportions of activation products. Three methods are proposed for shutting down reactors, all of which require removing radioactive wastes: (1) mothballing. which would make the total facility inoperable and would require expensive security measures; (2) entombment, which would remove all external parts to a federal respository or place them inside the vessel, would require minimal security; and (3) dismantling, the only safe method, would be dangerous and expensive, but would shift all radioactive materials to permanent and appropriate burial sites. 6 references.

SUBJECT CATEGORY: Remedial Action, FUSRAP

ORIGIN: Commercial

KEYWORDS: ACTIVATION ENERGY; COBALT 60; CONCRETES; ECONOMICS; ENVIRONMENTAL EFFECTS; HALF-LIFE; IRON 55; NICKEL 59; NICKEL 63; NUCLEAR POWER PLANTS; PNPF REACTOR; RADIATION HAZARDS; RADIOACTIVITY; REACTOR DECOMMISSIONING; REACTOR SAFETY; SAFEGUARDS; SAFETY; SECURITY; STEELS; WASTE DISPOSAL

742

Tennessee Valley Authority, Chattanooga, TN

RESPONSE TO QUESTION 011.9 - CAPITAL COSTS FOR AUGMENTS TO THE REACTOR BUILDING RADWASTE BUILDING. DOCKET-STN-50553-15; DOCKET-STN-50554; Amendment 2 to Phipps Bend 12 License Application, 12 pp. (1976)

6 tabs.

Capital costs for augments to the reactor buildings and radwaste buildings were furnished by the General Electric Company, and details as requested in NRC attachment 011.9 are not available. The breakdown of costs as transmitted by GE appear in table Q011.9-1. Capital costs for augments to the turbine buildings and central service facilities were estimated by 'TVA on the basis of historical cost data and information from vendors of the type equipment being estimated.

\section{SUBJECT CATEGORY: General}

ORIGIN: Commercial

KEYWORDS: BWR TYPE REACTORS; BUILDINGS; COST; CAPITAL; PHIPPS BEND-2 REACTOR; PHIPPS BEND-1 REACTOR 
743

Tennessee Valley Authority, Chattanooga, TN

RESPONSE TO QUESTION D.3.A. - COSTBENEFIT ANALYSIS. DOCKET-STN-50518-90; DOCKET-STN-50519; DOCKET-STN-50520; DOCKET-STN-50521; Amendment 15 to Hartsville 1, 2,3, 4 License Application, 1 p. (1976)

Describes the methods and parameters used in the cost-benefit analysis and provides bases for all parameters. Includes the following information: Decontamination factors assigned to each augment and fraction of "on-line" time assumed, i.e., hours per year used.

\section{SUBJECT CATEGORY: General}

ORIGIN: Commercial

KEYWORDS: HARTSVILLE-1 REACTOR; HARTSVILLE-2 REACTOR; HARTSVILLE-3 REACTOR; HARTSVILLE-4 REACTOR; BWR TYPE REACTORS; COST BENEFIT ANALYSIS; REPORTS; DECONTAMINATION

\section{4}

Kniazewycz, B.G.; TERA Corp., Berkeley, CA

ROLE OF VOLUME REDUCTION PROCESSES IN LWR RADWASTE TREATMENT. Am. Soc. Mech. Eng., Pap. no. 76-WA/NE-5, (pp. 111). (1976)

10 references

In current LWR technology large quantities of radioactive or potentially radioactive waste are generated due to the formation and release of corrosion and fission products to the process fluids: From the earliest stages of LWR development various means of reducing the volume of radwaste have been developing - filtration; demineralization, evaporation, and recently membrane technology. These treatment techniques have produced manageable quantities of sludges, spent resin, and evaporator bottoms from early generation plants. However, with the inception of large multi-unit facilities, change in regulatory criteria, and the large increase in capital and operating costs, additional emphasis on the economics of radwaste treatment is required. A review of the economics of radwaste management from waste inception to final disposal and burial is presented with emphasis on the necessity of an integrated design philosophy.
SUBJECT CATEGORY: HLW; LLW

ORIGIN: Commercial

KEYWORDS: BWR TYPE REACTORS; CAPITAL; CORROSION PRODUCTS; COST; EVAPORATORS; FISSION PRODUCT RELEASE; FLUIDIZED BED; OPERATION; PWR TYPE REACTORS; RADIOACTIVE EFFLUENTS; RADIOACTIVE WASTE DISPOSAL; RADIOACTIVE WASTE PROCESSING; WATER MODERATED REACTORS; WORKING FLUIDS

745

Miller, W.B.; Texas A and M University, College Station, TX

NOMOGRAM PREDICTS SPENT NUCLEAR FUEL DECAY HEAT PRODUCTION. (1976)

Vol 80

A nomogram is presented for determining the heat load produced by spent reactor fuel in connection with the sizing of spent fuel storage pool cooling systems.

SUBJECT CATEGORY: Spent Fuel

ORIGIN: Commercial; Defense

KEYWORDS: AFTER-HEAT; COOLING SYSTEMS; DECAY; FORECASTING; HEAT; NOMOGRAMS; SPENT FUEL STORAGE; SPENT FU. ELS

\section{6}

U.S. Congress, Joint Committee on Atomic Energy, Washington, DC

ERDA AUTHORIZING LEGISLATION FISCAL YEAR 1977. HEARING BEFORE THE JOINT COMMITTEE ON ATOMIC ENERGY, CONGRESS OF THE UNITED STATES, NINETY-FOURTH CONGRESS, SECOND SESSION ON OVERALL BUDGET. PART 1. VOLUME I. HEARING AND APPENDIXES 1 TO 11. VOLUME II. APPENDIX MATERIALS. Hearing, January 21,$1976 ; 1350$ pp. (1976)

Dr. Robert Seamans and John M. Teem headed a group of Energy Research and Development Administration witnesses in support of appropriations 
for the fiscal year 1977 budget. Of particular concern were nuclear waste management, commercial siting, safeguards, and overall development of nuclear power with emphasis on the breeder reactor program. Seamans advised against a moratorium on nuclear exports at this time. Sen. Pastore raised the question of U.S. reactor capability as compared to that of Great Britain, France, and the Soviet Union. Fusion power requests are increased 57\% over the 1976 level in response to recent research breakthroughs. Organization, staffing, and all budgeted activities are covered in the support material, which includes the authorizing bill and a dollar breakdown and justification of the budget.

SUBJECT CATEGORY: General

OKİGIN: Defense

KEYWORDS: ENERGY POLICY; LEGISLATION; HEARINGS; BUDGETS; PLANNING; FINANCING; NUCLEAR POWER; SITE SELECTION; SAFEGUARDS; INTERNATIONAL AGREEMENTS; ENVIRONMENT; FISSION; RADIOACTIVE WASTE MANAGEMENT; SAFETY; REACTORS; US ERDA

747

Lewis, J.B.; UKAEA Research Group, Harwell. Atomic Energy Research Establishment

RADIOACTIVE WASTES AND NUCLEAR POWER: METHODS OF TREATMENT. Phys. Technol. 7(2):77-84. (19'/6)

The techniques of processing, storage and treatment of radioactive wastes are reviewed under the headings; reactor wastes, fuel reprocessing (storage and decanning, gaseous effluents, highly active liquids, medium-level liquids, low-level liquids), disposal and storage of solids (high, medium and low-level solid wastes, nuclear transmutation), and long-range problems. Environmental and cost considerations are discussed.

SUBJECT CATEGORY: LLW; HLW; Spent Fuel; TRU

ORIGIN: Commercial

KEYWORDS: COST; ENVIRONMENT; GASEOUS WASTES; LIQUID WASTES; RADIOACTIVE EFFLUENTS; RADIOACTIVE WASTE DISPOSAL; RADIOACTIVE WASTE MANAGEMENT; RADIOACTIVE WASTE PROCESSING;
RADIOACTIVE WASTE STORAGE; REPROCESSING; REVIEWS; SOLID WASTES

\section{8}

Dabrowski, T.E.; United Nuclear Industries Inc., Environmental and Radiation Control, Richland, WA

MANAGEMENT OF LOW-LEVEL RADIOACTIVE WASTE IN UNITED NUCLEAR INDUSTRIES, INC.-MANAGED FACILITES. UNI-SA-00034; 12 pp. (1976)

United Nuclear Industries manages the N reactur, a light-water-cooled graphite moderated reactor, locuted near Richland, WA, for ERDA. This report describes the basic sources of radiation, the treatment and handling of the waste, and the impact of the radwaste discharges on the environment. Airborne waste comes from either the gas atmosphere surrounding the graphite moderator, or from the primary coolant. The 50 year whole body population dose commitment due to all airborne effluent discharged from $\mathrm{N}$ reactor during CY 1975 was 0.84 man rem, compared to 25,000 man rem from background radiation. The 50 year whole body population dose commitment due to airborne uranium discharges during $\mathrm{CY} 75$ was 0.00056 man rem. Liquid radwaste is released to a soil column, and to date many thousands of curics have becn rclcased and retained by the soil column. Included in the report is a cost assessment of a storage basin conling water resirculation system, a fulul puality monitor system, and a waste treatment facility, which would eliminate the usc of soil columns.

SUBJECT CATEGORY: LLW

ORIGIN: Commcrcial

KEYWORDS: LIQUID WASTES; COST; NUCLEAR FACILITIES; RADIOACTIVE WASTE MANAGEMENT; DECOMMISSIONING; SOLID WASTES; RADIOACTIVE WASTES; RADIOAC TIVE AEROSOLS; LOW-LEVEL RADIOACTIVE WASTES; GRAPHITE MODERATED REACTORS

\section{9}

Cohen, B.L., and J.L. (Ed.) Jackson; University of Pittsburgh, Pittsburgh, PA 
DISPOSAL OF NUCLEAR WASTES: PROCEEDINGS OF NATIONAL ENERGY FORUM. VOLUME I. CONF-760761-Part 1; National Energy Forum, University of Akron, Akron, OH, July 26, 1976. (1976)

In a discussion of nuclear waste disposal, a comparison of nuclear and non-nuclear wastes from power generation is made. Other discussions are concerned with properties of solid radioactive wastes, preparation of wastes, and transport of wastes. The toxicity of plutonium is examined.

SUBJECT CATEGORY: General; TRU

ORIGIN: Commercial

KEYWORDS: COST; ENVIRONMENTAL EFFECTS; FUEL CYCLE; LECTURES; PLUTONIUM; RADIOACTIVE WASTE DISPOSAL; RADIOACTIVE WASTES; SOLIDIFICATION; SPENT FUEL CASKS; 'TOXICI'IY' 'TRANSPORT

$\mathbf{7 5 0}$

Collins, J.T.; US Nuclear Regulatory Commission, Washington, DC

THE IMPACT OF APPENDIX I TO 10 CFR PART 50 ON ATMOSPHERE CLEANUP SYSTEMS. Paper 12-3; Fourteenth ERDA Air Cleaning Conference, Sun Valley, Idaho, Aug. 2-4, 1976, 8 pp. (1976)

This paper will discuss dose design objectives in Appendix I to 10 CFR part 50 for gaseous effluents from light-water-cooled nuclear power plants, the need for a cost-benefit analysis for certain proposed facilities, one acceptable method for performing a cost-benefit analysis, and the cost of ventilation equipment considered by the staff in its evaluation. The cost-benefit analysis will be used to show when additional radwaste equipment will be required.

SUBJECT CATEGORY: Airborne

ORIGIN: Commercial

KEYWORDS: COST BENEFIT ANALYSIS; AIR POLLUTION; RADIOACTIVE AEROSOLS

751

US Nuclear Regulatory Commission, Washington, DC
FINAL GENERIC ENVIRONMENTAL STATEMENT ON THE USE OF RECYCLE PLUTONIUM IN MIXED OXIDE FUEL IN LIGHT WATER COOLED REACTORS. VOLUME 1. NUREG-0002(Vol.1); 125 pp. (1976)

This volume is a summary of the environmental statement. The body of the statement is contained in volumes 2 through 4 . All chapters of the statement are summarized and include the following subjects: Background and experience with plutonium; projected $\mathrm{Pu}$ recycle industry; environmental impact due to the implementation of $\mathrm{Pu}$ recycle; safeguards reference; probable adverse environmental effects that cannot be avoided; means for mitigating adverse environmental effects; alternative dispositions of plutonium; commitments of resources; and economic analysis and cost-benefit balancing.

SUBJECT CATEGORY: TRU

ORIGIN: Defense; Commercial

KEYWORDS: ECONOMICS; PLUTONIUM; LWR TYPE REACTORS; REPROCESSING; SAFEGUARDS; COST BENEFIT ANALYSIS; OXIDES; ECONOMICS

752

US Nuclear Regulatory Commission, Washington, DC

COST-BENEFIT ANALYSIS FOR RADWASTE SYSTEM FOR LIGHT-WATERCOOLED NUCLEAR POWER REACTORS. NRC Regulatory Guide 1.110; 90 pp. (1976)

7 tables, 3 references

To implement the requirements of appendix 1 of 10CFR50 the NRC staff has developed a series of guides providing methods acceptable to the staff for the calculation of effluent releases, dispersion of effluents in the atmosphere and different water bodies, associated radiation doses in man, and costbenefit aspects of treating radwaters. This regulatory guide describes a method for performing a costbenefit analysis for liquid and gaseous radwaste system components.

\section{SUBJECT CATEGORY: LLW}

ORIGIN: Commercial 
KEYWORDS: WASTE PROCESSING; LIQUID WASTES; POWER REACTORS; GASEOUS WASTES; ECONOMICS; LWR TYPE REACTORS; COST BENEFIT ANALYSIS; REGULATIONS; REGULATORY GUIDES; US NRC

\section{3}

Dlouhy, Z., and J. Marek; Ustav Jaderneho Vyzkumu, rez, Czechoslovakia

MANAGEMENT OF RADIOACTIVE WASTE FROM NUCLEAR POWER PLANTS. CONF7609150-9; AED-CONF-76-660-014; Nuclear Power Project Planning and Implementation, LAEA International Training Course, Karlsruhe, Germany, F.R., Septèmbèr 6,1976 . (1976)

4 figures, 5 tables; available from NTIS, PC A02/MF A01.

The authors give a survey of the sources, types and amounts of radioactive waste in LWR nuclear power stations $(1,300 \mathrm{MWe})$. The amount of solid waste produced by a Novovorenezh-type PWR reactor $(2 \mathrm{x}$ 400 resp. $1 \times 1,000 \mathrm{MWe}$ ) is given in a table. Treatment, solidification and final storage of radioactive waste are shortly discussed with special reference to the problems of final storage in the CSR.

SUBJECT CATEGORY: General; Isolation

ORIGIN: Forcign

KEYWORDS: BWR TYPE REACTORS; CZECHOSLOVAKIA; DIAGRAMS: LIRUID WASTES; PWR TYPE REACTORS; RADIOACTIVE WASTE MANAGEMENT; RADIOACTIVE WASTE PROCESSING; RADIOACTIVE WASTE STORAGE; RADIOACTIVE WASTES; RADIOACTIVITY; RADIOISOTOPES; SOLID WASTES; VOLUME

754

Twite, G.M.; Veterans Administration Hospital, Minneapolis, MN

METHOD FOR THE DISPOSAL OF LIQUID SCINTILLATION VIALS. Health Phys. 30(6):99. (1976)

A simple, manually-operated glass vial crusher designed and constructed specifically for the disposal of liquid scintillation vials is described Construction details, operation and estimated costs are given.

\section{SUBJECT CATEGORY: LLW}

ORIGIN: Institutional

KEYWORDS: CONTAINERS; COST; CRUSHING; FABRICATION; GLASS; LIQUID SCINTIL LATTON DETECTORS; OPERATION; RADIOACTIVE WASTE DISPOSAL; SPECIFICATIONS

\section{5}

Hladky, E.; Vyzkumny Ustav Energeticky, Jaslovike Bohunice, Crochoslovakia

COMPARISON OF ENVIRONMENTAL EFFECTS OF CONVENTIONAL AND NUCLEAR POWER PLANTS. Energetika 26(5):213217. (1976)

In Czech

The relations are defined permitting the comparison of the effects of conventional and nuclear power plants on the living environment on the basis of the amount of annually discharged emissions. The function of relative damage of the living environment (mainly of population) is determined from the maximum calculated values of emission concentrations.

SUBJECT CATEGORY: LLW

ORIGIN: Foreign

KEYWORDS: BODY BURDEN; CHEMICAL EFFLUENTS; COMPARATIVE EVALUATIONS; CONTAMINATION; ENVIRONMENTAL EFFECTS; FORECASTING; FOSSILFUEL POWER PLANTS; GASEOUS WASTES; HEALTH HAZARDS; HUMAN POPULATIONS; NUCLEAR POWER PLANTS; POLLUTIONं; RADIOACTIVE EFFLUENTS

756

Wernèr Pfleiderer Corp., Waldwick, NJ

RADWASTE VOLUME REDUCTION AND SOLIDIFICATION SYSTEM. WPCVRS-1; 74 pp. (1976)

14 tables, 17 figures, 23 references 
Describes the design and operation of a Werner and Pfleiderer Corp. volume and solidification system. The system utilizes an extruder/evaporator to provide volume reduction by evaporation while concurrently mixing the residual radsalts with an asphalt (or bitumen) binder. The solidified waste is a homogeneously dispersed mix of radsalts in an asphalt matrix. The system accepts the feed material (either liquid, slurry, or dry waste) from LWR's or heavy water reactors and produces a solidified end product in the binder of asphalt. The volume is reduced by a factor of 3 to 20 depending upon concentration of the input stream.

SUBJECT CATEGORY: LLW

ORIGIN: Commercial

KEYWORDS: SOLIDIFICATION; LIQUID WASTES; VOLUME; EVAPORATORS; SOLID WASTES; BWR TYPE REACTORS; PWR TYPE REACTORS; RADIOACTIVE WASTE MANAGE. MENT

757

Winnowski, W.S.; Westinghouse Electric Corp., Madison, PA

PROCESSING OF RADIOACTIVE LIQUID WASTE BY ION EXCHANGE AT THE WESTINGHOUSE WALTZ MILL SITE. CONF-760469; American Power Conference, Chicago, IL, April 20, 1976; Proc. Am. Power Conf. 38:913-920. (1976)

Ion-exchange treatment is a very satisfactory method for the processing of radioactive waste water and provides the following results: A total operating cost of about 11 cents per gallon for water whose grose beta activity is initially $10(\mathrm{E}-2)$ to 10 (E3) $\mathrm{muCi} / \mathrm{ml}$; an ultimate activity, without ultrafiltration, of less than $3 \times 10(\mathrm{E}-8) \mathrm{muCi} / \mathrm{ml}$ gross ${ }^{35 \%}$ (DF $=12 ; 000$ or greater); easily attained concentrations of a few percent of MPCs for nearly all fission and corrosion product nuclides; no high-level liquid wastes are generated during the processing since the spent resin and charcoal are easily packaged and disposed of as solid radioactive waste; the ionexchange process exhibits a high degree of reliability and a virtually trouble-free, unattended operation; and any significant changes in process water composition can be accommodated with only slight modification of the system in view of the multitude of ion-exchange materials currently available.

SUBJECT CATEGORY: LLW
ORIGIN: Commercial

KEYWORDS: ADSORPTION; DECONTAMINATION; ECONOMICS; EFFICIENCY; FILTRATION; FLOWSHEETS; ION EXCHANGE; PERFORMANCE; RADIOACTIVE EFFLUENTS; RADIOACTIVE WASTE PROCESSING; LIQUID WASTES; WASTE WATER

758

Bebbington, W.P.

REPROCESSING OF NUCLEAR FUELS. Scientific American 235(6):30-41. (1976)

This survey of nuclear fuel reprocessing begins with a description of the composition of spent fuels and of the treatment and storage of radioactive wastes. $A$ discussion of technology and engineering design for reprocessing plants is accompanied by schematic diagrams of equipment and processes; and an account is given of attempts to build and operate the plants. Safety considerations, environmental aspects, and public opinion of the various methods of waste treatment are discussed.

SUBJECT CATEGORY: Spent Fuel

ORIGIN: Commercial

KEYWORDS: ECONOMICS; FUEL REPROCESSING PLANTS; PLUTONIUM; PUREX PROCESS; RADIOACTIVE WASTE MANAGEMENT; REDOX PROCESS; REPROCESSING; SPENT FUELS; URANIUM 235

759

Blomeke, J.O., and J.J. Perona

CONTROLLING AIRBORNE EFFLUENTS FROM FUEL CYCLE PLANTS. CONF-760806; Controlling Airborne Effluents from Fuel Cycle Plants, Proceedings of a Symposium, Sun Valley, Idaho, August 5-6, 1976, (pp. 1-16). (1976)

No measured data estimates and predictions.

This paper serves as a brief introduction into sources of wastes, their treatment and atmospheric levels both present and projected. High-, intermediate- and low-level wastes are defined and a brief description of their disposal is presented. Cladding 
wastes, noble gases, iodine, tritium, carbon-14, nonTRU wastes, and ore tailings are dealt with in the same way. The treatment of these wastes in both LWR and HTGR fuel processing is also discussed. Projections are then made as to the types and levels of nuclear wastes in the year 2000 . This information is presented on charts for every year from 1970 to the year 2000. A chart predicting nuclear generating capacity also up to the year 2000 provides a frame of reference. The impact of Fuel Cycle Centers on the environment is examined. Finally, projected estimates of the global buildup of airborne effluents are given.

SUBJECT CATEGORY: Fuel Cycle Centers; Airborne; HLW; LLW

ORIGIN: Commercial

KEYWORDS: FORECASTING; RADIOACTIVE AEROSOLS; FUEL REPROCESSING PLANTS; HIGH-LEVEL RADIOACTIVE WASTES; INTERMEDIATE-LEVEL RADIOACTIVE WASTES; LOW-LEVEL RADIOACTIVE WASTES; TRANSURANIUM ELEMENTS; RADIOACTIVE WASTE MANAGEMENT; FUEL CYCLE; MILL TAILINGS; IODINE; TRITIUM; CARBON 14; TRANSURANIUM ELEMENTS; FUEL FABRICATION PLANTS; RADIOACTIVE WASTE PROCESSING; ENVIRONMENTAL EFFECTS

7kn

Bonzon, L.L., and J.V. Otts

SPECIAL CLOSURE FOR STEEL DRUM SHIPPING CONTAINERS. CONF-760813; IAEA-SR-10/19; Design, Construction and Testing of Packaging for the Safe Transport of Radioactive Materials, Proceedings of a Symposium, Vienna, Austria, August 23-27, 1976 (pp. 195-204). (1976)

The closures on the steel drum shipping containers were found to be inadequate so ERDA requested new closures be developed. The lids were redesigned with the following criteria: as strong and resistant to a drop as the bottom of the container; have minimal economic impact on the overall container cost; maximize the use of existing container designs; consider crush load; and result in less dependence on personnel and loading procedures. From the tests on various closure techniques (lid extension, inner lid, C-clamp, and clips) are the following conclusions: Critical container weight of a standard $17 \mathrm{C}$ closure is $270 \mathrm{~kg}$, without the closure the critical weight is a minimum of $454 \mathrm{~kg}$; " $152-\mathrm{mm}$ lid extension" technique strengthens the closure to a critical container weight of $680 \mathrm{~kg}$ minimum; " 152 mm internal lid" technique strengthens the closure to a critical weight of $454 \mathrm{~kg}$ mimimum; "C-clamp" strengthens the closure to $454 \mathrm{~kg}$ minimum with $6 \mathrm{C}$ clamps; "clip" technique using eight clips strengthens the closure to $340 \mathrm{~kg}$ maximum; a $490-\mathrm{kN}$ static load causes the $17 \mathrm{C}$ lid closure to fail; both the "152-mm lid extension" and "152-mm internal lid" techniques extend the crush load capability beyond the container bottom capability of $535-\mathrm{kN}$ static load; and using $6 \mathrm{C}$-clamps and lock ring, the "Cclamp" technique fails to improve the closure crush limit beyond the standard closure capability of 490kN static load. While all four techniques were proven to be more than adequate in meeting the specified criteriu of structural integrity, economics, and minimum impact on existing container designs, the "152-mm lid extension" offers more advantages than the other methods and is recommended.

SUBJECT CATEGORY: Transportation

ORIGIN: General

KEYWORDS: RADIOACTIVE WASTES; CONTAINERS; WASTE TRANSPORTATION; EQUIPMENT

761

Carter, T.J., and Gi.A. Mentes

ONTARIO HYDRO WASTE STORAGE CONCEPTS AND FACILITIES. CONF-761020; Waste Management, Proceedings of a Symposium held in Tucson, Arizona, October 3-6, 1976, 15 pp. (1976)

Waste storage concepts and facilities at Ontario Hydro are outlined. To handlo the low and mediumlevel wastes produced by their heavy water reactors a Radioactive Waste Operations Site (RWOS) was established within the Bruce Nuclear Power Development on Lake Huron. The site includes a $1 \dot{y}$ acre Storage Site and a Radioactive Waste Volume Reduction Facility (RWVRF) consisting of a radioactive incinerator and waste compactor. At present only 4.5 acres of the site has been developed and will be adequate until 1980. The Atomic Energy Control Board (AECB) regulates and licenses waste management operations and Ontario. Hydro has established criteria to meet the AECB requirements. These requirements are: storage facilities are to be 
located in a low seismic area away from population centers and drinking water supplies; radiation dose to members of the public are to be $1 \%$ of the ICRP dose limits; two "control envelopes" are required for storage facilities and the waste package is not a barrier; all wastes are to be stored retrievably; no liquids are to be stored in this facility; and all surface and subsurface drainage is to be controlled and monitored. The RWOS is underlain by bedrock of interbedded silty to sandy dolomites and sandstones that have a permeability of $10(\mathrm{E}-3)$ to $10(\mathrm{E}-4)$ $\mathrm{cm} / \mathrm{sec}$. Overlying the bedrock is a few feet of granular, very dense soil which is overlain by very dense gray glacial till some $30 \mathrm{ft}$-thick. The permeability of the till is 10 (E-6) to $10(E-7) \mathrm{cm} / \mathrm{sec}$. A brown, compact till containing gravel and cobbles overlies the gray till and averages $5 \mathrm{ft}$ thick. A $3 \mathrm{ft}$ layer of top soil rests on the brown till. The water table is $25 \mathrm{ft}$ below the site. The dual envelope for the in-ground facilities are reinforced concrete structures. For above-ground facilities two independent structural concrete barriers are used. Surface drainage, leakage detection, and radiological aspects are covered. The facilities are also described in detail. At present, the cost of waste storage is 0.1 mills $/ \mathrm{kWh}$ and only tritium escape has been a problem.

SUBJECT CATEGORY: Isolation; LLW; HLW

ORIGIN: Foreign

KEYWORDS: AQUIFERS; ECONOMICS; COST; UNDERGROUND DISPOSAL; ENVIRONMENT; REVIEWS; RADIOACTIVE WASTE STORAGE; RADIOACTIVE WASTE DISPOSAL; INTERMEDIATE-LEVEL RADIOACTIVE WASTES; LOWLEVEL RADIOACTIVE WASTES; VOLUME; COMPACTING; INCINERATORS

\section{2}

Cooley, C.R., and R.E. Lerch

NUCLEAR FUEL CYCLE AND PRODUCTION PROGRAMS PROGRESS REPORT FOR JULY-DECEMBER, 1975. HEDL TME-7622; 70 pp. (1976)

A summary of the Nuclear Fuel Cycle and Froduction programs being conducted at Hanford Engineering Development Laboratory. These programs include a commercial alpha waste program and a chemical processing of combustible solid wastes program. Data on commercial burial of radioactive wastes, operational data on the Acid
Digestion Test Unit and the design basis for an acid digestion unit for treating radioactive wastes are also discussed.

SUBJECT CATEGORY: LLW; TRU

ORIGIN: Commercial

KEYWORDS: LOW-LEVEL RADIOACTIVE WASTES; REPROCESSING; VOLUME; RADIOACTIVE WASTE STORAGE; RADIOACTIVE WASTE DISPOSAL; PWR TYPE REACTORS; LIQUID WASTES; HAPO; GROUND DISPOSAL; ALPHA-BEARING WASTES

763

Dippel, T.H., D. Hentschel, and S. Kunze

DECONTAMINATION AND DECONTAMINATION WASTES. Kerntechnik 18(12):52631. (1976)

5 tables, 1 figure

The decontamination of surfaces, as practiced at present, generates large volumes of radioactive liquid wastes with considerable loads of nonradioactive matter. Optimisation work aimed at reducing the quantity of these wastes has been carried out on a liquid cleaning agent, a washing agent for contaminated protective clothing, a decontamination paste and decontamination with molten salt. The pastes and molten salts, unlike the other decontamination agents, can be applied in thin layers, resulting in considerably smaller amounts of waste. These agents are therefore useful alternatives to liquid decontamination media.

SUBJECT CATEGORY: I.I.W

ORIGIN: Foreign

KEYWORDS: DECONTAMINATION; RADIOACTIVE WASTES; LIQUID WASTES; VOLUME; LOW-LEVEL RADIOACTIVE WASTES

764

Eichholz, G.G.

ENVIRONMENTAL ASPECTS OF NUCLEAR POWER. Ann Arbor Science Publishers, Inc., Ann Arbor, MI. (1976) 
The book deals with the environmental effects of the growing nuclear industry. The subject is discussed under the following chapter headings: introduction; the passive environment; the dynamic environment; radiation effects; nuclear power plants; waste heat dissipation; treatment of radioactive effluents; environmental dispersion of radioactive effluents; power plants siting; transportation of nuclear materials; the fuel cycle industries; radioactive waste disposal; and technological assessment.

SUBJECT CATEGORY: General

ORIGIN: General

KEYWORDS: COST BENEFIT ANALYSIS; ENVIRONMENTAL EFFECTS; NUCLEAR POWER PLANTS; RADIATION HAZARDS; RADIOACTIVE WASTES

765

Faust, G.R.

POSITIVE RATIONALE FOR NEGATIVE NET SALVAGE. Public Util. Fortn. 98(3):2529. (1976)

The author believes the most satisfactory method of dealing with the net salvage problem is to establish a separate net salvage reserve and adjust the annual accruals to it to reflect current price levels. This will not necessarily improve the forecasting techniques either for life estimates or net salvage estimates, except that it may cause more serious consideration of terminal retirement tasks and obligations. However, the net salvage reserve will be more readily controllable, while at the same time the depreciation reserve at any date will directly reflect the actual amount of invested capital recovered to that date. When, inevitably, the net salvage reserve must be adjusted for overestimates or underestimates of gross salvage or cost of removal, or of both, the adjustment amount can be more readily identified. If the reserve is properly administered and kept current in respect to future requirements at regular intervals, ratepayers should be affected minimally.

SUBJECT CATEGORY: General

ORIGIN: Commercial

KEYWORDS: DECOMMISSIONING; ECONOMICS; POWER PLANTS; PUBLIC UTILITIES
766

Gat, U., J.D. Thomas, and D.T. Clark

RADIOACTIVE WASTE INVENTORY AT THE MAXEY FLATS NUCLEAR WASTE BURIAL SITE. Health Physics 30(3):281289. (1976)

A general review and evaluation of the radioactive shipment records of Maxey Flats. Deposited activity is corrected for decay and the postulated present (1974) activity is presented.

In March 1963 burial operations at the Maxey Flats Disposal Site were initiated. Information rontained. in the radioactive shipment records were transferred to magnetic computer tape in 1973 . Inventory is given by several classifications: activity of the site and burial pits; accumulated activity by isotope; and waste volume. The total activity on site in 1974 was estimated at $1.9 \times 1 \cup\left(E^{\prime}+7\right)$. 'l'he total volume of waste disposed of on site until 1974 was calculated to be $5.98 \times 10(\mathrm{E}+6)$ cubic feet of solids and $5.11 \times$ $10(E+5)$ gallons of liquid. Review of the records indicate various discrepancies between recorded quantities and actual quantities.

\section{SUBJECT CATEGORY: LLW}

ORIGIN: Commercial

KEYWORDS: RADIOACTIVE WASTE DISPOSAL; SOLID WASTES; LIQUID WASTES; VOLUME; SITE EVALUATION; RADIOISOTOPES; ISOTOPES; INVENTORIES; GROUND DISPOSAL

\section{7}

Greenhalgh, W.O.

PRODUCT STÓRAGE AND DISPOSAL EVALUATION. HEDLTME-76-22; 79 pp. (1976)

Applicable to shallow land burial in that it addresses certain fixation properties of sorbent material. Data presented does not address leach rates or leachate characteristics.

Liquid fixation tests were performed on three readily available sorbent materials-i.e. vermiculite, Zorb-All, and San-i-cel. A 3:1 volume ratio of sorbent to liquid resulted in a 100 percent sorption of the test liquid. Reduction of this ratio to 2:1 left 5 to 40 percent of the liquid unabsorbed. The fixation ability of Portland cement was also investigated: 
Mixtures with contents of less than 26 percent by weight were difficult to mix, while those with a water content of greater than 34 percent by weight resulted in the formation of free water when allowed to set in a closed system. The effects of organic liquids on the fixation ability of Portland cement and sorbent materials were also investigated. In addition to the sorption studies, data are presented on the annual amount of radioactive waste disposed of at the six commercial burial grounds, including the four NECO sited, the NES site and the ChemNuclear site. In these compilations, wastes are segregated as by-product materials, special nuclear materials, and source materials.

SUBJECT CATEGORY: LLW; TRU

ORIGIN: Commercial

KEYWORDS: VERMICULITE; CEMENTS; TRANSURANIUM ELEMENTS; LIQUID WASTES; LOW-LEVEL RADIOACTIVE WASTES; IMMOBILIZATION; UREA FORMALDEHYDE; POLYMERS; GLASS; RADIOACTIVE WASTE PROCESSING; SOLID WASTES; VOLUME; GROUND DISPOSAL; REVIEWS

768

Gruhier, F.

NUCLEAR REPROCESSING BET. Sci. Avenir 347:22-27. (1976)

In French

Problems associated with nuclear fuel reprocessing (in particular light water reactor fuels) are represented: techniques involved, release of radioactive elements, waste storage, criticality risk, personnel irradiation, cusly.

SUBJECT CATEGORY: HLW; Spent Fuel

ORIGIN: Foreign

KEYWORDS: CONTAMINATION; COST; CRITICALITY; ENRICHED URANIUM REACTORS; FUEL REPROCESSING PLANTS; RADIATION HAZARDS; REPROCESSING; SPENT FUEL STORAGE; SPENT FUELS

769

Hamer, J.
POLLUTION CONTROL: COSTS AND BENEFITS. Ed. Res. Rep. 1(8):147-164. (1976)

Cost-benefit analysis of pollution abatement is reviewed for water and air pollution. The actual positive influence on employment opportunities opened up by the pollution-control industry is stressed as well as economic and health benefits from the improved environmental quality. No estimates are available for noise control or for stripmined land reclamation. The status of present air and water quality laws is discussed from both federal and industrial viewpoints.

SUBJECT CATEGORY: Airborne; LLW

ORIGIN: Commercial

KEYWORDS: AIR POLLUTION ABATEMENT; AUTOMOBILES; COST BENEFIT ANALYSIS; ECOLOGY; ECONOMICS; ENERGY; ENVIRONMENT; EXHAUST GASES; LAND USE; MINING; POLLUTION; POLLUTION CONTROL EQUIP. MENT; POWER PLANTS; QUALITY CONTROL; RADIOACTIVE WASTES; SOCIO-ECONOMIC FACTORS; SOLID WASTES; WATER POLLUTION ABATEMENT

770

Kee, C.W., A.G. Croff, and J.O. Blomeke

UPDATED PROJECTIONS OF RADIOACTIVE WASTES TO BE GENERATED BY THE U.S. NUCLEAR POWER INDUSTRY. ORNL/TM-5427; 131 pp. (1976)

Gives predictions of volume, activity, physical and chemical forms, weights, thermal power and hazards of fuel cycle wastes on a yearly and accumulated basis so that shallow land burial site requirements can be determined. 72 tables.

Eleven types of radioactive wastes to be generated within the fuel cycle operations of the U.S. nuclear power industry are defined, and projections are presented of their annual generation rates, shipping requirements, and accumulated characteristics over the remainder of this century. The power reactor complex is assumed to consist of uranium- and plutonium-fueled LWRs, HTGRs, and LMFBRs, and the installed nuclear electric capacity of the U.S. is taken as $68.1,252$, and $510 \mathrm{GW}$ at the ends of 1980,1990 , and 2000, respectively. (Auth)

SUBJECT CATEGORY: HLW; LLW; TRU 
ORIGIN: Commercial

KEYWORDS: NUCLEAR POWER; WASTE TRANSPORTATION; VOLUME; FORECASTING; WATER COOLED REACTORS; HTGR TYPE REACTORS; LMFBR TYPE REACTORS; FUEL CYCLE; URANIUM; PLUTONIUM; RADIOACTIVE WASTE MANAGEMENT

771

Khonikevich, A.A., M.F. Yakushev, I.L. Rybal'chenko, and A.A. Permyakov

TREATMENT OF LIQUID RADIOACTIVE WASTES AT THE LENINGRAD STATION. Isotopenpraxis 12(4):177-179. (1976)

In German; Translated from Izotopy v SSSR no. 37 p. 28

Decontamination of low-level liquid radioactive wastes in the Leningrad waste water processing plant is described. The plant has a capacity of 36,000 cubic/year and works with a three-stage process consisting of 1 ) coagulation nd coprecipitation, 2) distillation with steam cleaning and 3) ion exchange using the resins $\mathrm{KCl}-2$ and EDE-10P. Finally, operation costs are given.

SURJFCT CATEGORY: LI.W

ORIGIN: Foreign

KEYWORDS: COPRECIPITATION; COST; DECONTAMINATION; DISTILLATION; ION EXCHANGE; LENINGRAD-1 REACTOR; LIQUID WASTES; OPERATION; RADIOACTIVE WASTE PROCESSING; RADIOACTIVE WASTES; USSR

772

Lefillatre, $G$.

FIXATION OF LOW AND MEDIUM-ACTIVE RADIOACTIVE WASTES IN BITUMEN. CONF-760587; Bituminization of Low- and Medium-Level Radioactive Wastes, Proceedings of an NEA Seminar held in Antwerp, Belgium, May 1819, 1976, (24 pp.). (1976)

Development studies of fixation by bitumens has been concerned with a number of approaches. Fixation of evaporation concentrates and wastes produced by light-water reactors, both boiling water and pressurized are briefly presented. Direct bituminization of effluents is a new process that has as yet been applied industrially. Spent fuels with the characteristics of $\mathrm{pH}=9.2,2.02 \mathrm{~g} / \mathrm{l}$ salts containing $320 \mathrm{mg} / \mathrm{l}$ boron, total gamma activity $1.3 \times 10(\mathrm{E}-2)$, total beta activity 1.26 and total alpha activity of 8.5 $x 10$ (E-5) $\mathrm{Ci} / \mathrm{cu} \mathrm{m}$ from the PWR of SENA have been solidified. Other reactor effluents are listed. The decontamination factors range from 860 to 1200 according to process compared against and radioisotope considered. Characterization of the distillates and coated wastes is presented. Also considered are the fixation abilities of trilaurylamine and tributyl phosphate. Leaching tests showed that in demineralized water the rates ranged from $3 \times 10$ (E9) to $1 \times 10(\mathrm{E}-5) \mathrm{cm} /$ day for a variety of radioisotopes. Studies were also undertaken as to the thermal and biological stabilities of the bituminized radwastes. At present bituminization assures storage of low and intermediate-level radwastes with an acceptable degree of safety and of cost.

SUBJECT CATEGORY: LLW; HLW; Spent Fuel

ORIGIN: Foreign

KEYWORDS: ALPHA PARTICLES; BETA PARTICLES; BITUMINOUS MATERIALS; GAMMA RADIATION; IMMOBILIZATION; LOW-LEVEL RADIOACTIVE WASTES; INTERMEDIATELEVEL RADIOACTIVE WASTES; COST BENEFIT ANAL,YSIS; SOLIDIFICATION; WATER COOLED REACTORS

773

Lefillatre, $\mathrm{G}$.

PROGRESS IN THE TECHNIQUES OF BITUMINIZING LIQUID EFFLUENTS OF PिRESSURIZEED-WATER NUUCLEAR POWER PLANTS. CONF-760310-13; BNWL-tr-196; SM-207/29; Management of radioactive waste, proceedings of a Symposium, Vienna, Austria, March 22, 1976. International Atomic Energy Agency, Vienna, Austria. (1976)

The report concerns recent advances in the technqiue of direct bituminization, without preconcentration, of spent effluents from a light-water nuclear power plant of the PWR type. Direct bituminization consists in complete dehydration in a thin-film vertical evaporator of the dilute emulsion formed by the mixture of bituminous emulsion and effluents at $\mathrm{pH}$ 9.6. The bituminous coating containing 40 to 50 percent salts and at least 1 percent water flows by 
gravity into a drum where it solidifies. Decontamination of the distillates is perfected by passage through columns of active carbon and ion-exchange resins. The process was developed in the pilot plant of the Cadarache Center, which is equipped with a LUWA L150 evaporator with which 60 liters per hour of effluents of activity around $1 \mathrm{Ci}$ /cubic m can' be treated. The decontamination factors of the devices are between $10(E+3)$ and $10(E+5)$, and the real concentration factor attains 290 with effluents having a concentration of $2 \mathrm{~g} / \mathrm{l}$. The properties of the solidified waste are mentioned: density, bitumen content, softening point, leaching rate and thermal stability. Finally, on the basis of an industrial direct bituminization plant with a capacity of 3 cubic per hour, the annual cost of treating the spent effluents of two 900-MWe PWR nuclear power plants is estimated to be one and one half million francs. Comparison of the number of barrels packed by bitumen and cement reveals a volume gain of 2.7 in favor of bitumen for the solidified wastes to be stored.

\section{SUBJECT CATEGORY: Spent Fuel}

ORIGIN: Foreign

KEYWORDS: BITUMINOUS MATERIALS; DECONTAMINATION; DENSITY; ECONOMICS; EFFICIENCY; LEACHING; LIQUID WASTES; PWR TYPE REACTORS; RADIOACTIVE WASTE PROCESSING; SOLIDIFICATION; STABILITY; TEMPERATURE EFFECTS

\section{4}

Lenneman, W.L., H.E. Parker, and P.J. West

MANAGEMENT OF RADIOACTIVE WASTES. Annals of Nuclear Energy 3:285-295; CONF-750411; European Nuclear Conference held in Paris, France, April 21-25, 1975, 11 pp. (1976)

Good overview of the state of the art and potential problems is presented.

Areas bordering on or regarding radioactive waste management in the nuclear fuel cycle are discussed. Better management and control over mill tailings, a shortage of irradiated fuel storage space, and decommisioning criteria are areas that require immediate attention or preparation for future implications. Radium 226 is the chief concern with respect to mill tailings not because of its low concentration, $800 \mathrm{pCi} / \mathrm{g}$, but due to its long halflife, $1.620 \mathrm{yr}$ and the radon gas decay daughter. The tailings should be disposed of in areas where they care ultimately be stabilized and revegetated. It has been tactly assumed that the fuel reprocessor would provide for adequate management of spent fuel so now there is a problem of fuel storage space. But storage is and will be aviable alternative to reprocessing for the next 10 years. Storage maybe achieved with existing technology at reactors with appropriately planned storing capability. Decommissioning of facilities should be included in the design. Criteria should be set up by governmental regulatory bodies. Techniques need to be developed for concentrating and containing Krypton and tritium from fuel reprocessing effluents. The work is as yet experimental and involves incorporation in to polymers and resins. Another serious problem is resolving how high-level and alpha-bearing wastes are disposed. The most promising disposal method is disposal in suitable (salt; granites and shales) geologic formations. This method should be proven as the problem is a critical issue to the nuclear power industry. Regional fuel and managenes centers have been shown by cost analysis to best way of handling the wastes with the exception of tailings and fuel storage. It minimizes the potential hazard of handling. International cooperation is a must to achieve nuclear maturity.

SUBJECT CATEGORY: Remedial Action, Mill Tailings; Spent Fuel

ORIGIN: Defense; Commercial

KEYWORDS: ACTINIDES; ALPHA PARTICLES; BIOSPHERE; CONTAINMENT; COST BENEFIT ANALYSIS; DAUGHTER PRODUCTS; EVALUATION; REPROCESSING; FUEL CYCLE; GASES; GEOLOGIC STRUCTURES; GEO. LOGIC TIME; GROUND WATER; HAZARDS; LITHOLOGY; NUCLEAR FACILITIES; DECOMMISSIONING; REPROCESSING; SALT DEPOSITS; MILL TAILINGS; URANIUM COMPOUNDS; RADIOACTIVE WASTE MANAGEMENT; RADIOACTIVE WASTE STORAGE; HIGH-LEVEL RADIOACTIVE WASTES; LIQUID WASTES; LOW-LEVEL RADIOACTIVE WASTES; SOLID WASTES

775

Martin, W.

NUCLEAR RESEARCH TAKES STOCK. REPROCESSING IS JUSTIFIABLE FROM THE ECONOMIC POINT OF VIEW. VDI (Ver. Dtsch. Ing.) Nachr. 30(1):2. (1976) 


\section{In German}

The first report on the state of the Reprocessing and Waste Treatment Project (PWA) of the Nuclear Research Centre Karlsruhe introduces the main research and development activities: Meeting the requirements concerning safety and licensing, process and components development in order to improve the availability and economy of reprocessing plants, waste treatment, and final storage. The task the project is to solve is a contribution of industry towards the construction of a German reprocessing plant with an output of 1,500 for CWR fuel elements. Cooperation of the partners of industry, international cooperation, and the responsibility of the State for the particular problems of waste disposal and finale storage are outlined. Medium-term budgetary accounting provides for expenditures amounting to 44 million DM and 210 man years.

SūB̈JECT CATEGORY: HLW; Spent Fuel; Isolation; LLW

ORIGIN: Foreign

KEYWORDS: ECONOMICS; FUEL REPROCESSING PLANTS; INTERNATIONAL COOP. ERATION; KERNFORSCHUNGSZENTRUM KARLSRUHE; NUCLEAR MATERIALS MANAGEMENT; ORGANIZING; RADIOACTIVE WASTE DISPOSAL; RADIOACTIVE WASTE STORAGE; REPROCESSING; SAFETY; SPENT FUELS; COST

776

Merline, R.J., D.L. Ush, and K. Terada

RADIOACTIVE WASTE PACKAGE DEVELOPMENT AT THE ROCKY FLATS PLANT. IAEA-SR-10/26; Transport Packaging for Radioactive Material, Proceedings of a Seminar, Vienna, Austria, 1976, (pp. 153-161). (1976)

A review of the historical and current package developments for Pu 239 wastes generated at the Rocky Flats Plant.

Current federal regulations require that alpha contaminated wastes (specific activity greater than $10 \mathrm{nCi} / \mathrm{g}$ ) be contained in containers which can be placed in retrievable storage for twenty years after which the external surface of the package must be contamination free and capable of being rehandled.
The paper reviews Rocky Flat's package development program in light of these requirements. The average annual volume of plutonium contaminated wastes produced at the facility exceeds $3500 \mathrm{cu} \mathrm{m}$. These wastes are transported after interim storage on site, to the surface storage facility at INEL. These wastes are mostly frequently transported in 215 liter steel drums lined with 0.23 minimum thickness polyethylene liner. This liner is molded from a cross-linkable resin and is designed for stiffness. This stiffness permits stacking even if corrosion of the steel drum occurs. Real-time aging experience with $0.15 \mathrm{~cm}$ steel and $0.23 \mathrm{~cm}$ polyethylene indicates a life time in excess of 20 years. Alternative liners considered include (1) a thermally formed open-head liner (0.04-0.20 cm thick) (2) a blow-molded closed heat-liner ( $0.1 n-0.2 n \mathrm{rm}$ thick) and (3) a fiber glass reinforced polyester resin $(0.15$ $\mathrm{cm}$ thick). Wastes are also packaged in plywood boxes $3 \mathrm{cu} \mathrm{m}$ capacity, walled on the exterior with 0.32 to $0.65 \mathrm{~cm}$ fiberglass reinforced polyester

\section{SUBJECT CATEGORY: TRU}

ORIGIN: Defense

KEYWORDS: PACKAGING; RADIOACTIVE WASTE MANAGEMENT; PLUTONIUM; CONTAMINATION; STABILITY; VOLUME; STAND. ARDS; STEELS; RESINS; ECONOMICS; PLUTONIUM 239

777

Oyen, L.C.

SOLVING RaDWASTE PROBLEMS. Power 120(3):75-77. (1876)

The combination of regulatory changes and increased waste volume has resulted in design changes in waste processing systems. Problems resulting from waste segregation as a basis for design philosophy are considered, and solutions to the problems are suggested. The importance of opcrator training, maintenance procedures, good housekeeping, water management, and nffaite shipment of solids is discussed. Flowsheets for radioactive waste processing systems for boiling water reactors and pressurized water reactors are included.

SUBJECT CATEGORY: HLW; LLW; Transportation

ORIGIN: Commercial 
KEYWORDS: DESIGN; FLOWSHEETS; RADIOACTIVE WASTE MANAGEMENT; RADIOACTIVE WASTE PROCESSING; VOLUME; SOLID WASTES; PWR TYPE REACTORS; REACTORS

\section{8}

Powers, P.W.

HOW TO DISPOSE OF TOXIC SUBSTANCES AND INDUSTRIAL WASTES. Noyes Data Corp., Park Ridge, NJ. (1976)

Book

\begin{abstract}
All recognized and allowed ultimate disposal methods for toxic materials and industrial wastes are discussed in detail, and a long list of specific recommendations for specific substances plus alternative disposal or recovery methods are presented. Ultimate waste disposal implies the final disposition of nondegradable, persistent, harmful, and cumulative wastes that may be solid, liquid, or gaseous. Workable solutions to ultimate disposal problems are described including conversion to harmless end products, subsurface storage in ponds or landfills, and disposal in the ocean. The five general categories of hazardous wastes are toxic chemicals; radioactive materials; flammable materials; explosive materials; and toxic biological materials. Many toxic or hazardous wastes contain valuable materials. Whenever this is the case, recovery and reuse is one of the most desirable methods of hazardous waste avoidance. The book is based on government-sponsored reports (often elaborated by highly qualified personnel from industrial companies), U.S. Patents, and on pertinent articles in authoritative journals.
\end{abstract}

\section{SUBJECT CATEGORY: General}

ORIGIN: Commercial

KEYWORDS: AUTOMOBILE INDUSTRY; CHEMICAL INDUSTRY; COMBUSTION; ECONOMICS; ELECTRIC UTILITIES; EXPLOSIVES; FOOD INDUSTRY; GASEOUS WASTES; HOSPITALS; INDUSTRIAL WASTES; LIQUID WASTES; MARINE DISPOSAL; METAL INDUSTRY; NUCLEAR INDUSTRY; PAPER INDUSTRY; PETROLEUM INDUSTRY; POLLUTION CONTROL; SOLID WASTES; TECHNOLOGY TRANSFER; TEXTILE INDUSTRY; TOXIC MATERIALS; UNDERGROUND DISPOSAL; RADIOACTIVE WASTE DISPOSAL; WASTE PROCESSING; WASTES
779

Rohwer, P.S., and W.H. Wilcox

RADIOLOGICAL ASPECTS OF ENVIRONMENTAL TRITIUM. Nucl. Saf. 17(2):216223. (1976)

See Nuclear Science Abstracts 1976, 33(12), 29132

SUBJECT CATEGORY: Airborne; LLW

ORIGIN: Commercial; Defense

KEYWORDS: BODY BURDEN; DIFFUSION; ENVIRONMENT; FOOD CHAINS; FORECASTING; GASEOUS WASTES; HEALTH HAZARDS; HUMAN POPULATIONS; LIQUID WASTES; NUCLEAR POWER PLANTS; QUALITY CONTROL; RADIATION DOSES; RADIATION HAZARDS; RADIATION PROTECTION; RADIOACTIVE EFFLUENTS; RADIOACTIVE WASTE MANAGEMENT; RADIONUCLIDE KINETICS; RADIONUCLIDE MIGRATION; THERMONUCLEAR REACTORS; TRITIUM; TRITIUM COMPOUNDS

780

Schueller, W.

NUCLEAR WASTE DISPOSAL. REPORT ON A SYMPOSIUM OF THE GERMAN ATOMIC FORUM, MAYENCE, 19 AND 20 JANUARY 1976. Kerntechnik 18(3):133-134. (1976)

In German

The article cites and summarizes the papers on the topics: economic and ecological importance of waste management, reprocessing of nuclear fuel and recycling of uranium and plutonium, waste management and final storage, transports and organizational aspects of waste management, presented at this symposium.

SUBJECT CATEGORY: TRU; Spent Fuel

ORIGIN: Foreign

KEYWORDS: ECONOMICS; MEETINGS; RADIOACTIVE WASTE DISPOSAL; RADIOACTIVE WASTE MANAGEMENT; RADIOACTIVE WASTE PROCESSING; RADIOACTIVE WASTE STORAGE; REPROCESSING; SPENT FUELS; TRANSPORT 
781

Smiley, S.H., M.L. Ernst, G. Sege, and R.T. Jaske

FEEDING THE GLUTTON. CITIES IX. . (1976)

The Nuclear Energy Center Site Survey (NECSS) was a study of a potential alternative siting approach for nuclear power and fuel-cycle facilities that would cluster such facilities on a relatively small number of sites, as contrasted with current "dispersed" siting practices. Among the fuel-cycle facilities of primary interest were those involved in recycling plutonium recovered from spent fuel into reactors and facilities for waste handling and storage. Fuel-cycle facilities represent fewer units than the power plants they serve-only ten fuelreprocessing plants and ten mixed-oxide fuel fabrication plants of the size of present commercial designs could accommodate all of the nuclear reactors forecast in the U.S. for the year '2000. 'I'hree basic types of NECs were considered: power centers, consisting of 10 to 40 nuclear electric generating units of 1200-MW electric capacity each; fuel-cycle centers, consisting of fuel-reprocessing plants, mixed-oxide fuel-fabrication facilities, and radioactive waste management facilities; and combined centers, containing both generating units and fuelcycle facilities. Concentrating on differences from dispersed siting approaches, the survey evaluates both the feasibility and the practicality of the NEC concept. The major technical feasibility issues include the dissipation of waste heat; the design, reliability, and economics of transmission systems; the economics of energy center construction; and radiological and environmental impacts. In addition, questions related to accident risk, natural disasters, and national security, and the safeguarding of strategic special nuclear materials from theft and nuclear plants from sabotage were dealt with. A screening effort was done for each of the nine electric reliability regions into which the contiguous U.S. is divided.

\section{SUBJECT CATEGORY: Fuel Cycle Centers}

ORIGIN: Foreign

KEYWORDS: CONSTRUCTION; ECONOMICS; FEASIBILITY STUDIES; FUEL REPROCESSING PLANTS; NUCLEAR FACILITIES; POWER GENERATION; SITE SELECTION

782

Stiehl, H.H., M. Neumann, and D. Sinhuber
AIR FILTRATION PLANTS OF WALL-TYPE FOR SEPARATION OF FISSION IODINE IN NUCLEAR REACTORS. PAPER 4-10; Fourteenth ERDA Air Cleaning Conference, Sun Valley, ID, August 2-4, 1976; 7 pp. (1976)

The increasing density of nuclear power stations and increased safety requirements will lead to future to higher flow rates and longer residence times in the adsorption filter layer of the iodine sorption filter plants of nuclear power stations. The safety requirements in the Federal Republic of Germany have been complied with so far in the conventional way by means of duct-type filter constructions. For the higher flow rates and longer residence times necessary in future, we propose a filter constuction of wall-type, which complies with the sufety regulations of the Federal Republic of Germany. The economic and technical advantages are discussed.

SUBJECT CATEGORY: LLW

ORIGIN: Foreign

KEYWORDS: AIR CLEANING; DESIGN; FISSION PRODUCTS; ADSORPTION; SAFETY; IODINE; FILTERS; REACTORS

783

Van de Voorde, N., and K. Peeters

EXPERIENCE WITH BITUMINIZATION IN BELGIUM. CB-31674; CONF-760587; Bituminization of Low-and Medium-Level Radioactive Wastes, Proceedings of an NEA Seminar held in Antwerp, Belgium, May 18-19, 1976, (pp. 99-107). (1976)

The bituminization of low-level liquid radwastes in Belgium is described. The process is a "high temperature" vne und consisty of two steps. The first is to prepare the sludge to be incorporated in the bitumen. This is primarily to extract as much water as possible from the sludge and this is done by: decantation of the liquid sludges by centrifuging; filtration of the decanted sludges, which have been frozen for some time; and filtration on a suction filter until a solid material contains around $60 \%$ water. The sludge is then added to the bitumen and the mixture is heated and intensely agitated by a high-speed mixer to achieve a monomolecular coating (step two). The plant consists of: 1 ) a unit for storage and transfer of sludges from the collecting reservoir to a centrifuge; 2) a thickened sludge reservoir; 3) the freezing unit, consisting of 2 well 
insulated tanks of $1 \mathrm{cu}$ m capacity; 4) a reservoir to feed the suction filter; 5) a drum type suction filter; and 6) an insolubilizer for mixing the filtered sludges with bitumen. The steam released from the bitumen bath is condensed and collected. The average activity of the residual non-condensible gases is $10(\mathrm{E}-11) \mathrm{uCi} / \mathrm{ml}$ alpha and $10(\mathrm{E}-9) \mathrm{uCi} / \mathrm{ml}$ beta-gamma. The activity of the scrubbing solutions averages $10(\mathrm{E}=7) \mathrm{uCi} / \mathrm{ml}$ alpha and $5 \times 10$ (E-5) $\mathrm{uCi} / \mathrm{ml}$ beta-gamma. Every 6 months during the maintenance period the mixer blades are replaced due to abrasive action of some types of sludge (BaSO4). The "MUMMIE" system has been operating since mid-1964 and has processed a total of about 750 tons of wet sludge (300 tons dry sludge). One and a half million cu $\mathrm{m}$ of liquid wastes were treated to obtain the above tonnage. The ultimate volume was about $550 \mathrm{cu} \mathrm{m}$ with a total activity of $10,000 \mathrm{Ci}$. The leaching rate of the bitumen was 10 (E-6) to $10(\mathrm{E}-7) \mathrm{g} / \mathrm{sqcm} /$ day after 90 days. The reduction factor using this process is on the order of 2000. For operation of the plant since 1964 the cost was 14,750 Belgian Francs. A pilot plant for processing liquid rudioactive wastes and for insolubilizing them in bitumen was also discussed.

\section{SUBJECT CATEGORY: LLW}

ORIGIN: Foreign

KEYWORDS: BITUMENS; COST BENEFIT ANALYSIS; FILTERS; GAMMA RADIATION; BETA PARTICLES; ALPHA PARTICLES; SLUDGES; VOLUME; LIQUID WASTES; LOW-LEVEL RADIOACTIVE WASTES; COST

\section{4}

IRRADIATED CORE COMPONENT DISPOSAI.. The Nugletter 13(3):11. (1976)

\section{2 figures}

One of the problems faced by nuclear plant personnel is the disposition of irradiated core components that are no longer able to perform their design function and have been removed from the reactor for modification or repair. Core components, such as in-core detectors, poison curtains, control rods and sometimes core structural materials, are often too large or too bulky to be shipped conveniently. NUS engineering laboratory and operating plant services department personnel have devised tools and fixtures for cutting these components to a size compatible with available waste shipping casks, and disposing of the material in an economi- cally feasible manner without interfering with plant operations.

SUBJECT CATEGORY: LLW; HLW

ORIGIN: Commercial

KEYWORDS: RADIOACTIVE WASTE DISPOSAL; SOLID WASTES; REACTOR COMPONENTS; REACTOR CORES; CONTROL ELEMENTS

\section{5}

WASTE DISPOSAL IN NUCLEAR ENGINEERING. At. Strom 22(2):49-51; Waste Disposal in Nuclear Engineering, Proceedings of a Symposium, Mainz, Germany, F.R., January .19, 1976. (1976)

The symposium 'Waste Disposal in Nuclear Engineering' dealt in separate lectures with four topics: 1) The economic and ecological importance of waste disposal, 2) Reprocessing and recycling, 3) Waste treatment and final storage, 4) Transport and organization of waste disposal.

SUBJECT CATEGORY: HLW; TRU; Transportation

ORIGIN: Commercial

KEYWORDS: ECONOMICS; FUEL CYCLE; GASES; MEETINGS; RADIATION PROTECTION; RADIOACTIVE WASTE DISPOSAL; RADIOACTIVE WASTE PROCESSING: RADIOACTIVE WASTE STORAGE; REPROCESSING; REVIEWS; SAFETY; SALT DEPOSITS

\section{6}

WILL NUCLEAR POWER PLANTS BE SHUT DOWN. Umsch. Wiss. Tech. 76(12):532-533. (1976)

\section{In German}

The Committee for Research and Technology of the German Bundestag has performed a hearing on the peaceful use of nuclear energy. The experts have pointed out that in the eighties a shut-down of nuclear power plants is impending if the nuclear fuel cycle is not closed. This means the creation of storage dumps for spent fuel elements, building a reprocessing plant and provision for highly radioactive waste. 
SUBJECT CATEGÓRY: HLW; Spent Fuel

ORIGIN: Foreign

KEYWORDS: FORECASTING; FUEL CYCLE; FUEL REPROCESSING PLANTS; GERMAN FEDERAL REPUBLIC; PLANNING; RADIOACTIVE WASTE DISPOSAL; RADIOACTIVE WASTE MANAGEMENT; REACTOR DECOMMISSIONING; SPENT FUEL STORAGE

787

NUCLEAR ENERGY CENTER SITE SURVEY: 1975. Nucl. Saf. 17(4):411-421. (1976)

36 references

'I'he E'nergy Keorganization Act of 1 $1 y^{\prime} / 4$ authorized and directed the Nuclear Regulatory Commission to make a Nuclear Energy Center Site Survey (NECSS). Nuclear energy centers could include nuclear power plants or other appropriate elements of the nuclear fuel cycle or both. The NECSS provision of the Act (Section 207) is reproduced in NUREG-0001 as the frontispiece. The purpose of this report is to present the results of the Survey conducted in accordance with the legislative mandale.

SUBJECT CATEGORY: Fuel Cycle Centers

ORIGIN: Commercial

KEYWORDS: ECONOMICS; FUEL REPROCESSING PLANTS; GOVERNMENT POLICIES; LEGISLATION; MIXED OXIDE FUEL FABRICATION PLANTS; NUCLEAR FACILITIES; NUCLEAR POWER PLANTS; PUBLIC UTILITIES; RADIOACTIVE WASTE FACILITIES; RADIOACTIVE WASTE PROCESSING; REAC-
TOR SAFETY; SITE SELECTION; SOCIOECONOMIC FACTORS

788

RESULTS OF THE SURVEY ON RADIOACTIVE WASTES IN RADIOISOTOPE UTILIZATION. Genshiryoku linkai Geppo 21(4):916. (1976)

In Japanese

With expansion in the usage of radioisotopes in recent years, the radinactive wastes from the enterprises using unsealed RIs are on the increase, and their treatment and disposal are now major problems. The wastes are stored tempnrarily on the, sites of the enterprises, or treated collectively and stored in Japan Atomic Energy Research Institute. The results of the survey on radioactive wastes from 996 locations of enterprises (including radioactive medical compounds, but excluding nuclear materials) are summarized as follows: the quantities of RIs consumed in fiscal 1974; the amounts of radioactive wastes generated in fiscal 1974 , the stored quantities of radioactive wastes as of October 1,1975 , and the quantities of radioactive wastes expected in fiscal 1980; pretreatment of radioactive wastes at the enterprises, and consignees of radioactive wastes.

SUBJECT CATEGORY: LLW

ORIGIN: Foreign

KEYWORDS: FORECASTING; GASEOUS WASTES; JAPANESE ORGANIZATIONS; LIQUID WASTES; RADIOACTIVE WASTE DISPOSAL; RADIOACTIVE WASTE PROCESSING; RADIOACTIVE WASTES; RADIOISOTOPES; SOLID WASTES; INVENTORIES; LABELLED COMPOUNDS; NUCLEAR MEDICINE 
1977

\section{9}

Baehr, W., W. Hempelmann; and H. Krause; Abt. zur Behandlung Radioaktiver Abfaelle, Kernforschungszentrum Karlsruhe, Federal Republic of Germany; Abt. Dekontaminationsbetriebe, Kernforschungszentrum Karlsruhe, Federal Republic of Germany

INCINERATION PLANT FOR RADIOACTIVE WASTE AT THE NUCLEAR RESEARCH CENTER KARLSRUHE. CONF760944-5; KFK-2418; IEEE-ASME Joint Power Generation Conference, Buffalo, NY, September 19, 1976. (1977)

Available from NTIS, PC A03/MF A01.

In 1971 a large incineration plant started operation in the Nuclear Research Center Karlsruhe. This plant is serving for routine incineration of up to 100 $\mathrm{kg}$ of combustible radioactive solids or 40 liter of contaminated organic liquids and oils per hour. A dry off-gas cleaning system has been developed for this installation in which the flue gases are cleaned by ceramic filter candles. After passing the filtering system and cooling the off-gas is discharged directly through a stack. The activity concentration in the off-gas is measured by a continuous monitoring system. The ashes arising from the incineration are mixed with cement grout and filled into 200 liter drums. By this way approximately one drum of fixed ashes results from 100 drums of combustible wastes. During the first four years of operation, more than 4,000 cubic meters of combustible solids and about 60 cubic meters organic solvents have been incinerated in the plant. The uperaling experiences are presented.

\section{SUBJECT CATEGORY: Airborne; LLW}

\section{ORIGIN: Foreign}

KEYWORDS: AIR FILTERS; ASHES; CERAMICS; COMBUSTION; CONCRETES; CONTAINERS; COST; DECONTAMINATION; FLOW. SHEETS; HIGH TEMPERATURE; INCINERATORS; LOW PRESSURE; OFF-GAS SYSTEMS; OPERATION; ORGANIC SOL VENTS; RADIOACTIVE WASTE PROCESSING; RADIOACTIVE WASTES; RADIOACTIVITY; SOLIDIFICATION; TRITIUM; VERY HIGH TEMPERATURE; RADIOACTIVE AEROSOLS
790

Schindler, R.E., J.R. Berreth, G.G. Simpson, J.H. Valentine, and M.S. Walker; Allied Chemical Corp., Idaho Chemical Programs - Operations Office, Idaho Falls, ID

DEVELOPMENT OF A FLUIDIZED-BED CALCINER AND PAST-TREATMENT PROCESSES FOR SOLIDIFICATION OF COMMERCIAL FUEL-REPROCESSING LIQUID WASTES. ICP-1136. (1977)

Available from NTIS, PC A11/MF A01.

The results of development efforts to adapt fluidized-bed-calcination technology, demonstrated by plant operation since 1963 with radioactive wastes at the ICPP Waste Calcining Facility; to the solidification of radioactive liquid wastes from the reprocessing of commercial nuclear-reactor fuels are presented. Pilot-plant calcining tests with simulated wastes verify the feasibility of fluidizedbed calcination of a variety of projected waste compositions. The status of development of metalmatrices and sintered glass-ceramics as alternative waste forms to glass is given. Development needs. are presented for fluidized-bed calcination and for alternative waste forms.

SUBJECT CATEGORY: HLW

ORIGIN: Commercial

KEYWORDS: CALCINATION; FEASIBILITY STUDIES; FLUIDIZED BED; FUEL CYCLE; HIGH-LEVEL RADIOACTIVE WASTES; INFORMATION NEEDS; LIQUID WASTES; PILOT PLANTS; RADIOACTIVE WASTE PROCESSING; SOLIDIFICATION; WATER COOLED REACTORS

791

Hammond, J.D., J. Dugone, D.E. Black, J.A. Hagel, and D.R. Wojciechowski (Ed.); Allied Chemical Corp., Idaho Falls, ID

COMPARISONS OF NUCLEAR FUEL STORAGE OPTIONS-REMOTE DRY, REMOTE SHALLOW POOL, AND CONVENTIONAL DEEP-POOL CONCEPTS: PROCEEDINGS OF THE 25TH CONFERENCE ON REMOTE SYSTEMS TECHNOLOGY. CONF-771117-; Remote Systems Technology, Proceedings of the 25th Symposium, San Francisco, CA, November 27, 
1977. American Nuclear Society, Inc., La Grange Park, IL. (1977)

Conceptual designs are presented for conventional, remote air-cooled and remote water-cooled storage of irradiated nuclear fuels. Detailed comparisons of the three concepts are made on the bases of operation/maintenance, safety, and cost/schedule considerations. The remote water-cooled concept was judged to be the most attractive from the overall technical basis. acceptance of new technology and timing for the decision-making process led to the selection of the conventional (deep-pool) storage concept for construction at the Idaho Chemical Processing Plant.

SQUBJECT CATEGORY: HLW; Spent Fuel

ORIGIN: Defense; Commercial

KEYWORDS: COMPARATIVE EVALUATIONS; COST; IDAHO CHEMICAL PROCESSING PLANT; MAINTENANCE; OPERATION; REMOTE HANDLING; SAFETY; SPENT FUEL STORAGE

792

Trevorrow, L.E.; D.L. Warner, and M.J. Steindler; Argonne National Laboratory, Chemical Engineering Division, Argonne, IL; University of Missouri, Rolla, MO

CONSIDERATIONS AFFECTING DEEPWELL DISPOSAL OF TRITIUM-BEARING LOW-LEVEL AQUEOUS WASTE FROM NUCLEAR FUEL REPROCESSING PLANTS. ANLr76-76; 190 pp. (1977)

Germane to tritium-bearing low-level waste deposited in deep wells.

Factors to be considered with respect to the deep well disposal of low-level aqueous wastes are discussed. Present concepts of disposal of low-level aqueous wastes (LLAW) that contain much of the fission-product tritium from light-water reactors, involve dispersal to the atmosphere or to surface streams at fuel reprocessing plants. These concepts have been challenged in recent years. Deep-well injection of low-level aqueous wastes, an alternative to biospheric dispersal, is the subject of this presentation. Many factors must be considered in assessing its feasibility, including technology, costs, environmental impact, legal and regulatory constraints, and siting. Examination of these factors indicates that the technology of deep-well injection, extensively developed for other industrial wastes, would require little innovation before application to low-level aqueous wastes. Costs would be low, of the order of magnitude of 10 (E-4) mill/kWh. The environmental impact of normal deep-well disposal would be small, compared with dispersal to the atmosphere or to surface streams; abnormal operation would not be expected to produce catastrophic results. Geologically suitable sites are abundant in the U.S., but a well would best be colocated with the fuel-reprocessing plant where the LLAW is produced. Legal and regulatory constraints now being developed will be the most important determinants of the feasibility of applying the method. Sections 2,3 , and 5 were separately entered into the data base.

\section{SIJB.IECT CATEGORY; LLW}

ORIGIN: Defense; Commercial

KEYWORDS: IRON; BARIUM; CADMIUM; SOLUTIONS; GEOLOGY; HYDROLOGY; SHALES; CLAYS; HYDRODYNAMICS; FAULTS; WELL LOGGING; LINERS; CEMENTS; DRINKING WATER; LIQUID WASTES; LOW-LEVEL RADIOACTIVE WASTES; TRITIUM; WATER COOLED REACTORS; DILUTION;ZIRCONIUM; PLUTONIUM; WATER; AQUIFERS; FRACTIONATION; CORROSION; ENVIRONMENT; DECOMMISSIONING; COST BENEFIT ANALYSIS; INJECTION WELIS; SALT DEPOSITS

\section{3}

Arnett, R.C., D.J. Brown, and R.G. Baca; Atlantic Richfield Hanford Co., Richland, WA

HANFORD GROUNDWATER TRANSPORT ESTIMATES FOR HYPOTHETICAL RADIUACETIVE WASTE INCIDEINTS. ARHLD-162. (1977)

\section{Available from N'IIS, PC A04/MF A01}

This report presents an analysis of the impact of subsurface contamination resulting from a series of hypothetical leaks or accidents involving Hanford high-level radioactive defense waste. Estimates of the amounts and concentrations of radionuclides reaching the Columbia River through the Hanford unconfined aquifer flow path were obtained by means of predictive models. The results of the study showed that the spatially averaged concentrations of Tc 99, H 3, and Ru 106 in the ground water as it discharges into the Columbia River are at all times far below the respective ERDA Manual Chapter 
0524 Concentration Guides for uncontrolled areas. Upon entering the Columbia River, additional large dilutions of the water containing trace quantities of contaminants wil occur.

\section{SUBJECT CATEGORY: HLW}

\section{ORIGIN: Defense}

KEYWORDS: ACCIDENTS; AQUIFERS; COLUMBIA RIVER; ENVIRONMENTAL TRANSPORT; FLUID FLOW; FORECASTING; GROUND WATER; HAPO; LEAKS; RADIOACTIVE WASTE MANAGEMENT; RADIOACTIVE WASTES; RUTHENIUM 106; TECHNETIUM 99; TRITIUM

\section{$\mathbf{7 9 4}$}

Kusler, L.E.; Atlantic Richfield Hanford Co., Richland, WA

SURVEY OF DECONTAMINATION AND DECOMMISSIONING TECHNIQUES. Report; 19 pp. (1977)

Available from NTIS A02/MF A01; ERA citation 03:027894

Reports and articles on decommissioning have been reviewed to determine the current technology status and also attempt to identify potential decommissioning problem areas. It is concluded that technological road blocks, which limited decommissioning facilities in the past have been removed. In general, techniques developed by maintenance in maintain. ing the facility have been used to decommission facilities. Some of the more promising development underway which will further simplify decommissioning activities are: electrolytic decontamination which simplifies some decontaminating operations; arc saw and vacuum furnace which reduce the volume of metallic contaminated material by a factor of 10; remotely operated plasma torch which reduces personnel exposure; and shaped charges, water cannon and rock splitters which simplify concrete removal: Areas in which published data are limited are detailed costs identifying various components included in the total cost and also the quantity of waste generated during the decommissloning activities. With the increased awareness of decommissioning requirements as specified by licensing requirements, design criteria for new facilities are taking into consideration final decommissioning of buildings. Specific building design features will evolve as designs are evaluated and implemented.
SUBJECT CATEGORY: Remedial Action, FUSRAP; Remedial Action, Surplus Facilities

ORIGIN: Commercial; Defense

KEYWORDS: DECOMMISSIONING; DECONTAMINATION; COST; NUCLEAR FACILITIES; TECHNOLOGY ASSESSMENT

\section{5}

Morgan, W.W.(Ed.); Atomic Energy of Canada Ltd., Whiteshell Nuclear Research Establishment, Pinawa, Manitoba, Canada

REPORT BY THE COMMITTEE ASSESSING FUEL STORAGE. PART 1: SUMMARY. AECL-5959/1. (1977)

Available from NTIS (US Sales Only), PC A03/MF A01.

Various concepts for interim storage of spent nuclear fuel have been considered. Preliminary design studies and cost estimates have been prepared for the following concepts: two with water cooling - prolonged pool storage at a generating station and pool storage at a central site -, three with air cooling at a central site - "canister", "convection vault", and "conduction vault" - and one underground storage scheme in rock salt. Costs (1972 dollars) were estimated including transportation and a perpetual care fund for maintenance and periodical renewal of the storage facility. Part 1 of this report summarizes the findings. All concepts gave moderate costs providing a contribution of about $0.1 \mathrm{~m} \$ / \mathrm{kWh}$ to the total unit energy cost. Advantages and disadvantages of the respective schcmes are compared.

SUBJECT CATEGORY: HLW; Spent Fuel

ORIGIN: Foreign

KEYWORDS: CANADA; COST; FORECASTING; FUEL POOLS; HIGH.LEVEL RADIOACTIVE WASTES; PLANNING; SPENT FUELSTORAGE; UNDERGROUND STORAGE

\section{6}

Morgan, W.W.(Ed.); Atomic Energy of Canada Ltd., Whiteshell Nuclear Research Establishment, Pinawa, Manitoba, Canada 
REPORT BY THE COMMITTEE ASSESSING FUEL STORAGE. PART 2: APPENDICES. AECL-5959/2. (1977)

Available from NTIS (US Sales Only), PC A10/MF A01:

Various concepts for interim storage of spent nuclear fuel have been considered. Preliminary design studies and cost estimates have been prepared for the following concepts: two with water cooling - prolonged pool storage at a generating station and pool storage at a central site -, three with air cooling at a central site - "canister", "convection vault", and "conduction vault" - and one underground storage scheme in rock salt. Costs (1972 dollars) were estimated including transportation and a perpetual care fund for maintenance and periodical renewal of the storage facility. Part 2 provides details of the concepts and costing methods. All concepts gave moderate costs providing a contribution of about $0.1 \mathrm{~m} \$ / \mathrm{kWh}$ to the total unit energy cost. Advantages and disadvantages of the respective schemes are compared.

SUBJECT CATEGORY: HLW; Spent Fuel

ORIGIN: Foreign

KEYWORDS: CANADA; COST; FORECASTING; FUEL POOLS; HIGH-LEVEL RADIOACTIVE WASTES; PLANNING; SPENT FUELSTORAGE; UNDERGROUND STORAGE

\section{7}

Unsworth, G.N.; Atomic Energy of Canada Ltd., Whiteshell Nuclear Research Establishment, Pinawa, Manitoba, Canada

\section{DECOMMISSIONING OF CANDU NU-} CLEAR STATIONS: NUCLEAR POWER: THE CANADIAN ISSUES. A SUBMISSION FROM ATOMIC ENERGY OF CANADA LIMITED TO THE ROYAL COMMISSION ON ELECTRIC POWER PLANNING IN RESPONSE TO THE COMMISSION'S ISSUE PAPER NO. 1 'NUCLEAR POWER IN ONTARIO'. AECL-5800, (pp. 49-67). (1977)

Several scenarios are presented for decommission. ing of a $600 \mathrm{MW}(\mathrm{e}) \mathrm{CANDU}$ power station. Time and cost estimates are given. Problems peculiar to the art like activity, decontamination, and dismantling procedures are analyzed. Man-rem exposures are predicted.
SUBJECT CATEGORY: Remedial Action, Surplus Facilities

\author{
ORIGIN: Foreign
}

KEYWORDS: CANDU TYPE REACTORS; COST; DECONTAMINATION; RADIATION DOSES; RADIOACTIVE WASTE STORAGE; RADIOACTIVITY; REACTOR DECOMMISSIONING; REACTOR DISMAN'TLING

\section{8}

Davis, D.K., J.A. Partridge, and O.H. Koski; Battelle Pacific Northwest Laboratory, Richland, WA

SELECTION AND EVALUATION OF PROCESSES FOR RECOVERY OF BENEFICIAL ISOTOPES FROM COMMERICAL REACTOR WASTES. BNWL-2063. (1977)

Available from NTIS, PC A03/MF A01.

Conceptual processes were prepared for recovering isotopes from stored high-level liquid wastes to define equipment and facility requirements. Capital costs were estimated for each process. Four different facilities were studied for potential isotope recovery. 'The processes were for the recovery of: cesium only; strontium only; cesium and strontium; and cesium, strontium, promethium; americium, curium, neptunium, and the platinum metals. The selection of these recovery orocesses was determined by their. possible effect on the waste management system. The isotope recovery processes selected tended to have a minimal effect on this system. Preliminary capital investment costs for the four types of facilities processing HLLW from a $5 \mathrm{MT} /$ day reprocessing plant were estimated to be: $\$ 37$ million for a cesium or a strontium recovery facility; $\$ 51$ million for a facility recovering cesium and strontium; and \$143 million for a multi-product facility. In all cases the recovery facility was assumed to be closely integrated with a fuel reprocessing plant and designed along with the reprocessing plant. Recovery costs were estimated for the various products, assuming 50 percent recovery from the HLLW for all of the products, except the platinum metals; 25 percent recovery was assumed for these metals. In general, product price estimates (in 1977 dollars) assumed a market for all of the recovered materials. Estimates for cesium ranged from 45 cents/Ci of Cs 137 (at $69 \mathrm{MCi} / \mathrm{yr}$ ) in a cesium-only recovery facility to 31 cents/ $\mathrm{Ci}$ in a plant recovering both cesium and strontium. Strontium estimates ranged from $60 \mathrm{cents} / \mathrm{Ci}$ of $\mathrm{Sr} 90$ (at $51 \mathrm{MCi} / \mathrm{yr}$ ) in a 
strontium-only recovery facility to 42 cents/ $\mathrm{Ci}$ in a cesium and strontium recovery facility.

SUBJECT CATEGORY: HI.W

ORIGIN: Defense

KEYWORDS: CESIUM 137; COST; ECONOMICS; FUEL REPROCESSING PLANTS; ION EXCHANGE; LIQUID WASTES; RADIOACTIVE WASTE FACILITIES; RADIOACTIVE WASTE PROCESSING; RADIOACTIVE WASTES; RADIOISOTOPES; RECOVERY; RESOURCE CONSERVATION; STRONTIUM 90

\section{9}

Jarrett, J.H.; Battelle Pacific Northwest Laboratory, Richland, WA

LWR FUEL RECYCLE PROGRAM QUARTERLY PROGRESS REPORT, APRIL-JUNE 1977. BNWL-2080-5. (1977)

Available from NTIS, PC A04/MF A01. 11 figures, 7 tables

The LWR Fuel Recycle Program is designed to provide information needed by industry to close the back end of the commercial light water reactor (LWR) fuel cycle. Included in this program are activities in support of specific design studies as well as activities with more general application to fuel recycle technology: economic and environmental studies; spent fuel receipt and storage; headend processes; off-gas treatment; purex process (solvent extraction); finishing processes; waste management; environmental effects; and general support

SUBJECT CATEGORY: Spent Fuel; HLW

ORIGIN: Commercial

KEYWORDS: CRITICALITY; ECONOMICS; ENVIRONMENTAL IMPACTS; FUEL CYCLE; HEAD END PROCESSES; LMFBR TYPE REACTORS; OFF-GAS SYSTEMS; PUREX PROCESS; RADIOACTIVE WASTE MANAGEMENT; REPROCESSING; RESEARCH PROGRAMS; SAFEGUARD'S; SPENT FUEL STORAGE; SPENT FUELS; WATER COOLED REACTORS
800

Koehmstedt, P.L., J.N. Hartley, and D.K. Davis; Battelle Pacific Northwest Laboratory, Richland, WA

USE OF ASPHALT EMULSION SEALANTS TO CONTAIN RADON AND RADIUM IN URANIUM TAILINGS. BNWL-2190; 67 pp. (1977)

The results of a study evaluating asphalt emulsions as a sealant to retain radium in $U$ mill tailings led to the following conclusions. A $3.2 \mathrm{~mm}$ Armak E-63 or Armak 13 MR cationic asphalt seal prevented radon diffusion to the environment. Radon diffusion rates through such a seal were calculated to be about $9 \mathrm{X}$ 10 (E-4) pCi/sq cm sec. A $6.4 \mathrm{~mm}$ thick Armak E-63 seal prevented radium, radon, and nitrogen permeation under $3.5 \mathrm{~kg} / \mathrm{sq} \mathrm{cm}$ (50 psi) overpressure for 17 days. The physico-chemical properties. of the tailings surface must be detailed in order to identify asphalt emulsion and or additive requirements for good seals. The moisture content of the tailings surface must be controlled to facilitate the good penetration of emulsion required for good sealing. The integrity of the seal was not affected when asphalt emulsion tailings seal was exposed to 19 freeze/thaw ( 0 to 72 degrees $F$ ) cycles. The seal integrity was not affected by exposure to $100,000 \mathrm{R}$ gamma radiation. UV radiation and $\mathrm{O} 2$ exposure could cause deterioration of the emulsion. A layer of soil would prevent UV deterioration and anaerobic burial would prevent $\mathrm{O} 2$ exposure. Microorganisms can attack asphalt, but degradation is very slow. Airless spray application of asphalt emulsion is less likely to cause bubble formation than is conventional air pressure spray equipment. It appears that such cationic asphalt emulsion applied to $U$ tailings can be cost-effective. Additional studies are suggested before widespread use is made of such emulsions. The areas of study involve primarily the properties of tailings, their interactions with the sealant, technology of emulsion application, and cost estimation.

SUBJECT CATEGORY: Remedial Action, Mill Tailings

ORIGIN: Commercial

KEYWORDS: URANIUM; RADON; RADIUM; ASPHALTS; SEALS; EVALUATION; MILL TAILINGS; GAMMA RADIATION; MICROORGANISMS; OXYGEN; SOILS; ECONOMICS; SAFEGUARDS; COST 
801

Libby, R.A.; Battelle Pacific Northwest Laboratory, Richland, WA

\section{SOURCE EFFICIENCY CALCULATIONS FOR CS-137 IRRADIATORS. BNWL-2064. (1977)}

Available from NTIS, PC A03/MF A01.

The efficiency of radiation sources used for radiation treatment is important in the overall economics of irradiators. The report examines design optimization for a Cs137 radiation source. The initial source design used is currently being fabricated at the Waste Encapsulation and Storage Facility (WESF). Although the current source was intended for long term storage and isolation of the cesium, it has potential for use as an irradiator. Modifications to the source which were examined include: optimum cylinder dia is 1 in.; optimum stainless steel wall thickness is about 0.1 in., thicker walls will reduce source efficiency, while thinner walls increase the likelihood of wall failure; and a cesium-titanate ceramic combines the advantages of good source efficiency with low solubility and low leachability. The cost to modify the present WESF facility does not appear to justify these design changes. However, new facilities could incorporate this design to obtain optimum source efficiency.

SUBJECT CATEGORY: General

ORIGIN: Cummercial

KEYWORDS: CESIUM 137; DESIGN; ECONOMICS; EFFICIENCY; GAMMA SOURCES; OPTIMIZATION; RADIOACTIVE WASTES

\section{2}

Litchfield, J.W., and J.C. King; Battelle Pacific Northwest Laboratory, Richland, WA

PLANNING FOR DECOMMISSIONING AND DECONTAMINATION OF HANFORD NUCLEAR FACILITIES. CONF-771102-26; BNWL SA-6450; Twentieth Annual AICHE Meeting, New York, New York, November 13, 1977, 47 pp. (1977)

Available from NTIS A03/MF A01; (ERA citation 03:055586)

The 570-square mile Hanford Project contains facilities with varying degrees of radioactive contamination as a result of plutonium production operations. With the evolution of production re- quirements and technology, many of these have been retired and will be decommissioned and decontaminated (D and D). Planning for $D$ and $D$ at Hanford requires identification and characterization of contaminated facilities, prioritization of facilities for decommissioning, selection of $D$ and $D$ modes, estimating costs and other characteristics of $D$ and $D$ activities, definition of future scenarios at Hanford, and preparation and assessment of plans to achieve defined scenarios. A multiattributed decision model using four criteria was used to prioritize facilities for decommissioning. A computer-based interactive planning system was developed to facilitate preparation and assessment of $D$ and D plans.

SUBJECT CATEGORY: Remedial Action, Surplus Facilities

ORIGIN: Defense

KEYWORDS: NUCLEAR FACILITIES; COST; DECOMMISSIONING; DECONTAMINATION; HANFORD RESERVATION; PLUTONIUM

803

Litchfield, J.W., and J.C. King; Battelle Pacific Northwest Laboratory, Richland, WA

DECOMMISSIONING AND DECONTAMINATION PLANNING FOR HANFORD NUCLEAR FACILITIES USING MULTIATTRIBUTED DECISION ANALYSIS. BNWLSA-6007. (1977)

Available from NTIS, PC A03/MF A01.

'I'he 570-square mile Hanford Project contains facilities with varying degrees of radioactive contamination as a result of plutonium production operations. With the evolution of production requirements and technology, many of these have been retired and will be decommissioned and decontaminated ( $D$ and $D$ ). Because of the large number of facilities and high cost of decontamination strategies, a multiattributed decision model was used to develop individual facility $D$ and $D$ priorities. Each facility was treated as an alternative and four prioritization criterion were developed. Because this approach required approximately 2400 performance estimates (approx. 600 facilities on each of four criteria), computerized models were developed to determine these performance estimates utilizing a computer-based information system as the data base. The relative importance of each criterion was determined by experts from the 
Energy Research and Development Administration and the major Hanford contractors using a modified Delphi technique. The importance rankings (or weights) were combined with utility functions, also determined by the experts, to give an importance function that responded to the level of each criteria as well as to its overall intrinsic importance. The importance functions and the performance estimates of each facility on each criterion were combined in a prioritization model that determined a priority index for each facility. This index is an integral part of the overall decommissioning and decontamination plan.

SUBJECT CATEGORY: Remedial Action, Surplus Facilities

ORIGIN: Defense

KEYWORDS: COMPUTER CALCULATIONS; DATA ANALYSIS; DATA COMPILATION; DECISION MAKING; DECOMMISSIONING; DECONTAMINATION; DELPHI METHOD; HANFORD RESERVATION; MATHEMATICAL MODELS; NUCLEAR FACILITIES; PLANNING

804

Platt, A.M.; Battelle Pacific Northwest Laboratory, Richland, WA

NUCLEAR WASTE MANAGEMENT AND TRANSPORTATION QUARTERLY PROGRESS REPORT JULY - SEPTEMBER, 1976. BNWL-2179; 53 pp.; NTIS A04/MF A01. (1977)

3 tables, 13 figures; ERA Citation 02:033845; ERDA052000, 050900, 420204

Major areas reported on include: alternative waste management systems, decontamination and densification of chop-leach cladding residues, krypton solidification, decommissioning of retired contaminated facilities at Hanford, transportation safety studies, transportation problems $1976-2000$, a safety and economic study of special trains, and development of high-level solid waste shipping cask models.

SUBJECT CATEGORY: Remedial Action, Surplus Facilities; Transportation; HLW

ORIGIN: Defense

KEYWORDS: RADIOACTIVE WASTE MANAGEMENT; TRANSPORT; KRYPTON; SOLIDI-
FICATION; WASTE TRANSPORTATION; SAFETY; ECONOMICS; CONTAINERS; DECONTAMINATION; FUEL DENSIFICATION

805

Sande, W.E., W.J. Bjorklund, and N.A. Brooks; Battelle Pacific Northwest Laboratory, Richland, WA

COST ANALYSIS FOR APPLICATION OF SOLIDIFIED WASTE FISSION PRODUCT CANISTERS IN U.S. ARMY STEAM PLANTS. BNWL-2266. (1977)

Available from NTIS, PC A08/MF A01.

The main objectives of the present study are to design steam plants using projected waste fission product canister characteristics, to analyze the overall impact and cost/benefit to the nuclear fuel cycle associated with these plants, and to develop plans for this application if the cost analysis so warrants it. The construction and operation of a steam plant fueled with waste fission product canisters would require the involvement and cooperation of various government agencies and private industry; thus the philosophies of these groups were studied. These philosophies are discussed, followed by a forecast of canister supply, canister characteristics, and strategies for Army canister use. Another section describes the safety and licensing of these steam plants since this affects design and capital costs. The discussion of steam plant design includes boiler concepts, boiler heat transfer, canister temperature distributions, steam plant size, and steam plant operation. Also, canister transportation is discussed since this influences operating costs. Details of economics of Army steam plants are provided including steam plant capital costs, operating costs, fuel reprocessor savings due to Army canister storage, and overall economics. Recommendations are made in the final section.

SUBJECT CATEGORY: HLW

ORIGIN: Defense

KEYWORDS: BOILERS; CENTRAL HEATING PLANTS; COST BENEFIT ANALYSIS; ECONOMICS; HEAT SOURCES; MILITARY FACILITIES; RADIOACTIVE WASTES; STEAM; USES; CANISTERS 
806

Schneider, K.J., C.E. Jenkins, and R.E. Rhoads; Battelle Pacific Northwest Laboratory, Richland, WA

TECHNOLOGY, SAFETY, AND COSTS OF DECOMMISSIONING A REFERENCE NUCLEAR FUEL REPROCESSING PLANT. VOLUME 2. NUREG-0278(Vol.2). (1977)

Appendices only

Volume 2 comprises six appendices on: facility description; residual radioactivity inventory estimates; description and contamination levels of reference site; derivation of residual contamination levels; decommissioning mode detail; and decommissioning safety assessment details.

SUBJECT CATEGORY: Remedial Action, Surplus Facilities; Remedial Action, FUSRAP

ORIGIN: Defense; Commercial

KEYWORDS: COST; DECOMMISSIONING; FUEL REPROCESSING PLANTS; RADIATION HAZARDS; RADIOACTIVE WASTES; SAFETY; TECHNOI,OGY ASSESSMENT; INVENTORIES

\section{7}

Schneider, K.J., C.E. Jenkins, R.E. Rhoads, and J. Mishima; Battelle Pacific Northwest Laboratory, Richland, WA

TECHNOLOGY, SAFETY, AND COSTS OF DECOMMISSIONING A REFERENCE NUCLEAR FUEL REPROCESSING PLANT. NU. REG-0278(Vol. 12); 770 pp. (1977)

188 tables, 92 figures

Safety and cost information were developed for the conceptual decommissioning of a fuel reprocessing plant with characteristics similar to the Barnwell Nuclear Fuel Plant. The main process building, spent fuel receiving and storage station, liquid radioactive waste storage tank system, and a conceptual high-level waste solidification facility were postulated to be decommissioned in this study. The plant was conceptually decommissioned to 3 decommissioning states or modes; layaway, protective storage, and dismantlement. These 3 modes range from minimal decommissioning requiring significant continued maintenance and surveillance to complete removal of radioactivity with subsequent release of the site for unrestricted use.
SUBJECT CATEGORY: Remedial Action, Surplus Facilities

ORIGIN: Commercial; Defense

KEYWORDS: TECHNOLOGY ASSESSMENT; REPROCESSING; BARNWELLFUEL PROCESSING PLANT; ECONOMICS; RADIOACTIVE WASTE DISPOSAL; DECOMMISSIONING; COST

\section{8}

Uresk, V.A., L.E. Rogers, and W.H. (Ed.) Rickard; Battelle Pacific Northwest Laboratory, Richland, WA

INTRODUCTION: ECOLOGY OF THE 200 AREA PLATEAU WASTE MANAGEMENT ENVIRONS: A STATUS REPORT. PNI -2253, (pp. 1.1-1.18). (1977)

A general description of ecosystem functioning introduces the need for comprehensive ecological studies as part of the overall waste management operations on the 200 Area plateau. A history of waste management operations and location of 200 Area facilities is provided. An estimate of invento. ries of radioactive materials in the Hanford 200 Area cribs, ponds, and ditches at the end of September 1976 is included.

SUBJECT CATEGORY: LLW; TRU; HLW

ORIGIN: Defense

KEYWORDS: BIRDS; CESIUM 137; COBALT 60; ECOLOGY; ENVIRONMENTAL TRANSPORT; GASEOUS WASTES; GROUND RELEASE; HANFORD RESERVATION; HAPO; INVENTORIES; LIQUID WASTES; PI.ANTS; PLUTTONIUM 239: PONDS; RADIOACTIVE WASTE MANAGE: MENT; RADIOACTIVITY; RUTHENIUM 106; SOLID WASTES; STRONTIUM 90; TERRESTRIAL ECOSYSTEMS; TIME DEPENDENCE; UNDERGROUND DISPOSAL; URANIUM 233; WILD ANIMALS

\section{9}

Zima, G.E.; Battelle Pucific Northwest Laboratory, Richland, WA

ORDER OF MAGNITUDE COST APPRAISAL FOR SELECTED ASPECTS OF CLAD WASTE MANAGEMENT. BNWL-2185; 50 pp. (1977) 
Available from NTIS, PC A04/MF A01.

A simple formula, incorporating the fixed charge rate principle, is applied to a clad waste management exercise involving densification, canning, transportation and salt disposal. For the purpose of comparison with the bulk of published nuclear waste management costs, cost and fixed charge rate data appropriate to roughly the period 1970 to 1973 are used. Within the context of this order of magnitude appraisal, densification displays some cost advantage, reflected principally in the transportation cost. Dependent on the degree of densification, above a certain clad waste generation rate the transportation savings may be expected to exceed reasonable densification costs. There is no explicit consideration of the decontamination step in this appraisal. The limited accessibility of surface effect decontamination to internal transuranic and activation product contamination suggests a quite small influence of decontamination on the transportation and disposal costs. Decontamination may, however, have a significant effect on the ease of establishing a practicable containment envelope of high reliability throughout the clad waste history. A brief comparison is made of clad waste management costs with the major costs of the nuclear power economy. This comparison implies a virtually unlimited technical latitude for clad waste treatment in accommodating the public safety without significant perturbation of nuclear power costs. It is submitted that clad waste management optimization will be under the primal constraint of maximizing thelong term public safety, with economic analysis useful only as a discriminator between waste handling alternatives of sensibly equivalent containment qualities. Some areas of clad waste treatment meriting increased attention are noted.

SUBJECT CATEGORY: Spent Fuel; HLW

ORIGIN: Defense; Commercial

KEYWORDS: COST; RADIOACTIVE WASTE DISPOSAL; RADIOACTIVE WASTE MANAGE: MENT; RADIOACTIVE WASTE PROCESSING; SALT DEPOSITS; WASTE TRANSPORTATION; FUEL DENSIFICATION; CLADDING; COST; CAPITAL

810

Schneider, K.J., C.E. Jenkins, R.E. Rhoads, P.J. Pelto, and R.I. Smith; Battelle Pacific Northwest Laboratory, Richland, WA; Nuclear Regulatory Commission, Washington, DC; Energy Research and Development Administration, Washington, DC
TECHNOLOGY, SAFETY, AND COSTS OF DECOMMISSIONING A REFERENCE NUCLEAR FUEL REPROCESSING PLANT. VOLUME 1. FINAL TECHNICAL REPORT OCT. 74-SEPT. 77. NUREG-0278(Vol.1). (1977)

Available from NTIS. Appendices in Vol. 2.

Safety and cost information were developed for the conceptual decommissioning of a fuel reprocessing plant with characteristics similar to the Barnwell Nuclear Fuel Plant. The main process building, spent fuel receiving and storage station, liquid radioactive waste storage tank system, and a conceptual high-level waste-solidification facility were postulated to be decommissioned. The plant was conceptually decommissioned to three decommissioning states or modes; layaway, protective storage, and dismantlement. Assuming favorable work performance, the elapsed time required to perform the decommissioning work in each mode following plant shutdown was estimated to be 2.4 years for layaway, 2.7 years for protective storage, and 5.2 years for dismantlement. In addition to these times, approximately 2 years of planning and preparation are required before plant shutdown. Costs, in constant 1975 dollars, for decommissioning were estimated to be $\$ 18$ million for layaway, $\$ 19$ million for protective storage and $\$ 58$ million for dismantlement. Maintenance and surveillance costs were estimated to be $\$ 680,000$ per year after layaway and $\$ 140,000$ per year after protective storage. The combination mode of protective storage followed by dismantlement deferred for 10,30 , and 100 years was estimated to cost $\$ 64$ million, $\$ 67$ million and $\$ 77$ million, respectively, in nondiscounted total 1975 dollars. Present values of these costs give reduced costs as dismantlement is deferred. Safety analyses indicate that radiological and nonradiological safety impacts from decommissioning activities should be small. The 50 -year radiation dose commitment to the members of the public from airborne releases from normal decommissioning activities were estimated to be less than 11 man-rem.

SUBJECT CATEGORY: Remedial Action, Surplus Facilities; Remedial Action, FUSRAP

ORIGIN: Defense; Commercial

KEYWORDS: COST; DECOMMISSIONING; FUEL REPROCESSING PLANTS; RADIATION HAZARDS; SAFETY; TECHNOLOGY ASSESSMENT 
811

Bechtel, Inc.

CAPITAL COST ESTIMATE AND CONSTRUCTION IMPACTS, SPENT FUEL INTERIM STORAGE REFERENCE FACILITY 18-54, WATER BASIN STORAGE OF PACKAGED FUEL. Final Report 18-54. (1977)

Nu Alsstract

SUBJECT CATEGORY: Spent Fuel

ORIGIN: Commercial

KEYWORDS: ECONOMICS; SPENT FUEL STORAGE; NUCLEAR FACILITIES; CAPITAL; COST

\section{2}

Bechtel, Inc.

CAPITAL COST ESTIMATE AND CONSTRUCTION IMPACTS, SPENT FUEL INTERIM STORAGE REFERENCE FACILITY 18-53, SPENT FUEL PACKAGING. Final Report 18-53. (1977)

No Abstract

SUBJECT CATEGORY: Spent Fuel

ORIGIN: Commercial

KEYWORDS: ECONOMICS; SPENT FUEL STORAGE; NUCLEAR FACILITIES; PACKAGING; COET

\section{3}

Bechtel, Inc.

CAPITAL COST ESTIMATE AND CONSTRUCTION IMPACTS, SPENT FUEL INTERIM STORAGE REFERENCE FACILITIES 18-52A AND 18-62B, WATER BASIN STORAGE OF UNPACKAGED FUEL. Report 18.52a(Draft). (1977)

No Abstract

SUBJECT CATEGORY: Spent Fuel

ORIGIN: Commercial
KEYWORDS: ECONOMICS; SPENT FUEL STORAGE; NUCLEAR FACILITIES; COST

\section{4}

Boeing Engineering and Construction Co., Seattle, WA

PROJECT CONTROL SUPPORT SERVICES FOR THE NATIONAL WASTE TERMINAL STORAGE PROGRAM. Y/OWI. /SUB-77/16534. (1977)

Available from NTIS, PC A07/MF A01.

The Boeing Engineering and Construction Company has the responsibility to recommend and assist in designing and implementing a project control system for the Office of Waste Isolation. BEC, after analysis of the OWI management structure and techniques utilized, has recommended the implementation of a Program Control System (PCS) for use by OWI. This system embraces the scope of management needs for visibility and control of cost and schedule performance as well as providing a framework for all the various segments of a complete program control system. Because of the schedule constraints placed on OWI by DOE it was not deemed practical to implement all segments of PCS but rather those that are basic to the concept. and can return the greatest short-term benefit. The area of cost and schedule control appears to provide the greatest benefit when combined with the control room techniques for visibility and control. Techni: cal performance is not buvered in this report. The segment of PCS titled Integrated Cost/Schedule (IC/S) was used to identify those functions unique to oost and schedule control.

SUBJECT CATEGORY: Isolation

ORIGIN: Defensc

KEYWORDS: CON'IRUL; CUST; MANAGEMENT; PERFORMANCE; PLANNING; RADIOACTIVE WASTE STORAGE; RESEARCH PROGRAMS

815

Clelland, D.W., and J.S. (Ed.) Forrest; British Nuclear Fuels Ltd., London, England

MANAGEMENT OF RADIOACTIVE WASTES FROM REPROCESSING OPERA- 
TIONS: BREEDER REACTOR. CONF7703103-; Meeting on the Breeder Reactor, Strathclyde, UK, March 25, 1977. (1977)

The paper summarizes the extensive experience gained in the U.K. over 25 years in the reprocessing of spent fuels from thermal nuclear power reactors and from dealing with the radioactive wastes. The amounts and forms of all wastes are given, with present and future management plans outlined. The risks from public exposure to the low levels of radioactivity released to the environment are examined and put into perspective. High-level waste management is dealt with in particular detail and is demonstrated as giving rise to one centimeter cube of glass containing half gram fission products per person supplied with entirely nuclear electricity over a year, the very compact form enabling the highest standards of processing, containment and isolation to be employed. Total release of radioactivity to the environment from the nuclear power cycle are examined and shown controlled to very low levels, constituting only very small additions to the natural background levels. Variation due to different modes of living in different localities are demonstrated as very much more important than exposure from present or future radioactive waste disposal. Finally, risks from nuclear power generation and radioactive waste disposal are interpreted in terms of risks to the public and shown very much less than those occurred in most common everyday activities. If the present U.K. nuclear industry is expanded ten times to supply all present electricity requirements, the risk of death from disposal of nuclear wastes is about five times less than that of being killed by lightning.

SUBJECT CATEGORY: Spent Fuel; HLW

ORIGIN: Foreign

KEYWORDS: ENVIRONMENT; FORECASTING; FUEL CYCLE; FUEL REPROCESSING PLANTS; HIGH-LEVEL RADIOACTIVE WASTES; RADIATION HAZARDS; RADIATION PROTECTION; RADIOACTIVE WASTE MANAGEMENT; RADIOACTIVE WASTES; REPRO: CESSING; THERMAL REACTORS; UNITED KINGDOM

\section{6}

Clelland, D.W., and J. Robtblat (Ed.); British Nuclear Fuels Ltd., London, England; Taylor and Francis, London, England
RADIOACTIVE WASTE MANAGEMENT IN THE UNITED KINGDOM. CHAPTER 5: NUCLEAR REACTORS. TO BREED OR NOT TO BREED. (1977)

A nuclear fuel cycle is described briefly. A speculative UK nuclear programme for the period up to the year 2000 is shown. A summary is given of waste management under the headings; highly-active liquid waste, medium-active liquid waste, low-active liquid waste, highly-active solid waste, low-active solid waste, and gaseous waste.

SUBJECT CATEGORY: HLW; LLW; Airborne

ORIGIN: Foreign

KEYWORDS: FORECASTING; FUEL CYCLE; NUCLEAR POWER; RADIOACTIVE WASTE MANAGEMENT

\section{7}

Botts, T., and J.R. Powell; Brookhaven National Laboratory, Upton, NY

WASTE MANAGEMENT PROCEDURES FOR CTR CENTRAL POWER STATIONS. Transactions of the American Nuclear. Society (26):28-29, American Nuclear Society, Transactions of the 1977 Annual Meeting, New York, NY, June 12, 1977. (1977)

SUBJECT CATEGORY: Fuel Cycle Centers

ORIGIN: Commercial

KEYWORDS: COST; MATERIALS HANDLING; POWER PLANTS; RADIOACTIVE WASTE DISPOSAL; SPENT FUELS; THERMONUCLEAR REACTORS

\section{8}

Goldstein, M.K., R.N. Anderson, T. Gangwer, and R. Malone; Brookhaven National Laboratory, Upton, NY

WASTE MANAGEMENT AND PROLIFERATION: AN ASSESSMENT OF TECHNOLOGIES AND POLICIES RELEVANT TO NUCLEAR POWER. BNL-50694; 129 pp. (1977)

This study examines long-term hazards from radioactive waste management and problems in 
safeguarding plutonium. Several alternative fuel cycle options are presented and assessed. Effects of these options on U.S. and transnational policies are examined. Technical and economic feasibilities of photochemical methods are analyzed. Two photochemical schemes for improving existing reprocessing technology by reducing materials unaccounted for (MUF) are presented. Applicability of this technology is examined relative to waste management alternatives including the partitioning and transmutation option. A computer model to determine the effectiveness of transmutation as a function of separation efficiency has been developed. To estimate health impacts from fuel cycle options, the Brookhaven energy system network simulator has been integrated with an atmospheric dispersion and pathway analysis model.

\section{SUBJECT ĊATEGURY: TRU}

\section{ORIGIN: Defense}

KEYWORDS: SAFEGUARDS; NUCLEAR MATERIALS; PROLIFERATION; FUEL CYCLE; RADIOACTIVE WASTE MANAGEMENT; REPROCESSING; COMPUTER CODES; PLUTO. NIUM

\section{9}

Selvaduray, G.S., M.K. Goldstein, and R.N. Anderson; Brookhaven National Laboratory, Ùpton, $\mathrm{N} \bar{Y}$

\section{METHODOLOGY FOR EVALUATION OF ALTERNATIVE TECHNOLOGIES APPLIED TO NUCLEAR FUEL REPROCESSING. BNL-50700. (1977)}

Available from NTIS, PC A06/MF A01.; 7 tables, 15 figures

An analytic methodology has been developed to compare the performance of various nuclear fuel reprocessing techniques for advanced fuel cycle applications including low proliferation risk systems. The need to identify and to compare those processes, which have the versatility to handle the variety of fuel types expected to be in use in the next century, is becoming increasingly imperative. This methodology allows processes in any stage of development to be compared and to assess the effect of changing external conditions on the process.

SUBJECT CATEGORY: Spent Fuel

ORIGIN: Defense; Commercial
KEYWORDS: COMPARATIVE EVALUATIONS; ECONOMICS; MAINTENANCE; PERFORMANCE; REGULATIONS; RELIABILITY; REPROCESSING; RISK ASSESSMENT; SAFEGUARDS; SAFETY; SEPARATION PROCESSES; NUCLEAR FUELS

\section{0}

Hagen, M.; Bundesministerium fuer Forschung und Technologie, Bonn, Germany, F.R.

WHY REPROCESS. Atomwirtsch. Atomtech. 22(11):566-570; Reactor Congress 1977, Mannheim, Germany, F.K., March 29-April 1, 1877. (1977)

\section{In German}

The problem of whether to reprocess spent nuclear fuel elements has been studied already in the early days of the commercial utilization of nuclear power and has been answered positively. This also, and in particular, applies to the United States. Under the new American nuclear policy reprocessing is rejected only for reasons of non-proliferation. Although these are valid reasons, the effectiveness of a ban on reprocessing, as far as the nonprofileration of nuclear weapons is concerned, is not accepted worldwide because the necessary knowledge either already exists in many countries or can be obtained. Only if there had been a realistic chance to prevent the proliferation of nuclear weapons, also the other industrialized countries would have seconded the policy of the United States. A country like the Federal Republic of Germany, with a substantlal long-term nuclear power program based initially on light water reactors, subsequently on advanced reactor systems, cannot do without a complete nuclear fuel cycle. This reasnning is outlines in the light of economic and radioecological aspects. Extensive experience on a technical scale is available in the reprocessing sector. The technical problems associated with this activity have been solved in principle and have largely been demonstrated to function in practice.

SUBJECT CATEGOKY: Spent Fuel

ORIGIN: Foreign

KEYWORDS: ECONOMICS; ENERGY POLICY; FUEL CYCLE; NON.PROLIFERATION TREATY; NUCLEAR ENGINEERING; PLANNING; PLUTONIUM RECYCLE; RADIOACTIVE WASTES; REPROCESSING; SPENT FUELS 
821

Mueller, P.G.; Canadian Institute of International Affairs, Toronto, Ontario, Canada

THINGS NUCLEAR: THE CANADIAN DEBATE. Canadian Institute of International Affairs Report. (1977)

An unbiased overview is given of the nuclear industry in Canada, with emphasis on its history, fundamentals of nuclear power plants and the CANDU reactor system, the need and ideal mix of future energy sources, economics of nuclear power, uranium supplies, radioactive releases, thermal pollution, physical security, and safety of nuclear power plants, and export of CANDU technology vs. nuclear proliferation.

SUBJECT CATEGORY: General

ORIGIN: Foreign

KEYWORDS: CANADA; CANDU TYPE REACTORS; COST; ECONOMICS; ENERGY CONSUMPTION; ENERGY POLICY; NUCLEAR INDUSTRY; NUCLEAR POWER; PUBLIC RELATIONS; RADIOACTIVE EFFLUENTS; RA. DIOACTIVE WASTE DISPOSAL; SAFETY; SECURITY; THERMAL POLLUTION

\section{2}

Lo Moro, A., and G. Panciatici; Centro Applicazioni Militari Energia Nucleare, S. Piero A Grado, Italy

ESTIMATION OF THE CONDITIONING AND STORAGE COSTS OF LOW- AND INTERMEDIATE-LEVEL SOLID RADIOACTIVE WASTES. Energ. Nucl.24(8):443-447. (1977)

In Italian

The conditioning and storage costs of low- and intermediate-level solid radioactive wastes are analyzed. The cost of direct labor is assumed as the reference cost for their computation and the storage cost is considered as resulting from the contract cost "una tantum" and from the leasing cost. As an example, the cost trends are reported, relevant to the solution adopted at CAMEN (conditioning in concrete containers and storage on concrete open. air bed).

SUBJECT CATEGORY: LLW; HLW

ORIGIN: Foreign
KEYWORDS: COST; ECONOMICS; INTERMEDIATE-LEVEL RADIOACTIVE WASTES; LOWLEVEL RADIOACTIVE WASTES; RADIOACTIVE WASTE DISPOSAL; RADIOACTIVE WASTE STORAGE; SOLID WASTES

823

Couture, J., C. Buck, and W. Issel; COGEMA/Retraitment Service Commercial, Chatillon, France

PRESENT STATUS OF REPROCESSING TECHNOLOGY: BASIC OUTLINES OF LARGE REPROCESSING PLANTS. Transactions of the American Nuclear Society, Suppl. 25(1):122-123; Transfer of Nuclear Technology, Proceedings of a Conference, Persepolis/Shiraz, Iran, April 10, 1977. (1977)

No Abstract

SUBJECT CATEGORY: HLW

ORIGIN: Foreign

KEYWORDS: ACCOUNTING; CONSTRUCTION; COST; EUROPE; FUEL REPROCESSING PLANTS; NUCLEAR MATERIALS MANAGEMENT; OPERATION; RADIOACTIVE WASTE DISPOSAL; RELIABILITY; SAFETY

824

Schmidt, E.; Commission of the European Communities, Joint Research Centre, Ispra, Italy

PREDICTION FOR THE HIGH-LEVEL ALPHA-ACTIVE WASTE TO BE GENERATED BY NUCLEAR POWER STATIONS IN THE MEMBER STATES OF THE EUROPEAN COMMUNITIES. EUR-5690. (1977)

Available from NTIS (US Sales Only), PC A02/MF A01.

Starting with a forecast for the nuclear power generating capacity to be installed in the Member States of the European Communities before the end of this century, a prediction is made of the annual production of high-level alpha-active waste from reprocessing plants and the corresponding accumulation up to the year 2000 . The isotopic composition of the alpha-active waste from individual reactor types was calculated and an estimation of the 
influence of recycling plutonium through light water reactors on the produced quantity of higher actinides is made.

\section{SUBJECT CATEGORY: TRU; HLW}

ORIGIN: Foreign

KEYWORDS: ACTINIDES; EUROPE; FORECASTING; HIGH-LEVEL RADIOACTIVE WASTES; NUCLEAR POWER PLANTS; PLUTONIUM RECYCLE; WASTE MANAGEMENT

\section{5}

Comptroller General of the United States, Washington, DC

ISSUES RELATED TO THE CLOSING OF THE NUCLEAR FUEL SERVICES, INCORPORATED, REPROCESSING PLANT AT WEST VALLEY, NEW YORK. EMD-77-27; Report to the Conservation, Energy, and National Resources Subcommittee, House Committee on Government Operations; 34 pp. (1977)

When the Nuclear Fuel Services Reprocessing Plant at West Valley, NY was shut down for enlargement and reduction of radiation exposure by the employees a number of questions was raised about the operation of such a plant. The site consists of 4 highlevel storage tanks containing 612,000 gallons of waste, a high-level burial ground containing about $100,000 \mathrm{cu} \mathrm{ft}$ and a low-level burial ground containing about 2 million cu $\mathrm{ft}$ of solid rad wastes. The tank integrity is in doubt, and before the wastes can be extracted and solidified the tank condition must be verified. There is also a question as to whether or not the tanks could withstand an earthquake. Since there has been a floatation problem below the tanks and vault system, the soil characteristics should be determined in case of a tank rupture. A priority item is the characterization of the physical and chemical properties of the high-level waste sludge for satisfactory extraction. No solidification process has been developed for managing the wastes. The government will have to provide technical assistance to NFS and New York for studying and correcting many of the site problems. Also the government will have to establish guidelines and plans for 1) handling the spent fuel stored and buried and decommissioning the re-processing plant and 2) long term care requirements for the high- and low-level waste burial sites. A policy of assistance to New York State should be developed with the Federal government.
SUBJECT CATEGORY: Remedial Action, FUSRAP

ORIGIN: Commercial

KEYWORDS: CONTAINERS; CONTAMINATION; COST BENEFIT ANALYSIS; DECOMMISSIONING; FUEL ELEMENTS; HAZARDS; LEGISLATION; RADIOACTIVE WASTE MANAGEMENT; HIGH-LEVEL RADIOACTIVE WASTES; LIQUID WASTES; LOW-LEVEL RADIOACTIVE WASTES; INVENTORIES; SOLID WASTES; SPENT FUEL STORAGE

\section{6}

Sinhuber, D., H.H. Stiehl, and W. Schroth; DelbagLuftfilter G.m.b.H., Berlin, F.R. Germany

NEW LOOK AT THE ECONOMIC DISPOSAL OF CONTAMINATED AEROSOL FILTERS. CONF-761145; Proceedings of a Seminar, High Efficiency Aerosol Filtration in the Nuclear Industry, Aix-en-Provence, France, November 23, 1976. (1977)

\section{In German}

HEPA filter elements loaded with radioactive aerosols represent a large percentage of the radioactive waste of nuclear plants. The HEPA filter elements used at present in air filter units are not suitable to an economic disposal and space-saving final storage on account of their construction. New concepts for HEPA filters are necessary from the point of view of waste disposal. The criteria of these new designs are as follows: reduction of space required for HEPA filters used at the same or even increased flow rates and with the same efficiency; essentially smaller dimensinns of HF,PA filters for storage in waste containers; removal without contamination, volume reduction (without contamination) for disposal of the HEPA filters; smallest possible volume of the HEPA filters after processing for final storage. The construction of HEPA filters as a result of the requirements mentioned above and taking into consideration the present stage of technology is explained. The advantages of such construction with regard to the criteria mentioned before are presented in comparison with the HEPA filters at present in use.

\section{SUBJECT CATEGORY: Airborne; LLW}

ORIGIN: Foreign 
KEYWORDS: AIR FILTERS; COST; DESIGN; DIMENSIONS; RADIOACTIVE AEROSOLS; RADIOACTIVE WASTE DISPOSAL; RADIOACTIVE WASTE PROCESSING; SOLID WASTES; SPECIFICATIONS

827

Cohen, B.L.; Department of Physics, University of Pittsburgh, Pittsburgh, PA

HIGH-LEVEL RADIOACTIVE WASTE FROM LIGHT-WATER REACTORS. Rev. Mod. Phys. 49(1):1-20. (1977)

The production of radioactive nuclei during the operation of a light-water reactor is traced, and their decay history is followed. The potential environmental impacts of this waste are calculated and shown to be comparable to those of other materials we produce. Assuming deep burial, it is shown that there are important time delays which prevent the waste from reaching the biosphere in the first few hundred years while its toxicity is decreasing by several orders of magnitude. In the long term,,the most important pathway to man was found to be through ground water into food and water supplies, with consequences calculated $t$ to be 0.4 fatalities in $10(E+6)$ years from each year of all-nuclear power in U.S. Other pathways considered and found to be less important include meteorites, volcanism, release through ground water to airborne particulate, and human intrusion by drilling and mining for unspecified materials and for salt. For time scales longer than $10(\mathrm{E}+6)$ years, nuclear power is shown to reduce man's exposure to radiation by consuming uranium. A cost-benefit analysis is developed for surveillance of buried waste. It is shown that buried high-level waste is environmentally much less dangerous than uranium mill tailings.

SUBJECT CATEGORY: HLW

ORIGIN: Commercial

KEYWORDS: COST BENEFIT ANALYSIS; DECAY; ENVIRONMENTAL EFFECTS; FISSION PRODUCTS; RADIATION HAZARDS; RADIOACTIVE WASTE DISPOSAL; RADIOACTIVE WASTE STORAGE; RADIOACTIVE WASTES; RELEASE LIMITS; WATER COOLED REACTORS

\section{8}

Energy Research and Development Administration, Savannah River Operations Office, Aiken, SC
LWR SPENT FUEL DISPOSITION CAPABILITIES, 1977-1986. 1977 EDITION. ERDA-77-25; 18 pp. (1977)

Available from NTIS, PC A02/MF A01.

This report presents a compilation of data depicting the national light water reactor spent fuel disposition situation through 1986 based on utility and spent fuel storage industry forecasts and plans as of April 1, 1977. Also provided is a comparison of 1977 projections with similar projections as of January 1 , 1976.

SUBJECT CATEGORY: Spent Fuel

ORIGIN: Commercial; Defense

KEYWORDS: DATA COMPILATION; FORECASTING; FUEL POOLS; NUCLEAR POWER PLANTS; SPENT FUEL STORAGE; US ERDA; USA; WATER COOLED REACTORS

\section{9}

Energy Research and Development Administration, Washington, $\mathrm{DC}$

MANAGEMENT OF INTERMEDIATELEVEL RADIOACTIVE WASTE, OAK RIDGE NATIONAL LABORATORY, OAK RIDGE, TENNESSEE. DRAFT ENVIRONMENTAL IMPACT STATEMENT. ERDA-1553(Draft). (1977)

Available from Office of NEPA Coordination, Washington, DC.

This environmental impact statement was prepared in accordance with the National Environmental Policy Act of 1969 to support an administrative action by the Energy Research and Development Administration to select a preferred tèchnique for the management of intermediate-level radioactive liquid waste at the Oak Ridge National Laboratory (ORNL), Oak Ridge, Tennessee, and cover construction of a facility to implement this technique. Reasonable alternative techniques are analyzed. The facility requirements necessary to implement the technique are analyzed and the potential environmental impacts of the available alternatives are assessed. The primary benefit anticipated from a new process facility is the permanent removal of large volumes of mobile radioactive wastes from existing near-surface storage facilities and the fixation of these wastes in a solid form that would pose little risk of environmental contamination. Both currently stored wastes and wastes that 
are generated in future routine operations would be processed by this facility.

\section{SUBJECT CATEGORY: HLW}

\section{ORIGIN: Defense}

KEYWORDS: CLIMATES; COST BENEFIT ANALYSIS; ECOLOGY; ENVIRONMENTAL EFFECTS; ENVIRONMENTAL IMPACT STATEMENTS; FRACTIONATION; GEOLOGY; GLASS; HYDROLOGY; LIMESTONE; LIQUID WASTES; ORNL; RADIATION MONITORING; RADIOACTIVE WASTE FACILITIES; RADIOACTIVE WASTE MANAGEMENT; RADIOACTIVE WASTE PROCESSING; RADIOACTIVE WASTES; RADIOACTIVITY; SEISMOLOGY; SHALES; SITE SELECTION; SLUDGES; SOILS; SOLIDIFICATION; UNDERGROUND DISPOSAL; ORNL

\section{0}

Energy Research and Development Administration, Washington, DC

PORTSMOUTH GASEOUS DIFFUSION PLANT SITE, PIKE COUNTY, PIKETON, OHIO. DRAFT ENVIRONMENTAL IMPACT STATEMENT. VOLUME 1. ERDA-1555D(Vol.1)(Draft). (1977)

A detailed analysis of the environmental effects associated with continued operation of the Portsmouth Gaseous Diffusion Plant is given. The Portsmouth facility, which has been operating for over twenty years, is located in Pike County, Ohio, on a 4000 -acre federally-owned reservation. The uranium enrichment capacity of the plant is currently being increased through a cascade improvement program (CIP) and a cascade uprating program (CUP). The environmental statement evaluates the Portsmouth facility at the fully uprated CUP production level. Environmental impacts of the production of offaite electric power for the Portsmouth facility are also assessed. The document describes the foreseeable environmental, social, economic, and technological cost and benefits of expanding the Portsmouth enrichment plant beyond the CIP/CUP level.

SUBJECT CATEGORY: General

ORIGIN: Commercial

KEYWORDS: ACCIDENTS; AIR POLLUTION; BIOLOGICAL EFFECTS; CHEMICAL EFFLU-
ENTS; COST BENEFIT ANALYSIS; ECOLOGY; ECONOMICS; ENRICHED URANIUM; ENVIRONMENTAL EFFECTS; ENVIRONMENTAL IMPACT STATEMENTS; FLUORIDES; FOSSIL FUEL POWER PLANTS; GASEOUS WASTES; GEOLOGY; GOVERNMENT POLICIES; HEALTH HAZARDS; HYDROLOGY; LAND USE; METEOROLOGY; NITROGEN OXIDES; NOISE POLLUTION; PORTSMOUTH GASEOUS DIFFUSION PLANT; POWER DEMAND; RADIOACTIVE EFFLUENTS; RADIOACTIVE WASTE MANAGEMENT; RECOMMENDATIONS; SAFEGUARDS; SOCIO-ECONOMIC FACTORS; SUL FUR DIOXIDE; THERMAL EFFLUENTS; URANIUM ISOTOPES; WASTE MANAGEMENT; WATER; WATER POLLUTION

\section{1}

Energy Research and Development Administration, Washington, DC

REPORT TO THE LMFBR STEERING COMMITTEE ON RESOURCES, FUEL AND FUEL CYCLES, AND PROLIFERATION ASPECTS. ERDA-77-60. (1977)

Available from NTIS, PC A03/MF A01.

This report attempts to bound the range of approaches to resolving the issues associated with the nuclear fuel cycle by presenting opposing views in a common format. It discusses alternatives within the nuclear fuel cycle and does not discuss nonnuclear electrical generation concepts. It is designed to identify key determinants and issues with regard to timing, economirs, sefegiards, and resnurce utilization and to provide an assessment of FBR alternatives.

SUBJECT CATEGORY: TRU; Spent Fuel

ORIGIN: Commercial; Defense

KEYWORDS: FORECASTING; FUEI. CYCLE; HAZARDS; LMFBR TYPE REACTORS; NU. CLEAR FUELS; NUCLEAR MATERIALS DIVERSION; NUCLEAR POWER; PLUTONIUM; PROLIFERATION; SPENT FUEL STORAGE; THORIUM; URANIUM RESERVES

832

Energy Research and Development Administration, Washington, DC 
WASTE MANAGEMENT OPERATIONS, IDAHO NATIONAL ENGINEERING LABORATORY, IDAHO. FINAL ENVIRONMENTAL IMPACT STATEMENT. ERDA-1536. (1977)

Available from NTIS, PC A99/MF A01.

Chapters are provided on background; anticipated benefits; characterization of the INEL environment; environmental impact of operations; unavoidable adverse environmental effects; relationship between short-term uses and long-term productivity; relationship of waste management to land use, policies, and controls; irreversible and irretrievable commitments of resources; alternatives; and cost-benefit analysis. The five appendices are: References; Glossary of terms and abbreviations; Listing and disposition of past INEL releases; Calculational methods; and Summary of INEL waste statistics and improvements for 1975 and 1976 with projections of future wastes and projects.

SUBJECT CATEGORY: HLW; General

ORIGIN: Defense

KEYWORDS: COST BENEFIT ANALYSIS; EN. VIRONMENTAL EFFECTS; ENVIRONMENTAL IMPACT STATEMENTS; GASEOUS WASTES; IDAHO NATIONAL ENGINEERING LABORATORY; LIQUID WASTES; RADIATION MONITORING; RADIOACTIVE EFFLUENTS; RADIOACTIVE WASTE DISPOSAL; RADIOACTIVE WASTE MANAGEMENT; RADIOACTIVE WASTE PROCESSING; RADIOACTIVE WASTE STORAGE; SAFETY; SOLID WASTES; SOLIDIFICATION

\section{3}

Energy Research and Development Administration, Washington, DC

MANAGEMENT OF INTERMEDIATELEVEL RADIOACTIVE WASTE, OAK RIDGE NATIONAL LABORATORY, OAK RIDGE, TENNESSEE. FINAL ENVIRONMENTAL IMPACT STATEMENT. ERDA-1553. (1977)

Available from NTIS, PC A14/MF A01.

Chapters are devoted to the following topics: background and description; environmental impact of the proposed action; unavoidable adverse environmental effects; alternatives; relationship between short-term uses and long term productivity; state, local, or regional conflicts; irreversible and irretrievable commitments of resources; and cost benefit analysis. Four Appendices are provided: Glossary of terms; Characterization of existing environment; Calculations; Environmental monitoring of existing environment.

\section{SUBJECT CATEGORY: HLW}

ORIGIN: Defense

KEYWORDS: CEMENTS; COST BENEFIT ANALYSIS; ENVIRONMENTAL EFFECTS; ENVIRONMENTAL IMPACT STATEMENTS; GEOLOGIC DEPOSITS; GLASS; ORNL; RADIOACTIVE WASTE DISPOSAL; RADIOACTIVE WASTE MANAGEMENT; RADIOACTIVE WASTE STORAGE; RADIONUCLIDE MIGRATION; SAFETY; TANKS; UNDERGROUND DISPOSAL; UNDERGROUND STORAGE

834

Energy Research and Development Administration, Washington, DC

ALTERNATIVES FOR LONG-TERM MANAGEMENT OF DEFENSE HIGH-LEVEL RADIOACTIVE WASTE, HANFORD RESERVATIONS, RICHLAND, WASHINGTON. ERDA-77-44; 300 pp. (1977)

Available from NTIS, PC A14/MF A01.

The objective of this document is to provide information or alternatives that are being considered for the long-term management of defense highlevel radioactive waste stored at Hanford in underground tanks and in stainless steel-lined concrete basins. For purposes of basic programmatic decision making, four major alternatives based on disposal location are considered. The steps leading to placement of the waste in the following locations are illustrated: existing waste tanks; onsite engineered surface facilities; onsite geologic repository; and offsite geologic repository. The four major disposal alternatives are expanded into 27 alternative plans by considering: (1) variations in the final form of the high-level fraction (with radionuclide removal) to include glass, concrete, and powder; (2) variations in the final form of the dehydrated waste product to include glass, calcined clay, and powder; and (3) variations in the treatment and handling of encapsulated waste to include packaging of capsules in canisters and conversion of the strontium fluoride and cesium chloride to 
glass; canisters stored in sealed casks on the surface are disposed of in a surface vault after the radionuclides have decayed sufficiently to avoid a heattransfer problem. A description of the technology, a preliminary risk assessment, and preliminary cost estimates for each of these 27 plans are presented. The technology required to implement any of the 27 alternative plans has not been developed to the point where any plan can be considered completely technically sound annd feảsible.

\section{SUBJECT CATEGORY: HLW}

ORIGIN: Defense

KEYWORDS: CONCRETES; COST; GLASS; HANFORD RESERVATION; POWDERS; RADIOACTIVE WASTE DISPOSAL; RADIOACTIVE WASTE MANAGEMENT; RADIOACTIVE WASTE STORAGE; RISK ASSESSMENT; SOLID WAS'I'E'S; 'I'ANKS'

\section{5}

Energy Research and Development Administration, Washington, DC

ALTERNATIVES FOR LONG-TERM MANAGEMENT OF DEFENSE HIGH-LEVEL RADIOACTIVE WASTE: IDAHO CHEMICAL PROCESSING PLANT, IDAHO FALLS, IDAHO. ERDA-77-43; 172 pp. (1977)

Available from NTIS, PC A09/MF A01.

This document presents alternatives for the longterm treatment and disposition of high-level radioactive defense wastes presently stored as solids in bins at the Idaho Chemical Process Plant (ICPP) area of the Idaho National Engineering Laboratory. 'These defense wastes were generated by defense and test programs as opposed to wastes from commercial nuclear power programs. Presently, all high-level waste produced at the ICPP is converted to a granular solid (calcine) by a calcination process. The calcine is stored in stainless steel bins which in turn are contained in underground, reinforced-concrete vaults. This storage mode has been demonstrated to be safe. Consistent with ERDA policy, alternatives for long-term management of high-level wastes are being evaluated. These methods, using the existing calcine as starting material, are described in the parent document. The document first describes the existing waste management facilities and processes in use at the ICPP (Section 2). The alternatives for disposition and processing are discussed in Section 3 . The technology pertaining to the various alternatives being considered for the ICPP waste is described in Section 4. In Section 5; the risks associated with the various alternatives are evaluated. Costs are presented in Section 6 , and the costs and risks are evaluated in Section 7.

\section{SUBJECT CATEGORY: HLW}

ORIGIIV: Defense

KEYWORDS: CALCINATION; COST; HIGHLEVEL RADIOACTIVE WASTES; IDAHO CHEMICAL PROCESSING PLANT; MILITARY FACILITIES; RADIOACTIVE WASTE MANAGEMENT; RADIOACTIVE WASTE PROCESSING; RADIOACTIVE WASTE STORAGE; RISK ASSESSMENT; SOLIDIFICATION; TECHNOL OGY ASSESSMENT; SOLID WASTES

\section{6}

Encrgy Research and Development Administration, Washington, DC

SUMMARY ALTERNATIVES FOR LONGTERM MANAGEMENT OF DEFENSE HIGHLEVEL RADIOACTIVE WASTE, SAVANNAH RIVER PLANT. ERDA-77-42/2(Vol.2); 26 pp. (1977)

Implementation costs and risk costs are calculated in the text for 23 alternative plans for long-range management and isolation of the SRP high-level radioactive waste. For purposes of basic programmatic decision making, these 23 plans can be grouped into four main classes. (1) Convert the waste to a highly leach-resistant form, such as canned glass cylinders, and ship it offsite to a federal repository. (2) Convert the waste to a highly leach-resistant form, and store the waste in an engineered surface facility at SRP. (3) Reconstitute the waste to a slurry, and dispose of it in a bedrock cavern under the SRP site. (4) Continue storage in tanks with the waste as salt cake and sludge. Most of the alternative plans are in turn divided into four main functional modules: (1) Removal form tanks. (2) Processing. (3) Transportation. (4) Storage.

\section{SUBJECT CATEGORY: HLW}

\section{ORIGIN: Defense}

KEYWORDS: COST BENEFIT ANALYSIS; RADIOACTIVE WASTE MANAGEMENT; RADIOACTIVE WASTE STORAGE; SAVANNAH RIVER PLANT; RADIOACTIVE EFFLUENTS; 
WIND; EARTHQUAKES; SABOTAGE; AIRCRAFT

\section{7}

Environmental Protection Agency, Office of Radiation Programs, Washington, DC

PROCEEDINGS: A WORKSHOP ON ISSUE PERTINENT TO THE DEVELOPMENT OF ENVIRONMENTAL PROTECTION CRITERIA FOR RADIOACTIVE WASTES. CONF770218; ORP/CSD-7-1; Environmental Criteria Development for Radioactive Waste Management, Proceedings of an EPA Workshop, Reston, VA, February 3, 1977. (1977)

Available from Environmental Protection Agency, Office of Radiation Programs, Washington, DC.

The results are presented from three working groups on approaches to radioactive waste management criteria development, risk considerations of radioactive waste management, and long-term implications of radioactive waste management.

SUBJECT CATEGORY: General

ORIGIN: Defense; Commercial

KEYWORDS: ECONOMICS; ENVIRONMENTAL EFFECTS; MEETINGS; RADIATION HAZARDS; RADIOACTIVE WASTE DISPOSAL; RADIOACTIVE WASTE MANAGEMENT; RISK ASSESSMENT

838

Exxon Nuclear Co., Richland, WA

RESPONSE TO QUESTION PP-38-65: 7.5.2.4.A - ESTIMATED MISCELLANEOUS COMBUSTIBLE WASTES. DOCKET-50564; Amendment 2 to Nuclear Fuel Recovery Recycling Center License Application, Fuel Reprocessing Plant, (pp. 20.21). (1977)

The basis for the total annual volume of miscellaneous combustible wastes generated by operation of the NFRRC, as presented in section 7.5.2.4.A, is shown. The estimated quantities of waste generated in each category were obtained from a combination of sources. Fxtensive use was made of waste volume estimations and projections from operating commercial and government reprocessing plant in the
United States and europe. In addition, information was obtained from ERDA and ERDA contractor (ORNL, HEDL, etc) reports on estimated waste generation rates from current and future reprocessing plants.

SUBJECT CATEGORY: LLW

ORIGIN: Commercial

KEYWORDS: FUEL CYCLE; REPROCESSING; REPORTS; COMBUSTION; MATERIALS; FORECASTING; FUEL REPROCESSING PLANTS; INVENTORIES; VOLUME

\section{9}

Exxon Nuclear Co., Richland, WA

RESPONSE TO QUESTION PP-38-67: 7.5.2.2 TABLES 7.1-7 THROUGH 7.1-9 - ANNUAL SPENT FILTER VOLUMES. DOCKET-50564; Amendment 2 to Nuclear Fuel Recovery Recycling Center License Application, Fuel Reprocessing Plant, 21 pp. (1977)

The volume of spent filters (5200 cubic $\mathrm{ft} / \mathrm{yr}$ ) presented in section 7.5.2.2 is consistent with the values presented in tables 7.1-7, 7.1-8, and 7.1-9. The volume of spent filters generated per year from operation of the NFRRC is shown, based on rounded-off values from the indicated tables: Table 7.1-7 - filters (uncompacted) - 2,100 cubic ft/ $\mathrm{yr}$; table 7.1-8 - filters (uncompacted) - 2,500 cubic ft/yr; table 7.1-9 - filters (uncompacted) - $600 \mathrm{cubic} \mathrm{ft} / \mathrm{yr}$; total $5,200 \mathrm{cubic} \mathrm{ft} / \mathrm{yr}$.

SUBJECT CATEGORY: LLW

ORIGIN: Commercial

KEYWORDS: FUEL CYCLE; REPROCESSING; REPORTS; FORECASTING; FILTERS; MATERIALS; FUEL REPROCESSING PLANTS; VOLUME

840

Ford, Bacon and Davis Utah, Inc., Salt Lake Lity, UT

PHASE II - TITLE I, ENGINEERING ASSESSMENT OF INACTIVE URANIUM MILL TAILINGS, RIVERTON SITE, RIVERTON, WYOMING. GJT-19; 116 pp. (1977) 
An engineering assessment was performed of the problems resulting from the existence of radioactive uranium mill tailings at the Riverton, Wyoming site. Services include: the performance of core drillings; soil, water and other sample analyses; radiometric measurements to determine areas with radium-contaminated materials; the evaluation of resulting radiation exposure of individuals and nearby populations; the investigation of site geology, hydrology, and meteorology; and the evaluation and costing of alternative corrective actions. Radon gas release from the 900,000 tons of tailings at the Riverton site constitutes the main environmental impact. The two alternative actions presented are fencing and maintenance of the site and offsite remedial action, and decontamination of the millsite and ore storage areas and additional stabilization cover to a minimum of $2 \mathrm{ft}$. The cost estimates for the options are $\$ 460,000$ and $\$ 1,140,000$, respectively. Estimated costs for moving the tailings and all contaminated materials to unspecified sites 5 and $10 \mathrm{mi}$ from the present location are $\$ 6,000,000$ and $\$ 6,400,000$, respectively. Reprocessing the tailings for uranium is not economically attractive at present.

SUBJECT CATEGORY: Remedial Action, Mill Tailings

ORIGIN: Defense; Commercial

KEYWORDS: URANIUM; MILL TAILINGS; HAZARDS; HYDROLOGY; METEOROLOGY;GEOL OGY; COST BENEFIT ANALYSIS; DECONTAMINATION; RADON; MAPS; ENVIRONMENTAL IMPACTS; GASEOUS WASTES; COST

\section{1}

Ford, Bacon and Davis Utah, Inc., Salt Lake City, ITT

MILL TAILINGS STABILIZATION. GJT-5; Engineering Assesment of Inactive Mill Tailings, Tuba City Site, Tuba City, Arizuna, (pp. 6-1-68). (1977)

Information pertinent to shallow land burial of uranium mill tailings is presented. CORPAUTH address is 357 Chipeta Way, Salt Lake City, UT 84108

All present methods, technology, and research data on stabilization that are available were reviewed to determine the best approach for the Tuba City mill tailings. In addition, experiments are being conducted to determine the relative effectiveness of various stabilization techniques. Ideally, complete stabilization of radioactive tailings should permanently eliminate the possibilities of wind and water erosion, leaching of radioactive materials and other chemicals, radon exhalation from the tailings, and gamma radiation emitted from the tailings. Wind and water erosion can be prevented by chemical stabilization of the surface, complete chemical stabilization, physical stabilization, and vegetative stabilization. In some arid regions, where the potential for successful stabilization is slight, physical stabilization may be the preferred alternative. Since aquifers are not threatened at the Tuba City site, prevention of leaching is not essential: From simplified diffusion theory estimates, about $13 \mathrm{ft}$ of dry soil are needed to reduce Rn flux by $95 \%$, but only a few feet of soil are needed if a high moisture content in the cover material is maintained. The effects of applying various chemical stabilizers and varying thicknesses of stabilizing earth covers and combinations of material are being investigated. A few feet of cover material are sufficient to reduce gamma radiation to acceptable levels. In conclusion, available data indicatc that none of the methods used thus far to stabilize uranium tailings sites has been a totally satisfactory solution. Some of the methods examined have exhibited short-term advantages, but no economical longterm solutions have become apparent. (Auth)

SUBJECT CATEGORY: Remedial Action, Mill Tailings

ORIGIN: Commercial

KEYWORDS: MILL TAILINGS; RADIOACTIVE WAS'I'E DISPOSAL; RADIOAĆTIVE WASTE MANAGEMENT; COST BENEFIT ANALYSIS; PLANTS; LEACHIING: EROSION: RADON

842

Ford, Bacon and Davis Utah, Inc., Salt Lake City, ŪT

GENERIC ENVIRONMENTAL ASSESSMENT FOR IMPLEMENTING A RADIOACTIVE WASTE CLASSIFICATION SYSTEM. UCRL-13771. (1977)

Available from NTIS, PC A02/MF A01.

Potential impact on the environent, compliance with applicable water and air quality standards, cost-benefits due to the interface, unavoidable 
adverse effects, alternatives to the proposed action, and irreversible commitments of resources are discussed.

SUBJECT CATEGORY: General

ORIGIN: Commercial

KEYWORDS: CLASSIFICATION; COST BENEFIT ANALYSIS; ENVIRONMENTAL IMPACTS; RADIOACTIVE WASTE DISPOSAL; RADIOACTIVE WASTES

\section{3}

Ford, Bacon and Davis Utah, Inc., Salt Lake City, UT

PHASE II, TITLE I ENGINEERING ASSESSMENT OF INACTIVE URANIUM MILL TAILINGS, MONUMENT VALLEY SITE, MONUMENT VALLEY, ARIZONA. GJT-4. (1977)

Environmental effects, health hazards, and options for stabilization of tailings or fencing of site; Available from NTIS, PC A08/MF A01.

An engineering assessment was made of the problems resulting from the existence of radioactive uranium mill tailings at the Monument Valley millsite in Arizona. The Phase II, Title I services include the preparation of topographic maps, the performance of core drillings and radiometric measurements sufficient to determine areas and volumes of tailings and other radium-contaminated materials, the evaluation of resulting radiation exposures of individuals residing nearby, the investigation of site hydrology and meteorology and the evaluation and costing of alternative corrective actions. Radon gas release from the tailings on the site constitutes the most significant environmental impact, although windblown tailings and external gamma radiation are also factors. The sparse population and relatively low radiation levels yield minimal immediate environmental impact; hence, the two alternative actions presented are directed towards restricting access to the site and returning the windblown tailings to the pile and stabilizing the pile. Both options include remedial action costs for offsite locations where tailings have been placed. Cost estimates for the two options are $\$ 585,000$ and $\$ 1,165,000$.

SUBJECT CATEGORY: Remedial Action, Mill Tailings

ORIGIN; Commercial
KEYWORDS: ARIZONA; COMPARATIVE EVALUATIONS; COST; DAUGHTER PRODUCTS; ENVIRONMENT; ENVIRONMENTAL EFFECTS; ENVIRONMENTAL TRANSPORT; HEALTH HAZARDS; HUMAN POPULATIONS; MILL TAILINGS; RADIOACTIVITY; RADON; SECURITY; STABILIZATION; URANIUM ORES; WASTE STORAGE

\section{4}

Ford, Bacon and Davis Utah, Inc., Salt Lake City, UT

ENGINEERING ASSESSMENT OF INACTIVE URANIUM MILL TAILINGS, SHIPROCK SITE, SHIPROCK, NEW MEXICO. PHASE II, TITLE I. GJT-2. (1977)

Available from NTIS, PC A10/MF A01.

Ford, Bacon and Davis Utah Inc. has performed an engineering assessment of the problems resulting from the existence of radioactive uranium mill tailings at Shiprock, New Mexico. The Phase II, Title I services include the preparation of topographic maps, the performance of core drillings and radiometric measurements sufficient to determine areas and volumes of tailings and other radiumcontaminated materials, the evaluation of resulting radiation exposures of individuals and nearby populations, the investigation of site hydrology and meteorology and the evaluation and costing of alternative corrective actions. Radon gas release from the 1.7 million tons of tailings at the Shiprock site constitutes the most significant environmental impact, although windblown tailings and external gamma radiation are also factors. The 11 alternative actions presented range from completion of the present ongoing EPA site decontamination plan (Option I), to stabilizing in-place with varying depths of cover material (Options II-IV), to removal to an isolated long-term disposal site (Options V$\mathrm{XI})$. All options indude remedial action costs for offsite locations where tailings have been placed. Costs estimates for the 11 options range from $\$ 540,000$ to $\$ 12,500,000$. Reprocessing the tailings for uranium is not economically feasible.

SUBJECT CATEGORY: Remedial Action, Mill Tailings

ORIGIN: Commercial

KEYWORDS: COST; DRILL CORES; ENVIRON. MENTAL IMPACTS; GAMMA RADIATION; HUMAN POPULATIONS; HYDROLOGY; METE- 
OROLOGY; MILL TAILINGS; NEW MEXICO; ORE PROCESSING; RADIATION DOSES; RADIOACTIVE WASTE DISPOSAL; RADON; TOPOGRAPHY; URANIUM ORES

\section{5}

Ford, Bacon and Davis Utah, Inc., Salt Lake City, UT

ENGINEERING ASSESSMENT OF INACTIVE URANIUM MILL TAILINGS, MEXICAN HAT SITE, MEXICAN HAT, UTAH. A SUMMARY OF THE PHASE II, TITLE I. GJT-3S. (1977).

Available from NTIS, PC A04/MF A01.

F'ord, Bacon and Davis Utah Inc. has performed an engineering assessment of the problems resulting from the existence of radioactive uranium mill tailings at the Mexican Hat millsite in Utah. The Phase II, 'Iitle I services include the preparation of topographic maps, the performance of core drillings and radiometric measurements sufficient to determine areas and volumes of tailings and other radium-contaminated materials, the evaluation of resulting radiation exposures of individuals residing nearby, the investigation of site hydrology and meteorology, and the evaluation and costing of alternative corrective actions. Radon gas release from the $2,200,000$ tons of tailings on the site constitutes the most significant environmental impact. The six alternative actions presented are directed towards restricting access to the site (Option I), returning the windblown tailings to the piles and stabilizing the piles with cover material (Options II, III, and IV), and consolidating the two piles into one pile and stabilizing it with cover material (Options V and VI). Fencing around the site or the tailings and the decontamination of mill buildings is included in all options. Options II and V provide $2 \mathrm{ft}$ of cover material on the tailings, Options III, IV, and VI provide $4 \mathrm{ft}, 13 \mathrm{ft}$, and $10 \mathrm{ft}$ of cover, respectively. Costs of the options range from $\$ 370,000$ to $\$ 4,390,000$. Reprocessing the tailings for uranium is not feasible al present.

SUBJECT CATEGORY: Remedial Action, Mill Tailings

ORIGIN: Commercial

KEYWORDS: COST; DRILL CORES; ENVIRONMENTAL IMPACTS; GAMMA RADIATION; HUMAN POPULATIONS; HYDROLOGY; MAPS, METEOROLOGY; MILL TAILINGS; ORE PRO-
CESSING; RADIATION DOSES; RADIOACTIVE WASTE DISPOSAL; RADON; TOPOGRAPHY; URANIUM ORES; UTAH

846

Ford, Bacon and Davis Utah, Inc., Salt Lake City, UT

ENGINEERING ASSESSMENT OF INACTIVE URANIUM MILL TAILINGS, MONUMENT VALLEY SITE, MONUMENT VALLEY, ARIZONA. A SUMMARY OF THE PHASE II, TITLE I. GJT-4S. (1977)

Available from NTIS, PC A03/MF A01.

Ford, Bacon and Davis Utah Inc. has performed an engineering assessment of the problerns resulting from the existence of radioactive uranium mill tailings at the Monument Valley millsite in Arizona. The Phase II, Title I services include the preparation of topographic maps, the performance of core drillings and radiometric measurements sufficient to determine areas and volumes of tailings and other radium-contaminated materials, the evaluation of resulting radiation exposures of individuals residing nearby, the investigation of site hydrology and meteorology and the evaluation and costing of alternative corrective actions. Radon gas release from the tailings on the site constitutes the most significant environmental impact, although windblown tailings and external gamma radiation are also factors. The sparsc population and relatively low radiation levels yield minimal immediate environmental impact; hence, the two alternative actions presented are directed towards restricting access to the site (Options I and II), and returning the windblown tailings to the pile and stabilizing the pile with $2 \mathrm{ft}$ of cover material (Option II). Both options include remedial action costs for offsite locations where tailings have been placed. Cost estimates for the two options are $\$ 585,000$ and $\$ 1,165,000$. Reprocessing the tailings for uranium is not economically feasible.

SUBJECT CATEGORY: Remedial Action, Mill Tailings

ORIGIN: Commercial

KEYWORDS: ARIZONA; COST; DRILL CORES; ENVIRONMENTAL IMPACTS; GAMMA RADIATION; HUMAN POPULATIONS; HYDROLOGY; MAPS; METEOROLOGY; MILL TAILINGS; ORE PROCESSING; RADIATION DOSES; RADIOACTIVE WASTE DISPOSAL; RADON; TOPOGRAPHY; URANIUM ORES 
847

Ford, Bacon and Davis Utah, Inc., Salt Lake City, UT

ENGINEERING ASSESSMENT OF INACTIVE URANIUM MILL TAILINGS, TUBA CITY SITE, TUBA CITY, ARIZONA. PHASE II, TITLE I. GJT-5. (1977)

Available from NTIS, PC A08/MF A01.

Ford, Bacon and Davis Utah Inc. has performed an engineering assessment of the problems resulting from the existence of radioactive uranium mill tailings at the Tuba City millsite in Arizona. The Phase II, Title I services include the preparation of topographic maps, the performance of core drillings and radiometric measurements sufficient to determine areas and volumes of tailings and other radium-contaminated materials, the evaluation of resulting radiation exposures of individuals residing nearby, the investigation of sile hydrology and meteorology and the evaluation and costing of alternative corrective actions. Radon gas release from the tailings on the site constitutes the most significant environmental impact to the inhabited area near the site. In the downwind direction, to the northeast of the site, airborne radioactivity is greater than Federal guidelines but there are no dwellings in that direction in the area of concern. Gamma radiation is significant over the tailings but is near background levels in the housing area. The sparse population and relatively low radiation levels yield minimal immediate environmental impact; hence, the four alternative actions presented are directed towards restricting access to the site (Option I), and returning the windblown tailings to the pile and stabilizing the pile with cover material (Options II, III, and IV). Fencing around the site or the tailings pile and the removal or decontamination of mill buildings is included in all options. Option II provides $2 \mathrm{ft}$ of cover material on the tailings, Option III provides $4 \mathrm{ft}$ of cover, and Option IV provides $13 \mathrm{ft}$ of cover. Costs of the options range from $\$ 671,000$ to $\$ 2,904,000$. Reprocessing the tailings for uranium is only marginally feasible and would require a more detailed economic evaluation before any action was taken.

SUBJECT CATEGORY: Remedial Action, Mill Tailings

ORIGIN: Commercial

KEYWORDS: ARIZONA; COST; DRILL CORES; ENVIRONMENTAL IMPACTS; GAMMA RADIATION; HUMAN POPULATIONS; HYDROLOGY; MAPS; METEOROLOGY; MILL TAILINGS; ORE
PROCESSING; RADIATION DOSES; RADIOACTIVE WASTE DISPOSAL; RADON; TOPOGRAPHY; URANIUM ORES

\section{8}

Ford, Bacon and Davis Utah, Inc., Salt Lake City, UT

ENGINEERING - ASSESSMENT OF INACTIVE URANIUM MILL TAILINGS, DURANGO SITE, DURANGO, COLORADO. A SUMMARY OF THE PHASE II, TITLE I. GJT-6S. (1977)

Available from NTIS, PC A04/MF A01.

Ford, Bacon and Davis Utah Inc. has performed an engineering assessment of the problems resulting from the existence of radioactive uranium mill tailings at Durango, Colorado. The Phase II, Title I services include the preparation of topographic maps, the performance of core drillings and radiometric measurements sufficient to determine areas and volumes of tailings and other radiumcontaminated materials, the evaluation of resulting radiation exposures of individuals and nearby populations, the investigation of site hydrology and meteorology and the evaluation and costing of alternative corrective actions. Radon gas release from the 1.555 million tons of tailings at the Durango site constitutes the most significant environmental impact, although windblown tailings and external gamma radiation are also factors. The eight alternative actions presented range from vegetative stabilization (Option $I$ ), to contouring and stabilizing in-place with varying depths of cover material (Options II and III), to removal to an isolated long-term disposal site (Options V to VIII). All options include remedial action costs for offsite locations where tailings have been placed. Costs estimated for the eight options range from $\$ 4,340,000$ to $\$ 13,590,000$. Reprocessing the tailings for uranium is sufficiently economically attractive to justify reprocessing in conjunction with each of the options.

SUBJECT CATEGORY: Remedial Action, Mill Tailings

\section{ORIGIN: Commercial}

KEYWORDS: COLORADO; COST; DRILL CORES; ENVIRONMENTAL IMPACTS; GAMMA RADIATION; HUMAN POPULATIONS; HYDROLOGY; MAPS; METEOROLOGY; MILL TAILINGS; ORE PROCESSING; RADIA- 
TION DOSES; RADIOACTIVE WASTE DISPOSAL; RADON; TOPOGRAPHY; URANIUM ORES

849

Ford, Bacon and Davis Utah, Inc., Salt Lake City, UT

ENGINEERING ASSESSMENT OF INACTIVE URANIUM MILL TAILINGS, SLICK ROCK SITES, SLICK ROCK, COLORADO. PHASE II, TITLE I. GJT-7. (1977)

Available from NTIS, PC A09/MF A01.

Ford, Bacon and Davis Utah Inc. has performed an engineering assessment of the problems resulting from the existence of radioactive uranium mill tailings at the two millsites in Slick Rock, Colorado. The Phase II, Title I services include the preparation of topographic maps, the performance of core drillings and radiometric measurements sufficient to determine areas and volumes of tailings and other radium-contaminated materials, the evaluation of resulting radiation exposures of individuals residing nearby, the investigation of site hydrology and meteorology, and the evaluation and costing of alternative corrective actions. The Union Carbide site has 350,000 tons of tailings and the North Continent site now owned by Union Carbide has 37,000 tons of tailings. Both tailings piles have been Stabilized in accordance with regulations of the State of Colorado. Radon gas release from the tailings on the sites constitute the most significant environmental impact, although windblown tailings and external gamma radiation are also factors. The sparse population and relatively low radiation levels yield minimal immediate environmental impact. Hence the three alternative actions presented are directed towards restricting access to the sites (Option II), and returning the windblown tailings to the piles and stabilizing the piles with cover material (Option II), and consolidating the two piles on the UC site and stabilizing with $2 \mathrm{ft}$ of cover (Option III). Fencing around the tailings piles is included in all options. Uptions $1 \mathrm{I}$ and III provide $2 \mathrm{ft}$ of cover material on the tailings. Costs of the options range from $\$ 370,000$ to $\$ 1,100,000$. Reprocessing the tailings for uranium is not economically feasible.

SUBJECT CATEGORY: Remedial Action, Mill Tailings

ORIGIN: Commercial

KEYWORDS: COLORADO; COST; DRILL CORES; ENVIRONMENTAL IMPACTS;
GAMMA RADIATION; HUMAN POPULATIONS; HYDROLOGY; MAPS; METEOROLOGY; MILL TAILINGS; ORE PROCESSING; RADIATION DOSES; RADIOACTIVE WASTE DISPOSAL; RADON; TOPOGRAPHY; URANIUM ORES

850

Ford, Bacon and Davis Utah, Inc., Salt Lake City, UT

ENGINEERING ASSESSMENT OF INACTIVE IIRANIUM MILL TAILINGS, SLICK ROCK SITES, SLICK ROCK, COLORADO. A SUMMARY OF THE PHASE 11 , 'TI'TLE 1. GJT-7S. (1977)

Available from N'IIS, PC A04/MF A01.

Ford, Bacon and Davis Utah Inc. has performed an engineering assessment of the problems resulting from the existence of radioactive uranium mill tailings at the two millsites in Slick Rock, Colorado. The Phase II, Title I services include the preparation of topographic maps, the performance of core drillings and radiometric measurements sufficient to determine areas and volumes of tailings and other radium-contaminated materials, the evaluation of resulting radiation exposures of individuals residing nearby, the investigation of site hydrology and meteorology, and the evaluation and costing of alternative corrective actions. The Union Carbide site has 350,000 tons of tailings and the North Continent site now owned by Union Carbide has 37,000 tons of tailings. Both tailings piles have been stabilized in accordance with regulations of the State of Culurado. Radon gas release from the tailings on the sites constitute the most significant environmental impact, although windblown tailinğg and external gamma radiation ure ulsu fuclurs. The sparse population and relatively low radiation levels yield minimal immediate environmental impact. Hence the three alternative actions presented are directed towards restricting access to the sites (Oplion I), und relurning the windblown tailings to the piles and stabilizing the piles with cover material (Option II), and consolidating the two piles on the UC site and stabilizing with $2 \mathrm{ft}$ of cover (Option III). Fencing around the tailings pilcs is included in ull options. Options II and III provide $2 \mathrm{ft}$ of cover material on the tailings. Costs of the options range from $\$ 370,000$ to $\$ 1,100,000$. Reprocessing the tailings for uranium is not economically feasible.

SUBJECT CATEGORY: Remedial Action, Mill Tailings 
ORIGIN: Commercial

KEYWORDS: COLORADO; COST; DRILL CORES; ENVIRONMENTAL IMPACTS; GAMMA RADIATION; HUMAN POPULATIONS; HYDROLOGY; MAPS; METEOROLOGY; MILL TAILINGS; ORE PROCESSING; RADIATION DOSES; RADIOACTIVE WASTE DISPOSAL; RADON; TOPOGRAPHY; URANIUM ORES

851

Ford, Bacon and Davis Utah, Inc., Salt Lake City, UT

ENGINEERING ASSESSMENT OF INACTIVE URANIUM MILL TAILINGS, NATURITA SITE, NATURITA, COLORADO. A SUMMARY OF THE PHASE II, TITLE I. GJT-8S. (1977)

Available from NTIS, PC A04/MF A01.

Ford, Bacon and Davis Utah Inc. has performed an engineering assessment of the problems resulting from the existence of radioactive uranium mill tailings at Naturita, Colorado. The Phase II, Title I services include the preparation of topographic maps, the performance of core drillings sufficient to determine areas and volumes of tailings, the performance of radiometric measurements to determine the extent of radium contamination, the evaluation of resulting radiation exposures of individuals and nearby populations, the investigation of site hydrology and meteorology, and the costing of alternative corrective actions. Radon gas release from the 704,000 tons of tailings at the Naturita site constitutes the most significant environmental impact although windblown tailings and external gamma radiation are also factors. Ranchers Exploration and Development Company has been licensed by the State of Colorado to reprocess the tailings at a location $3 \mathrm{mi}$ from the present site where they will be stabilized for long. term storage. The remedial action options include remedial action for structures in Naturita and Nucla (Option I) at an estimated cost of $\$ 270,000$ and remedial action for structures and open land adjacent to the tailings site (Option In) at an estimated cust of $\$ 950,000$.

SUBJECT CATEGORY: Remedial Action, Mill Tailings

ORIGIN: Commercial
KEYWORDS: COLORADO; COST; DRILL CORES; ENVIRONMENTAL IMPACTS; GAMMA RADIATION; HUMAN POPULATIONS; HYDROLOGY;.MAPS; METEOROLOGY; MILL TAILINGS; ORE PROCESSING; RADIATION DOSES; RADIOACTIVE WASTE DISPOSAL; RADON; TOPOGRAPHY; URANIUM ORES

852

Ford, Bacon and Davis Utah, Inc., Salt Lake City, UT

ENGINEERING ASSESSMENT OF INACTIVE URANIUM MILL TAILINGS, GRAND JUNCTION SITE, GRAND JUNCTION, COLORADO. A SUMMARY OF THE PHASE II, TITLE I. GJT-9S. (1977)

Available from NTIS, PC A04/MF A01.

Ford, Bacon and Davis Utah Inc. has performed an engineering assessment of the problems resulting from the existence of radioactive uranium mill tailings at Grand Junction, Colorado. The Phase II, Title I services include the preparation of topographic maps, the performance of core drillings and radiometric measurements sufficient to determine areas and volumes of tailings and radiation exposures of individuals and nearby populations, the investigation of site hydrology and meteorology, and the evaluation and costing of alternative corrective actions. Radon gas release from the 1.9 million tons of tailings at the Grand Junction site constitutes the most significant environmental impact, although windblown tailings and external gamma radiation are also factors. The eight alternative actions presented range from millsite decontamination (Option I), to adding various depths of stabilization cover material (Options II and III), to removal of the tailings to long-term storage sites and decontamination of the present site (Options IV through VIII). Cost estimates for the eight options range from $\$ 470,000$ to $\$ 18,130,000$. Reprocessing the tailings for uranium recovery does not appear to be economically attractive at present.

SUBJECT CATEGORY: Remedial Action, Mill Tailings

ORIGIN: Commercial

KEYWORDS: COLORADO; COST; DRILL CORES; ENVIRONMENTAL IMPACTS; HUMAN POPULATIONS; HYDROLOGY; MAPS; 
METEOROLOGY; MILL TAILINGS; ORE PROCESSING; RADIATION DOSES; RADIOACTIVE WASTE DISPOSAL; RADON; TOPOGRAPHY; URANIUM ORES

853

Ford, Bacon and Davis Utah, Inc., Salt Lake City, UT

ENGINEERING ASSESSMENT OF INACTIVE URANIUM MILL TAILINGS, SHIPROCK SITE, SHIPROCK, NEW MEXICO. A SUMMARY OF THE PHASE II, TITLE I. GJ'I'-2S: (1977)

Available frum NTIS, PC A04/MF A01.

Ford, Bacon and Davis Utah Inc. has performed an engineering assessment of the problems resulting from the existence of radioactive uranium mill tailings at Shiprock, New Mexico. The Phase II, Title I services include the preparation of topographic maps, the performance of core drillings and radiometric measurements sufficient to determine areas and volumes of tailings and other radiumcontaminated materials, the evaluation of resulting radiation exposures of individuals and nearby populations, the investigation of site hydrology and meteorology and the evaluation and costing of alternative corrective actions. Radon gas release from the 1.7 million tons of tailings at the Shiprock site constitutes the most significant environmental impact, although windblown tailings and external gamma radiation are also factors. The 11 alternative actions presented range from completion of the present ongoing EPA site decontamination plan (Option I), to stabilizing in-place with varying depths of cover material (Options II-IV), to removal to an isolated long-term disposal site (Options V. XI). All options include remedial action costs for offsite locations where tailings have been placed. Costs estimates for the 11 options range from $\$ 540,000$ to $\$ 12,500,000$. Reprocessing the tailings for uranium is not economically feasible.

SUBJECT CATEGORY: Remedial Action, Mill Tailings

ORIGIN: Commercial

KEYWORDS: CONTAMINATION; COST; DECONTAMINATION; DRILL CORES; ENVIRONMENTAL EFFECTS; MILL TAILINGS; NEW MEXICO; ORE PROCESSING; RADIOMETERS; RADIUM; RADON; URANIUM MINES; URANIUM ORES
854

Ford, Bacon and Davis Utah, Inc., Salt Lake City, UT

ENGINEERING ASSESSMENT OF INACTIVE URANIUM MILL TAILINGS NEW AND OLD RIFLE SITE, RIFLE, COLORADO. PHASE II, TITLE I. GJT-10. (1977)

Available from NTIS, PC A11/MF A01.

Ford, Bacon and Davis Utah Inc. has performed an engineering assessment of the problems resulting from the existence of radioactive uranium mill tailings at Rifle, Colorado. The Phase II-Title I services include the preparation of topographlc maps, the performance of core drillings and radiometric measurements sufficient to determine areas and volumes of tailings and other radiumcontaminated materials, the evaluation of resulting radiation exposures of individuals and nearby populations, the investigation of site hydrology and meteorolngy and the evaluation and costing of alternative corrective actions. Radon gas release from the 3.1 million tons of tailings at the two Rifle sites, constitutes the most significant environmental impact. Windblown tailings, external gamma radiation and localized contamination of surface waters are other environmental effects. The 15 alternative remedial action options presented range from millsite derontamination and nff-site remedial action (Options $I$ and IV), to adding various depths of stabilization cover material (Options II, V, VI and VII), to removal of the tailings to long-term storage sites and decontamination of the present sites (Options III and VIII through XV). Cost estimates for the first 14 options range from $\$ 224,000$ to $\$ 20,300,000$. Option $X V$, estimated at $\$ 32,200,000$, includes the cost for moving both Rifle tailings piles and the Grand Junction tailings pile to DeBeque for long-term storage and site decontamination after removal of the piles. Reprocessing of the tailings for uranium appears to be economically attractive at present.

SUBJECT CATEGORỸ: Remedial Action, Mill Tailings

ORIGIN: Commercial

KEYWORDS: COLORADO; COST; ENVIRONMENTAL EFFECTS; FEED MATERIALS PLANTS; GAMMA RADIATION; HYDROLOGY; METEOROLOGY; MILL TAILINGS; RADIOACTIVE WASTE DISPOSAL; RADON; URANIUM MINES 
855

Ford, Bacon and Davis Utah, Inc., Salt Lake City, UT

ENGINEERING ASSESSMENT OF INACTIVE URANIUM MILL TAILINGS, MAYBELL SITE, MAYBELL, COLORADO. PHASE II, TITLE I. GJT-11; 116 pp. (1977)

Ford, Bacon and Davis Utah Inc. has performed an engineering assessment of the problems resulting from the existence of radioactive uranium mill tailings at Maybell, Colorado. The Phase II-Title I services include the preparation of topographic maps, the performance of core drillings sufficient to determine areas and volumes of tailings and radiometric measurements to determine radiumcontaminated materials, the evaluation of resulting radiation exposures of individuals and nearby populations, the investigation of site hydrology and meteorology and the evaluation and costing of alternative corrective actions: Radon gas release from the 2.6 million tons of tailings at the Maybell site constitutes the most significant environmental impact, although windblown tailings and external gamma radiation are also factors. The three alternative actions presented range from fencing and maintenance (Option I), to placing the tailings in an open-pit mine and adding $2 \mathrm{ft}$ of stabilization cover material (Option III). Cost estimates for the three options range from $\$ 250,000$ to $\$ 4,520,000$. Reprocessing the tailings for uranium does not appear to be economically attractive at present.

SUBJECT CATEGORY: Remedial Action, Mill Tailings

ORIGIN: Commercial

KEYWORDS: COLORADO; COST; COST BENEFIT ANALYSIS; ENVIRONMENTAL IMPACTS; FEED MATERIALS PLANTS; MILL TAILINGS; ORE PROCESSING; RADIOACTIVE WASTE DISPOSAL; RADON; STABILITY; URANIUM MINES; URANIUM ORES

856

Ford, Bacon and Davis Utah, Inc., Salt Lake City, UT

SUMMARY OF THE PHASE II, TITLE I, ENGINEERING ASSESSMENT OF INACTIVE URANIUM MILL TAILINGS, GUNNISON SITE, GUNNISON, COLORADO. GJT-125. (1977)

Available from NTIS, PC A04/MF A01.
Ford, Bacon and Davis Utah Inc. has performed an engineering assessment of the problems resulting from the existence of radioactive uranium mill tailings at Gunnison, Colorado. The Phase II-Title I services include the preparation of topographic measurements sufficient to determine areas and volumes of tailings and other radium-contaminated materials, the evaluation of resulting radiation exposures of individuals and nearby populations, the investigation of site hydrology and meteorology, and the evaluation and costing of alternative corrective actions. Radon gas release from the 0.5 million tons of tailings at the Gunnison site constitutes the most significant environmental impact, although windblown tailings and external gamma radiation are also factors. The nine alternative actions presented range from millsite decontamination (Option I), to adding various depths of stabilization cover material (Options II and III), to removal of the tailings to long-term storage sites and decontamination of the present site (Options IV through IX). Cost estimates for the nine options range from $\$ 480,000$ to $\$ 5,890,000$. Reprocessing the tailings for uranium does not appear to be economically attractive at present.

SUBJECT CATEGORY: Remedial Action, Mill Tailings

ORIGIN: Commercial

KEYWORDS: COLORADO; COST; ENVIRONMENTAL IMPACTS; HUMAN POPULATIONS; HYDROLOGY; METEOROLOGY; MILL TAIL INGS; ORE PROCESSING; RADIATION HAZARDS; RADIOACTIVE WASTE DISPOSAL; RADON; URANIUM ORES

\section{7}

Ford, Bacon and Davis Utah, Inc., Salt Lake City, UT

ENGINEERING ASSESSMENT OF INACTIVE URANIUM MILL TAILINGS, LAKEVIEW SITE, LAKEVIEW, OREGON. SUMMARY OF PHASE II, TITLE I. GJT-18S. (1977)

Available from NTIS, PC A03/MF A01.

Results are reported from an engineering assessment of the problems resulting from the existence of radioactive uranium mill tailings at the Lakeview, Oregon site. Data ore included from the analyses of soil, water, and other samples; radiometric measurements to determine areas with radiumcontaminated materials; evaluation of resulting 
radiation exposures of individuals and nearby populations; investigation of site geology, hydrology, and meteorology; and evaluation and costing of alternative corrective actions. Radon gas release from the 130,000 tons of tailings at the Lakeview site constitutes the main environmental impact, which is minimal. The two alternative actions presented are maintenance of the site now that the ARCO reclamation program has been completed (Option I); and addition of stabilization cover to a minimum depth of $2 \mathrm{ft}$, improved fencing, and removal of a few isolated spots of contamination (Option II). The cost estimates for these options are $\$ 40,000$ and $\$ 290,000$, respectively.

SUBJECT CATEGORY: Remedial Action, Mill Tailings

ORIGIN: Commercial

KEYWORDS: AIR; COST BENEFIT ANALYSIS; ENVIRONMENTAL EFFECTS; ENVIRONMENTAL TRANSPORT; GASEOUS WASTES; HEALTH HAZARDS; HUMAN POPULATIONS; LAND POLLUTION ABATEMENT; MILL TAIL INGS; OREGON; RADIATION MONITORING; RADIOACTIVE WASTE MANAGEMENT; RADIOACTIVE WASTES; RADIUM; RADON; SAMPLING; SOILS; STABILIZATION; SURFACE CONTAMINATION; SURFACE WATERS; URANIUM; COST

858

Ford, Bacon and Davis Utah, Inc., Salt Lake City. UT

ENGINEERING ASSESSMENT OF INACTIVE URANIUM MILL TAILINGS, RAY POINT SITE, RAY POINT, TEXAS. PHASE II, TITLE I. GJT-20. (1977)

Available from NTIS, PC A07/MF A01.

Results are reported from an engineering assessment of the problems resulting from the existence of radioactive uranium mill tailings at Ray Point, Texas. The Phase III-Title I services generally include the preparation of topographic maps, the performance of soil sampling and radiometric measurements sufficient to determine areas and volumes of tailings and other radium-contaminated materials, the evaluation of resulting radiation exposures of individuals and nearby populations, the investigation of site hydrology and meteorology and the evaluation and costing of alternative corrective actions. About 490,000 tons of ore were processed at this mill with all of the uranium sold on the commercial market. None was sold to the AEC; therefore, this report focuses on a physical description of the site and the identification of radiation pathways. No remedial action options were formulated for the site, inasmuch as none of the uranium was sold to the AEC and Exxon Corporation has agreed to perform all actions required by the State of Texas. Radon gas release from the tailings at the Ray Point site constitutes the most significant environmental impact. Windblown tailings, external gamma radiation and localized contamination of surface waters are other environmental effects. Exxon is also studying the feasibility of reprocessing the tailings.

SUBJECT CATEGORY: Remedial Action, Mill Tailinge

ORIGIN: Commercial

KEYWORDS: ENVIRONMENTAL EFFECTS; ENVIRONMENTAL TRANSPORT; HEALTH HAZARDS; HUMAN POPULATIONS; HYDROL OGY; METEOROLOGY; MILL TAILINGS; RADIATION MONITORING; RADIOACTIVE WASTE MANAGEMENT; RADIOACTIVE WASTES; RADIUM; RADON; SOILS; SURFACE WATERS; TEXAS; URANIUM; VOLUME

859

Ford, Bacon and Davis Utah, Inc., Salt Lake City, UT

PHASE II, TITLE I ENGINEERING ASSESSMENT OF INACTIVE URANIUM MILL TAILINGS, PHILLIPS/UNITED NUCLEAR SITE, AMBROSIA LAKE, NEW MEXICO. GJT-13; 112 pp. (1977)

Avăilublı from NTIS, PC A08/MF A01.

An enginecring assessment was performed of the problems resulting from the existence of radioactive uranium mill tailings at the Phillips/United Nuclear site at Ambrosia Lake, New Mexico. Services included the preparation of topographic maps, the performance of core drillings sufficient to determine areas and volumes of tailings, and radiometric measurements to determine radium-contaminated materials, the evaluation of resulting radiation exposures of individuals and nearby populations, the investigation of site hydrology and meteorology, and the evaluation and costing of alternative corrective actions. Radon gas release from the 2.6 million tons of tailings at the Phillips/United 
Nuclear site constitutes the most significant environmental impact, although windblown tailings and external gamma radiation are also factors. The estimated radiological health effects to the general population are considered to be minimal. The two alternative actions presented are: dike stabilization, fencing, and maintenance; and adding $2 \mathrm{ft}$ of stabilization cover material. Both options include remedial action at off-site structures and on-site decontamination around the tailings pile. Cost estimates for the two options are $\$ 920,000$ and $\$ 2,230,000$, respectively.

SUBJECT CATEGORY: Remedial Action, Mill Tailings

ORIGIN: Commercial

KEYWORDS: COST BENEFIT ANALYSIS; ENVIRONMENTAL EFFECTS; ENVIRONMENTAL TRANSPORT; HEALTH HAZARDS; HUMAN POPULATIONS; HYDROLOGY; LAND POLLUTION ABATEMENT; LAND RECLAMATION; METEOROLOGY; MILL TAILINGS; NEW MEXICO; PHYSICAL PROTECTION DEVICES; RADIATION MONITORING; RADIOACTIVE WASTES; RADIUM; RADON; STABILIZATION; TOPOGRAPHY; URANIUM MINERALS; COST

860

Ford, Bacon and Davis Utah, Inc., Salt Lake City, UT

SUMMARY OF THE PHASE II, TITLE I ENGINEERING ASSESSMENT OF INACTIVE URANIUM MILLTAILINGS, PHILLIPS/UNITED NUCLEAR SITE, AMBROSIA LAKE, NEW MEXICO. GJT-1.3S. (1977)

Available from NTIS, PC A03/MF A01.

An engineering assessment was performed of the problems resulting from the existence of radioactive uranium mill tailings at the Phillips/United Nuclear site at Ambrosia Lake, New Mexico. Services included the preparation of topographic maps, the performance of core drillings sufficient to determine areas and volumes of tailings and radiometric measurements to determine radium-contaminated materials, the evaluation of resulting radiation exposures of individuals and nearby populations, the investigation of site hydrology and meteorology, and the evaluation and costing of alternative corrective actions. Radon gas release from the 2.6 million tons of tailings at the Phillips/United Nuclear site constitutes the most significant environmental impact, although windblown tailings and external gamma radiation are also factors. The estimated radiological health effects to the general population are considered to be minimal. The two alternative actions presented are: dike stabilization, fencing, and maintenance; and adding $2 \mathrm{ft}$ of stabilization cover material. Both options include remedial action at off-site structures and on-site decontamination around the tailings pile. Cost estimates for the two options are $\$ 920,000$ and $\$ 2,230,000$, respectively.

SUBJECT CATEGORY: Remedial Action, Mill Tailings

\section{ORIGIN: Commercial}

KEYWORDS: AIR POLLUTION; COST BENEFIT ANALYSIS; ENVIRONMENTAL EFFECTS; ENVIRONMENTAL TRANSPORT; GASEOUS WASTES; HEALTH HAZARDS; HUMAN POPULATIONS; LAND POLLUTION; LAND RECLAMATION; MILL TAILINGS; NEW MEXICO; PARTICLE RESUSPENSION; PHYSICAL PROTECTION DEVICES; RADIATION MONITORING; RADIOECOLOGICAL CONCENTRATION; RADIUM; RADON; SOLID WASTES; STABILIZATION; URANIUM ORES; COST

861

Ford, Bacon and Davis Utah, Inc., Salt Lake City, UT

PHASE II, TITLE I ENGINEERING ASSESSMENT OF INACTIVE URANIUM MILL TAILINGS, GREEN RIVER SITE, GREEN RIVER, UTAH. GJT-14. (1977)

Available from NTIS, PC A08/MF A01.

An engineering assessment was performed of the problems resulting from the existence of radioactive uranium mill tailings at the Green River site, Utah. Services included the preparation of topographic maps, the performance of core drillings and radiometric measurements sufficient to determine areas and volumes of tailings and other radiumcontaminated materials, the evaluation of resulting radiation exposures of individuals and nearby populations, the investigation of site hydrology and meteorology and the evaluation and costing of alternative corrective actions. Radon gas release from the 123 thousand tons of tailings at the Green River site constitutes the most significant environ- 
mental impact, although windblown tailings and external gamma radiation are also factors. The three alternative actions presented are dike stabilization, fencing, on- and off-site decontamination and maintenance (Option I); improvements in the stabilization cover and diking plus cleanup of the site and Browns Wash, and realignment of Browns Wash (Option II); and addition of stabilization cover to a total of $2 \mathrm{ft}$, realignment of Browns Wash and placement of additional riprap, on-site cleanup and drainage improvements (Option III). All options include remedial action at off-site structures. Cost estimates for the three options range from $\$ 700,000$ to $\$ 926,000$.

SUBJECT CATEGORY: Remedial Action, Mill Tailings

ORIGIN: Commercial

KEYWORDS: AIR POLLUTION; COST BENEFIT ANALYSIS; ENVIRONMENTAL EFFECTS; GASEOUS WASTES; HEALTH HAZARDS; HUMAN POPULATIONS; LAND POLLUTION; LAND RECLAMATION; MILL TAILINGS; PHYSICAL PROTECTION DEVICES; RADIATION MONITORING; RADIOECOLOGICAL CONCENTRATION; RADIUM; RADON; SOLID WASTES; STABILIZATION; URANIUM ORES; UTAH; COST

\section{2}

Ford, Bacon and Davis Utah, Inc., Salt Lake City, UT

ENGINEERING ASSESSMENT OF INACTIVE URANIUM MILL TAILINGS, SPOOK SITE, CONVERSE COUNTY, WYOMING. PHASE II, TITLE I. GJT-15. (1977)

Avallable from N'I'IS, NC A07/MF'A01.

An engineering assessment of the problems resulting from the existence of radioactive uranium mill tailings was performed at the Spook Site, Converse County, Wyoming. Data are presented from soil, water and other sample analyses, radiometric measurements to determine areas with radiumcontaminated materials, the evaluation of resulting radiation exposures of individuals and nearby populations, the investigation of site geology, hydrology, and meteorology, and the evaluation and costing of alternative corrective actions. Radon gas release from the 187,000 tons of tailings at the Spook Site constitutes the main environmental impact, which is negligible. The two alternative actions presented are better fencing of the site in its present state and placing tailings and contaminated on-site materials and soil in the open-pit mine and covering the resulting pile with $2 \mathrm{ft}$ of overburden material. The cost estimates for the options are $\$ 81,000$ and $\$ 142,000$, respectively. Reprocessing the tailings for uranium at a nearby operating uranium mill is worthy of economic consideration at this time.

SUBJECT CATEGORY: Remedial Action, Mill Tailings

ORIGIN: Commercial

KEYWORDS: COST BENEFIT ANALYSIS: ENVIRONMENT; ENVIRONMENTAL EFFECTS; GASEOUS WASTES; HEALTH HAZARDE; HUUMAN POPULATIONS; LAND RECLAMATION; MILL TAIIINGS; PHYSICAL PROTECTION DEVICES; RADIATION MONITORING; RADIOACTIVE WASTE DISPOSAL; RADIOACTIV. ITY; RADIUM; RADON; SAMPLING; SOILS; SURFACE AIR; SURFACE WATERS; URANIUM MINERALS; COST

863

Ford, Bacon and Davis Utah, Inc., Salt Lake City, UT

PHASE II, TITLE I ENGINEERING ASSESSMENT OFINACTIVE IIRANIIIM MIIITAILINGS, FALLS CI'TY SI'IE, FALLS CITY, TEXAS. GJT-16. (1977)

Available from NTIS, PC A08/MF A01.

An engineering assessment was performed of the problems resulting from the existence of radioactive uranium mill tailings at Falls City, Texas. Serviccs included taking soil samples, the performance of radiometric measurements sufficient to determine areas and volumes of tailings and other radiumcontaminated materials, the evaluation of resulting radiation exposures of individuals and nearby populations, the investigation of site hydrology and meteorology and the evaluation and costing of alternative corrective actions. Radon gas release from the 2.5 million tons of tailings at the Falls City site constitutes the most significant environmental impact. Windblown tailings, external gamma radiation and localized contamination of surface waters are other environmental effects. The two 
alternative remedial action options presented include on-site and off-site cleanup, fencing, and hydrological monitoring, and in addition, stabilization of pile 2 with $2 \mathrm{ft}$ of cover material. The costs are $\$ 1.84$ million for Option I and $\$ 2.45$ million for Option II.

SUBJECT CATEGORY: Remedial Action, Mill Tailings

ORIGIN: Commercial

KEYWORDS: AIR POLLUTION; COST BENEFIT ANALYSIS; ENVIRONMENTAL EFFECTS; ENVIRONMENTAL TRANSPORT; GASEOUS WASTES; HEALTH HAZARDS; HUMAN POPULATIONS; LAND POLLUTION; LAND RECLAMATION; MILL TAILINGS; PARTICLE RESU. SPENSION; PHYSICAL PROTECTION DEVICES; RADIATION MONITORING; RADIOECOLOGICAL CONCENTRATION; RADIUM; RADON; SOLID WASTES; STABILIZATION; TEXAS; URANIUM ORES; WATER POLLUTION; COST

864

Ford, Bacon and Davis Utah, Inc., Salt Lake City, UT

SUMMARY OF THE PHASE II, TITLE I ENGINEERING ASSESSMENT OF INACTIVE URANIUM MILL TAILINGS, FALLS CITY SITE, FALLS CITY, TEXAS. GJT-16S. (1977)

Available from NTIS, PC A04/MF A01.

An engineering assessment was performed of the problems resulting from the existence of radioactive uranium mill tailings at Falls City, Texas. Services included taking soil samples, the performance of radiometric measurements sufficient to determine areas and volumes of tailings and other radiumcontaminated materials, the evaluation of resulting radiation exposures of individuals and nearby populations, the investigation of site hydrology and meteorology and the evaluation and costing of alternative corrective actions. Radon gas release from the 2.5 million tons of tailings at the Falls City site constitutes the most significant environmental impact. Windblown tailings, external gamma radiation and localized contamination of surface waters are other environmental effects. The two alternative remedial action options presented include on-site and off-site cleanup, fencing, and hydrological monitoring and, in addition, stabilization of pile 2 with $2 \mathrm{ft}$ of cover material. The costs are $\$ 1.84$ million and $\$ 2.45$ million.

SUBJECT CATEGORY: Remedial Action, Mill Tailings

ORIGIN: Commercial

KEYWORDS: AIR POLLUTION; COST BENEFIT ANALYSIS; ENVIRONMENTAL EFFECTS; ENVIRONMENTAL TRANSPORT; GASEOUS WASTES; HEALTH HAZARDS; HUMAN POPU. LATIONS; LAND POLLUTION; LAND RECLAMATION; MILL TAILINGS; PARTICLE RESU. SPENSION; RADIATION MONITORING; RADIOECOLOGICAL CONCENTRATION; RAD IUM; RADON; SOLID WASTES; STABILIZATION; TEXAS; URANIUM ORES; WATER POLLUTION; WIND; COST

\section{5}

Ford, Bacon and Davis Utah, Inc., Salt Lake City, UT

PHASE II, TITLE I ENGINEERING ASSESSMENT OF RADIOACTIVE SANDS AND RESIDUES, LOWMAN SITE, LOWMAN IDAHO. GJT-17. (1977)

Available from NTIS, PC A07/MF A01.

An engineering assessment was performed of the problems resulting from the existence of radioactive uranium sand residues at the Lowman, Idaho, site. Services normally include the preparation of topographic maps, the performance of core drillings and radiometric measurements sufficient to determine areas and volumes of tailings and other radium-contaminated materials, the evaluation of resulting investigations of site hydrology and meteorology, and the evaluation and costing of alternative corrective actions. Radon gas release from the 90,000 tons of sand residues at the Lowman site constitutes the most significant environmental impact, although external gamma radiation is also a factor. The two alternative actions presented are dike construction, fencing, and maintenance $(\mathrm{Op}$ tion I); and consolidation of the piles, addition of a 2 ft-thick stabilization cover, and on-site cleanup (Option II). Both options include remedial action at off-site structures. Cost estimates for the two options are $\$ 393,000$ and $\$ 590,000$.

SUBJECT CATEGORY: Remedial Action, Mill Tailings 
ORIGIN: Commercial

KEYWORDS: AIR POLLUTION; CONTAMINA. TION; COST BENEFIT ANALYSIS; ENVIRONMENTAL EFFECTS; GASEOUS WASTES; IDAHO; LAND POLLUTION; LAND RECLAMATION; MILL TAILINGS; PHYSICAL PROTECTION DEVICES; RADIATION MONITORING; RADIOECOLOGICAL CONCENTRATION; RADIUM; RADON; SAND; SOLID WASTES; STABILIZATION; URANIUM ORES; COST

\section{6}

Ford, Bacon and Davis Utah, Inc., Salt Lake City, UT

SUMMARY OF THE PHASE II, TITLE I ENGINEERING ASSESSMENT OF INACTIVE URANIUM MILL TAILINGS, LOWMAN SITE, LOWMAN, IDAHO. GJT-17S. (1977)

Available from NTIS, PC A03/MF A01.

An engineering assessment was performed of the problems resulting from the existence of radioactive uranium sand residues at the Lowman, Idaho site. Services included the preparation of topographic maps, the performance of core drillings and radiometric measurements sufficient to determine areas and volumes of tailings and other radiumcontaminated materials, the evaluation of resulting investigation of site hydrology and meteorology, and the evaluation and costing of alternative corrective actions. Kadon gas release from the 90,000 tons of sand residues at the Lowman site constitutes the most significant environmental impact, although external gamma radiation is also a factor. The two alternative actions presented are dike construction, fencing, and maintenance; and consolidation of the piles, addition of a 2-ft-thick stabilization cover, and on-site cleanup. Both options include remedial action at off-site structures. Cost estimates for the two options are $\$ 393,000$ and $\$ 590,000$.

SUBJECT CATEGORY: Remedial Action, Mill Tailings

ORIGIN: Commercial

KEYWORDS: AIR POLLUTION; COST BENE. FIT ANALYSIS; ENVIRONMENTAL EFFECTS; ENVIRONMENTAL TRANSPORT; GASEOUS WASTES; HEALTH HAZARDS; HUMAN POPU-
LATIONS; IDAHO; LAND POLLUTION; LAND RECLAMATION; MILL TAILINGS; PHYSICAL PROTECTION DEVICES; RADIATION MONITORING; RADIOECOLOGICAL CONCEN'IRATION; RADIUM; RADON; SAND; SOLID WASTES; STABILIZATION; URANIUM ORES

\section{7}

Ford, Bacon and Davis Utah, Inc., Salt Lake City, UT

SUMMARY OF THE PHASE II, TITLE I ENGINEERING ASSESSMENT OF INACTIVE URANIUM MILL TAILING, RIVERTON SITE, RIVERTON, WYOMING. GrJT-19S. (1977)

Available from NTIS, PC A04/MF A01.

An engineering assessment was performed of the problems resulting from the existence of radioactive uranium mill tailings at the Riverton, Wyoming site. The soil, water and other sample analyses; radiometric measurements to determine areas with radium-contaminated materials; the evaluation of resulting radiation exposures of individuals and nearby populations; the investigation of site geology, hydrology, and meteorology; and the evaluation and costing of alternative corrective actions. Radon gas release from the 900,000 tons of tailings at the Riverton site constitutes the main environmental impact. The two alternative actions presented are fencing and maintenance of the site and off-site remedial action, and decontamination of the millsite and ore storage areas and additional stabilization cover to a minimum of $2 \mathrm{ft}$. The cost estimates for the uptions are $\$ 460,000$ and $\$ 1,140,000$, respectively. Estimated costs for moving the tailings and all contaminated materials to unspecified sites 5 and iU $\mathrm{ml}$ from the present location are $\$ 6,000,000$ and $\$ 6,400,000$, respectively.

SUBJEC'I CA'TEGOKY: Remedial Action, Mill Tailings

ORIGINi Defense; Commercial

KEYWORDS: COST BENEFIT ANALYSIS; ENVIRONMENTAL EFFECTS; ENVIRONMENTAL TRANSPORT; HEALTH HAZARDS; HUMAN POPULATIONS; HYDROLOGY; LAND PULLU'IIUN ABA'I'EMEN'I; LAND KE'CLAMATION; METEOROLOGY; MILL TAILINGS; PHYSICAL PROTECTION DEVICES; RADIATION MONITORING; RADIOACTIVE WASTES; RAD. 
IUM; RADON; STABILIZATION; TOPOGRAPHY; TRANSPORT; URANIUM MINERALS; WYOMING; COST

\section{8}

Ford, Bacon and Davis Utah, Inc., Salt Lake City, UT

SUMMARY OF THE PHASE II, TITLE I ENGINEERING ASSESSMENT OF INACTIVE URANIUM MILL TAILINGS, TUBA CITY SITE, TUBA CITY, ARIZONA. GJT-5S. (1977)

Available from NTIS, PC A04/MF A01.

An engineering assessment was performed of the problems resulting from the existence of radioactive uranium mill tailings at the Tuba City millsite in Arizona. Services include the preparation of topographic maps, the performance of core drillings and radiometric measurements sufficient to determine areas and volumes of tailings and other radiumcontaminated materials, the evaluation of resulting radiation exposures of individuals residing nearby, the investigation of site hydrology and meteorology and the evaluation and costing of alternative corrective actions. Radon gas release from the tailings on the site constitutes the most significant environmental impact to the inhabited area near the site.

SUBJECT CATEGORY: Remedial Action, Mill Tailings

ORIGIN: Commercial

KEYWORDS: ARIZONA; COST BENEFIT ANALYSIS; DRILL CORES; ENVIRONMENTAL EFFECTS; ENVIRONMENTAL TRANSPORT; HEALTH HAZARDS; HUMAN POPULATIONS; HYDROLOGY; MAPS; METEOROLOGY; MILI TAILINGS; RADIATION MONITORING; RADIOACTIVE WASTE STORAGE; RADIOMETRIC ANALYSIS; RADIUM; RADON; TOPOGRAPHY; URANIUM ORES

869

Ford, Bacon and Davis Utah, Inc., Salt Lake City, UT

SUMMARY OF THE PHASE II, TITLE I ENGINEERING ASSESSMENT OF INACTIVE URANIUM MILL TAILINGS, GREEN
RIVER SITE, GREEN RIVER, UTAH. GJT-14S. (1977)

Available from NTIS, PC A03/MF A01.

An engineering assessment was performed of the problems resulting from the existence of radioactive uranium mill tailings at the Green River site, Utah. The services include the preparation of topographic maps, the performance of core drillings and radiometric measurements sufficient to determine areas and volumes of tailings and other radium. contaminated materials, the evaluation of resulting radiation exposures of individuals and nearby populations, the investigation of site hydrology and meteorology and the evaluation and costing of alternative corrective actions. Radon gas release from the 123 thousand tons of tailings at the Green River site constitutes the most significant environmental impact, although windblown tailings and external gamma radiation are also factors. The three alternative actions presented are dike stabilization, fencing, on- and off-site decontamination and maintenance; improvements in the stabilization cover and diking plus cleanup of the site and Browns Wash, and realignment of Browns Wash; and addition of stabilization cover to a total of $2 \mathrm{ft}$, realignment of Browns Wash and placement of additional riprap, on-site cleanup and drainage improvements. All options include remedial action at off-site structures. Cost estimates for the three options range from $\$ 700,000$ to $\$ 926,000$.

SUBJECT CATEGORY: Remedial Action, Mill Tailings

ORIGIN: Commercial

KEYWORDS: AIR POLLUTION; COST BENEFIT ANALYSIS; ENVIRONMENTAL EFFECTS; GASEOUS WASTES; HEALTH HAZARDS; HUMAN POPULATIONS; LAND POLLUTION; LAND RECLAMATION; MILL TAILINGS; PHYSICAL PROTECTION DEVICES; RADIATION MONITORING; RADIOACTIVE WASTES; RADIUM; RADON; SOLID WASTES; STABILIZATION; URANIUM ORES; UTAH; COST

870

Heimerl, W., and U. Grahmann; Gelsenberg A.G., Essen, Germany, F.R.;Nuklear-Chemie und Metallurgie GmbH (NUKEM), Hanau, Germany, F.R.

TECHNICAL CONCEPT OF A VITRIFICATION PLANT USING THE PAMELA PRO- 
CESS FOR HIGHLY ACTIVE LIQUID WASTES: REAKTORTAGUNG, MANNHEIM, 29.3.-1.4.1977. SEKTION 3: BRENNSTOFFKREISLAUF. ZAED, EggensteinLeopoldshafen, Germany, F.R.; Reactor Congress 1977, Mannheim, Federal Republic of Germany, March 29, 1977. (1977)

In German; 2 figures. Short communication only

No Abstract

SUBJECT CATEGORY: HLW

ORIGIN: Foreign

KEYWORDS: COST; FLOWSHEETS; LIQUID WASTES; PILOT PLANTS; PLANNING; RADIOACTIVE WASTE PROCESSING; RADIOACTIVE WASTES; SOLIDIFICATION; VITRIFICATION

871

General Accounting Office, Energy and Minerals Div., Washington, DC

CLEANING UP THE REMAINS OF NUCLEAR FACILITIES-A MULTIBILLION DOLLAR PROBLEM: ENERGY RESEARCH AND DEVELOPMENT ADMINISTRATION. NUCLEAR REGULATORY COMMISSION. REPORT TO THE CONGRESS. EMD-77-46; PB-369745. (1977)

Available from NTIS PC A03/MF A01.

The problem of protecting the public from the hazards of radiation, lingering at nuclear facilities which are no longer operating, needs Federal attention if a strategy for finding a solution is to be developed. The solution doubtless will be expensive-but the expense should be known so the responsible parties can plan for the inevitable cost. A strategy to clean up these privately and federally owned nuclear facilities, which continue to accumulate, cannot be developed until basic questions on the magnitude of the problem, such as costs, radioactivity, and timing, have been answered.

SUBJECT CATEGORY: Remedial Action, FUSRAP; Remedial Action; Surplus Facilities

ORIGIN: Defense; Commercial

KEYWORDS: COST; DECOMMISSIONING; DECONTAMINATION; GOVERNMENT POLICIES;
HEALTH HAZARDS; NUCLEAR FACILITIES; REACTOR DECOMMISSIONING; FEASIBILITY STUDIES

872

General Accounting Office, Washington, DC

CLEANING UP THE REMAINS OF NUCLEAR FACILITIES: A MULTIBILLION DOLLAR PROBLEM.. NP-22292; EMD-7746. (1977)

Report to the Congress by the Comptroller General of the United Statos

NRC and ERDA programs for disposing of nuclear facilities after their shutdown are reviewed. The costs involved are discussed and some recommendations are presented.

SUBJECT CATEGORY: Remedial Action, FUSRAP; Remedial Action, Surplus Facilities

ORIGIN: Commercial; Defense

KEYWORDS: COST; FORECASTING; NU. CLEAR FACILITIES; NUCLEAR POWER PLANTS; PLANNING; REACTOR DECOMMISSIONING; REACTOR DISMANTLING; US NRC

873

General Atomic Co., San Diego, CA

THORIUM UTILIZATION PROGRAM, QUARTERLY PROGRESS REPORT FOR THE PERIOD ENDING FEBRUARY 28, 1977. GA. A-14304; 245 pp. (1977)

General Atomic Thorium Utilization Program activities progressed on schedule with continuation of the head-end reprocessing equipment testing program. Individual testing of tertiary oversize crushers and the screener was completed. Equipment is being prepared for testing as a system. Tests on the tertiary crusher revealed no operating problems. Design modifications were completed on the secondary crusher. The initial issue of a functional level diagram for the Fuel Element Size Reduction System has been prepared for preliminary review. Results of calculating heat transfer coefficients from data obtained in $0.40-\mathrm{m}$ primary burner heatup runs indicated smaller wall-to-bed heat transfer for deep beds heated with dual 
induction coils than with shallow beds and the single, lower coil. Six runs were made to test different aspects of the $0.20-\mathrm{m}$ primary burner. Additional work included fabrication and initial testing of an electrical resistance probe bed level sensor and preliminary heat transfer design calculations for determining cooling requirements. The $0.10-\mathrm{m}$ secondary burner is ready for burning tests. The conceptual design of the engineering-scale dissolver-centrifuge for incorporation into the headend line was completed. Bench-scale dissolution runs were made on ThO2. Three solvent extraction feed adjustment runs and three solvent extraction runs were completed. Progress with dry solids handling component and system testing continues. The work plan for the Maintainability and Reliability Phase I study was prepared and methodology development was initiated. The HET conceptual design has been completed to the $90 \%$ level and the Conceptual Design Report is in progress. HET Technical Review meetings were held. System description and design criteria activities were initiated for an integrated HRDF-Reprocessing Head-End and Solvent Extraction remote maintenance system. Efforts have been focussed on completion of HET fuel shipping conceptual design report, development of detailed costs, and identification of all system interfaces. Various reports are in preparation, review, or are available for distribution.

\section{SUBJECT CATEGORY: HLW}

ORIGIN: Commercial

KEYWORDS: THORIUM; FUEL CYCLE; DESIGN; EVALUATION; EQUIPMENT; SOLVENT EXTRACTION; THORIUM OXIDES; ECONOMICS; WASTE TRANSPORTATION; REPROCESSING; FABRICATION; FUEL ELEMENTS; URANIUM; HTGR TYPE REACTORS; ACTINIDES; HEAD END PROCESSES

\section{4}

Ferrigno, D.P., and R.M. Klingaman; Gilbert Associates, Reading, PA

NUCLEAR PLANT MODIFICATION FEASIBILITY FOR RADWASTE VOLUME REDUCTION EQUIPMENT. Transactions of the Amer1can Nuclear Society, Suppl. 26(1):18-19; Reactor Operating Experience, Proceedings of the American Nuclear Society Conference, Chattanooga, TN, August 7, 1977. (1977)

No Abstract
SUBJECT CATEGORY: LLW

ORIGIN: Commercial

KEYWORDS: COST; NUCLEAR POWER PLANTS; PWR TYPE REACTORS; RADIOACTIVE WASTE MANAGEMENT; RADIOACTIVE WASTE PROCESSING; SEPARATION PROCESSES

\section{5}

Camp, F.W.; Great Canadian Oil Sands Ltd., Edmonton, Alberta

PROCESSING ATHABASCA TAR SANDS: TAILINGS DISPOSAL. Can. J. Che. Eng. 55(5):581-591. (1977)

Public awareness and concern over the tailings disposal aspects of tar sand development are increasing. This paper describes why the hot water extraction process can lead to an accumulation of tailings sludge. A theory is proposed to predict tailings accumulation rate; predictions are compared with GCOS' operating experience. Using this theory, future projects can be evaluated on their merits without extrapolating GCOS' experience, which may or may not be applicable. Several unsuccessful approaches to reducing sludge accumulation are described to encourage others to seek new approaches.

SUBJECT CATEGORY: Remedial Action, Mill Tailings

ORIGIN: Foreign

KEYWORDS: BITUMENS; CLAYS; COMPARATIVE EVALUATIONS; DISPERSIONS; ECOL OGY; ECONOMICS; ENVIRONMENTAL IMPACTS; EXTRACTION; LIQUID WASTES; MILL TAILINGS; OIL SANDS; SLUDGES; SOLID WASTES

\section{6}

Fletcher, J.F.; Hanford Engineering Development Laboratory, Richland, WA

HEDL CONTRIBUTION TO SRL FUEL RECYCLE PROGRAM: QUARTERLY REPORT FOR APRIL, MAY, AND JUNE 1977. HEDL TC-902-2. (1977)

Available from N'TIS, PC A03/MF A01. 
Work is being done in five LWR categories: economic studies (capital cost of $1 \mathrm{MT} /$ day LMFBR fuel fabrication facility); spent fuel receipt and storage (fuel failure, radioactivity releases); fuel materials preparation (review of safeguards and standards); reduce generation of TRU waste (treatment of HEPA filters); and environmental effects (hydrologic data for WTRAN code and modifications to DOSE code).

SUBJECT CATEGORY: Spent Fuel; TRU; HLW

ORIGIN: Defense

KEYWORDS: AIR FILTERS; CAPITAL; COMPUTER CODES; COST; ECONOMICS; ENVIRONMENTAL IMPACTS; FISSION PRODUCT RELEASE; FUEL CYCLE; FUEL FABRICATION PLANTS; FUEL POOLS; HYDROLOGY; LMFBR TYPE REACTORS; RADIATION DOSES; RADIOACTIVE WASTES; RADIOACTIVITY; RESEARCH PROGRAMS; SPENT FUELSTORAGE; TRANSURANIUM ELEMENTS; WATER COOLED REACTORS

\section{7}

Fletcher, J.F.; Hanford Engineering Development Laboratory, Richland, WA

HEDLL CONTRIBUTION TO SRL FUEL RECYCLE PROGRAM. QUARTERLY REPORT, JANUARY-MARCH 1977. HEDL-TC-9021. (1977)

Sensitivity analysis of LMFBR fuel fabrication cost; Available from NTIS, PC A03/MF A01.

Research on LWR fuel cycle is being done in the following categories: economic studies (sensitivity analysis of LMFBR fuel fabrication costs), spent fuel receipt and storage (failure of PWR and BWR fuel assemblies), fuel materials preparation or finishing processes, reduction of TRU waste generation, and environmental impacts. 12 tables.

SUBJECT CATEGORY: Spent Fuel; TRU; HLW

ORIGIN: Defense

KEYWORDS: BWR TYPE REACTORS; COST; ENVIRONMENTAL IMPACTS; FUEL CYCLE; FUEL ELEMENT FAILURE; FUEL FABRICATION PLANTS; LMFBR TYPE REACTORS; NUCLEAR FUELS; PWR TYPE REACTORS; RADIOACTIVE WASTES; RESEARCH PRO-
GRAMS; SENSITIVITY; SPENT FUEL ELE MENTS; TRANSURANIUM ELEMENTS; WATER COOLED REACTORS

878

Fletcher, J.F.; Hanford Engineering Development Laboratory, Richland, WA

HEDL CONTRIBUTION TO SRL ALTERNATE FUEL CYCLE TECHNOLOGY PROGRAM. QUARTERLY REPORT, JULY-SEPTEMBER 1977. HEDLTC-902-3. (1977)

Available from NTIS, PC A03/MF A01.

Work for the LWR Alternate Fuel Cycle Technology Research and Development Program is being done in five categories: economic studies, spent fuel receipt and storage, finishing processes, reduce generation of TRU waste, and environmental effects.

SUBJEC'I CATEGORY: Spent Fuel; 'TRU; HLW

ORIGIN: Defense

KEYWORDS: ECONOMICS; ENVIRONMENTAL IMPACTS; FUEL CYCLE; FUEL ELEMENTS; PRODUCTION; RADIOACTIVE WASTES; RESEARCH PROGRAMS; SPENT FUEL STORAGE; TRANSURANIUM ELE. MENTS; WATER COOLED REACTORS

\section{9}

Darrin, J.C.; Hittman Nuclear and Development Corporation, Columbia, MD

RADIOACTIVE WASTE DISPOSAL: AFTER IT LEAVES THE PLANT. Transactions of the American Nuclear Society, Suppl. 26(1):17-18; Reactor Operating Experience, Transactions of the American Nuclear Society Conference, Chattanooga, TN. August 7, 1977. (1977)

Nó Abstract

SUBJECT CATEGORY: Isolation

ORIGIN: Commercial

KEYWORDS: COST; NUCLEAR POWER PLANTS; RADIOACTIVE WASTE DISPOSAL; RADIOACTIVE WASTE MANAGEMENT 
880

Card, D.H., and D.K. Wang; Idaho National Engineering Laboratory, Idaho Falls, ID

INITIAL DRUM RETRIEVAL INTERIM REPORT JULY 1974 TO SEPTEMBER 1976. TREE-1079; 24 pp. .(1977)

A program for retrieval of drums containing wastes contaminated with transuranic elements was instituted in 1974. The program provided for the safe removal of the 55 gallon drums from 3 waste trenches, repackaging of the drums and their removal to the Transuranic Storage Area nearby. Methods of drum retrieval and repackaging are discussed and improvements in techniques and per drum costs described. Most physical damage to the drums and leakage of radioactive materials are attributed to deterioration of the drums resulting from water which was allowed to accumulate in the trenches during the initial burial program. The cost of overpack containers for storage of retrieved drums has been reduced from $\$ 52$ to $\$ 28.51$ per retrieved drum.

SUBJECT CATEGORY: Isolation; TRU

ORIGIN: Defense

KEYWORDS: RADIOACTIVE WASTE DISPOSAL; TRANSURANIUM ELEMENTS; RADIOACTIVE WASTE STORAGE; COST; GROUND DISPOSAL

881

Dieckhoner, J.E.; Idaho National Engineering Laboratory, Idaho Falls, ID

SOURCES, PRODUCTION RATES AND CHARACTERISTICS OF ERDA LOW-LEVEL WASTES. CONF-770512; Management of LowLevel Radioactive Wastes, Proceedings of a Symposium held in Atlanta, Georgia, May 23-27, 1977, (31 pp.). (1977)

The system will not be available until 1978 .

A system called SWIMS, developed for ERDA at INEL to store and retrieve information on solid nonhigh-level radioactive waste characteristics encompassing all ERDA owned burial sites and waste generators, is described. It includes all categories under the solid, nonhigh-level radioactive waste classification, e.g., TRU, fission products, beta-gamma TRU, etc, and all modes of disposal, e.g., retrievable storage, burial, etc. It is undergoing trial in 1977, and is expected to be operational in 1978.

SUBJECT CATEGORY: LLW; TRU

ORIGIN: Defense

KEYWORDS: RADIOACTIVE WASTES; RADIOACTIVE WASTE STORAGE; LOW-LEVEL RADIOACTIVE WASTES; SOLID WASTES; VOLUME; RADIOACTIVE WASTE MANAGEMENT

\section{2}

Karlsson, D.W.; Idaho National Engineering Laboratory, Idaho Falls, ID

SAFETY REVIEW DOCUMENT FOR THE RADIOACTIVE WASTE MANAGEMENT COMPLEX AT THE IDAHO NATIONAL ENGINEERING LABORATORY. TREE-1064; 173 pp. (1977)

16 tables, 30 figures

Topics discussed are (1) historical backgrounds, (2) physical characteristics of the site, (3) radioactive waste management complex, (4) control factors, (5) environmental effects, (6) waste disposal, (7) waste storage, (8) waste retrieval, (9) waste volume reduction, (10) decontamination facility south, (11) documentation, (12) summary of waste handled at RWMC, (13) previous surveys, (14) environmental monitoring, (15) normal operations, (16) credible deviations from normal operations, and (17) residual risks.

SUBJECT CATEGORY: TRU; HLW; LLW

ORIGIN: Defense

KEYWORDS: SAFETY; RADIOACTIVE WASTE STORAGE; RADIOACTIVE WASTE MANAGEMENT; TRANSURANIUM ELEMENTS; VOLUME; DECONTAMINATION

883

Idaho National Engineering Laboratory, Idaho Falls, ID

LONG-RANGE WASTE MANAGEMENT PLANNING FOR EFFECTIVE UTILIZATION OF THE SUBSURFACE DISPOSAL AREA. TID-29329. (1977) 
Available from NTIS, PC A03/MF A01.

Six alternatives considered for disposal of nonroutine waste expected from decontamination and decommissioning and contaminated soil are: maximum use of space between pits at the Radioactive Waste Management Complex (RWMC); subsurface expansion adjacent to current disposal areas at the RWMC; multi-tiering waste within the RWMC; multi-tiering waste adjacent to the RWMC; subsurface disposal at other INEL disposal or storage sites; and subsurface disposal at Site 14. Evaluation of these six alternatives leads to two possible solutions which offer long-term potential. These are multi-tiering of waste on land adjacent to the RWMC and subsurface disposal at Site 14. Preliminary feasibility studies of these two methods are presented. Relative advantages and disadvantages of each are discussed. A recommended plan of action and time tables are given. The plan incorporates these two alternatives and a backup approach of multi-tiered storage within the Radioactive Waste Management Complex.

\section{SUBJECT CATEGORY: LLW; HLW}

ORIGIN: Defense

KEYWORDS: FEASIBILITY STUDIES; PLANNING; RADIOACTIVE WASTE DISPOSAL; RADIOACTIVE WASTE MANAGEMENT; UNDERGROUND DISPOSAL

\section{4}

Idaho National Engineering Laboratory, Waste Management Operations, Idaho Falls, ID

INEL SOLID RADIOACTIVE WASTE MANAGEMENT AREA. ERDA-1536; Final Environmental Impact Statement, Waste Management Operations, Idaho National Engineering Laboratory, ID, (pp. II-163 - II-179), 709 pp. (1977)

A good general description of the radioactive waste management facilities at INEL including the shallow land burial facility. Some data on waste characteristics are provided.

Several areas within the INEL boundries are or have been used for the storage and/or disposal, by burial, of radioactive wastes. One of these areas is the Radioactive Waste Management Complex (RWMC) which was initially established to handle the radioactive wastes generated by the laboratory. The RWMC is subdivided into the Subsurface Disposal Area, the Transuranic Disposal Area and the Transuranic Storage Area. The Subsurface Disposal Area (SDA) is an 88 acre section used for the burial of nontransuranic radioactive wastes. These wastes are disposed of in trenches or pits. The trenches average about $900 \mathrm{ft}$ in length, $6 \mathrm{ft}$ in width and $12 \mathrm{ft}$ deep. Prior to 1974, most of the onsite solid low-level radioactive wastes were packaged in $12 \mathrm{cu}$ $\mathrm{ft}$ carboard boxes prior to burial. The wastes were compressed while in the trench. Since 1974 the waste is packaged in fiberboard boxes. Pits are on the average, $12 \mathrm{ft}$ deep, $100 \mathrm{ft}$ wide and of various lengths. These pits handle bulky irregular sized wastes. During 1974, over 18,000 curies of activity were disposed of at the SDA. Of this activity approximately $17.8 \%$ was identified as mixed fission products, $42.6 \%$ was attributed to $\mathrm{Co} 60,8.8 \%$ was $\mathrm{Sr} 90$, and $7.9 \%$ as Cs 137 . The total activity of waste disposed of at the RWMC during the period 1952 to 1974 is $5.978 \times 10(\mathrm{E}+6)$ curies with a volume of $4.99 \times 10(E+6)$ cuhic feet. Additional descriptions and data on the SL1 Burial Ground, the ICPP Calcined Solid Storage Facilities and the ANL Radioactive Scrap Waste Facility are provided.

SUBJECT CATEGORY: TRU; LLW

ORIGIN: Defense

KEYWORDS: PACKAGING; VOLUME; RADIOACTIVE WASTE MANAGEMENT; RADIOACTIVE WASTE STORAGE; SOLID WASTES; LOWLEVEL RADIOACTIVE WASTES; TRANSURANIUM ELEMENTS; GROUND DISPOSAL; INVENTORIES; FISSION PRODUCTS; COBALT 60; STRONTIUM 90; CESIUM 137

\section{5}

Weinberg, A.M.; Institute for Energy Analysis, Oak Ridge, TN

TO BREED, OR NOT TO BREED. Across the Board 14(9):4-12, 14-24. (1977)

Dr. Weinberg, reviewing the development of nuclear energy since his involvement in the Manhattan Projest that hegan in 1942, describes the golden vision that saw the transition to a second phase of unlimited energy provided by breeder reactors. He explains in depth the problem of the self-limiting nature of uranium-based technology and the present dependence on uranium-235-fueled light water reactors. Breeder reactors capable of fueling an expanding nuclear industry are fueled by the moreplentiful uranium 238. The ability of the breeder reactor to produce more energy and eliminate resource uncertainty was assumed to make it more 
cost-effective and to justify a larger capital investment. Dr. Weinberg gives a general description of breeder research programs, followed by a discussion of the major issues of opponents: proliferation, waste disposal, toxicity, reactor safety, and economics. Recognizing the dilemma entailed, he outlines five steps for proceeding with Phase II. These would involve limiting the land area committed to radioactive operations, restructuring the nuclear industry, imposing heavy security, training a professional cadre, and insuring immortality to the responsible institutions.

\section{SUBJECT CATEGORY: HLW; TRU}

ORIGIN: Commercial

KEYWORDS: BREEDER REACTORS; COST BENEFIT ANALYSIS; ECONOMICS; ENERGY POLICY; ENERGY SUPPLIES; - ENVIRONMENTAL IMPACTS; FOREIGN POLICY; MANAGEMENT; NUCLEAR ENERGY; NUCLEAR FACILITIES; NUCLEAR FUELS; NUCLEAR PARKS; NUCLEAR POWER PLANTS; PERSONNEL; PROLIFERATION; RADIOACTIVE WASTES; REACTOR SAFETY; REACTOR SITES; SECURITY; SOCIAL IMPACT

\section{6}

Bennett, L., R. Catlin, and V. Meckoni; International Atomic Energy Agency, Vienna, Austria

REGIONAL NUCLEAR FUEL CYCLE CENTERS STUDY PROJECT. CONF-770505-275; IAEA-CN-36/487; Nuclear Power and Its Fuel Cycles, Proceedings of an International Conference, Salzburg, Austria, May 2, 1977. International Atomic Energy Agency, Vienna, Austria. (1977)

\section{Available from NTIS PC A02/MF A01.}

The concept of regional fuel cycle centers (RFCC) has attracted wide interest. The concept was endorsed by many countries in discussions at the General Conference of the International Atomic Energy Agency and at the General Assembly of the United Nations. Accordingly, in 1975, the IAEA initiated a detailed study of the RFCC concept. The Agency study has concentrated on what is referred to as the "back-end" of the fuel cycle because that is the portion which is currently problematic. The study covers transport, storage, processing and recycle activities starting from the time the spent fuel leaves the reactor storage pools and through all steps until the recycled fuel is in finished fuel elements and shipped to the reactor. A detailed evaluation of the specific features of large regional fuel cycle centers established on a multinational basis vis-a-vis smaller dispersed fuel cycle facilities set up on a national basis has been carried out. The methodology for assessment of alternative strategies for fuel storage, reprocessing, and recycling of plutonium has been developed, characteristic data on material flows and cost factors have been generated, and an analytic system has been developed to carry out such evaluations including appropriate sensitivity analysis. Studies in related areas on institutional and legal, organizational, environmental, materials control and other essential aspects have also been made. The material developed during the course of this Study would enable any group of interested Member States to examine and work out alternative strategies pertinent to their present and projected nuclear fuel cycle needs, as well as evolve institutional, legal and other appropriate frameworks or agreements for the establishment of fuel cycle centers on a multinational cooperative basis.

SUBJECT CATEGORY: Fuel Cycle Centers

ORIGIN: Foreign

KEYWORDS: COMPARATIVE EVALUATIONS; FEASIBILITY STUDIES; FUEL CYCLE; FUEL FABRICATION PLANTS; FUEL REPROCESSING PLANTS; LEGAL ASPECTS; SPENT FUEL ELEMENTS; SPENT FUEL STORAGE; TRANSPORT

\section{7}

Dejonghe, P.; International Atomic Energy Agency, Vienna, Austria

RADIOACTIVE WASTE MANAGEMENT IN BELGIUM. CONF-770505-215; IAEA-CN-36/187; BNWL-tr-264; Nuclear Power and Its Fuel Cycles, Proceedings of an International Conference, Salzburg, Austria, May 2, 1977. (1977)

In French; 4 figures; available from NTIS, PC A02/MF A01.

In 1975 the research association BELGOWASTE was founded in order to prepare a technical and administrative plan for radioactive waste management in Belgium and to take the preliminary steps for establishing an organization which would be responsible for this activity. The association made a survey of all forecasts concerning radioactive waste production by power reacturs and the fuel cycle industry based on various schemes of development 
of the nuclear industry. From the technical point of view, the reference plan for waste management envisages: Purification at the production site of large volumes of low-level effluents; construction of a central facility for the treatment and intermediate storage of process concentrates (slurries, resins, etc.) and medium-level waste; centralization assumes the making of adequate arrangements for transporting waste before final treatment; maximum recovery of plutonium from waste and treatment of resiudal material by incineration at very high temperatures; treatment at the production site of high-level effluents from irradiated fuel reprocessing; construction of an underground longterm storage site for high-level treated waste and plutonium fuel fabrication waste; deep clay formations are at present preferred; disposal of low-level treated waste into the Atlantic ocean. It is intended to entrust the entire responsibility for treatment, disposal and storage of treated waste to a single body with participation by the State, the Nuclear Energy Research Centre (CEN/SCK), the electricity companies and Belgonucleaire. The partners intend to set up their facilities and services in the area of Mol.

SUBJECT CATEGORY: General

ORIGIN: Foreign

KEYWORDS: BELGIUM; FORECASTING; GEOLOGIC DEPOSITS; INCINERATORS; INVENTORIES; LIQUID WASTES; RADIOACTIVE WASTE MANAGEMENT; RADIOACTIVE WASTE STORAGE; SOLID WASTES; WASTE PROCESSING

\section{8}

Dolgov, V.V., B.S. Kolychev, A.A. Konstantinovich, V.V. Kulichenko, B.V. Nikipelov, A.S. Nikiforov, Y.P. Martynov, S.N. Oziraner, V.M. Sedov, and V.G. Shatsillo; International Atomic Energy Agency, Vienna, Austria

DEVELOPMENT OF METHODS FOR SOLIDIFICATION AND DISPOSAL OF FUEL CYCLE RADIOACTIVE WASTES. CONF. 770505-225; IAEA-CN-36/350; Nuclear Power and Its Fuel Cycles, Proceedings of an International Conference, Salzburg, Austria, May 2, 1977. (1977)

In Russian; 3.2.-1.2./08; Available from NTIS (US Sales Only), PC A03/MF A01.

The report deals with methods for disposal of radioactive wastes from reprocessing plants. Appa- ratuses and flow-sheets developed in the USSR for solidification of low-and intermediate-level wastes are discussed. The main research and developement results on the high-level waste treatment by two methods are presented. The first method comprises production of vitreous materials in an electric furnace without pre-calcination. The second one involves pre-dehydration and calcination of liquid wastes in a fluidized bed facility followed by vitrification in a ceramic crucible. Processes for the intermediate-level wastes solidification are also discussed. The study of behaviour of various solidified wastes (vitreous, bitumenized, etc.) in storage has allowed the disposal conditions to be developed. The paper considers the design of storages located directly at fuel reprocessing plants. The main technical and economic data are given on the solidification and storage processes for solids.

SUBJECT CATEGORY: Isolation

ORIGIN: Foreign

KEYWORDS: CALCINATION; COMPARATIVE EVALUATIONS; ECONOMICS; FUEL CYCLE; FUEL REPROCESSING PLANTS; RADIOACTIVE WASTE DISPOSAL; RADIOACTIVE WASTE FACILITIES; RADIOACTIVE WASTE PROCESSING; SOLIDIFICATION; VITRIFICATION; WASTE PROCESSING

\section{9}

Dolle, L., C. Bernard, J. Bazin, P. Miquel, and M. Briec; International Atomis knergy Agensy, Vienna, Austria

TRITIUM FORMATION AND ELIMINATION IN LIGHT-WATER ELECTRONUCLEAR PLANTS. CONF-770505-165; IAEA-CN-36/238; On Nuclear Power and Its Fuel Cycles, Proceedings of an International Conference, Salzburg, Austria, May 2, 1977. (1977)

In French; 4 figures; Availahle from NTIS PC A02/MF A01.

In light-waler resclors, the tritium balunce slivuld be considered from both the working constraint and environmental pollution aspects. In light-water electronuclear stations with pressurized reactors using boric acid in solution for reactivity control, the amounts of tritium formed in the primary circuit are worthy of note. The estimations concerning the tritium production in a hypothetical $1000 \mathrm{MWe}$ reactor are discussed. In the tritium build-up, the part which takes the tritium formed by fission in the 
fuel, owing to diffusion through cladding, is still difficult to estimate. The tritium balance in different working nuclear power stations are consequently of interest. But the tritium produced by ternary fission in the fuel is always much more abundant, and remains almost entirely confined in the uranium oxide if the fuel is clad with zircaloy. The annual quantity stored in the fuel elements is more than 20 times larger than that of the built up free tritium in the primary circuit water of a reactor. It reaches about $12,400 \mathrm{Ci}$ in the hypothetical reactor. In the presently operated reprocessing plants, tritium is all going over in the effluents, and is almost entirely released in the environment. Taking into account the increasing quantities of high irradiated fuel to be reprocessed, it seems necessary to develop separation processes. Development work and tests have been achieved jointly by CEA and SAINTGOBAIN TECHNIQUES NOUVELLES in order to: contain the tritium in the high activity part of the plant; and keep small the tritiated effluent volume, about 300 liters per ton of reprocessed uranium. It is then possible to envisage a storage for decay of isotopic separation processes. Such separation processes have been estimated by CEA assuming a daily output of 1500 liters of water containing 2,3 Ci.1\$sup - $1 \$$ of tritium, the desired decontamination factor being 100 .

\section{SUBJECT CATEGORY: LLW}

ORIGIN: Foreign

KEYWORDS: INVENTORIES; PRIMARY COOLANT CIRCUITS; PWR TYPE REACTORS; RADIONUCLIDE MIGRATION; REMOVAL; TRITIUM

\section{0}

Guillet, H., R. Delayre, J.C. Mougniot, and A. Ferrari; International Atomic Energy Agency, Vienna, Austria

USE OF PLUTONIUM RAPIDES SURREGENERATEURS ASPECTS TECHNIQUES ET ECONOMIQUES. CONF-770505-251; IAEA$\mathrm{CN}-36 / 570$; International Conference on Nuclear Power and its Fuel Cycles, Salzburg, Austria, May 2, 1977. (1977)

In French; Available from NTIS (US Sales Only), PC A02/MF A01. 2.5.-T.2./03 Also available in English

Nuclear energy production utilizing $U 235$ and $U$ 238 inevitably results in the formation of plutonium.
Some of this is directly used by the reactor in power production. Some reactors, e.g. the Candu type, burn most of their plutonium "in situ". However the surplus quantity of plutonium produced is increasing, and by 1990 the world stock of plutonium is predicted to be about 1000 tons (300 tons in Europe and 400 in the USA). This represents approximately $0.1 \mathrm{Q}$ of potential power, where $\mathrm{Q}=10(\mathrm{E}+21)$ joules. Proposals for dealing with this plutonium include its storage, either as irradiated fuel or as a refined substance (plutonium nitrate or oxide); its use in thermal reactors as a substitute for $U 235$; its use in fast breeder reactors which can act as consumers of plutonium as well as producers and which can therefore regulate the world's plutonium stocks. Leaving aside the question of storage, certain technical conditions must be fulfilled. It is essential that reprocessing plants should be operational and available in adequate numbers. An industry able to make use of plutonium should be developed with large capacity units. There seem to be no problems with plutonium use in reactors. Experience acquired during the past ten years permits us to deal with the safety and safeguards problem of using plutonium. Many economic questions remain, however, including questions affecting the utilization of plutonium, such as the cost of regenerating irradiated fuel and of making fuel, and questions affecting the strategy of using plutonium in different ways, such as the price at which it should be sold. Also the cost of producing electricity using plutonium is not yet clear. It is unavoidable that plutonium will be used in nuclear power development. The technical and economic problems may be specific and sometimes difficult, but can be solved.

SUBJECT CATEGORY: TRU; HLW

ORIGIN: Foreign

KEYWORDS: COST; FAST REACTORS; FBR 'TYYE REACTORS; FUEL CYCLE; NUCLEAR MATERIALS MANAGEMENT; PLUTONIUM; PLUTONIUM RECYCLE; REPROCESSING; SPENT FUEL STORAGE; THERMAL REACTORS

891

Hagen, M.; International Atomic Energy Agency, Vienna, Austria

FUEL CYCLE CENTERS. CONF-770505-18; IAEA-CN-36/97; Nuclear Power and its Fuel Cycles, Proceedings of an International Conference, Salzburg, Austria, May 2, 1977. (1977) 
Available from NTIS (US Sales Only), PC A02/MF A01.

The concept of co-locating and integrating fuel cycle facilities at one site is discussed. This concept offers considerable advantages, especially in minimizing the amount of radioactive material to be transported on public roads. Safeguards and physical protection as relating to such an integrated system of facilities are analyzed in detail, also industrial and commercial questions. An overall risk-benefit evaluation turns out to be in favor of fuel cycle centers. These centers seem to be specifically attractive with regard to the back end of the fuel cycle, including on-site disposal of radioactive wastes. The respective German approach is presented as an example. Special emphasis is given to the site selection procedures in this case. Time scale and cost for the implementation of this concept are important factors to be looked at. Since participation of governmental institutions in these centers seems to be indispensable their respective roles as compared with industry must be clearly defined. The idea of adjusting fuel cycle centers to regional rather than national use might be an attractive option, depending on the specific parameters in the region, though results of existing multinational ventures are inconclusive in this respect. Major difficulties might be expected e.g. because of different national safety regulations and standards as well as commercial conditions among partner countries. Public acceptance in the host country seems to be another stumbling block for the realization of this type of multinational facilities.

SUBJECT CATEGORY: Fuel Cycle Centers

\section{ORIGIN: Foreign}

KEYWORDS: COST; FEASIBILITY STUDIES; FUEL CYCLE; FUEL FABRICATION PLANTS; FUEL REPROCESSING PLANTS; INTERNATIONAL COOPERATION; NUCLEAR MATERIALS MANAGEMENT; NUCLEAR PARKS; PHYSICAL PROTECTION DEVICES; RADIOACTIVE WASTE DISPOSAL; RADIOACTIVE WASTE FACILITIES; RADIOACTIVE WASTE PROCESSING; RADIOACTIVE WASTE STORAGE; RADIOACTIVE WASTES; REPROCESSING; SAFEGUARDS

\section{2}

Lopez Perez, B., L. Ramos Salvador, and A. Martines Martinez; International Atomic Energy Agency, Vienna, Austria
SPANISH PROGRAM ON DISPOSAL OF RADIOACTIVE WASTES. CONF-770505-230; IAEA-CN-36/206; Nuclear Power and its Fuel Cycles, Proceedings of a International Conference, Salzburg, Austria, May 2, 1977. (1977)

In Spanish; 3.2.-.T.1./06; available from NTIS (US Sales Only), PC A02/MF A01.

The Spanish Energetic Program assumes an installed nuclear electrical power of $23.000 \mathrm{MWe}$ by the year 1985. Therefore, Spain is making an effort in the managment of radioactive wastes, that can be synthesized in the following points: 1 .- Make-up and review of the regulation on the management of radioactive wastes. 2.- Development of the processes and equipment for the treatment of solid, liquid and gaseous wastes from the CNEN "Juan Vigon", as well as those from the Nuclear Center of Soria. Solidification studies of RAA wastes arisen from the reprocessing. 3.- Evaluation of radioactive waste treatment systems of the new installed nuclear power plants. Assistance to the nuclear and radioactive facilities operators. 4.- Increase the storage capacity of the pilot repository for solid radioactive wastes of categories 1 and 2 IAEA, located in Sierra Albarrana. Studies of adequate geological formation for storage of solid wastes of IAEA categories 3 and 4. 5.-Studies about long term surface storage systems for solidified RAA wastes arisen from the reprocessing.

SUBJECT CATEGORY: HLW; LLW

ORIGIN: Foreign

KEYWORDS: FORFCASTING; TASEOIIS WASTES; LIQUID WASTES; PLANNING; RADIOACTIVE WASTE DISPOSAL; RADIOACTIVE WASTE MANAGEMENT; RADIOACTIVE WASTE STORAGE; REPROCESSING; SOLID WASTES; SPAIN; UNDERGROUND DISPOSAL; GROUND DISPOSAL

\section{3}

Marcus, F.R., and F. Seynaeve; International Atomic Energy Agency, Vienna, Austria

INDUSTRIAL ASPECTS OF RADIOACTIVE WASTE MANAGEMENT IN WESTERN EUROPE. CONF-770505-288; IAEA-CN-36/8; Nuclear Power and its Fuel Cycles, Proceedings of an International Conference, Salzburg, Austria, May 2,1977 . (1977) 
Available from NTIS (US Sales Only), PC A02/MF A01. 6 Tables

In 1980 there will be about 120 nuclear power reactors with 70,000 MWe in operation in Western Europe, and this number will be doubled by 1985 , when the nuclear capacity in operation is expected to be $180,000 \mathrm{MWe}$. Predictions are made of the waste management requirements resulting from this nuclear expansion. Until a few years ago waste from nuclear research and from the use of isotopes in medicine has been the dominating source. Now there is a much larger proportion from the day to day operation of nuclear power reactors. Waste amounts from reprocessing of spent reactor fuel will rise more slowly. Waste production in other fuel cycle industries is relatively insignificant. There will be around 30 reactors and other nuclear plants to take out of operation in Western Europe around 1990. The large-scale handling of these wastes calls for overall management schemes, based on clear policies for storage and disposal. Questions are identified which have to be answered within the next few years in order to allow the orderly development of such large-scale waste management. These questions deal with: (i) rules and regulations, (ii) new technical evidence, (iii) administrative frameworks and responsibilities. Several areas of waste management are well suited to commercial waste operating firms, already established at present in a number of European countries. The scope for waste operators may include waste transportation, operating of own or government owned treatment and storage installations, and the carrying out of disposal operations. In the paper, development needs originally suggested by the Foratom waste study group will be discussed in the light of a late 1976 review to be carried through by European industry.

SUBJECT CATEGORY: LLW; HLW; TRU

ORIGIN: Foreign

KEYWORDS: ECONOMICS; ENERGY POLICY; EUROPE; FORECASTING; PLANNING; RADIOACTIVE WASTE DISPOSAL; RADIOACTIVE WASTE FACILITIES; RADIOACTIVE WASTE MANAGEMENT; RADIOACTIVE WASTE STORAGE; RECOMMENDATIONS; REGULATIONS; WASTE TRANSPORTATION

894

Meckoni, V., R. Catlin, and L.L. Bennett; International Atomic Energy Agency, Vienna, Austria
REGIONAL NUCLEAR FUEL CYCLE CENTRES: IAEA STUDY PROJECT. Energy Policy 5(4):267-281; Nuclear Power and its Fuel Cycle, Proceedings of an International Conference, Salzburg, Austria, May 2-13, 1977; IAEA-CN36/487. (1977)

There is an increasing need for detailed planning of the entire nuclear fuel cycle, especially with regard to storage and reprocessing of spent fuel, and subsequent recycling of recovered fissionable materials. The Study Project on Regional Nuclear Fuel Cycle Centres (RFCC) was initiated by the International Atomic Energy Agency (IAEA) in 1975 to examine the economic, safety, safeguards, and security aspects of a multinational rather than wholly national approach to planning and establishment of nuclear fuel cycle facilities, and to develop a methodology for member states to evaluate alternative strategies and make joint decisions to meet their fuel cycle requirements. The primary objective of the study was to evaluate the relative merits and drawbacks of multinational fuel cycle centres versus national facilities, taking into account the quantities of spent fuel expected to be removed from power reactors over the next 25 years. One of the project's aims was to provide a forum in which interested countries and other entities could work out alternative strategies pertinent to their present and projected nuclear fuel cycle needs, as well as develop appropriate legal, institutional and organizational arrangements for multinational fuel cycle centres.

SUBJECT CATEGORY: Fuel Cycle Centers

ORIGIN: Foreign

KEYWORDS: ECONOMICS; ENERGY FACILITIES; EVALUATION; FISSIONABLE MATERIALS; FUEL CYCLE; IAEA; INTERNATIONAL AGREEMENTS; INTERNATIONAL COOPERATION; NUCLEAR FACILITIES; NUCLEAR FU. ELS; ORGANIZING; PLANNING; PROLIFERATION; RADIOACTIVE WASTE MANAGEMENT; RECYCLING; REGULATIONS; REPROCESSING; SAFETY; SECURITY

\section{5}

Smiley, S.H., and K.M. Black; International Atomic Energy Agency, Vienna, Austria

LARGE-SCALE FUEL CYCLE CENTERS. CONF-770505-348; IAEA-CN-36/562; Nuclear Power and Its Fuel Cycles, Proceedings of an 
International Conference, Salzburg, Austria, May 2, 1977: (1977)

Available from NTIS (US Sales Only), PC A02/MF A01; 2.9-T.1./02

The United States Nuclear Regulatory Commission (NRC) has considered the nuclear energy center concept for fuel cycle plants in the Nuclear Energy Center Site Survey. For the study, NRC defined fuel cycle centers to consist of fuel reprocessing and mixed oxide fuel fabrication plants, and optional high-level waste and transuranic waste management facilities. A range of fuel cycle center sizes corresponded to the fuel throughput of power plants with a total capacity of $30,0000-300,000 \mathrm{MWe}$. Siting of fuel cycle centers presents a considerably smaller problem than the siting of reactors. Some construction economies may be attainable with fuel cycle centers; such centers offer opportunities for improved waste management systems. Combined centers consisting of reactors and fuel reprocessing and mixed oxide fuel fabrication plants were also studied.

SUBJECT CATEGORY: Fuel Cycle Centers

ORIGIN: Foreign

KEYWORDS: FEASIBILITY STUDIES; FUEL CYCLE: FUEL FABRICATION PLANTS; FUEL REPROCESSING PLANTS; NUCLEAR PARKS; NUCLEAR POWER PLANTS; RADIOACTIVE WASTE FACILITIES; SITE SELECTION; USA

\section{6}

Stefanovic. D., P. Strugar, M.V. Matausek, J. PopJordanov, D. Popovic, M. Copic, and Z. Gabrovsek; International Atomic Energy Agency, Vienna, Austria

\section{NUCLEAR FUEL CYCLE FOR RESEARCH AND POWER REACTORS. . (1977)}

Estimating the optimal nuclear fuel management and $\mathrm{Pu}$ recycling strategy in power reactors or in research reactors of higher power, and the practical realization of this management, are the important tasks in the nuclear power programme realization. This is particularly true for developing countries, which buy their first reactors and nuclear fuel and thus have an open fuel cycle. This paper deals with some basic problems to be solved by a developing country, wishing to control and rule its nuclear fuel cycle. Particular attention is paid to the following topics: the use of fuel in power and research reactors in the first and the subsequent cores, economically preferable reprocessing strategy and the safeguard aspects of storing and transporting the spent fuel and the spent fuel materials.

SUBJECT CATEGORY: TRU; Spent Fuel

ORIGIN: Foreign

KEYWORDS: DEVELOPING COUNTRIES; ECONOMICS; FUEL CYCLE; NUCLEAR FUELS; POWER REACTORS; REPROCESSING; RESEARCH AND TEST REACTORS; SAFEGUARDS; SPENT FUEL ELEMENTS; SPENT FUELS

\section{7}

Vollradt, J.; International Atomic Energy Agency, Vienna, Austria

DECOMMISSIONING OF NUCLEAR POWER PLANTS. CONF-7709147-36; AED-CONF-77-498083; Construction and Operation Management of Nuclear Power, Proceedings of a Meeting, Karlsruhe, Germany, F.K., September 5, 1977. (1977)

Available from NTIS (US Sales Only), PC $\Lambda 02 / \mathrm{MF}$ A01.

A survey of the main questions of decommissioning of nuclear power plants will be given in the sight of German utilities (VDEW-Working group 'Stillegung'). The main topics are: 1) definitions of decommissioning, entombment, removal and combinations of such alternatives; 2) radionctive inventory (build up and decay); 3) experience up to now; 4) possibilities to dismantle are given by possibility to repair nuclear power plants; 5) Estimated costs, waste, occupational radiation dose; 6) German concept of decommissioning.

SUBJECT CATEGORY: Remedial Action, Surplus Facilities

ORIGIN: Foreign

KEYWORDS: COST; ENGINEERING; GERMAN FEDERAL REPUBLIC; NUCLEAR POWER PLANTS; RADIATION DOSES; RADIOACTIVITY; REACTOR DECOMMISSIONING; REACTOR DISMANTLING; REACTOR OPERATION

\section{8}

International Atomic Energy Agency, Vienna, Austria 
REGIONAL NUCLEAR FUEL CYCLE CENTRES. VOL. 1 - SUMMARY, 1977 REPORT OF THE IAEA STUDY PROJECT. STI/PUB/445(Vol.1); 127 pp. (1977)

The results of the study project on regional nuclear fuel cycle centers (RFCC) are very encouraging. Certain elements of this study, specifically nonproliferation considerations, waste management aspects, and economics have shown that there are advantages to be gained by the RFCC approach to fuel cycle activities in contrast to the alternative of states setting up their own smaller national plants. There are a number of reasons why different states may wish to encourage the formation of RFCCs or may wish to participate in a specific RFCC for their own requirement of fuel cycle services. Some of the important considerations which have been analysed in some depth in the course of this study project are reviewed.

SUBJECT CATEGORY: Fuel Cycle Centers

ORIGIN: Foreign

KEYWORDS: FUEL CYCLE; PROLIFERATION; RADIOACTIVE WASTE MANAGEMENT; REPROCESSING; ECONOMICS; FEED MATERIALS PRODUCTION CENTER; IAEA

\section{9}

International Atomic Energy Agency, Vienna, Austria

REGIONAL NUCLEAR FUEL CYCLE CENTRES. VOL. II. BASIC STUDIES, 1977 REPORT OF THE IAEA STUDY PROJECT. STI/PUB/445(Vol. 2); 309 pp. (1977)

In the Regional Nuclear Fuel Cycle Centres (RFCC) concept, a number of States would sponsor, by intergovernmental agreement, a multinational enterprise at a site carefully chosen on the basis of economic, non-proliferation and environmental considerations, and would agree in advance on the organizational structure and rules acceptable to them which would govern the RFCC. The RFCC concept is considered to be entirely flexible and an RFCC could thus be established by any group of Member States having mutual economic, gengraphical and/or socio-political interests. Therefore, this Study Project did not attempt to determine any actual regions or groupings of participants' countries. The Study Project developed basic studies on important areas related to the RFCC concept, such as non-proliferation and safeguards; nuclear material control; physical protection; institutional-legal arrangements; organization and administration; health, safety and environment; and general financing considerations. The Study examined the back-end of the fuel cycle and covered spent fuel transport, storage, reprocessing and recycle activities, starting from the time the spent fuel leaves the nuclear power reactor through all subsequent steps until recycled fuel, in the form of fuel elements, is ready for shipment to the reactor. Production of new uranium fuel and enrichment activities were not included, but the Study did include those activities involving management of radioactive wastes generated in the back-end of the fuel cycle, and extended storage of spent fuel.

SUBJECT CATEGORY: Fuel Cycle Centers; Spent Fuel

ORIGIN: Foreign

KEYWORDS: COST; ECONOMICS; ENVIRONMENTAL IMPACTS; FINANCING; FUEL CYCLE; LEGAL ASPECTS; MATHEMATICAL MODELS; MIXED OXIDE FUEL FABRICATION PLANTS; NUCLEAR FACILITIES; NUCLEAR MATERIALS MANAGEMENT; PHYSICAL PROTECTION DEVICES; PLANNING; RADIOACTIVE WASTE MANAGEMENT; REPROCESSING; SAFEGUARDS; SAFETY; SPENT FUEL STORAGE; SPENT FUELS; TRANSPORT

900

International Atomic Energy Agency, Vienna, Austria

COST DATA, ASSUMPTIONS, CONSTRAINTS AND OTHER FACTORS RELATED TO ECONOMIC ANALYSES: REGIONAL NUCLEAR FUEL CYCLE CENTRES.. Basic Studies, 1977 Report of the IAEA Study Project, Vol. 2. (1977)

Economic data on different features of fuel cycle are given (cost data for spent fuel management, fixed charge rates applied to investments, constraints).

SUBJECT CATEGORY: Fuel Cycle Centers

ORIGIN: Foreign

KEYWORDS: CAPITAL; COST; ECONOMICS; FINANCING; FUEL CYCLE; FUEL REPROCESSING PLANTS; INVESTMENT; MIXED OXIDE FUEL FABRICATION PLANTS; RADIOACTIVE WASTE MANAGEMENT; SPENT FUEL STORAGE; SPENT FUELS; NUCLEAR PARKS 
901

International Atomic Energy Agency, Vienna, Austria

ECONOMIC STUDIES AND COST EVALUATIONS: REGIONAL NUCLEAR FUEL CYCLE CENTRES. Basic Studies, 1977 Report of the IAEA Study Project, Vol. 2. (1977)

Economic studies on a model RFCC (Regional Nuclear Fuel Cycle Centre) having characteristics of those that might exist for actual RFCCs are presented. Economic results for spent fuel reprocessing, recycle, and waste management operations are derived:

SUBJECT CATEGORY: Fuel Cycle Centers

ORITIN: Fonreign

KEYWORDS: COST BENEFIT ANȦLYSIS; ECONOOMICS; FINANCING; FUEL CYCLE; FUEL REPROCESSING PLANTS; MATHEMATICAL MODELS; MIXED OXIDE FUEL FABRICATION PLANTS; OPTIMIZATION; RADIOACTIVE WASTE MANAGEMENT; SPENT FUEL STORAGE; NUCLEAR PARKS

\section{2}

International Atomic Energy Agency, Vienna, Austria

SPENT FUEL STORAGE: REGIONAL NUCLEAR FUEL CYCLE CENTRES. Basic Studies, 1977 Report of the IAEA Study Project, Vol. 2. (1977)

A general description of the Fuel Receiving and Storage Facility (FRSF), the purpose of the storage functions and their main aspects, as well as the estimated cost and schedules of an FRSF are discussed.

SUBJECT CATEGORY: Fuel Cycle Centers

ORIGIN: Foreign

KEYWORDS: COST; FORECASTING; INVESTMENT; NUCLEAR FACILITIES; SPENT FUEL STORAGE; STORAGE FACILITIES; NUCLEAR PARKS

\section{3}

International Atomic Energy Agency, Vienna, Austria
DESCRIPTION OF MATHEMATICAL MODELS AND COMPUTER PROGRAMS: REGIONAL NUCLEAR FUEL CYCLE CENTRES. Basic Studies, 1977 Report of the IAEA Study Project, Vol. 2. (1977)

The paper gives a description of mathematical models and computer programs for analysing possible strategies for spent fuel management, with emphasis on economic analysis. The computer programs developed, describe the material flows, facility construction schedules, capital investment schedules and operating costs for the facilities used in managing the spent fuel. The computer programs use a combination of simulation and optimization procedures for the economic analyses. Many of the fuel cycle steps (such as spent fuel discharges, storage at the reactor, and transport to the RFCC) are describod in phyoical and economic terms through simulation modeling, while others (such as reprocessing plant size and commissioning schedules, interim storage facility commissioning schedules etc.) are subjected to economic optimization procedures to determine the approximate lowestcost plans from among the available feasible alternatives.

SUBJECT CATEGORY: Fuel Cycle Centers

ORIGIN: Foreign

KEYWORDS: COMPUTER CALCULATIONON; COST; DYNAMIC PROGRAMMING; ECONOMICS; F CODES; FUEL CYCLE; FUEL REPROCESSING PLANTS; INVESTMENT; MANAGEMENT; MATHEMATICAL MODEI.S; MIXED UXIDE FUEL FABRICATION PLANTS; NUCLEAR MATERIALS MANAGEMENT; OPERATION; OPTIMIZATION; RADIOACTIVE WASTE FACILITIES; SIMULATION; SPENT FUEL STORAGE; SPENT FUELS; TRANSPORT; WASTE MANAGEMENT; NUCLEAR PARKS

904

International Atomic Energy Agency, Vienna, Austria

WASTE MANAGEMENT: REGIONAL NUCLEAR FUEL CYCLE CENTRES. Basic Studies, 1977 Report of the IAEA Study Project, Vol. 2. (1977)

This paper describes the waste management processes adopted for the purpose of the RFCC study, and the plants needed for handling and storage of the waste. Rather than present a detailed technical explanation of the processes, this description aims 
at discussing those aspects which appear in the model and which are of importance when colocation is weighed against individual local construction of plants serving the back-end of the fuel cycle. The input to the waste management part of the model is derived from the material flows from the other units at the RFCC. They are summarized for the spent fuel storage facility, for the reprocessing plant, and for the mixed oxide (MOX) fuel fabrication plant.

SUBJECT CATEGORY: Fuel Cycle Centers

ORIGIN: Foreign

KEYWORDS: COMPARATIVE EVALUATIONS; COST BENEFIT ANALYSIS; FUEL CYCLE; FUEL REPROCESSING PLANTS; MATHEMATICAL MODELS; MIXED OXIDE FUEL FABRICATION PLANTS; NUCLEAR MATERIALS MANAGEMENT; RADIOACTIVE WASTE DISPOSAL; RADIOACTIVE WASTE FACILITIES; RADIOACTIVE WASTE MANAGEMENT; RADIOACTIVF. WASTE PROCESSING; RADIOACTIVE WASTE STORAGE; SIMULATION; SPENT FUEL STORAGE; SPENT FUELS; WASTE TRANSPORTATION; NUCLEAR PARKS

905

International Atomic Energy Agency, Vienna, Austria

FUEL REPROCESSING: REGIONAL NUCLEAR FUEL CYCLE CENTRES. Basic Studies, 1977 Report of the IAEA Study Project, Vol. 2. (1977)

A report based on experience with fuel reprocessing is presented, containing technical and economical data. Characteristics of LWR and HWR spent fuels is given (table) and the reprocessing process and plant facilities are described. The different stages of the solvent extraction process are described more in detail and the flowsheet for a process based on Purex solvent extraction is given. Specifications on the uranyl nitrate and plutonium nitrate solutions and of end-product uranium oxides and plutonium oxides are given (tables). Radioactive wastes (gaseous, liquid and solid) generated during the reprocessing are considered and methods for their processing are discussed. Finally, cost estimates for construction and operation of fuel reprocessing plants are given.

SUBJECT CATEGORY: Fuel Cycle Centers
ORIGIN: Foreign

KEYWORDS: CONSTRUCTION; COST; DECONTAMINATION; FLOWSHEETS; FUEL REPROCESSING PLANTS; NUCLEAR MATERIALS MANAGEMENT; OPERATION; PLANNING; PLUTONIUM NITRATES; PLUTONIUM OXIDES; PUREX PROCESS; RADIOACTIVE WASTE PROCESSING; REPROCESSING; SOLVENT EXTRACTION; SPENT FUELS; URANIUM OXIDES; URANYL NITRATES; NUCLEAR PARKS

906

International Atomic Energy Agency, Vienna, Austria

MIXED OXIDE FUEL FABRICATION: REGIONAL NUCLEAR FUEL CYCLE CENTRES. Basic Studies, 1977 Report of the IAEA Study Project, Vol. 2. (1977)

This report describes present experience with plutonium recycling in thermal reactors and identifies a model facility and process, taking into account the current state of technology. The model facility is then costed and the information organized for use in the mathematical modeling of the total facility.

SUBJECT CATEGORY: Fuel Cycle Centers

ORIGIN: Foreign

KEYWORDS: CONSTRUCTION; COST; FUEL CYCLE; FUEL ELEMENTS; ISOTOPE RATIO; MIXED OXIDE FUEL FABRICATION PLANTS; OPERATION; PERSONNEL; PLANNING; PLUTONIUM; PLUTONIUM DIOXIDE; PRODUCTION; RADIOACTIVE WASTES; THERMAL REACTORS; URANIUM DIOXIDE; NUCLEAR PARKS

907

International Atomic Energy Agency, Vienna, Austria

TRANSPORT OF RADIOACTIVE MATERIALS: REGIONAL NUCLEAR FUEL CYCLE CENTRES. Basic Studies, 1977 Report of the IAEA Study Project, Vol. 2. (1977)

The study deals with the transfers and shipments of radioactive materials which will have to be moved 
to and from the RFCC. The relevant data needed as input to the mathematical model for the RFCC concept are given.

\section{SUBJECT CATEGORY: Fuel Cycle Centers}

ORIGIN: Foreign

KEYWORDS: CASKS; COST; FORECASTING; INVESTMENT; PLUTONIUM DIOXIDE; RADIOACTIVE WASTES; SPENT FUELS; TRANSPORT; WASTE TRANSPORTATION; NUCLEAR PARKS

\section{8}

International Atomic Energy Agency, Vienna, Austria

HEALTH, SAFETY, AND ENVIRONMENT: REGIONAL NUCLEAR FUEL CYCLE CENTRES. Basic Studies, 1977 Report of the IAEA Study Project, Vol. 2. (1977)

This part is concerned with the overall evaluation of the radiological and environmental aspects. It attempts to analyze problems such as: Does the establishment of a large regional center with colocated facilities for storage, reprocessing, fuel fabrication, and waste management create unacceptable radiological and environmental problems. If such a center can be safely designed and operated, what guidance could be given to Member States wishing to explore the potential of an RFCC. For such a venture, what are the key ingredients of an adequate program for the protection of workers and the environment under normal and emergency conditions. The approach has been taken of keeping as many parameters as possible constant while making a comparison between a multinational fuel cycle center and a smaller national fuel cycle center. The following two options are considered: a) A national fuel cycle center with a 100-600t/a reprocessing plant co-located with a 20-120t/a mixed oxide fuel fabrication plant. b) An RFCC with one or more 700-1500t/a reprocessing plants, a 125-300t/a mixed oxide fabrication plant and waste management facilities.

SUBJECT CATEGORY: Fuel Cycle Centers

ORIGIN: Foreign

KEYWORDS: COMPARATIVE EVALUATIONS; ENVIRONMENT; ENVIRONMENTAL IMPACTS; NUCLEAR PARKS; FEASIBILITY STUDIES; FUEL CYCLE; FUEL REPROCESS-
ING PLANTS; HEALTH HAZARDS; MIXED OXIDE FUEL FABRICATION PLANTS; RADIATION PROTECTION; RADIOACTIVE WASTE FACILITIES; RADIOACTIVE - WASTE PROCESSING; RADIOACTIVE WASTE STORAGE; SAFETY; SITE SELECTION; WASTE MANAGEMENT; WORKING CONDITIONS

\author{
909 \\ International Atomic Energy Agency, Vienna, \\ Austria
}

REGIONAL NUCLEAR FUEL CYCLE CENTRES. Summary, 1977 Report of the IAE $\Lambda$ Study Project. (1977)

The Study Project was initiated in 1975 to examine the economic, safety, sufeguards and security aspects of a multinational as opposed to wholly national nuclear fuel cycle approach, and to develop a methodology whereby Member States might make decisions together as appropriate in order to meet their fuel requirements. To cover the whole range of fuel cycle activities a number of basic studies were made and were synthesized in Vol. I.

SUBJECT CATEGORY: Fuel Cycle Centers

ORIGIN: Foreign

KEYWORDS: RESEARCH PROGRAMS; COST; ECONOMICS; FEASIBILITY STUDIES; FINANCING; FUEL CYCLE; IAEA; INTERNATIONAL COOPERATION; NON-PROLIFERATION 'I'REA'Y'Y; NULLL'AK MA'I'E'KIALS MIANAGEMENT; RADIOACTIVE WASTES; REGIONAL ANALYSIS; REPROCESSING; SAFEGUARDS; SPENT FUEL STORAGE; WASTE MANAGEMENT; NUCLEAR PARKS

\section{0}

Glauberman, H., and W.J. Manion; International Atomic Energy Agency, Vienna, Austria; Nuclear Energy Services, Inc., Danbury, CT; Energy Research and Development Administration, Washington, DC

TECHNICAL AND ECONOMIC ASPECTS OF NUCLEAR POWER PLANT DECOMMISSIONING. IAEA-CN-36/16; CONF- 770505-249; Nuclear Power and ito Fuel Cycles, Proceedings of an International Conference, Salzburg, Austria, May 2, 1977, 11 pp. (1977) 
Available from UNIPUB, Inc, P.O. Box 433, New York, NY; Also available from NTIS PC A02/MF A01; Atomindex citation 08:303858

Nuclear power plants may be decommissioned by one of three primary methods, namely, mothballing, entombing, or dismantling or by using combinations such as mothballing or entombing for a period of time followed by dismantling. Mothballing or entombing both result in an end-product which require surveillance and maintenance for a significant period of time to ensure protection of public health and safety. This paper discusses costs for each of the decommissioning methods, including factors that will influence the method selected as well as the total costs. Decommissioning costs have been estimated for a $1100 \mathrm{MW}(\mathrm{e})$ light water reactor within one year after shutdown following forty years of operation. The basic economic parameters for each decommissioning method were developed using unit cost factors based on known costs of previously decommissioned reactors. Decommissioning cost estimates range from less than four million dollars for mothballing to about forty million dollars for complete dismantling. Estimated cost of entombment is about ten million dollars. Subsequent annual cost of surveillance and maintenance for a reactor facility using the mothballing or entombment method could be as high as $\$ 200,000$. Although some tooling development will be needed for the removal of the highly activated reactor vessel segments and internals, technology is currently available and has been demonstrated on prior decommissionings, e.g., the BONUS and HALLUM reactor entombments and the Elk River Reactor complete dismantling. Costs associated with decommissioning are significant; however, allowance for them either as a one-time construction period sinking fund or annual depreciation type operating allowance will have little impact on either construction or operating costs.

SUBJECT CATEGORY: Remedial Action, FUSRAP; Remedial Action, Surplus Facilities

ORIGIN: Foreign; Commercial

KEYWORDS: NUCLEAR POWER PLANTS; REACTOR DECOMMISSIONING; COST; ECONOMICS; ENVIRONMENT; RADIATION PROTECTION; RADIOACTIVE WASTE DISPOSAL; REACTOR DISMANTLING

911

Fukuda, K., I. Nishizawa, K. Katsuyama, A. Matsumoto, and S. Sakata; Japan Atomic Energy Research Inst., Tokyo, Japan
BITUMINIZATION OF CHEMICAL SLUDGE AND EVAPORATION CONCENTRATE. JAERI-M-7373. (1977)

In Japanese; Available from NTIS (US Sales Only), PC A03/MF A01.

A batchwise bituminization system has been installed in 1973 to treat chemical sludge and evaporation concentrate. Volume reduction efficiency of both the wastes and characteristics of the system, and properties of the bitumen blocks were studied in cold and hot runs. Volume reduction ratios obtained for the sludge (about 6 wt\% solid content) and the concentrate (about $10 \mathrm{wt} \%$ solid content) were $1 / 11.4$ and more than $1 / 2$, respectively. Radioactivity in the condensate was about $1 / 10(E+5)$ that in the sludge cake, and about $1 / 5 \times 10(\mathrm{E}+4)$ that in the concentrate: Radioactivity entrained in the off-gas was about $1 / 10(E+7)$ of that in the sludge and about $1 / 10(E+6)$ that in the concentrate. As the ratio of sludge to bitumen, 40 $45 \mathrm{wt} \%$ was found to be appropriate both in liquidity and dispersibility of the bitumen, sludge mixture. The leaching rate of radioactivity from bitumen blocks in distilled water for about a year was about $0.01 \%$ for the bitumen block with the sludge and about $0.1 \%$ for the bitumen block with the concentrate, sludge.

SUBJECT CATEGORY: LLW

ORIGIN: Foreign

KEYWORDS: ASPHALTS; DECONTAMINATION; EFFICIENCY; EVAPORATION; LEACHING; PERFORMANCE; PILOT PLANTS; RADIOACTIVE WASTE PROCESSING; RADIOACTIVITY; SLURRIES; SOLIDIFICATION; VOLUME; BITUMENS; SLUDGES

912

Ikari, K. , and A. Matsumoto; Japan Atomic Energy Research Inst., Tokyo, Japan

QUANTITIES OF RADIOACTIVE WASTES FROM NUCLEAR FUEL CYCLE. Genshiryoku Kogyo 23(1):15.21. (1977)

In Japanese

Radioactive wastes result more or less from the nuclear fuel cycle of mining, refining, enrichment, fuel fabrication, power generation, and fuel reprocessing. The quantity generaled in each stage is obtained as the product of the quantity per unit 
operation and facility operation. These radioactive wastes are treated and disposed of so that they will not affect the livelihood environment of the humanity. Treatment is divided in two steps, i.e. volume reduction and packaging. The final amounts of radioactive waste packages can be calculated by the following procedure: setting up the suitable means of treatment for respective types of wastes, and multiplication of the volume reduction ratio and the volume increase ratio in packaging. Under the assumptions of fuel cycle, facility operation and waste treatment and on the basis of the up-to-date information, the quantities of radioactive waste packages up to A.D.2000 are estimated.

\section{SUBJECT CATEGORY: HLW; LLW}

ORIGIN: Foreign

KEYWORDS: FORECASTING; FUEL CYCLE; FUEL FABRICATION PLANTS; FUEL REPROCESSING PLANTS; NUCLEAR POWER PLANTS; PACKAGING; RADIOACTIVE WASTE DISPOSAL; RADIOACTIVE WASTE PROCESSING; RADIOACTIVE WASTES; SOLIDIFICATION; VOLUME

\section{3}

Kjellbert, N.; Kaernbraenslesaekerhet, Stockholm, Sweden

RADIONUCLIDE INVENTORIES IN PWR SPENT FUEL AND HIGH-LEVEL WASTE CALCULATED BY USE OF THE ORIGEN OODE. KBS-TR-01. (1977)

In Swedish; available from NTIS (US Sales Only), PC A04/MF A01.

Radionuclide inventories in PWR spent fuel and high-level waste have been computed. Apart from fission products and heavy nuclides the activation products emanating from the cladding have been included for the spent fuel case. As times-toreprocessing 1,3 , and 10 years of cooling have been used and the inventories have been calculated for times from 1 year through $10(E+7)$ years after shutdown. (Auth).

\section{SUBJECT CATEGORY: HLW; Spent Fuel}

ORIGIN: Foreign

KEYWORDS: COMPUTER CODES; HIGHLEVEL RADIOACTIVE WASTES; INVENTORIES; O CODES; PWR TYPE REACTORS; RADI-
OACTIVE WASTE PROCESSING; RADIOISOTOPES; REPROCESSING; SPENT FUELS; WASTE MANAGEMENT

914

Kaiser Engineers, Oakland, CA

COMPARISON OF SLAGGING PYROLYSIS AND MOLTEN SALT INCINERATORS FOR TREATING TRU WASTE AT THE INEL. TID-29095. (1977)

Available from NTIS, PC A03/MF A01.

For the comparioon, it is assumed that the waste product is required to mest the acceptance criteria of the Waste Isolation Pilot Plant, i.e., low leachability. Slagging pyrolysis incinerates combustible waste and melts noncombustible waste; the resulting slag forms a glass of low leachability. In the molten salt incinerator, combustion occurs at low temperatures with no accumulation of explosive gases, but the waste must have been previously sorted into combustibles and noncombustibles and then shredded. The economics, safety, and technical features are compared. Advantages, disadvantages, and areas of technical uncertainty of the two systems are listed. Development costs and schedules for the two types of incinerators are discussed.

SUBJECT CÁTEGORY: TRU

ORIGIN: Defense; Commercial

KEYWORDS: COMBUSTION; COMPARATIVE EVALUATIONS; COS'I; DESIGN; INCINERATORS; MOLTEN SALTS; PYROLYSIS; RADIOACTIVE WASTE PROCESSING; SLAGS; SOILS; TRANSURANIUM ELEMENTS

\section{5}

Mallek, H.; Kernforschungsanlage Juelich $\mathrm{GmbH}$, Germany, F.R.

TREATMENT AND PROCESSING OF CONTAMINATED FILTERS: SEMINAR ON HIGH EFFICIENCY AEROSOL FILTRATION IN THE NUCLEAR INDUSTRY. CONF-761145; High Efficiency Aerosol Filtration in the Nuclear Industry, Proceedings of a Seminar, Aix-enProvence, France, November 23, 1976. Commission of the European Communities, Luxembourg, Germany, F.R. (1977)

In German 
Preparation for storage constitutes an integral part of the costs of a filter used in radioactive areas. A filter prepared for storage should be considerably reduced in volume and should meet storage requirements which differ to some extent in the individual Lander. It is advisable to separate combustible and non-combustible components of the filter and to process them in different ways. The incineration of combustible components of a filter leads to a reduction in volume of up to $1: 100$. Non-combustible elements, in particular filter media, can be reduced in volume by compression by up to $1: 6$. For these reasons KFA Juelich (Federal Republic of Germany) uses, where possible, filters with a high proportion of combustible components. The processing methods and costs are discussed more fully in the paper.

\section{SUBJECT CATEGORY: LLW}

\section{ORIGIN: Foreign}

KEYWORDS: AIR FILTERS; CONTAMINATION; COST; GERMAN FEDERAL REPUBLIC; KERNFORSCHUNGSANLAGE JUELICH; RADIOACTIVE WASTE PROCESSING; RADIOACTIVE WASTE STORAGE

\section{6}

Inoue, Y., S. Morisawa, Y. Wadachi, K. Kato, and T. Kawano; Kyoto Univ., Japan

LAND DISPOSAL OF RADIOACTIVE WASTE. Nippon Genshiryoku Gakkaishi 19(12):822-829. (1977)

In Japanese

A report on the land disposal of radioactive waste is described by members of Research Committee on Radiological Safety for Ground Storage of Waste. Current situations on the land disposal of foreign countries and Japan are shown respectively. Policy of Japanese Government for the disposal is also presented with the lapse of time. In view of research and development, repository, packaging and cost estimate are discussed and particularly research items concerning the evaluation of internal radiation dose due to the disposal are indicated with radiological sense.

\section{SUBJECT CATEGORY: LLW}

ORIGIN: Foreign

KEYWORDS: COMPARATIVE EVALUATIONS; COST; FUNCTIONAL MODELS; JAPAN; LAND
USE; LEACHING; PACKAGING; RADIOACTIVE WASTE DISPOSAL; RADIOACTIVE WASTE STORAGE; RADIOACTIVE WASTES; REVIEWS; SAFETY; UNDERGROUND DISPOSAL

917

Smith, W.J., E.B. Fowler, and R.G. Stafford; Los Alamos Scientific Laboratory, Los Alamos, NM

EXPERIENCE IN THE CLEANUP OF PLUTONIUM-CONTAMINATED LAND. LA6731MS; 18 pp.; NTIS, PC A02/MF A01. (1977)

5 tables, 6 figures

During the summer of 1974 , two accidental releases from a radioactive liquid-waste line at the Los Alamos Scientific Laboratory (LASL) resulted in plutonium contamination of a small area of land, a portion of a laboratory parking lot, and a strip along an adjacent street. This report documents the immediate control actions and radiation surveys made in response to these leaks, and the subsequent exhumation and decontamination processes, including the physical operations, operational health physics, and soil sample analysis. The cost and results of the decontamination and restoration are also covered.

\section{SUBJECT CATEGORY: TRU}

ORIGIN: Defense

KEYWORDS: PLUTONIUM; LASL; CONTAMINATION; RADIOACTIVE WASTE DISPOSAL; COST; LEAKS; RADIATION ACCIDENTS; RADIATION PROTECTION; LIQUID WASTES; DECONTAMIN:ATION

\section{8}

Dangelmaier, P., and R. Lukes; Muenster University, Institute fuer Arbeits- und Wirtschaftsrecht, Muenster, Germany, F.R.

ECONOMICAL PROBLEMS IN CONNECTION WITH THE DECOMMISSIONING OF NUCLEAR FACILITIES. CONF-761257-; Fifth Symposium on Nuclear Law, Muenster, Germany, F.R., December 8, 1976. (1977)

In German; papers and discussions

Discussed are: basic questions of financing, to bring in the decommissioning costs with reference to the 
various types of enterprises, questions of taxes, use of the accumulated liquid means, the economy of nuclear facilities taking into account the decommissioning expenses.

SUBJECT CATEGORY: Remedial Action, Surplus Facilities

ORIGIN: Foreign

KEYWORDS: COST; ECONOMICS; FINANCING; NUCLEAR POWER PLANTS; REACTOR DECOMMISSIONING

\section{9}

Cagnetta, J.P.; Northeast Utilities Service Co., Hurtford, CT

SPENT FUEL STORAGE-UTILITY PERSPECTIVE. Transactions of the American Nuclear Society 26:254; Proceedings of the ANS Annual Meeting, New York, June 12-16, 1.977. (1.977)

Describes in detail the electric utilities actions to date in the storage of spent fuel and the future options open to the utilities.

SUBJECT CATEGORY: Spent Fuel

URIGIN: Commercial

KEYWORDS: ELECTRIC UTILITIES; SPENT FUEL STORAGE; FORECASTING

920

Woodhall, C.B.; Nuclear Assurance Corp., Atlanta, GA

\section{US LWR SPENT FUEL INVENTORY AND PROTECTION. Y/OWI/SUB-77/45200. (1977)}

Available from NTIS, PC A10/MF A01.

Information concerning discharged fuel characteristics for every US light water reactor (LWR) expected to operate and discharge fuel through 1986 is presented. These characteristics include: (1) the date, number of assemblies, and weight (Metric Tons of Heavy Metal-MTHM) of each projected discharge; (2) the batch average burnup, U-235 enrichment, total plutonium, and percent fissile plutonium for each projected discharge; and (3) the expected location of the discharged fuel.
SUBJECT CATEGORY: Spent Fuel

ORIGIN: Defense

KEYWORDS: BWR TYPE REACTORS; FORECASTING; INVENTORIES; PWR TYPE REACTORS; SPENT FUEL STORAGE; TABLES; USA; PLUTONIUM; WEIGHT; URANIUM 235

921

Nuclear Regulatory Commission, Office of Nuclear Material Safety and Safeguards, Washington, DC

DRAFT ENVIKUNMEN'T STATEMENT RELATED TO OPERATION OF MOAB URANIUM MIIL, GRAND COUNTY, UTAH. NU. REG-U341; LUC'KE'l'-403453-1. (1977)

Available from NTIS, PC A07/MF A01.

This draft environmental impact statement was prepared by the staff of the U.S. Nuclear Regulatory Commission and issued by the Commission's Office of Nuclear Material Safety and Safeguards. The proposed action is the continuation of Source Material License SUA-917 issued to Atlas Corporation for the operation of the Atlas Uranium Mill in Grand County, Utah, near Moab (Docket No. 403453). This authorizes a 600-tsn (450-MT) per day acid leach circuit (for recovery of vanadium as well as uranium) and a 600-ton (450-MT) per day alkaline leach circuit (for other ores, including copperbearing ores).

SUBJECT CATEGORY: General

ORIGIN: Commercial

KEYWORDS: BY-PRODUCTS; COPPER; ECONOMICS; ENVIRONMENTAL EFFECTS; ENVIRONMFNTAI IMPACTS; ENVIRONMENTAL TRANSPORT; FEED MATERIALS PLANTS; GASEOUS WASTES; LEACHING; MILL TAIL INGS; PRODUCTION; RADIOACTIVE EFFLUENTS; RADIOACTIVE WASTE STORAGE; RADIOACTIVITY; RADIUM; RADON; RECOVERY; SOCIO-ECONOMIC FACTURS; SURFACE AIR; URANIUM; URANIUM CONCENTRATES; URANIUM ORES; VANADIUM; WASTES

\section{2}

Cardile, F.P., M.J. Bell, F.C. Congel, W.L. Britz, and J.T. Collins; Nuclear Regulatory Commission, Office of Nuclear Reactor Regulation, Washington, DC 
COST-BENEFIT ANALYSIS REQUIREMENTS OF APPENDIX I TO 10 CFR PART 50: THEIR APPLICATION TO CERTAIN NUCLEAR POWER PLANTS DOCKETED BEFORE JANUARY 2,1971 , NU. REG-0389. (1977)

The NRC staff has performed a generic cost-benefit analysis for radwaste systems for BWRs and PWRs, whose applications for construction permits were docketed prior to January 2,1971 . This generic costbenefit analysis was performed to determine if there are potential augments which could be added, for a favorable cost-benefit ratio, to existing radwaste systems if the systems meet the design objectives set forth in RM 50-2. In doing this analysis, the staff reviewed radwaste systems currently proposed or installed, which are designed to satisfy design objectives similar to RM 50-2. Base case systems were chosen to represent the least amount of treatment of the systems the staff reviewed. The staff performed generic cost-benefit analysis for the base case systems at 3 reference sites; lake, river, and ocean site. The results of the analysis are presented.

SUBJECT CATEGORY: General

ORIGIN: Commercial

KEYWORDS: BWR TYPE REACTORS; COST BENEFIT ANALYSIS; PWR TYPE REACTORS; RADIOACTIVE WASTE PROCESSING; RADIOACTIVE WASTES; REGULATIONS

\section{3}

Scarano, R.A., and E.D. (Ed.) Harward; Nuclear Regulatory Commission, Washington, DC

CURRENT URANIUM MILL LICENSING ISSUES: METHODS FOR MEASURING RADIATION IN AND AROUND URANIUM MILLS. CONF-770581-; Methods for Measuring Radiation in and Around Uranium Mills, Proceedings of a Workshop, Albuquerque, NM, May 23, 1977. Atomic Industrial Forum, Inc., Washington, DC. (1977)

The problems encountered to insure envirnnmentally safe mining and milling of uranium ores are reviewed. Emphasis is placed on the management of tailings resulting from milling operations. It is pointed out that although the concentration of radioactivity in the tailings is relatively low, control measures are necessary because of the large quantities involved and because of the long half-life of the parent radionuclides present. The major concerns with mill tailings are radon release to the atmosphere and isolation of the tailings from the human environment. Since it is anticipated that the amount of tailings created by the year 2000 will be more than an order of magnitude greater than the quantities that have been generated during the past 30 years, it is recommended that all mill tailings storage areas be located remote from public contact and in areas such that disruption and dispersion by natural forces and seepage of toxic materials into ground water systems are reduced to the maximum extent achievable. Technical issues that receive attention during the NRC licensing process for uranium mills and the preparation of environmental impact statements are discussed briefly:

SUBJECT CATEGORY: Remedial Action, Mill Tailings

ORIGIN: Commercial

KEYWORDS: ALPHA PARTICLES; COST BENEFIT ANALYSIS; DAUGHTER PRODUCTS; ENVIRONMENTAL EFFECTS; ENVIRONMENTAL IMPACTS; ENVIRONMENTAL TRANSPORT; FEED MATERIALS PLANTS; GAMMA SOURCES; HEALTH HAZARDS; HUMAN POPULATIONS; LICENSING; MILL TAIL INGS; RADIATION PROTECTION; RADIOACTIVE WASTE MANAGEMENT; RADIOACTIVITY; RADON 222; RECOMMENDATIONS; SITE SELECTION; US NRC; URANIUM ORES

924

Nuclear Regulatory Commission, Washington, DC

NRC TASK FORCE REPORT ON REVIEW OF THE FEDERAL/STATE PROGRAM FOR THE REGULATION OF COMMERCIAL LOWLEVEL RADIOACTIVE WASTE BURIAL GROUND. NUREG-0217; 60 pp. (1977)

A review of the regulatory and legal concerns associated with the disposal of low-level radioactive waste. Directly applicable to low-level waste disposal.

This report is a general review of the programs conducted by the NRC and the various state governments to regulate the disposal of commercial low-level radioactive waste. The standards, criteria, and regulations concerning site selection, operation, monitoring, decommissioning, and post- 
operational maintenance are reviewed and deficiencies identified. The report projects that there is an adequate capacity available at the present sites to handle the volume of low-level radioactive waste generated to the year 1990 . The report concludes that (1) the present system for low-level waste management lacks national organization and direction; (2) at the present time, a comprehensive set of standards, criteria and regulations does not exist; and (3) a national plan must be developed to insure against the uncontrolled proliferation of sites. Alternatives to shallow land burial include, placement in deep geologic formations, in existing salt mines, disposal on ocean floors, hydraulic fracturing, disposal on-site (nuclear park) and retrievable engineered storage.

\section{SUBJECT CATEGORY; LLWW}

ORIGIN: Commercial

KEYWORDS: STANDARDS; FORECASTING; SITE SELECTION; MONITORING; DECOMMISSIONING; VOLUME; RADIOACTIVE WASTE MANAGEMENT; REGULATIONS; US NRC; GROUND DISPOSAL

\section{5}

Lieberman, J.A., W.A. Rodger, and F.P. Baranowski; Nuclear Safety Associates, Bethesda, MD

\section{HIGH-LEVEL WASTE MANAGEMENT.} NP-21978. (1977)

The testimony covered the following areas of waste management: research and development on waste disposal; permanent disposal of high-level waste; waste conditioning tecnhnology; packaging, storage, and transport; cost of waste disposal; risk assessment of the high-level waste management system; and institutional and policy issues.

\section{SUBJECT CATEGORY: HLW}

\author{
ORIGIN: Commercial; Defense
}

KEYWORDS: COST; RADIOACTIVE WASTE DISPOSAL; RADIOACTIVE WASTE MANAGEMENT; RADIOACTIVE WASTE PROCESSING; RADIOACTIVE WASTE STORAGE; TRANSPORT

\section{6}

Dyroff, H., F.K. Fleischmann, and H. Witte; Nuklear-Chemie und -Metallurgie GmbH (NUKEM), Hanau, Germany, F.R.
RADIOACTIVE WASTE IN THE FEDERAL REPUBLIC OF GERMANY: NUCLEAR POWER AND ITS FUEL CYCLE. VOL. 4. IAEA-CN-36/121; CONF-770505-; Nuclear Power and Its Fuel Cycles, Proceedings of an International conference, Salzburg, Austria, May 2, 1977. (1977)

From 1974 to 1976 a system study was made of radioactive waste in the Federal Republic of Germany. To this study, ordered by the Federal Ministry for Research and Technology and directed by NUKEM, members of the nuclear industry and Government research centres contributed. The results are presented in the paper. The growth of nuclear power and the corresponding nuclear industry, the development of research centres and of the other facilities involved, were projected up to 1990 and are presented with foreseeable trends up to the year 2000 . On the basis of this growth, the total amount of radioactive waste to be expected in the FRG through 1990-2000 is calculated and categorized according to physico-chemical and radiological properties and nuclide content. The state of technology and current $R$ and $D$ activities in the fields of interim storage, conditioning, transport and ultimate storage, and their usefulness for the establish. ment of a comprehensive waste-management system are described und discussed. Using these results as well as the present waste management situation and the general principles laid down by the Federal Guvernment, waste management systems fitted to tho requiromonto of the FRG arc drafted and examined with regard to technical feasibility, security and cost. The next step is to define a manugernent system, suited to the FRG, which could be realized by 1990-1995. A progrumme of action has been designed to implement this system; it contains particulars of facilities and commissioning dates as well as rough cost estimates. On the basis of the available technology, current $R$ and $D$ programmes, and the exigencies of the envisaged management system, an $K$ and $L$ programme, arranged in an order of urgency, is proposed. For an adequate assessment of the security of the recommended system and its component parts, a methodology of risk analysis was developed.

SUBJECT CATEGORY: General

ORIGIN: Foreign

KEYWORDS: COST; FEASIBILITY STUDIES; FORECASTING; GERMAN FEDERAL REPUBLIC; PLANNING; RADIOACTIVE WASTE MANAGEMENT; RADIOACTIVE WASTE PROCESSING; RADIOACTIVE WASTE STORAGE; RADIOACTIVE WASTES; SAFETY; TRANSPORT; VOLUME 


\section{7}

Klein, D., and H. Pirk; Nuklear-Chemie und Metallurgie GmbH, (NUKEM), Hanau, Germany, F.R.

PROJECT OF A CONTINUATION STORE FOR BURNED-UP FUEL ELEMENT FROM HIGH-TEMPERATURE REACTORS. Kerntechnik 19(4):180-187. (1977)

In English, German

The project described concerns the technical concept and preliminary design of a store for burned-up fuel elements of the thorium high-temperature reactor THTR-300 and the AVR pebbel bed reactor in Juelich and also absorber and moderator elements of the thorium high-temperature reactor THTR-300. The store is designed so that the afterheat of the fuel elements which is taken up with air in free convection can be passed through the cell walls to the atmosphere, that by geometrically safe arrangement of the fuel elements criticality safety is ensured and that sufficiently dimensioned shielding walls protect the operating personnel against ionizing radiation. The capacity is dimensioned for the storage of the fuel elements of the reactor accumulated over ten years of operation.

SUBJECT CATEGORY: Spent Fuel

ORIGIN: Foreign

KEYWORDS: AFTER-HEAT; AVR REACTOR; COST; CRITICALITY; FUEL POOLS; NATURAL CONVECTION; PLANNING; RADIOACTIVITY; SPENT FUEL STORAGE; THTR-300 REACTOR

928

Alexander, C.W., C.W. Kee, A.G. Croff, and J.O. Blomeke; Oak Ridge National Laboratory, Oak Ridge, TN

PROJECTIONS OF SPENT FUEL TO BE DISCHARGED BY THE U.S. NUCLEAR POWER INDUSTRY. ORNL/TM-6008; 85 pp. (1977)

\section{Available from NTIS, PC AO5/MF AO1}

Calculated properties of spent fuel projected to be discharged and accumulated by the U.S. nuclear power industry through the year 2031 A.D. are presented. The projections are based on installed nuclear capacities of 380 and $543 \mathrm{GW}(\mathrm{e})$ in the year 2000 and 2030 , respectively. They include compila- tions of the grams of the elements, curies of radioactivity, thermal decay power, photon and neutron emission rates, and radiotoxicities of the assemblies that are accumulated at a Spent Unreprocessed Fuel Facility (SURFF), allowing for delays of 5 and 10 years before shipment to SURFF.

SUBJECT CATEGORY: Spent Fuel

ORIGIN: Commercial

KEYWORDS: BWR TYPE REACTORS; FORECASTING; INVENTORIES; PWR TYPE REACTORS; SPENT FUEL STORAGE; SPENT FUELS

\section{9}

Blanco, R.E., R.C. Dahlman, W. Davis, Jr., B.C. Finney, W.S. Groenier, G.S. Hill, A.H. Kibbey, F.G. Kitts, R.B. Lindauer, and R.E. Moore; Oak Ridge National Laboratory, Oak Ridge, TN

COST/BENEFIT ANALYSIS OF METHODS FOR CONTROLLING THE RELEASE OF RADIOACTIVE MATERIALS IN THE NUCLEAR FUEL CYCLE. CONF-770505-276; IAEA-CN-36/429; Nuclear Power and Its Fuel Cycles, Proceedings of an International Conference, Salzburg, Austria, May 2, 1977. International Atomic Energy Agency, Vienna, Austria. (1977)

Cost/benefit surveys were made to determine the cost (in dollars) and effectiveness of radwaste treatment systems for decreasing the release of radioactive materials from model fuel cycle facilities, and to determine the benefits in terms of reduction in radiological dose commitment to individuals and populations in the surrounding areas. The studies include milling of uranium ores, conversion of virgin uranium and recycle uranium to UF\$sub $6 \$$, fabrication of light-water reactor (LWR) fuels containing enriched uranium or enriched uranium and plutonium, fabrication of high. temperature gas-cooled reactor (HTGR) fuels containing \$sup 233\$U and thorium, and reprocessing of LWR and HTGR fuels. Conceptual flowsheets were prepared for each model facility illustrating the treatment methods for gaseous and liquid effluents. The "base" case represents the lowest treatment cost, current treatment technology, and highest radiological dose. In succeeding cases, increasingly efficient radwaste treatment equipment is added to the "base" plant to reduce the amounts of radioactive materials released. The technology ranges from that currently available to that which may be developed over the next 30 years. The status of development for these technologies is 
discussed. The dose estimates are for maximum individual total body and organ doses at the plant boundary and for population total-body and organ doses out to $89 \mathrm{~km}$. Comparisons of the doses vs annual costs in dollars are presented. In summary, they indicate that (1) the annual doses can be reduced to very low fractions of the natural background dose by the successful development and application of the radwaste treatment methods; and (2) excluding mills, the capital costs for the treatment methods vary from 0.02 to $8 \%$ of the capital cost of the base plants and the total annual operating costs (fixed charges plus operating costs) vary from 0.009 to $7.0 \%$ of the capital costs for the plant.

SUBJECT CATEGORY: Airborne

ORIGIN: Commercial

KEYWORDS: BWR TYPE REACTORS; COST BENEFIT ANALYSIS; FEED MATERIALS PLANTS; FUEL CYCLE; FUEL FABRICATION PLANTS; FUEL REPROCESSING PLANTS; HTGR TYPE REACTORS; MILLING; NUCLEAR FACILITIES; PWR TYPE REACTORS; RADIOACTIVE EFFLUENTS; GASEOUS WASTES; URANIUM; RADIOACTIVE WASTE MANAGEMENT; ECONOMICS; RADIATION DOSES; DOSE COMMITMENTS

\section{0}

Croff, A.G., D.W. Tedder, J.P. Drago, J.O. Blomeke, and J.J. Perona; Oak Ridge National Laboratory, Oak Ridge, TN

PRELIMINARY ASSESSMENT OF PARTITIONING AND TRANSMUTATION AS A RADIOACTIVE WASTE MANAGEMENT CONCEPT. ORNL/TM-5808. (1977)

27 tables, 50 tigures

Partitioning (separating) the actinide elements from nuclear fuel cycle wastes and transmuting (burning) them to fission products in power reactors represents a potentially advanced concept of radioactive waste management which could reduce the long-term (greater than 1000 years) risk associated with geologic isolation of wastes. The greatest uncertainties lie in the chemical separations technology needed to recover greater than 99 percent of the actinides during the reprocessing of spent fuels and their refabrication as fresh fuels or target elements. Preliminary integrated flowsheets based on modifications of the Purex process and supplementary treatment by oxalate precipitation and ion exchange indicate that losses of plutonium in reprocessing wastes might be reduced from about 2.0 percent to 0.1 percent, uranium losses from about 1.7 percent to 0.1 percent, neptunium losses from 100 percent to about 1.2 percent, and americium and curium from 100 percent to about 0.5 percent. Mixed oxide fuel fabrication losses may be reduced from about 0.5 percent to 0.06 percent for plutonium and from 0.5 percent to 0.04 percent for uranium. Americium losses would be about 5.5 percent for the reference system. Transmutation of the partitioned actinides at a rate of 5 to 7 percent per year is feasible in both fast and thermal reactors, but additional studies are needed to determine the most suitable strategy for recycling them to reactors and to assess the major impacts of implementing the concept on fuel cycle operations and costs. It is recommended that the ongoing program to evaluate the feasibility, impacts, costs, and incentives of implementing partitioning-transmutation be continued until a firm assessment of its potentialities can be made. At the present level of effort, achievement of this objective should be possible by 1980.

SUBJECT CATEGORY: TRU

ORIGIN: Commercial

KEYWORDS: ACTINIDES; FEASIBILITY STUDIES; FLOWSHEETS; FUEL CYCLE; FUEL REPROCESSING PLANTS; LOSSES; MIXED OXIDE FUEL FABRICATION PLANTS; PUREX PROCESS; RADIOACTIVE WASTE MANAGEMENT; RADIOACTIVE WASIIE PROCESSING; SEPARATION PROCESSES; TRANSMUTA. TION

\section{1}

Hudson, C.R. II; Oak Ridge National Laboratory, Oak Ridge, 'I'N

NUCLEAR SHIPPING AND WASTE DISPOSAL COST ESTIMATES, ORNL/TM-5976: 22 pp. (1977)

Available from NTIS, PC A03/MF A01.

Cost estimates for the shipping of spent fuel from the reactor, shipping of waste from the reprocessing plant, and disposal of reprocessing plant wastes have been made for five reactor types. The reactors considered are the light-water reactor (LWR), the mixed-oxide-fueled light-water reactor (MOX), the 
Canadian deuterium-uranium reactor (CANDU), the fast breeder reactor (FBR), and the hightemperature gas-cooled reactor (HTGR). In addition to the cost estimates, this report provides details on the bases and assumptions used to develop the cost estimates.

SUBJECT CATEGORY: Transportation; Spent Fuel

ORIGIN: Commercial

KEYWORDS: BWR TYPE REACTORS; CANDU TYPE REACTORS; COST; LMFBR TYPE REAC. TORS; PWR TYPE REACTORS; RADIOACTIVE WASTE DISPOSAL; RADIOACTIVE WASTES; SPENT FUELS; TRANSPORT; WASTE TRANSPORTATION; REPROCESSING

\section{2}

Jacobs, D.G.; Oak Ridge National Laboratory, Oak Ridge, TN

\section{COST-BENEFIT ANALYSIS FOR MANAGE-} MENT OF LOW-LEVEL RADIOACTIVE WASTE. CONF-770512-8; Management of Low Level Radioactive Waste, Proceedings of a Symposium, Atlanta, GA, May 23, 1977. (1977)

Available from NTIS, PC A02/MF A01.

There are several types of cost-benefit analyses that can be used in evaluating a technical activity such as waste management. A direct comparison can be made of the benefits to be gained versus the costs to be accrued. If the balance is favorable, the activity is considered to be acceptable. In many cases, however, a number of alternatives may be available requiring a comparative cost-benefit analysis so that the most favorable option is chosen. After the basic option is chosen, a further analysis is required in which additional control technologies can be considered to further reduce specific types of impact; this represents a differential cost-benefit analysis or, perhaps more properly, a study of costeffectiveness. Also, because of the wide variety of parameters that go into a cost-benefit analysis and the range of value judgements that may be applied by different interest groups, it is likely that each additional increment of technology will have a slightly different balance point. Factors and impacts that need to be considered in management of low-level wastes will be discussed and a simplified example will be used to demonstrate the difficulties that may be encountered.
SUBJECT CATEGORY: LLW

ORIGIN: Commercial

KEYWORDS: COST BENEFIT ANALYSIS; ENVIRONMENTAL EFFECTS; LAND USE; MONITORING; RADIOACTIVE WASTE MANAGEMENT; RESOURCE CONSERVATION

933

Roddy, J.W., R.E. Blanco, B.C. Finney, G.S. Hill, R.E. Moore, and J.P. Witherspoon; Oak Ridge National Laboratory, Oak Ridge, TN

CORRELATION OF RADIOACTIVE WASTE TREATMENT COSTS AND THE ENVIRONMENTAL IMPACT OF WASTE EFFLUENTS IN THE NUCLEAR FUEL CYCLE: CONVERSION OF RECYCLE URANIUM TO UF 6. ORNL/NUREG/TM-37. (1977)

Available from NTIS, PC A07/MF A01; 34 tables, 11 figures

A cost/benefit study was made to determiine the cost and effectiveness of various radioactive waste (radwaste) treatment systems for decreasing the amount of radioactive materials released from a model recycle uranium conversion and uranium hexafluoride (UF 6) production plant and to determine the radiological impact (dose commitment) of the released radioactive materials on the environment. This study is designed to assist the US NRC in defining the term "as low as reasonably achievable" as it applies to these nuclear facilities. The base case model plant is representative of a licensable UF 6 production plant and has an annual capacity of 1500 metric tons of uranium. Additional radwaste treatment systems are added to the base case plant in a series of case studies to decrease the amounts of radioactive materials released and to reduce the radiological dose commitment to the population in the surrounding area. The cost for the added waste treatment operations and the corresponding dose commitments is calculated for each case. In the final analysis, radiological dose is plotted vs the annual cost for treatment of the radwastes. The status of the radwaste treatment methods used in the case studies is discussed. The methodology used in estimating the costs is presented.

SUBJECT CATEGORY: LLW; Airborne

ORIGIN: Commercial 
KEYWORDS: COST; COST BENEFIT ANALYSIS; ENVIRONMENTAL IMPACTS; FEED MATERIALS PLANTS; FUEL CYCLE; HUMAN POPULATIONS; NUCLEAR FACILITIES; RADIATION DOSES; RADIOACTIVE WASTE PROCESSING; URANIUM HEXAFLUORIDE; GASEOUS WASTES; DOSE COMMITMENTS

\section{4}

Sears, M.B., R.E. Blanco, B.C. Finney, G.S. Hill, R.E. Moore, and J.P. Witherspoon; Oak Ridge National Laboratory, Oak Ridge, TN

CORRELATION OF RADIOACTIVE WASTE TREATMENT COSTS AND THE ENVIRONMENTAL IMPACT OF WASTE EFFLUENTS IN THE NUCLEAR FUEL CYCLE - CONVERSION OF YELLOW CAKE TO URANIUM HEXAFLUORIDE. PART 1. THE FLUORINATION-FRACTIONATION PROCESS. ORNL/NUREG/TM-7; 305 pp. (1977)

A cost/benefit study was made to determine the cost and effectiveness of radioactive waste (radwaste) treatment systems for decreasing the release of radioactive materials and chemicals from a model uranium hexafluoride (UF6) production plant using the fluorination-fractionation (dry hydrofluor) process, and to evaluate the radiological impact (dose commitment) of the released materials on the environment. This study is designed to assist in defining the term "as low as is reasonable achievable" (ALARA) in relation to limiting the release of radioactive materials from nuclear facilities. The model plant processes 10,000 metric tons of uranium per year. Base-case waste treatment is the minimum necessary to operate the process. Effluents meet the radiological requirements listed in the Code of Federal Regulations, Title 10, Part 20 (10 CFR 20), Appendix B, Table II, but may not be acceptable chemically at all sites. Additional radwaste treatment techniques are applied to the base-case plant in a series of case studies to decrease the amounts of radioactive materials released and to reduce the radiological dose commitment to the population in the surrounding area. The costs for the added waste treatment operations and the corresponding dose commitment are calculated for each case. In the final analysis, radiological dose is plotted vs the annual cost for treatment of the radwastes. The status of the radwaste treatment methods used in the case studies is discussed. Much of the technology used in the advanced cases will require development and demonstration or else is proprietary and unavailable for immediate use. The methodology and assumptions for the radiological doses are found in ORNL 4992. (Auth)
SUBJECT CATEGORY: LLW; Airborne

ORIGIN: Commercial

KEYWORDS: COST BENEFIT ANALYSIS; URANIUM OXIDES; FRACTIONATION; URANIUM FLUORIDES; THORIUM 230; RADIUM 226; FUEL FABRICATION PLANTS; DOSE COMMITMENTS; RADIOACTIVE EFFLUENTS; RADIATION DOSES; HUMAN POPIIIATIONS; BONES; LUNGS; KIDNEYS; GASTROINTESTINAL TRACT; THYROID; MUSCLES; LIVER; SPLEEN; TESTES; OVARIES; COST; GASEOUS WASTES; DOSE COMMITMENTS

935

Spiewak, I.; Oak Ridge National Laboratory, Oak Ridge, TN

THORIUM ASSESSMENT STUDY QUARTERLY PROGRESS REPORT FOR FIRST QUARTER FISCAL 1977. (1977)

The objective of the program described is to contribute to the ongoing assessment of the potential role of thorium fuel cycles for alleviating safeguards concerns. Scenarios include (1) no fuel recycle permitted, (2) fuel recycle permitted only in secure regions ("energv parks") with denatured (chemically non-separable) fuels only outside these regions, and (3) no limits on fuel recycle. A further objective is to provide nuclear mass balance data on HTGRs required by ERDA contractors for comparative cost-benefit studies.

\section{SUBJECI' CATEGORY: Spent Fuel}

ORIGIN: Commercial; Defense

KEYWORDS: ECONOMICS; FUEL CYCLE; HTGR TYPE REACTORS; LMFBR TYPE REACTORS; PLANNING; PWR TYPE REACTORS; REPROCESSING; SAFEGUARDS; THORIUM; THORIUM 232; URANIUM 233; URANIUM 238; THORIUM CYCLE

\section{6}

Tamura, T., O.M. Sealand, and J.O. Duguid; Oak Ridge National Laboratory, Oak Ridge, TN

PRELIMINARY INVENTORY OF PU-239, PU-240, SR-90, AND CS-137 IN WASTE POND NO. 2 (3513). ORNL/TM-5802; 38 pp. (1977) 
Available from NTIS, PC A03/MF A01.

Preliminary inventory of the Pu 239, 240, Sr 90, and Cs 137 was made in Waste Pond No. 2 (Facility No. 3513) in preparation for decommissioning of the facility. Based on the activity in the recovered cores and the areal distribution of bottom sediments, the inventory of $\mathrm{Pu} 239,240$ was approximately $80 \mathrm{~g}$ equivalent to $5 \mathrm{Ci}$. The $\mathrm{Sr} 90$ inventory was $0.24 \mathrm{~g}$ equivalent to $33.6 \mathrm{Ci}$. The Cs 137 inventory was $2.3 \mathrm{~g}$ or $200 \mathrm{Ci}$. The least squares fit of the power curve $y=$ a $x$ /sup b/shows that significant relationship exists among the three nuclides in the pond. The coefficient of determination, $r(E+2)$, was 0.79 for Cs$\mathrm{Pu}, 0.84$ for $\mathrm{Sr}-\mathrm{Pu}$, and 0.81 for $\mathrm{Cs}-\mathrm{Sr}$. The regression lines were determined using all the data sets $(n=58)$; if three suspected points of the Cs-Pu plot are rejected, the $r(E+2)$ increases to 0.91 . Assumptions used to derive the inventory and the radionuclide relationships are discussed.

SUBJECT CATEGORY: Remedial Action, Surplus Facilities

ORIGIN: Defense

KEYWORDS: CESIUM 137; DECOMMISSIONING; INVENTORIES; PLUTONIUM 239; PLUTONIUM 240; PONDS; RADIOACTIVE WASTE DISPOSAL; STRONTIUM 90; FISSION PRODUCTS; SEDIMENTS

\section{7}

Weeren, H.O.; Oak Ridge National Laboratory, Oak Ridge, TN

WASTE DISPOSAL BY SHALE FRACTURING AT ORNL. CONF-770512-13; Management of Low Level Radioactive Waste, Proceedings of a Symposium, Atlanta, GA, May 23, 1977. (1977)

Available from NTIS, PC A02/MF A01.

The shale fracturing process is a method of waste disposal currently in use at ORNL for the permanent disposal of certain locally generated radioactive waste solutions. In this process, the waste solution is mixed with a solids blend of cement and other additives; the resulting grout is injected into an impermeable shale formation at a depth of 700 to $1000 \mathrm{ft}(200$ to $300 \mathrm{~m})$. A few hours after completion of the injection, the grout sets, fixing the radioactive waste in the shale formation. The operational experience with this process since 1966 , the monitoring techniques that have been developed, and some considerations of the impact on the environment are discussed.
SUBJECT CATEGORY: HLW; LLW

ORIGIN: Defense

KEYWORDS: CEMENTS; COST; ENVIRONMENTAL IMPACTS; HYDRAULIC FRACTURING; MONITORING; OPERATION; ORNL; RADIOACTIVE WASTE DISPOSAL; SAFETY; SHALES; UNDERGROUND DISPOSAL

938

Witherspoon, J.P., M.B. Sears, and R.E. Blanco; Oak Ridge National Laboratory, Oak Ridge, TN

RELEASES OF RADIOACTIVITY FROM URANIUM MILLS AND EFFLUENT TREATMENT COSTS. CONF-771109-63; Proceedings of the ANS Winter Meeting, San Francisco, CA, November 27, 1977; Transactions of the American Nuclear Society 27:151-152. (1977)

Stabilization of uranium mill tailings; Available from NTIS, PC A02/MF A01.

Airborne releases of radioactive materials from uranium milling to the environment consist of ore dust, yellowcake dust; tailings dust, and radon gas while the mill is active. After a mill has ceased operations, tailings may be stabilized to minimize or prevent airborne releases of radioactive particulates. However, radon gas will continue to be released in amounts inversely proportional to the degree of stabilization treatment (and expense). Liquid waste disposal is by evaporation and natural seepage to the ground beneath the tailings impoundment area. The release of radioactive materials (and potential radiation exposures) determines the majority of costs associated with minimizing the environmental impact of uranium milling. Radwaste treatments to reduce estimated radiation doses to individuals to 3 to $5 \%$ of those received with current milling practices are equivalent to $\$ 0.66$ per pounds of U3O8 and 0.032 mill per $\mathrm{kWhr}$ of electricity. This cost would cover a high efficiency reverse jet bag filter and high energy venturi scrubbers for dusts, neutralization of liquids, and an asphalt-lined tailings basin with a clay core dam to reduce seepage. In addition, this increased cost would cover stabilization of tailings, after mill closure, with a 1-in. asphalt membrane topped by 2 $\mathrm{ft}$ of earth and $0.5 \mathrm{ft}$ of crushed rock to provide protection against future leaching and wind erosion. The cost of reducing the radiological hazards associated with uranium milling to this degree would contribute about $0.4 \%$ to the current total cost of nuclear power. 
SUBJECT CATEGORY: Remedial Action, Mill Tailings; Airborne

ORIGIN: Commercial

KEYWORDS: AIR POLLUTION; COST BENEFIT ANALYSIS; ENVIRONMENT; ENVIRONMENTAL EFFECTS; ENVIRONMENTAL TRANSPORT; GASEOUS WASTES; HEALTH HAZARDS; HUMAN POPULATIONS; LIQUID WASTES; MILL TAILINGS; MILLING; RADIATION PROTECTION; RADIOACTIVE AEROSOLS; RADIOACTIVE EFFLUENTS; RADIOACTIVE WASTE STORAGE; RADIOACTIVITY; RADON; SOLID WASTES; STABILIZATION; IJRANIUM; COST

939

Oak Ridge National Laboratory, Oak Ridge, TN

WASTE MANAGEMENT: CHEMICAL TECHNOLOGY DIVISION ANNUAL PROGRESS REPORT FOR PERIOD ENDING MARCH 31, 1977. ORNL-5295, (pp. 5-9). (1977)

The following programs are reported: partitioning and transmutation, removal of radionuclides and nitrate from liquid waste streams, biological removal of organic contaminants and tritium from reprocessing effluent streams, fixation of wastes in concretes (leach tests were conducted), updating of ORIGEN code, and projections of wastes from nuclear fuel cycle (forecasts for year 2000).

SUBJECT CATEGORY: General

ORIGIN: Defense

KEYW.ORDS: COMPUTER CODES; CONCRETES; FORECASTING; FUEL CYCLE; IODINE; LEACHING; LIQUID WASTES; O CODES; ORGANIC COMPOUNDS; PARTITION; RADIOACTIVE WASTE MANAGEMENT; RADIOACTIVE WASTE PROCESSING; RADIOACTIVE WASTES; REMOVAL; RESEARCH PROGRAMS; SEPARATION PROCESSES; SOLIDIFICATION; TRANSMU'I'A'IIUN; TRITIUM

\section{0}

Struxness, E.G., J.L. Duggan (Ed.), and R.J. (Ed.) Cloutier; Oak Ridge National Laboratory, Oak Ridge, TN; Oak Ridge Associated Universities, Inc., Special Training, Oak Ridge
ASSESSMENT OF IMPACTS AND THE PREPARATION OF ENVIRONMENTAL IMPACT STATEMENTS FOR THE LICENSING OF NUCLEAR POWER PLANTS: ENERGY SOURCES FOR THE FUTURE. CONF-760744-; Energy Sources of the Future, Proceedings of a Conference Oak Ridge, TN, July 5, 1976, (pp. 369 . 388). (1977)

The National Environmental Policy Act of 1969 (NEPA) established the nation's policy of protecting the environment. The Atomic Energy Commission (AEC) then, and the Energy Research and Development Administration (ERDA) and the Nuclear Regulatory Commission (NRC) now, have enlisted the aid of three national laboratories, including Dak Ridge National Laboratory (ORNL), to aseist in the preparation of Firvirunmental Impact Slatements required by NEPA in connection with the licensing of nuclear power plants. The ORNL approach to the assessment of potential environmental impacts and the preparation of Environmental Impact Statements (EIS) for the NRC and the manner in which the EIS is used in NRC's licensing procedure are described.

SUBJECT CATEGORY: General

ORIGIN: Commercial

KEYWORDS: AQUATIC ECOSYSTEMS; CHEMICAL ËFFLUENTS; ENVIRONMENTAL IMPACT STATEMENTS; ENVIRONMENTAL IMPACTS; NUCLEAR POWER PLANTS; RADIOACTIVE EFFLUENTS; REACTOR LICENSING; SOCIO-ECONOMIC FACTORS; TERKESTRIAL ECOSYSTEMS; THERMAL EFFLUENTS

941

Parsons (Ralph M.) Co., Pasadena, CA

GAC-ANL TNS SCOPING STUDIES. STATUS REPORT FOR FY-77, OCTOBER 1, 1976-SEPTEMBER 30, 1977. VOLUME $X$. ENGINEERING SIPPORT: FACILITY S'TUDIES. GA-A-14614(Vol.10). (1977)

Available from NTIS, PC A08/MF A01.

In this conceptual scoping study, a supporting facility was arranged around a baseline $3.8 \mathrm{~m}$ ignition test reactor (ITR) designed by the General Atomic Company (GAC). During the study, the Ralph M. Parsons Company conceptually designed 
and estimated the constructed costs of the balanceof-plant (BOP) supporting buildings and systems necessary for the ITR operation. In addition to facility design and cost estimate, this scoping study also includes the program planning and quality assurance for the TNS program. In terms of BOP functional design assurance, schedule implication, and preliminary cost tradeoff, Parsons has exa. mined the potential impacts evolving from developmental changes to the tokamak parameters and from various ITR upgrade scenarios. Recommendations have been made in this study suggesting areas of consideration which may lead to further cost savings in the TNS program.

\section{SUBJECT CATEGORY: General}

\section{ORIGIN: Commercial}

KEYWORDS: BUILDINGS; COOLING SYST. EMS; COST; DESIGN; ENGINEERING; PLANNING; POWER SUPPLIES; RADIOACTIVE WASTE DISPOSAL; REMOTE HANDLING; SPECIFICATIONS; THERMONUCLEAR REACTOR COOLING SYSTEMS; TNS REACTORS; TOKAMAK TYPE REACTORS

\section{2}

Sato, S., Y. Takashima, S. Tamiya, T. Tsujino, E. Yagi, and K. Nakajima; Power Reactor and Nuclear Fuel Development Corp., Tokyo, Japan

TREATMENT AND DISPOSAL OF RADIOACTIVE WASTES: KAKUNERYO SAISHORI. (1977)

\section{In Japanese}

Explanation is made about the disposal of solid, liquid and gas wastes which are released from the reprocessing plant of nuclear fuel in this report. The spent fuel which is taken out of a light water reactor contains uranium of about $950 \mathrm{~kg} / \mathrm{t}$ of anti $\mathrm{U}$, plutonium of $7-10 \mathrm{~kg} / \mathrm{t}$ of anti $U$ and fission products of $28-36 \mathrm{~kg} / \mathrm{t}$ anti $\mathrm{U}$. As for the radioactive solid waste of high level from the reprocessing plant, the hull has to be considered because this contains about $0.1 \%$ of anti $U$ and $\mathrm{Pu}$. The hull is usually buried underground in USA, and the solidification in concrete and other treatments are also to be considered. The radioactive solid waste of low level like ion exchange resin is solidified in asphalt or concrete. The radioactive liquid waste of high level from the reprocessing plant is stored in stainless steel tanks, and then solidified by the glass solidifying process or pot calcination process. The characteristics of the solidified matters are shown in detail. The final disposal for high level wastes is made by transmutation and extraterrestrial disposal for the elimination, and the disposal in geologic formations, seabed and ice sheet for the earth disposal. These methods are explained, and the cost for each process is also estimated. As the waste gas such as $\mathrm{Kr}$ and Xe has to be removed before venting from stacks, several methods are presented for this removal. The treatment of $\mathrm{H} 3$ and I-129 for the waste from the reprocessing plant is finally explained in this paper.

SUBJECT CATEGORY: Spent Fuel; HLW; LLW; TRU

ORIGIN: Foreign

KEYWORDS: CALCINATION; COST; DECONTAMINATION; FISSION PRODUCTS; FUEL REPROCESSING PLANTS; GASEOUS WASTES; GEOLOGIC DEPOSITS; GLACIERS; HIGHLEVEL RADIOACTIVE WASTES; LIQUID WASTES; MARINE DISPOSAL; RADIOACTIVE WASTE DISPOSAL; RADIOACTIVE WASTE PROCESSING; RADIOACTIVE WASTE STORAGE; SAFETY; SOLID WASTES; SOLIDIFICATION; SPENT FUELS; TRANSMUTATION; TRANSURANIUM ELEMENTS

943

Krugmann, H., and F. Von Hippel; Princeton Univ., Princeton, NJ

RADIOACTIVE WASTES: A COMPARISON OF U.S. MILITARY AND CIVILIAN INVENTORIES. Science 197(4306):883-885. (1977)

Contrary to widespread belief, the accumulated inventory of fission products generated by the still small U.S. civilian nuclear power industry may already be comparable to that generated in the past by U.S. military nuclear programs. Although the volumes of the military wastes are very large, they are on the average almost 100 times more dilute than projected commercial high-level wastes.

\section{SUBJECT CATEGORY: HLW}

ORIGIN: Defense; Commercial

KEYWORDS: COMMERCIAL SECTOR; FISSION PRODUCTS; INVENTORIES; RADIOACTTVE WASTE MANAGEMENT; RADIOACTIVE WASTES; COMPARATIVE EVALUATIONS 
944

Grams, W.H., R.J. Pine,P.F. Gnirk, F.D. Wang (Ed.), and G.B. (Ed.) Clark; RE/SPEC Inc., Rapid City, SD

CONCEPTUAL DESIGN OF A RADIOACTIVE WASTE ISOLATION FACILITY IN PLUTONIC ROCK: ENERGY RESOURCES AND EXCAVATION TECHNOLOGY. CONF770628-P1; Rock Mechanics in Geothermal Develupment, Proceedings of the Symposium on Rock Mechanics, Keystone, CO, June 22, 1977. Colorado School of Mines, Golden, CO. (1977)

A program was recently initiated by Atomic Energy of Canada Limited (AECL) to develop techniques and procedures for the ultimate disposal of highlevel radioactive wastes in geological formations. One segment of this program involves the design, construction, and operation of an underground repository which will satisfactorily isolate the waste. In 1976, a preconceptual design study for such a repository situated in plutonic rock in the Canadian Shield was undertaken. Those aspects of the study that were concerned with the underground facility layout are summarized. The single-level facility layout for a repository in plutonic rock, with a 250-watt canister emplacement in vertical drillholes (baseline emplacement concept), has been designated as the reference repository concept. From the viewpoint of the reference repository concept presented, the disposal of 250-watt canisters of radioactive waste requires approximately 14 $\mathrm{m} \$$ sup $3 \$$ of rock excavation per canister, at an associated capital cost expenditure of about $\$ 660$ per canister. Comparatively, the disposal of 2,500 watt canisters necessitates about $134 \mathrm{~m} \$$ sup $3 \$$ of rock excavation per canister, at a capital cost of some $\$ 3,800$ per canister. This dollar (1976) estimate excludes the costs of the ventilation equipment for cooling the disposal rooms after canister emplacement, and the overhead crane tracks for canister transporters. Apart from modifications of equipmeil fur efficient drilling of the canister emplacement holes, the currently-available equipment for the mining appears adequate. Development of an efficient canister haulage system will be necessary in view of the large number of 250-watt canisters that must be omplaced.

SUBJECT CATEGORY: Isolation; HLW

ORIGIN: Foreign

KEYWORDS: CANADA; COST; EXCAVATION; HIGH-LEVEL RADIOACTIVE WASTES; IGNEOUS ROCKS; MINING EQUIPMENT; RADIOACTIVE WASTE STORAGE; UNDERGROUND STORAGE
945

Mandel, H.; Rheinisch-Westfaelisches Elektrizitaetswerk A.G., Essen, Germany, F.R.

IMPORTANCE OF WASTE DISPOSAL IN ENERGY POLICY. At. Strom 23(1):7-10; Nuclear Energy of the RWE, Proceedings of the 4th Workshop, Hahnenklee, German F.R., November 10, 1976. (1977)

In German; 4 figures

A survey of the problem as a whole concerning waste management of nuclear power plants is presented. From the present-day point of view, the costs for the reprocessing, conditioning, and final stsrage of radioactive wasto will mnkc up for about a third of the fucl cycle costs, nind sume $12 \%$ when taking into account the proceeds from recovered uranium and plutonium. Despite fuel costs having gone up to 1.6 Pfennig/KWh, the competitiveness of nuclear energy has not changed as the costs of fossil primary energy carriers increased at the same time. It is important to cater in good time for sufficient storage capacities. The quantities of irradiated fucl to be deposited are expected to reach about 7,500 tU. A time schedule for the planning and the erection of a fuel reprocessing centre, and a survey of fields of responsibilities are presented.

SUBJECT CATEGORY: General

ORIGIN: Foreign

KEYWORDS: COST; ECONOMICS; FUEL CYCI.F; FUEL REPROCESSING PLANTA, NUCLEAR POWER PLANTS; PLANNING; RADIOACTIVE WASTE DISPOSAL; RADIOACTIVE WASTE FACILITIES; RADIOACTIVE WASTE MANAGEMENT; REVIEWS; SPENT FUEL STORAGE

\section{6}

Raudenbush, M.H., and L. Geller; S.M. Stoller Corp., Boulder, CO

SUMMALY UF COST PROJECTION FUK REGULATORY UNCER'IAINTIES IN THE BACK END OF THE FUEL CYCLE. CONF770554; Plutonium Fuel Cycle, Proceedings of a Topical Meeting, Miami Beach, FL, May 2, 1977. American Nuclear Socicty, La Grange Park, IL. (1977)

Contribution from HLW disposal, alpha-waste criteria, and in-plant material control/accountability for safeguards 
Fuel recycle cost deviations resulting from regulatory changes in the back end of the fuel cycle are examined from a number of different data sources, and three potentially large cost uncertainties are identified; HLW disposal, alpha-waste criteria, and in-plant material control/accountability for safeguards. Present and past methods of regulatory cost effectiveness determinations are critiqued and in some cases found wanting.

SUBJECT CATEGORY: HLW; LLW; TRU

ORIGIN: Commercial

KEYWORDS: ACCOUNTING; ALPHA SOURCES; COST; FUEL CYCLE; HIGH-LEVEL RADIOACTIVE WASTES; NUCLEAR MATERIALS MANAGEMENT; RADIOACTIVE WASTE DISPOSAL; SAFEGUARDS

947

Field, F.R.; Savannah River Laboratory, Aiken, SC

ECONOMIC ANALYSES OF LWR FUEL CYCLES. ERA 02:047745; 42 pp. (1977)

Available from NTIS, PC A03/MF A01

An economic comparison was made of three options for handling irradiated light-water reactor (LWR) fuel. These options are reprocessing of spent reactor fuel and subsequent recycle of both uranium and plutonium, reprocessing and recycle of uranium only, and direct terminal storage of spent fuel not reprocessed. The comparison was based on a peakinstalled nuclear capacity of 507 GWe by CY 2000 and retirement of reactors after 30 years of service. Results of the study indicate that: Through the year 2000 , recycle of uranium and plutonium in LWRs saves about $\$ 12$ billion (FY 1977 dollars) compared with the throwaway cycle, but this amounts to only about $1.3 \%$ of the total cost of generating electricity by nuclear power. If deferred costs are included for fuel that has been discharged from reactors but not reprocessed, the economic advantage increases to $\$ 17.7$ billion. Recycle of uranium only (storage of plutonium) is approximately $\$ 7$ billion more expensive than the throwaway fuel cycle and is, therefore, not considered an economically viable option. The throwaway fuel cycle ultimately requires $40 \%$ more uranium resources (U3O8) than does reprocessing spent fuel where both uranium and plutonium are recycled.

SUBJECT CATEGORY: Spent Fuel
ORIGIN: Commercial

KEYWORDS: FUEL CYCLE; WATER COOLED REACTORS; COST; COST BENEFIT ANALYSIS; PLUTONIUM; RADIOACTIVE WASTE STORAGE; REPROCESSING; SPENT FUEL ELEMENTS; URANIUM; COMPARATIVE EVALUATIONS; SPENT FUEL STORAGE; RADIOACTIVE WASTE PROCESSING; ECONOMICS

948

Jennings, A.S.; Savannah River Laboratory, Aiken, $\mathrm{SC}$

PLAN FOR SOLIDIFICATION OF SAVANNAH RIVER PLANT HIGH-LEVEL WASTE. DP-MS-77-23; AICHE Annual Meeting, Proceedings of the 70th Meeting, New York, NY, November 13-17, 1977, (32 pp.). (1977)

Plans for the long-term management of high-level wastes at Savannah River Plant, presently stored as alkaline salts and sludges in underground tanks, are for their conversion to high-integrity solids for transport to a Federal respoitory. Estimates are that by 1985 , when waste removal is planned to begin, there will be 31 waste storage tanks containing 13.3 million gal. of damp salts, 3.4 million gal. of sludge, and 5.6 million gal. of liquid waste. Hydraulic removal of salts from the tanks will require 42 million gal. of water. This solution will be combined with supernate in the sludge storage tanks and circulated by in-tank pumps to slurry the sludge, producing 60 million gal. of waste. This waste will be approximately 2.2 molar NaNO3 and 1.1 molar NaNO2 and should contain (by 1985) about 2.1 $\mathrm{Ci} / \mathrm{gal}$. Sr 90, 2.2 Ci/gal. Cs 137,0.77 Ci/gal.Pm 147, and $0.19 \mathrm{Ci} / \mathrm{gal}$. Ce 144-Pr 144. The sludge will be centrifuged out, taking with it most of the activity except for Cs 137; the remaining solution will be decontaminated by ion exchange, the salt evaporated to a solid and stored at SRP. The ion exchange eluate and sludge are combined, dried to a powder by spray calcination, combined with glass frit, and melted in a continuous electric melter. The melt is poured into stainless steel containers, solidified, the containers sealed, leak-checked, decontaminated, and placed in stainless steel overpacks for shipment. Off-gas from the melter/calciner is scrubbed, filtered, and released.

SUBJECT CATEGORY: HLW; Transportation

ORIGIN: Defense 
KEYWORDS: SALT DEPOSITS; SLUDGES; HIGH-LEVEL RADIOACTIVE WASTES; RADIOACTIVE WASTE MANAGEMENT; LIQUID WASTES; ION EXCHANGE; EVAPORATION; CALCINATION; VITRIFICATION; SOLIDIFICATION; NITRATES; NITRITES; STRONTIUM; CESIUM; WASTE PROCESSING; VOLUME; TRANSPORT

\section{9}

Savannah River Laboratory, Aiken, SC

LIGHT WATER REACTOR FUEL RECYCLE. COMPOSITE QUARTERLY REPORT, JANUARY-MARCH 1977. DPST-LWR-77-2-1. (1977)

The LWR fuel recycle research and development program includes the following categories: economic studies, environmental studies, fuel receipt, head-end processes, off-gas treatment, Purex process, finishing processes, waste management, environmental effects, and safeguards. The status of each is reported.

\section{SUBJECT CATEGORY: LLW}

ORIGIN: Commercial

KEYWORDS: BETA DECAY RADIOISOTOPES; BETA-MINUS DECAY RADIOISOTOPES; BUTYL PHOSPHATES; CARBON ISOTOPES; CHALCOGENIDES; ESTERS; EVEN-EVEN NUCLEI; INTERMEDIATE MASS NUCLEI; INTERNAL CONVERSION RADIOISOTOPES; IODINE ISOTOPES; ISOTOPES; LIGHT NUCLEI; MANAGEMENT; NITROGEN COMPOUNDS; NUCLEI; ODD-EVEN NUCLEI; ORGANIC COMPOUNDS; ORGANIC PHOSPHORUS COMPOUNDS; OXIDES; OXYGEIN COMPOUNDS; PHOSPHORIC ACID ESTERS; RADIOISOTOPES; REACTORS; REPROCESSING; SEPARATION PROCESSES; WASTE MANAGEMENT; WASTE PROCESSING; WATER COOLED REACTORS; WATER MODERATED REACTORS; YEARS LIVING RADIOISOTOPES

\section{0}

Savannah River Laboratory, Aiken, SC

LIGHT WATER REACTOR FUEL RECYCLE, SAVANNAH RIVER LABORATORY QUARTERLY REPORT, OCTOBER-DECEMBER 1976. (1977)
The economics of seven alternatives for the back end of the nuclear fuel cycle were evaluated. For a 10-MTU/day reprocessing plant, annual operating costs of receiving facilities plus transportation would be $\$ 10.2$ million/year higher if spent fuel is transported by truck rather than by rail. Calculations indicate that recycle of dissolved dirty scrap from MOX fuel fabrication to the LWR fuel separations plant is probably more economical than recycle within the MOX facility, although internal recycle is otherwise desirable. Test shearing of irradiated fuel rods from H.B. Robinson 2 reactor showed that hydraulic shearing is satisfactory. Dissolution tests were continued using irradiated UO2 fuel to prepare feed for solvent-extraction studies. Solvent extraction flowsheets for the recovery and purification of uranium and plutunium from irradiated LWR fuel are being developed, based on SRP operating experience, theoretical calculations, and tests in miniature mixer-settlers. A conceptual process is being developed to convert plutonium nitrate solutions from solvent extraction and from mixed-oxide (MOX) recycle to a ceramicgrade plutonium oxide powder suitable for blending with $\mathrm{UO} 2$ and fabrication into MOX fuel pellets. Safeguards required against materials theft or sabotage for a 10-MTU/day spent fuel reprocessing plant are being studied. A combinéd radiochemical extraction-neutron activation procedure was developed to determine I 129 in dissolver solution and offgas caustic trap solutions. A simple colorimetric procedure was developed to determine traces of uranium in the presence of large amounts of fission products.

SUBJECT CATEGORY: Spent Fuel; TRU

ORIGIN: Defense

KEYWORDS: ABSORPTION SPECTROSCOPY; ACTIVATION ANAI.YSIS; FICNNOMIRS; FISSION PRODUCTS; FLOWSHEETS; FUEL CYCLE; FUEL REPROCESSING PLANTS; HEAD END PROCESSES; IODINE 129; NEUTRON REACTIONS; PLUTONIUM NITRATES; PUREX PROCESS; RESEARCH PROGRAMS; SAFEGUARDS; SOLVENT EXTRACTION; SPENT FUELS; URANIUM; WATER COOLED REACTORS

951

Savannah River Laboratory, Aiken, SC

ALTERNATIVES FOR LONG-TERM MANAGEMENT OF DEFENSE HIGH-LEVEL RA- 
DIOACTIVE WASTE. ERDA-77-42/1; 334 pp. (1977)

Available from NTIS, PC A15/MF A01.

Implementation costs and risk costs are calculated in the text for 23 alternative plans for long-range management and isolation of the SRP high-level radioactive waste. For purposes of basic programmatic decision making, these 23 plans can be grouped into four main classes: (1) Convert the waste to a highly leach-resistant form, such as canned glass cylinders, and ship it offsite to a Federal repository. (2) Convert the waste to a highly leach-resistant form, and store the waste in an engineered surface facility at SRP. (3) Reconstitute the waste to a slurry, and dispose of it in a bedrock cavern under the SRP site. (4) Continue storage in tanks with the waste as salt cake and sludge. Costs for accomplishing each alternative were established from preliminary engineering studies that were based on the best available process specifications. The estimates are not budget quality, but they are sufficiently accurate for gross cost ranking of the alternatives. All of the alternatives are expensive to implement, but there are also large differences between them. Costs range from several hundred million to several billion dollars. The large cost differences between alternatives directly reflect the large differences in effort required between, at the low end, slurrying waste directly into an onsite cavern and, at the high end, constructing and operating extensive new processing and storage facilities.

SUBJECT CATEGORY: HLW

ORIGIN: Defense

KEYWORDS: COST; DECISION MAKING; FLOWSHEETS; GEOLOGIC DEPOSITS; RADIOACTIVE WASTE DISPOSAL; RADIOACTIVE WASTE MANAGEMENT; RADIOACTIVE WASTE PROCESSING; RADIOACTIVE WASTE STORAGE; SALT DEPOSITS; SAVANNAH RIVER PLANT; TANKSS

952

Savannah River Laboratory, Miken, SC

ALTERNATIVES FOR LONG-TERM MANAGEMENT OF DEFENSE HIGH-LEVEL RADIOACTIVE WASTE. ERDA-7742/2(Vol.2). (1977)

23 alternative plans; Available from NTIS, PC A02/MF A01.
The purpose of this site-specific document is to describe the different alternatives along with their probable relative costs, risks, and uncertainties. A secondary purpose is to raise the issue of methodology for decisionmaking in nuclear waste management. The document does not attempt to arrive at any recommendations. Before any long-range waste management plan is implemented, an environmental statement will be prepared to assess in detail the potential environmental impact of all the alternatives.

\section{SUBJECT CATEGORY: HLW}

ORIGIN: Defense

KEYWORDS: COST BENEFIT ANALYSIS; DECISION MAKING; RADIOACTIVE WASTE DISPOSAL; RADIOACTIVE WASTE MANAGEMENT; RADIOACTIVE WASTE PROCESSING; SAVANNAH RIVER PLANT; SOLIDIFICATION

953

Savannah River Laboratory, Aiken, SC

SAVANNAH RIVER LABORATORY LIGHT WATER REACTOR FUEL RECYCLE. QUARTERLY REPORT, JANUARY-MARCH 1977. DPST-LWR-77-1-1; 72 pp. (1977)

Available from NTIS, PC A04/MF A01.

The efforts are directed primarily at reprocessing and recycle of uranium and plutonium from spent LWR fuel. Efforts in the following areas are reported: economic studies, fuel receipt, head-end processes, Purex process, finishing processes, waste management, environmental effects, and safeguards.

SUBJECT CATEGORY: TRU; Spent Fuel

ORIGIN: Defense

KEYWORDS: CONTAINERS; DISSOLUTION; DISSOLVERS; ECONOMICS; ENVIRONMENTAL IMPACTS; FUEL CYCLE; HEAD END PROCESSES; PUREX PROCESS; RADIOACTIVE WASTE MANAGEMENT; REPROCESSING; RESEARCH PROGRAMS; SAFEGUARDS; SOLIDIFICATION; SPENT FUEL STORAGE; SPENT FUELS; VOLOXIDATION PROCESS; WATER COOLED REACTORS

954

Southern California Edison Co., Rosemead, CA 
RESPONSE TO QUESTION 321.6 - COSTBENEFIT ANALYSIS. DOCKET-50361; DOCKET-50362; Amendment 3 to San Onofre 23 License Application, p. QR 11.3-3. (1977)

1 reference given

In the cost-benefit analysis provided in appendix $5 \mathrm{~A}$ of the environmental report, the augments considered were a charcoal/hepa filtration system on the auxiliary building ventilation system for gaseous releases and operation of the coolant radwaste evaporator or further demineralization for liquid releases. The basis for the cost-benefit analysis is presented in table 321.6-1 using the cost-estimate sheets of regulatory guide 1.110 , cost-benefit analysis for radwaste systems for light-water-cooled nuclear power reactors. (Cost-benefit analysis indicates it would cost $\$ 284,400 /$ year for the charcoal/hepa filtraation system; $\$ 1 y, 400 /$ year for further demineralization; and $\$ 72,700$ for use of the radwaste evaporator.

\section{SUBJECT CATEGORY: LLW}

ORIGIN: Commercial

KEYWORDS: SAN ONOFRE-2 REACTOR; SAN ONOFRE-3 REACTOR; PWR TYPE REACTORS; REPORTS; COST BENEFIT ANALYSIS; FIL TERS; COST; EVAPORATORS

\section{5}

Barbur, I., A. Barchenkov, L. Molnar, A. Panasenkov, V. Tolpygo, V. Hake, and B. Shcherbinin; Sovet Ehkonomicheskoj Vzaimopomoshchi, Moscow, USSR

CO-OPERATION OF THE CMEA MEMBER COUNTRIES IN THE DEVELOPING POWER REACTORS OF VARIOUS TYPES, INCLUDING SOME ASPECTS OF THEIR NUCLEAR FUEL CYCLES. CONF-770505; IAEA-CN-36/6; Nuclear Power and its Fuel Cycles, Proceedings of a Conference, Salzburg, Austria, May 2, 197'7. International Atomic Energy Agency, Vienna, Austria. (1977)

\section{In Russian}

The report gives an account of the problems of projected development of atomic power and evaluates its role in the fuel and power complex and longrange development of interconnected power systems of the CMEA member countries. The report emphasizes the importance of scientific and technical co-operation in the creation of power reactors on thermal and fast neutrons with 1000-1500 MW unit electric capacity as well as in the elaboration of nuclear plants for heating services. It notes the positive experience of the International scientific and research group of scientists of the CMEA member countries carrying out reactor-physical studies on the critical assembly and its contribution to the elaboration of power reactors. The report contains basic conclusions from the development forecast for nuclear power of the CMEA member countries up to 1990 including forecasting methodology; role of nuclear power plants in saving natural and enriched uranium for a projected period; impact of nuclear power development rates on its structure (thermal and fast reactor ratin); relation between the beginning of mass commis. sioning of nuclear power plants with fast reactors and the integral demand for nuclear fuel; scale of required capacities of fuel cycle services; time dependence of fuel cycle on nuclear fuel requirements. It examines the problems and lists the results of scientific and technical co-operation of the CMEA member countries in the field of fuel cycle, including the transport of spent nuclear fuel, its recovery, reprocessing and radioactive waste disposal. Questions of co-operation of the CMEA member countries to secure radiation safety of nuclear power plants and environmental protection are analyzed. The report notes the role of international economic associations - "Interatomenergo" and "Interatominstrument" - in the accelerated development of nuclear power on the basis of conperation and epooialisation in the manufacture of equipment for nuclear power plants.

\section{SUBJECT CATEGORY: General}

ORIGIN: Foreign

KEYWORDS; ECONOMICS; FNVIRONMENT; FORECASTING; FUEL CYCLE; NUCLEAR POWER; NUCI.EAR POWER PLANTS; PLANNING; POWER REACTORS; RADIATION PROTECTION; RADIOACTIVE WASTE DISPOSAI; RADIOACTIVE WASTE PROCESSING; SPENT FUELS; 'TRANSPORT

956

Ausset, R.; Technip, 92 * Rueil-Malmaison, France

FUEL REPROCESSING. Tech. Energ. 12:37. 43. (1977)

In French 
The reprocessing of UO2 fuels from water cooled reactors is described. The process used (PUREX process) consists of dissolving the fuel in nitric acid, separating the nitrates by solvent extraction with TBP diluted in dodecane and purification of $U$ and $\mathrm{Pu}$. The operation scheme is given. The processing of the wastes produced (fission products, gaseous, liquid and solid wastes) is presented. The cost of the reprocessing is analyzed.

\section{SUBJECT CATEGORY: Spent Fuel}

ORIGIN: Foreign

KEYWORDS: COST; DISSOLUTION; FISSION PRODUCTS; PLUTONIUM; PUREX PROCESS; PURIFICATION; RADIOACTIVE WASTE PROCESSING; SOLVENT EXTRACTION; SPENT FUELS; TBP; URANIUM; URANIUM DIOXIDE

\section{7}

Melin, T.; Technische Hochschule Aachen, Inst. fuer Verfahrenstechnik, Germany, F.R.

\section{CONTINUOUS DECONTAMINATION OF RADIOACTIVE LIQUID WASTES FROM HOSPITALS. ISU Mitt. 2:65-68. (1977)}

\section{In German}

The problems connected with the decontamination of radioactive liquid waste from hospitals are discussed. The conventional, discontinuous storage installations are compared with two new concepts. Air-mixed cascades and cyclic multichamber reactors. Safety, maintenance and investment costs all favour continuous systems, in particular the lastmentioned system. It may be hoped that these or other processing systems may solve the problem of liquid radioactive waste from hospitals in an 'environmental' and inexpensive way.

SUBJECT CATEGORY: LLW

ORIGIN: Institutional

KEYWORDS: COST; DECONTAMINATION; HOSPITALS; LIQUID WASTES; NUCLEAR MEDICINE; RADIOACTIVE EFFLUENTS; RADIOACTIVE WASTE PROCESSING
PRODUCTION OF SOLIDIFIED HIGH LEVEL WASTES: A COST COMPARISON OF SOLIDIFICATION PROCESSES. UCRL-13740. (1977)

Available from NTIS, PC A07/MF A01.

Differential cost estimates of the annual operating and maintenance costs and the capital costs for five HLW Waste Solidification Alternates were developed. The annual operating and maintenance cost estimates included the cost of labor, consumables, utilities, shipping casks, shipping and disposal at a federal repository. The capital cost included the cost of the component, installation and building. The differential cost estimates do not include equipment and facilities which are either shared with the reprocessing facility or are common between all of the alternates. Total annual cost differential between the five waste form alternates is summarized in tabular form. The Borosilicate Glass Alternate has the lowest total annual cost. The other alternates have higher costs which range from $\$ 6.6 \mathrm{M}$ to $\$ 7.4 \mathrm{M}$ per year higher than the Glass alternate with the Supercalcine being the highest cost at $\$ 7.4 \mathrm{M}$ per year differential. The major items in the cost estimates are then disposal costs in the operating cost estimates and the HLW Storage Tanks in the capital cost estimates. The Supercalcine Multibarrier Alternate ships 180 canisters per year more than the other alternates and consequently has a significantly higher operating cost. However, offsetting this the Supercalcine Multibarrier Alternate does not require HLW Storage Tanks for decay because of the high heat conductivity of this product and correspondingly the capital cost for this alternate is significantly lower than the other alternates. The radiological risk values are correlated with the cost evaluation normalized to cost (\$)/MWe-yr.

\section{SUBJECT CATEGORY: HLW}

\section{ORIGIN: Commercial}

KEYWORDS: BORON SILICATES; COMPARATIVE EVALUATIONS; COST; ENVIRONMENTAL IMPACT STATEMENTS; GLASS; RADIATION HAZARDS; RADIOACTIVE WASTE PROCESSING;' SOLIDIFICATION; SOLID WASTES; WASTE TRANSPORTATION; RADIOACTIVE WASTE STORAGE

959

Kniazewycz, B.G.; TERA Corp., Berkeley, CA

\section{8}

Teknekron, Inc., Berkeley, CA 
DESIGN AND OPERATING CONSIDERATIONS FOR COMMERCIAL LWR VOLUME REDUCTION SYSTEMS. Transactions of the American Nuclear Society, Suppl. 26(1):19-20; Reactor Operating Experience, Proceedings of a Conference, Chattanooga, TN, August 7, 1977. American Nuclear Society, New York, NY. (1977)

SUBJECT CATEGORY: General

ORIGIN: Commercial

KEYWORDS: COST; ECONOMICS; NUCLEAR POWER PLANTS; RADIOACTIVE WASTE PROCESSING; SOLIDIFICATION

960

TERA Corp., Berkeley, CA

PERFORMANCE CRITERIA FOR SOLIDIFIED HIGH-LEVEL RADIOACTIVE WASTES. ENVIRONMENTAL IMPACT STATEMENT. REVISION 1 . UCRL-13764. (1977)

Available from NTIS, PC A12/MF A01.

This draft Environmental Impact Statement on performance criteria for solidified high-level radioactive wastes (PCSHLW) covers: considerations for PCSHLW development, the proposed rulemaking, characteristics of the PCSHLW, environmental impacts of the proposed PCSHLW, alternatives to the PCSHLW criteria, and cost/benefit/risk evalua. tion. Five appendices are included to support the technical data required in the Environmental Impact Statement.

SUBJECT CATEGORY: HLW

ORIGIN: Commercial; Defense

KEYWORDS: COST BENEFIT ANALYSIS; ENVIRONMENTAL IMPACT STATEMENTS; ENVIRONMENTAL IMPACTS; LICENSING; PERFORMANCE; RADIOACTIVE WASTE MANAGEMENT; RADIOACTIVE WASTE PROCESSING; SOLID WASTES

\section{1}

U.S. Congress, House of Representatives, Washington, DC

DECOMMISSIONING AND DECONTAMINATION. HEARING BEFORE THE HOUSE
COMMITTEE ON SCIENCE AND TECHNOLOGY, CONGRESS OFTHE UNITED STATES, NINETY-FIFTH CONGRESS, FIRST SESSION. Hearing, June 15-16, 1977; 279 pp. (1977)

4 photos, 3 tables

Hearing transcript :Hearings were held to consider the problems of decommissioning and decontaminating nuclear facilities and disposing of nuclear wastes. The waste disposal problems at the Nuclear Fuel Services commercial reprocessing plant at West Valley, N. Y., which operated from 1966-72, were investigated. Technical and institutional aspects of nuclear waste management and disposal and the costs of management and disposal were discussed. Environmental, health, and safety issues assoociāted with decommissıoning nuclear facilities, including reactors, were examined. ERDA, GAO, and NRC officials; representatives of the nuclear industry; nuclear energy consultants; and the chairman of the New York State Energy RD Authority testified. Statements are transcribed.

SUBJECT CATEGORY: Remedial Action, FUSRAP

ORIGIN: Commercial

KEYWORDS: REACTOR DECOMMISSIONING; DECONTAMINATION; RADIOACTIVE WASTE DISPOSAL; RADIOACTIVE WASTE STORAGE; REPROCESSING; ECONOMICS; NUCLEAR POWER; NEW YORK; US NRC; DECOMMISSIONING; RADIOACTIVE WASTE MANAGEMENT

9 R2

Pigford, T.H.; Univ. of California; Rerkeley, CA

FUEI. CYCLE ALTERNATIVES FOR NUCLEAR POWER REACTORS. Industrial Engineering Chemistry Fundamentals 16(1):7581. (1977)

15 references

Annual and lifetime requirements of uranium and thorium resources for light-water and heavy-water nuclear reactore, a gas-cooled reactor, and a fastbreeder reactor are calculated for alternate uranium and thorium fuel cycles. Recycling uranium and plutonium in a light-water reactor reduces the lifetime ore requirement by $40 \%$. Compared to a uranium-plutonium recycle water reactor generating the same electrical energy, the lifetime uranium 
ore consumption is $37 \%$ less for a heavy-water reactor with plutonium recycle, $18 \%$ less for the $U$ Th fueled gas-cooled reactor with uranium recycle, and $82 \%$ less for the first-generation fast breeder reactor. The theoretical ingestion toxicity of stored discharge fuel or of high-level radioactive wastes is greatest during the first 600 years when dominated by fission products.

\section{SUBJECT CATEGORY: TRU}

ORIGIN: Commercial; Defense

KEYWORDS: COMPARATIVE EVALUATIONS; CONVERSION RATIO; ECONOMICS; FLOW. SHEETS; FUEL CYCLE; FUEL REPROCESSING PLANTS; HELIUM COOLED REACTORS; LMFBR TYPE REACTORS; NUCLEAR FUELS; NUCLEAR POWER PLANTS; PLUTONIUM ISOTOPES; PLUTONIUM RECYCLE; PWR TYPE REACTORS; RADIOACTIVE WASTES; RECYCLING; THORIUM CYCLE; THORIUM ISOTOPES; URANIUM ISOTOPES; WATER MODERATED REACTORS

\section{3}

Smith, R.D., T.A. Parish, and M.S. Lubell (Ed.); University of Texas, Austin, TX

\section{STRUCTURE ACTIVATION IN AN EXPERI-} MENTAL POWER REACTOR. CONF771029-P2; Fusion Research Project, Vol. II, Proceedings of the 7th Symposium, Knoxville, TN, October 25, 1977. Institute of Electrical and Electronics Engineers, Inc., New York. (1977)

A calculational procedure for determination of the radioactive waste generated via neutron activation of the strucutral components of fusion devices is presented. Significant features of the procedure are the large number of activation products which can be treated, the methods employed to prepare the necessary data, and the large number of reaction types which are included. Neutron spectra are determined with the ANISN transport code and activation calculations are performed with a version of the Oak Ridge National Laboratory (ORNL) isotope generation and depletion code ORIGEN. This procedure is applied to the analysis of the stainless steel structure of the proposed ORNL Experimental Power Reactor (EPR). Results indicate that most of the strucutral activity is shortlived, resides in the vacuum wall and first wall of the blanket, and reaches equilibrium at about ten years of operation. The activity per unit of energy generated by the ORNL EPR is determined to be about ten times lower than for a typical PWR, and the biological hazard potential is determined to be about twenty times lower.

\section{SUBJECT CATEGORY: LLW}

ORIGIN: Commercial

KEYWORDS: DATA ACQUISITION; INVENTORIES; MECHANICAL STRUCTURES; NEUTRON REACTIONS; NEUTRON SPECTRA; RADIOACTIVATION; RADIOACTIVE WASTES; THERMONUCLEAR REACTORS; COMPUTER CODES

\section{4}

Macek, V.; Virginia Polytechnic Inst. and State Univ., Blacksburg, VA

OPTIMIZATION OF TIME AND LOCATION DEPENDENT SPENT NUCLEAR FUEL STORAGE CAPACITY. University Microfilms Order No. 78-01,595. (1977)

A linear spent fuel storage model is developed to identify cost-effective spent nuclear fuel storage strategies. The purpose of this model is to provide guidelines for the implementation of the optimal time-dependent spent fuel storage capacity expansion in view of the current economic and regulatory environment which has resulted in phase-out of the closed nuclear fuel cycle. Management alternatives of the spent fuel storage backlog, which is created by mismatch between spent fuel generation rate and spent fuel disposition capability, are represented by aggregate decision variables which describe the time dependent on-reactor-site and off-site spent fuel storage capacity additions, and the amount of spent fuel transferred to off-site storage facilities. Principal constraints of the model assure determination of cost optimal spent fuel storage expansion strategies, while spent fuel storage requirements are met at all times. A detailed physical and economic analysis of the essential components of the spent fuel storage problem, which precedes the model development, assures its realism. The effects of technological limitations on the on-site spent fuel storage expansion and timing of reinitiation of the spent fuel reprocessing on optimal spent fuel storage capacity expansion are investigated. The principal results of the study indicate that (a) expansion of storage capacity beyond that of currently planned facilities is necessary, and (b) economics of the post-reactor fuel cycle is extremely sensitive to the timing of reinitiation of spent fuel reprocessing. Postponement of reprocessing beyond 
mid-1982 may result in net negative economic liability of the back end of the nuclear fuel cycle.

SUBJECT CATEGORY: Spent Fuel

ORIGIN: Commercial; Defense

KEYWORDS: COST; ECONOMICS; FUEL CYCLE; FUEL POOLS; NUCLEAR POWER PLANTS; OPTIMIZATION; PLANNING; REPROCESSING; SPENT FUEL STORAGE; MATHEMATICAL MODELS

\section{5}

Kupinski, A.F.; Washington Public Power Supply System, Richland, WA

ECONOMIC EVALUATION OF HIGHDENSITY STORAGE ALTERNATIVES. Transactions of the American Nuclear Society, Suppl. 26(1):81-82; Transactions of the Reactor Operating Experience, Proceedings of a Conference, Chattanooga, TN, August 7, 1977. American Nuclear Society, New York, NY. (1977)

No Abstract

SUBJECTT CATEGORY: Spent Fuel

URIGIN: Commercial

KEYWORDS: COMPARATIVE EVALUATIONS; COST; FUEL POOLS; NUCLEAR POWER PLANTS; SPENT FUEL STORAGE

\section{6}

Olson, R.E., J. Goodman, and M.C. Gilchrist; Westinghouse Nuclear Energy Systems, Pittsburgh, PA

\section{REVIEW OF WASTE MANAGEMENT FOR A LARGE-SCALE MIXED OXIDE FUEL FA- BRICATION FACILITY. WCAP-9144. (1977)}

Available from NTIS, PC A03/MF A01.

The points of origin and types of transuranic and low-level wastes to be expected from a large-scale mixed oxide fuel fabrication facility have been defined. Estimates of quantities by source and type are also made, and plans for disposition detailed. Shipping and disposal costs are predicted, insofar as parameters are known at present.
SUBJECT CATEGORY: LLW; TRU

ORIGIN: Commercial

KEYWORDS: COST; LIQUID WASTES; LOWLEVEL RADIOACTIVE WASTES; MIXED OXIDE FUEL FABRICATION PLANTS; RADIOACTIVE WASTE DISPOSAL; RADIOACTIVE WASTE MANAGEMENT; RADIOACTIVE WASTES; SOLID WASTES; TRANSPORT; TRANSURANIUM ELEMENTS

967

Huppert, K.L.; Zentralstelle fuer AlomkernenergieDukumenlation (ZAED), EggensteinLeopoldshafen, Germany, F.R.

RADIUACTIVE WASTES FROM REPROCESSING PLANTS. AED-CONF-77-389-006; CONF-7709146-7; 17th Meeting of the Gesellschaft Deutscher Chemiker, Muenchen, Germany, F.R., September 12, 1977. (1977)

In German; available from NTIS (US Sales Only), PC A03/MF A01.

The lecture deals with definition, quantity and type of radioactive waste products occurring in a fuel reprocessing plant. Solid; liquid and gaseous fission and activation products are formed during the dissolution of the fuel and during the extrartion process, and they must be separated from the fissionalble uranium and plutonium not spent. The shemical hehaviour of these producte $(\mathrm{Zr}, \mathrm{Ru}, \mathrm{Np}$, gaseous substances, radiolysis products), which is sometimes very problematic, necessitates careful process control. Howovor, tho lifotimc of nuelides is just as important for the conditions of the reprocessing procedure. The types of waste obtained after reprocessing are classified according to their state of aggregation and level of activity and on the basis of the operational data of a prototy pe plant - they are quantitatively extrapolated for the operation of a large-scale facility of 1,400 tons of fuel annually.

SUBJECT CATEGORY: HLW; Spent Fuel; LLW

ORIGIN: Foreign

KEYWORDS: CHEMICAL PROPERTIES; DATA; FISSION PRODUCTS; FORECASTING; FUEL REPROCESSING PLANTS; IODINE ISOTOPES; KRYPTON 85; RADIOACTIVE WASTES; RADIOACTIVITY; RADIOLYSIS; RUTHENIUM; SOL VENT EXTRACTION; TABLES; TBP; TRANSURANIUM ELEMENTS; ZIRCONIUM 
968

Salander, C.; Zentralstelle fuer AtomkernenergieDokumentation (ZAED), EggensteinLeopoldshafen, Germany, F.R.

CONCEPT OF THE GERMAN ELECTRIC POWER INDUSTRY FOR THE MANAGEMENT OF WASTE FROM NUCLEAR POWER PLANTS. CONF-7710151-1; AEC-CONF-77-470001; Problems of Radioactive Wastes in Nuclear Technology, Proceedings of a Conference, Esssen, Germany, F.R., Oct 20, 1977. (1977)

Available from NTIS (US Sales Only), PC A02/MF A01. In German

In the course of the last few years the project of a large reprocessing plant in the Federal Republic, originally in the hands of the nuclear industry, has been taken over by the public utilities. In 1977, the 'Projektgesellschaft Wiederaufarbeitung von Kernbrennstoffen' (PWK), founded in 1975 for this purpose, became the 'Deutsche Gesellschaft fuer die Wiedcraufarbeitung von Kernbrennstoffen mbH' (DWK), the purpose of which is the planning, crection, acquisition, and operation of plants and services of all kinds for the management of waste from nuclear power plants, especially the storage and processing of spent fuel elements. This does not apply to plants for the final storage of radioactive waste, which come under the authority of the Federal government. Tasks and structure of this society are described. In the concept of the fuel cycle center, which is explained here in some detail, all process steps necessary for the treatment of spent fuel elements after their transport from nuclear power plants, i.e. acceptance and storage of the spent fuel elements, plutonium recycling and reuse of recoverable uranium, waste treatment and ultimate storage are carried out on a single site. In addition, the schedule for this long-term project is illustrated by a few examples, and cost and financing are briefly mentioned along with interim solutions for fuel element storage and the necessary public information work.

SUBJECT CATEGORY: Spent Fuel; Fuel Cycle Centers

ORIGIN: Foreign

KEYWORDS: BWR TYPE REACTORS; COST; FINANCING; GERMAN FEDERAL REPUBLIC; INDUSTRY; NUCLEAR POWER PLANTS; ORGANIZING; PLANNING; PLANTS; PLUTONIUM RECYCLE; PUBLIC RELATIONS; PWR TYPE REACTORS; RADIOACTIVE WASTE MANAGEMENT; REPKOCESSING; SPENT FUEL STORAGE; SPENT FUELS; ELECTRIC POWER
969

Bernero, R.M., D.F. Harmon, and K.G. Steyer; Zentralstelle fuer AtomkernenergieDokumentation, (ZAED), EggensteinLeopoldshafen, Germany, F.R.

COST-BENEFIT CONSIDERATIONS OF REDUCING ENVIRONMENTAL EXPOSURES AND EFFLUENTS FROM URANIUM FUEL CYCLE FACILITIES TO LEVELS BELOW LIMITS SET BY THE U.S. ENVIRONMENTAL PROTECTION AGENCY. CONF-771139-11; AED-CONF-77-473-030; Radioactive Effluents from Nuclear Fuel Reprocessing Plants, Proceedings of a Seminar, Karlsruhe, Federal Republic of Germany, November 22, 1977. (1977)

Cost-benefit analyses have been made for further reducing effluent releases and environmental exposures from uranium fuel cycle facilities below the limits established by the EPA. The primary purpose for the analyses is to examine whether the effluent releases and en vironmental exposures from fuel cycle facilities in the US conforming to EPA standards can be considered to be 'as-low-asreasonably-achievable' as required by regulations established by the NRC. The analyses are based on studies performed by the ORNL under contract with NRC. The analyses indicate that it would cost significantly in excess of 1000 per organ-person-rem to further reduce environmental exposures and effluent releases below the EPA standards from uranium mills, uranium oxide fuel fabrication plants, and uranium fuel reprocessing facilities. Although 1000 per organ-person-rem is an interim guideline value set for consideration of effluents, its use here indicates that NRC may consider that releases from fuel cycle facilities will be as-low-asreasonably-achievable if they meet the EPA limits.

SUBJECT CATEGORY: General

ORIGIN: Foreign

KEYWORDS: COST BENEFIT ANALYSIS; FISSION PRODUCT RELEASE; FUEL FABRICATION PLANTS; FUEL REPROCESSING PLANTS; RADIATION DOSES; RADIATION HAZARDS; RADIOACTIVE EFFLUENTS; TRANSURANIUM ELEMENTS

970

Castellani, F., G. Curzio, and A. Gentili; Zentralstelle fuer Atomkernenergie-Dokumentation, (ZAED), Eggenstein-Leopoldshafen, Germany, F.R.

TRAPPING KR-85 DISCHARGED BY FUEL REPROCESSING PLANTS - A COST EFFEC- 
TIVENESS ANALYSIS. CONF-771139-7; AEDCONF-77-473-031; Radioactive Effluents from Nuclear Fuel Reprocessing Plants, Proceedings of a Seminar, Karlsruhe, Germany, F.R., November 22, 1977. (1977)

In French; Available from NTIS (US Sales Only), PC A02/MF A01.

The problem of trapping the Kr-85 discharged by fuel processing facilities was studied from the point of view of cost effectiveness, taking account of the most generally accepted theories on: 1) the biological effects of ionising radiation at very low levels;2) man-rem cost; 3) average dose to the world population from release into the atmosphere of all $\mathrm{Kr}-85$ produced. Our investigation shows that trapping this product is justified - from the economic point of view - only if operational and depreciation costs for the separation and storage facilities do not exceed a few hundred thousand dollars per year per plant. This is of the same order as the indicated cost for the Morris plant (Ill., U.S.A.) where the cryogenic process is used. However, it must not be forgotten that the present situation and the operating experience gained to date do not constitute an adequate basis for final conclusions.

SUBJECT CATEGORY: LLW; General

ORIGIN: Foreign

KEYWORDS: COST BENEFIT ANALYSIS; FUEL REPROCESSING PLANTS; KRYPTON 85; OFF-GAS SYSTEMS; RADIOACTIVE WASTE PROCESSING; SEPARATION PROCESSES

971

Belitzky, B.

SOVIET ANSWER TO NUCLEAR WASTE. New Sci. 74(1048):128-129. (1977)

The problem of radioactive waste disposal in the Soviet Union is discussed. Selection of burial sites includes thorough hydrogeological surveying of the region as was done in the case of Dimitrovgrad where 32,000 curies of low and medium level activity in 775,000 cubic meters of liquid were pumped into three boreholes during the period April 1966 to October 1975. It is considered that this technique has substantial economic advantages over the evaporation method. For high-level wastes Soviet experts regard vitrification as the most reliable though expensive method. Methods involving cementation, bituminization and fixation in ceram- ics or asphalt are being investigated. It is felt that the problems of radioactive waste disposal are an area in which such countries as the Soviet Union and Britain with their respective highly advanced nuclear power industries, could cooperate to mutual advantage.

SUBJECT CATEGORY: Isolation; LLW; HLW

ORIGIN: Foreign

KEYWORDS: ECONOMICS; EVAPORATION; RADIOACTIVE WASTE DISPOSAL; RADIOACTIVE WASTE PROCESSING; SITE SELECTION; SOLIDIFICATION; UNDERGROUND DISPOSAL; VITRIFICATION

972

Duguid, J.O.

ASSESSMENT OF DOE LOW-LEVEL RADIOACTIVE SOLID WASTE DISPOSAL STORAGE ACTIVITIES. BMI-1984; 97 pp. (1977)

Contains some of the only published information on the DOE disposal-storage facilities at PantexAmarillo, Texus, Sandia Laboratories, New Mexico, Feed Materials Production Center at Fernald, Ohio, National Lead Co. at Niagara Falls, the Paducah Gaseous Diffusion Plant, Paducah, Kentucky, Portsmouth Gaseous Diffusion Plant, Ohio, and the Weldon Spring Missouri facility.

This report presents the results of a survey of fifteen Department of Energy (DOE) low-level radioactive solid waste disposal/storage facilities. The facilities inclunde thnse nperater at. Ins Alamne Srientifir. Laboratory, the Pantex Plant in Amarillo, Texas, Sandia Laboratory, Idaho National Engineering Laboratory, tho Novada Tost Sito, Food Matoriale Production Center at Fernald, Ohio, National Lead Co. at Niagara Falls, New York, Oak Ridge National Laboratory, Paducah Gaseous Diffusion Plant in Kentucky, the Portsmouth Gaseous Diffusion Plant in Ohio, the Weldon Spring facility in Missouri, Hanford Reservation, and the Savannah River Plant. Information on rainfall, surficial geology, primary permeability, bedrock, depth to water table, depth to existing confined aquifers, surface water proximity, surface materials and principal release pathways is presented in tabular form and discussed in the text. Discussions of existing facilities, operating practices, buried/stored volumes and activities (curies) are included. Future DOE programs related to shallow land burial are discussed including the shallow land 
burial abstracting program site selection criteria development, waste form criteria development, future operational criteria, systems analysis, and a proposed demonstration facility. Recommendations for future research and site improvements are presented.

SUBJECT CATEGORY: LLW; Isolation

ORIGIN: Defense

KEYWORDS: RADIOACTIVE WASTE DISPOSAL; LOW-LEVEL RADIOACTIVE WASTES; SOLID WASTES; HYDROLOGY; VOLUME; ENVIRONMENT

\section{3}

Ferrigno, D.P., and D.P. White

FEASIBILITY OF RADWASTE VOLUME REDUCTION AT THE THREE MILE ISLAND NUCLEAR GENERATING STATION. Power Generation, Proceedings of Pennsylvania Electric Association Committee Spring Meeting, Harrisburg, PA, May 5-6, 1977, (16 pp.). (1977)

A review of those volume reduction systems considered technically and economically compatable with the Three Mile Island Station system. No significant data are presented.

Burial costs for radioactive waste have been increasing at an annual rate of $28 \%$ to $250 \%$. Due to this inflation rate, a study was undertaken to assess the technical and economic feasibility of incorporating commercial volume reduction (VR) systems into the radwaste systems at Three Mile Island (TMI). The results indicate that the following VR systems are technically compatable: crystallization (forcedcirculation evaporator), fluid bed dryer (anhydrous salt in a polyester binder), an extruder/evaporator (using bitumen) and incineration (calciner and incinerator). Economic evaluation was based on estimated waste quantities, projected operation and maintenance costs, solid waste packaging systems and burial cost projections.

SUBJECT CATEGORY: LLW

ORIGIN: Commercial

KEYWORDS: VOLUME; DRYING; EVAPORATORS; RESINS; EVAPORATION; ACIDS; CRYSTALLIZATION; BITUMENS; SOLID WASTES; COST BENEFIT ANALYSIS; COMBUSTION; INCINERATORS; FORECASTING; COST; THREE MILE ISLAND-1 REACTOR; PWR TYPE REACTORS
974

Foster, J.S., and S.H. Russell

CANDU: CANADIAN EXPERIENCE AND EXPECTATIONS WITH THE HEAVYWATER REACTOR. CONF-770505-117; IAEACN-36/179; Nuclear Power and its Fuel Cycles, Proceedings of an International Conference, Salzburg, Austria, May 2, 1977. International Atomic Energy Agency, Vienna, Austria, 8 pp. (1977)

1.C.-.P.1./01 3 tables, 2 figures. Available from NTIS (US Sales Only, PC A02/MF A01. Also available in French

With the commissioning of the first two $750 \mathrm{MWe}$ units of the Bruce generating station of Ontario Hydro there will be 9 nuclear-electric units with a total capcity of $4000 \mathrm{MWe}$ operating in Canada. They represent nearly 7 per cent of the total installed electric generating capacity in the country and will supply about 9 per cent of the electrical energy consumed. Five similar units have been sold to other countries. All of these units employ CANDU natural-uranium-fuelled heavy-watermoderated pressure-tube reactors. Because of the high moderating efficiency of heavy water, reactors of this type are not only efficient units for operation on todays once-through fuel cycles but promise, with little or no alteration, to make very effective use of heavy-element resources through fuel cycles entailing the recycling of fissile material. The paper describes the evolution of the CANDU nuclearpower plants with particular reference to the objectives of safety, reliability and economy; the development of industrial capacity for the supply of fuel, components and heavy water; and the prospective development of advanced fuel cycles and the projected results. It provides data on radiation, releases, and exposures, internal and external to the power plants; plant availability, capacity factors and other performance data; economic data for operating plants in Canada; fuel and component manufacturing data; heavy water production data with reference to safety, reliability, and economics; projections of the performance of CANDU reactors operating on a thorium - U-233 cycle and the development required to establish this cycle; and intent with respect to spent-fuel management and radioactive-waste storage. The development of the CANDU reactor, of the associated supply industry, and of the thorium - U-233 advanced fuel cycle is seen as an integrated, evolutionary program, permitting increasingly efficient use of the world's heavy-element resources with thermal reactor technology.

SUBJECT CATEGORY: Spent Fuel; General

ORIGIN: Foreign 
KEYWORDS: CANADA; CANDU TYPE REACTORS; COST; DECONTAMINATION; FUEL CYCLE; HEAVY WATER; NUCLEAR INDUSTRY; PERFORMANCE; PLANNING; PLUTONIUM RECYCLE; RADIATION PROTECTION; RADIOACTIVE WASTE STORAGE; RELEASE LIMITS; RELIABILITY; THORIUM

\section{5}

Giardina, P.A., M.F. DeBonis, J. Eng, and G.L. Meyer

SUMMARY REPORT ON THE LOW-I.EVEL RADIOACTIVE WASTE BURIAL SI'TE, WEST VALLEY, NEW YORK (1963-1975). USGGS Open File Report. (1.977)

The comparisons to hazardous waste disposal site selection criteria are informative. Lithologic data from cores near trenches are somewhat generalized.

This report discussed the status of the state-licensed low-level radioactive waste burial site at the Nuclear Fuel Services center in West Valley, New York. The stated purposes of this report were to present the results of shallow drilling in the immediate vicinity of the trenches to investigate the possibility of migration, to provide a thorough compilation of data on the West Valley site in one document to assist in waste management criteria, and to relate the operational history, problem development, and remedial work information which may prove useful to site selection decision-makers in the future. 'l'he report contains a summary of a literature survey describing the previous work at the site performed by Nuclear Fuel Services, the New York State Department of Environmental Conservation, New York State ERDA, and the New York State Geological Survey. The results of a NY. SERDA funded subsurtace investigation which included the drilling of eighteen borings in the vicinity of the burial trenches is described in detail. Shelby tube samples from these holes were analyzed for radionuclides. Elevated concentrations of tritium were observed in localized horizons. A discussion of the burial site inventory is also included. The site conditions are compared with EPA and USGS recommendations for site selection criteria for lowlevel radioactive and hazardous waste burial sites. Recommendations for site improvements and future research are presented. The enclosed appendices include descriptions of site geology, hydrology, the conditions and amendments of the burial ground license, low-level waste parameters, and secure hazardous waste landfill disposal criteria.

\section{SUBJECT CATEGORY: LLW}

ORIGIN: Commercial

KEYWORDS: GEOLOGY; HYDROLOGY; VOLUME; TRITIUM; RADIONUCLIDE MIGRATION; MONITORING; SAND; RADIATION DOSES; REVIEWS; SITE SELECTION; LOWLEVEL RADIOACTIVE WASTES; RECOMMEN. DA'IIUNS; GRUUND DISPUSAL

\section{6}

Glen, $\mathrm{R}$.

AECL ASSESSES THE COST OF DFCOMMISSIONING. Nucl. Eng. Int. 23(258):37 28. (1977)

A standard 600 MWe Candu could be in service for well over 35 years. The actual life is guesswork. The total cost of decommissioning at 1976 prices could be $\$ 60 \mathrm{M}$, half being for dismantling the reactor. Perfection of the thorium cycle could give added life.

SUBJECT CATEGORY: Remedial Action, Surplus Facilities

ORIGIN: Foreign

KEYWORDS: CANDU TYPE REACTORS; COST; FORECASTING; REACTOR DECOMMISSIONING; HEAVY WATER MODERATED REAC. TORS

977

Jaeger, T.A., and B.A. Boley

SWEDISH UNDERGROÜND CONTAINMENT STUDIES STATE OF ART: STRUCTURAL MECHANICS IN REACTOR TECHNOLOGY. CONF-770807-(Part.JA); INIS-mf-4373; Structural Mechanics in Reactor Technology, Proceedings of the 4th International Conference, San Francisco, CA, August 15, 1977. (1977)

Since May of 1973 studies of underground siting for nuclear power plants have been going on in Sweden. War protection being the primary aim in accordance with the instructions the first containment study has lead to siting in rock. The second study was aimed at surveying the advantages and disadvantages of a rock sited $1000 \mathrm{MW}$ BWR nuclear power plant from a reactor safety standpoint, compared to 
a plant above ground. Based on the instructions and considerations within the study group, the following criteria for the plant design have been established: (1). The plant should be designed to give protection against external acts of war with conventional weapons. (2) The plant should have a safety level equal to that of an above ground plant. (3) The design of the plant should moreover utilize the possibilities of improving the safety afforded by rock siting. The chosen technical design of the reactor plant demands a cavern with a 45-50 metre spar. Studies of the stability of such caverns show that a safety level is attainable corresponding to the safety required for the other parts of the nuclear power plant. The conditions are that the rock is of high quality, that necessary strengthening measures are taken and that careful studies of the rock are made before and during the blasting, and also during operation of the plant. The third study now under way is planned to be delivered to the government in June 1977. One part in this study is going deeper in certain questions (safety, operation, maintenance, sabotage, war protection, cost and decommissioning). Another part aims to a broader view of risks and consequences in peace and war and also advantages and disadvantages of nuclear power plant for district heating.

SUBJECT CATEGORY: General

ORIGIN: Foreign

KEYWORDS: BWR TYPE REACTORS; CAVES; CONTAINMENT SHELLS; COST; DESIGN BASIS ACCIDENTS; FIRES; REACTOR DECOMMISSIONING; REACTOR SAFETY; REACTOR SITES; SABOTAGE; SITE SELECTION; SWEDEN; UNDERGROUND NUCLEAR STATIONS

\section{8}

Keleghan, W.T.H.

WHIMS FOR LOW GRADE URANIUM. Nucl. Act. 16:3-5. (1977)

Wet high-intensity magnetic separation of magnetic minerals from slurries

The tailings dams of South African gold mines contain substantial quantities of low grade uranium. Wet high-intensity magnetic separation (WHIMS), a technique for the concentration of feebly magnetic minerals, shows considerable promise as a method for upgrading these residues and facilitating uranium extraction.
SUBJECT CATEGORY: Remedial Action, Mill Tailings

ORIGIN: Foreign

KEYWORDS: COST; GOLD; MAGNETIC MATERIALS; MILL TAILINGS; ORE CONCENTRATES; ORE ENRICHMENT; RESOURCES; SEPARATION PROCESSES; SLURRIES; URANIUM

979

McGinley, F.E., and W.E. Haldane

INACTIVE URANIUM MILLSITES AND TAILINGS PILES PROGRAM. CONF-770581; Methods for Measuring Radiation in and Around Uranium Mills, Program Report, E.D. Harward (Ed.), Volume 3, No. 9, Proceedings of a Workshop held in Albuquerque, New Mexico, May 23-26, 1977, (pp. 15-34), 411 pp. (1977)

A general summary of the survey program conducted, jointly by the AEC, EPA, the State and the Navajo Nation in discussing remedial actions needed to be taken at inactive mines and millsites.

A summary of the joint program being conducted by ERDA, EPA, eight western states and the Navajo Nation on the remedial actions required at 22 inactive Mine-Mill-Tailing sites. The Phase I portion of the program determined site conditions, corrective actions required, location to populated areas and environmental problems. Phase II is designed to assess the engineering aspects of remedial actions. The phase II report includes a review of plant operation, current condition of the mill site and tailings and discusses local geology, hydrology and meteorology. Of the site problems addressea, inhalation of radon daughters was considered the most significant pathway, and presented the greatest potential for health effects. General cost estimates are provided for the remedial actions.

SUBJECT CATEGORY: Remedial Action, FUSRAP; Remedial Action, Mill Tailings

ORIGIN: Commercial

KEYWORDS: URANIUM; MINES; RADON; ENVIRONMENT; COST BENEFIT ANALYSIS; RESIDUAL FUELS; MILL TAILINGS

980

Metz, W.D. 
REPROCESSING: HOW NECESSARY IS IT FOR THE NEAR TERM. (1977)

The argument of the values of reprocessing spent reactor fuels versus the risks of plutonium proliferation is detailed. A brief history of reprocessing efforts and a brief description of the purex process is presented. The economic advisability of reprocessing is questioned. It is argued that technology used for reprocessing present spent fuels would not be applicable to reprocessing breeder reactor fuel; therefore, reprocessing present fuels could not be considered valuable experience for reprocessing breeder fuels.

\section{SUBJEC"I CATEGORY: Spent Fuel}

ORIGIN: Cummercial; Defense

KEYWORDS: BREEDER REACTORS; COST BENEFIT ANALYSIS; ECONOMICS; PLUTO. NIUM; REPROCESSING; SPENT FUELS; URANIUM; PUREX PROCESS

981

Metzger, J.C., and A.M. Snyder

TRANSPORT, HANDLING, AND INTERIM STORAGE OF INTERMEDIATE-LEVEL TRANSURANIC WASTE AT THE INEL. TREE-1172; 44 pp. (1977)

The transport, handling and interim storage of intermediate-level transuranic (TRU) waste at the Idaho National Engineering Laboratory (INEL) is discussed. 'I ransuranium-contaminated solid waste is considered as such when the alpha-emitting radionuclides of long half-life and high specific radiotoxicity is greater than $10 \mathrm{n} \mathrm{Ci} / \mathrm{g}$. Waste form criteria and packaging criteria are outlined for the Waste Isolation Pilot Plant and Radioactive Waste Management Complex. The current intermediatelevel TRU storage facility contains 26 storage vaults. Twelve of these vaults has an inside diameter of $0.59 \mathrm{~m}$ and the remaining have an inside diameter of $0.39 \mathrm{~m}$. The storage vaults are carbon steel pipe implanted vertically in a long, narrow berm with a crushed gravel base course and a subbase of pit run gravel. Each vault consists of a long, straight-walled lead-in section. A lid attached to the vault body seals the vault and any moisture is prevented by a bag of desiccant between the lid and the shield plug. Additional storage vaults can be accommodated at the facility. These newer vaults have been redesigned to better meet the Waste
Isolation Pilot Plant criteria. Environmental monitoring is also done. The total cost of storage at the facility is $\$ 6921 /$ cu m or $\$ 196 /$ cu ft. Waste generators as well as transportation and handling are included in the presentation.

SUBJECT CATEGORY: TRU; HLW; Transportation Isolation

ORIGIN: Defense

KEYWORDS: ALPHA PARTICLES; CONTAINMENT; ECONOMICS; ENVIRONMENT; PACKAGING; RADIOACTIVE WASTE MANAGEMENT; RADIOACTIVE WASTE STORAGE; INTERMEDIATE-LEVEI. RADIOACTIVE WASTES; SOLID WASTES; TRANSURANIUM ELEMEN'TS; COST; WIPP

982

Miller, K.L., L.A. Varano, and B.H. Brosey

RAD WASTE COMPACTION PROGRAM FOR A MEDICAL CENTER. CONF-770409; Proceedings of the 4th International congress of the International Radiation Protection Association. Paris, 24-30 April 1977. Vol. 2. Association Internationale de Protectioncontre les Rayonnements, Fontenay-aux-Roses, France. (1977)

Available from M. Gilbert Bresson, General Secretary IRPA, B.P. No. 33, 92260 Fontenay-aux-Roses, France

The inflationary spiral and the closing of nearhy radioactive waste burial sites have made radioactive waste disposal a major expenditure in many Health Physics operating budgets. Increased incineration, onsite burial and disposal via the sanitary sewer can certainly reduce the volume of waste requiring commercial disposal, but they adversely increase environmental contamination. A successful method of offsetting increased transportation and burial costs is through waste volume reduction. Use of an industrial type trash compactor provides a significant volume reduction but can lead to personnel exposure and facility contamination through generation of airborne contamination. At our facility the airborne contamination problem has been eliminated by exhausting the compaction chamber through appropriate filtration. The complete compaction program including airborne contamination potential, filtration effectiveness, waste reduction efficiency and cost effectiveress of the program is presented. 
SUBJECT CATEGORY: Airborne; LLW

ORIGIN: Institutional

KEYWORDS: COMPACTING; COST; EFFICIENCY; FILTRATION; NUCLEAR MEDICINE; RADIOACTIVE WASTE PROCESSING; VOLUME; AIR POLLUTION

983

Phillips, J.W., and G.A. Gaul

AN ANALYSIS OF LOW-LEVEL SOLID RADIOACTIVE WASTES FROM LWRS THROUGH 1975. ORP-TAD-77-2. (1977)

Numerous tables summarizing the waste radionuclide composition data available in semi-annual reports to the NRC.

The results of a study on the volume and radioactive contents of solids wastes shipped from LWRs in the United States to commercial burial sites are presented in this document. The relative radionuclide composition of these wastes is also discussed. One of the major purposes of this study was to update the EPA waste generation rates used in waste projection studies and to improve the data base available for environmental impact analysis, radioactive waste management criteria, and for improvement of the existing predictive models. Summaries of actual quantities shipped from LWRs from 1969 through 1975 are presented in tabular form. The power generated each operating year is stated and the waste generation rates for all plants over $400 \mathrm{MWe}$ are prorated to a $3400 \mathrm{MWe}$ reference plant size. This prorated data is then best-fitted by regression analysis to generated equations relating generation rates and activity concentrations to length of operation. The 1977 Atomic Industrial Forum Study on radioactive wastes suggests steady state generating rates of $55 \mathrm{sq} \mathrm{ft}$ of waste per MWe (55 cu ft/MWe) for BWRs and $40 \mathrm{cu} \mathrm{ft} / \mathrm{MWe}$ for PWRs. These figures are compared in the text to older (1975) EPA estimates of $35 \mathrm{cu} \mathrm{ft} / \mathrm{MWe}$ for BWRs and $21 \mathrm{cu} \mathrm{ft} / \mathrm{MWe}$ for PWRs and recent (1977) NRC estimates of $35 \mathrm{cu} \mathrm{ft} / \mathrm{MWe}$ for BWRs and 15.5 cu ft/MWe for PWRs and the newly generated rates of this study suggesting $55 \mathrm{cu} \mathrm{ft} / \mathrm{MWe}$ for BWRs and less than $15.5 \mathrm{cu} \mathrm{ft} / \mathrm{MWe}$ for PWRs.

SUBJECT CATEGORY: LLW

ORIGIN: Commercial
KEYWORDS: VOLUME; FORECASTING; SLUDGES; EVAPORATORS; RESINS; RADIOACTIVE WASTE MANAGEMENT; SOLID WASTES; BWR TYPE REACTORS; EQUATIONS; PWR TYPE REACTORS; STATISTICS

984

Phillips, J.W., and J. Gruhlke

SUMMARY OF RADIOACTIVITY RELEASED IN EFFLUENTS FROM NUCLEAR POWER PLANTS FROM 1973 THRU 1976. EPA-520/3-77-012; 118 pp. (1977)

Good summary data gathered together in one location. Unfortunately the information is neither radionuclide specific nor waste form specific.

The report is the second annual summary of radioactive releases and wastes shipped offsite by nuclear power plants in the United States. The information contained in these summaries is extracted from the individual plant semi-annual or annual operating reports filed by the operating utility. The information in this summary report is from all plants operating on or before December 31, 1976 and includes data from 25 operating BWR units and 36 operating PWR units. The report consists primarily of tables listing annual power production, airborne releases, liquid releases, and solid waste generation. The solid waste information given includes volume, activity, and the number of waste shipments.

SUBJECT CATEGORY: Airborne; LLW; HLW; TRU

ORIGIN: Commercial

KEYWORDS: SOLID WASTES; LIQUID WASTES; VOLUME; WASTE TRANSPORTATION; REACTORS; PWR TYPE REACTORS; RADIOACTIVE WASTE DISPOSAL; RADIOACTIVE. EFFLUENTS; UNDERGROUND DISPOSAL; NUCLEAR POWER PLANTS; INVENTO. RIES

985

Phillips, J.W., J. Gruhlke, and G.A. Gaul

SUMMARY OF RADIOACTIVITY RELEASED IN EFFLUENTS FROM NUCLEAR 
POWER PLANTS FROM 1972 THRU 1975. EPA-520/3-77-006; 111 pp. (1977)

This report is updated annually dropping the first reporting year of the previous report and adding the new data from the latest year. See EPA-520/3-77012.

This report is the first annual summary of radioactive releases and wastes shipped offsite by nuclear power plants in the United States. The information contained in these summaries is extracted from the individual plant semi-annual operating reports filed by the operating utility. The information in this summary report is from all plants operating on or before December 31, 1975 and includes data from 23 operating BWR units and 30 operating PWR units. The report consists primarily of tables listing annual power production, airborne releases, liquid releases, and solid waste generation. The solid waste information given includes volume, activity, and the number of waste shipments.

SUBJECT CATEGORY: Airborne; HLW; LLW; TRU

ORIGIN: Commercial

KEYWORDS: SOLID WASTES; LIQUID WASTES; VOLUME; REACTORS; PWR TYPE REACTORS; RADIOACTIVE WASTE DISPOSAL; UNDERGROUND DISPOSAL; INVENTORIES

\section{6}

Sanders, $M$.

ASSESSMENT OF SOLID LOW-LEVEL RADIOACTIVE WASTE MANAGEMENT. Y/DD238 (Rev.); 27 pp. (1977)

The low-level radwaste burial areas for the Y-12 plant are assessed as to their effect on the environment: The burial areas are located in highly deformed, unmetamorphosed limestones, dolomites, and calcareous shales. Also there are areanaceous and arglllaceous shales and sands. Bear Creek and the East Fork of Poplar Creek drain the Y-12 plant area and ultimately flow into the Tennessee-Ohio-Mississippi water system. Average annual precipitation is between 50 and 60 inches. The soils in the burial area are of the ultisol group which includes red and yellow podzolic soils. The low-level waste burial sites are in Bear Creek Valley 1.8 miles to the west on the main plant. Burial Ground 1-A contains low-level solid waste such as wood and paper which is generated at 1000 tons per year and the area will be sufficient for the next 60 years. The burial ground stays 3 to 30 feet above the water table depending on the weather conditions. Burial Ground 2-B contains purer, depleted uranium which is accountable and recoverable. This material is generated at the rate of 800 tons per year and the site will be sufficient for the next 30 years of continuous operation. Burial Ground 2-C is used to dispose of materials contaminated with enriched uranium and natural thorium. The wastes are of the solid type disposed of in 1-A. With 500 tons of waste generated annually, the site will be sufficient for the next 50 years. Burial Ground 2-B and 2-C are 80 to 110 and 2 to 6 feet, respectively above the water table at various times of the year. Monitoring these areas showed the uranium in the drinking water to be less than $2 \times 10(\mathrm{E}-7) \mathrm{uCi} / \mathrm{cu} \mathrm{cm}$ which is well below the Radiation Protection Guide (RPG). No deleterious effects are revealed.

\section{SUBJECT CATEGORY: LLW}

\section{ORIGIN: Defense}

KEYWORDS: DRINKING WATER; ENVIRONMENT; GEOLOGIC STRATA; GEOLOGIC STRUCTURES; GROUND WATER; HYDROLOGY; LAND USE; LIMESTONE; METEOROLOGY; SHALES; SOILS; STREAMS; THORIUM COMPOUNDS; URANIUM COMPOUNDS; RADIOACTIVE WASTE DISPOSAL; GROUND DISPOSAL; RADIOACTIVE WASTE MANAGEMENT; LOW-LEVEL RADIOACTIVE WASTES; COST BENEFIT ANALYSIS; DOSE RATES

\section{7}

Scheuten, G.H.

TOPICAL PROBLEMS IN REPROCESSING NUCLEAR FUELS. Encrgic 39(6):173-176. (1977)

\section{In German}

In the Federal Republic of Germany, it is the reponsibility of the electric power industry as a result of the originator principle - to set the preconditions for the waste disposal of the nuclear power plants operated by it. The economic and political factors which render a reprocessing and waste treatment in the fuel cycle necessary, as well as an intermediary storage of irradiated fuel elements, are discussed and the tasks and targets of the nuclear industry are described.

SUBJECT CATEGORY: Spent Fuel 
ORIGIN: Foreign

KEYWORDS: ECONOMICS; FINANCING; FUEL REPROCESSING PLANTS; GERMAN FEDERAL REPUBLIC; GOVERNMENT POLICIES; NUCLEAR INDUSTRY; PLANNING; RADIOACTIVE WASTE PROCESSING; REPROCESSING; SPENT FUEL STORAGE

988

Smith, D.

INTERNATIONAL FUEL CYCLE CENTERS OFFER LARGE ECONOMICS AND EASIER FINANCING. Nucl. Eng. Int. 22(257):56-59. (1977)

The summary report of the IAEA study project on multi-national regional nuclear fuel cycle indicates that for facilities of reasonable size such projests offer very decisive advantages in fuel cycle costs and resource availability over national facilities in general, and more markedly over the other alternative of the open ended, non-recycle fuel route. The economic evaluation of alternative fuel cycle strategies, one of the basic studies summarised in the report, is considered.

SUBJECT CATEGORY: Fuel Cycle Centers; Spent Fuel

ORIGIN: Foreign

KEYWORDS: COST; ECONOMICS; FINANCING; FUEL CYCLE; FUEL REPROCESSING PLANTS; INTERNATIONAL COOPERATION; SPENT FUEL STORAGE

\section{9}

Tomlinson, M., S.A. Mayman, H.Y. Tammemagi, W.F. Merritt, J.A. Morrison, H.S. Irvine, G.A. Vivian, J. Gale, B. Sanford, and P.J. Dyne

\section{MANAGEMENT OF RADIOACTIVE WASTFS FROM NUICLEAR FUELS AND POWER PLANTS IN CANADA. CONF. 770505-212; IAEA-CN-36/187; Nuclear Power and its Fuel Cycles, Proceedings of an International Conference, Salzburg, Austria, May 2, 1977. Inter- national Atomic Energy Agency, Vienna, Aus- tria. (1977)}

Available from NTIS (US Sales Only), PC A02/MF A01; 3.B.-.P.1./05 2 tables, 3 figs.
The nature of Canadian nuclear fuel and nuclear generating plant radioactive wastes are summarized. The status of the development and construction program is indicated. We plan to select a site in either a hard rock formation or in a suitable salt bed by 1981 so that a repository can be constructed to begin a demonstration phase in 1986. The repository is to be capable of eventual expansion to accomodate all Canadian nuclear wastes to at least 2050 when in full-scale operation. Extensive geotechnical studies have been initiated in order to select a site, and design and test the repository. We have demonstrated incorporation of fission products in solids that in the short term (17 years) dissolve more slowly than plutonium decays. A demonstration of dry storage of fuel in concrete containers is in progress. The quantities of CANDU generating-station wastes and the principles and methods for managing them are summarized. Methods for volume reduction and immobilization by solidification are well advanced. A radioactivewaste operations site is being developed with several different types of surface storage, each with multiple barriers against leakage. A reactor decommissioning study has been completed. Estimated costs of the various waste management operations are summarized.

SUBJECT CATEGORY: Isolation; HLW; LLW; TRU

ORIGIN: Foreign

KEYWORDS: CANADA; CANDU TYPE REACTORS; COST; GEOLOGIC STRUCTURES; IGNEOUS ROCKS; RADIOACTIVE WASTE DISPOSAL; RADIOACTIVE WASTE FACILITIES; RADIOACTIVE WASTE MANAGEMENT; RADIOACTIVE WASTE PROCESSING; RADIOACTIVE WASTE STORAGE; RADIOACTIVE WASTES; REACTOR DECOMMISSIONING; SOLID WASTES; SOLIDIFICATION; SPENT FUEL STORAGE; UNDERGROUND DISPOSAL; VITRIFICATION

990

Zech, II.J., and F.K. Pickert

ECONOMIC CONSIDERATIONS FOR THE NUCLEAR FUEL CYCLE. Chem. Ztg. 101(1):921. (1977)

A discussion covers global and German uranium production and consumption statistics which indicate that German requirements are secured by contract to 1979 and that global uranium shortages 
may occur after 1985; market trends which include $\$ 1.20 / \mathrm{lb}$ uranium oxide exploration cost in longterm contracts; capacities for uranium enrichment; the price structure of enriched uranium, which was originally based on plants built by the U.S. for military production and did not reflect capital investment and has recently been changed to provide incentive for private industry; producers, cost, and the international market for fuel elements; an analysis of investment and supply of spent fuel elements for the recovery of residual uranium and generated plutonium which shows that the 1500 ton $/ y$ integrated storage-disposal-recovery plant planned in Germany will require a staff of 3600 and cost DM 1000/kg uranium handled; the amount and cost of radioactive waste disposal; and the investment and operating cost of nuclear power plants.

SUBJECT CATEGORY: Spent Fuel; TRU

ORIGIN: Foreign

KEYWORDS: CONTRACTS; COST; ECONOMICS; FUEL CYCLE; GERMAN FEDERAL REPUBLIC; GLOBAL ASPECTS; MARKET; PLUTONIUM; RADIOACTIVE WASTE DISPOSAL; SPENT FUELS; SUPPLY AND DEMAND; URANIUM; REPROCESSING

991

Zelac, R.E., J.W. Bernsee, and D. Han

EFFECTIVENESS IN A UNIVERSITY HEALTH CENTER SETTING OF A COMMERCIAL COMPACTOR FOR DRY SOLID RADIOACTIVE WASTE. Health Physics 32:452453. (1977)

Since the volume of solid radwaste had increased from $322 \mathrm{cu} \mathrm{ft}$ in 1967 to $2215 \mathrm{cu} f \mathrm{ft}$ in 1974, a compactor was bought for Temple University. The compactor incorporates a hood with an absolute filter to control the dust that is frequently found in the $20 \mathrm{gal}$ plastic bags from the radwaste. After compaction the radwaste is placed in $55 \mathrm{gal}$ steel drums. During the first eight months of operation the compactor reduced the solid dry waste volume to approximately $1 / 3$ to $1 / 4$ of the original volume of the wastes collected. The unit is definitely costeffective. The net saving over the 20 month period covered in the report was $\$ 5800$ with no down time. Anticipated yearly savings are expected to be at least $\$ 6700$. The savings are realized in the form of reduced drum storage space, record keeping, labels, and technician time.
SUBJECT CATEGORY: LLW

ORIGIN: Institutional

KEYWORDS: COMPACTING; COST BENEFIT ANALYSIS; DUSTS; PACKAGING; VOLUME; RADIOACTIVE WASTE MANAGEMENT; SOLID WASTES; COST

\section{2}

A LAYAWAY PLAN FOR NUCLEAR FUEL RODS. Business Week August 22, 1977:25. (1977)

The federal government has dovolopod a plan for handling spent fuel from nuclear reactors. The U.S. will take over ownership of spent fuel rods and store them in pools of water pending President Carter's decision on whether to reprocess them. The U.S. will also store spend rods for foreign governments to prevent nuclear proliferation. Eventually, if not reprocessed, the rods will move to terminal storage in shale or granite. The government is considering owning the storage plants and contracting their operation out to such companies as G.E. Exxon, or Allied Chemical. Many nuclear-power plants may soon have to shut down because they are running out of storage space. The government estimates that 10,000 tons of spent fuel will need storage hy 1.985 and that the cost will run into hundreds of millions of dollars. Industry doubts that the government's plan is the must econumical.

SUBJEOT OATEQORY: Spent Fùel

ORIGIN: Commercial; Defense

KEYWORDS: SPENT FUELS; FUEL RODS; REACTORS; ECONOMICS; RADIOACTIVE WASTE STORAGE; GOVERNMENT POLICIES; ECONOMICS

\section{3}

FEDERAL ENERGY OFFICIALS WILL TRY TO INTEREST COMPANIES IN OPERATING INTERIM STORAGE FACILITIES.... Business Week October 31, 1977:40. (1977)

Federal energy officials will try to interest companies in operating interim storage facilities for spent fuel from the nation's atomic power plants. Under the Carter Administration's plan for handling the rapid accumulation of used fuel, the government would take TTTLE to fuel rods, contract with private companies to put them in cooling pools for up to 20 
years, and build permanent underground storage sites (BW-Aug. 22). The estimated fee to be paid by utilities would increase electric bills by up to $2.5 \%$. Energy Dept. officials say they will start talking this month with companies interested in the proposal. Companies that already have experience in handling nuclear fuel include Exxon, Allied Chemical, Gulf Oil, Royal Dutch/Shell, and Getty Oil.

\section{SUBJECT CATEGORY: Spent Fuel}

ORIGIN: Commercial

KEYWORDS: GOVERNMENT POLICIES; SPENT FUEL STORAGE; NUCLEAR FACILITIES; ECONOMICS; FUEL RODS

\section{4}

COSTING OF NUCLEAR POWER. Important for the Future 11(2):9-11. (1977)

No generally accepted method for costing nuclear power has been agreed upon. Nuclear power stations also have certain cost items that do not exist for other types of power generation and should not be forgotten in a comparison of nuclear generating costs with non-nuclear generating costs. Therefore, 10 cost items that are higher in the case of nuclear power stations or do not exist in the case of non-nuclear power generation stations are discussed briefly. Some of these cost factors are not always included in nuclear power costs because such costs are borne by governments. The cost items discussed are: capital cost, repair and maintenance, capacity factor, the cost of long construction periods, insurance, land cost, disposal of radioactive wastes, dismantling nuclear power stations, protection, and training.

\section{SUBJECT CATEGORY: General}

ORIGIN: Commercial

KEYWORDS: CAPITAL; COMPARATIVE EVALUATIONS; CONSTRUCTION; COST; ECONOMICS; EDUCATION; GOVERNMENT POLICIES; LAND USE; MAINTENANCE; NUCLEAR INSURANCE; NUCLEAR POWER; NUCLEAR POWER PLANTS; PERSONNEL; RADIOACTIVE WASTE DISPOSAL; REACTOR DISMANTLING; SECURITY
995

PROMPT DISMANTLING VS. MOTHBALLING DECOMMISSIONED PLANT SAFETY, COST STUDIES. Nuclear Industry 24(2): 610. (1977)

A major engineering evaluation by the Atomic Industrial Forum concludes that it is practical to decommission reactors and outlines practical and cost-effective methods. the study estimates show a large reactor can be mothballed or entombed for over 100 years and then dismantled for between $\$ 13$ and $\$ 15$ million, not-including the costs of a security force or dismantling nonradioactive structures. For about $\$ 10$ million more, all other nonradioactive structures such as cooling towers can be removed from the site. The study lists alternative ways of decommissioning reactors that will assist utilities and their consultants in complying with NRC regulations.

SUBJECT CATEGORY: Remedial Action, FUSRAP

ORIGIN: Commercial

KEYWORDS: NUCLEAR POWER PLANTS; REACTOR DECOMMISSIONING; COST; REACTOR DISMANTLING

\section{6}

RADIOACTIVE WASTE MANAGEMENT. Transactions of the American Nuclear Society 26:15-20; Reactor Operating Experience, Proceedings of a Conference, August 7-10, 1977. American Nuclear Society, New York, NY. (1977)

This session of the conference presented papers on radioactive waste management for a $B W R$ : factoring operating experience into PWR radwaste systems design; Vermont yankee's radwaste system; radwaste system operating experience - Brunswick; radioactive waste disposal - after it leaves the plant; treatment of radioactive waste generated during the chemical cleaning of Dresden 1; nuclear plant modification feasibility for radwaste volume reduction equipment; economics of radwaste volume reduction and solidification systems; and design and operating considerations for commercial LWR volume reduction systems.

SUBJECT CATEGORY: General 
ORIGIN: Commercial

KEYWORDS: RADIOACTIVE WASTE MANAGEMENT; BWR TYPE REACTORS; PWR TYPE REACTORS; VERMONT YANKEE REACTOR; DRESDEN-1 REACTOR; DESIGN; ECONOMICS; RADIOACTIVE WASTE DISPOSAL; BRUNSWICK-1 REACTOR; SOLIDIFICATION; VOLUME

\section{7}

STUDY SHOWS FAVORABLE COSTS FOR COMPRESSED AIR STORAGE IN ALABAMA. Electric Light Power 55(6):12. (1977)

No economic, technical, or environmental barriers have been found to bar construction of a large-scale compressed air storage plant now in the conceptual design stage. 'l'he design plant 18 sited over an Alabama salt dome, allowing storage in four 670,000 cubic meter underground caverns that will be created by solution mining. Four models above ground each contain identical generating and compression equipment that will operate for five days and recharge during the night and on weekends. Recharging will be done by a nuclear plant's excess baseload. Capital for the plant is projected to be $\$ 158$ million, or $\$ 200$ per kilowatt, which makes it competitive with gas turbines. Environmental concerns will require care that brine is not spilled during the mining operation, but that is already a well-developed process. Studies of a West German compressed air storage project suggest the need for a hlgh relallve humidily and recommend the experimental plant be done in conjunction with a radioactive waste disposal project.

SUBJECT CATEGORY: Isolation

ÖRIGIIIN: Commercial

KEYWORDS: BRINES; CAPITAL; COMPKE'SSEL AIK ENEKGY S'IUKALIE; CUNSTRUCTION; DESIGN; ECONOMICS; ENVIRONMENTAL IMPACTS; PILOT PLANTS; POWER PLANTS; RADIOACTIVE WASTES; SAL'T DEPOSIIS'; SOLU'TION MINING; STORED ENERGY; WASTE DISPOSAL 
1978

998

Acres American, Inc., Buffalo, NY

INJECTION OF RADIOACTIVE WASTE BY HYDRAULIC FRACTURING AT WEST VALLEY, NEW YORK. VOLUME 2. TEXT. ANL K-78-4238-1(Vol.2). (1978)

Available from NTIS, PC A08/MF A01.

Results of a preliminary study are presented of the technical feasibility of radioactive waste disposal by hydraulic fracturing and injection into shale formations below the Nuclear Fuel Services Incorporated site at West Valley, New York. At this time there are approximately 600,000 gallons of high level neutralized Purex waste, including both the supernate (liquid) and sludge, and a further 12,000 gallons of acidic Thorex waste stored in tanks at the West Valley facilities. This study assesses the possibility of combining these wastes in a suitable grout mixture and then injecting them into deep shale formations beneath the West Valley site as a means of permanent disposal. The preliminary feasibility assessment results indicated that at the 850 to 1,250 feet horizons, horizontal fracturing and injection could be effectively achieved. However, a detailed safety analysis is required to establish the acceptability of the degree of isolation. The principal concerns regarding isolation are due to existing and possible future water supply developments within the area and the local effects of the buried valley. In addition, possible future natural gas developments are of concern. The definition of an exclusion zone may be appropriate to avoid problems with these developments. The buried valley may require the injections to be limited to the lower horizon depending on the results of further investigations.

SUBJECT CATEGORY: HLW

ORIGIN: Commercial

KEYWORDS: FEASIBILITY STUDIES; GROUTING; HYDRAULIC FRACTURING; NEW YORK; PUREX PROCESS; RADIOACTIVE WASTE DISPOSAL; RADIOACTIVE WASTES; THOREX PROCESS; UNDERGROUND DISPOSAL; WEST VALLEY PROCESSING PLANT
999

Burgess, A.S., and S.N. Thompson; Acres American, Inc., Buffalo, NY; Terra Tek, Inc., Salt Lake City, UT

INJECTION OF RADIOACTIVE WASTE BY HYDRAULIC FRACTURING AT WEST VALLEY, NEW YORK. VOLUME 4. SUPPLEMENT 1: COST ESTIMATE. ANL-K-78-42381(Vol.4). (1978)

The costs for injecting 3 million gallons of waste/grout mix in 200,000-gallon batches over 2 years are estimated to be 9.75 million dollars (including direct, indirect, operational, and decommissioning costs).

\section{SUBJECT CATEGORY: LLW}

ORIGIN: Commercial

KEYWORDS: COST; FLUID INJECTION; HYDRAULIC FRACTURING; RADIOACTIVE WASTE DISPOSAL; WEST VALLEY PROCESSING PLANT; VOLUME

\section{0}

Acres American, Inc., Buffalo, NY; Terra Tek, Inc., Salt Lake City, UT

INJECTION OF RADIOACTIVE WASTE BY HYDRAULIC FRACTURING AT WEST VALLEY, NEW YORK. VOLUME 1. EXECUTIVE SUMMARY. PRELIMINARY FEASIBILITY STUDY. ANL-K-78-4238-1(Vol.1). (1978)

Available from NTIS, PC A02/MF A01.

Results of a preliminary study, of the technical feasibility of radioactive waste disposal by hydraulic fracturing and injection into shale formations below the West Valley, New York site. In the hydraulic fracturing and injection process the liquid waste would be diluted, and mixed with cement, clay and other additives to form a stable solid matrix after injection. The waste could be injected into the shale beds, 800 to 1,500 feet below the existing site in zones suitable for horizontal fracturing and to provide satisfactory long term isolation. Hydraulic fracturing has been in use for the disposal of radioactive wastes at Oak Ridge National Laboratory (ORNL), Tennessee since the mid 1960 's. To date, over 1.8 million gallons of grout 
containing radioactive waste have been successfully injected at that site. In this study the West Valley site has been assessed in terms of the requirements for satisfactory disposal of radioactive waste by hydraulic fracturing on the basis of currently available information. A program of research and development, required to confirm or reject this means of disposal at the West Valley site, has been outlined.

\section{SUBJECT CATEGORY: LLW}

\section{ORIGIN: Commercial}

KEYWORDS: FEASIBILITY STUDIES; GROUTING; HYDRAULIC FRACTURING; NEW YORK; PUREX PROCESS; RADIOACTIVE WASTE DISFOSAL; RADIOACTIVE WASTES; THOREX PROCESS; UNDERGROUND DISPOSAL; WEST VALLEY PROCESSING PLANT

\section{1}

Adcock (Larry) and Associates, Albuquerque, NM

WASTE ISOLATION PILOT PLANT ENVIRONMENTAL IMPACT REPORT: SOCIOECONOMIC PORTION. AN OUTLINE OF THE INPUT-OUTPUT MODEL AND THE IMPACT PROJECTIONS METHODOLOGY. EAND-78-7061. (1978)

Available from NTIS, PC A07/MF A01.

A static model in the form of a regional input-output model was constructed for Eddy and Lea Counties, New Mexico. This modeling process has been used to assess the economic impacts of the following activities and for the following agencies: San Juan Generating Units Nos. 1, 3, and 4 for Public Service Company of New Mexico, and general economic impacts (an ongoing process) for the Bureau of Business and Economic Research, University of New Mexico. The regional modeling process adjusts a national model by means of location quotients and aggregating techniques. The national model, or base model, used in this process contains 407 economic categories or subsectors of the economy, 389 of which represent the private economy, and 18 of which represent activities mostly dealing with the public sector. The 389 identified sub-sectors were used in the modeling process; the government impact was computed after the private sector analysis.

SUBJECT CATEGORY: Isolation
ORIGIN: Commercial; Defense

KEYWORDS: ECONOMIC IMPACT; ENVIRONMENTAL IMPACT STATEMENTS; INPUT. OUTPUT ANALYSIS; NEW MEXICO; PILOT PLANTS; RADIOACTIVE WASTE FACILITIES; RADIOACTIVE WASTE STORAGE; SOCIOECONOMIC FACTORS; WIPP

1002

Anderson, R.T., D.G. Darr, W.L. Godfrey, R.B. Keely, E.C. Lusk, R.W. Peterson, J.L. Ridihalgh, F.A. Shallo, and M. Young; Allied-General Nuclear Services, Barnwell, SC

CURRENT STATUS AND FUTURE CONSIDERATIONS FOR A TRANSPORTATION SYSTEM FOR SPENT FUEL AND RADIOACTIVE WASTE. Y/OWI/SUB-77/42513. (1978)

Available from NTIS, PC A21/MF A01.

This report is part of the OWI Transportation/Logistics systems analysis of problems associated with shipping these wastes to waste terminal storage facilities. It covers governmental regulations and functional responsibilities, highway and rail transportation status and economic considerations, assessment of present industry capabilities and business-related considerations, important receiving facility considerations, necessary engineering and licensing-related aspects of packaging systems, and essential elements of reprocessing plant waste activities including packaging and transportation.

SUBJECT CATEGORY: Transportation; Spent Fuel

ORIGIN: Commercial

KEYWORDS: COST; ECONOMICS; MATERIALS HANDLING; NUCLEAR INDUSTRY; PACKAGING; RADIOACTIVE WASTE FACILITIES; RADIOACTIVE WASTES; REGULATIONS; SPENT FUELS; SYSTEMS ANALYSIS; TRANSPORT; TRANSPORTATION SYSTEMS; WASTE TRANSPORTATION

1003

Shallo, F.A.; Allied-General Nuclear Services, Barnwell, SC 
STUDIES AND RESEARCH CONCERNING BNFP: LWR SPENT FUEL STORAGE. AGNS-1040-1.4-20. (1978)

Available from NTIS, PC A07/MF A01. NTIS, PC A07/MF A01.

This report describes potential spent fuel storage expansion programs using the Barnwell Nuclear Fuel Plant-Fuel Receiving and Storage Station (BNFP-FRSS) as a model. Three basic storage arrangements are evaluated with cost and schedule estimates being provided for each configuration. A general description of the existing facility is included with emphasis on the technical and equipment requirements which would be necessary to achieve increased spent fuel storage capacity at BNFP-FRSS.

SUBJECT CATEGORY: Spent Fuel

ORIGIN: Commercial

KEYWORDS: BARNWELL FUEL PROCESSING PLANT; COST; DESIGN; EQUIPMENT; FUEL CYCLE; SPENT FUEL ELEMEN'TS; SPEN'I FUEL STORAGE; STORAGE FACILITIES; WATER COOLED REACTORS

1004

Busch, L, A.J. Zielen, and S.J.S. Parry; Argonne National Laboratory, Argonne, IL

ECONOMIC IMPACTS OF THE TOTAL NUCLEAR WASTE MANAGEMENT PROGRAM ENVISIONED FOR THE UNITED STATES. CONF-780316-11; Waste Management Fuel Cycles, Proceedings of a Conference, Tucson, AZ, March 5, 1978. (1978)

Available from NTIS, PC A02/MF A01. 7 tables

This paper presents information on the costs of nuclear waste management and on the impacts of those costs on the price of power and on the capital and labor markets. It is assumed that the LWR would he the sole commercial reactor used through the year 2000. Two fuel cycle options are considered: the throwaway mode (spent fuel is waste), and the full recycle for comparison. Total costs are calculated for all facilities needed to store, package, and reposit all the spent fuel through the lifetime of 380 GW capacity installed by 2000 and operating for 30 $y$. The economic impact is: the price of power produced by the reactors would be increased by $1.4 \%$; the capital for nuclear plants would apply to waste management; the average annual labor effort needed over the next 50 to 75 years is 3000 to 5000 man years; and the unit cost of spent fuel disposal is $\$ 129 / \mathrm{kg}$ ( $\$ 119 / \mathrm{kg}$ for full recycle).

SUBJECT CATEGORY: General

ORIGIN: Commercial; Defense

KEYWORDS: COMPARATIVE EVALUATIONS; COST; ECONOMICS; FORECASTING; FUEL CYCLE; NUCLEAR POWER; RADIOACTIVE WASTE DISPOSAL; RADIOACTIVE WASTE FACILITIES; RADIOACTIVE WASTE MANAGEMENT; REPROCESSING; SPENT FUELS; WATER COOLED REACTORS

\section{5}

Trevorrow, L.E., and M.J. Steindler; Argonne National Laboratory, Argonne, IL

CONTROL OF ENVIRONMENTAL IMPACT OF LOW-LEVEL AQUEOUS FUEL REPROCESSING WASTES BY DEEP-WELL DISPOSAL. CONF-781110-14; Proceedings of the 71st Meeting of the AICHE, Miami, FL, Nov 12, 1978. (1978)

Available from NTIS, PC A03/MF A01.

The following conclusions are made: (1) the technology and much experience for this disposal method are available; (2) large areas of the U.S. offer geological formations suitable for deep well disposal, but substantial effort may be required in the choice of a specific site; (3) although costs are substantial, they are small compared to associated environmental and energy benefits; (4) impacts on water consumers would be minimized through regulatory checks of siting, construction, and monitoring, and also through natural dilution and radioactive decay; (5) disposal wells must satisfy regulations, of recently-increased stringency, on siting, design, construction, operation, monitoring, and decommissioning.

\section{SUBJECT CATEGORY: LLW}

ORIGIN: Defense; Commercial

KEYWORDS: CAPITAL; COST; ENVIRONMENTAL IMPACTS; FLUID INJECTION; FUEL REPROCESSING PLANTS; GEOLOGIC STRATA; LIQUID WASTES; LOW-LEVEL RADIOACTIVE WASTES; MINERALOGY; RADIOACTIVE WASTE DISPOSAL; REGULATIONS; UNDERGROUND DISPOSAL; WELLS 


\section{6}

Richards, L.M., and M.J. Szulinski; Atlantic Richfield Co., Philadelphia, PA; American Nuclear Society, Chicago, IL

SUBSURFACE STORAGE OF COMMERCIAL SPENT NUCLEAR FUEL: BACK END OF THE LWR FUEL CYCLE. CONF-780304-; ANS: Back End of the LWR Fuel Cycle, Proceedings of a Conference, Savannah, GA, March 19, 1978. (pp. V1.19-V1.21). (1978)

In this concept, a spent fuel element aged 2 to 3 years in water basin is moved into a hot cell, the heat evolution rate is measured, and the fuel element is welded in a helium-filled can. The canned fuel element is then inserted into a shallow lined hole in dry alluvial soil on a square or hexagonal grid with spacings of 20 to 25 feet. A radiation-opaque cap is lowered into the top of the hole; about 8 feet of soil is above the top of the fuel can. Data are given on the effect of hole diameter and heat evolution rate on fuel can temperatures. For substantial tonnages of spent fuel (2000 MT), the proposed storage concept would have costs of bout one half those for conventional water basin storage.

SUBJECT CATEGORY: Spent Fuel; Isolation

ORIGIN: Commercial; Defense

KEYWORDS: ECONOMICS; HEATING; SOILS; SPENT FUEL ELEMENTS; SPENT FUEL STORAGE; UNDERGROUND STORAGE; RADIOACTIVE WASTE DISPOSAL

1007

Atomic International Div., Rockwell Hanford Operations, Richland, WA

ENGINEERING STUDY OF DRY NEARSURFACE INTERIM STORAGE OF FAST FLUX TEST FACILITY SPENT FUEL. RHOLD-66. (1978)

Dep. NTIS, PC A04/MF A01.

A brief study was conducted to assess methods for dry, near-surface storage of FFTF spent driver fuel assemblies in the 200 Area at Hanford. The disposable cask, drywell and vault concepts are the most promising approaches for FFTF spent fuel storage in the Hanford 200 Area starting in 1986. The cost and risk for the vault concept are higher than for either the disposable cask or drywell concepts. The disposal cask and drywell concepts are both satisfactory for this application. The risk for any of these concepts is minimal. Design and construction of a disposable cask or drywell facility can be completed within the constraint of a 1986 startup date if the project is initiated in FY-1980.

SUBJECT CATEGORY: Spent Fuel

ORIGIN: Defense

KEYWORDS: FEASIBILITY STUDIES; FFTF REACTOR; HANFORD RESERVATION; SPENT FUEL CASKS; SPENT FUEL STORAGE

1008

Pobereskin, M., F.A. O'Hara, W.J. Madia, W.J. Zielenbach, and K.R. Yates; Battelle Columbus Laboratory, Columbus, $\mathrm{OH}$

EVALUATION OF COPROCESSING AS AN ALTERNATIVE FUEL CYCLE. CONF-780622; Proceedings of the ANS Annual Meeting, San Diego, CA, June 18, 1978; 'Iransactions of the American Nuclear Society 28:68-69. (1978)

To make U-Pu fuel cycle proliferation resistant

No Abstract

SUBJECT CATEGORY: TRU

ORIGIN: Defense

KEYWORDS: ECONOMICG; FEABIDILITY STUDIES; FUEI CYCLE; PROLIFERATION; RADIOACTIVE WASTE MANAGEMENT; REPROCESSSING: SAFEGUARDS; SPENT FITFI S; TECHNOLOGY ASSESSMENT

\section{9}

Battelle Columbus Laboratory, Columbus, $\mathrm{OH}$

TRANSITION REPORT FOR THE QUARTER JULY 1-SEPTEMBER 30, 1978 . ONWI-9. (1978)

Available from NTIS, PC A05/MF A01.

Activities monitored by the Office of Nuclear Waste Isolation during the report period are summarized. Work devoted to identifying issues related to waste isolation and performance of system studies to assure comprehensive programs are reported along 
with equipment and procedures testing. Research is also reported on methodologies and data relative to chemical properties of radioactive wastes, and isolation materials for use in nuclear waste terminal storage projects. Summaries of work on site and repositories development are included.

SUBJECT CATEGORY: General

ORIGIN: Defense

KEYWORDS: BOREHOLES; ECONOMIC ANAL YSIS; ECONOMIC IMPACT; FUEL FABRICATION PLANTS; GEOTHERMOMETRY; OKLO PHENOMENON; .PHYSICAL RADIATION EFFECTS; PLUGGING; PUBLIC OPINION; RADIOACTIVE WASTE DISPOSAL; RADIOACTIVE WASTES; RESEARCH PROGRAMS; ROCK MECHANICS; ROCK-FLUID INTERACTIONS; SALT DEPOSITS; SHALES; SITE SELECTION; SPENT FUEL ELEMENTS; TRANSPORT; WATER COOLED REACTORS

\section{0}

Boegel, A.J., M.K. White, and C.E. Willingham; Battelle Pacific Northwest Laboratory, Richland, WA

\section{PROJECTED SPENT FUEL STORAGE RE-} QUIREMENTS. PNL-2564.' (1978)

This analysis identifies the post-reactor basin storage capacity requirements between now and 1990 for various combinations of utility actions in order to establish the full range of possible storage requirements. The combined actions of reracking reactor basins, transferring spent fuel within utilities, and relaxing the policy of reserving reactor basin capacity for a full core discharge are insufficient to meet pre-1985 spent fuel storage capacity requirements. Additional storage capacity is required before 1985 for at least 1000 BWR assemblies and 2000 PWR assemblies. Storage capacity must be provided for a minimum of 12,000 BWR assemblies and 7,000 PWR assemblies by 1990 . If none of the possible industry actions are taken, additional storage capacity is required for over 23,000 BWR and 17,000 PWR assemblies before 1985 and over 63,000 BWR and 40,000 PWR assemblies by 1990 . The amount of spent fuel which would be shipped to a post reactor basin storage facility between 1985 and 1990 depends on whether utilities continue the activities and policies required to meet spent fuel storage requirements before 1985. (no full core reserve, intra-utility fuel shipments) or seek to regain their pre-storage shortage posture (full core reserve capacity, no intra-utility fuel shipments). If utilities take the former approach, storage capacity . is required between 1985 and 1990 for approximately 11,000 BWR assemblies and 5,000 PWR assemblies. If the latter philososphy prevails, storage capacity must be provided between 1895 and 1990 for approximately $27,000 \mathrm{BWR}$ assemblies and 23,000 PWR assemblies.

SUBJECT CATEGORY: Spent Fuel

ORIGIN: Commercial

KEYWORDS: BWR TYPE REACTORS; FORECASTING; SPENT FUEL STORAGE; RADIOACTIVE WASTE STORAGE; SPENT FUELS; PWR TYPE REACTORS

1011

Enderlin, W.I.; Battelle Pacific Northwest I.aboratory, Richland, WA

AN ASSESSMENT OF U.S. DOMESTIC CAPACITY FOR PRODUCING REACTORGRADE THORIUM DIOXIDE AND CONTROLLING ASSOCIATED WASTES AND EFFLUENTS. PNL2593; 49 pp. (1978)

This study assesses U.S. capacity for producing reactor-grade $\mathrm{ThO} 2$ and controlling the wastes and effluents. A 28,000 MWe Th-U fuel cycle can be sustained using domestic $\mathrm{ThO} 2$ byproduct if purification capacity is expanded, the market for rareearth products remains stable, and sufficient imported monazite remains available. Analysis of the information obtained in this investigation gave the results that follow. Waste water, tailings, dust, smoke and gas, and radionuclides (primarily Th $232, \mathrm{Ra} 226$ ) associated with $\mathrm{ThO} 2$ production are quantified. There are 1,500 short tons of crude Th hydroxide, readily convertible to reactor-grade ThO2 that is impounded with rare-earth wastes at Chattanooga, Tn. Crude byproduct is produced at 250 ton/ year of equivalent ThO2. Eighty one percent is produced from imported monazite and $19 \%$ from domestic monazite. The maximum domestic capacity for producing reactor-grade $\mathrm{ThO} 2$ is about 65 to 100 ton/year. This capacity can sustain a Th fuel cycle up to $11,000 \mathrm{MWe}$ without recycling Th depending on the reactor types. This range can be increased to $28,000 \mathrm{MWe}$ by expanding $\mathrm{ThO} 2$ purification capacity. Constraints which could affect domestic $\mathrm{ThO} 2$ production are: uncertainity in the marketplace; limited Th for production of ThO2; limited production capacity; mounting concern over radioactivity in production. If demand for 
domestic $\mathrm{ThO} 2$ exceeds 250 ton/year, expanded research on costs, reserves, extraction, impact, and production constraints will be required.

SUBJECT CATEGORY: General

ORIGIN: Commercial

KEYWORDS: BY-PRODUCTS; DEMAND FACTORS; FEED MATERIALS PLANTS; FORECASTING; MONAZITES; PRODUCTION; RADIOACTIVE WASTE MANAGEMENT; THORIUM CYCLE; THORIUM OXIDES

\section{2}

Gore, B.F., J.D. Kaser, and T.J. Kabele; Battelle Pacific Northwest Laboratory, Richland, WA

FUSION FUEL CYCLE SOLID RADIOACTIVE WASTES. PNL-2719; 29 pp.; Pergamon Press, Elmsford, NY. (1978)

Eight conceptual deuterium-tritium fueled fusion power plant designs have been analyzed to identify waste sources, materials, and quantities. All plant designs include the entire $\mathrm{D}$ - $\mathrm{T}$ fuel cycle within each plant. The choice of materials within the reactor blanket is the controlling factor in fusion reactor waste generation. Choice of blanket structural material controls radiation damage rates and activation products created; chemical compatibility of blanket structure with fertile material and coolant controls corrosion rates and limits the blanket operating temperatures. The 8 conceptual fusion power plant designs studied in this report are the UWMAK-1, BNL Blanket, UWMAK-II, princeton, and ORNL Tokamak systems, the LLL Mirror, the LASL Theta Pinch, and the LASL Inertial systems. Primary fusion reactor radwastes identified from design documents were replaced blanket structures, corrosion products and spent getters, containment air tritium absorbents, bred tritium recovery materials, fuel recycle purification wastes, vacuum system materials, miscellaneous failed equipment, and decontamination and laundry wastes. E'stimated annual wastes quantities from replacement of structures in the blanket in $t$ /GWe were: stainless steel, $110-490$ for the UWMAK and Princeton Tokamak systems, 192 for the LLL Mirror, and 90 for the LASL Laser; niobium, 27 for ORNL Tokamak, 19 for LASL Theta Pinch; aluminum, 144 for BNL Tokamak; and other materials, $140-212$ for the BNL, ORNL and UWMAK-II Tokamak systems, 66 for LLL Mirror, and 34 for LASL Theta Pinch. Thirty-two metric tons of
LWR spent fuel rods would be removed per GWe. Estimated volumes (in cu $\mathrm{m} / \mathrm{GWe}$ ) of solid radwaste generated by the conceptual designs analyzed are: blanket replacement, 20-160; molecular sieve material, 30; getters and recovered products, $3-60$; failed equipment, 15-35; and decomtamination wastes, 80 220 . Total waste generated would be $150-600 \mathrm{cu}$ $\mathrm{m} / \mathrm{GWe}$, as compared with $500-1300 \mathrm{cu} \mathrm{m} / \mathrm{GWe}$ estimated for the LMFBR fuel cycle. The estimates for decontamination wastes are very uncertain; also, current research efforts to increase fusion reactor economy should considerably reduce blanket replacement wastes.

SUBJECT CATEGORY: HLW; LLW; Spent Fuel

ORIGIN: Commercial; Defense

KEYWORDS: THERMONUCLEAR REACTORS; RADIOACTIVE WASTE MANAGEMENT; VOIIIMF; T.ILIIII WASIIES; TRITIUM; SOLID WASTES; DECONTAMINATION; EQUIPMENT; FILTERS; STAINLESS STEELS; SPENT FUEL ELEMENTS; INVENTORIES

1013

Schneider, K.J., and C.E. Jenkins; Battelle Pacific Northwest Laboratory, Richland, WA

ANALYSIS OF THE DECOMMISSIOONNING OF A NUCLEAR FUEL REPROCESSING PLANT. CONF-780622; Proceedings of the ANS Annual Meeting, San Diego, California, June 18, 1978; Transactions of the American Nuclear Society 28: 366-367. (1978)

No Abstract

SUBJECT CATEGORY: Remedial Action, Surplus Facilities; Remedial Action, FUSRAP

ORIGIN: Defense; Commercial

KEYWORDS: BARNWELL FUEL PROCESSING PLANT; COST; DECOMMISSIONING; FUEL REPROCESSING PLANTS

1014

Smith, R.I.; Battelle Pacific Northwest Laboratory, Richland, WA

COST AND OCCUPATIONAL RADIATION EXPOSURE ESTIMATES FOR DECOMMISSIONING NUCLEAR POWER PLANTS. 
CONF-780622; Proceedings of the ANS Annual Meeting, San Diego, California, June 18, 1978; Transactions of the American Nuclear Society 28:666-667. (1978)

No Abstract

SUBJECT CATEGORY: Remedial Action, Surplus Facilities; Remedial Action, FUSRAP

ORIGIN: Commercial; Defense

KEYWORDS: COST; NUCLEAR POWER PLANTS; RADIATION DOSES; RADIATION HAZARDS; REACTOR DECOMMISSIONING; REACTOR DISMANTLING

1015

Smith, R.I., G.J. Konzek, and W.E. Kennedy, Jr.; Battelle Pacific Northwest Laboratory, Richland, WA

TECHNOLOGY, SAFETY AND COSTS OF DECOMMISSIONING A REFERENCE PRESSURIZED WATER REACTOR POWER STATION. NUREG/CR-0130 (Vol. 1 2); 800 pp. (1978)

Available from NTIS, US Department of Commerce, Springfield, VA 22161

Safety and cost information was developed for the conceptual decommissioning of a large $1175 \mathrm{MW}(\mathrm{e})$ PWR. Two approaches to decommissioning, immediate dismantlement and safe storage with deferred dismantlement, were studied to obtain comparisons between costs, occupational radiation doses; potential radiation dose to the public, and other safety impacts. The safety impacts of the decommissioning operations on the public were found to be small, compared with those of the operating power station. The principal impact on the public is the radiation dose resulting from the transport of radioactive materials to a disposal site.

SUBJECT CATEGORY: Remedial Action, Surplus Facilities; Remedial Action, FUSRAY

ORIGIN: Defense; Commercial

KEYWORDS: PWR TYPE REACTORS; DECOMMISSIONING; ECONOMICS; COST BENEFIT ANALYSIS; COST; RADIATION PROTECTION; RADIATION DOSES
1016

Smith, R.I., G.J. Konzek, and W.E. Kennedy, Jr.; Battelle Pacific Northwest Laboratory, Richland, WA

TECHNOLOGY, SAFETY, AND COSTS OF DECOMMISSIONING A REFERENCE PRESSURIZED WATER REACTOR POWER STATION. VOLUME 1. FINAL REPORT, JANUARY 76-MAY-1978.. NUREG/CR-0130 (Vol.1). (1978)

Available from NTIS, PC A14/MF A01.

Safety and cost information was developed for the conceptual decommissioning of a large [1175 MW(e)] pressurized water reactor (PWR) power station. Two approaches to decommissioning, Immediate Dismantlement and Safe Storage with Deferred Dismantlement, were studied to obtain comparisons between costs, occupational radiation doses, potential radiation dose to the public, and other safety impacts. Immediate Dismantlement was estimated to require about six years to complete, including two years of planning and preparation prior to final reactor shutdown, at a cost of $\$ 42$ million, and accumulated occupational radiation dose, excluding transport operations, of about 1200 man-rem. Preparations for Safe Storage were estimated to require about three years to complete, including $1 \$$ sup $1 \$ / \$$ sub $2 \$$ years for planning and preparation prior to final reactor shutdown, at a cost of $\$ 13$ million and an accumulated occupational radiation dose of about 420 man-rem. The cost of continuing care during the Safe Storage period was estimated to be about $\$ 80$ thousand annually. Accumulated occupational radiation dose during the Safe Storage period was estimated to range from about 10 man-rem for the first 10 years to about 14 man-rem after 30 years or more. The cost of decommissioning by Safe Storage with Deferred Dismantlement was estimated to be slightly higher than Immediate Dismantlement. Cost reductions resulting from reduced volumes of radioactive material for disposal, due to the decay of the radioactive containments during the deferment period, are offset by the accumulated costs of surveillance and maintenance during the Safe Storage period.

SUBJECT CATEGORY: Remedial Action, FUSRAP; Remedial Action, Surplus Facilities

ORIGIN: Defense; Commercial

KEYWORDS: COMPARATIVE EVALUATIONS; COST; PWR TYPE REACTORS; REACTOR DEC- 
OMMISSIONING; REACTOR DISMANTLING; SAFETY

\section{7}

Smith, R.I., G.J. Konzek, and W.E. Kennedy, Jr.; Battelle Pacific Northwest Laboratory, Richland, WA

TECHNOLOGY, SAFETY, AND COSTS OF DECOMMISSIONING A REFERENCE PRESSURIZED WATER REACTOR POWER STATION. APPENDICES. NUREG/CR-0130 (Vol.2); 494 pp. (1978)

Availablc from NTIS, PC $\Lambda 21 / \mathrm{MF} \Lambda 01$.

Detailed appendices are presented under the following headings: reference PWR facility description, reference PWR site description, estimates of residual radioactivity, alternative methods for financing decommissioning, radiation dose methodology, generic decommissioning activities, intermediate dismantlement activities, safe storage and deferred dismantlement activities, compilation of unit cost factors, and safety assessment details.

SUBJECT CATEGORY: Remedial Action, FUSRAP; Remedial Action, Surplus Facilities

ORIGIN: Defense; Commercial

KEYWORDS: COST; DATA; PWR TYPE REACTORS; RADIATION DOSES; RADIATION HAZARDS; REACTOR DECOMMISSIONING: REACTOR DISMANTLING; RISK ASSESSMEIVT; SAFETY

\section{8}

Smith, R.I., G.J. Konzek, and W.E. Kennedy, Jr.; Battelle Pacific Northwest Laboratory, Richland, WA

TECHNOLOGY, SAFETY AND COSTS OF DECOMMISSIONING A REFERENCE PRESSURIZED WATER REACTOR POWER STATION. VOLUME 2. APPENDICES. FINAL REPORT JANUARY 1976-MAY 1978. PB-282863;NUREG/CR-0130(Vol. 2). (1978)

Available from PC A18/MF A01.

Safety and cost information was developed for the conceptual decommissioning of a large (1175 MW(e)) pressurized water reactor (PWR) power station. Two approaches to decommissioning, Immediate Dismantlement and Safe Storage With Deferred Dismantlement, were studied to obtain comparisons between costs, occupational radiation doses, potential radiation dose to the public, and other safety impacts.

SUBJECT CATEGORY: Remedial Action, FUSRAP; Remedial Action, Surplus Facilities

ORIGIN: Defense; Commercial

KEYWORDS: COST; PWR TYPE REACTORS; RADIATION HAZARDS; REACTOR DECOMMISSIONING; REACTOR DISMANTLING; SAFETY

\section{9}

White, M.K., M.A. Lewallen, E.T. Merrill, and R.M. Fleischman; Battelle Pacific Northwest Laboratory, Richland, WA

SENSITIVITY OF THE FEDERAL FEE FOR MANAGING SPENT FUEL TO FINANCIAL AND LOGISTICAL VARIATIONS. PNL-2637. (1978)

Available from NTIS, PC A03/MF A01.

Three types of fees for federal spent fuel management service were calculated for a reference case and a number of variations. These fee types are a uniform fee applicable to all customers, a fee for disposal of spent fuel, and a fee for interim storage plus disposal of spent fuel. Results ranged from $\$ 124 / \mathrm{kg}$ to $\$ 256 / \mathrm{kg}$ for the uniform fee, $\$ 112 / \mathrm{kg}$ to $\$ 213 / \mathrm{kg}$ for the disposal fee, and $\$ 144 / \mathrm{kg}$ to $\$ 319 / \mathrm{kg}$ for the storage plus disposal fee. The reference case assumed that spent fuel would first be received by the government in 1983 at a 5,000 MT away fromreactor (AFR) basin. The first repository $(45,000$ MT) was assumed ready for fuel in 1988 , and the second $(100,000 \mathrm{MT})$ in 1997. The reference case results in fees of $\$ 129 / \mathrm{kg}$ for the uniform fee, $\$ 117 / \mathrm{kg}$ for disposal, and $\$ 232 / \mathrm{kg}$ for storage plus disposal. The sensitivity cases were grouped in five general categories of variations from the reference case assumptions: demand for storage/disposal services, facility schedules and characteristics, methodology for calculating the fee, discount rate and AFR financing, and delays or failure of the first repository.

SUBJECT CATEGORY: Spent Fuel

ORIGIN: Defense 
KEYWORDS: CHARGES; COST; DEMAND FACTORS; FINANCING; FUEL POOLS; RADIOACTIVE WASTE DISPOSAL; RADIOACTIVE WASTE FACILITIES; RADIOACTIVE WASTE MANAGEMENT; SPENT FUEL STORAGE; SPENT FUELS

\section{0}

Willenberg, H.J., T.J. Kabele, R.P. May, and C.E. Willingham; Battelle Pacific Northwest Laboratory, Richland, WA

MATERIALS FLOW, RECYCLE AND DISPOSAL FOR DEUTERIUM-TRITIUM FUSION. PNL-2830. (1978)

Available from NTIS, PC A06/MF A01.

The flow of materials to and from a deuterium-tritium fusion power plant is investigated. Three tokamak conceptual reactor designs are described and materials requirements are detailed. Various process options are considered for the reprocessing segment of materials cycle. A conceptual materials resource cycle is selected from these options and details of a conceptual reprocessing segment are described. Environmental control technology considerations associated with the reprocessing segment are outlined.

SUBJECT CATEGORY: LLW; HLW

ORIGIN: Defense; Commercial

KEYWORDS: BREEDING BLANKETS; COOL ING SYSTEMS; DEUTERIUM; ENVIRONMENTAL EFFECTS; ENVIRONMENTAL IMPACTS; HAZARDS; INVENTORIES; LITHIUM; RADIOACTIVE WASTE DISPOSAL; RADIOACTIVITY; REPROCESSING; SAFETY; THERMONUCLEAR REACTOR MATERIALS; TOKAMAK TYPE REACTORS; TRITIUM; REPROCESSING

1021

Boeing Engineering and Construction Co., Seattle, WA

GLOBAL SPENT FUEL LÖGISTICS SYSTEMS STUDY (GSFLS). VOLUME I. GSFLS SUMMARY REPORT. SAN-1583-1. (1978)

Available from NTIS, PC A20/MF A01.
An important element in the implementation of international nuclear energy policies is the creation of viable systems for transporting, handling, storing, and disposing of the world's spent nuclear fuel. There is an urgent need to implement selected global spent fuel logistics systems (GSFLS) which can best bridge the interests of countries throughout the world and provide the necessary means for transporting, handling, storing and disposing of spent nuclear fuel. The viability of these systems depends upon their compatibility with governmental policies and nonproliferation concerns; their adequacy in support of projected global nuclear power programs; and their adaptation to realistic technological and institutional constraints. The United States Department of Energy contracted with Boeing Engineering and Construction (BEC), a division of the Boeing Company, and its subcontractors, International Energy Associates Limited (IEAL) and the firm of Doub, Purcell, Muntzing and Hansen to conduct a study of issues and options in establishing GSFLS and to develop preliminary GSFLS concepts. BEC conducted the study integration and developed the technological/economic framework; IEAL researched and developed the institutional framework; and the firm of Doub, Purcell, Muntzing and Hansen conducted the legal/regulatory research associated with the study. BEC also consulted with the First Boston Corporation regarding generic financial considerations associated with GSFLS. This report provides a summarization of the GSFLS study findings.

SUBJECT CATEGORY: Spent Fuel

ORIGIN: Defense; Commercial

KEYWORDS: ECONOMIC ANALYSIS; GLOBAL ASPECTS; HIGH-LEVEL RADIOACTIVE WASTES; LEGAL ASPECTS; MATERIALS HANDLING; RADIOACTIVE WASTE DISPOSAL; RADIOACTIVE WASTE MANAGEMENT; REGULATIONS; SPENT FUEL ELEMENTS; SPENT FUEL STORAGE; TECHNOLOGY ASSESSMENT; TRANSPORT

1022

Botts, T., and J.R. Powell; Brookhaven National Laboratory, Upton, NY

EFFECTS OF WASTE MANAGEMENT ON THE IMPACT OF FUSION POWER. BNL-24566; CONF-780508-58; Technology of Con- 
trolled Thermonuclear Fusion, Proceedings of a Meeting, Santa Fe, NM, May 9, 1978. (1978)

Throughputs and inventories of radioactive materials that would have to be managed by a country whose primary form of electrical generation is fusion are estimated. Whole body dose rates for the entire population due to normal and off-normal incidents are calculated. For the case of equilibrium systems, two fusion cases are compared to an advanced fission power case. Comparisons are made for various stages of the fuel cycle and activated materials cycles. Fission reactor radiological impact is dominated by fuel reprocessing facility releases. These releases will decrease significantly if methods of containing $\mathrm{Kr} 85$ are implemented. Tritium releases during normal plant operations comprise most of the radiologic impact for both fusion cases. Total dose rates are estimated to be roughly two orders of magnitude lower for fusion than for fission reactors.

SUBJECT CATEGORY: General

ORIGIN: Cummercial

KEYWORDS: ENVIRONMENTAL IMPACTS; FUEL CYCLE; INVENTORIES; KRYPTON 85; RADIOACTIVE WASTE MANAGEMENT; RADIOACTIVE WASTES; RELEASE LIMITS; THERMONUCLEAR REACTORS; TRITIUM; RADIATIOON DOSES

\section{3}

Bathellier, A.; CEA Centre d'Etudes Nucleaires de Fontenay-aux-Roses, 92, France

MINIMIZATION OF THE PRODUCTION OF ALPHA-BEARING WASTES IN FUEL REPROCESSING PLANTS. Battelle-Pacific Northwest Laboratories Translation-323. (1978)

Available from NTIS, PC A02/MF A01.

Various methods for concentrating and separating alpha contaminants are reviewed: evaporation, combustion, washing and lixiviation. Their effects on the operation of a fuel reprocessing plant are considered. Guidelines for design of the plant are given. Finally, economic aspects are considered briefly.

SUBJECT CATEGORY: HLW; Spent Fuel

ORIGIN: Foreign
KEYWORDS: COMBUSTION; ECONOMICS; EVAPORATION; FUEL REPROCESSING PLANTS; RADIOACTIVE WASTE PROCESSING; RADIOACTIVE WASTES; LEACHING; WASHING

\section{4}

Comptroller General of the United States, General Accounting Office, Washington, DC

THE URANIUM MILL TAILINGS CLEANUP: FEDERAL LEADERSHIP AT LAST. PB283064; EMD-78-90; 39 pp. (1978)

The General Accounting Office (GAO) addresses the need for a Federal program to cleanup the 22 inactive uranium mill tailings sites; the adequacy of the proposed legislation that would authorize such a program, and the progress and problems of an existing, but much smaller, cleanup program at Grand Junction, Colorado. Proposed legislation would allow DOE to enter into cooperative arrangements with a number of states to cleanup 22 inactive uranium mill tailings sites. Advantages include 1) reducing a possible health hazard to the public as a result of radiation from the tailings; 3 ) taking a first step towards some of the problems of safely disposing of radioactive wastes; and 3) improving the otherwise depressed value of snme of the land on which the mill tailings are located. Areas of the proposed legislation (Residual Radioactive Materials Act 1978) that need clarification are as follows: exclusion of some mill tailings sites from the program; noed for more specific definition of custs; lack of time limit of the cleanup program; perpetual ownership of the tailings disposal sites; improving congressional control over the cleanup program; and designation of EPA to prescribe standards and criteria. The Grand Junction remedial action program starter in 1.97? with the basic objeotivo of cleaning up tailings-contaminated lorations where a potential health hazard existed. In six years only half of the project is finished and significant problems exist that may prevent the rest from being completed in an effective manner.

SUBJECT CATEGORY: Remedial Action, Mill Tailings

ORIGIN: Commercial

KEYWORDS: URANIUM; MILL TAILINGS; LEGISLATION; RADIOACTIVE WASTE DISPO. SAL; COST BENEFIT ANALYSIS; DECONTAMINATION; DECOMMISSIONING; RADIATION HAZARDS 
1025

Department of Energy, Washington, DC

DRAFT ENVIRONMENTAL IMPACT STATEMENT. STORAGE OF U.S. SPENT POWER REACTOR FUEL. DOE/EIS-0015D. (1978)

Available from W.H. Pennington, Office of NEPA Affairs, Washington, DC.

The environmental impact of implementing or not implementing the policy for interim storage of U.S. spent fuel is analyzed. The same quantity of spent fuel $(72,200$ MTU from U.S. power reactors by the year 2000) is assumed throughout the statement. The statement is prepared on a generic, rather than a facility-specific basis. Two options associated with implementing the policy are examined: (A) centralized storage in large independent spent fuel storage (ISFS) basins owned or operated by the U.S. Government, and (B) decentralized storage in reactor basins and small privately owned ISFS basins. The work force will be exposed to radiation and will experience occupational accidents at rates comparable to those in similar industries. Uses of natural resources, releases of thermal and nonradioactive effluents, and secondary effects on biota are judged to have very minor impact. The population doses from environmental release of radioactivity determined for local (within $80 \mathrm{~km}$ of the facility), United States, and the world populations are given. Effects of long-lived nuclides in the 100-year period following the end of the study are included to provide an assessment of effects of persistent nuclides. The doses range from about 1000 man-rem to the world population for Alternative 1A, with disposition beginning in 1985 , to 20,000 man-rem if fuel disposition is delayed until 1995 . The number of facilities expected in the work force, including transportation workers, is about 11 for all the alternatives. The analyses find that the environmental risks from major abnormal events and accidents are very small and essentially the same for all alternatives. The differences in environmental impact between the options are small and for all options the associated environmental effects are within existing national standards and guidelines.

SUBJECT CATEGORY: Spent Fuel

ORIGIN: Defense; Commercial

KEYWORDS: ENVIRONMENTAL IMPACT STATEMENTS; FORECASTING; FUEL CYCLE; FUEL POOLS; GOVERNMENT POLICIES; HUMAN POPULATIONS; RADIATION DOSES;
RADIATION HAZARDS; SAFEGUARDS; SPENT FUEL STORAGE; STORAGE FACILITIES; TRANSPORT; WATER COOLED REACTORS

1026

Department of Energy, Washington, DC

PRELIMINARY ESTIMATES OF THE CHARGE FOR SPENT-FUEL STORAGE AND DISPOSAL SERVICES. DOE/ET-0055. (1978)

Available from NTIS, PC A04/MF A01.

The purpose of this report is to stimulate discussion among a wide range of interested parties concerning a one-time charge by the U.S. Government for disposal, or interim storage and disposal, of spent unreprocessed nuclear fuel. The report contains a set of estimates of the charge based on current cost figures and a variety of demand, logistical, institutional, and cost overrun assumptions. The services are to be offered to domestic utilities by the U.S. Government in connection with the spent fuel policy approved by the President and announced by the Department of Energy (DOE) on October 18, 1977. This policy is a direct result of the indefinite deferral of all commercial reprocessing of spent fuel announced by President Carter on April 7, 1977. The services will also be offered to foreign governments on a limited basis in cases where this action would contribute to U.S. goals for nonproliferation of nuclear weapons. The report does not establish new policy and it does not commit DOE to any specific program, schedule or charge. No scenario or case is to be considered most important, no methodology is to be considered definitive, and no charge is to be considered most likely or to represent a proposed charge. The report describes basic principles and methodologies for calculating the charge and highlights primary cost centers. Current estimates of program and facility costs are used. Various aspects of the DOE Spent Fuel Storage Program are brought into focus through this analysis. Interested parties should find these assessment criteria helpful for their planning and useful in discussions concerning the program.

SUBJECT CATEGORY: Spent Fuel

ORIGIN: Commercial; Defense

KEYWORDS: CHARGES; COST; RADIOACTIVE WASTE DISPOSAL; SPENT FUEL STORAGE 
1027

Department of Energy, Washington, DC

REPORT OFTHE SUBGROUP ON MANAGEMENT OF SPENT FUEL FROM COMMERICAL POWER REACTORS OF THE INTERAGENCY REVIEW GROUP ON NUCLEAR WASTE MANAGEMENT. TID. -28904(Draft). (1978)

Available from NTIS, PC A02/MF A01.

In October 1977, a new policy was announced by DOE, under which the U.S. Government would accept fuel for storage. This document discusses the current status of the policy implementation of the poilcy, including the GEIS, storage/disposal fee, AFR requirements and storage facilities. The schedule and work plan are discussed. Congressional activity is also covered. 3 tables, 1 figure.

SUBJECT CATEGORY: Spent Fuel

ORIGIN: Commercial

KEYWORDS: CHARGES; FORECASTING; GOVERNMENT POLICIES; NUCLEAR MATERIALS MANAGEMENT; PLANNING; POWER REACTORS; REVIEWS; SPENT FUEL STORAGE; STORAGE FACILITIES

\section{8}

Buschmann, W.; Deutsche Gesellschaft fuer Wiederaufarbeitung von Kernbrennstoffen M.L. H. (DWK). İ̃anover, Germany, F.R.

DISMANTLING OF INACTIVE NUCLEAR POWER PLANTS WITH PRESSURIZED WATER REACTOR. Kerntechnik 20(4):185189. (1978)

6 tablès, 1 figure; in Gierman and Ninglish

The end of reactor operation must be expected after 30 or 40 years. After final shutdown of the reactor, it would be possible to dismantle the reactor partially or completely. This article shows how radiation exposure and costs can be determined in relation to the various possibilities for treating shutdown nuclear power plants. In addition, disposal of radioactive plant sections is discussed briefly.

SŪBJECT CATEGORY: Remedial Action, Surplus Facilities

ORIGIN: Foreign
KEYWORDS: NUCLEAR FACILITIES; DECOMMISSIONING; RADIOACTIVE WASTE DISPOSAL

\section{9}

Buschmann, W.; Deutsche Gesellschaft fuer Wiederaufarbeitung von Kernbrennstoffen M.L.H. (DWK), Hanover, Germany, F.R.

DISMANTLING OF SHUTDOWN NUCLEAR POWER PLANTS WITH PRESSURIZED WATER REACTORS, USING THE OBRIGHEIM NUCLEAR POWER PLANT AS AN EXAMPLE. Fortschr.-Ber. VDI Z., Reihe 4 52:1-163. (1978)

In Gcrman; 27 references.

A hypothetical dismantling of the Obrigheim nuclear power plant, the first commercially operated nuclear power plant with a pressurized water reactor in the Federal Republic of Germany, is discussed. The total radiation load for the dismantling and removal of radioactive components of this power plant after 40 years of operation is determined on the basis of dose value calculations and measurements. Using an empirically obtained cost factor, the costs stemming from the radiation load are determined, and, taking into account the maximum permissible radiation load per person, an estimate is made of the number of persons required for the dismantling and removal of the radioactive components. In a similar maimer, sume alternative solutions to the problem of total dismantling of a nuclear powcr plant are discussed.

SUBJECT CA'LGURY: Remedial Action, Surplus Facilities

ORIGIN: Foreign

KEYWORDS: COST; FCONOMICS, NUCLEAR FACILITIES; PWR TYPE REACTORS; DECOMMISSIONING

1030

Du Pont de Nemours (E.I.) and Co., Engineering Dept., Wilmington, DE

CONCEPTUAL DESIGN REPORT FOR THE AWAY FROM REACTOR SPENT FUEL STORAGE FACILITY, SAVANNAH RIVER PLANT. DPE-3547. (1978)

Available from NTIS, PC A14/MF A01. 
The Department of Energy (DOE) requested that Du Pont prepare a conceptual design and appraisal of cost for Federal budget planning for an away from reactor spent fuel storage facility that could be ready to store fuel by December 1982. This report describes the basis of the appraisal of cost in the amount of $\$ 270,000,000$ for all facilities. The proposed action is to provide a facility at the Savannah River Plant. The facility will have an initial storage capacity of 5000 metric tons of spent fuel and will be capable of receiving 1000 metric tons per year. The spent fuel will be stored in water-filled concrete basins that are lined with stainless steel. The modular construction of the facility will allow future expansion of the storage basins and auxiliary services in a cost-effective manner. The facility will be designed to receive, handle, decontaminate and reship spent fuel casks; to remove irradiated fuel from casks; to place the fuel in a storage basin; and to cool and control the quality of the water. The facility will also be designed to remove spent fuel from storage basins, load the spent fuel into shipping casks, decontaminated loaded casks and ship spent fuel. The facility requires a license by the Nuclear Regulatory Commission (NRC). Features of the design, construction and operations that may affect the health and safety of the workforce and the public will conform with NRC requirements. The facility would be ready to store fuel by January 1983, based on normal Du Pont design and construction practices for DOE. The schedule does not include the effect of licensing by the NRC. To maintain this option, preparation of the documents and investigation of a site at the Savannah River Plant, as required for licensing, were started in FY '78.

\section{SUBJECT CATEGORY: Spent Fuel}

\section{ORIGIN: Defense}

KEYWORDS: AWAY-FROM-REACTOR STORAGE; BWR TYPE REACTORS; COST; DESIGN; ENERGY CONSUMPTION; ENVIRONMENTAL IMPACTS; FUEL POOLS; PWR TYPE REACTORS; SAFETY; SAVANNAH RIVER PLANT; STORAGE FACILITIES

1031

EA and T Co., Inc., Marina del Rey, CA

DECOMMISSIONING HIGH-LEVEL WASTE SURFACE FACILITIES. UCRL-13844; 120 pp. (1978)

Available from NTIS, PC A06/MF A01
The protective storage, entombment and dismantlement options of decommissioning a High-Level Waste Surface Facility (HLWSF) was investigated. A reference conceptual design for the facility was developed based on the designs of similar facilities. State-of-the-art decommissioning technologies were identified. Program plans and cost estimates for decommissioning the reference conceptual designs were developed. Good engineering design concepts were on the basis of this work identified.

SUBJECT CATEGORY: Remedial Action, FUSRAP; Remedial Action, Surplus Facilities

ORIGIN: Commercial; Defense

KEYWORDS: COST; DECOMMISSIONING; HIGH-LEVEL RADIOACTIVE WASTES; RADIOACTIVE WASTE FACILITIES; RADIOACTIVE WASTE STORAGE

1032

Rothstein, H.L.; Ebasco Services Inc., New York

CONSIDERATIONS IN SIZING SPENTFUEL POOLS. Transactions of the American Nuclear Society 28:699-701; CONF-780622; Proceedings of the ANS Annual Meeting, San Diego, CA, June 18, 1978. (1978)

PWR; BWR

No Abstract

SUBJECT CATEGORY: Spent Fuel

ORIGIN: Commercial; Defense

KEYWORDS: BWR TYPE REACTORS; CONFIGURAT̄ION; COST; FUEL POOLS; PWR TYPE REACTORS; SPECIFICATIONS; SPENT FUEL STORAGE

1033

Sani, L., and U. Belelli; Ente Nazionale per l'Energia Elettrica, Rome, Italy

EVALUATION OF THE PROBLEMS ASSOCIATED WITH ENEL'S IRRADIATED FUEL MANAGEMENT. CONF-780658-20; INIS-mf4483; Storage of Spent Fuel Elements, Proceedings of a Seminar, Madrid, Spain, June 1978. (1978)

The present difficulties in the reprocessing field, which will continue for a period of time not easily 
definable, impose on the nuclear utilities the research of adequate solutions to solve the problem associated with storage of the fuels discharged by the nuclear power stations in operation. In this context, the paper examines the technical aspects of the various possible alternatives and on the basis of the Italian nuclear program, possible storage strageties are discussed on the assumption of the development of an adequate oxide-fuel reprocessing capacity. The problems related to storage in pools at the station or away from reactor are described in the light of the recent experience made in Italy with the adaptation of an old pool reactor out of service, that is, the Avogadro reactor in Saluggia, to store the fuels of the stations now in operation. Finally some economic aspects are considered in order to ascertain their impact on the cost of energy produced.

SUBJECT CATEGORY: Spent Fuel

ORIGIN: Foreign

KEYWORDS: AVOGADRO RS-1 REACTOR; DIAGRAMS; ECONOMICS; FUEL POOLS; ITALY; SPENT FUEL STORAGE

1034

Holcomb, W.F.; Environmental Protection Agency, Washington, DC

A SUMMARY OF SHALLOW LAND BURIAL OF RADIOACTIVE WASTES AT COMMERCIAL SITES BETWEEN 1962 AND 1976, WITH PROJECTIONS. Nuclear Safety 19(1):5059. (1978)

Good single source for inventory data on all six commercial sites, 10 tables, 2 figures, 32 references

The results of an inventory survey by the U.S. Environmental Prótection Agency of six commercial low-level burial sites are presented. The six sites include Maxey Flats, Kentucky; Beatty, Nevada; Barnwell, South Carolina; Sheffield, Illinois; Richland, Washington; and West Valley, New York. The current status of the six buried sites is discussed with respect to both regulatory restrictions and existing capacity. Waste volumes, curies of byproduct material, mass of special nuclear materials, and mass of source materials data are presented in tabular form for all six sites. Projections of future waste volumes through the year 2000 are presented.

SUBJECT CATEGORY: LLW; TRU

ORIGIN: Commercial
KEYWORDS: TRANSURANIUM ELEMENTS; STANDARDS; STANDARDS; VOLUME; FORECASTING; INVENTORIES

\section{5}

Environmental Protection Agency, Washington, DC

CONSIDERATIONS OF ENVIRONMENTAL PROTECTION CRITERIA FOR RADIOACTIVE WASTE. Background Report; 61 pp. (1978)

Control of radioactive materials duc to the potential risk to present and future generations is important. Difficulties are encountered when trying to derive risk estimates of long-lived radwastes such as $\mathrm{C} 14$, $\mathrm{Pu} 239$, and I 129 and then trying to base criteria on such calculations. Development of radwaste protection requirements involves: 1) designation of radioactive materials and their hazard potentials over time of decay; 2). use of risk estimates to determine the level of control; 3) the goals of control and the type of control that would best achieve the goal; 4) allowable levels of short-and long-term risks associated with various means of disposal; and 5) other environmental considerations such as retrievability, monitoring, and transfer of information to succeeding generations. Low-level wastes are those materials that would not present an acute hazard to maximally exposed individuals. This classification may exclude reactor wastes and discrete medical and industrial sources. The potential hazard from low-level wastes is radwastes leaching into the water which may ultimately be ingested by humans through the food chain. Such exposure depends upon the rate of transfer of the radionuclide through the surrounding soil and groundwater, the amount of dilution or concentration that occurs, and other factors. Also radioactive dust could pose a serious hazard if inhaled. 'Through 1976, the commercial sector generated 15 million cubic feet of waste packages with 3.8 million curies of low-level waste. Government sites in 1974 were estimated to contain 17 million curies in 42 million cubic feet of waste. Waste generation in the commercial sector is at 2 million cuhic feet/year and increasing while wastes from government programs is produced at a stable rate of 1.3 million cubic feet/year. Other wastes considered in this report are high-level and longlived wastes as well as fabricated naturally radioactive and diffuse wastes of naturally-occuring radionuclides. Risk considerations for radioactive wastes, control of radioactive wastes, risk perspectives and other consideration for radioactive waste are also included in the report. 
SUBJECT CATEGORY: HLW; LLW

ORIGIN: Commercial; Defense

KEYWORDS: EARTH ATMOSPHERE; ' BIOSPHERE; COST BENEFIT ANALYSIS; DOSE RATES; DRINKING WATER; DUSTS; ENVIRONMENT; GROUND WATER; HAZARDS; INHALATION; MONITORING; STANDARDS; RADIOACTIVE WASTE MANAGEMENT; LOW-LEVEL RADIOACTIVE WASTES; HIGH-LEVEL RADIOACTIVE WASTES; INVENTORIES

1036

Fenix and Scisson, Inc., Mercury, NV

MINEABILITY STUDY OF THE TERMINAL WASTE STORAGE PROGRAM: ELEANA INVESTIGATION. NVO-0038-35. (1978)

Argillites; Available from NTIS, PC A03/MF A01.

A mineability study was undertaken to determine if shafts, drifts and large open chambers could be mined in the Eleana argillite, and to estimate mining costs. The assumption was made that the facility would contain 30,000 cannisters emplaced at the rate of 1,000 per year in holes drilled both horizontally in the pillars and vertically down in the floor of the emplacement rooms at a $5 \mathrm{~m}$ spacing. An area 3,500 feet by 10,000 feet ( 800 acres) would be required. Not included in the study were effects due to seismic activity or thermal loading. It is concluded, based on present information, which is scanty, that much of the ground appears to be poor due to extensive faulting and fracturing; tunneling will be slow, difficult and expensive. The total estimated cost for disposal of 30,000 waste cannisters using the conceptual configuration assumed for this study, is $\$ 811,350,000$. Time required for initial development work prior to first cannister emplace ment is estimated to be 2.22 years. The following report gives the detailed analyses, time required and costs arrived at during this study.

SUBJECT CATEGORY: Isolation; HLW

ORIGIN: Commercial; Defense

KEYWORDS: COST; GEOLOGIC DEPOSITS; MINING; RADIOACTIVE WASTE DISPOSAL; SHAFT EXCAVATIONS; UNDERGROUND DIS. POSAL
1037

Rogers, V.C.; Ford, Bacon and Davis Utah, Inc., Salt Lake City, UT

ENVIRONMENTAL IMPACT OF URANIUM MILL TAILINGS GENERATED BETWEEN 1975 AND 2030. CONF-7811109; Proceedings of the 1978 Winter Meeting of American Nuclear Society, Washington DC, November 12, 1978; Trans. Am. Nucl. Soc. 30:91-92. (1978)

No Abstract

SUBJECT CATEGORY: Remedial Action, Mill Tailings

ORIGIN: Commercial

KEYWORDS: DAUGHTER PRODUCTS; ENVIRONMENTAL EXPOSURE PATHWAY; ENVIRONMENTAL IMPACTS; FEED MATERIALS PLANTS; FORECASTING; MILL TAILINGS; RADIUM 226; RADON

1038

Fields, S.R.; Hanford Engineering Development Laboratory, Richland, WA

STORE: A SYSTEM DYNAMICS MODEL OF SPENT FUEL STORAGE AND LOGISTICS IN THE LWR FUEL CYCLE. HEDLTME-7750. (1978)

Available from NTIS, PC A03/MF A01.

A system dynamics model has been developed to study the production and flow of spent fuel assemblies in the light water reactor (LWR) fuel cycle, and to determine the number of assemblies accumulated in storage by the year 2000 .

SUBJECT CATEGORY: Spent Fuel

ORIGIN: Commercial

KEYWORDS: BWR TYPE REACTORS; COMPUTER CALCULATIONS; COMPUTER CODES; FORECASTING; FUEL CYCLE; MATHEMATICAL MODELS; PWR TYPE REACTORS; S CODES; SPENT FUEL STORAGE; WATER COOLED REACTORS; RADIOACTIVE WASTE STORAGE; FORECASTING 
1039

Mochon, J.L., and R. Quintana; Hidroelectrica Fspanola, Madrid

COST AND IMPLICATIONS OF A MIDDLETERM PROGRAM FOR STORAGE OF SPENT FUEL IN A NUCLEAR POWER STATION (BWR). CONF-780658-18; INIS-mf-4478; Storage of Spent Fuel Elements, Proceedings of a Seminar, Madrid, Spain, June 1978. (1978)

Available from NTIS (US Sales Only), PC A02/MF A01.

The experience gained with the Cofrentes Nuclear Power Station Project is presented. Originally the station had two spent fuel storage pools, in the fuel building, plus a little pool inside the containment, and all were to be fitted with extensive aluminium storage racks with a total capacity for $1+-1 / 3$ cores. Due to the present world situation with regard to the "back-end" of the fuel cycle, it was decided to enlarge the pools size and to change the design of the racks, to obtain a final storage capacity of $5^{+-1 / 4}$ cores, so covering over 18 years of operation. The changes introduced in the project, as well as its costs, and the possibilities of election still open are examined in the paper.

\section{SUBJECT CATEGORY: Spent Fuel}

ORIGIN: Foreign

KEYWORDS: COFRENTES REACTOR; DESIGN; DIAGRAMS; ECONOMICS; FUEL POOLS; NUCLEAR FACILITIES; SPAIN; SPECIFICATIONS; SPENT FUEL STORAGE; BWR TYPE REACTORS

1040

Vegors, S.H. Jr., and E.B. Nieschmidt; Idaho National Engineering Laboratory, Idaho Falls, ID

PRELIMINARY INVESTIGATION OF A CRITICALITY MONITORING TECHNIQUE FOR A 'I'RANSURANIC WASTE INCINERATOR. TREE-1285. (1978)

Available from NTIS, PC A06/MF A01.

This report contains a detailed investigation of the feasibility of using photo induced fission to monitor the amount of transuranic material present in the waste streams flowing into and out of a proposed slagging pyrolysis incinerator which will be used to convert these wastes into a glassy-like slag. In addition to the feasibility study, areas of $R$ and $D$ necessary to confirm the viability of the proposed technique are identified; as well as other $R$ and $D$ efforts which will be needed to implement the proposed technique. A suggested timetable and estimated costs for such $R$ and $D$ are given.

\section{SUBJECT CATEGORY: TRU}

ORIGIN: Defense

KEYWORDS: COST; CRITICALITY; FEASIBIL ITY STUDIES; INFORMATION NEEDS; MONITORING; NUCLEAR REACTION ANALYSIS; PHU'TOFISSION; PYROLYSIS; RADIOACTIVE WASTE PROCESSING; RADIOACTIVE WASTES; SOLIDIFICATION; VITRIFICATION; TRANSURANIUM ELEMENTS; INCINERATORS

\section{1}

Idaho National Engineering Laboratory, Idaho Falls, ID

\section{ALTERNATIVES FOR LONG-TERM MAN- AGFMENT OF DEFENSE TRANSURANIC WASTE AT THE IDAHO NATIONAL ENGINEERING LABORATORY. IDO-10075. (1978)}

Available from NTIS, PC A10/MF A01.

The study reported here has identified, developed, and evaluated alternatives for long-term management of low-level TRU waste buried or stored at the INEL. The technology required for managing the waste, the risks to the publio, the radiological hazards to workers, and the estimated costs are discussed. The results of the study will assist in the preparation of a Programmatic EIS un the same subject. The costs of the alternatives were found to vary greatly. For the time period studied, the radiological risks to the public from all of the alternatives were calculated to be very small compared with the population risk due to natural background radiation.

SUBJECT CATEGORY: TRU

ORIGIN: Defense

KEYWORDS: COMPARATIVE EVALUATIONS; COST; IDAHO NATIONAL ENGINEERING LABORATORY; LOW-LEVEL RADIOACTIVE WASTES; RADIATION HAZARDS; RADIOACTIVE WASTE MANAGEMENT; RECOMMENDATIONS; TECHNOLOGY ASSESSMENT 
1042

Idaho National Engineering Laboratory, Idaho Falls, ID

DRAFT PROGRAMMATIC ENVIRONMENTAL IMPACT STATEMENT FOR MANAGEMENT OF DEFENSE HIGH-LEVEL RADIOACTIVE WASTE: IDAHO CHEMICAL PROCESSING PLANT, IDAHO FALLS, IDAHO. TID-29097. (1978)

Available from NTIS, PC A10/MF A01.

The Idaho Chemical Processing Plant processes irradiated nuclear fuel from test and research reactors for the recovery of fissionable uranium. The waste stream generated, containing radioactive fission products, cladding components, and chemical additives, is converted to a free-flowing granular solid (calcine) by fluidized-bed calcination. The calcine is stored in stainless steel bins located in reinforced concrete vaults built on bedrock and extending above the ground surface. This programmatic environmental impact statement was prepared to assess the full range of environmental impacts that could occur if the present waste management program were followed by implementation of one of the six alternative waste management options described. One of the options is to continue the present program. For each option the process is described and the potential radiological and non-radiological impacts are evaluated. Unavoidable adverse environmental effects are also cited. Program costs for implementation of the six options and to have all operations on a current basis by the year 2003 were estimated.

\section{SUBJECT CATEGORY: HLW}

ORIGIN: Defense

KEYWORDS: COST; ENVIRONMENTAL IMPACTS; IDAHO CHEMICAL PROCESSING PLANT; RADIATION DOSES; RADIATION HAZARDS; RADIOACTIVE WASTE MANAGEMENT; RADIOACTIVE WASTE PROCESSING; RADIOACTIVE WASTE STORAGE

\section{3}

Interagency Review Group on Nuclear Waste Management, Washington, DC

REPORT TO THE PRESIDENT BY THE INTERAGENCY REVIEW GROUP ON NUCLEAR WASTE MANAGEMENT. TID-28817 (Draft). (1978)
Available from NTIS, PC A09/MF A01.

President Carter has signaled his determination to develop a national nuclear waste management policy and program. Recognizing the numerous Federal agencies, as well as State and local interests, involved in such a program, the President established an Interagency Review Group (IRG) and charged it with developing a strategy for dealing with the waste management problem. In carrying out the Presidential mandate, the IRG has attempted, by a variety of means, to obtain a broad range of inputs and views from many sources, including Congress, State and local governments, Indian nations, industry, the scientific and technical community, public interest and environmental organizations, and the public. A draft report is presented which documents the tentative findings of the IRG, based on consideration of the possible strategies which have been identified for managing nuclear wastes. The report is issued for comment by members of the public. When these comments have been received, reviewed and incorporated, as appropriate, the report will be forwarded to the President for his consideration and guidance for further action.

SUBJECT CATEGORY: HLW; TRU

ORIGIN: Defense; Commercial

KEYWORDS: COST; DECISION MAKING; EVALUATION; HIGH-LEVEL RADIOACTIVE WASTES; PLANNING; PUBLIC OPINION; RADIOACTIVE WASTE DISPOSAL; RADIOACTIVE WASTE MANAGEMENT; SAFETY; STANDARDS; TRANSPORT; TRANSURANIUM ELEMENTS; USA

1044

International Atomic Energy Agency, Vienna, Austria

DECOMMISSIONING OF NUCLEAR FACILITIES, 1977 EDITION. REPORT OF A TECHNICAL COMMITTEE MEETING ON THE DECOMMISSIONING OF NUCLEAR FACILITIES ORGANIZED BY THE IAEA AND HELD IN VIENNA, 24-28 OCTOBER 1977. IAEA-205. (1978)

Available from NTIS (US Sales Only), PC A03/MF A01.

The need for development or refinement of some technical aspects of decommissioning and for 
international acceptance of definition of "stages" is reviewed. The bases for a code of practice and a guide to the code for decommissioning land based reactors are outlined.

SUBJECT CATEGORY: Remedial Action, Surplus Facilities

ORIGIN: Foreign

KEYWORDS: BIBLIOGRAPHIES; COST; DECOMMISSIONING; DECONTAMINATION; IAEA; NUCLEAR FACILITIES; NUCLEAR POWER PLANTS; REACTOR DECOMMISSIONING; RECOMMENDATIONS; RELEASE LIMITS

\section{5}

International Atomic Energy Agency, Vienna, Austria

REMOVAL, STORAGE AND DISPOSAL OF GASEOUS RADIONUCLIDES FROM AIRBORNE EFFLUENTS. Report of a Technical Committee Meeting Organized by the IAEA and Held in Vienna, 20-24 September 1976. IAEA-209. (1976.)

IAEA-209. (1978)

Available from NTIS (US Sales Only), PC A05/MF A01.

Radioisotopes in the gaseous effluents arising from fuel reprocessing plants are examined and the state of the art to remove, store and dispose of them are discussed. The generation and discharge of krypton-85, iodine 129 , tritium and carbon- 14 are treated in details. A comparison of the various separation processes is made. Economic aspects of removal of the radionuclides are analysed.

SUBJECT CATEGORY: Airborne

ORIGIN: Forèign

KEYWORDS: CARBON 14; COST; FUEL REPROCESSING PLANTS; GASEOUS WASTES; IODINE 129; KRYPTON 85; RADIOACTIVE WASTE DISPOSAL; RADIOACTIVE WASTE FACILITIES; RADIOACTIVE WASTE STORAGE; RADIOACTIVE WASTES; RELEASE LIMITS; TRITIUM

1046

Johnson (E.R.) Associates, Inc., Vienna, VA
FINAL REPORT, TASK 3: POSSIBLE USES OF THE NUCLEAR FUEL SERVICES, INC. REPROCESSING PLANT AT WEST VALLEY, NEW YORK. ANL-K-78-4190-3. (1978)

Available from NTIS, PC A04/MF A01. For research on alternative fuel cycles, spiking, coprocessing, waste solidification, and recovery of radioactive gases

The West Valley Plant could readily be used for work on reprocessing of alternative fuels, spiking, coprocessing (including CIVEX), waste solidification, and the recovery of radioactive gases. The plant could be easily modified for any scale between small-scale experimental work to production-scale demonstration, involving virtually any combination of fissile/ferlile fuel materials that might he. used in the future. The use of this plant for the contemplated experimental work would involve lower capital costs than the use of other facilities at DOE sites, except possibly for spiking of recovered products; the operating costs would be no greater than at other sites. The work on reprocessing of alternative fuels and coprocessing could commence within about one year; on recovery of radioactive gases, in 3 to 5 years; on spiking, in 4 years; and on waste solidification demonstration, in ubout 5 years. The contemplated work could be begun at this plant at least as early as at Barnwell, although work on spiking of recovered products could probably be started in existing hot cells earlior than at Weat Valley.

\section{SUBJECT CATEGORY: HLW}

ORIGIN: Commercial

KEYWORDS: COST; FEASIBILITY STUDIES; FUEL CYCLE; GASEOUS WASTES; PLUTONIUM RECYCLE; RADIOACTIVE WASTE PROCESSING; RADIOACTIVE WASTES; RECOVETIY; REGULA'TIONS; REPROCESSING; RESEARCH PROGRAMS; SOLIDIFICATION; USES; WEST' VALLEY PROCESSING PLANT

1047

Johnson (E.R.) Associates, Inc., Vienna, VA

FINAL REPORT, TASK 1: REMOVAL OF WAS'TE FROM NUCLEAR FUEL SERVICES, INC. HIGH LEVEL WASTE STORAGE TANKS. ANL-K-78-4190-1. (1978)

Available from NTIS, PC A04/MF A01. 
The feasibility was evaluated of sluicing and chemical cleaning of two high-level wastes from the West Valley tanks 8D2 and 8D4. Costs were estimated.

\section{SUBJECT CATEGORY: HLW}

ORIGIN: Commercial

KEYWORDS: COST; FEASIBILITY STUDIES; HIGH-LEVEL RADIOACTIVE WASTES; RADIOACTIVE WASTE STORAGE; REMOVAL; TANKS; WEST VALLEY PROCESSING PLANT

\section{8}

Johnson (E.R.) Associates, Inc., Vienna, VA

FINAL REPORT, TASK 4: OPTIONS FOR ON-SITE MANAGEMENT OF NUCLEAR FUEL SERVICES, INC. HIGH LEVEL WASTE. ANL-K-78-4190-4. (1978)

In-tank cement solidification or perpetual tank storage; available from NTIS, PC A03/MF A01.

Two on-site management options for handling the NFS high-level waste were analyzed: in-tank cement solidification and perpetual tank storage of the liquid waste. The cost of converting the $8 \mathrm{D} 4$ plus $8 \mathrm{D} 2$ waste to a cementitious solid; including mixing, grout preparation, and transfer to tank 8D1 would require $\$ 3,651,000$; the cost of cooling the solidified solid for 15 years, plus the cost of filling the rest of the tank space and annulus with grout, plus the cost of minimum surveillance are $\$ 10,002,000$. Modification of tank 8D2 would be required; prior to transfer of the waste, tank $8 D 1$ would also be modified for cooling of the grout mass. Estimated costs of perpetual tank storage (replacing the existing neutralized waste tank after 10 years, then transferring contents at 50-y intervals for $1000 \mathrm{y}$, with replacement of ventilation system and auxiliaries at 30-y intervals) would require a sinking fund of $\$ 11,039,000$. The acidic $8 \mathrm{D} 4$ waste would be transferred at 50-y intervals. The sinking fund requirements are sensitive to the difference between the intorest rato and the osealation rate, and aloo to the time assumed from present to the first tank replacement.

\section{SUBJECT CATEGORY: HLW}

ORIGIN: Commercial

KEYWORDS: CEMENTS; COST; HIGH-LEVEL RADIOACTIVE WASTES; RADIOACTIVE
WASTE MANAGEMENT; RADIOACTIVE WASTE PROCESSING; RADIOACTIVE WASTE STORAGE; SOLIDIFICATION; TANKS; WEST VALLEY PROCESSING PLANT

1049

Johnson (E.R.) Associates, Inc., Vienna, VA

FINAL REPORT, TASK 2: ALTERNATIVE WASTE MANAGEMENT OPTIONS, NUCLEAR FUEL SERVICES, INC., HIGH LEVEL WASTE. ANLKK-78-4190-2. (1978)

Available from NTIS, PC A08/MF A01.

Of the alternatives considered for disposal of the high-level waste in tanks 8D2 and 8D4, the following process is recommended: homogenization of the contents of tank $8 \mathrm{D} 2$, centrifugation of the sludge and supernate, mixing of the $8 \mathrm{D} 4$ acid waste with the centrifuged sludge, and converting the mixture to a borosilicate glass using the Hanford spray calciner/in-can melter.

\section{SUBJECT CATEGORY: HLW}

ORIGIN: Commercial

KEYWORDS: COST; HIGH-LEVEL RADIOACTIVE WASTES; RADIOACTIVE WASTE MAN AGEMENT; RADIOACTIVE WASTE PROCESSING; SOLIDIFICATION; VITRIFICATION; WEST VALLEY PROCESSING PLANT

\section{0}

Beckurts, K.H.; Kernforschungsanlage Juelich GmbH, Germany, F.R.

ROLE OF NUCLEAR ENERGY IN THE NEXT DECADES. Phys. Bl. 34(1):19-28; Annual meeting of the Oesterreichische Physikalische Gessellschaft joint with the Oesterreichische Gessellschaft fuer Elektronenmikroskopie, Leoben, Austria, September 26 - 30, 1977. (1978)

\section{In German}

The dispute over nuclear energy has led in many countries to an extremely involved entanglement of technology, politics, economy, judiciary and ideology. The role of nuclear energy will be determined in the next decades more by politico-psychological factors than by economic-technical ones; predictions for the future are thus - as in many other fields - 
uncertain. However, as the case may be, the role of nuclear energy will very decisively depend on the state of development which the fuel cycle will have reached. The article concentrates therefore on this sector, and the questions of uranium supply, waste management and proliferation are dealt with in detail.

\section{SUBJECT CATEGORY: General}

ORIGIN: Foreign

KEYWORDS: FORECASTING; FUEL CYCLE; NUCLEAR ENERGY; NUCLEAR MATERIALS MANAGEMENT: NUCLEAR POWER; NIJCLEAR POWER PLANTS; RADIOACTIVE WASTES; SAFEGUARDS; SECURI'TY

\section{1}

Kurfurst, P.J., T. Hugo-Persson, and G. Rudolph; Lawrence Berkeley Laboratory, Berkeley, CA; Hagby-Bruk AB, Nora, Sweden; VIAK, AB, Falun, Sweden

BOREHOLE DRILLING AND RELATED ACTIVITIES AT THE STRIPA MINE. LBL 7080; SAC-05; 47 pp. (1978)

Drilling operations for the Swedish-U.S. radioactive waste storage program at Stripa, Sweden were conducted from August 1977 to April 1978. One hundred sixty boreholes totalling over $2500 \mathrm{~m}$ were drilled. Two boreholes were diamond drilled from the surface to depths of $385 \mathrm{~m}$ and $360 \mathrm{~m}$. Seven water table holes were dry drilled from the surface to 50-100 m depths. A pattern of over 150 subsurface boreholes were diamond drilled in the full-scale, time-scaled, extensometer, and ventillation drifts. Cores were from $38 \mathrm{~mm}$ to $406 \mathrm{~mm}$ in diameter and $4.5 \mathrm{w} 14.5 \mathrm{~m}$ deep. All core from holes larger than 56 $\mathrm{mm}$ diameter was oriented. Seventy-six $38 \mathrm{~mm}$ instrumentation and heater boreholes were drilled to depths of 6-14 $\mathrm{m}$ using the Diamec 250 drill. Four $46 \mathrm{~mm}$ boreholes were drilled to depths of $11-13 \mathrm{~m}$ for the geophysical survey. Two $56 \mathrm{~mm}$ boreholes were drilled with the Diamec 250 and XF 60/90 drills to $5.5 \mathrm{~m}$ in the full-scale drift for use as pilot holes for the $406 \mathrm{~mm}$ main heater boreholes; 6 other $56 \mathrm{~mm}$ boreholes were drilled for the geophysical survey. Fifty-five $76 \mathrm{~mm}$ instrumentation and hydrological boreholes were drilled in the full-scale, time-scaled, extensometer, and ventilation drifts. Eight $127 \mathrm{~mm}$ heater boreholes were drilled in the time-scaled drift to depths of $11 \mathrm{~m}$. Subsurface drilling rates ranged from $1.6 \mathrm{~m} / 8 \mathrm{hr}$ shift for the $127 \mathrm{~mm}$ boreholes to $10.7 \mathrm{~m} / 8 \mathrm{hr}$ shift for the $46 \mathrm{~mm}$ boreholes. Surface rates averaged $5.3 \mathrm{~m} / 8 \mathrm{hr}$ shift. Rate depended on size of the borehole, type of core barrel used (single, double, or triple tube), location of drill, orientation of the borehole, lithology, etc. Total drilling costs in Swedish $\mathrm{krona} / \mathrm{m}$ ranged from 651 for the $38 \mathrm{~mm}$ boreholes to 1779 for the $127 \mathrm{~mm}$ holes. Core logging was done according to recommendations set forth by the Geological Society of London, 1970, with some modifications. Surveying results show that the specifications for accuracy and precision of drilling have been achieved and surpassed for all boreholes. Several new methods have been devel. oped during the operation, including a smooth wall blasting technique to excavate large drift openings, techniques for drilling and rccovery of $406 \mathrm{~mm}$ core, and slot drilling for $1 \mathrm{~m}$ and larger cores. Other operations conducted during this period included construction of surface inotallationo, gcophysical surveys, geologic mapping, stereophotography and fracture mapping in the drifts, TV logging, measurement of water influx to boreholes, geochemical water sampling, and pressure and injection tests.

SUBJECT CATEGORY: HLW; Isolation

ORIGIN: Foreign; Defense

KEYWORDS: FIELD TESTS; DRILLING; DRILL CORES; BOREHOLES; UNDERGROUND DISPOSAL; ECONOMICS; METHODS; EXCAVATION; GEOPHYSICAL SURVEYS; SWEDEN; RADIOACTIVE WASTE STORAGE

1052

Cohen, J.J., and W.C. King; Lawrence Livermore Laboratory, Livermore, $\mathrm{CA}$

DETERMINATION OF A RADIOACTIVE WAS'IE CLASSIFICATION SŸSTEM. UCRL-52535. (1978)

Available from NTIS, PC A08/MF A01.

Several classification systems for radioactive wastes are reviewed and a system is developed that provides guidance on disposition of the waste. The system has three classes: high-level waste (HLW), which requires complete isolation from the biosphere for extended time periods; low-level waste (LLW), which requires containment for shorter periods; and innocuous waste (essentially nonradioactive), which may be disposed of by conventional means. The LLW/innocuous waste interface was not defined in this study. Reasonably conservative analytical scenarios were used to calculate that 
HLW/LLW interface level which would ensure compliance with the radiological exposure guidelines of $0.5 \mathrm{rem} / \mathrm{y}$ maximum exposure for a few isolated individuals and $0.005 \mathrm{rem} / \mathrm{y}$ for large population groups. The recommended HLW/LLW interface level for $\mathrm{Pu} 239$ or mixed transuranic waste is $1.0 \mathrm{mu} \mathrm{Ci} / \mathrm{cm} 3$ of waste. Levels for other radionuclides are based upon a risk equivalent to this level. A cost-benefit analysis in accordance with as low as reasonably achievable (ALARA) and National Environmental Protection Act (NEPA) guidance indicates that further reduction of this HLW/LLL interface level would entail marginal costs greater than $10(\mathrm{E}+8)$ per man-rem of dose avoided. The environmental effects considered were limited to those involving human exposure to radioactivity.

SUBJECT CATEGORY: HLW; LLW

ORIGIN: Commercial

KEYWORDS: CLASSIFICATION; COST BENEFIT ANALYSIS; HIGH-LEVEL RADIOACTIVE WASTES; LOW-LEVEL RADIOACTIVE WASTES; RADIATION DOSES; RADIATION HAZARDS; RADIATION PROTECTION; RADIOACTIVE WASTE DISPOSAL; RADIOACTIVE WASTES

\section{3}

Heckman, R.A.; Lawrence Livermore Laboratory, Livermore, CA

DECOMMISSIONING OF SURFACE FACILITIES ASSOCIATED WITH REPOSITORIES FOR THE DEEP GEOLOGICAL DISPOSAL OF HIGH-LEVEL NUCLEAR WASTES. CONF-781180-2; IAEA-SM-234/19; UCRL-81094; Decommissioning of Nuclear Facilities, Proceedings of an International Symposium, Vienna, Austria, November 13, 1978. (1978)

Available from NTIS, PC A03/MF A01.

A methodology is presented in this paper to evaluate the decommissioning of the surface facilities associated with repositories for the deep geological disposal of high-level nuclear wastes. A cost/risk index (igure of merit), expressed as $\$ /$ manrem, is proposed as an evaluation criteria. On the basis of this cost/risk index, we gain insight into the advisability of adapting certain decontamination design options into the original facility. Three modes are considered: protective storage, entomb- ment, and dismantlement. Cost estimates are made for the direct labor involved in each of the alternative modes for a baseline design case. Similarly, occupational radiation exposures are estimated, with a larger degree of uncertainty, for each of the modes. Combination of these estimates produces the cost/risk index. To illustrate the methodology, an example using a preliminary baseline repository design is discussed.

SUBJECT CATEGORY: HLW; Remedial Action, Surplus Facilities

ORIGIN: Defense

KEYWORDS: COST; DECOMMISSIONING; HIGH-LEVEL RADIOACTIVE WASTES; RADIATION DOSES; RADIOACTIVE WASTE DISPOSAL; RADIOACTIVE WASTE FACILITIES; UNDERGROUND DISPOSAL

1054

Heckman, R.A., and B.G. Kniazewycz; Lawrence Livermore Laboratory, Livermore, CA

ANAL YSIS OF CAPITAL AND OPERATING COSTS ASSOCIATED WITH HIGH LEVEL WASTE SOLIDIFICATION PROCESSES. UCRL-80064; CONF-780304; Back End of the LWR Fuel Cycle, Proceedings of a Conference, Savannah, GA, March 19, 1978. American Nuclear Society, (pp. 1X.15-1X.21). (1978)

Available from NTIS, PC A02/MF A01; 2 tables.

An analysis was performed to evaluate the sensitivity of annual operating costs and capital costs of waste solidification processes to various parameters defined by the requirements of a proposed Federal waste repository. Five process methods and waste forms examined were: salt cake, spray calcine, fluidized bed calcine, borosilicate glass, and supercalcine multibarrier. Differential cost estimates of the annual operating and maintenance costs and the capital costs for the five HLW solidification alternates were developed.

\section{SUBJECT CATEGORY: HLW}

ORIGIN: Commercial

KEYWORDS: CAPITAL; COMPARATIVE EVALUATIONS; COST; HIGH-LEVEL RADIOACTIVE WASTES; OPERATION; RADIOACTIVE WASTE PROCESSING; SOLIDIFICATION 
1055

Orphan, R.C.; Lawrence Livermore Laboratory, Livermore, CA

STUDY OF APPLYINGTHEATMOSPHERIC
RELEASE ADVISORY CAPABILITY TO
NUCLEAR P POWER PLANTS N U CLE A R
UCRL-52525. (1978)

Use of ARAC to forecast hazards of accidental release of radionuclides to the atmosphere. Available from NTIS, PC A12/MF A01.

Each utility licensee for a nuclear power reactor is required to minimize the adverse effects from an accidental radionuclide release into the atmosphere. In the past the ability to forecast quantitatively the extent of the hazard from such a release has been limited. Now powerful atmospheric modeling techniques are available to assist nuclear reactor site officials with greatly improved assessments. Lawrence Livermore Laboratory. (LLL) has developed a prototype system called the Atmospheric Release Advisory Capability (ARAC) which is designed to integrate the modeling with advanced sensors, data handling techniques, and weather data in order to provide timely, usable advisories to the site officials. The purpose of this project is to examine the ways and means of adapting ARAC for application to many nuclear power reactors widely dispersed across the nation. The project will emphasize the management aspects, including government-industry relationships, technology transfer, organizational structure, staffing, implementing procedures, and costs. Benefits and costs for several alternative systems will be compared. The results will be reviewed and evaluated by the management and staff of the ARAC project at LLL and also by selected staff members of the sponsoring government agency.

\section{SUBJECT CATEGÜY: Airborne}

\section{ORIGIN: Commercial}

KEYWORDS: COMPARATIVE EVALUATIONS; COST BENEFIT ANALYSIS; DATA PROCESSING; EARTH ATMOSPHERE; ENVIRON MENTAL TRANSPORT; FISSION PRODUCT RELEASE; HUMAN POPULATIONS; MANAGEMENT; MATHEMATICAL MODELS; METEOROLOGY; NUCLEAR POWER PLANTS; RADIATION HAZARDS; RADIATION MONITORING; RADIATION MONITORS; RADIOACTIVE EFFLUENTS; RADIONUCLIDE MIGRATION; TECHNOLOGY TRANSFER
1056

Sauter, G.D.; Lawrence Livermore Laboratory, Livermore, CA

ARAC FEASIBILITY STUDY FOR THE NRC PHASE I: PROGRESS REPORT. UCI-179228. (1978)

Atmospheric Release Advisory Capability; available from N'TIS, PC A03/MF A01.

The report describes the results obtained and preliminary conclusions drawn to date from an NRC-funded study of the feasibility of incorporating the services of the Atmospheric Release Advisory Capability (AKAC) into the emergency response plans and programs of the Rancho Seco Nuclear Generating Station and the appropriate state and local agencies. The report describes the reasons why Rancho Seco was selected as the study site, the roles of the various agencies in response to an abnormal radiological release at Rancho Seco, and the potential benefits and costs of implementing ARAC at Rancho Seco.

SUBJECT CATEGORY: General

ORIGIN: Commercial

KEYWORDS: EMERGENCY PLAN; FEASIBIL ITY STUDIES; FISSION PRODUCT RELEASE; RADIOACTIVE EFFLUENTS; RANCHO SECO-1 REACTOR; RANCHO SECO-2 REACTOR; REACTOR ACCIUEN'IS; RECOMMENDATIONS; COST

1057

Ferguson, J.S.; Middle West Service Company

A CASE FUR FUNUING NUCLEAR RLAN'T DFCOMMISSIONINC COST. Power Engineering 82(12):53-56 1978). (1978)

Decommissioning alternatives include initial mothhalling with remnval after a conldown period, initial entombment with removal after a cooldown period, and prompt removal at the end of operating life. The last alternative, with funding of the cost during the life of the plant, would provide the greatest benefit to all concerned. Financial considerations result in a strong case for funding nuclear decommissioning cost; but successfully doing 80 will require enabling income tax regulations and, probably, legislation. 
SUBJECT CATEGORY: Remedial Action, FUSRAP

ORIGIN: Commercial

KEYWORDS: DECOMMISSIONING; COST BENEFIT ANALYSIS; ECONOMICS; NUCLEAR POWER PLANTS; COST

1058

Blane, D.E., and W.R. Herald; Mound Laboratory, Miamisburg, $\mathrm{OH}$

REMOVAL OF PLUTONIUM FROM HIGHLEVEL CAUSTIC WASTE SOLUTIONS USING BONE CHAR - PILOT STUDY. MLM-2534; 10 pp. (1978)

Pilot studies have been completed using 275 micrometer bone char as an absorbent for the removal of plutonium from Mound Facility caustic waste solutions. Bone char is the commercial name for a natural product made from granulated cattle bone and is a form of calcium hydroxyapatite [Ca10(PO4)6(OH)2]. The waste solutions emanate primarily from the three following sources: (1) a $4 \%$ $\mathrm{NaOh}$ corrosive vapor scrubber solution from the corrosive vapor system constituting about $90 \%$ of the volume; (2) filtrates from the $\mathrm{NH} 4 \mathrm{OH}$ precipitation of plutonium constituting about $8 \%$ of the volume, and (3) scrubber solutions for off-gases from an incinerator, analytical solutions, and other miscellaneous caustic solutions, constituting about $2 \%$ of the total volume. These sources generated about 1600 gallons of caustic waste during the calendar year 1977 . The waste stream was characterized by radioactivity levels in the range of 0.5 to $1.3 \mathrm{mg}$ of plutonium/liter (maximum near $8 \mathrm{mg} / \mathrm{li}$ ter), a pH of 8 to 13 , and a moderate amount of suspended solids. During the experiment, the waste solutions were adjusted to an approximate $\mathrm{pH}$ of 8 before they were passed through the columns of bone char. Overall decontamination factors of about $5 \times 10(E+9)$ were obtained in the study and a tentative design of a caustic waste treatment system utilizing cartridge filters and bone char columns was made. This proposed system has economic advantages over the current disposal methods and it offers a 10:1 reduction in the volume of solid waste that must be buried.

SUBJECT CATEGORY: TRU; HLW

ORIGIN: Commercial
KEYWORDS: PLUTONIUM; SORPTION; VOLUME; RADIOACTIVE WASTE PROCESSING; DECONTAMINATION; ECONOMICS; TRANSURANIUM ELEMENTS; HIGH-LEVEL RADIOACTIVE WASTES; CALCIUM COMPOUNDS

\section{9}

Bond, W.H., J.W. Koenst, and D.F. Luthy; Mound Laboratory, Miamisburg, $\mathrm{OH}$

TREATMENT OF LOW-LEVEL WASTE AT MOUND LABORATORY. CONF-771208; Treatment, Conditioning and Storage of Solid AlphaBearing Waste and Cladding Hulls, Proceedings of a Technical Seminar, Paris, France, December 5, 1977. Organization for Economic Co-Operation and Development, Paris, France. (1978)

The program at Mound Laboratory to handle lowlevel radioactive waste has two major objectives: 1 ) to design a volume reduction system for low-level combustible waste, both solid and liquid, and 2) to develop separation methods for removing radionuclides from liquid waste, both, low-level and intermediate-level. The result of the former effort is the Cyclone Incinerator which provides a volume reduction of 35:1. In meeting the latter objective, ultrafiltration has been demonstrated to be a feasible way of reducing the generation of secondary waste. Development of such techniques will significantly reduce waste management costs in the nuclear industry.

\section{SUBJECT CATEGORY: LLW}

ORIGIN: Commercial

KEYWORDS: RADIOACTIVE WASTES; RADIOACTIVE WASTE MANAGEMENT; RADIOACTIVE WASTE PROCESSING; LOW-LEVEL RADIOACTIVE WASTES; VOLUME; INCINERATORS; COST; ECONOMICS; MOUND LABORATORY

\section{0}

Edling, D.A., D.R. Hopkins, and H.C. Walls; Mound Laboratory, Miamisburg, $\mathrm{OH}$

TRU WASTE TRANSPORT ECONOMICS: AN OVERVIEW. CONF-780506-34; MLM-2524; Packaging and Transportation of Radioactive Materials, Proceedings of the Fifth Symposium, Las Vegas, NV, May 7, 1978. (1978) 
Portions of document are illegible. Available from NTIS, MF A01.

There are currently three predominant methods used to transport transuranium contaminated waste. These are: (1) ATMX Railcars-500 and 600 series, (2) Super Tigers, and (3) Poly Panthers. Both the ATMX-500 and 600 series railcars are massive doubly walled steel railcars which provide the equivalent protection of a Type B package. In ATMX-600 the rapid loading and unloading of the 9 $\times 9 \times 50$ feet cargo space is achieved by prepackaging the TRU waste into standard 20-foot steel cargo containers. The ATMX-500 railcars are divided into three inside bays, having dimensions of 16 (l) $\times 9.25$ (w) x 6.25 (h) feet. A typical load consists of 12855 gallon drums (however, space can accommodate 192 drums), 12 fiberglass boxes ( $4 \times 4 \times 7)$, or a combination of palletized drums and boxes. A Super Tiger is an overpack authorized for Type A. Type B, and large quantities of radioactive materials having outside dimensions of $8 \times 8 \times 20$ feet. Maximum payload is approximately $28,700 \mathrm{lb}$ with a gross weight of $45,000 \mathrm{lb}$. The primary factors influencing transport costs are examined including freight rates of transport mode, effective cargo (weight and volume) management, effective utilization of available space (package design), transport mileage, and rental fees or initial capital outlay. Miscellaneous factors are also examined.

SUBJECT CATEGORY: Transportation; TRU

ORIGIN: Commercial

KEYWORDS: COST; COST BENEFIT ANALYSIS; HIGH-LEVEL RADIOACTIVE WASTES; PACKAGING; SAFETY; SOLID WASTES; TRANSPORTATION SYSTEMS; TRANSURANIUM ELEMENTS; WASTE TRANSPORTATION

\section{1}

Mound Laboratory, Miamisburg, $\mathrm{OH}$

\section{TRITIUM WASTE CONTROL: APRIL-JUNE} 1978. MLM-2542. (1978)

Catalytic exchange detritiation; liquid waste decontamination; fixation in polymer impregnated concrete; management of high specific activity tritiated wastes; Available from NTIS, PC A02/MF A01.

The Combined Electrolysis Catalytic Exchange system was operated to experimentally determine mass transfer coefficients and to test the process controller. Values for $\mathrm{H} /$ sub OG/ and K/sub tilde $\mathrm{y} / \mathrm{a}$ were obtained at three separate molar flow ratios (tilde $\mathrm{L} /$ tilde G). Replicate values of $\mathrm{K}$ /sub tilde $\mathrm{y} / \mathrm{a}$ from additional runs agreed with initial results to within $16 \%$. Two process controller tests were completed that demonstrated the reliability of the system hardware and the feasibility of the digital controller software. The feasibility of using a xenon flashing. Source in the uv photodissociation step of the two-photon water hydrogen laser isotope separation (LIS) process has been demonstrated with $\mathrm{H} 2 \mathrm{O} / \mathrm{O} 2$ and $\mathrm{D} 2 \mathrm{O} / \mathrm{H} 2$ photodissociation step of the two-photon water-hydrogen laser isotope separation (LIS) process has been demonstrated with $\mathrm{H} 2 \mathrm{O} / \mathrm{D} 2$ and $\mathrm{D} 2 \mathrm{O} / \mathrm{H} 2$ photocatalyzed exchange experiments. A nearly $10: 1$ isotopic selectivity between the photodissociation of ground state $\mathrm{H} 2 \mathrm{O}$ and $\mathrm{D} 2 \mathrm{O}$ was observed with an unfiltered xenon flashlamp source. The effectiveness of the hydrogen scavenger system was also demonstrated in these experiments. Tests continued on samples of cement and cement-plaster mixtures which were injected with tritiated water, cured, and then impregnated with catalyzed styrene monomer. After polymerization the samples were put into uncontaminated water and the tritium concentration was monitored. No significant differences were noted except in two cases when the polyethylene bottle had been removed; which resulted in 35 times more tritium being released into the surrounding water. The samples still in the polyethylene bottles have released an average of $2.3 \mathrm{Ci}$ to the water. The tritium release study of actual burial packages is continuing. Two additional drums containing octane waste were added to the study, and now all types of liquid waste packaged are represented in the test. The average fractional release from three packages containing oil or water waste is $5 \times 10$ (E-7) after 180 weeks.

\section{SUBJECT CATEGORY: HLW}

ORIGIN: Commercial

KEYWORDS: CEMENTS; CONCRETES; ELECTROI.YSIS; FEASIRITITY STUDIES; HIGH. LEVEL RADIOACTIVE WASTES; LIQUID WASTES; MASS TRANSFER; POLYMERS; RADIOACTIVE WAETE FRUCËSSING; RESEARCH PROGRAMS; TRITIUM; RADIONUCLIDE MIGRATION

\section{2}

Kispert, R.C.; National Lead Co. of Ohio, Cincinnati, $\mathrm{OH}$ 
RECOVERY OF URANIUM FROM PIT SLUDGES AND COLD METAL OXIDE. NLCO-1149. (1978)

Available from NTIS, PC A03/MF A01.

Economic incentives do not currently exist for recovering uranium from either GAT pond sludge or the FMPC pit sludges and cold metal oxide. This conclusion is based on a detailed process engineering and economic analysis for recovering $184 \mathrm{MTU}$ from the low-level radioactive waste materials having a combined value of nearly eight million dollars. Processing the pond sludge may become desirable at some future time when economic factors could provide the proper incentive for making the venture attractive.

\section{SUBJECT CATEGORY: LLW}

ORIGIN: Commercial

KEYWORDS: ECONOMICS; FEASIBILITY STUDIES; FEED MATERIALS PRODUCTION CENTER; FLOWSHEETS; OXIDES; RADIOACTIVE WASTE PROCESSING; RECOVERY; SLUDGES; URANIUM

\section{3}

Hill, M.D., and P.D. Grimwood; National Radiological Protection Board, Harwell, England

\section{PRELIMINARY ASSESSMENT OF THE RA- DIOLOGICAL PROTECTION ASPECTS OF DISPOSAL OF HIGH-LEVEL WASTE IN GEOLOGIC FORMATIONS. NRPB-R69; 75 pp. (1978)}

Extensive tables are given of discussed parameters. Illustrations show disposal concepts, and leaching and discharge rates of selected radionuclides.

The purpose of this study is to carry out a preliminary assessment of the potential radiological consequences of disposing of vitrified high-level radioactive waste in geologic formations. The events which could lead to the release of radioactivity from a geologic repository are reviewed and ingress of groundwater is identified as the principal mechanism by which radioactivity may be transported back to the biosphere. A mathematical model of radionuclide migration with groundwater is used to predict possible rates of release of radioactivity into fresh water from a hypothetical repository containing all the high-level waste which may be generated in the UK up to the year 2000. The individual and collective doses which could be received as a result of man's use of contaminated fresh water are evaluated. The numerical results of the study depend very much on the assumptions made and cannot be used to draw any detailed conclusions. The main result is the identification of areas where further studies are required in order to carry out a full evaluation of this disposal option. (Auth)

SUBJECT CATEGORY: HLW; Isolation

ORIGIN: Foreign

KEYWORDS: REVIEWS; ECOSYSTEMS; AQUATIC ECOSYSTEMS; HIGH-LEVEL RADIOACTIVE WASTES; RADIOACTIVE WASTE DISPOSAL; VITRIFICATION; SOLIDIFICATION; GROUND WATER; RADIONUCLIDE MIGRATION; THEORETICAL STUDIES; MATHEMATICAL MODELS; RADIATION DOSES; SURFACE WATERS; SEISMOLOGY; ROCKS; FAULTS; CONTAINMENT; METEORITES; VOL CANOES; EROSION; METEOROLOGY; VOLUME; RADIATION EFFECTS; GROUND SUBSIDENCE; THERMAL PROPERTIES; DRILLING; SABOTAGE; LEACHING; CONTAINERS; MAN; EQUATIONS; SITE SELECTION; LAKES; DRINKING WATER; SORPTION; INGESTION; TECHNETIUM 99; CESIUM 135; RADIUM 226; SELENIUM 79; ZIRCONIUM 93; IODINE 129; CURIUM 245; NEPTUNIUM 237; URANIUM 233; THORIUM 229; PLUTONIUM 241; AMERICIUM 241

1064

May, J.R.; Newport News Industrial Corp., New port News, VA

RADIOACTIVE WASTE VOLUME REDUCTION. Power Engineering 82(10):68-71. (1978)

\section{4 figures}

New method for reducing the volume of low-level radioactive wastes combines evaporation and combustion into a single waste handling system. Substantial volume reduction and cost savings are indicated. The first commercial version of the new system for reducing the volume of low-level radwaste is planned for Unit 1 of the Nine Mile Point Nuclear Station. The system is expected to be delivered by the end of 1979 and to be operational in 1980 . 
SUBJECT CATEGORY: LLW

ORIGIN: Commercial

KEYWORDS: SOLIDIFICATION; RADIOACTIVE WASTE DISPOSAL; NINE MILE POINT-1 REACTOR; COMBUSTION; EVAPORATION; VOLUME; LOW-LEVEL RADIOACTIVE WASTES

\section{5}

Ewers, B.J. Jr.; Northern State Power Co., Minneapolis, MN

FINANCIAL EVALUATION OF NUCI.FAR PLANT DECOMMISSIONING COSTS. Transactions of the American Nuclear Society 30:554-555; CONF-7811109-; American Nuclear Society, 1978 Winter Meting, Washington DC, November 12, 1978. (1978)

No Abstract

SUBJECT CATEGORY: Remedial Action, Surplus Facilities

ORIGIN: Commercial

KEYWORDS: COST; NUCLEAR POWER PLANTS; REACTOR DECOMMISSIONING

\section{6}

Allen, J.H.; Nuclear Assurance Corp., Atlanta, GA

U.S. LWR SPENT FUEL INVENTORIES. ORNL/SUB-78/4258/1. (1978)

Available from NTIS, PC A01/MF A01,

The spent fuel disposition of the utilities is changing month to month due to the shift in the nature and direction of private and government efforts to close the backend of the fuel cycle. This report provides inventory and projection information concerning fuel discharged from each US reactor that will refuel prior to 1991.

SUBJECT CATEGORY: Spent Fuel

ORIGIN: Commercial

KEYWORDS: BWR TYPE REACTORS; FORECASTING; FUEL CYCLE; INVENTORIES; NU. CLEAR POWER PLANTS; PWR TYPE REAC-
TORS; REACTOR OPERATION; SPENT FUEL ELEMENTS; SPENT FUEL STORAGE; LWBR TYPE REACTORS; LWGR TYPE REACTORS; RADIOACTIVE WASTES; VOLUME

1067

Manion, W.J.; Nuclear Energy Services, Inc., Danbury, CT

GENERIC APPROACHES TO DECOMMISSIONING COMMERCIAL NUCLEAR POWER REACTORS. Transactions of the American Nuclear Society 28:665-666, Proceedings of the ANS Annual Moeting, San Diogo, California, June 18, 1978. (1978)

Available from TIC, Oak Ridge, TN. See CONF780622

No Abstract

SUBJECT CATEGORY: Remedial Action, Surplus Facilities

ORIGIN: Commercial

KEYWORDS: COMPARATIVE EVALUATIONS; COST; FEASIBILITY STUDIES; NUCLEAR POWER PLANTS; REACTOR DECOMMISSIONING; REACTOR DISMANTILING

1068

Manion, W.e., and '1.s. LaGuardia; Nuclear Energy Services, Inc., Danbury, CT

REACTOR DECOMMISSIONING-INFORMATINN PF.RTINENT TO PLANNING. Transactions of the American Nuclear Sociely 30:551; CONF-7811109; Proceedings of the 1978 Winter Meeting of the American Nuclear Society, Washington, DC, 1978. (1978)

No Abstract

SUBJECT CATEGORY: Remedial Action, Surplus Facilities

ORIGIN: Commercial

KEYWORDS: DECOMMISSIONING; COST; ECONOMICS; ENVIRONMENTAL IMPACTS; LEGAL ASPECTS; REACTOR DECOMMISSIONING 
1069

Oldham, W.A.; Nuclear Fuels Services, Inc., West Valley, NY

NUCLEAR FUEL SERVICES INC., QUARTERLY REPORT. NP-23489. (1978)

This quarterly report for the period July 1-September 30,1978 gives a summary of environmental monitoring, low-level liquid effluents, gaseous effluents, surveillance tests, and low-level liquid waste treatment at the West Valley processing plant. There was no processing of fuel during this period. The nuclear fuel and waste status are also summarized. Equipment functions are reported.

SUBJECT CATEGORY: LLW; Airborne

ORIGIN: Commercial; Institutional

KEYWORDS: ENVIRONMENTAL EFFECTS; EXPERIMENTAL DATA; GASEOUS WASTES; INVENTORIES; ISOLATED VALUES; NUCLEAR FUELS; PERFORMANCE; RADIATION MONITORING; RADIOACTIVE EFFLUENTS; RADIOACTIVE WASTES; 'TESTING; WEST VALLEY PROCESSING PLANT

1070

Watson, R.A., W.P. Bishop, I.R. Hoos, N. Hilberry, D.S. Metlay, and R.A. Watson; Nuclear Regulatory Commission, Division of Fuel Cycle and Material Safety, Washington, DC; Washington University, St. Louis, MO

GOALS FOR NUCLEAR WASTE MANAGEMENT: ESSAYS ON ISSUES RELEVANT TO THE REGULATION OF RADIOACTIVE WASTE MANAGEMENT. NUREG-0412, (pp. 6094). (1978)

Establishing a publicly, politically, economically, and technologically acceptable waste management system for the fuel cycle is a necessary condition for accepting the nuclear program as a national energy option. Findings are given on the technology, politice, cconomics, morality, aesthetics, and societal impact of waste management. Proposed goals are outlined for the regulation of waste management.

SUBJECT CATEGORY: General

ORIGIN: Defense; Commercial
KEYWORDS: ECONOMICS; GOVERNMENT POLICIES; PUBLIC OPINION; PUBLIC RELATIONS; RADIOACTIVE WASTE MANAGEMENT; REGULATIONS; SOCIAL IMPACT

1071

Nuclear Regulatory Commission, Fuel Process Systems Standards Branch, Washington, DC

PLAN FOR REEVALUATION OF NRC POLICY ON DECOMMISSIONING OF NUCLEAR FACILITIES. NRC Staff Report; 136 pp. (1978)

Available from NTIS A07/MF A01

Present NRC criteria and requirements for decommissioning nuclear facilities, as embodied in NRC regulations and guides, are identified and explained. Also identified and discussed are plans and programs now underway for reevaluating these criteria and requirements and for developing more explicit decommissioning criteria for light water reactors and for facilities and plants involving byproduct, source, and special nuclear materials. The overall program includes technical studies at the Battelle Pacific Northwest Laboratory on engineering methodology, radiation risks, and estimated costs of decommissioning light water reactors and associated fuel cycle facilities. The scope and purpose of these studies are presented and discussed. Schedules for each component of the overall program have been developed and are presented and discussed.

SUBJECT CATEGORY: Remedial Action, FUSRAP; Remedial Action, Surplus Facilities

ORIGIN: Commercial

KEYWORDS: GOVERNMENT POLICIES; WATER COOLED REACTORS; STANDARDS; REGULATIONS; RADIATION HAZARDS; COST; FUEL CYCLE; REACTOR DECOMMISSIONING; NUCLEAR FACILITIES

1072

Nuclear Regulatory Commission, Office of Inspection and Enforcement, Washington, DC

LICENSED FUEL FACILITY STATUS REPORT. VOLUME 1, NUMBER 1. DATA FOR 
DECISIONS, FUEL CYCLE OPERATIONS. SEMIANNUAL SUMMARY REPORT. NUREG-0430(Vol.1)(No.1); PB-281494. (1978)

Available from NTIS PC A04.

The report identified fuel cycle facility licensees and plant status along with NRC inspection results and summaries. The report includes licensee performance data such as inventory difference data commonly referred to as MUF; liquid and gaseous effluents released to the environment, and licensee event reports required by NRC regulations.

SUBJECT CATEGORY: General

ORIGIN: Commercial

KEYWOKDS: ACCIDENTS; FUEL CYCLE CEN. TERS; INSPECTION; INVENTORIES; LIQUID WASTES; MATERIAL UNACCOUNTED FOR; RADIOACTIVE EFFLUENTTS

\section{3}

Kleimola, F.W., and O.B. Falls, Jr.; NucleDyne Engineering Corp., Jackson, MT

RECOMMISSIONING-AN ALTERNATIVE TO DECOMMISSIONING. Transactions of the American Nuclear Society 30:555-556; CONF7811109-; ANS 1978 Winter Meeting, Washington DC, November 12, 1970. (1978)

SUBJECT CATEGORY: Remedial Action, FUSRAP

ORIGIN: Commercial

KEYWORDS: COMPARATIVE EVALUATIONS: COS'I'; NUCLEAR POWER PLANTS; REACTOR COMMISSIONING; REACTOR DECOMMISSIONING; REACTOR DISMANTLING

1074

Bardtenschlager, R., D. Bottger, and A. Gasch; Nuklear-Ingenieur Service GmbH, Hanau, Germany, F.R.

DECOMMISSIONING OF LIGHT-WATER REACTOR NUCLEAR POWER PLANTS. Nuclear Engineering and Design 45(1):1-51. (1978)

34 tables, 11 figures
This study deals with the technical and economic questions posed by the decommissioning of lightwater reactor nuclear power plants of the 900-1300 MW class, account being taken of the distinctions between boiling- and pressurized-water reactors. Possible decommissioning alternatives and the disposal or confinement of activity are discussed. It emerges from the discussion that decommissioning, and even total dismantlement of these nuclear power plants is in principle feasible. The activity inventory, one year after shutdown, is calculated to be about $3 \times 10(\mathrm{E}+7) \mathrm{Ci}$ for the BWR and $4 \times 10(\mathrm{E}+6)$ $\mathrm{Ci}$ for the PWR; 40 years after shutdown these figures are reduced to $2 \mathrm{X} 10(\mathrm{E}+6)$ and $4 \mathrm{X} 10(\mathrm{E}+5) \mathrm{Ci}$, respectively. The decommissioning costs to be expected are also estimated. 'l'his estimatc serves as the basis for an cconomic comparison by the present worth method. The econumic comparison shows that total dismantlement after a cooling time of one year is more than four timcs as expensive as interim confinement followed by total dismantlement waiting period of 40 years. The present worths for immediate total dismantlement are estimated at DM 200 million for the BWR and DM 170 million for the PWK; for the other alternativc, they are put at DM 45 million for the BWR and DM 42 million for the PWR. A still upein question is posed by the final storage of the large quantities of bulky radioactive waste arising in partial or total dismantlement. Since no decision on the storage method has yet been taken, disposal in casks is stipulated as a boundary condition in the estimation of the costs, although this is an unrealistic assumption. It is to be presumed that the costs of disposal can be reduced given appropriate final storage.

SUBJECT CATEGORY: Remedial Action, Surplus Facilities

ORIGIN: Foreign

KFYWORDS: ECONOMICS; COST; RADIOAOTIVE WASTE DISPOSAL; NUCLEAR FACILITIES; REACTOR DECOMMISSIONING; BWR TYPE RFACTORS; PWR TYPE REACTORS

\section{5}

Martinett, R., R.J. Stouky, and P.M. Garrett; NUS Corp., Rockville, MD

ON-SITE LOW-LEVEL RADWASTE MANAGEMENT ALTERNATIVES. CONF-7811109; ANS 1978 Winter Meeting, Washington, DC, Nov 12, 1978; Trans. Am. Nucl. Soc. 30:675. (1978)

No Abstract 
SUBJECT CATEGORY: LLW

ORIGIN: Commercial

KEYWORDS: COST; LOW-LEVEL RADIOACTIVE WASTES; NUCLEAR POWER PLANTS; RADIOACTIVE WASTE DISPOSAL; RADIOACTIVE WASTE MANAGEMENT; UNDERGROUND DISPOSAL

1076

Stouky, R.J.; NUS Corp., Rockville, MD

FACTORS AFFECTING POWER REACTOR DECOMMISSIONING COSTS FOR COMPLETE REMOVAL. CONF-780622; Proceedings of the ANS Annual Meeting, San Diego, CA, June 18, 1978; Transactions of the American Nuclear Society 28:667-669. (1978)

PWR, BWR

No Abstract

SUBJECT CATEGORY: Remedial Action, FUSRAP

ORIGIN: Commercial

KEYWORDS: BWR TYPE REACTORS; COST; NUCLEAR POWER PLANTS; PWR TYPE REACTORS; RADIATION HAZARDS; REACTOR DECOMMISSIONING; REACTOR DISMANTLING;

\section{7}

Blomeke, J.O., D.E. Ferguson, and A.G. Croff; Oak Ridge National Laboratory, Oak Ridge, TN

DISPOSAL OF SPENT FUEL. CONF-780316-4; Waste Management Fuel Cycles, Proceedings of a Conference, Tucson, AZ, March 5, 1978. (1978)

Based on preliminary analyses, spent fuel assemblies are an acceptable form for waste disposal. The following studies appear necessary to bring our knowledge of spent fuel as a final disposal form to a level comparable with that of the solidified wastes from reprocessing: 1. A complete syslems analysis is needed of spent fuel disposition from reactor discharge to final isolation in a repository. 2 . Since it appears desirable to encase the spent fuel assembly in a metal canister, candidate materials for this container need to be studied. 3 . It is highly likely that some "filler" material will be needed between the fuel elements and the can. 4. Leachability, stability, and waste-rock interaction studies should be carried out on the fuels. The major disadvantages of spent fuel as a disposal form are the lower maximum heat loading, $60 \mathrm{~kW} /$ acre versus $150 \mathrm{~kW} /$ acre for high-level waste from a reprocessing plant; the greater long-term potential hazard due to the larger quantities of plutonium and uranium introduced into a repository; and the possibility of criticality in case the repository is breached. The major advantages are the lower cost and increased near-term safety resulting from eliminating reprocessing and the treatment and handling of the wastes therefrom.

SUBJECT CATEGORY: Spent Fuel

ORIGIN: Commercial

KEYWORDS: FEASIBILITY STUDIES; FORECASTING; FUEL ASSEMBLIES; FUEL CYCLE; RADIOACTIVE WASTE DISPOSAL; RADIOACTIVE WASTE STORAGE; SPENT FUELS; WATER COOLED REACTORS; RADIOACTIVE WASTE MANAGEMENT

1078

Copeland, G.L., R.L. Heestand, and R.S. Mateer; Oak Ridge National Laboratory, Oak Ridge, TN

VOLUME REDUCTION OF LOW-LEVEL CONTAMINATED METAL WASTE BY MELTING. ORNL/TM-6388; Transactions of the American Nuclear Society 30:285-286; CONF7811109-; American Nuclear Society 1978 Winter Meeting, Proceedings, Washington DC, November 12, 1978. (1978)

Drip melting and induction melting

A review of the literature and prior experience led to selection of induction melting as the most promising method for volume reduction of low-level transuranic contaminated metal waste. The literature indicates that melting with the appropriate slags significantly lowers the total contamination level of the metals by preferentially concentrating contaminants in the smaller volume of slag. Surface contamination not removed to the slag is diluted in the ingot and is contained uniformly in the metal. This dilution and decontamination offers the potential of lower cost disposal such as shallow burial rather than placement in a national repository. A processing plan is proposed as a model for economic analysis of the collection and volume 
reduction of contaminated metals. Further development is required to demonstrate feasibility of the plan.

SUBJECT CATEGORY: LLW; TRU

ORIGIN: Defense

KEYWORDS: LOW-LEVEL RADIOACTIVE WASTES; MELTING; RADIOACTIVE WASTE PROCESSING; VOLUME; ECONOMICS; METALS; TRANSURANIUM ELEMENTS

1079

Ferguson, D.E.; Oak Ridge National Laboratory, Oak Kidge, TN

WASTE MANAGEMENT: CHEMICAL TECHNOLOGY DIVISION ANNUAL PROGRESS REPORT FOR PERIOD ENDING MARCH 31, 1978. ORNL-5383; pp. 23-31. (1978)

Work in the following fields is reported:partitioning and transmutation, removal and segregation of radionuclides and nitrates from liquid wastes, removal of organic contaminants and tritium from fuel reprocessing effluent streams, fixation of wastes in concretes, cement grouts for waste sludge disposal by hydrofracture, cements for plugging boreholes, updating ORIGEN, projection of wastes from fuel cycle, and assistance to OWI.

SUBJECT CATEGORY: General

ORIGIN: Commercial

KEYWORDS: CEMENTS; COMPUTER CODES; CONCRETES; DENITRIFICATION; FORECASTING; FUEL CYCLE; HYDRAULIC FRACTURING; RADIOACTIVE EFFLUENTS; RADIOACTIVE WASTE MANAGEMENT; RADIOACTIVE WASTE PROCESSING; RADIOACTIVE WASTES; REMOVAL; RESEARCH PROGRAMS; SLUDGES; SOLIDIFICATION; SPENT FUEL ELEMENTS; TRANSMUTATION; TRITIUM; PARTITION; REPORTS

\section{0}

Jenkins, J.D., E.J. Allen, and E.D. Blakeman; Oak Ridge National Laboratory, Oak Ridge, TN

MATERIAL CONTROL AND ACCOUNTABILITY PROCEDURES FOR A WASTE ISOLATION REPOSITORY. ORNL/TM-6162; 28 pp. (1978)
Addressed are control and accountability needs and requirements of a nuclear waste terminal storage facility. Such accountability will be to protect the health and welfare of the public by preventing theft, diversion, loss, and subsequent use of nuclear material by unauthorized personnel. Four types of waste are considered: high-level, cladding, intermediate-level, and low-level wastes. Standard containers will be used for storage and the high-level, cladding and intermediate-level wastes will have external shielding. Low-level wastes will probably be stored in 55 gallon drums. Lead, thorium, protactinium, uranium, neptunium, americium, cerium and all of their radioisotopes are considered. It is projected that by the year $2005,35,320$ canisters of HLW, CW, and II.W will be stored along with 76,000 drums of LLW. For accountability, record keeping is an absolute nectessily. Other wastes may be accepted at the waste storage facilities if spent fuel reprocessing is not performed. Three levels of control are needed at the facility: identification and item control: tamper indication; and quantitative material assay. Present measures for high-level waste accountability are sufficient, which is to insure and demonstrate safe delivery of the material. The same is true for cladding wastes, due to the nature of the wastes. Intermediate-level wastes need both item identification and tamper indicators as a result of their nature. Low-level wastes are the most difficult to control because of the variety of sources, hence material control should occur at the place where they are encapsulated. Technical options for item control, tamper indication, and nuclear material assuy are presented.

SUBJECT CATEGORY: HLW; LLW; Isolation

ORIGIN: Commercial

KEYWORDS: LOW-LEVEL RADIOACTIVE WASTES; INTERMEDIATE-LEVEL RADIOACTIVE WASTES; HIGH-LEVEL RADIOACTIVE WASTES; CLADDING; CLASSIFICATION;CONTAINERS; HAZARDS; NUCLEAR MATERIALS; RADIOISOTOPES; SAFETY; VOLUME

1081

Joy, D.S., and B.D. Holcomb; Oak Ridge National Laboratory, Oak Ridge, TN

LOGISTICS MODELS FOR THE TRANSPORTATION OF RADIOACTIVE WASTE AND SPENT FUEL. ORNL/TM-6192; 49 pp. (1978)

Logistics models for the transportation of low-level waste and spent fuel have been developed at ORNL in cooperation with the Office of Waste Isolation. 
The Low-Level Waste Model evaluates optimal transportation policies for shipping waste directly from the sources to a final destination without intermediate stops. The Spent Fuel Logistics Model evaluates optimal transportation policies for shipping unreprocessed spent fuel from nuclear power plants (1) indirectly, to an Away-From-Reactor (AFR) storage facility, with subsequent transshipment to a repository, or (2) directly to a repository. The models permit determination of shipping schedules, costs, transportation modes, minimal transportation equipment, minimal personnel exposure, optimal routes, etc., allowing repositories to balance work loads, evaluate surge capacity requirements, and estimate projected shipping cask fleets. The programs are tailored to utilize information on the types of wastes being received, location of repositories and waste generating facilities, shipping distances, time required for a given shipment, availability of equipment, above-ground storage capabilities and locations, projected waste through-put rates, etc. While each model was designed to simulate a particular waste movement, either model could be used to optimize the shipment of any commodity which would be shipped within the constraints outlined. In addition to these models, a Nuclear Reactor Data Base describing all U.S. nuclear power plants operating, under construction, or on order as of March 1, 1977 has been developed, together with a Spent Fuel Shipment Program to predict annual spent fuel shipments from U.S. reactors.

SUBJECT CATEGORY: Spent Fuel; Transportation; LLW

ORIGIN: Commercial

KEYWORDS: LOW-LEVEL RADIOACTIVE WASTES; FUELS; WASTE TRANSPORTATION; MATHEMATICAL MODELS; RADIOACTIVE WASTE STORAGE; RADIOACTIVE WASTE DISPOSAL; RADIOACTIVE WASTE MANAGEMENT; COST BENEFIT ANALYSIS; VOLUME; SPENT FUELS

\section{2}

Lotts, A.L., and P.R. Kasten; Oak Ridge National Laboratory, Oak Ridge, TN

HIGH-TEMPERATURE GAS-COOLED REACTOR FUEL RECYCLE DEVELOP. MENT. ANNUAL PROGRESS REPORT FOR PERIOD ENDING SEPTEMBER 30, 1977. ORNL-5423. (1978)
Available from NTIS, PC A12/MF A01.

The status of the following tasks is reported: program management, studies and analysis, fuel processing, refabrication development, in-plant waste treatment, research general support, and major facilities including HTGR recycle reference facility, hot engineering test facility and cold prototype test facility-refabrication.

SUBJECT CATEGORY: HLW; Spent Fuel

ORIGIN: Commercial

KEYWORDS: COST BENEFIT ANALYSIS; DEMONSTRATION PROGRAMS; ENVIRONMENTAL EFFECTS; FABRICATION; FILTERS; FUEL CYCLE; FUEL ELEMENTS; HEAD END PROCESSES; HIGH-LEVEL RADIOACTIVE WASTES; HTGR TYPE REACTORS; IODINE 129; MANAGEMENT; OFF-GAS SYSTEMS; PLANNING; QUALITY ASSURANCE; RADIOACTIVE WASTE PROCESSING; REMOVAL; REPROCESSING; RESEARCH PROGRAMS; SOLVENT EXTRACTION; SPENT FUELS; THORIUM CARBIDES; THORIUM CYCLE; URANIUM 233

\section{3}

Tamura, T., S.I. Auerback, D.E. Reichle, and E.G. Struxness; Oak Ridge National Laboratory, Oak Ridge, TN

\section{EARTH SCIENCES: ENVIRONMENTAL SCIENCES DIVISION ANNUAL PROGRESS REPORT FOR PERIOD ENDING SEPTEM- BER 30, 1977. ORNL-5365, (pp. 115-137). (1978)}

The following waste management studies were conducted: assessment of ORNL radioactive solid waste disposal practices and facilities; assessment of stream monitoring network in White Oak Creek watershed; discharge of $\mathrm{Sr} 90$ from burial ground 4; evaluation of burial ground corrosive measures; halocarbons as ground water tracers; Co 60 transport mechanisms; Co 60 adsorption kinetics; and soil chromatograph $\mathrm{K} / \mathrm{sub} \mathrm{d} /$ values. Other studies were conducted on cycling and transport of fusionactivation products in the terrestrial environment; Clinch River inventory; biological denitrification; leachates from stored fossil-fuel solids; coal storage piles; and disposal of solid wastes.

SUBJECT CATEGORY: LLW

ORIGIN: Commercial 
KEYWORDS: CLINCH RIVER; COAL; COBALT 60; CONTAMINATION; DENITRIFICATION; ENVIRONMENTAL TRANSPORT; FOSSIL FUELS; GROUND WATER; HALOGEN COMPOUNDS; INVENTORIES; LEACHING; MONITORING; ORNL; RADIOACTIVE WASTE DISPOSAL; RADIOACTIVE WASTE MANAGEMENT; SOILS; SOLID WASTES; STREAMS; STRONTIUM 90; UNDERGROUND DISPOSAL; WATERSHEDS

\section{4}

Kenchington, J.M., W.B. Stewart, and T.S. Drolet; Ontario IIydro, Toronto, Canada

EVALUATION OF LIQUID RADIOACTIVE WASTE TREATMENT SYSTEMS FOR CANDU-PHW REACTORS. Am. Soc. Mech. Eng., Yap. No. 78-J PGC-NE, (pp. 1-8). (1978)

The possibility of batches of liquid radioactive waste requiring treatment arising at Pickering and Bruce nuclear power stations has led to the installation of contingency treatment equipment. Concern for future stations has resulted in a study of the most suitable processing equipment to immobilize and package activity for storage. At present, worth cost comparison between filtration/ion exchange and evaporation/bituminization systems is presented for contingency and continuous operation.

\section{SUBJECT CATEGORY: LLW; HLW}

ORIGIN: Foreign

KEYWORDS: CANDU TYPE REACTORS; COST; EVAPORATION; FILTRATION; ION EXCHANGE; PHWR TYPE REACTORS; RADIOACTIVE WASTE PROCESSING; LIQUID WASTES

\section{5}

Parsons, Brinckerhoff, Quade and Douglas. Inc.. New York, NY

TECHNICAL SUPPORT FOR GEIS: RADIOACTIVE WASTE ISOLATION IN GEOLOGIC FORMATIONS. FACILITY CONSTRUCTION FEASIBILITY AND COSTS BY ROCK TYPE. Y/OWI/TM-36/18; 120 pp. (1978)

This report presents the results of a study comparing the general engineering feasibility and unit costs associated with sinking shafts and mining storage rooms for a radioactive waste repository in salt, granite, shale, or basalt. The wastes considered are from three LWR fuel cycles: uranium and plutonium recycling, no recycling of spent fuel, and uranium-only recycling. The report includes a discussion of the general effects of rock characteristics on shaft and mine design, the application of these considerations to the specific designs developed for the draft GEIS, shaft and mine construction techniques, and the unit cost comparison. The repository designs upon which this comparison was based are presented in other volumes of this series. Results of this study show that when all five shafts for the facility are considered jointly, the cost of sinking the five shafts is $\$ 62,391 /$ linear foot in ealt, $\$ 02,391 /$ linear fuul in granite, $\$ 49,898 /$ linear foot in shale, and $\$ 41,275 /$ linear fuol in basalt. Costs for shafts in salt, shale, and basalt are significantly higher than shaft costs in granite because shafts sunk in these three media are expected to traverse water-bearing zones which require extensive water control engineering during the shaft sinking operations. It should also be noted that the unit cost for shaft sinking in salt reflects the special water control techniques required to prevent dissolution of salt layers lying below water-bearing zones as the salt layers are penetrated. The effort required to control water inflows is expected to add approximately 49 weeks to the shaft construction schedule in salt, four weeks to the granite schedule, 33 weeks to the shale schedule, and 22 weeks to the basalt schedule. During the operation phase of a repository designed for Cycle II waste forms, total unit costs for mining werc calculated to be $\$ 14.23 / \mathrm{cu}$ yd for salt, $\$ 23.77 /$ cu yd for granite, $\$ 16.55 /$ cu yd for shale, and $\$ 24.95 / \mathrm{cu}$ yd for basult. These costs, which include mining, underground haulage, hoisting, surface disposal, power, equipment, and support, differ only minimally for repositories designed for Cycles I and III waste forms.

SUBJECT CATEGORY: HLW; Isolation; TRU; Spent Fuel

UKIGIN: Commercial

KEYWORDS: MINING; SALT DEPOSITS; GRANITES; BASALT; SHALES; ROCKS; DESIGN; ECONOMICS; GROUND WATER; HIGHLEVEL RADIOACTIVE WASTES; SPENT FUELS; RADIOACTIVE WASTE STORAGE; RADIOACTIVE WASTE DISPOSAL; SITE SELECTION; COST BENEFIT ANALYSIS; UNDERGROUND DISPOSAL; COST; GEOLOGY 
1086

Witzig, W.F., and M.E. Foster; Pennsylvania State Univ., University Park, PA

NUCLEAR WASTES AS A HEAT SOURCE. Nucl. Technol. 38(2):258-263; Low-Temperature Nuclear Heat, Proceedings of a Conference, Otaniemi, Finland, August 21, 1977. (1978)

In boiler to produce low-pressure steam

The concept of utilizing processed fission product wastes as a heat source to produce low-pressure steam in a nuclear waste boiler (NWB) has been analyzed. The conceptual NWB design utilizes solidified wastes from spent fuel reprocessing plants in a natural circulation boiler that is sectionalized to permit continuous operation during refueling. Any one of several proposed commercial solidification processes provides wastes in a containerized form suitable, without modification, to be used in this concept. The NWB is analyzed in terms of its fuel cycle, design, safety, and economic potential. It is competitive with fossil plants of similar capacity in limited applications when substantial quantities of waste are available.

SUBJECT CATEGORY: Spent Fuel; HLW

ORIGIN: Commercial

KEYWORDS: BOILERS; DESIGN; ECONOMICS; FISSION PRODUCTS; FUEL CYCLE; HEAT SOURCES; HIGH-LEVEL RADIOACTIVE WASTES; RADIOACTIVE WASTES; SAFETY; SOLIDIFICATION; SPENT FUEL ELEMENTS; STEAM GENERATION; USES; WASTE HEAT UTILIZATION

\section{7}

Witzig, W.F., M.E. Foster, and D.A. Dougherty (Ed.); Pennsylvania State University Park, PA

NUCLEAR WASTES AS A HEAT SOURCE: WORKSHOP PROCEEDINGS: DUAL ENERGY USE SYSTEM. CONF-7709152; Dual Energy Use Systems, Proceedings of a Workshop, Yarmouth, ME, September 19, 1977; EPRI-EM-7182, (pp. 3.85-3.99). (1978)

Nuclear Waste Boiler

One of the major problems facing the world today is the depletion of fossil-fuel energy sources. A stumbling block to a readily available solution to this problem, the use of nuclear energy, is the question of how to handle the radioactive waste byproducts. This paper presents a concept for utilizing nuclear wastes as a heat source to produce lowpressure steam, providing partial alleviation of fossil-fuel depletion, and rad-waste utilization. In addition to reducing the consumption of fossil fuel and utilizing energy that would otherwise be wasted, the method fits naturally and beneficially into current U.S. proposals for ultimate disposal of high-level radioactive wastes. The feasibility of the Nuclear Waste Boiler (NWB) presented here will be demonstrated in terms of its fuel cycle, design, safety analysis, and economic potential.

\section{SUBJECT CATEGORY: HLW}

ORIGIN: Commercial

KEYWORDS: BOILERS; BY-PRODUCTS; COMPARATIVE EVALUATIONS; DESIGN; ECONOMICS; FUEL CYCLE; HEAT SOURCES; LIQUID WASTES; NUCLEAR POWER PLANTS; RADIOACTIVE WASTES; SAFETY; WASTE HEAT; WASTE HEAT UTILIZATION; WASTE PRODUCT UTILIZATION; STEAM GENERATION

1088

Philadelphia Electric Co., Philadelphia, PA

DECOMMISSIONING PEACH BOTTOM UNIT 1. FINAL REPORT. NP-23584. (1978)

Available from Philadelphia Electric Co., 2301 Market Street, Philadelphia, PA.

This report documents the activities of decommissioning Peach Bottom 1, the first high-temperature gas-cooled reactor (HTGR) to operate in the United States. The report also presents the status of systems in the reactor facility; it will be a resource for the facility until such time as dismantlement and disposal of the remaining systems is carried out. A portion of this report covers the radiological conditions encountered and their impact on work progress. However, one of the principal observations during the progress of the decommissioning was that the plant was relatively uncontaminated compared with a pressurized water reactor or a boiling water reactor. In addition, the piping and systems were relatively easy to remove and dispose of.

SUBJECT CATEGORY: Remedial Action, FUSRAP 
ORIGIN: Commercial

KEYWORDS: COST; INSPECTION; PEACH BOTTOM-1 REACTOR; RADIATION

\section{9}

Kress, H.W.; Potomac Research, Inc., McLean, VA

WORKSHOPS FOR STATE REVIEW OF SITE SUITABILITY CRITERIA FOR HIGHLEVEL RADIOACTIVE WASTE REPOSITORIES. ANALYSIS AND RECOMMENDATION. VOLUME 1. PB-278113. (1978)

Available from NTIS, PC A04/MF A01.

The purpose of this report is to present the views and recommendations of State officials and legislators participating in a workshop concerned with preliminary site suitability criteria for high-level radioactive waste repositories. The workshops were open to the public and were conducted by the U.S. Nuclear Regulatory Commission (NRC) during September 1977 in three regional locations across the United States. This contractor report is the second of two reports and consolidates the discussion by State officials to the role of a State in siting a repository, NRC's waste management program, the transportation of high-level wastes, the number and location of repositories and concerns with the socioeconomic impacts of siting a repository in a community. 'The recommendations to the NRC can be categorized into four areas. These are: (1) general recummendations, (2) procedural recommendations, (3) recommendations for improving communications, and (4) specific recommendations on the preliminary siting criteria. The recommendations emphasized the need for early State involvement in the siting process, the need for an impacted State to assèsis repository operations, and the requirement that any repository developed insure the protection of the public health and safety as its most important characteristic.

BUDJECT CATEGORY: HLW; Isolation

ORIGIN: Commercial

KEYWORDS: GOVERNMENT POLICIES; HIGH-LEVEL RADIOACTIVE WASTES; MEETINGS; PLANNING; PUBLIC OPINION; RADIUACTIVE WASTE DISPOSAL; RADIOACTIVE WASTE FACILITIES; RECOMMENDATIONS; SITE SELECTION; SOCIO-ECONOMIC FACTORS; UNDERGROUND DISPOSAL; US NRC
1090

Krugmann, H.; Princeton Univ, Cent. for Environ. Stud., Princeton, NJ

WEST GERMANY'S EFFORTS TO CLOSE THE NUCLEAR FUEL CYCLE: STRATEGIES FOR RADIOACTIVE WASTE MANAGEMENT. Int. J. Energy Res. 2(2):107121. (1978)

2 figures and 45 references.

The radioactive wastes that would be generated in a closed nuclear fuel cycle are described. A brief discussion is given of the mulives that underlie the current international disagreement regarding the desirability of, and the need for, cloeing the nuclcar fucl cycle. West Germany's cuncept fur clusing the nuclear fuel cycle is outlined including institutional arrangements and responsibilities. A discusainn of radioactive waste classification follows. Expected volumes and inventories of radioactive wastes are pointed out. Current practices, and research and development work in the treatment and disposal of radioactive wastes are outlined. A final section is devoted to the history, circumstances and implications of the current requirement for a 'solution' for the back end of the nuclear fuel cycle as a precondition for continued expansion of nuclear power in West Germany.

SUBJECT CATEGORY: Spent Fuel

ORIGIN: Foreign

KEYWORDS: CLASSIFICATION; ECONOMICS; FUEL CYCLE; GERMAN FEDERAL REPUBLIC; PLANNING; RADIOACTIVE WASTE MANAGEMENT; RADIOACTIVE WASTES; REPROCESSING; INVENTORIES; VOLUME; FORECASTING

1091

Resources Agency of California, Sacramento CA

RADIOACTIVE MATERIALS IN CALIFORNIA. NP-23549. (1978)

Available from Resources Agency, Sacramento, CA.

This draft report covers: radioactive materials at fixed facilities, nuclear power plants and radioactive wastes, environmental surveillance and radiation monitoring, and decommissioning and decont- 
amination of radioactive facilities. Licensing, hazards, problem areas, etc. are covered, and recommendations are given for these problem areas.

SUBJECT CATEGORY: General; Remedial Action, FUSRAP

\section{ORIGIN: Commercial}

KEYWORDS: CALIFORNIA; COST; DECOMMISSIONING; EMERGENCY PLAN; FINANCING; HEALTH HAZARDS; HIGH-LEVEL RADIOACTIVE WASTES; INSPECTION; LICENSING; LOW-LEVEL RADIOACTIVE WASTES; NUCLEAR FACILITIES; NUCLEAR POWER PLANTS; RADIATION ACCIDENTS; RADIATION MONITORING; RADIOACTIVE MATERIALS; RADIOACTIVE WASTE DISPOSAL; REACTOR DECOMMISSIONING; REACTOR SAFETY; RECOMMENDATIONS; REGULATIONS; SPENT FUEL STORAGE

\section{2}

Beukema, F., K. Bronsema, J. Kemmink, H. Damveld (Ed.), R. Kramer (Ed.), and G. Kuiper (Ed.) Rijksuniversiteit Groningen, Netherlands

RADIOACTIVE WASTE, CH. 4: STORAGE OF RADIOACTIVE WASTE IN SALT CAVES. INIS-mf-4221, (pp. 52-79). (1978)

In Dutch

A survey of the amounts and composition of radioactive wastes produced at various stages is given. Incorporating the waste processing in the uranium and plutonium cycle reduces the production by $50 \%$.

SUBJECT CATEGORY: Isolation

ORIGIN: Foreign

KEYWORDS: FORECASTING; NUCLEAR POWER PLANTS; PLUTONIUM; RADIOACTIVE WASTE MANAGEMENT; RADIOACTIVE WASTES; URANIUM; SALT DEPOSITS; UNDERGROUND DISPOSAL; RADIOACTIVE WASTE STORAGE

1093

McKenzie, D.E., R.B. Paulson, and L.F. Grantham; Rockwell International, Canoga Park, CA
VOLUME REDUCTION OF SOLID ALPHA BEARING WASTE BY MOLTEN SALT COMBUSTION: TRAITEMENT, CONDITIONNEMENT ET STOCKAGE DES DECHETS SOLIDES ALPHA ET DES COQUES DE DEGAINAGE. CONF-771208; Treatment, Conditioning and Storage of Solid Alpha-Bearing Waste and Cladding Hulls, Proceedings of a Technical Seminar, Paris, France, December 5, 1977. Organization for Economic Co-operation and Development, Paris, France. (1978)

Atomics International is designing and constructing a Molten Salt Combustion System to reduce the volume of solid radioactive waste received and generated at the Idaho National Engineering Laboratory (INEL) in the United States. This 45 $\mathrm{kg} / \mathrm{hr}$ system will be used, initially, for the reduction of beta, gamma-contaminated waste and then later for alpha-bearing waste. This paper describes the Molten Salt Combustion concept of oxidizing combustible waste with air in molten sodium carbonate and summarizes the background development work. The paper will also discuss the design and equipment selection for the INEL unit.

SUBJECT CATEGORY: HLW; TRU

ORIGIN: Defense

KEYWORDS: ALPHA SOURCES; COMBUSTION; INCINERATORS; LIQUID WASTES; MOLTEN SALTS; RADIOACTIVE WASTE PROCESSING; SODIUM CARBONATES; SOLID WASTES; VITRIFICATION; VOLUME; ALPHABEARING WASTES

1094

Dennis, A.W., J.A. Milloy, L.W. Scully, H.C. Shefelbine, R.E. Stinebaugh, and W.E. Wowak; Sandia Laboratory, Albuquerque, NM

REVISED CONCEPT FOR THE WASTE ISOLATION PILOT PLANT. SAND-78-1429. (1978)

\section{Available from NTIS, PC A03/MF A01}

The quantities of remotely handled wastes that must be handled at the Waste Isolation Pilot Plant have been reduced from $250 \times 10(\mathrm{E}+3) \mathrm{cubic} \mathrm{ft} / \mathrm{y}$ to $10 \times 10(\mathrm{E}+3)$ cubic $\mathrm{ft} / \mathrm{y}$; the capital cost of the facility will be reduced from 534 to 428 million dollars. Changes in the facility design due to the reduction in the amount of remote-handled waste are discussed. If DOE should exercise its option to 
construct a high-level waste repository concurrently with the construction of the revised design, with both facilities receiving waste in 1985 , the combined cost would be about 580 million dollars. However, it is unlikely that significant quantities of high-level waste in a form suitable for geologic disposal would be available until after 1990 .

SUBJECT CATEGORY: Isolation

ORIGIN: Defense

KEYWORDS: COST; DESIGN; PILOT PLANTS; PLANNING; RADIOACTIVE WASTE DISPOSAL; REMOTE HANDLING: UNDERGROIND DISPOSAL; HIGH-LEVEL RADIOACTIVE WASIIES; WIPP

\section{5}

Driggers, F.E.; Savannah River Laboratory, Aiken, SC

ECONOMICS OF WATER BASIN STORAGE OF SPENT LIGHT WATER REACTOR FUEL. CONF-780622-35; DP-MS-78-1; Transactions of the American Nuclear Society 28:331-333; American Nuclear Society Annual Meeting, San Diego, CA, June 18, 1978. (1978)

Available from NTIS, PC A02/MF A01; 8 tables

As part of the International Spent Fuel Storage program, a preliminary Venture Guidance Assessment of the cost was made. The escalated cost of a reference facility with a capacity to receive 2000 $\mathrm{MT} / \mathrm{y}$ of spent LWR fuel and to store $5000 \mathrm{MT}$ in water-filled pools was converted to $\$ 180$ million in 1978 dollars for a stand-alone facility. It was estimated that the receiving rate could be increased to $3000 \mathrm{MT} / \mathrm{y}$ for an additional $\$ 15$ million and that increments could be added to the storage capacity for $\$ 13$ million per $1000 \mathrm{MT}$. If a receipt rate of more than $3000 \mathrm{MT} / \mathrm{y}$ is required, a new facility in another part of the country might be built to reduce total costs including transportation. Operating costs are determined by the number of penple employed and by the costs of stainless steel baskets. An operating crew of 150 is required for the reference facility; the associated cost, including overhead and supplies, is $\$ 6$ million. During an extended storage-only period, this cost is assumed to drop to $\$ 4$ million. Fuel baskets are estimated to cost $\$ 6.20 / \mathrm{kg}$ of spent fuel averaged over a reactor mix of two-thirds PWRs and one-third BWRs. The nominal basket requirements of $\$ 10$ million for the first year are capitalized. If the facility is financed by the government and a one-time fee is charged to recover all of the away-from-reactor (AFR) basin costs, the fee is about $\$ 60 / \mathrm{kg}$ of spent fuel plus any government surcharge to cover research and development, overhead, and additional contingencies. If the facility is financed by industry with an annual charge that includes a fixed charge on capital of $25 \%$, the annual fee is about $\$ 16 / \mathrm{kg}$-y. In calculating both fees, it is assumed that each storage position is occupied for ten years.

SUBJECT CATEGORY: Spent Fuel

ORIGIN: Commercial

KEYWORDS: COST; ECONOMICS: SPENT FITELS; RADIOACTIVE WASTF, STORAGE; SPENT FIIFI, STORAGL

1096

Sheldon, E.B.; Savannah River Laboratory, Aiken, SC

NATURE AND ORIGIN OF SAVANNAH RIVER PLANT WASTES AND CURRENT WASTE MANAGEMENT PRACTICES: MEETING OF THE PANEL ON SAVANNAH RIVER PLANT WASTE, AIKEN, SOUTH CAROLINA: 'TEX'I' OF SRP PRESENTATIONS. TID-29335; pp. 7-25. (1978)

SRP produces nuclear materials, primarily plutonium and tritium, for nuclear weapono: The major SRP facilities were built during 1950-1955. These facilities include three large operating nuclear reactors, a fuel and target fabrication plant, two chemical separations plants for the irradiated fuels and targets, a facility for processing and packaging tritium, and a heavy water production plant. Waste effluents from all plant onerations are controlled to protect the health and safety of employees and the puhlic. Major waste storage facilitics are two tank farms for liquid waste storage in the two reprocessing areas and a burial ground for solid waste storage between these areas. 13 figures.

SUBJECT CATEGORY: TRU; LLW; HLW

ORIGIN: Defense

KEYWORDS: CHEMICAI COMPOSITION; INVENTORIES; LIQUID WASTES; NUCLEAR FACILITIES; RADIOACTIVE WASTE MANAGEMENT; RADIOACTIVE WASTE STORAGE; SAVANNAH RIVER PLANT; SOLID WASTES; TANKS; UNDERGROUND STORAGE; TRITIUM 
1097

Savannah River Laboratory, Aiken, SC

WASTE MANAGEMENT. SAVANNAH RIVER LABORATORY QUARTERLY REPORT, APRIL-JUNE 1978. DPST-78-1252. (1978)

Available from NTIS, PC A08/MF A01; 65 figures, 60 tables

The following were studied: environmental impact of long-term management of high-level radioactive waste at SRP (draft programmatic statement), Defense Waste Solidification Facility, cost analysis of defense waste processing facilities, improved reference process for defense waste supernate clarification, removal of $\mathrm{Sr} 90$ from waste supernate, removal of $\mathrm{Al}$ from sludges by caustic washing, ion chromatographic determination of nitrite, demonstration of large-scale calciner, radiolytic gas production from TRU waste in concrete, incorporation of TRU incinerator ash into glass, improved glass frit, test of small-scule joule-heated melter, evaluation of candidate alloys for in-can molting canisters, residual solids from Tank 16 annulus, waste monitors, chemical form of $\mathrm{Pu}$ in burial ground soil, alpha waste trench coring, corrosion of buried drums, radionuclide release and migration from buried wastes, ground water flow pattern from burial ground wells, and radionuclide uptake by pine trees from buried irradiated scrap metal.

SUBJECT CATEGORY: HLW; TRU

\section{ORIGIN: Defense}

KEYWORDS: ALUMINIUM; CALCINATION; CHROMATOGRAPHY; CONCRETES; CORROSION; COST; DEGASSING; EXPERIMENTAL DATA; FLUID FLOW; GLASS; GROUND WATER; HIGH-LEVEL RADIOACTIVE WASTES; ISOLATED VALUES; MELTING; NITRITES; PINES; PLUTONIUM; RADIATION MONITORING; RADIOACTIVE WASTE DISPOSAL; RADIOACTIVE WASTE FACILITIES; RADIOACTIVE WASTE MANAGEMENT; RADIOACTIVE WASTE PROCESSING; RADIOLYSIS; RADIONUCLIDE KINETICS; RADIONUCLIDE MIGRATION; RESEARCH PROGRAMS; SAVANNAH RIVER PLANT; SEPAKATION PROCESSES; SLUDGES; SOILS; SOLIDIFICATION; STRONTIUM 90; TRANSURANIUM ELEMENTS; UNDERGROUND DISPOSAL; UPTAKE
1098

Savannah River Laboratory, Aiken, SC

WASTE MANAGEMENT. QUARTERLY REPORT, JULY-SEPTEMBER 1978. DPST-78125-3. (1978)

The following were studied: alternatives for longterm management of solid transuranium waste at SRP, factors affecting osmosis in geologic materials, analysis of waste sludge for cations, alpha waste incineration and off-gas treatment, slag formation during glass melting, large-scale continuous glass melting (simulation tests), brine leaching of glass waste forms, long-term heating tests of candidate alloys (Cor-Ten A, 304L ss, Inconel 600) for waste storage canisters, chemical decomposition of oxalic acid, sludge dissolution tests, and burial ground well assays (comparison of 1976 and 1977). (DLC)

SUBJECT CATEGORY: TRU

ORIGIN: Defense; Commercial

KEYWORDS: COMPARATIVE EVALUATIONS; EXPERIMENTAL DATA; ISOLATED VALUES; RADIOACTIVE WASTE MANAGEMENT; RESEARCH PROGRAMS; SAVANNAH RIVER PLANT; SIMULATION

\section{9}

Ziskind, R.A., and D.F. Hausknecht; Science Applications, Inc., Los Angeles, CA

FINANCING THE MANAGEMENT OF URANIUM MILL TAILINGS PILES. Transactions of the American Nuclear Society 28:381-383; CONF780622; Proceedings of the ANS Annual Meeting, San Diego, CA, June 18, 1978. (1978)

No Abstract

SUBJECT CATEGORY: Remedial Action, Mill Tailings

ORIGIN: Commercial

KEYWORDS: COST; FINANCING; MILL TAILINGS; ORE PROCESSING; RADIOACTIVE WASTE MANAGEMENT; URANIUM ORES 
1100

Goellner, D., D. Vogt, and G. Kniazewycz; Teknekron, Inc., Washington, DC

RADIOACTIVE WASTE MANAGEMENT STUDY. TASK 1: REVIEW OF WASTE PROJECTION MODELS. FINAL REPORT. NU. REG/CR-0032. (1978)

Available from NTIS

A survey of existing fuel cycle projection models was conducted to identify the most suitable framework for developing an NRC waste projection model. Several models with characteristics that broadly satisfy NRC requirements were examined. ' 1 'wo were judged to be superior, based not only on teçhnical capabilities but also on more intangible considerations; these preferred models were NUFUEL and ENFORM. Each was reviewed in considerable detail using available documents, and the individuals responsible for the most recent versions of the models were contacted directly. Although ENFORM has certain features that make it an attractive program for projecting waste characteristics, it also displays deficiencies when compared to NUFUEL. These may be the result of the fact that it is relatively new and therefore has not benefitted from the constructive modifications that NUFUEL has undergone during the course of many government projects. The report contains a summary of the information obtained during the documentation review of NUFUEL and ENFORM, and for the four other candidate projection models-ORSAC, KWIKPLAN, FLYER, and ALPS. It also presents a general discussion of model capability and limitations, and indicates the positive and negative attributes of each model as a framework for this project.

SUBJECT CATEGORY: General

OHIGIN: Commercial

KEYWORDS: FORECASTING; FUEL CYCLE; RADIOACTIVE WASTE MANAGEMENT; RADIOACTIVE WASTES; MATHEMATICAL MOD. FI S; COMPITTFR CODES

1101

TERA Corp., Berkeley, CA

DRAFT ENVIRONMENTAL IMPACT STATEMENT. HIGH-LEVEL WASTE REPOSITORY SITE SUITABILITY CRITERIA. UCRL-13804. (1978)
Available from NTIS, PC A07/MF A01.

The purpose of HLWRSSC is to present guidelines which will help in the development of safe waste management schemes. Current regulations require solidification of all high-level waste within 5 years of their generation and transfer to a Federal waste repository within 10 years. Development of the proposed HLWRSSC is part of the overall NRC program to close the "back end" of the commercial LWR fuel cycle. In this document, the need for the HLWRSSC is reviewed, and the national energy policy, the need for electrical energy, and the nuclear fuel cycle are discussed. Considerations for HLWRSSC are presented, including the nature of the repository, important site-related factors, and radiological risk assessment methodology. Radiological and nonradiological environment impacts associated with the HLWRSSC are defined. Alternatives to the criteria are presented, and the costbenefit-risk evaluation is reviewed.

\section{SUBJECT CATEGORY: HLW}

ORIGIN: Defense; Commercial

KEYWORDS: COST BENEFIT ANALYSIS; ENVIRONMENTAL IMPACT STATEMENTS; FUEL CYCLE; HIGH-LEVEL RADIOACTIVE WASTES; RADIOACTIVE WASTE DISPOSAL; RISK ASSESSMENT; US NRC

1102

TERA Corp., Berkeley, CA

INVENTORY AND SOURCES OF TRANSURANIC SOLID WAS'I'E. UCRL-13934. (1978)

Available from NTIS, PC A12/MF A01.

In the past, solid radioactive waste has often been buried in the most accessible and convenient vacant place, without a great deal of thought for the long. term consequences. The transuranium (TRU) elements were very strictly conserved and, at first, solld wastc containing scparated flesion producto was not a serious land burial problem. Wartime pressures for production and lack of knowledge or understanding led to siting and operational practices that, in many situations, are unsatisfactory by present day standards. Purpose of this report is to support the development of standards and criteria which will specifically address the problem of TRU contaminated waste generated by Department of Energy (DOE) nuclear programs and commercial application of nuclear technology. This report 
covers: DOE facilities, commercial disposal sites, commercial nuclear industry, TRU-contaminated waste inventory, and waste projections.

SUBJECT CATEGORY: TRU

ORIGIN: Defense; Commercial

KEYWORDS: FORECASTING; INVENTORIES; NUCLEAR FACILITIES; NUCLEAR INDUSTRY; RADIOACTIVE WASTE DISPOSAL; RADIOACTIVE WASTES; TRANSURANIUM ELEMENTS; US DOE

1103

TRW, Inc., Energy Systems Planning Div., McLean, VA

ECONOMICS OF NATIONAL WASTE TERMINAL STORAGE SPENT FUEL PRICING STUDY. Y/OWI/SUB-78/42512/2. (1978)

Available from NTIS, PC A06/MF A01.

The methodology for equitably pricing commercial nuclear spent fuel management is developed, and the results of four sample calculations are presented. The spent fuel management program analyzed places encapsulated spent fuel in bedded salt while maintaining long-term retrievability. System design was reasonable but not optimum. When required, privately-owned Away From Reactor (AFR) storage is provided and the spent fuel placed in AFR storage is eventually transported to final storage. Applicable Research and Development and Government Overhead are included. The cost of each component by year was estimated from the most recent applicable data source available. These costs were input to the pricing methodology to establish a one-time charge whose present value exactly recovered the present value of the expenditure flow. The four cases exercised were combinations of a high and a low quantity of spent fuel managed, with a single repository (venture) or a multiple repository (campaign) approach to system financial structure. The price for spent fuel management calculated ranged from 116 to 152 dollars (1978) per kilogram charged initially to the reactor. The effect of spent fuel receiving rate on price is illustrated by the fact that the extremes of price did not coincide with the cases having the extremes of undiscounted cost. These prices for spent fuel management are comparable in magnitude to other fuel cycle costs. The range of variation is small because of compensating effects, i.e., additional costs for high early deliveries (AFR and transporta- tion) versus lower present.value of future revenue for later delivery cases. The methodology contains numerous conservative assumptions, provisions for contingencies, and covers the complete set of spent fuel management expenses.

SUBJECT CATEGORY: Isolation; Spent Fuel

ORIGIN: Commercial

KEYWORDS: CHARGES; COST; RADIOACTIVE WASTE MANAGEMENT; SALT DEPOSITS; SPENT FUEL STORAGE; STORAGE FACILITIES; UNDERGROUND STORAGE

\section{4}

U.S. Department of Energy, Washington, DC

WESTERN NEW YORK NUCLEAR SERVICE
CENTER STUDY, FINAL REPORT FOR
PUBLIC COMMENT. TID-28905-1; 56 pp. (1978)

Appendices include the authorizing legislation for solving the reprocessing center problem, and a glossary of important terms.

Recommendations for responsibility allocation, description of the Western New York Service Center (WNYSC), potential impacts, and estimated costs of options for the future of the Center are presented. From 1966 to 1972 about 640 MT of nuclear fuel were processed. Of that waste $380 \mathrm{MT}$ were from AEC's production reactor and $100 \mathrm{MT}$ were from commercial reactor fuel supplied under the baseload contract. The rest came from public utilities. In 1972 the plant was shutdown to make modifications and at that time new criteria were imposed for the tornado and seismic integrity plant. Existing facilitles at the site are spent fuel receiving and storage, reprocessing plant, high-level liquid waste storage, NRC-licensed waste burial ground, and New York state-licensed waste burial grounds. The burial grounds contain $139,000 \mathrm{cu} \mathrm{ft}$ of spent fuel hardware and other solid wastes and 2.4 million cu $\mathrm{ft}$ of contaminated wastes. Recommendations provided include development of immobilization technology for the high-level liquid wastes and enough funding be provided such that short-term and long-term risks can be determined with confidence and minimized. Technical options are decontamination, decommissioning and waste disposal; continued nuclear use of the site; nonnuclear use of the site. Each of the options is analyzed in accordance with the existing facilities. Institutional and financial responsibilities are also outlined. 
SUBJECT CATEGORY: HLW; Spent Fuel

ORIGIN: Defense; Commercial; Institutional

KEYWORDS: COST BENEFIT ANALYSIS; DECOMMISSIONING; DECONTAMINATION; METHODS; IMMOBILIZATION; NUCLEAR FACILITIES; REPROCESSING; SAFETY; SPENT FUELS; RECOMMENDATIONS; HIGH-LEVEL RADIOACTIVE WASTES; SOLID WASTES; LIQ. UID WASTES; COST; INVENTORIES; FUEL REPROCESSING PLANTS

\section{5}

Kisner, R.A., J.R. Marshall, D.W. Turner, and J.E. Vath; Union Carbide Corp., Office of Waste Isolation, Oak Ridge, TN.

NUCLEAR WASTE PROJECTIONS AND SOURCE-TERM DATA FOR FY 1977. Y/OWI/TM-34. (1978)

Available from NTIS, PC A05/MF A01.

A description of the light-water reactor (LWR) fuel cycle and the nature of the radioactive wastes is basic to the design and evaluation of terminal waste repositories. For these projections, the fuel cycle is represented as a typical system of operations related to the back end of the LWR fuel cycle. Wastes, as prepared for disposal, are described in terms of form, volume, radioactivity, heat generation, and weight. To obtain these waste projections, three fuel management computer codes were used: ORIGEN, KWIKPLAN, and WASPR. A brief description of these codes and their usage is included. Also included are descriptions of the containers assumed to be used for the handling and geologic disposal of the various waste types. The data generated for the Office of Waste Isolation (OWI) and its subcontractors are documented. Projections of LWR fuel cycle wastes are based on OWI modification of the ERDA mid-case forecast of 1976 for nuclear power growth in the United States. In this case, the installed nuclear electric capacity rises from a nominal $50 \mathrm{GW}(\mathrm{e})$ in year 1977 to a nominal $480 \mathrm{GW}(\mathrm{e})$ in the year 2000 . The power reactor grid is assumed to consist entirely of LWRs. The four basic fuel cycle scenarios considered follow the same growth curve. These fuel cycles range from spent unreprocessed fuel (SURF) through full recycle of both uranium and plutonium. The overall objective is to compare the impacts of the alternative fuel cycles rather than to describe the impacts of reactor growth scenarios or the use of raw materials for power generation.
SUBJECT CATEGORY: HLW; LLW; TRU

ORIGIN: Commercial; Defense

KEYWORDS: COMPUTER CODES; CONTAINERS; FORECASTING; FUEL CYCLE; HIGHLEVEL RADIOACTIVE WASTES; INTERMEDIATE-LEVEL RADIOACTIVE WASTES; K CODES; LOW-LEVEL RADIOACTIVE WASTES; O CODES; PLUTONIUM; RADIOACTIVE WASTE STORAGE; RECYCLING; SITE SELECTION; URANIUM; W CODES; WATER COOLED REACTORS

\section{6}

Dorian, J.J., and V.R. Richards; United Nuclear Industrles, Inc., Richland, WA

\section{RADIOLOGICAL CHARACTERIZATION OF} THE RETIRED 100 AREAS. UNI-946. (1978)

Portions of document are illegible; available from NTIS, MF A01.

A study was conducted to establish radionuclide inventories and concentrations in the retired 100 Area radioactive solid and liquid waste disposal facilities, leakage areas, reactors, and associated facilities. The data are intended to aid in establishing the long-term disposition and control procedures for these facilities. The purpose of the longterm controls would be to place all facilities in a stable condition such that the possibility of polluting the environs with radioactive material or of affecting the local ecology through radiation exposure is minimized. Adequate short-term control of the contaminated deactivated 100 Area facilities and disposal sites has been established. Maintaining this radiological control requires an ongoing maintenance/surveillance program. Costs associated with this maintenance/surveillance program are expected to increase due to facility deterioration. Future stabilization and/or removal attempts to establish long-term contamination controls will be dependent upon the definition of radiological release criteria for future decommissioning activities at Hanford. Guidance on acceptable levels of surface contamination is provided in AEC Regulatory Guide 1.86 'Termination of Operating Licenses for Nuclear Reactor." Only limited guidance has been provided on acceptable activity levels when radionuclides are uniformly distributed in some matrix. Battelle North west is establishing radiological release criteria for future decommissioning activities at Hanford as part of the "Disposition of Retired Contaminated Facilities at Hanford"study. 
Based on dose calculations, radiological release criteria are being derived that will provide longterm public protection from any residual contamination remaining in decontaminated facilities.

SUBJECT CATEGORY: Isolation

\section{ORIGIN: Defense}

KEYWORDS: DECOMMISSIONING; HANFORD RESERVATION; INVENTORIES; MAINTENANCE; RADIATION MONITORING; RADIATION PROTECTION; RADIOACTIVE WASTE MANAGEMENT; RADIOACTIVE WASTE STORAGE; RADIOISOTOPES

1107

Munson, L.F., J.F. Nemec, and A.K. Koochi; United Nuclear Industries, Inc., Richland, WA

DECOMMISSIONING ALTERNATIVES FOR THE WEST VALLEY, NEW YORK, FUEL REPROCESSING PLANT. ANL-78-XX96. (1978)

Available from NTIS, PC A18/MF A01.

The methodology and numerical values of NUREG0278 were applied to four decommissioning alternatives for the West Valley Fuel Reprocessing Plant. The cost and impacts of the following four alternatives for the process building, fuel receiving and storage, waste tank farm, and auxiliary facilities were assessed: (1) layaway, (2) protective storage, (3) preparation for alternate nuclear use, and (4) dismantlement. The estimated costs are 5.7, 11, 19, and 31 million dollars, respectively.

SUBJECT CATEGORY: Remedial Action, FUSRAP

ORIGIN: Commercial

KEYWORDS: COMPARATIVE EVALUATIONS; COST; DECOMMISSIONING; FEASIBILITY STUDIES; TABLES; WEST VALLEY PROCESSING PLANT

\section{8}

Rochlin, G.I., M. Held, G. Kaplan, and L. Kruger; Univ. of California, Berkeley, CA; New York State Energy Research and Development Authority
WEST VALLEY: REMNANT OF THE AEC. Bulletin of the Atomic Scientists 34(1):17-26. (1978)

Presents an historical review of the West Valley Plant and the fuel reprocessing industry. From 1966 to 1972 , NFS reprocessed about 625 metric tons of spent nuclear fuel. Sixty one percent was from the Hanford N-reactor and thus provided little experience for reprocessing commercial fuel. In March 1972, the plant was shut down for expansion estimated to cost $\$ 15$ million. Legalities resulted in delays and by 1976 the expansion cost estimate was $\$ 600$ million. In the fall of 1976, NFS withdrew from the reprocessing business. The disposition of the wastes at the West Valley Site is uncertain.

SUBJECT CATEGORY: Spent Fuel

ORIGIN: Defense

KEYWORDS: REPROCESSING; REGULATIONS; US AEC; REVIEWS; ECONOMICS; NEW YORK; WEST VALLEY PROCESSING PLANT; FUEL REPROCESSING、PLANTS; COST; NUCLEAK FACILITIES

1109

Yanev, P.I., and G.N. Owen; URS/John A. Blume and Associates, Engineers, San Francisco, CA

DESIGN COST SCOPING STUDIES. NEVADA TEST SITE TERMINAL WASTE STORAGE PROGRAM, SUBTASK 1.3: FACILITY HARDENING STUDIES. JAB-99123. (1978)

Available from NTIS, PC A07/MF A01.

As part of a program being conducted by the U.S. Depa rtment of Energy, Nevada Operations Office, to determine the feasibility of establishing a terminal waste storage repository at the Nevada Test Site, URS/John A. Blume and Associates, Engineers, made approximate determinations of the additional costs required to provide protection of structures against seismic forces. A preliminary estimate is presented of the added costs required to harden the surface structures, underground tunnels and storage rooms, and vertical shafts of the repository against ground motion caused by earthquakes and underground nuclear explosions (UNEs). The conceptual design of all of the structures was adapted from proposed bedded-salt waste-isolation repositories. Added costs for hardening were calculated for repositories in three 
candidate geological materials (Eleana argillite, Climax Stock granite, and Jackass Flats tuff) for several assumed peak ground accelerations caused by earthquakes $(0.3 \mathrm{~g}, 0.5 \mathrm{~g}$, and $0.7 \mathrm{~g})$ and by UNEs $(0.5 \mathrm{~g}, 0.7 \mathrm{~g}$, and $1.0 \mathrm{~g})$. Hardening procedures to protect the tunnels, storage rooms, and shafts against incremental seismic loadings were developed from (1) qualitative considerations of analytically determined seismic stresses and (2) engineering evaluations of the dynamic response of the rock mass and the tunnel support systems. The added costs for seismic hardening of the surface structures were found to be less than $1 \%$ of the estimated construction cost of the surface structures. For the underground structures, essentially no hardening was required for peak ground accelerations up to $0.3 \mathrm{~g}$; however, added costs became significant at $0.5 \mathrm{~g}$, with a possible increase in structural costs for the underground facilities of as much as $35 \%$ at $1.0 \mathrm{~g}$.

SUBJECT CATEGORY: Isolation; HLW

ORIGIN: Defense

KEYWORDS: COST; EARTHQUAKES; GRANITES; NEVADA TEST SITE; NUCLEAR EXPLOSIONS; RADIOACTIVE WASTE STORAGE; TUFF; UNDERGROUND STORAGE; US DOE; DESIGN; SEDIMENTS

1110

Western Interstate Energy Board, Denver, $\mathrm{CO}$

URANIUM MINING AND MILLING. THE NEED, THE PROCESSES, THE IMPACTS, THE CHOICES. ADMINISTRATOR'S GUIDE. FINAL REPORT. PB-286034. (1978)

Available from NTIS PC A12/MF A01.

The primary objective of the Guide is to address the technical, economic, social, and environmental factors that influence uranium mining and the siting of milling facilities in the western United States. Although the Guide is not a regulatory document, the information should be useful to local, state, and federal administrators, legislators, policy makers, planners, and regulators involved in the review or approval process for uranium projects. The information should also be of interest to citizens who would be affected by a proposed project. The Guide also highlights information that is considered by industry during the planning process. For example, site-specific aspects of mill tailings man- agement are receiving increased attention from regulators and industry, and some earlier tailings disposal practices are no longer acceptable. A secondary objective of the Guide is to inform developers of the various options that may be available when planning uranium development projects. Although the location of the mine is fixed, there are options available in the design of the mill, such as alternative sites, process methods, waste disposal locations and pollution control techniques.

SUBJECT CATEGORY: Remedial Action, Mill Tailings

ORIGIN: Commercial

KEYWORDS: ECONOMICS; ENVIRON. MENTAL IMPACTS; FEED MATERIALS PLANTS; MANUAIS; MIT.I. TAIIINTSS; PI.ANNING; REGULATIONS; SOCIAL IMPACT; URANIUM MINES; USA

1111

Blake, E.M.

THE COST OF STORAGE. Nuclear News, May 1978. (1978)

No Abstract

SUBJECT CATEGORY: Isolation

ORIGIN: General

KEYWORDS: ECONOMICS; SPENT FUELS; RADIOACTIVE WASTES; RADIOACTIVE WASTE STORAGE

1112

Boehm, H.

SPENT FUEL PROCESSING AND WASTE MANAGEMENT OF NUCLEAR POWER PLANTS. Waerme 84(5):106-111; 41. Physicists' Meeting, Karlsruhe, Federal Republic of Germany, September 20-23, 1977. (1978)

In German

The concept of spent fuel and waste management, i.e. all steps of the nuclear fuel cycle starting with the discharge of the fuel assemblies from the reactor, is presented. The individual steps, the 
quantities activities arising, and the reprocessing tecnology are treated. The alternatives 'reprocessing' or 'direct ultimate storage' of the fuel assemblies are discussed. Risk and potential hazard of the nuclear fuel and waste management with respect to ultimate storage as compared with other, not radioactive but chemically toxic substances are dealt with in detail.

SUBJECT CATEGORY: Spent Fuel

ORIGIN: Foreign

KEYWORDS: ECONOMICS; FISSION PRODUCTS; FUEL CYCLE; HAZARDS; HEAD END PROCESSES; PUREX PROCESS; RADIOACTIVE WASTE DISPOSAL; RADIOACTIVE WASTE MANAGEMENT; RADIOACTIVE WASTE PROCESSING; RADIOACTIVE WASTE STORAGE; RADIOACTIVE WASTES; RADIOACTIVITY; REPROCESSING; SAFETY; SALT DEPOSITS; SOLIDIFICATION; SPENT FUELS

1113

Cline, J.E., and D.C. Hetzer

STUDY OF TRANSURANIUM CONCENTRATION LEVELS IN SOLID RADIOACTIVE WASTE FROM COMMERCIAL POWER REACTORS. EPRI NP-631; Research Project 613; 96 pp. (1978)

Although the radiochemical data is somewhat difficult to decipher with respect to labelling of samples, the data base presented here is very valuable.

The results of isotopic analysis of the waste sources in operating light-water reactors with particular emphasis on the content of transuranic elements are presented in this study. Samples from seven different reactors including 5 BWRs and 2 PWRs were obtained and subjected to radiochemical analysis. Potential indirect methods of determining transuranic concentrations were investigated which are capable of providing rapid, and economical determinations of the acceptability of radioactive waste with respect to future concentration limits for transuranics suitable for shallow land burial. Concentration limits of transuranics in LWR low-level waste have not been set as of yet, however, these limits are discussed with respect to the 10 $\mathrm{nCi}$ /gram limitation of transuranics for fuel reprocessing low-level waste. General description of the radioactive waste systems at the seven LWRs and the solid wastes generated at these plants are provided. The samples taken include reactor coolant water dissolved radionuclides, reactor coolant water insolubles, spent resins, crud, centrifuge sludges, filter sludges, fuel pool filters, waste holdup tank filters, let-down filters, and evaporator bottoms. Descriptions of sample preparation and analytical procedures are provided. The results of a sample splitting round robin interlaboratory comparison are presented. The preliminary results of the studies on indirect assay for transuranic content suggest that the gamma emitters $\mathrm{Ru} 106$ and $\mathrm{Ce} 144$ may be used as transuranic indicators in low-level waste.

SUBJECT CATEGORY: TRU; LLW

ORIGIN: Commercial

KEYWORDS: RADIOACTIVE WASTE MAN. AGEMENT; LOW-LEVEL RADIOACTIVE WASTES; TRANSURANIUM ELEMENTS; ECONOMICS; BWR TYPE REACTORS; PWR TYPE REACTORS; SOLID WASTES; RADIOACTIVITY

1114

Deese, D.A.

NUCLEAR POWER AND RADIOACTIVE WASTE: A SUB-SEABED DISPOSAL OP. TION. Lexington Books, Lexington, MA. (1978)

Available from D.C. Heath and Co., Lexington, MA.

The radioactive waste disposal programs of most countries are still focused on investigation of landbased geologic formations as possible containment media for radioactive wastes. Important discoveries in geological oceanography and amazing advances in ocean engineering over the past decade have, however, led several countries to investigate another promising possibility for geologic disposal of radioactive waste-isolation within the deep seabed or sub-seabed disposal. Beyond the various technical advantages and disadvantages involved, use of the international seabed for radioactive waste disposal raises a multitude of social, economic, political, legal, institutional, and ethical issues. These issues are analyzed in this volume.

SUBJECT CATEGORY: Isolation

ORIGIN: General

KEYWORDS: ECONOMIC IMPACT; ENVIRON. MENTAL EFFECTS; ENVIRONMENTAL IMPACTS; FEASIBILITY STUDIES; GLOBAL 
ASPECTS; GOVERNMENT POLICIES; INTERNATIONAL COOPERATION LAWS; LEGAL ASPECTS; MARINE DISPOSAL; MULTINATIONAL OWNERSHIP; NUCLEAR POWER; RADIOACTIVE WASTE DISPOSAL; RADIOACTIVE WASTES; REPROCESSING; SEA BED; SOCIAL IMPACT

\section{5}

Feese, H.L., and W.T. Gregory, III

VOLUME REDUCTION OF LIQUID RADIOACTIVE WASTES USING MECHANICALLY AGITATED THIN-FILM EVAPORATORS. American Institue of Chemical Ėngineers, Proceedings of the 85th National Meeting, Philadelphia, PA, June 4-8, 1978, (37 pp.). (1978)

The potential and ability of mechanically agitated thin-film evaporators to reduce the volume of liquid radwaste at nuclear power plants is discussed. Specifications for a variety of evaporators as well as maintainence is presented. With the waste streams of both types of light water reactors producing from $76,000 \mathrm{gal} /$ day to $365,000 \mathrm{gal} /$ day volume reduction is necessary. A radwaste evaporator may concentrate the wastes to evaporator bottoms containing $25 \%$ total solids. Some designs however, may only concentrate to the level of 10 to $15 \%$ before fouling or encrustation occurs. An evaporator-crystallizer system has an advantage over most systems because it can reduce the waste by about $50 \%$. The cost for the first year of operation of a radwaste facility may run as high as $\$ 11.2$ million, with the cost running about 1.5 million for the succeeding years. Hence, it is necessary to have volume reduction. Several sample problems of waste concentration are illustrated in detail. Thin-film evaporator reliability is demonstrated, and encapsulation in bitumen and polymers is briefly discussed.

\section{SUBJECT CATEGORY: LLW}

ORIGIN: Cummercial

KEYWORDS: BITUMENS; DECONTAMINATION; ECONOMICS; EVAPORATION; EVAPORATORS; POLYMERS; LWR TYPE REACTORS; VOLUME; RADIOACTIVE WASTE MANAGEMENT; LIQUID WASTES; SOLIDIFICATION; E'NCAAYSULA'IIUN
1116

Ferguson, J.S.

SALVAGE IS ALSO IMPORTANT. Public Util. Fortn. 102(3):19-24. (1978)

The author stresses the salvage aspect of utility property depreciation accounting, seeing indications that it may have been unduly neglected for some time now as a factor in the determination of depreciation rates for recovery of capital invested in utility property. His comments are pertinent to the decommissioning costs of nuclear power plants and the removal costs of offshore pipeline and gas distribution systems. His discussion concludes with a set of guidelines by depreciation analysts. The guidelines stress the need to allow sufficient time for analysis of data as it applies to the current situation.

SUBJECT CATEGORY: Remedial Action, FUSRAP

ORIGIN: Commercial

KEYWORDS: ACCOUNTING; COST; ECONOMICS; HAZARDOUS MATERIALS; INFLATION; INVESTMENT; MATERIALS RECOVERY; OFFSHORE PLATFORMS; PIPELINES; PUBLIC UTILITIES; SCRAP; RADIOACTIVE WASTE MANAGEMENT; CAPITAL

1117

Friedlander, G.D.

DECOMMISSIONING COMMERCIAL REACTORS. Electrical World 189(4):44-48. (1978)

3 diagrams, 1 photo, 1 table

Feature article:The problem of decommissioning commercial nuclear reactors after their useful lifetime of 35-40 yr expires, is analyzed. Five decommissioning methods recommended by the Alumic Industrial Forumothballing, entombing, immediate removal/dismantling, the combination of mothballing and delayed removal/dismantling, and the combination of entombing and delayed removal/dismantlingnd associated NRC guidelines are outlined. Planning for decommissioning is now under way by NRC, the Atomic Industrial Forum, Battelle Memorial Inst.-Pacific Northwest 
Labs., and others. The press offers warnings that decommissioning nuclear plants may cost more than the original construction. The NRC indicated that if a sinking fund were established with an annual payment of $\$ 255,000$, enough funds would be generated in 30 years to cover decommissioning and long-term maintenance of a retired reactor. In addition, future plans for decommissioning must be included in the decision-making process during the initial operating license application and review period.

SUBJECT CATEGORY: Remedial Action, FUSRAP

ORIGIN: Commercial

KEYWORDS: REACTOR DECOMMISSIONING; REACTORS; RADIOACTIVE WASTE MANAGEMENT; ECONOMICS; NUCLEAR POWER; COST

\section{8}

Garrett, P.

NUCLEAR POWER REACTOR DECOMMISSIONING. Chemtech 8(5):297-301. (1978)

3 tables

Technical report:An Atomic Industrial Forum report on the costs, environmental radiation exposures and generic environmental effects of nuclear power reactor decommissioning is summarized. Initial costs for the three major decommissioning alternativesothballing, entombing, and prompt removal/dismantlingre estimated for the PWR, BWR, and HTGR types. For mothballing and entombing, the termination of a possession-only license would take from $51,350-505,000 \mathrm{yr}$, depending on the reactor type. Costs for the combination mothballing-delayed removal/dismantling alternative and for the entombing-delayed removal/dismantling alternative are estimated. Of these five alternatives, either of the two combination alternatives would be the most cost-effective means of terminating a possession-only license. Occupational radiation doses, airborne radiation doses, and generic environmental effects are also predicted for each type of decommissioning scheme.

SUBJECT CATEGORY: Remedial Action, FUSRAP

ORIGIN: Commercial

KEYWORDS: REACTOR DECOMMISSIONING; REACTORS; ECONOMICS; NUCLEAR POWER;
CAPITAL; DECONTAMINATION; SAFETY; PWR TYPE REACTORS; BWR TYPE REACTORS; HTGR TYPE REACTORS

\section{9}

Iwler, L.

REGULATORY BODIES READY FOR NPLANT RETIREMENTS. Electrical World 190(2):19-20. (1978)

1 photo

Feature article:At least six state regulatory commissions and several European countries are starting to provide long-term funding to decommission existing and future nuclear power plants. On the federal level, the House Committee on Government Operations is evaluating the process of plant dismantling and the treatment of nuclear wastes. A study by the committee found that dismantling costs for a single plant could range from $\$ 31-100$ million in 1977 dollars. These figures do not include perpetual care costs for radioactive materials. After the $30-40 \mathrm{yr}$ lifespan of a nuclear plant being built now, decommissioning costs would quadruple, given $5 \%$ annual inflation. Funding requests for dismantling plants in Pennsylvania, Florida, California, and Oregon are described.

SUBJECT CATEGORY: Remedial Action, FUSRAP

ORIGIN: Commercial

KEYWORDS: REACTOR DECOMMISSIONING; ECONOMICS; FLORIDA; EUROPE; PENNSYL VANIA; CALIFORNIA; OREGON; REGULATIONS

1120

La Porte, T.R.

NUCLEAR WASTE: INCREASING SCALE AND SOCIOPOLITICAL IMPACTS. Science 201:22-28. (1978)

The article argues that insufficient attention has been paid to the operational aspects of the U.S. radioactive waste management system when it grows to the scale necessary to handle wastes produced by a fully deployed plutonium economy. Without such information, many of the unsettling speculations which have become part of the public debate and are summarized herein cannot be clearly 
addressed. The article then outlines the types of information necessary to begin estimating the costs and consequences of radioactive waste management. Finally, an index of social exposure to radioactive hazard is proposed to improve the basis for policy decisions in this area. (Auth)

SUBJECT CATEGORY: TRU; HLW; LLW

ORIGIN: Commercial

KEYWORDS: ECONOMICS; REPROCESSING; INFORMATION; LEGISLATION; PERSONNEL; PLUTONIUM; RADIOACTIVE WASTE MANAGEMENT

1121

Parkinson, G.

CU/U ORE-LEACHING ROUTE CUTS POLLUTION, TRIMS COSTS. Chem. Eng. 85(10):5465. (1978)

This paper describes the "thin layer" (TL) leading process and its application to treatment of copperand uranium ores. Greatly reducing the chance of groundwater and airborne pollution, the TL process also eliminates a considerable amount of the large equipment associated with conventional leaching routes. The process is said to be as effective, where applicable, as agitation leaching, but only about 50 to $70 \%$ as expensive to build, and 5 to $15 \%$ less costly to operate. Water requirements may be as little as one fourth the amount needed for agitation leaching, and tailings are produced in moist, solid, granular form instead of as a conventional slurry that contains $50 \%$ water, by weight. Process details are given; economic considerations are included.

SUBJECT CATEGORY: Remedial Action, Mill Tuilingy

ORIGIN: Commercial

KEYWORDS: AIR POLLUTION ABATEMENT; CHILE; COPPER ORES; COST; LEACHING; MILL TAILINGS; ORE PROCESSING; PROCESS DEVĒEOPMENT UNITS; URANIUM ORES; WATER POLLUTION ABATEMENT; WATER REQUIREMENTS

1122

Rippon, S.
GERMANY PLANS INTEGRATED FUELCYCLE COMPLEX. Energy Int. 15(10):1720. (1978)

With the availability of a safe waste-disposal technique a precondition for the licensing of further nuclear power plants in the Federal Republic of Germany, the need for an integrated reprocessing, fuel-fabrication, and waste-disposal facility has acquired a new urgency. The Gorleben project may be seen as the ideal approach for management of wastes and recycling of valuable nuclear fuel. The project is intended to provide an integrated center capable of handling all spent fuel from German nuclear power plants at one site situated above a very large salt dome, which is idcal for gcological disposal of concentrated high-level waste products. A large reprocessing plant will provide for recovery of some $97 \%$ by weight of the spent fuol, mostly in the form of uranium but also some plutonium, which can bc recycled in thermal reactors to produce a $30 \mathrm{l}$, $40 \%$ increase in the energy produced from the original burn of the fuel or up to 60 times as much energy if the plutonium is used in fast reactors. Fabrication of the recycle materials into fuel pins, containing mixed oxides of uranium and plutonium in the form of ceramic pellets sealed into highintegrity Zircaloy or stainless steel tubes, will also be undertaken at the center.

SUBJECT CATEGORY: Spent Fuel; HLW; TRU

ORIGIN: Foreign

KEYWORDS: ECONOMICS; FABRICATION; FUEL CYCLE; FUEL FABRICATION PLANTS; FUEL PINS; FUEL REPROCESSING PLANTS; GERMAN FEDERAI_ REPUBLIC; SALT DEPOSITS; LICENSING; NUCLEAR FUELS; NU. CLEAR POWER PLANTS; PLANNING; PLUTONIUM OXIDES; PROLIFERATION; RADIOACTIVE WASTE DISPOSAL; RISK ASSE'SSME'N'I'; SI'I'E SE'LEC'IION; SPENT FUELS; URANIUM OXIDES;

\section{3}

Ross, D.E., R. Marsh, T. Wright, D. Weaver, and R.P. Stearns

STUDY OF ENGINEERING AND WATER MANAGEMENT PRACTICES THAT WILL MINIMIZE THE INFILTRATION OF PRECIPITATIOON INTO TRENCHES CONTAINING RADIOACTIVE WASTE. ORP-LV-78-5; 91 pp. (1978) 
Although some of the information provided in the general background section of the report is incorrect, the review of infiltration barriers, trench construction alternatives, and trench grouting is quite thorough.

The results of a study of engineering and water management practices to limit infiltration of water into radioactive waste burial trenches is presented. The study, commissioned by the U.S. Environmental Protection Agency, emphasized the comparison of barriers to minimize or eliminate percolation of water into disposal trenches, methods to stabilize the ground surface at disposal sites, and procedures to minimize the perpetual care and maintenance at these sites. Trench and site construction alternatives are discussed with respect to expected benefits, potential drawbacks, approximate costs per specified reference disposal trench, and applicability of the method. Trench caps and covers are discussed with respect to advantages, disadvantages, expected longevity of barrier, applicability of option, and the approximate cost per specified reference trench. A multilayer cover is stated to provide the best overall improvement and consists of a surface layer of gravel, a protective layer of soil, an impervious cap, and compacted soil directly over the solid waste cell. The general philosophies governing monitoring and maintenance are discussed in detail and a recommendation for installation of relatively inexpensive soil moisture cells to detect anomalous moisture accumulations in burial trenches is made.

\section{SUBJECT CATEGORY: LLW}

ORIGIN: Commercial; Defense

KEYWORDS: LINERS; CLAYS; CONCRETES; ASPHALTS; SOILS; GROUTING; MONITORING; MAINTENANCE; SEALING MATERIALS; SITE SELECTION; RADIOACTIVE WASTE MANAGEMENT; MOISTURE; COST BENEFIT ANALYSIS; SOLID WASTES; GROUND DISPOSAL

\section{4}

Traill, S.

BELGIAN REPORT PROPOSES REGIONAL NUCLEAR FUEL CENTRES. Energy Int. 15(10):21-23. (1978)

At a time when nuclear energy programs are being slowed down, or in some cases temporarily halted, owing to public fear of the dangers inherent in the nuclear cycle and in particular the recycling of spent fuels, the Belgian firm, Belgonucleaire, has drawn up a report on behalf of the EEC Commission on the possible development of regional nuclear fuel reprocessing centers. Such centers, either with an initial capacity of $1500 \mathrm{t} /$ year to serve a group of countries, or $375 \mathrm{t} /$ year for the purposes of a single medium sized country, would group all reprocessing and waste disposal activities on one site. The report underlines the safety advantages of such an arrangement as against scattered facilities, and points to cost benefits and improved efficiency. However, in summing up, Belgonucleaire stresses the importance of fully adequate design. An integrate center would be more sensitive to perturbations due to poor functioning. Also, if the infrastructure arrangements were insufficient, this could lead to congestion of traffic in radioactive materials.

SUBJECT CATEGORY: Fuel Cycle Centers

ORIGIN: Foreign

KEYWORDS: BELGIUM; BWR TYPE REACTORS; ECONOMICS; EFFICIENCY; FLOWSHEETS; FUEL CYCLE; FUEL FABRICATION PLANTS; FUEL REPROCESSING PLANTS; NUCLEAR FACILITIES; NUCLEAR FUELS; PLANNING; PUBLIC OPINION; PWR TYPE REACTORS; RADIOACTIVE WASTE FACILITIES; SAFETY; SITE SELECTION; TABLES

\section{5}

A REFERENCE REGIONAL NUCLEAR FUEL CENTRE. EUR-5955EN FR. (1978)

A nuclear fuel centre groups the facilities for spent fuel reprocessing, plutonium fuel fabrication, waste conditioning, and interim storage on a single site. The technical aspects of safety and protection, and the socio-economic consequences of two types of centres have been studied. The reference centre has an initial reprocessing capacity of 1500 tons. This capacity is quadraupled by the construction of two new units in 15 years. The other centre considered is a quarter of this size. A description is given of the processes used, the personnal and capital requirements for construction and operation of the plant, the transport of radioactive waste and products, and the quantities involved.

\section{SUBJECT CATEGORY: Fuel Cycle Centers}

ORIGIN: Foreign 
KEYWORDS: SPENT FUELS; REPROCESSING; RADIOACTIVE WASTE STORAGE; ECONOMICS; WASTE TRANSPORTATION; NUCLEAR PARKS

\section{6 \\ DOE POSES 'REFERENCE' SPENT FUEL FEE AT \$232/KG-PLUS 20\% CONTING- ENCY. Nucleonics Week 19(30). (1978)}

July 27 issue

No Abstract

3UBJECT CATEGORY: Spent Fuel

ORIGIN: Defonec; Commercial

KEYWORDS: ECONOMICS; SPENT FUELS; COST; US TOOE

\section{7}

CLEANUP COST ESTIMATED. Nuclear News 2(13):53. (1978)

\section{Abstract is complete text}

The average cost estimate for relocating uranium mill tailings and contaminated materials from the Riverton, Wyoming, site to storage sites is slightly over $\$ 8$ million, according to a report prepared for the Department of Energy by Ford, Bacon and Davis Utah, Inc. The report lists estimated costs of decontaminating the Riverton site and hauling materials to seven potential storage sites within a few miles of Riverton. The range of estimates is from $\$ 7$ million for site No. 13 , which is $10 \mathrm{~km}(6.2$ miles) from Riverton, to $\$ 9$ million for site No. 17 , which is $26.5 \mathrm{~km}$ (16.5 miles) from Riverton. The average estimate is $\$ 1.68$ million to $\$ 2.08$ million more than the estimates given by Ford, Bacon and Davis Utah, Inc. in their first report to the DOE, issued in December 1977. That report was made before specific sites were identified and included only distances of 8 and $16 \mathrm{~km}$ (5 and 10 miles) from the Riverton site. Ford, Bacon and Davis Utah, Inc.'s August 1978 report includes: the materials to be stored; removal of the materials from the existing site; criteria for long-term storage; preparation of storage sites; description of disposal site areas; and description of specific storage site areas and cost estimates.

SUBJECT CATEGORY: Remedial Action, Mill Tailings; Transportation

ORIGIN: Defense; Commercial

KEYWORDS: COST BENEFIT ANALYSIS; URANIUM; MILL TAILINGS; DECONTAMINATION;
RADIOACTIVE WASTE DISPOSAL; RADIOACTIVE WASTE STORAGE; COST; SITE PREPARATION; WASTE TRANSPORTATION

1128

DECOMMISSIONING OF NUCLEAR POWER PLANTS. Nuclear News 21(14):24. (1978)

Results of detailed decommissioning studies were considered by the NRC. The studies cover alternatives and cost estimates for representative nuclear facilities, including a reprocessing plant (Barnwell was used as the model), a pressurized water reactor (Trojan, the model), and a small mixed-oxide fabrication plant (Kerr-Mcgee, Cimarron, Okla). Decommissioning cost estimates run in the range of 5 to 10 percent of original capital costs for a plant. Trojan, for example, a figure of $\$ 42$ million (in 1978 dollars) was quoted, and this includes the immedi: ate dismantling of all nuclear components and the demolition of uncontained structures. Model studies were conducted by Battelle Pacific Northwest.

SUBJECT CATEGORY: Remedial Action, FUSRAP

ORIGIN: Commercial

KEYWORDS: DECOMMISSIONING; ECONOMICS; COST; BARNWELL FUEL PROCESSING PLANT; PWR TYPE REACTORS; TROJAN REACTOR; REACTOR DECOMMISSIONING

\section{9}

NATIONAL ATTENTION AND CONCERN FOCUSED ON NUCLEAR WASTES STORED AT WEST VALLEY. Aware 99:10-15. (1978)

Reprinted from special edition of NYSERDA Rcview

West Valley and the problems associated with decommissioning and decontaminating the facili ties, and with disposing of the nuclear wastes stored at the site are described.

SUBJECT CATEGORY: LLW; Remedial Action, FUSRAP

\section{ORIGIN: Commercial}

KEYWORDS: COST; HIGH.LEVEL RADIOACTIVE WASTES; LIQUID WASTES; PUREX PROCESS; RADIOACTIVE WASTE MANAGEMENT; RADIOACTIVE WASTE STORAGE; UNDERGROUND STORAGE; WEST VALLEY PROCESSING PLANT 
1979

\section{0}

Keely, R.B., M.W. Carter (Ed.), A.A. Moghissi (Ed.), and B. Kahn (Ed.); Allied-General Nuclear Services, Barnwell, SC

DESCRIPTION OF SOLID WASTE EXPECTED FROM A LARGE COMMERCIAL REPROCESSING PLANT: MANAGEMENT OF LOW-LEVEL RADIOACTIVE WASTE. VOLUME I. Pergamon Press, Elmsford, NY. (1979)

Both low-level and high-level solid wastes generated during reprocessing of spent nuclear fuel are characterized in this paper with respect to source, quantity, content, radioactivity, potential volume reduction, and transuranic content.

SUBJECT CATEGORY: LLW; HLW; Spent Fuel

ORIGIN: Commercial

KEYWORDS: CHEMICAL COMPOSITION; FUEL REPROCESSING PLANTS; HIGH.LEVEL RADIOACTIVE WASTES; LOW-LEVEL RADIOACTIVE WASTES; ORIGIN; RADIOACTIVITY; SOLID WASTES; VOLUME

1131

Luner, C., and E.G. Lazur; Argonne National Laboratory, Argonne, IL

TECHNICAL OPTIONS FOR THE FUTURE OF WEST VALLEY. CONF-790204-10; Waste Management and Fuel Cycles 1979, Proceedings of a Symposium, Tucson, AZ, February 28, 1979. (1979)

Available from NTIS, PC A02/MF A01.

The West Valley Processing Plant reprocessed spent fuel from 1966 to 1972 . It was shut down in 1972 for modifications, and in 1976 NFS decided not to renew the lease. This paper discusses the technical options for dealing with the financial responsibilities. The study shows that there is a range of options for both decommissioning and continued use of the plant with decommissioning involving either the immobilization or the off-site disposal of the wastes.
SUBJECT CATEGORY: Remedial Action, FUSRAP

ORIGIN: Commercial

KEYWORDS: COST; DECOMMISSIONING; EVALUATION; FORECASTING; OPERATION; RADIATION HAZARDS; RADIOACTIVE WASTE DISPOSAL; WEST VALLEY PROCESSING PLANT

\section{2}

Trevorrow, L.E., and M.J. Steindler; Argonne National Laboratory, Argonne, IL

TECHNOLOGY ASSESSMENT AND NUCLEAR WASTE MANAGEMENT. Chemtech 9(2):88-96. (1979)

The problems associated with the management of nuclear wastes are used to illustrate the methods of technology assessment (TA). A general review describes the origins and characterizations of the wastes, method of generation in nuclear facilities, how they might escape during reprocessing, the recovery of fissionable material, and the dangers involved. The sequence of technology and procedures for waste management consist of three steps: waste conversion, transportation, and final disposal. The following is a list of methods which have been used to assess nuclear waste technologies: (1) cost/benefit and risk/benefit ratios; (2) systems analysis; (3) decision analysis; (4) input-output analysis; (5) trend analysis; (6) survey and DELPHI methods; (7) modeling and simulation; (8) fault tree analysis. 6 figures, 3 tables.

SUBJECT CATEGORY: General ,

ORIGIN: Commercial; Defense

KEYWORDS: COST BENEFIT ANALYSIS; DECISION TREE ANALYSIS; DELPHI METHOD; FAILURES; FAULT TREE ANALYSIS; HAZARDS; INPUT-OUTPUT ANALYSIS; ORIGIN; PRODUCTION; RADIOACTIVE WASTE MANAGEMENT; RECOVERY; RISK ASSESSMENT; SIMULATION; SYSTEMS ANALYSIS; TECHNOLOGY ASSESSMENT

1133

Williams, P.M., A.J. Johnson, and J.A. Ledford; Atomics International, Rocky Flats Plant, Golden, $\mathrm{CO}$ 
VITRIFICATION OF TRU WASTES AT ROCKY FLATS PLANT. CONF-790204-2; RFP. 2881; Waste Management and Fuel Cycles, Proceedings of a Symposium, Tucson, AZ, February 28, 1979. (1979)

Available from NTIS, PC A02/MF A01.

Immobilization of incinerator ash and various noncombustible TRU wastes was investigated. In three different research projects borosilicate glass proved to be the best candidate for TRU waste fixation. This glass has excellent chemical durability, long-term stability in the presence of radiation, and will withstand continuous temperatures up to 400 degrees without devitrification. In addition, wastes prepared in the form of glass will attain densities of approximately $2500 \mathrm{~kg} /(\mathrm{E}+3)(2.5 \mathrm{~g} / \mathrm{cc})$. The free forming method of producing glass buttons provides a very simple, consistent, low maintenance way of producing a final waste form for transporting and either retrievable or permanent storage for TRU waste. The fitrification process produces a durable glass from the low density ash generated by the fluidized bed incinerator process and provides volume and weight reductions that are superior to other fixation processes. This results in decreased transportation and storage costs.

\section{SUBJECT CATEGORY: TRU}

ORIGIN: Defense

KEYWORDS: COST; DENSITY; GLASS; RADIOACTIVE WASTE PROCESSING; RADIOACTIVE WASTE STORAGE; SOLIDIFICATION; STORAGE; TRANSPORT; TRANSURANIUM ELEMENTS; VITRIFICATION; BOROSILICATES; ROCKY FLATS PLANT

\section{4}

Jenkins, C.E., E.S. Murphy, and K.J. Schneider; Battelle Pacific Northwest Laboratory, Richland, WA

'IECHNOLOGY, SAFETY AND COSTS OF DECOMMISSIONING A REFERENCE SMALL MIXED OXIDE FUEL FABRICATION PLANT, VOLUME 1 - MAIN REPORT. NUREG/CR-0129(Vol. 1); 315 pp. (1979)

Available from NTIS, PC A15/MF A01, Springfield, VA. 22161
Safety and cost information are developed for the conceptual decommissioning of a small mixed oxide fuel fabrication plant (MOX) with characteristics similar to the Cimarron plutonium facility. The process building, the contaminated sewage lagoon, and the conceptual liquid waste evaporation and uranium nitrate load-in facilities are postulated to be decommissioned in this study. The plant is conceptually decommissioned to three decommissioning states or modes: immediate dismantlement, safe storage with deferred dismantlement, and entombment. These modes range from complete removal of radioactivity above de minimus levels, with subsequent release of the site for unrestricted use, to minimal decommissioning requiring significant continued maintenance and surveillance.

SIIRITECT CATEGORY: Romedial Action, Surplus Facilities; Remedial Action, FUSRAP

ORIGIN: Defense; Commercial

KEYWORDS: ACCIDENTS; REGULATIONS; SAFEGUARDS; NUCLEAR MATERIALS; SITE SELECTION; LICENSING; DECOMMISSIONING; RADIOACTIVE WASTE STORAGE; PLUTONIUM; OXIDES; COST; MIXED OXIDE FUEL FABRICATION PLANTS; CIMARRON PLIJTONIUM PRODUCTION PLANT

1135

Jenkins, C.E., E.S. Murphy, and K.J. Schneider; Battelle Pacific Northwest Laboratory, Richland, WA

TECHNOLOGY, SAFETY AND COSTS OF DECOMMISSIONING A REFERENCE SMALL MIXED OXIDE FUEL FABRICATION PLANT. VOLUME 2. APPENDICES. NUREG/CR-U1zy(Vol.2)(App.). (1979)

Available from NTIS, PC A16/MF A01.

Volume 2 contains appendixes on small MOX fuel fábricaliun facility descrip̀tión, site description, residual radionuclide invontory cotimatca, dernmmissioning, financing, radiation dose methodology, general considerations, packaging and shipping of radioactive materials, cost assessment, and safety.

SUBJECT CATEGORY: Remedial Action, Surplus Facilities; Kemedial Action, FUSRAP

ORIGIN: Defense; Commercial 
KEYWORDS: COST; DECOMMISSIONING; DESIGN; FINANCING; INVENTORIES; MIXED OXIDE FUEL FABRICATION PLANTS; PACKAGING; RADIATION DOSES; RADIOACTIVE MATERIALS; RADIOISOTOPES; SAFETY; TRANSPORT

1136

Hafemeister, W.; California Polytechnic State Univ., San Luis Obispo, CA

NONPROLIFERATION AND ALTERNATIVE NUCLEAR TECHNOLOGIES. Technol. Rev. 81(3):58-62. (1979)

The International Nuclear Fuel Cycle Evaluations (I.N.F.C.E.) has undertaken a study of changes that could be made in the nuclear fuel cycle to conserve uranium and minimize proliferation risks. Alternative nuclear technologies will be evaluated in terms of their technical and economic feasibility, resource utilization, and their closeness to commercialization. Light water reactors (I.WR's) could be redesigned to improve fuel efficiency, reduce the need for poisons to eliminate the loss of neutrons, reduce tails assay of the waste strea, and achieve an overall uranium savings of as much as 45 percent by the year 2000 . The use of thorium or heavy water could also save uranium, although all of these modifications entail high capital costs that make them a marginal trade-off. Uncertainties in the capital costs of fast breeder reactors make it difficult to determine whether they will be more competitive than LWRs. Reprocessing by the PUREX method could be modified to prevent illegal diversion of reprocessing products through co-processing or the CIVEX system. The technical complexities of these alternatives are further intensified by political and institutional questions.

SUBJECT CATEGORY: General

ORIGIN: Commercial

KEYWORDS: CIVEX PROCESS; ECONOMICS; ENRICHED URANIUM; FEASIBILITY STUDIES; FUEL CYCLE; MODIFICATIONS; NUCLEAR ENGINEERING; NUCLEAR WEAPONS; PLUTONIUM; PROLIFERATION; PUREX PROCESS; RADIOACTIVE WASTES; REACTOR TECHNOLOGY; REPROCESSING; RESEARCH PROGRAMS; SAFEGUARDS; SPENT FUELS; TECHNOLOGY ASSESSMENT; URANIUM
1137

Department of Energy, Div. of Environmental Control Technology, Washington, DC; Department of Energy, Grand Junction Office, Grand Junction, CO; Colorado Dept. of Health, Denver, CO

\section{PROGRESS REPORT ON THE GRAND JUNCTION URANIUM MILL TAILINGS REMEDIAL ACTION PROGRAM. DO. E/EV-0033. (1979)}

Program to reduce human exposure from buildings involving the use of mill tailings in their construction; Available from NTIS, PC A08/MF A01.

The report provides a history of the program, an analysis of the current status of the program, problems encountered and measures being taken to solve them, and a forecast of future effort required. From the start of remedial efforts in 1973 through September 30,1978 , remedial action has been done on 325 individual structures, including 289 private residences, 14 schools, and 22 commercial business/church locations. As recently as one year ago, the total number of structures requiring remedial action was estimated to be about 600 . However, continuing measurements of radon daughter concentrations in structures which previously showed only slightly elevated gamma radiation have resulted in identificaion of additional structures exceeding the Surgeon General's guidelines for radon daughters. Because radon daughter concentrations in structures are highly variable depending on the season of the year and the level of activity, annual averages are used for determining eligibility under the guidelines. Based on this recent experience the estimate of the total number of structures which will eventually qualify for remedial action has been increased from 600 to 800 , and the estimated total program cost has been increased from $\$ 12,670,000$ to $\$ 16,960,000$. It must be emphasized that these estimates are based only on experience ratios of past measurements and are highly uncertain. It is not expected that further funding, if necessary, will be required before fiscal year 1982 .

SUBJECT CATEGORY: Remedial Action, Mill Tailings

\section{ORIGIN: Commercial}

KEYWORDS: BUILDING MATERIALS; COLORADO; COMMERCIAL BUILDINGS; COST; DAUGHTER PRODUCTS; FEED MATERIALS PLANTS; HOUSES; HUMAN POPULATIONS; INHALATION; MILL TAILINGS; PUBLIC 
HEALTH; RADIATION HAZARDS; RADIATION PROTECTION; RADIOACTIVITY; RADON; SCHOOL BUILDINGS

\section{8}

Department of Energy, Div. of Spent Fuel Storage and Transfer, Washington, DC

SPENT FUEL STORAGE REQUIREMENTS: THE NEED FOR AWAY-FROM-REACTOR STORAGE. DOE/ET-0075. (1979)

Available from NTIS, PC A04/MF A01.

The projected AFR requirements which have been developed represent data as of December 31,1978 on at reactor fuel pool expansion plans. The base case, which was identified for purposes of sensitivity analysis, assumes transshipments between reactor basins within the same utility. It is very likely that transshipment will not be utilized for all reactors. Hence the base case AFR requirements discussed in this report represent a minimum or lower bound for purposes of planning. If some assumptions are varied, a wide range of AFR requirements results. The smaller the amount of fuel shipped to other reactor basins within the utilities' systems, the greater are the AFR requirements. It is also possible that some utilities may be able to expand their reactor spent fuel pools beyond the base case data. On the other hand, some utilities may not be able to expand as much as currently planned because of licensing, engineering, or institutional problems. Clearly, a number of factors exist which can influence AFK requirements.

SUBJECT CATEGORY: Spent Fuel

ORIGIN: Commercial

KEYWORDS: SPENT FUEL STORAGE; AWAY: FROM-REACTOR STORAGE; EXPANSION; FORECASTING; FUEL POOLS

\section{9}

Department of Energy, Office of Nuclear Waste Management, Washington, DC

ENVIRONMENTAL AND OTHER EVALUATIONS OF ALTERNATIVES FOR LONGTERM MANAGEMENT OF STORED INEL TRANSURANIC WASTE. DOE/ET-0081. (1979)
Available from NTIS, PC A99/MF A01.

This study identifies, develops, and evaluates, in a preliminary manner, alternatives for longterm management of TRU wastc stored at the Radioac tive Waste Management Complex (RWMC) at the INEL. The evaluations concern waste currently at the RWMC and waste expected to be received by the beginning of the year 1985. The effects of waste that might be received after that date are addressed in an appendix. The technology required for managing the waste, the environmental effects, the risks to the public, the radiological and nonradiological hazards to workers, and the estimated costs are discussed.

\section{SUBJECT CATEGORY: TRU}

ORIGIN: Commercial; Defense

KEYWORDS: COMPARATIVE EVALUATIONS; COST; DECOMMISSIONING; DECONTAMINATION; ENVIRONMENT; ENVIRONMENTAL IMPACTS; IDAHO NATIONAL ENGINEERING LABORATORY; PERSONNEL; RADIATION HAZARDS; RADIOACTIVE WASTE FACILITIES; RADIOACTIVE WASTE MANAGEMENT; RADIOACTIVE WASTE PROCESSING; RADIOACTIVE WASTE STORAGE; RISK ASSESSMENT; TABLES; DATA COMPILATION

\section{0}

Department of Energy, Office of Nuclear Waste Management, Washington, DC

NUCLEAR WASTE MANAGEMENT PROGRAM. SUMMARY DOCUMENT. DOE/ET-0094. (1979)

Available from NTIS, PC A11/MF AŌ1.

This document outlines the operational and research and development ( $R$ and $D$ ) activities of the Office of Nuclear Waste Management (ETW) under the Assistant Secrelary for Energy Technology, DOE. The national energy policy as it applies to waste management and spent fuel storage is presented first. The program strategy, structure, budget, management approach, and public participation programs are then identified. The next section describes program activities and outlines their status. Finally, the applicability of departmental policies to ETW programs is summarized, including field and regional activities, commercialization plans, the environmental and socioeconomic 
implications of waste management activities, and international programs.

SUBJECT CATEGORY: Spent Fuel

ORIGIN: Defense

KEYWORDS: COMMERCIALIZATION; ENERGY POLICY; RADIOACTIVE WASTE MANAGEMENT; RESEARCH PROGRAMS; REVIEWS; SOCIO-ECONOMIC FACTORS; SPENT FUEL STORAGE; US DOE

1141

Department of Energy, Washington, DC

DRAFT ENVIRONMENTAL IMPACT STATEMENT: WASTE ISOLATION PILOT PLANT. DOE/EIS-0026-D(Vol.1). (1979)

Available from NEPA Coordination Office, Washington, DC.

This draft Environmental Impact Statement (EIS) has been prepared by the U.S. Department of Energy (DOE) in compliance with the National Environmental Policy Act (NEPA) to assess the environmental impacts of constructing and operating a proposed waste isolation pilot plant (WIPP) for the disposal of defense transuranic nuclear wastes (TRU), experimental research and development with high level waste forms and for the potential disposal of up to a thousand spent fuel assemblies in an intermediate scale facility (ISF). The WIPP would be licensed by the Nuclear Regulatory Commission (NRC) should project licensing be authorized by the Congress. The draft EIS is intended to serve as environmental in put into future decisions concerning construction phases of the proposed repository, inclusion of the spent fuel option, timing and specific location of the facility, and land withdrawal in Eddy County, New Mexico, if that site is chosen. Analyses show that there are no significant radiological health impacts resulting from the alternatives considered, and that there are no clear environmental bases for choosing amorig alternatives other than the alternative of no action which is considered unacceptable in the long term. Seven alternatives are covered in the draft EIS including: no action, alternatives to TRU-waste disposal, alternatives for the intermediate-scale facility, alternative time schedules and potential alternative locations. The range of options was intended to cover a reasonable envelop within which governmental decisions can be made.
SUBJECT CATEGORY: Isolation; TRU; HLW; Spent Fuel

ORIGIN: Defense

KEYWORDS: ECONOMIC IMPACT; ENVIRONMENTAL IMPACT STATEMENTS; ENVIRONMENTAL IMPACTS; GEOLOGIC DEPOSITS; HIGH-LEVEL RADIOACTIVE WASTES; PILOT PLANTS; RADIOACTIVE WASTE DISPOSAL; RADIOACTIVE WASTE FACILITIES; SOCIAL IMPACT; UNDERGROUND DISPOSAL; WIPP

1142

Department of Energy, Washington, DC

DRAFT ENVIRONMENTAL IMPACT STATEMENT: MANAGEMENT OF COMMERCIALLY GENERATED RADIOACTIVE WASTE. VOLUME 2. APPENDICES. DOE/EIS-0046-D(Vol.2). (1979)

Available from NEPA Coordination Office, Washington, DC.

This volume contains the 20 appendices to the Environmental Impact Statement on the Management of Commercially Generated Waste (DOE-1559).

SUBJECT CATEGORY: LLW; HLW; TRU

ORIGIN: Commercial

KEYWORDS: DECOMMISSIONING; ECONOMIC IMPACT; ENVIRONMENTAL IMPACT STATEMENTS; ENVIRONMENTAL IMPACTS; RADIOACTIVE WASTE DISPOSAL; RADIOACTIVE WASTE FACILITIES; RADIOACTIVE WASTE MANAGEMENT; RADIOACTIVE WASTE PROCESSING; RADIOACTIVE WASTE STORAGE; RADIOACTIVE WASTES; SOCIAL IMPACT; SOCIO-ECONOMIC FACTORS; SPENT FUELS; TRANSPORT

\section{3}

First, M.W.; Department of Energy, Washington, DC; Harvard University, Air Cleaning Laboratory, Boston, MA

PROCEEDINGS OF THE 15TH DOE NUCLEAR AIR CLEANING CONFERENCE HELD IN BOSTON, MASS. 7-10 AUGUST 1978. CONF-780819 (Vol. 1); 625 pp. (1979) 
Volume 1 of the proceedings presents the papers given for the first six sessions: waste treatment: volume reduction and preparation for storage; nuclear waste management, risk assessment, air cleaning failures, and standards for air and gas cleaning installations; tritium, carbon-14, and ozone; containment of accidental releases; adsorbents and absorbents; and off-gas treatment.

SUBJECT CATEGORY: Airborne

ORIGIN: Commercial

KEYWORDS: RADIOACTIVE WASTE MANAGEMENT; AIR CLEANING; OFF-GAS SYSTEMS; TRITIUM; CARBON; OZONE; ABSORPTION; ADSORPTION; CHARCOAL; FISSION PRODUCTS; IODINE; CONTAINMENT; GASEOUS WASTES; VOLUME; STANDARDS

1144

Meyer, G.L., M.W. Carter (Ed.), A.A. Moghissi (Ed.), and B. Kahn (Ed.); Environmental Protection Agcncy, Washington, DO

PROBLEMS AND ISSUES IN THE GROUND DISPOSAL OF LOW-LEVEL RADIOACTIVE WASTES, 1977: MANAGEMENT OF LOWLEVEL RADIOACTIVE WASTE. VOLUME II. Pergamon Press, Elmsford, NY. (1979)

Although alternative methods may be developed for disposal or management of some low-level radioactive wastes, shallow land burial will probably remain a primary management method for these wastes for the next ten to twenty years. This paper, which is oriented toward the technical and philosophical aspects of land burial, discusses today's sites, reviews projections for quantities of new wastes, and identifies technical problems and basic management issues which may influence the future development of land burial techniques and sites. Specific information is presented on the general performance of selected burial sites, projections of the availability of burial space to the year 2000 , problems associated with present and future wastes, problems encountered at burial sites, and research and development work being conducted by the U.S. Environmental Protection Agency (EPA) at burial sites. The relation of EPA's work on the ground disposal of low-level radioactive waste to research and development being conducted by other
Federal agencies is also discussed. Finally, a listing is given of certain basic management issues which should be resolved before shallow land burial can be fully implemented at the level needed to support the growth of nuclear power expected during the last quarter of this century.

\section{SUBJECT CATEGORY: LLW}

ORIGIN: Defense; Commercial; Institutional

KEYWORDS: FORECASTING; LOW-LEVEL RADIOACTIVE WASTES; RADIOACTIVE WASTE DISPOSAL; RADIOACTIVE WASTE MANAGEMENT; UNDERGROUND DISPOSAL

\section{5}

Fcrrigno, D.P., M.W. Carter (Ed.), A.A. Moghissi (Ed.), and B. Kahn (Ed.); Gilbert/Commonwealth, Reading, PA

VOLUME REDUCTION PROCESSES IN LIGHT WATER REACTOR RADWASTE TREATMENT: MANAGEMENT OF LOWLEVEL RADIOACTIVE WASTE. VULUME 1. Pergamon Press, Elmsford, NY. (1979)

State-of-the-art process equipment available to further reduce the quantity of radioactive waste shipped from an existing commercial nuclear power plant to the low-level burial site is described. The economic aspects and technical feasibility of installing a volume reduction system at an existing light water reactor are discussed. Realistic waste quantities from a two-unit pressurized water reactor are used to calculate the transportation, burial and in-plant solidification costs over a twenty-year period, with ten percent interest and ten percent escalation. Operation, maintenance, and capital backfit modification costs are compared to the potential operating savings when installing volume reduction equipment.

\section{SUBJECT CATEGORY: LLW}

ORIGIN: Commercial

KEYWORDS: COST; PERFORMANCE; PWR TYPE REACTORS; RADIOACTIVE WASTE FACILITIES; RADIOACTIVE WASTE PROCESS. ING; SPECIFICATIONS; VOLUME; WASTE TRANSPORTATION; RADIOACTIVE WASTE MANAGEMENT 
1146

Clark, D.E., R.E. Lerch, M.W. (Ed.) Carter, A.A. (Ed.) Moghissi, and B. (Ed.) Kahn; Hanford Engineering Development Laboratory, Richland, WA

VOLUME REDUCTION OPTIONS FOR THE MANAGEMENT OF LOW-LEVEL RADIOACTIVE WASTES: MANAGEMENT OF LOWLEVEL RADIOACTIVE WASTE. VOLUME I. Pergamon Press, Elmsford, NY. (1979)

Volume reduction options that are now or soon will be available for low-level wastes are examined. These wastes generally are in the form of combustible solids, noncombustible solids, and wet wastes (solid/liquid). Initially, the wastes are collected and stored onsite. Preconditioning may be required, e.g., sorting, shredding, and classifying the solids into combustible and noncombustible fractions. The volume of combustible solids can be reduced by compaction, incineration/pyrolysis, acid digestion, or molten salt combustion. Options for reducing the volume of noncombustible solids include compaction, size reduction and decontamination, meltdown-casting, dissolution and electropolishing. Burnable wet wastes (e.g., organic wastes) can be evaporated or combusted; nonburnable wet wastes can be treated by various evaporative or nonevaporative processes. All radioactive waste processing operations result in some equipment contamination and the production of additional radioactively contaminated wastes (secondary wastes). The additional waste quantities must be considered in evaluating performance and overall volume reduction factors for the various systems. In the selection of an optimum waste management plan for a given facility, other important factors (e.g., relative stability of the waste product form) should be considered along with the savings accrued due to volume reduction.

SUBJECT CATEGORY: LLW

ORIGIN: Defense; Commercial

KEYWORDS: CALCINATION; CLASSIFICATION; COMBUSTION; COMPACTING; DIGESTION; FILTRATION; FLOCCULATION; ION EXCHANGE; LIQUID WASTES; LOW-LEVEL RADIOACTIVE WASTES; NITRIC ACID; PYROLYSIS; RADIOACTIVE WASTE MANAGEMENT; RADIOACTIVE WASTE PROCESSING; SLURRIES; SOLID WASTES; SULFURIC ACID; VOLUME
1147

Kosiewicz, S.T., B.L. Barraclough, and A. Zerwekh; Los Alamos Scientific Laboratory, Los Alamos, NM

STUDIES OF TRANSURANIC WASTE STORAGE UNDER CONDITIONS EXPECTED IN THE WASTE ISOLATION PILOT PLANT (WIPP), OCTOBER 1-DECEMBER 15, 1978. LA-7649-PR; 15 pp. (1979)

Available from NTIS

This report describes progress in an experimental program to determine the effects of radiolytic, thermal, and catalyzed pyrolytic degradation of various forms of existing or proposed transuranic contaminated wastes. Preliminary data appear to indicate that $\mathrm{G}$ (gas) is dose-rate independent. The rate of evolution of radiolytically generated gases decreases with increasing exposure time. More gas is evolved by radiolysis at $70 \mathrm{C}$ than at $20 \mathrm{C}$. A summary of other work on alpha radiolysis of organics is provided. The rates of cement paste dewatering have been determined at 40 and $100 \mathrm{C}$. Characterization of (1) waste types, (2) waste containers, and (3) radionuclide occurrences are presented in detail in the Los Alamos Scientific Laboratory TRU waste inventory assessment. At the end of 1977,27 waste types comprised the total inventory of retrievably stored, solid, TRU contaminated waste. The total accumulated volume amounted to $1590 \mathrm{cu} \mathrm{m}, 20 \%$ of which is combustible. The total TRU waste inventory is stored in 2813 containers. Five different types of containers are in use: 210-1 drums, 110-l drums, CMP, FRP crates, and cement casks. The total curie content of the TRU waste inventory is estimated to be close to $8.0 \mathrm{x}$ 10(E+4) $\mathrm{Ci}$ with $\mathrm{Pu} 238, \mathrm{Pu} 239 \mathrm{w}$, and $\mathrm{Am} 241$ dominating the inventory's curie content.

SUBJECT CATEGORY: Isolation; TRU

ORIGIN: Defense

KEYWORDS: TRANSURANIUM ELEMENTS; RADIOACTIVE WASTE STORAGE; RADIOCHEMISTRY; GASES; DOSE RATES; ORGANIC COMPOUNDS; CEMENTS; CONTAINERS; CASKS; RADIOLYSIS; ALPHA PARTICLES; VOLUME; URANIUM 233; URANIUM 235; URANIUM 238; NEPTUNIUM 237; PLUTONIUM 238; PLUTONIUM 239; AMERICIUM 241; AMERICIUM 242; CURIUM 244; CALIFORNIUM 249; ACTINIUM 227; THORIUM 232; DECOMPOSITION; DECAY; WIPP 
1148

Kosiewicz, S.T., B.L. Barraclough, A. Zerwekh, and B.J. Barnhart; Los Alamos Scientific Laboratory, Los Alamos, NM

STUDIES OF TRANSURANIC WASTE STORAGE UNDER CONDITIONS EXPECTED IN THE WASTE ISOLATION PILOT PROJECT (WIPP), JULY 1-SEPTEMBER 30, 1978. LA-7582-PR. (1979)

Available from NTIS, PC A02/MF A01.

This is the fourth quarterly report describing progress in an experimental program to determine the effects of radiolytic, thermal, and catalyzed pyrolytic degradation of various forms of existing or proposed transuranic ('TKU) wastes. Thermal degradation of paper and composite ( $35 \%$ cellulosics, $23 \%$ polyethylene, $12 \%$ polyvinyl chloride, $15 \%$ neoprene, and $15 \% \overline{\mathrm{H}}$ ypalon) at 70 and 100 degrees $\mathrm{C}$ is occurring. Some radiolytic gas evolution appears to be occurring at a dose of $4 \times 10(\mathrm{E}+5) \mathrm{nCi} / \mathrm{g}$. The rates of sludge dewatering at $25,40,70$ and 100 degrees $C$ have been determined. Several highpressure $(1.5 \times 10(\mathrm{E}+4) \mathrm{kPa}$, or $150 \mathrm{~atm})$ experiments are in progress. In addition, an assessment of Los Alamos Scientific Laboratory (LASL) retrievably stored TRU waste for the calendar years 1971 to 1977 is in progress. The total volume of TRU waste stored at LASL during these years is 1589 cubic $m$, or about $3.5 \%$ of the national Department of Energy total. Progress is reported for the first quarter of the project designed to assess potential microbial interaction with plutonium and other transuranics in low-level radioactive waste as it is expected to occur in the Waste Isolation Pilot Project(WIPP). In the two months this project has been funded, we have compiled an extensive body of pertinent literature, ordered and received equipment and laboratory expendables, initiated the enumeration, isolation, and identification of bacteria and fungi from soil obtained from a LASL TRU burial site, and successfully performed the abiotic alkylation of a heavy metal (mercury) and identified the methylated product in preparation for subsequent abiotic and biological alkylation reaction of europium and plutonium.

SUBJECT CATEGORY: TRU; Isolation

ORIGIN: Defense

KEYWORDS: ALKYLATION; BACTERIA; BIOGEOCHEMISTRY; CATALYSIS; INVENTORIES; LOW-LEVEL RADIOACTIVE WASTES;
MICROORGANISMS; PYROLYSIS; RADIOACTIVE WASTE STORAGE; RADIOLYSIS; RADIONUCLIDE MIGRATION; RESEARCH PROGRAMS; SLUDGES; SOLID WASTES; THERMAL DEGRADATION; TRANSURANIUM ELEMENTS; WATER REMOVAL; WIPP

\section{9}

May, J.R., T.K. Thompson, J.W. McConnell, Jr., M.W. (Ed.) Carter, A.A. (Ed.) Moghissi, and B. (Ed.) Kahn; Newport News Industrial Corp., Newport News, VA

FLUIDIZED BED RADIOACTIVE WASTE VOLUME REDUCTION SYSTEM: MANAGEMENT OF LOW-LEVEL RADIOACTIVE WASTE. VOLUME I. Pergamon Press, Elmsford. NY. (1979)

A new fluidized bed radioactive waste treatment system has been developed which can substantially reduce the volume of low-level radioactive waste presently transported from nuclear power plants to disposal sites. The volume reduction system, designated RWR-1 and consisting of a fluidized bed evaporator/incinerator and off-gas treatment system, can reduce the volume of concentrated liquids, ion exchange resin beads, filter sludges, and various combustible solids such as protective clothing, rags, paper, wood, and plastics. Operational characteristics and parameters, process data, and economic benefits are presented.

\section{SUBJECT CATEGORY: LLW}

ORIGIN: Commercial

KEYWORDS: FLUIDIZED-BED COMBUSTION: FLUIDIZED-BED COMRUSTORS; LIQUID WASTES; LOW-LEVEL RADIOACTIVE WASTES; RADIOACTIVE WASTE PROCESSING; SOLID WASTES; VOLUME

1150

LaGuardia, T.S.; Nuclear Energy Services, Inc., Danbury, CT

NUCIEAR POWER-REACTOR DECOMMISSIONING. Nucl. Saf. 20(1):15-26. (1979)

7 tables, 2 figures, 9 references 
The article summarizes the major findings of an evaluation of several alternatives for decommis sioning 1100-MW(e) nuclear power reactors. The evaluation included the technical feasibility of decommissioning and the costs, schedule, environmental impacts, and occupational exposures for three decommissioning alternatives: mothballing, entombment, and prompt removal of radioactive components and dismantling. In addition, two combinations of these alternatives were evaluated: mothballing-delayed removal and dismantling and entombment-delayed removal and dismantling. The evaluation demonstrated that no new technology is required to safely decommission a large power reactor. The prompt removal of radioactive components and dismantling alternative is the highest in cost, requiring approximately $\$ 50$ million and approximately 6 years to remove all structures at the end of useful life. The radiation exposures and environmental impacts are low for all the alternatives so that decommissioning can be accomplished without undue risk to public health and safety.

SUBJECT CATEGORY: Remedial Action, FUSRAP

ORIGIN: Commercial

KEYWORDS: COMPARATIVE EVALUATIONS; COST; PLANNING; POWER REACTORS; RADIATION DOSES; RADIATION PROTECTION; REACTOR DECOMMISSIONING; REACTOR DISMANTLING

1151

Nuclear Regulatory Commission, Office of Inspection and Enforcement. Washington. DC

LICENSED FUEL FACILITY STATUS REPORT. STATUS SUMMARY REPORT. NUREG-0430(Vol.1)(No.2). (1979)

Available from NTIS, PC A04/MF A01.

This report is a periodic report routinely providing information on licensed fuel facilities, on a semiannual basis. It identifies the licensee and the plant status, along with NRC inspection results and summarizes through June 30,1978 . The licensee performance data given include licensee event reports, quantities of radioactive materials released to the environment, and inventory difference data (MUF).
SUBJECT CATEGORY: General

ORIGIN: Commercial

KEYWORDS: DATA COMPILATION; FEED MATERIALS PLANTS; FUEL FABRICATION PLANTS; INSPECTION; INVENTORIES; MATERIAL UNACCOUNTED FOR; NUCLEAR FACIL ITIES; RADIOACTIVE EFFLUENTS; TABLES; US NRC; WEST VALLEY PROCESSING PLANT

\section{2}

Stouky, R.J., M.W. Carter (Ed.), A.A. Moghissi (Ed.), and B. Kahn (Ed.); NUS Corp., Rockville, MD

OPERATING COST NUANCES OF NUCLEAR POWER PLANT RADIOACTIVE WASTE DISPOSAL: MANAGEMENT OF LOW-LEVEL RADIOACTIVE WASTE. VOLUME I. Pergamon Press, Elmsford, NY. (1979)

The annual operating costs associated with radioactive waste treatment and disposal at large power reactors, in many cases, exceed one million dollars per year; and all indications point to a continued increase due to larger waste volumes, increased cost, and more stringent shipping and burial requirements. The selection of systems and components in the plant design stage has been found to impact these costs by as much as a factor of 2 . The cost factors in the following areas are discussed: system selection, solidification agents, disposable container size, transportation, cask rental, and disposal. The equipment and service industries that provide systems, transportation and casks, and burial for containers are prepared to provide a.wide range of choices in the above areas. Cement and/or urea-formaldehyde polymer systems may be utilized, and other products such as polyester resins may soon be available. Containers ranging from drums to large containers are available, as are the shielded casks to transport them. The transportation costs associated with disposal will vary substantially as a function of cask utilization and distance. Cask rental/purchase arrangements range from outright ownership to full-time rental or per use rental. Disposal costs vary for basic services, and other costs as well as alternative burial sites must be considered when necessary. The use of volume reduction systems, while not discussed here specifically, is a viable alternative; and the methodologies are applicable to the product obtained from these systems.

SUBJECT CATEGORY: L.L.W 
ORIGIN: Commercial

KEYWORDS: CASKS; CEMENTS; CONTAINERS; COST; NUCLEAR POWER PLANTS; POLYMERS; RADIOACTIVE WASTE DISPOSAL; RADIOACTIVE WASTE MANAGEMENT; RADIOACTIVE WASTE PROCESSING; SOLIDIFICATION; TRANSPORT

\section{3}

Alexander, C.W., J.O. Blomeke, M.W. Carter (Ed.), A.A. Moghissi (Ed.), and B. Kahn (Ed.); Oak Ridge National Laboratory, Oak Ridge, TN

ÔRIGIN AND CHARACTERISTICS OF LOWLEVEL NON-TRANSURANIC W ASTE FROM THE NUCLEAR FUEL CYCLE: MANAGEMENT OF LOW-LEVEL RADIOACTIVE WASTE. VOLUME I. Pergamon Press, Elmsford, NY; CONF-770512-9; 32 pp.; Management of Low Level Radioactive Waste, Proceedings of a Symposium, Atlanta, GA, May 23, 1977. (1979)

Low-level non-transuranic wastes are generated in all nuclear fuel cycle operations. While the activity levels and radiotoxicities of these eftluents are generally of a lower magnitude than other fuel cycle wastes, their large volumes and their appearance throughout the fuel cycle make their management a very real concern regardless of the fuel cycle option being considered. For the purposes of this paper, low-level non-transuranic wastes are defined as wastes that contain less than about $10 \mathrm{nCi}$ of longlived alpha radiation per gram and have gamma radiations low enough to require only minimal biological shielding and remote handling. Wastes from uranium mining and milling, UF 6 conversion, enrichment, fuel fabrication, and fuel reprocessing are examined with respect to their radionuclide content, volume, and chemical composition. Projections of total quantities through the end of this century are also presented. Fuel cycles based on recycling only uranium, and on recycling both uranium and plutonium, are considered.

SUBJECT CATEGORY: LLW; Spent Fuel; Remedial Action, Mill Tailings

ORIGIN: Commercial

KEYWORDS: CARBON 14; CHEMICAL COMPOSITION; FEED MATERIALS PLANTS; FORECASTING; FUEL CYCLE; FUEL FABRICATION PLANTS; FUEL REPROCESSING PLANTS; IODINE; ISOTOPE SEPARATION PLANTS;
KRYPTON 85; LOW-LEVEL RADIOACTIVE WASTES; ORIGIN; TRITIUM; VOLUME; RADIOACTIVF WASTES; RADIOACTIVE WASTE PROCESSING; INVENTORIES

\section{4}

Jaculs, D.G., M.W. Carter (E'd.), A.A. Moghissi (Ed.), and B. Kahn (Ed.); Oak Ridge National Laboratory, Oak Ridge, TN

COST-BENEFIT ANALYSIS FOR MANAGEMENT OF LOW-LEVEL RADIOACTIVE WAS'IE: MANAGEMENT OF LOW-LEVEL RADIOACTRVE WASTE. VOLUME I. Por gamnn Press, Elmsford, NY. (1879)

There are several types of cost-benefit analyses that can be used in evaluating a technical activity such as waste management. A direct comparison can be made of the benefits to be gained versus the costs to be accrued. If the balance is favorable the activity is considered to be acceptable. In many cases, however, a number of alternatives may be available requiring a comparative cost-benefit analysis so that the most favorable option is chosen. After the basic option is chosen, a further analysis is required in which additional control technologies can be considered to further reduce specific ty pes of impact; this represents a differential cost-benefit analysis or, perhaps more properly, a study of costeffectiveness. Also, because of the wide variety of parameters that go into a cost-benefit analysis and the range of value judgements that may he applied by different interest groups, it is likely that each additional increment of technology will have a slightly different balance point. Factors and impacts that need to be considered in management of low-level wastes will be discussed and a simplified example will be used to demonstrate the difficulties that may be encountered.

SUBJECT CATEGORY: LLW

ORIGIN: Commercial; Defense

KEYWORDS: COST BENEFIT ANALYSIS; LOWLEVEL RADIOACTIVE WASTES; RADIOACTIVE WASTE MANAGEMENT

1155

Kibbey, A.H., and H.W. Godbee; Oak Ridge National Laboratory, Oak Ridge, TN 
SOURCES, AMOUNTS, AND CHARACTERISTICS OF LOW-LEVEL RADIOACTIVE SOLID WASTES. CONF-790209-6; Twelveth Health Physics Society Midyear Topical Symposium, Williamsburg, VA, February 12, 1979. (1979)

\section{Available from NTIS, PC A02/MF A01.}

Low-level radioactive solid wastes (LLW) are generated in the nuclear fuel cycle, national defense programs, institutional (especially medical/biological) applications, and other research and development activities. The estimated total accumulation of defense LLW, approx. $50.8 \times 10(\mathrm{E}+6)$ cubic $\mathrm{ft}$ (approx. $1.4 \times 10(\mathrm{E}+6)$ cubmic $\mathrm{m}$, is roughly three times that estimated for commercial LLW, mill tailings excepted. All nuclear fuel cycle steps generate some LLW, but power plants are the chief source. From 1975 through 1977, reactor process stream cleanup generated approx. 1 x $10(\mathrm{E}+6)$ (approx. $2.8 \times 10(\mathrm{E}+4)$ cubic) annually. Spent fuel storage (or reprocessing) and facility decontamination and decommissioning will become important LLW generators as the nuclear power industry matures. The LLW contains dry contaminated trash, much of which is combustible and/or compactible; discarded tools and equipment; wet filter sludges and ion-exchange resins; disposable filter cartridges; and solidified or sorbed liquids, including some organics. A distinguishing characteristic of LLW is a long-lived alpha-emitting transuranic content of $10 \mathrm{nCi} / \mathrm{g}$; this limit, however, is presently under review by NRC. If it is increased, the amount of LLW would also increase. The nonfuel-cycle waste generation rate in 1975 was estimated to be approx. $7.6 \times 10(\mathrm{E}+5)$ cubic (approx. $2.1 \times 10(E+4)$ cubic) $/ y$. The majority of these wastes, $6 \times 10(E+5)$ cubic $(1.7 \times 10(E+4)$ cubic), was medical and academic wastes which usually contained isotopes with induced activities of less than or equal to 00-duy lialf-life, neglecting II-3 and C-14.

\section{SUBJECT CATEGORY: LLW}

ORIGIN: Defense; Commercial; Institutional

KEYWORDS: CHEMICAL PROPERTIES; LOWLEVEL RADIOACTIVE WASTES; ORIGIN; PHYSICAL PROPERTIES; RADIOACTIVE WASTE MANAGEMENT; SOLIDS; VOLUME

\section{6}

Weeren, H.O., M.W. (Ed.) Carter, A.A. (Ed.) Moghissi, and $B$. (Ed.) Kahn; Oak Ridge National Laboratory, Oak Ridge, TN
WASTE DISPOSAL BY SHALE FRACTURING AT ORNL: MANAGEMENT OF LOWLEVEL RADIOACTIVE WASTE. VOLUME II. Pergamon Press, Elmsford, NY. (1979)

The shale fracturing process is a method of waste disposal currently in use at the Oak Ridge National Laboratory for the permanent disposal of certain locally generated radioactive waste solutions. In this process, the waste solution is mixed with a solids blend of cement and other additives; the resulting grout is injected into an impermeable shale formation at a depth of 700 to $1000 \mathrm{ft}$ (200 to $300 \mathrm{~m}$ ). A few hours after completion of the injection, the grout sets, fixed the radioactive waste in the shale formation. The operational experience with this process since 1966, the monitoring techniques that have been developed, and some considerations of the impact on the environment are discussed.

\section{SUBJECT CATEGORY: HLW; LLW}

ORIGIN: Defense

KEYWORDS: COST; ENVIRONMENTAL IMPACTS; GEOLOGIC DEP.OSITS; INTERMEDIATE-LEVEL RADIOACTIVE WASTES; ORNL; RADIOACTIVE WASTE DISPOSAL; SAFETY; SHALES; HYDRAULIC FRACTURING

\section{7}

Wymer, R.G.; Oak Ridge National Laboratory, Oak Ridge, TN

TECHNOLOGY OF THE LIGHT WATER REACTOR FUEL CYCLE. Nuclear Fuel Cycle Information, Proceedings of a Workshop, Oak Ridge, TN, March 13, 1979. (1979)

Available from NTIS, PC A07/MF A01; 40 figures, 34 tables.

This essay presents elements of the processes used in the fuel cycle steps and gives an indication of the types of equipment used. The amounts of radioactivity released in normal operation of the processes are indicated and related to radiation doses. Types and costs of equipment or processes required to lower these radioactivity releases are in some cases suggested. Mining and milling, conversion of uranium concentrate to UF 6 , uranium isotope separation, LWR fuel fabrication, fuel reprocessing, transportation, and waste management are covered in this essay. 
SUBJECT CATEGORY: HLW; LLW; Transportation; Spent Fuel

ORIGIN: Defense; Commercial

KEYWORDS: COMPARATIVE EVALUATIONS; COST; EQUIPMENT; EXPERIMENTAL DATA; FEED MATERIALS PLANTS; FORECASTING; FUEL CYCLE; FUEL FABRICATION PLANTS; FUEL REPROCESSING PLANTS; ISOLATED VALUES; ISOTOPE SEPARATION; RADIATION DOSES; RADIATION PROTECTION; RADIOACTIVE WASTE MANAGEMENT; RADIOACTIVITY; REPROCESSING; REVIEWS; SPENT FUELS; TRANSPORT; ITRANIUM HEXAFLUORIDE; URANIUM ISOTOPES; URANIUM MINES; WATER COOLED REACTORS

\section{8}

McKenzie, D.E., L.F. Grantham, R.B. Paulson, M.W. Carter (Ed.), A.A. Moghissi (Ed.), and B. (Ed.) Kahn; Rockwell International, Canoga Park, CA

VOLUME REDUCTION OF WASTE CONTAMINATED BY FISSION PRODUCT ELEMENTS AND PLUTONIUM USING MOLTEN SALT COMBUSTION: MANAGEMENT OF LOW-LEVEL RADIOACTIVE WASTE. VOLUME I. Pergamon Press, Elmsford, NY. (1979)

In the Molten Salt Combustion Process, transuranic or beta-gamma organic waste and air are continuously introduced beneath the surface of a sodium carbonate-containing melt at a temperature of about $800 \mathrm{C}$. Complete combustion of the organic material to carbon dioxide and steam occurs without the conversion of nitrogen to nitrogen oxides. The noxious gases formed by combustion of the chloride, sulfur or phosphorus content of the waste instantly react with the melt to form the corresponding sodium compounds. These compounds as well as the ash and radionuclides are retained in the molten salt. The spent salt is either fused cast into an engineered disposal container or processed to recover salt and plutonium. Molten salt combustion reduces the waste to about $2 \%$ of its original volume. Many reactor or reprocessing wastes which cannot be incinerated without difficulty are readily combusted in the molten salt. A 50 $\mathrm{kg} / \mathrm{hr}$ molten salt combustion system is being designed for the Radioactive Waste Management Complex at the Idaho National Engineering Laboratory. Construction of the combustor started during 1977 , and combustor startup was scheduled for the spring of 1978 .
SUBJECT CATEGORY: LLW; TRU

ORIGIN: Defense; Commercial

KEYWORDS: COMBUSTION; COMBUSTORS; FISSION PRODUCTS; LOW-LEVEL RADIOACTIVE WASTES; PLUTONIUM; RADIOACTIVE WASTE PROCESSING; VOLUME

\section{9}

Albrecht, W.L., M.W. Carter (Ed.), A.A. Moghissi (Ed.), and B. Kahn (Ed.); Tennessee Valley Authority, Knoxville, TN

APPLICATION OF VOLUME REDUCTION TO A RWR RA DWASTE 9YBTEM: MANAGEMENT OF LOW-LEVEL RADIOACTIVE WASTE. VOI.UME I, Pergamon Press, Elmsford, NY. (1979)

Boiling water reactors generally produce more waste than do pressurized water reactors. Studies show that radwaste volume reduction would be cost effective in a BWR radwaste system. TVA is giving consideration to installing volume reduction facilities in three two-unit BWR plants it is building or planning to build. These facilities would replace presently designed equipment for packaging waste in admixture with cement. The volume reduction facilities wuuld process evaporator concentrates, ion exchange resins, filter sludges, and possibly combustible trash. Various systems are being considered for this application, including fluid bed calciners and incinerators, extruder-evaporators, and thin-film evauurulurs. Two new systems, in which drying or combustion is carried out in a hot liquid medium, also are possibilities.

SUBJECT CATEGORY: Spent Fuel; LLW

ORIGIN: Commercial

KEYWORDS: BWR TYPE REACTORS; COMPARATIVE EVALUATIONS; COST; VOLUME; PERFORMANCE; RADIOACTIVE WASTE FACILITIES; RADIOACTIVE WAS'I'E PROCESSING; SPECIFICATIONS; LOW-LEVEL RADIOACTIVE WASTES

\section{0}

Dix, G.P.

RECYCLE NUCLEAR WASTE: WHY NOT? Energy 4(1);23-24. (1979) 
Estimates of the economics of recycling nuclear waste by-products for peaceful applications indicate that several new technologies are promising. The author believes that nuclear waste disposal will be simplified by extracting useful by-products because the heat removed will eliminate the thermal effects on waste containers. Among the useful components of spent fuel are platinum-family metals used for catalysts; radiocesium used for converting sewage to animal feed, food preservation, and radiationsterilization of medical equipment; radiostrontium used for navigation and weather instruments, fuel oil substitute, and down-hole oil well heating; plutonium-238 used for generating power in space vehicles and for cardiac pacemakers; neptunium237 used for making plutonium-238; americium-241 used for oil well logging and smoke detectors; krypton-85 used for nondestructive testing; stable krypton and xenon used for lighting, lasers, and anesthetics; and technetium used for catalyst and medical purposes.

SUBJECT CATEGORY: General

ORIGIN: General

KEYWORDS: ECONOMICS; HIGH-LEVEL RADIOACTIVE WASTES; RECYCLING; SPENT FUELS; TECHNOLOGY ASSESSMENT; TEMPERATURE EFFECTS; USES

1161

Greenhalgh, G.

INTERNATIONAL CONSENSUS SOUGHT ON PLUTONIUM STORAGE. Energy Int. 16(4):30-32. (1979)

If utilities are able to secure reprocessing of their spent reactor fuel, the separated plutonium must be stored until it can be used in fast reactors. A study by Russell W. Fox and Mason Willrich, "international custody of plutonium stocks: a first step toward an international regime for sensitive nuclear energy activities", proposes an international scheme for establishment of plutonium stores that would follow the ideas previously set out for the storage of untreated spent-fuel and fission-product wastes. The paper starts from the assumption that the world energy situation will be more difficult to manage, nationally and internationally, without nuclear power than if it is used wherever and whenever it can be reasonably justified on economic and other relevant grounds. With present unease over non-proliferation risks and the urgent need to create an international consensus on an acceptable regime for the necessary development of nuclear power to proceed, the authors propose that priority be given to negotiation of measures that will provide an effective international control over plutonium stocks. They draw attention to the fact that stocks of plutonium in excess of immediate needs for specific civil power and research purposes are likely to exist in an increasing number of countries in which reprocessing plants are in operation, or under construction, and that placing this excess plutonium under international control would reduce the proliferation risk without hampering the development of civil nuclear power. Specific criteria for releasing plutonium from the store, spent fuel storage needs, and national schemes are discussed.

SUBJECT CATEGORY: TRU

ORIGIN: Commercial; Foreign

KEYWORDS: CONTROL; DECISION MAKING; ECONOMICS; ELECTRIC UTILITIES; FAST REACTORS; FISSION PRODUCTS; INTERNATIONAL COOPERATION; PLUTONIUM; PROLIFERATION; REPROCESSING; SPENT FU. ELS; STORAGE

\section{2}

REPORT TO THE PRESIDENT BY THE INTERAGENCY REVIEW GROUP ON NUCLEAR WASTE MANAGEMENT. TID-29442; 239 pp. (1979)

This is the report to the president from the interagency review group on nuclear waste management (IRG) which was established last March at the direction of the president. In October a draft report was offered for public review, and extensive comments were received. This final report presents the findings, policy considerations, and recommendations reached by the IRG as of this date. Major topics include strategies of high-level and transuranic wastes, low level waste, and uranium mill tailings; institutional issues (siting, spent fuel, transportation); and management considerations (costs, financing, and legislation).

SUBJECT CATEGORY: HLW; TRU; LLW; Remedial Action, Mill Tailings

ORIGIN: Commercial; Defense; Institutional

KEYWORDS: RADIOACTIVE WASTE MANAGEMENT; REVIEWS; RADIOACTIVE WASTE 
DISPOSAL; LOW-LEVEL RADIOACTIVE WASTES; TRANSURANIUM ELEMENTS; SPENT FUELS; WASTE TRANSPORTATION; LEGISLATION; ECONOMICS; MILL TAILINGS; HIGH-LEVEL RADIOACTIVE WASTES; COST; FINANCING

\section{3}

HANDLING AND STORAGE OF SPENT FUEL FROM LIGHT-WATER POWER REACTORS. Nucl. Saf. 20(1):54-62. (1979)

The article deals with the Executive Summary of the Nuclear Regulatory Commission (NRC) report, Generic Environmental Impact Statement on Handling and Storage of Spent Light-Water Power Reactor Fuel (NUREG-0404). The report was prepared by the NRC staff in response to a directive from the Commissioners. Inasmuch as there have been-and continue to be-significant policy developments since the NRC's directive was issued, this impact statement is considered to be an interim action, not a final solution. The report covers the following concerns: (1) expected magnitude of the shortage of storage capacity, (2) the options for dealing with the problem, (3) a cost-benefit analysis of these options, (4) the impacts of additional transportation of spent fuels, and (5) the need for more regulations and guidance. The study concludes that the storage of spent fuel is a wellestablished technology, that the amount of spent fuel requiring away-from-reactor storage by year 2000 is not great. and that the envirnmmental impact of either at-reactor or away-from-reactor spent-fuel storage is insignificant.

SUBJECT CATEGORY: Spent Fuel

NRICIIN: Commercial

KEYWORDS: BWR TYPE REACTORS; COST; FUEL POOLS; PLANNING; PWR TYPE REACTORS; SPENT FUEL STORAGE

\section{4}

Carruthers, J.; Atomic Energy of Canada, Ltd., Chalk River, Ontario, Canada; Ontario Hydro, Toronto, Canada

NUCLEAR WASTE: TWENTY-FIVE YEARS HENCE ... AND BEYOND. AECL Report. ()
The Canadian federal and Ontario governments have agreed to initiation of studies by Atomic Energy of Canada, Ltd. (AECL) and Ontario Hydro on radwaste immobilization and geologic disposal techniques, and on interim storage and transportation of spent fuel. Over the next 3 years, AECL will do test drillings in syenites, anorthosites, gabbros, and granites in an effort to find 50-100 suitable plutons for geologic disposal sites. Information will be gathered on fracture density properties, chemical properties, groundwater migration, and geologic history. Heat distribution studies are planned using an INCO mine at Sudbury. Other scientists will be developing and testing designs for underground repositories. The most promising design currently under study would bury $1,082,000$ canisters $0.3 \mathrm{~m}$ in diameter by $0.3 \mathrm{~m}$ high in holes drilled in the floors of rooms $1000 \mathrm{~m}$ underground; there would be 500 canisters/room, with 44 separate panels of 50 rooms each. An estimated 15 million cu m of rock would be excavated for the rooms, and another $500,000 \mathrm{cu} \mathrm{m}$ for the storage holes. Cost would be $\$ 400-800$ million. Depending on the effectiveness of the bedrock as a barrier to migration, burial rooms might be filled with water-absorbing clays, or the waste containers enclosed in stainless steel (at an extra cost of $\$ 500$ million). Since a decision has not been made about reprocessing of used CANDU reactor fuel, AECL is studying two options: 1) longterm retrievable storage of fuel rod assemblies after a 5-year temporary storage, and 2) burial of only the wastes left over from epont fucl rcproccssing. Waste storage would he in the form of glass. AECL forsecs the following timetable for the program: 1) concept verification (test drilling, pathway analysis, etc.) - 3 years; 2 ) site sclection and confin'malury lesting - 2 years; 3 ) design and mnstruction of a demnnetra tion repository (holding the equivalent of 4 years' opent fucl from une Picker ing-ly pe CAINDU reactor') and of a fuel and waste immobilization pilot plant (1/100 scale), at costs of $\$ 50-100$ million and $\$ 15-20$ imilliun, respectively - 5 years; and finally, the community pliase - establishment of large-scale commercial facilities. The entire program will require 25 years to achieve operable full-scale facilities.

SUR.IFC.T CATEGORY; Ioolation; Snont. Fuel

\section{ORIGIN: Foreign}

KEYWORDS: SPENT FUELS; WASTE TRANSPORTATION; ECONOMICS; RADIOACTIVE WASTE MANAGEMENT; RADIOACTIVE WASTE DISPOSAL; COST; UNDERGROUND STORAGE; GLASS 
INTERNAL DISTRIBUTION

ORNL/TM-7385/V2

Distribution Category UC-70

1. W. S. Aaron

2. C. W. Alexander

3. C. F. Baes

4. R. E. Blanco

5. J. O. Blomeke

6. W. D. Bond

7. G. D. Brunton

8. W. L. Carter

9. J. M. Chandler

10. J. H. Coobs

11. D. F. Cope

12. A. G. Croff

13. N. H. Cutshall

14. B. C. Finney

15. R. B. Fitts

16. C. S. Fore

17. C. W. Forsberg

18. E. J. Frederick

19-23. P. A. Garland

24. H. B. Gerstner

25. H. W. Godbee

26. G. H. Jenks

27-31. C. A. Johnson

32. D. J. Joy

33. A. H. Kibbey

34. E. H. Kobisk
35. W. J. Lackey

36. A. L. Lotts

37. R. S. Lowrie

38. B. F. Maskewitz

39. J. D. McGaugh

40. J. M. McNair

41. J. G. Moore

42. G. W. Morrison

43-47. K. J. Notz

48. H. A. Pfuderer

49. G. D. Robbins

50. R. W. Schaich

51. L. B. Shappert

52. S. Stowe

53. T. Tamura

54. J. E. Vath

55. Biology Library

56-57. Central Research Library

58. Document Reference Section

59-108. Ecological Sciences Information Center, 2001

109. ICC Publications Office, 2001

110-119. ICC Resource Center, 2001

120-121. Laboratory Records

122. Laboratory Records, RC

123. ORNL Patent office

EXTERNAL DISTRIBUTION

124. S. W. Ahrends, Department of Energy, Oak Ridge Operations, Oak Ridge, Tennessee 37830.

125. W. H. Baker, Department of Energy, Savannah River Operations Office, P.o. Box A, Aiken, South Carolina 29801.

126. A. A. Bauer, Office of Nuclear Waste Isolation, 505 King Avenue, Columbus, Ohio 43201.

127. J. L. Bellows, Department of Energy, Albuquerque Operations Office, P.O. Box 5400, Albuquerque, New Mexico 87115.

128. P. F. Brown, Department of Energy, Oak Ridge Operations, Oak Ridge, Tennessee 37830.

129. R. A. Brown, Exxon Nuclear, P.o. Box 2800, Idaho Falls, Idaho 83401 .

130. R. H. Campbe11, Department of Energy, Albuquerque Operations office, P.0. Box 5400, Albuquerque, New Mexico 87115.

131. T. Chee, office of Nuclear Waste Management, Department of Energy, Washington, D.C. 20545. 
132. W. R. Cornman, Department of Energy, Savannah River Operations Office, P.O. Box A, Aiken, South Carolina 29801.

133. S. Cowan, Office of Nuclear Waste Management, Department of Energy, Washington, D.C. 20545.

134. P. A. Craig, Department of Energy, Richland Operations Office, P.O. Box 550, Richland, Washington 99352.

135. G. Daly, Office of Nuclear Waste Management, Department of Energy, Washington, D.C. 20545.

136. L. Dressen, Office of Nuclear Waste Management, Department of Energy, Washington, D.C. 20545.

137. E. Fray, EG\&G Idaho, Inc., P.O. Box 1625, Idaho Falls, Idaho 83401.

138. R. G. Garvin, Department of Energy, Savannah River Operations Ofiice, P.O. Box A, Aiken, South Carolina 29801.

139. E. S. Guldberg, Department of Energy, Savannāh Rivièr Üperations Office, P.o. Box A, Aikẹn, South Carulina 29801.

140. D. E. Gordon, Department of Energy, Savannah River Operations Office, P.O. Box A, Aiken, South Carolina 29801.

141. E. C. Hardin, Department of Energy, Albuquerque Operations Office, P.0. Box 5400, Albuquerque, New Mexico 87115.

142. K. Harmon, Pacific Northwest Laboratory, P.0. Box 999, Richland, Washington 99352.

143. C. A. Heath, Office of Nuclear Waste Management, Department of Energy, Washington, D.C. 20545.

144. T. B. Hindman, Department of Energy, Savannah River Operations Office, P.0. Box A, Aiken, South Carolina 29801.

145. P. L. Johnson, Oak Ridge Associated Universities, P.0. Box 117, Oak Ridge, Tennessee 37830.

146. G. F. Jones, UNC Nuclear Industries, P.O. Box 490, Richland, Washington 99352.

147. E. L. Keller, Department of Energy, Oak Ridge Operations, nak Ridge, Tennessee 37830.

148. J. L. Landon, Department of Energy, Richland Operations Office. P.O. Box 550, Richland, Washington 99352.

149-150. D. E. Large, Department of Energy, Uak Ridge Operations, Oak Ridge, Tennessee 37830.

151. M, J, Lawrence. Office of Nuclear Waste Management. Department. of Encrgy, Waohington, D.C. 20545.

152. G. B. Levin, EG\&G Idaho, Inc., P.0. Box 1625, Idaho Falls, Idaho 83401 .

153. E. F. Mastal, Office of Nuclear Waste Management, Department of Energy, Washingtun, D.C. 20545.

154. S. Meyere, Office of Nuclear Wastc Managcment, Department of Energy, Washington, D.C. 20545.

155. R. L. Miller, UNC Nuclear Industries, P.0. Box 490, Richland, Washington 99352.

156. E. E. Minor, Sandia National Laboratories, P.0. Box 5800, Albuquerque, New Mexico 87185.

157. J. 0. Neff, Department of Energy, Richland Operations Office, 505 King Avenue, Columbus, Ohio 43201.

158. G. K. Oertel, office of Nuclear Waste Management, Department of Energy, Washington, D.C. 20545. 
159. J. W. Peel, Department of Energy, Idaho Operations Office, 55.0 2nd Street, Idaho Falls, Idaho 83401.

160. B. Peterson, Rockwell International, Rocky Flats Plant, P.o. Box 464, Golden, Colorado 80401 .

161. R. W. Peterson, Office of Nuclear Waste Management, 505 King Avenue, Columbus, Ohio 43201.

162. A. M. Platt, Pacific Northwest Laboratory, P.0. Box 999, Richland, Washington 99352.

163. R. Ramsey, Office of Nuclear Waste Management, Department of Energy, Washington, D.C. 20545.

164. B. Rawles, Office of Nuclear Waste Management, 505 King Avenue, Columbus, Ohio 43201.

165. J. V. Robinson, Pacific Northwest Laboratory, P.0. Box 999, Richland, Washington 99352.

166. J. W. Rowen, Office of Nuclear Waste Management, Department of Energy, Washington, D.C. 20545.

167. S. Schneider, Office of Nuclear Waste Management, Department of Energy, Washington, D.C. 20545.

168. R. Scott, office of Nuclear Waste Management, Department of Energy, Washington, D.C. 20545.

169. L. J. Smith, Rockwell International, Rocky Flats Plant, P.0. Box 464, Golden, Colorado 80401.

170. A. L. Taboas, Department of Energy, Albuquerque Operations Office, P.0. Box 5400, Albuquerque, New Mexico 87115.

171. A. Thomas, Department of Energy, Savannah River Operations Office, P.O. Box A, Aiken, South Carolina 29801.

172. V. G. Trice, Office of Nuclear Waste Management, Department of Energy, Washington, D.C. 20545.

173. J. Wadde11, Office of Nuclear Waste Management, 505 King Avenue, Columbus, Ohio 43201.

174. E. J. Wahlquist, Office of Nuclear Waste Management, Department of Energy, Washington, D.C. 20545.

175. R. D. Walton, Office of Nuclear Waste Management, Department of Energy, Washington, D.C. 20545.

176. R. P. Whitfield, Department of Energy, Savannah River Operations Office, P.O. Box A, Aiken, South Carolina 29801.

177. J. B. Whitsett, Department of Energy, Idaho Operations Office, 550 2nd Street, Idaho Falls, Idaho 83401.

178-205. Office of Assistant Manager, Energy Research and Development, Department of Energy, Oak Ridge Operations, Oak Ridge, Tennessee 37830 .

179-492. Given distribution as shown in TID-4500 under UC-70 Nuclear Waste Management category (25 copies - NTIS). 